\title{
Aktuelle temaer i regnskap og revisjon
}

Tonny Stenheim, Kjell Magne Baksaas og Ellen M. Kulset (red.)

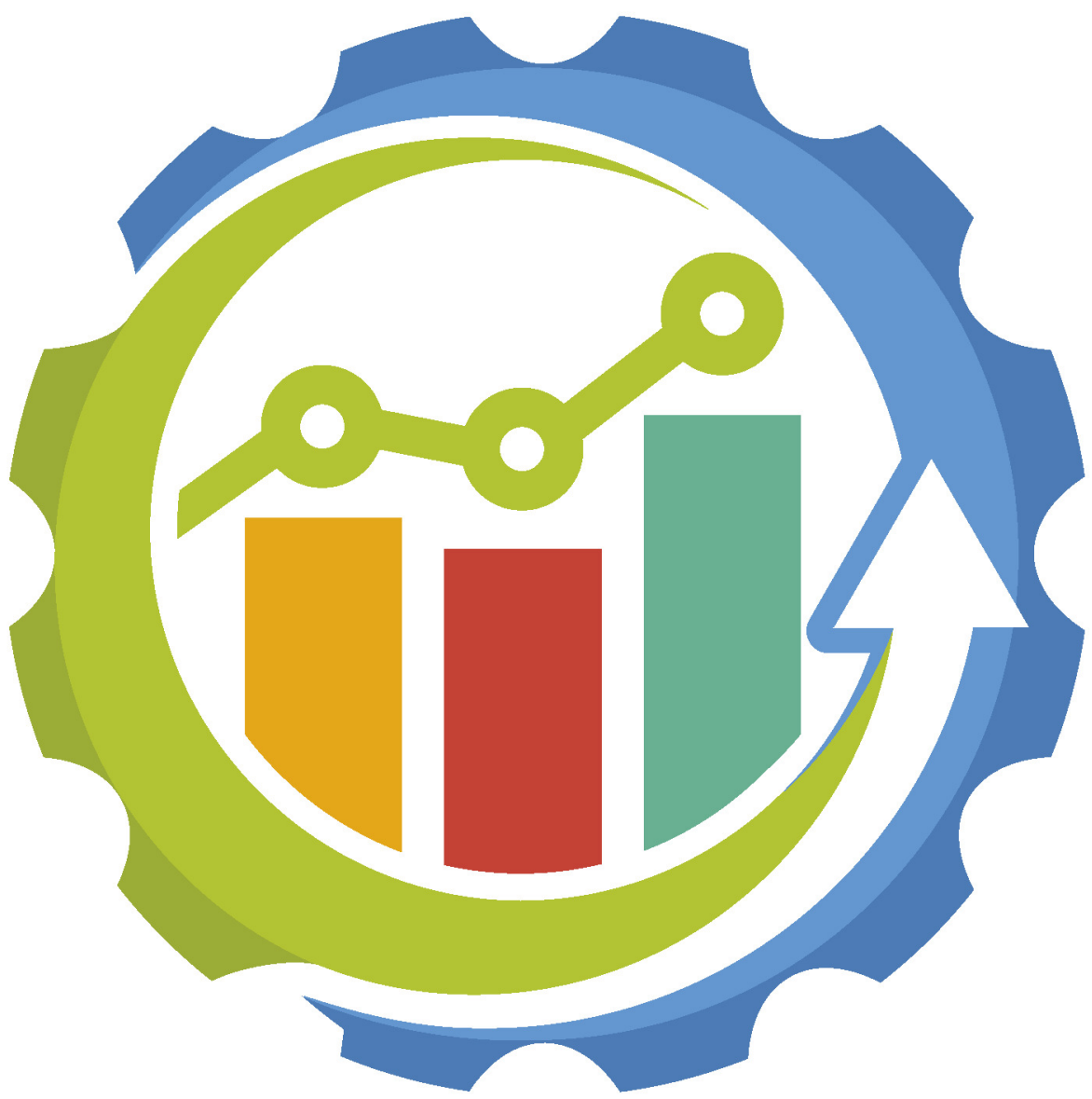


Aktuelle temaer i regnskap og revisjon 

Tonny Stenheim, Kjell Magne Baksaas og

Ellen M. Kulset (red.)

\section{Aktuelle temaer}

\section{i regnskap og revisjon}


(C) 2020 Tonny Stenheim, Kjell Magne Baksaas, Ellen M. Kulset, Sjur Annexstad, Even Fallan, Daniel Johanson, Per Ståle Knardal, Eivind Ludvigsen, Dag Øivind Madsen, Kirsti Helene Rødfjell Meidelsen, Anders Berg Olsen, André Opsahl, Kjell Ove Røsok, Sissel With Stephansen og Tom Erik Wiklund.

Dette verket omfattes av bestemmelsene i Lov om opphavsretten til åndsverk m.v. av 1961. Verket utgis Open Access under betingelsene i Creative Commons-lisensen CC-BY 4.0 (http://creativecommons.org/licenses/by/4.o/). Denne tillater tredjepart å kopiere, distribuere og spre verket i hvilket som helst medium eller format, og å remixe, endre, og bygge videre på materialet til et hvilket som helst formål, inkludert kommersielle, under betingelse av at korrekt kreditering og en lenke til lisensen er oppgitt, og at man indikerer om endringer er blitt gjort. Tredjepart kan gjøre dette på enhver rimelig måte, men uten at det kan forstås slik at lisensgiver bifaller tredjepart eller tredjeparts bruk av verket.

Boka er utgitt med støtte fra Universitetet i Sørøst-Norge, Høgskolen i Innlandet, Norges Handelshøyskole og Norges teknisk-naturvitenskapelige universitet.

ISBN trykt bok: 978-82-02-67223-2

ISBN PDF: 978-82-02-70646-3

ISBN EPUB: 978-82-02-70651-7

ISBN HTML: 978-82-02-70652-4

ISBN XML: 978-82-02-70653-1

DOI: https://doi.org/10.23865/noasp.112

Denne boken er fagfellegodkjent av en ekstern fagfelle med en dobbelblind prosess.

Omslagsdesign: Cappelen Damm AS

Cappelen Damm Akademisk/NOASP

noasp@cappelendamm.no 


\section{Innhold}

Forord

Kapittel 1 Regnskapsspråk og informasjonskvalitet hos selskaper

notert på uregulerte markedsplasser

André Opsahl, Tonny Stenheim, Kjell Magne Baksaas,

Sissel With Stephansen og Kirsti Meidelsen

Kapittel 2 IASBs syn på sammenlignbarhet i finansregnskapet.

.55

Kjell Ove Røsok

Kapittel 3 Regnskapsplikten for små foretak med forenklinger i fokus .83

Kjell Magne Baksaas og Tonny Stenheim

Kapittel 4 Fisjon under IFRS - mulige regnskapsmessige løsninger. 121

Tonny Stenheim

Kapittel 5 Standardisert elektronisk regnskapsrapportering i

Norge: bruk av XBRL.

Ellen M. Kulset og Kjell Magne Baksaas

Kapittel 6 Regnskapsestimater - når er dårlige vurderinger straffbare? ..... 167

Ellen M. Kulset, Eivind Ludvigsen og Kjell Magne Baksaas

Kapittel 7 Hva påvirker adopsjon av digitaliseringsverktøy

i revisjonsbransjen i Norge?

Tom Erik Wiklund, Sjur Annexstad og Even Fallan

Kapittel 8 Bruker norske revisorer konsistente og tilstrekkelige

stikkprøvestørrelser når de tester ukentlig

forekommende interne kontroller? En teoretisk analyse

Ellen M. Kulset

Kapittel 9 Bruk av informasjon fra foretaks miljørapportering til ressursallokerings- og kontrollformål

Even Fallan 
Kapittel 10 Attestasjon av rapportering om sosiale og miljømessige forhold i Norge og internasjonalt kort blikk på historie, standarder og praksis

Even Fallan

Kapittel 11 EUs nye retningslinjer for foretaksrapportering av klimarelaterte opplysninger - byggverk på utrygg grunn?

Anders Berg Olsen og Per Ståle Knardal

Kapittel 12 Om forholdet mellom revisjonens og skattemyn-

dighetenes vesentlighetsforståelse relatert til revisjon av skatterelevante regnskapsopplysninger

Eivind Ludvigsen og Ellen M. Kulset

Kapittel 13 Balansert målstyring som økonomistyringsverktøy

i norske foretak: Utviklingstendenser

i perioden 2015-2018

Daniel Johanson, Dag Øivind Madsen og Tonny Stenheim

Forfatteromtaler. 


\section{Forord}

Denne vitenskapelige antologien dekker utvalgte, aktuelle temaer innen fagfeltet regnskap og revisjon.

De enkelte kapitlene er selvstendige bidrag, er fagfellevurdert og kan leses uavhengig av hverandre. Del A omhandler finansiell rapportering og utgjør de seks første kapitlene. Kapittel 7 til 13 i del B omhandler ulike temaer som spenner fra revisjon til økonomistyring.

Målgruppen for boken er lesere som er interessert i forskningsbaserte bidrag innenfor bokens fagfelt. Den er også nyttig for masterstudenter innen regnskap og revisjon, og de enkelte bidragene vil kunne danne grunnlag for videre forskning. Til slutt mener vi at boken er nyttig også for praktikere innen regnskap og revisjon som vil forbedre egen virksomhet, bli bedre rådgivere eller få faglig påfyll.

Boken er resultatet av et initiativ fra redaktørene, som alle er ansatt ved USN Handelshøyskolen ved Universitetet i Sørøst-Norge. De fleste forfatterne er tilsatt i fagstillinger ved universiteter og høyskoler.

Vi vil takke anonyme fagfeller for verdifulle innspill og kommentarer. Takk også til forlagets redaktører og konsulenter, som har kommet med verdifulle bidrag underveis i prosessen.

Hønefoss, Tønsberg, Oslo, oktober 2020

Tonny Stenheim, Kjell Magne Baksaas og Ellen M. Kulset 



\section{KAPITTEL 1}

\section{Regnskapsspråk og informasjonskvalitet hos selskaper notert på uregulerte markedsplasser}

André Opsahl

Universitetslektor, Universitetet i Sørøst-Norge

Tonny Stenheim

Professor, Universitetet i Sørøst-Norge

Kjell Magne Baksaas

Dosent, Universitetet i Sørøst-Norge

Sissel With Stephansen

Førstelektor, Nord universitet

Kirsti Meidelsen

Førstelektor, Nord universitet

Sammendrag: I dette kapittelet vurderer vi informasjonskvaliteten til regnskaper utarbeidet av selskaper notert på de uregulerte markedsplassene Merkur Market, NOTC og «Family and Friends» per 31.12.2018. ${ }^{1}$ Studien bygger på en antagelse om at regnskaper utarbeidet etter IFRS, vil gi mer og bedre informasjon for investorer enn regnskaper utarbeidet etter God regnskapsskikk (GRS). Samtidig vil insentiver og press kunne medføre at selskaper som bruker GRS, gir mer informasjon enn det minimumskravene skulle tilsi, noe som gjør det nødvendig kvalitativt å vurdere den faktiske regnskapspraksisen (med utgangspunkt i sentrale avvik mellom IFRS og GRS).

1 I forbindelse med overgangen til Optiq i november 2020 skifter Oslo Børs navn på noen markedsplasser. Merkur Market skifter navn til Euronext Growth og NOTC skifter navn til Euronext NOTC (Oslo Børs, 2020).

Sitering av denne artikkelen: Opsahl, A., Stenheim, T., Baksaas, K. M., Stephansen, S. W. \& Meidelsen, K. (2020). Regnskapsspråk og informasjonskvalitet hos selskaper notert på uregulerte markedsplasser. I T. Stenheim, K. M. Baksaas og E. M. Kulset (Red.), Aktuelle temaer i regnskap og revisjon (Kap. 1, s. 9-53). Oslo: Cappelen Damm Akademisk. https://doi.org/10.23865/noasp.112.ch1

Lisens: CC-BY 4.0. 
Vi observerer at mange selskaper velger å være organisert som aksjeselskap fremfor allmennaksjeselskap, velger GRS som regnskapsspråk fremfor IFRS og generelt utarbeider regnskaper med lav informasjonskvalitet. Spesielt er det uventet at så mange små foretak velger å benytte forenklingsregler når de samtidig ønsker å hente inn risikovillig kapital i et notert aksjemarked. Interessant nok er det selskapene notert på Merkur Market, som er nivået før ordinær børsnotering på Oslo Børs (Hovedlisten) og Oslo Axess, som avgir regnskaper med lavest informasjonskvalitet. Våre observasjoner avdekker svakheter ved informasjonskvaliteten på flere sentrale områder. Dette kan medføre høyere kapitalkostnad, mindre tilgang på kapital og lavere likviditet på aksjene til disse selskapene. En markedsløsning for produksjon av regnskapsinformasjon hvor omfang og kvalitet på informasjonen bestemmes av tilbud og etterspørsel, synes ikke å fungere. Gjeldende regulering synes heller ikke å evne å ivareta investorenes informasjonsbehov i tilstrekkelig grad. Kapittelet viser at det trolig eksisterer for svake regnskapsplikter for selskaper notert på uregulerte markedsplasser.

Nøkkelord: informasjonskvalitet, regnskapsspråk, uregulerte markedsplasser

\subsection{Innledning}

Selskaper som er notert på hovedlisten på Oslo Børs eller på Oslo Axess (skifter navn til Euronext Expand i november 2020 (Oslo Børs, 2020)), er pålagt å benytte IFRS som regnskapsspråk ved utarbeidelse av konsernregnskapet. ${ }^{2}$ Men Oslo Børs ASA (og datterselskapet NOTC AS) drifter også de uregulerte markedsplassene Merkur Market (skifter navn til Euronext Growth i november 2020 (Oslo Børs, 2020)), NOTC (skifter navn til Euronext NOTC i november 2020 (Oslo Børs, 2020)) og «Family and Friends», der de noterte selskapene kan velge mellom GRS, GRS for små foretak, forenklet IFRS eller IFRS. Fra et investorperspektiv gir regnskaper utarbeidet etter IFRS mer beslutningsnyttig informasjon enn om de er utarbeidet etter nasjonale regnskapsregler (Daske et al., 2008). Ifølge Beyer mfl. (2010) vil det også kunne redusere informasjonsrisikoen, noe som i sin tur vil kunne medføre lavere kapitalkostnad, lettere tilgang til kapital, høyere aksjekurs og mer likviditet i omsetningen av aksjene. En naturlig antagelse er da at selskaper som søker eksterne investorer gjennom notering på en markedsplass, ønsker å oppnå lavere kapitalkostnad gjennom å utarbeide regnskaper med høy informasjonskvalitet. Det finnes også en omfattende litteratur som viser at overgang fra nasjonale

2 Jf. EU-forordning 1606/2002/EF artikkel 4. 
regler til IFRS gir høyere regnskapskvalitet. Dette resultatet holder uavhengig av om overgangen til IFRS er frivillig (Barth et al., 2008; Daske et al., 2008) eller pliktig (Christensen et al., 2015). Også denne litteraturen viser at selskaper som går over til IFRS, gjennomgående oppnår lavere kapitalkostnad, høyere likviditet på sine aksjer og lettere tilgang på kapital (blant annet kapital fra internasjonale investorer), men disse effektene er sterkere ved frivillig overgang til IFRS enn ved tvungen overgang (Christensen et al., 2015). Som årsaker pekes det på at regnskaper etter IFRS gjennomgående gir mer informasjon og informasjon av høyere kvalitet (for eksempel ved at informasjonen blir mer sammenlignbar, jf. Barth, 2018). Tilsvarende studier gjort på norske selskaper som ble pålagt å gå over til IFRS, gir de samme resultatene, nemlig at overgang fra GRS til IFRS gir regnskapsinformasjon av høyere kvalitet (Gjerde et al., 2008, Stenheim \& Madsen, 2017). Selv om insentivene for frivillig rapportering etter IFRS er åpenbare i et investorperspektiv, er det overraskende mange av selskapene på de uregulerte markedene som rapporterer etter GRS. Vi ønsker derfor å gjøre en kvalitetsvurdering av regnskapsrapporteringen til disse selskapene. Vår problemstilling er:

Hvor god informasjonskvalitet er det på regnskapsrapporteringen til selskapene som er notert på Merkur Market, NOTC og «Family and Friends»?

Vurderingen er gjort gjennom en kartlegging av avvik mot IFRS som kan identifiseres med utgangspunkt i informasjonen som er tilgjengelig i årsrapportene, og i hvilken grad disse avvikene medfører mindre beslutningsnyttig regnskapsinformasjon for de selskapene som har valgt GRS eller forenklet IFRS. Vi gjør også en kvalitetsmessig vurdering av noen sentrale områder i årsregnskapene og konkluderer med om de gir relevant og tilstrekkelig informasjon med utgangspunkt i investorenes antatte informasjonsbehov. Vi velger å ikke bruke regnskapskvalitet som begrep, men derimot informasjonskvalitet. Dette gjøres dels for å distansere studien fra tradisjonelle kvantitative studier (arkivstudier) på regnskapskvalitet og dels for å vise at det her også gjøres en vurdering av opplysninger i noter og årsberetning i tillegg til det som er innregnet som poster i resultatregnskap og balanse. 
Innledningsvis omtales regnskapets formål, investorers bruk av regnskapet som grunnlag for beslutninger og hvilke insentiver selskapene har for å velge IFRS som regnskapsspråk. Videre diskuteres den tradisjonelle tilnærmingen til måling av regnskapskvalitet og valgt fremgangsmåte i denne studien, der vi som nevnt benytter begrepet informasjonskvalitet i stedet for regnskapskvalitet. Metodedelen beskriver hvordan analysen av regnskapene er strukturert og gjennomført. I beskrivelsen av datagrunnlaget omtaler vi de aktuelle markedsplassene og utvalgskriteriene som er benyttet. Vi presenterer deretter våre observasjoner innen utvalgte temaer. Avslutningsvis diskuteres det om manglende oppmerksomhet fra reguleringsmyndighetene når det gjelder regnskapsplikter for disse selskapene, kan betegnes som en svakhet i regnskapsreguleringen.

\subsection{Teori og litteratur}

\subsubsection{Regnskapets formål og brukergrupper}

Formålet med regnskapet ${ }^{3}$ er å redusere eventuell asymmetrisk informasjon mellom selskapets ledelse og selskapets interessenter (Zeff, 1978; Watts \& Zimmerman, 1986, 1990). Ledelsen sitter normalt med mer og bedre informasjon enn interessentene, og regnskapet kan dermed bidra til å redusere denne asymmetriske informasjonen ved å gjøre intern informasjon om selskapet tilgjengelig. Selskapene må bestemme hvor mye informasjon som skal presenteres, og hvordan denne informasjonen skal presenteres i regnskapet. Det er to faktorer som er bestemmende her: Hvilke plikter og krav som pålegges selskapene ved utarbeidelse av regnskapet, og de behov sentrale interessenter har for informasjon. Regnskapsreguleringen pålegger selskapene å gjøre et visst minimum av informasjon tilgjengelig for selskapets interessenter, eksempelvis investorer, banker og myndigheter, slik at disse blir i stand til å ta bedre og mer informerte beslutninger (Elling et al., 2019). Men i 
en del sammenhenger vil etterspørselen etter informasjon, for eksempel fra investorer og banker, være større slik at det kan være fornuftig for selskapene frivillig å utarbeide mer informasjon (frivillig rapportering/ voluntary disclosure) (Watts \& Zimmerman, 1986, 1990; Botosan, 1997). Siden interessentene bruker denne informasjonen til å ta bedre og mer informerte beslutninger, kan formålet med regnskapet sies å være å gi beslutningsnyttig informasjon (se også IASB, 2018, punkt 1.2). Dette formålet kan spesifiseres ytterligere i et verdsettelsesformål og et kontrollformål, som dels er overlappende og dels i konflikt (Gjesdal, 1981; Kothari et al., 2010; Murphy et al., 2013). Regnskapspliktens omfang og innhold må balanseres slik at det tas hensyn til begge formålene (Cascino et al., 2013).

Vi har i dette kapittelet valgt å fokusere på kapitaltilbydere, og da spesielt investorer. Cascino mfl. (2013) deler investorer inn i profesjonelle og ikke-profesjonelle. Førstnevnte er blant annet pensjonskasser, fondsforvaltere og meglerforetak. Disse har ofte relevant kompetanse og ekspertise, nok tid og ressurser til å settes seg inn i investeringsobjektene og benytter sofistikerte metoder ved verdsettelse av selskapene. Ikke-profesjonelle investorer, ofte noe upresist omtalt som småaksjonærer, er privatpersoner som har mindre investeringskapital, kompetanse og kapasitet enn de profesjonelle investorene. Likevel har de samlet sett en viktig rolle som kapitaltilbydere i kapitalmarkedene (Kumar \& Lee, 2006). For begge investorgruppene vil informasjon som kan oppfylle et verdsettingsformål, stå sentralt, dvs. informasjon som kan brukes til å estimere fremtidige kontantstrømmer og usikkerheten i disse for investeringsobjektet. Men også informasjon som kan oppfylle kontrollformålet, er viktig ved at den kan verifisere oppnådde resultater og bidra til å ansvarliggjøre selskapets ledelse.

Både profesjonelle og ikke-profesjonelle investorer bruker regnskapet som informasjonsgrunnlag ved investeringsbeslutninger, men i ulik grad og på ulik måte. For profesjonelle investorer vil ofte den viktigste informasjonen komme fra regnskapet og fra møter med selskapets ledelse. Men denne informasjonen vil ivareta ulike behov, ved at møtene ofte dreier seg om strategiske diskusjoner og ledelsens fremtidige planer, mens regnskapet gir en kvantitativ status på selskapets historiske utvikling. 
Profesjonelle investorer fokuserer ofte mest på resultatregnskapet, men også balanse og kontantstrøm kan være av interesse (Cascino et al., 2013). Det fokuseres dessuten stadig mer på notene (Nelson \& Tayler, 2007). For ikke-profesjonelle investorer trekker Cascino mfl. (2013) frem informasjonskilder som media, investeringstips fra finansforetak, råd fra familie og venner og regnskapet. Selv om denne investorgruppen ikke fokuserer like sterkt på regnskapet, kan det argumenteres for at det har en viktig indirekte rolle ved at de andre informasjonskildene, kanskje med unntak av venner og familie, også benytter regnskapet i sin vurdering av selskapet. Ved direkte bruk av regnskapet fokuserer ikke-profesjonelle investorer på resultatregnskapet, men ser også på balanse og kontantstrøm (Cascino et al., 2013). Det er derimot sjelden det fokuseres på noteinformasjonen (Ernst et al., 2009). Siden ikke-profesjonelle investorer ofte har mindre aksjeposter, og dermed normalt ikke har adgang til å beramme møter med ledelsen, kompenserer de gjerne dette ved å fokusere mer på informasjonen i årsberetningen.

Selskaper utarbeider regnskapsinformasjon for å oppfylle regnskapsplikten og andre regulatoriske krav (pliktig rapportering), men omfanget og kvaliteten på den informasjonen som blir rapportert, vil også bli påvirket av forholdet mellom den nytten og den kostnaden som slik rapportering medfører (frivillig rapportering) (Beattie, 2014). Utarbeidelse av regnskapsinformasjon kan betraktes som en strategisk rapporteringsbeslutning, hvor frivillig rapportering vil bidra til mer åpenhet overfor kapitalmarkedet (investorer mv.). Dette vil kunne redusere informasjonsrisikoen, som i sin tur vil kunne medføre lavere kapitalkostnad, lettere tilgang til kapital, høyere aksjekurs og mer likviditet i aksjene (Beyer et al., 2010), jf. regnskapets verdsettingsformål. I tillegg til disse kapitalmarkedsinsentivene vil også mer informasjon, gjennom frivillig rapportering, gjøre det enklere for investorer og andre å kontrollere og følge opp selskapet, noe som vil redusere agentkostnader, jf. regnskapets kontrollformål. Samtidig vil mer informasjon i regnskapet også ha en kostnadsside ved at selskapet kan miste konkurransefortrinn gjennom publisering av konkurransesensitiv informasjon og ved at det blir påført direkte kostnader gjennom innsamling, behandling og presentasjon av informasjon (Elliott \& Jacobson 1994; Beattie, 2014). 


\subsubsection{Nasjonale regnskapsspråk, IFRS og regnskapskvalitet}

Selskapene som er analysert i dette kapittelet, kan velge mellom regnskapsspråkene GRS, GRS for små foretak, forenklet IFRS og IFRS. Flere studier ser på fordelene ved frivillig å implementere IFRS i tilfeller der det er valgadgang. I mange tilfeller konkluderes det med at utarbeidelse av regnskap etter IFRS gir mer beslutningsnyttig informasjon, spesielt for investorer, enn utarbeidelse av regnskap etter nasjonale regnskapsregler (Daske et al., 2008). I regnskapslitteraturen er beslutningsnytte ofte knyttet til begrepet regnskapskvalitet (Barth et al., 2001, Barth et al., 2008). Regnskapskvalitet er gjerne definert med utgangspunkt i omfanget av bevisste og ubevisste feil i regnskapet som kan påvirke regnskapets evne til å reflektere økonomiske realiteter. Selve målingen av regnskapskvalitet skjer som oftest ved at man forsøker å avdekke i hvilken grad regnskapet evner, eventuelt ikke evner, å reflektere disse økonomiske realitetene. En operasjonalisering er å måle i hvilken grad regnskapet evner å reflektere informasjon som er priset i aksjekursen eller aksjeavkastningen til selskapet (jf. studier av verdirelevans eller informasjonsinnhold: Kothari, 2001; Barth et al., 2001; Barth et al., 2008). En annen operasjonalisering er å måle i hvilken grad regnskapet har normale eller ikke-skjønnsmessige periodiseringer versus unormale eller skjønnsmessige periodiseringer (jf. studier av normale og unormale totale periodiseringer: Dechow et al., 1995; Kothari et al., 2005). En tredje operasjonalisering går ut på å måle i hvilken grad regnskapet evner å reflektere kontantstrøm over tid (jf. studier av kortsiktige periodiseringer: Dechow \& Dichev, 2002) eller har andre kvaliteter som er ønsket av regnskapsbrukerne, for eksempel om det evner å rapportere tap på tidsriktig måte (Ball \& Shivakumar, 2006).

Det finnes en omfattende litteratur som viser at overgang fra nasjonale regler til IFRS gir høyere regnskapskvalitet målt ved de tradisjonelle tilnærmingene som det er vist til over. Dette gjelder uavhengig av om overgangen til IFRS skjer frivillig (Barth et al., 2008; Daske et al., 2008), eller om den er pliktig (Christensen et al., 2015). Disse studiene presenterer også funn som tyder på at selskaper som går over til IFRS, gjennomgående får lavere kapitalkostnad, høyere likviditet på sine aksjer og lettere tilgang på kapital (blant annet kapital fra internasjonale investorer). 
Disse effektene er imidlertid sterkere ved frivillig enn ved tvungen overgang til IFRS (Christensen et al., 2015). Det kan være flere årsaker til disse effektene. Blant annet er det pekt på at regnskaper etter IFRS gir mer informasjon og informasjon av høyere kvalitet (for eksempel at informasjonen blir mer sammenlignbar, jf. Barth, 2018). Tilsvarende studier gjort på norske selskaper viser også at overgang fra GRS til IFRS gir høyere regnskapskvalitet (Gjerde et al., 2008, Stenheim \& Madsen, 2017).

IFRS har mer omfattende krav til innregning og måling av regnskapsposter enn nasjonale regler, for eksempel GRS, og vil også ha langt mer omfattende notekrav. IFRS har til sammen 3000 detaljerte notekrav. Hensikten med disse omfattende notekravene, er at regnskapsbrukerne skal kunne forstå innholdet, betingelsene, tidfestingen og usikkerheten i transaksjonene (se for eksempel IAS 1.79, IFRS $2.44 \mathrm{og}$ IFRS 7.7).

\subsection{Tradisjonelle tilnærminger til regnskapskvalitet}

\subsubsection{Innledning}

De tradisjonelle tilnærmingene til måling av regnskapskvalitet er å bruke mål på verdirelevans, på unormale periodiseringer og på tidsriktig rapportering av tap. Ingen av disse er spesielt egnet å bruke i vår studie. Mål på verdirelevans gjør bruk av aksjekurser for å vurdere i hvilken grad regnskapsmessige størrelser reflekterer informasjon som er priset av aksjemarkedet (Barth et al., 2001). Forutsetningen for at denne tilnærmingen skal si noe om regnskapskvalitet og beslutningsnytte, er at aksjekursene hentes fra et halvsterkt effisient aksjemarked hvor all offentlig tilgjengelig prisrelevant informasjon, også regnskapsinformasjon, umiddelbart og forventningsrett prises inn i aksjekursen (Holthausen \& Watts, 2001). De selskapene som undersøkes i denne studien, er notert på uregulerte markedsplasser med langt lavere likviditet i aksjene, noe som gjør at vi vurderer aksjekursene som lite effisiente. Mål på unormale periodiseringer er utsatt for store måleproblemer. Generelt er det vanskelig å avgjøre om estimerte unormale periodiseringer faktisk er å anse som unormale (Kothari et al., 2005; Dechow et al., 1995). Det er også 
problematisk å bruke disse hvis man ønsker å sammenligne unormale periodiseringer mellom selskap som rapporterer etter ulike regnskapsspråk, for eksempel etter IFRS, forenklet IFRS, GRS og GRS for små foretak, slik vi har intensjon om å gjøre i denne studien. Tidsriktig tapsføring som mål på regnskapskvalitet bygger på en antagelse om at umiddelbar innregning av urealiserte tap (men ikke nødvendigvis urealiserte gevinster) gir beslutningsnyttig informasjon for regnskapsbrukerne (Basu, 1997; Watts, 2003; Hope et al., 2013, 2016). I de fleste studier på regnskapskvalitet er mål på tidsriktig tapsføring tatt med som et av flere mål på regnskapskvalitet (for eksempel Barth et al., 2008; Hope et al., 2013, 2016) og da gjerne sammen med ulike mål på periodiseringskvalitet (mål på unormale periodiseringer).

Felles for alle disse tre tilnærmingene er at de gjør bruk av arkivdata (archival research method) og dermed store datasett for å kunne oppnå valide og reliable resultater fra statistiske tester, slik som regresjonsanalyser. De uregulerte markedsplassene i Norge er små (83 selskaper notert per 31.12.2018), og det skjer hyppige listeendringer, noe som gjør det umulig å etablere store datasett med sammenhengende selskapsinformasjon over tid (paneldatasett).

\subsubsection{Kvalitativt mål på informasjonskvalitet}

I denne studien ønsker vi heller å bruke en kvalitativ metodisk tilnærming. Sentralt i studien er å undersøke avvik mellom selskapenes aktuelle regnskapsrapportering og IFRS, og i hvilken grad disse avvikene medfører mindre beslutningsnyttig informasjon for investorene. Dette krever bruk av informasjon i noter, supplert med informasjon i årsberetningen. I det følgende velger vi også å bruke begrepet informasjonskvalitet i stedet for begrepet regnskapskvalitet fordi vi fokuserer særskilt på mengden og kvaliteten på informasjonen som finnes i notene til regnskapet. Det betyr derimot ikke at innholdet i begrepet informasjonskvalitet avviker vesentlig fra innholdet i begrepet regnskapskvalitet.

Informasjonen i noter er gjerne presentert i form av tekst, men kan også være kvantitativ og numerisk. Tidligere litteratur om narratives og additional disclosure er av spesiell relevans og interesse for studien 
(for litteraturgjennomgang, se Beattie et al., 2004, og Beattie, 2014). I denne litteraturen har en særlig fokusert på frivillig rapportering av tilleggsinformasjon i noter og $\mathrm{i}$ årsberetning (voluntary disclosure) og en hovedretning har vært såkalte informasjonsindeks-studier (disclosure index studies). Disse studiene forsøker å undersøke informasjonsmengden og i noen grad informasjonskvaliteten ved å rangere rapporteringen til selskapene ut fra informasjonsindekser. Disse kan være enkle og bare reflektere mengden informasjon, for eksempel ved at kodeskjemaet får verdien 1 hvis en bestemt informasjon er gitt, og o ellers, eller de kan være mer komplekse ved at det også gjøres en vurdering av kvaliteten på den informasjonen som gis, for eksempel ved at informasjonen rangeres som god, middels god eller dårlig (se for eksempel Botosan, 1997; Beattie et al., 2004; Beattie, 2014). Vi har funnet det hensiktsmessig å utvikle et tilsvarende kodeskjema som gjennomgås nærmere i neste avsnittet om metodisk tilnærming.

\subsection{Metodisk tilnærming}

Vi har valgt en kvalitativ metodisk tilnærming som innebærer en vurdering av avvik mellom den valgte regnskapsrapporteringen til selskapene notert på Merkur Market, NOTC og «Family and Friends», og den rapporteringen som ville vært pålagt etter IFRS. Antagelsen vår har vært at årsregnskap avlagt etter IFRS, generelt gir mer informasjon og informasjon av høyere kvalitet enn regnskap avlagt etter forenklet IFRS eller GRS (Barth et al., 2008; Daske et al., 2008; Gjerde et al., 2008; Stenheim \& Madsen, 2017).

Sentral informasjon vil være den som finnes i noter, supplert med informasjon i årsberetningen. Som et utgangspunkt for denne kartleggingen har vi utviklet et kodeskjema. Kodeskjemaet har vært todelt, der vi først har registrert regnskapsspråk, dato for fastsetting av regnskapet, om det foreligger utsatt skattefordel og hvorvidt denne er balanseført eller ikke, samt om driftsresultat, årsresultat og egenkapital har positiv verdi. I del to har vi identifisert mulige sentrale avvik mellom valgt rapportering og IFRS. Samtlige sjekkpunkter er presentert i vedlegg 10.2: «Kodeskjema 1: Selskapsform, regnskapsspråk og økonomiske forhold» og vedlegg 10.3: 
«Kodeskjema 2: Sentrale forskjeller mellom IFRS og GRS og forekomst av avvik fra IFRS blant selskapene i utvalget».

Selskapene ble fordelt slik at samme regnskap ble vurdert av to forfattere. Vi brukte en rullerende fordeling, der alle kombinasjoner av to forfatterne ble brukt. Ved eventuelle avvik i vurderingen kom man frem til en felles vurdering gjennom diskusjon. Årsregnskapene og årsberetningene er hentet fra de aktuelle selskapenes børsmeldinger på www.oslobors.no og fra Regnskapsregisteret. Med utgangspunkt i vår kartlegging observerte vi hvilke avvik som forekom hyppigst, og fokuserte deretter på disse i det videre arbeidet (fremkommer også i tabell 1.8.3).

For hvert av de ulike temaene vi har valgt å fokusere på, har vi gjort en kvalitativ vurdering av hva som kan anses som henholdsvis høy informasjonskvalitet og lav informasjonskvalitet. Vurderingen av høy informasjonskvalitet har tatt utgangspunkt i de aktuelle regulatoriske kravene etter IFRS. Siden utviklingen av IFRS har et klart investorfokus (se for eksempel IASB, 2018, punkt 1.2), vil det å legge informasjonspliktene etter IFRS til grunn for å vurdere informasjonsmengde og informasjonskvalitet innebære at vi også legger til grunn et investorperspektiv i vår vurdering. IFRS har gjennomgående mer omfattende rapporteringskrav enn GRS (Schwencke et al., 2020, s. 1175-1177), og rapportering etter dette regnskapsspråket vil normalt gi mer og bedre informasjon og høyere regnskapskvalitet enn rapportering etter GRS (Gjerde et al., 2008; Stenheim \& Madsen, 2017). Det betyr at selskaper som har valgt å rapportere i henhold til GRS, normalt vil bli vurdert å ha lavere informasjonskvalitet så lenge selskapet ikke gir mer og bedre informasjon enn det som oppfyller minimumskravene etter GRS. Dette forutsetter at GRS på det aktuelle området som vurderes, har regnskapsplikter som er mindre omfattende enn IFRS.

Men selskapene kan ha insentiver og kan være utsatt for press som gjør at de gir mer og bedre informasjon enn det som følger av minimumskravene for et gitt regnskapsspråk (Watts \& Zimmerman, 1986, 1990; Botosan, 1997). Det gjør at det ikke er tilstrekkelig bare å fastslå hvilket regnskapsspråk som er benyttet. I tillegg må vi vurdere i hvilken grad selskapet gir mer og bedre informasjon enn det som følger av minimumsplikter etter det valgte regnskapsspråket. I noen tilfeller har det også 
være vanskelig å trekke grensen mellom god og dårlig informasjon. En kvalitativ vurdering av den typen som er anvendt her, vil kreve bruk av faglig skjønn hos den aktuelle kontrolløren. Forfatterne har derfor vært avhengige av omfattende profesjonskunnskap som grunnlag for utøvelsen av det faglige skjønnet. Resultatene bør derfor leses som indikasjoner og ikke presise målinger. Vi mener likevel at framgangsmåten, ved å bruke to kontrollører og rullerende fordeling, reduserer risikoen for store vurderingsavvik.

\subsection{Datagrunnlag}

Datagrunnlaget er selskapene som var notert på Merkur Market, NOTC og «Family and Friends» per 31.12.2018. Disse markedsplassene inngår i Oslo Børs’ «trappetrinnsmodell», der en ordinær børsnotering kan skje gjennom en trinnvis prosess.

Første trinn er «Family and Friends»-listen, som retter seg mot oppstarts- og familieselskaper. Her er det få forpliktelser og krav til det registrerte selskapet, og det er valgfrihet knyttet til regnskapsspråk. Det er også mulig å benytte forenklingsreglene for små foretak hvis selskapet kommer under terskelverdiene i regnskapsloven $₫ 1-6$. Listen besto per 31.12.2018 av bare to selskaper.

Andre trinn er NOTC-listen, som benytter samme informasjonssystem som «Family and Friends»-listen. Selskapene søker ikke selv om notering, men blir registrert på anmodning fra meglerforetak i tilfeller der det foreligger vesentlig interesse for kjøp og salg av selskapets aksjer. Noen av selskapene har i tillegg inngått avtaler direkte med NOTC, der de forplikter seg til å publisere regnskapsinformasjon og annen kursrelevant informasjon. I motsetning til børsnoterte selskaper trenger ikke meglere å gjennomføre handler til innlagte kjøps- og salgskurser i NOTC-listen (NOTC, 2020). Det er få krav til de NOTC-registrerte selskapene, men noen flere registreringskriterier enn for «Family and Friends»-selskapene. Blant annet stilles det krav til selskapets levetid, markedsverdi og eierspredning (i form av antall aksjonærer). Det er imidlertid ikke noe krav om at årsregnskapet utarbeides etter IFRS. Selskaper på NOTClisten kan derfor også velge forenklet IFRS eller GRS. Men selskapene som 
har inngått avtale med NOTC-listen, blant annet om å publisere regnskapsinformasjon, er som et minimum pålagt å utarbeide resultatregnskap, balanse, noter, kontantstrømoppstilling og årsberetning. Det betyr at små selskaper som har inngått avtaler med NOTC-listen, er forpliktet til å utarbeide årsberetning og kontantstrømoppstilling, selv om de ellers er fritatt fra dette, jf. regnskapsloven $₫$ 3-1 annet ledd annet punktum og $\$$ 3-2 annet punktum. Derimot vil de ved utarbeidelse av årsregnskapet kunne benytte andre unntaksregler, for eksempel forenklede vurderingsregler og forenklede notekrav.

Merkur er det siste trinnet før ordinær børsnotering på Oslo Børs (hovedlisten) eller Oslo Axess. Det er færre krav og forpliktelser enn ved ordinær børsnotering, men i samsvar med den trinnvise modellen er kravene strengere enn for notering på NOTC- og «Family and Friends»-listen. Her er det også tilstrekkelig å avlegge årsregnskap etter forenklet IFRS eller GRS, men selskapene forplikter seg til å utarbeide en årsrapport som inneholder resultatregnskap, balanse, noteopplysninger, kontantstrømoppstilling og årsberetning. På samme måte som for små foretak som har inngått avtale med NOTC-listen, er det ved notering på Merkur Market ikke adgang til å benytte alle unntaksreglene for små foretak da de blant annet må utarbeide årsberetning og kontantstrømoppstilling. Men i tillegg til dette vil det ved notering på Merkur Market følge en mer omfattende informasjonsplikt enn for selskaper på NOTC-listen og «Family and Friends»-listen.

Utvalgsrammen for studien er alle selskaper notert på de tre overnevnte markedsplassene per 31.12.2018. Disse er gjengitt i vedlegg 10.1. I den videre prosessen med å avgrense utvalget for studien ekskluderte vi 1) selskaper som er registrert og har regnskapsplikt til et annet land enn Norge siden disse selskapene ikke omfattes av adgangen til å velge mellom GRS, forenklet IFRS og IFRS etter regnskapsloven $\$ 3-9$, og 2) norske selskaper som utarbeider årsregnskap etter egne forskrifter gitt med hjemmel i regnskapsloven eller etter særlovgivning. Banker og kredittforetak, som må følge egen forskrift gitt med hjemmel i regnskapsloven $\$ 10-1$, er en type selskaper som faller ut av utvalget etter det siste utvalgskriteriet. Enkelte selskaper måtte også tas ut av utvalget på grunn av manglende regnskapsrapportering for 2018. Vi satt da igjen med de norskregistrerte selskapene som kan velge 
regnskapsspråk og som har avlagt årsregnskap for 2018. Totalt antall selskaper i utvalgsrammen, reduksjon i antall selskaper som følge av utvalgskriterier, og endelig utvalg er presentert i tabell 1.1.

Tabell 1.1 Utvalg fordelt på de aktuelle markedsplassene

\begin{tabular}{lcccc}
\hline & $\begin{array}{c}\text { Merkur } \\
\text { Market }\end{array}$ & NOTC & $\begin{array}{c}\text { «Family and } \\
\text { Friends» }\end{array}$ & Totalt \\
\hline Antall selskaper 31.12.2018 & 24 & 57 & 2 & 83 \\
Utelukkes pga. hjemmehørende i et annet land & 6 & 15 & 0 & 21 \\
Utelukkes pga. særregulering & 7 & 8 & 0 & 15 \\
Utelukkes pga. manglende informasjon & 2 & 2 & 0 & 4 \\
\hline Utvalg & $\mathbf{9}$ & $\mathbf{3 2}$ & $\mathbf{2}$ & $\mathbf{4 3}$ \\
\hline
\end{tabular}

\subsection{Resultater}

Nedenfor presenterer vi de viktigste resultatene fra vår kvalitative gjennomgang av regnskapsinformasjonen til selskapene notert på Merkur Market, NOTC og «Family and Friends». Tabell 1.8.3 i vedlegg gir en oversikt over sentrale forskjeller mellom IFRS og GRS og forekomsten av avvik fra IFRS blant selskapene i utvalget. Av hensyn til rammen i dette kapittelet har vi valgt å fokusere på de avvikene med høyest forekomst.

\subsubsection{Selskapsrettslig organisasjonsform Aktuell regulering}

Selskaper notert på regulerte markeder, som Oslo Børs (hovedlisten) og Oslo Axess, må være registrert som allmennaksjeselskap (ASA). Denne selskapsformen legger til rette for større aksjonærspredning, og Bråthen (2019) omtaler derfor organisasjonsformen som «åpne selskaper». Selskapsformen aksjeselskap (AS) kan derimot betegnes som lukket mot en mindre aksjonærkrets, og lovgiver legger mer vekt på fleksibilitet, avtalefrihet og forenklinger.

Allmennaksjeloven legger også større vekt på investorbeskyttelse. Dersom et selskap ønsker å invitere «enhver» til å delta ved nyemisjoner, fordrer det at selskapet er et allmennaksjeselskap (ASA) jf. allmennaksjeloven $₫$ 10-1 sammenholdt med aksjeloven $₫ 10-1$. Aksjetegning av nye 
aksjer i et aksjeselskap (AS) er på sin side begrenset til eksisterende aksjonærer og/eller bestemte navngitte personer, jf. aksjeloven $\$$ 10-1. Det er imidlertid ikke noe til hinder for at de tegnede aksjene i neste omgang kan selges til «hvem som helst» (Bråthen, 2019, s. 257).

\section{Observasjoner}

Vårt utvalg på 43 selskaper består av 34 aksjeselskaper (AS) og ni allmennaksjeselskaper (ASA). Fordelingen på de aktuelle markedene er presentert i tabell 1.2 under. Vi registrerer at samtlige allmennaksjeselskaper (ASA) er å finne på NOTC.

Tabell 1.2 Selskapsrettslig organisasjonsform fordelt på aktuelle markeder

\begin{tabular}{lccccc}
\hline & $\begin{array}{c}\text { Merkur } \\
\text { Market }\end{array}$ & NOTC & $\begin{array}{c}\text { «Family and } \\
\text { Friends» }\end{array}$ & $\begin{array}{c}\text { Totalt } \\
\text { (Antall) }\end{array}$ & $\begin{array}{c}\text { Totalt } \\
\text { (\%) }\end{array}$ \\
\hline Allmennaksjeselskaper (ASA) & 0 & 9 & 0 & 9 & $21 \%$ \\
Aksjeselskaper (AS) & 9 & 23 & 2 & 34 & $79 \%$ \\
\hline Totalt & $\mathbf{9}$ & $\mathbf{3 2}$ & $\mathbf{2}$ & $\mathbf{4 3}$ & $\mathbf{1 0 0 \%}$ \\
\hline
\end{tabular}

\subsubsection{Fordeling regnskapsspråk \\ Aktuell regulering}

Selskaper som ikke er notert med verdipapirer på regulert marked, ${ }^{4}$ kan velge å utarbeide årsregnskapet etter IFRS, forenklet IFRS eller GRS, jf. regnskapsloven $\$ 3^{-9}$ tredje til femte ledd. Hvis selskapet er notert på regulert marked, må konsernregnskapet utarbeides etter IFRS, jf. regnskapsloven $\$$ 3-9 første ledd og annet ledd. Hvis dette selskapet ikke har konsernregnskapsplikt etter IFRS, skal selskapsregnskapet utarbeides etter IFRS.

Det innebærer at selskaper som er notert på de uregulerte markedsplassene Merkur Market, NOTC eller «Family and Friends», kan velge mellom IFRS, forenklet IFRS, GRS og i visse tilfeller GRS for små foretak ved utarbeidelse av årsregnskapet. Notering på Merkur Market og NOTC stiller derimot krav om utarbeidelse av årsberetning og

4 Jf. EU-forordning 1606/2002/EF artikkel 4. 
kontantstrømoppstilling selv om selskapet kan kategoriseres som små foretak etter regnskapsloven $₫ 1-6$.

\section{Observasjoner}

Tabell 1.3 viser fordelingen mellom de ulike regnskapsspråkene i de ulike markedene.

Tabell 1.3 Fordeling av regnskapsspråk

\begin{tabular}{|c|c|c|c|c|c|c|c|c|}
\hline \multirow[t]{2}{*}{ Regnskapsspråk } & \multicolumn{2}{|c|}{ Merkur Market } & \multicolumn{2}{|c|}{ NOTC } & \multicolumn{2}{|c|}{$\begin{array}{l}\text { «Family and } \\
\text { Friends» }\end{array}$} & \multicolumn{2}{|c|}{ Totalt } \\
\hline & Konsern & Selskap & Konsern & Selskap & Konsern & Selskap & Konsern & Selskap \\
\hline IFRS & 3 & 1 & 8 & 5 & 0 & 0 & 11 & 6 \\
\hline Forenklet IFRS & 0 & 0 & 2 & 4 & 1 & 0 & 3 & 4 \\
\hline GRS & 2 & 4 & 13 & 20 & 1 & 2 & 16 & 26 \\
\hline GRS små foretak & 2 & 4 & 0 & 3 & 0 & 0 & 2 & 7 \\
\hline Totalt & 7 & 9 & 23 & 32 & 2 & 2 & 32 & 43 \\
\hline
\end{tabular}

Antallet konsernregnskaper og selskapsregnskaper vil være forskjellig da ikke alle selskapene utarbeider konsernregnskap. Vi registrerer at 14 selskaper (40 prosent) velger IFRS eller forenklet IFRS ved utarbeidelse av konsernregnskapet. Når det gjelder selskapsregnskapene, er det derimot bare 10 selskaper (19 prosent) som velger dette. Vi kan derfor konkludere med at GRS (ordinær og små foretak) er det mest anvendte regnskapsspråket blant disse selskapene. Den største overraskelsen er at hele sju selskaper (16 prosent) benytter GRS for små foretak, og fire av disse er notert på Merkur Market. Som nevnt, forhindrer imidlertid noteringskriteriene at en tar i bruk enkelte av unntaksreglene for små foretak, deriblant unntaket fra plikt til å utarbeide årsberetning og kontantstrømoppstilling (jf. delkapittel 4: Datagrunnlag).

\subsubsection{Inntektsføring}

\section{Aktuell regulering}

Inntektsføring etter GRS gjøres i samsvar med opptjeningsprinsippet, jf. regnskapsloven $₫$ 4-1 første ledd nr. 2 og etter den rettslige standarden 
God regnskapsskikk, jf. regnskapsloven $\$$ 4-6. Regnskapsstandarder mv. utgitt av Norsk Regnskapsstiftelse vil normalt gi uttrykk for hva som er å anse som god regnskapsskikk innenfor det virkeområdet standarden gjelder (jf. Ot.prp. nr. 42 (1997-98) punkt 6.8.5). På inntektsområdet er det utgitt en veiledning, NRS (V) Regnskapsføring av inntekt, som er ment å angi akseptable løsninger for inntektsføring av driftsinntekter og visse finansielle inntekter. Denne veiledningen er i stor grad inspirert av den tidligere IFRS-standarden IAS 18 Driftsinntekter, som fra 1.1.2018 ble erstattet med IFRS 15 Regnskapsføring av kundekontrakter.5 Det er adgang for små foretak til å fravike opptjeningsprinsippet hvis dette følger av god regnskapsskikk for slike foretak, jf. regnskapsloven $\$$ 4-1 annet ledd første punktum. NRS 8 God regnskapsskikk for små foretak inneholder ikke særskilte unntaksregler for små foretak på inntektsområdet ut over de som ellers følger av loven. ${ }^{6}$

Prinsipper for inntektsføring skal beskrives som en del av oppfyllelsen av det generelle notekravet om regnskapsprinsipper, jf. regnskapsloven $\$ \$$ 7-2 første punktum og $\$$ 7-35 første ledd første punktum. I notebestemmelsen om regnskapsprinsipper er det særskilt angitt at inntektsføringsprinsippene skal beskrives, noe som må forstås som at det skal gis mer utfyllende informasjon om disse prinsippene enn om andre regnskapsprinsipper. Det er ikke gitt ytterligere notekrav i NRS (V) Regnskapsføring av inntekt, men notekrav følger av enkelte andre standarder som berører inntektsføring, for eksempel NRS 2 Anleggskontrakter. Krav om å gi noteopplysninger om inntektsføring kan også følge av det generelle kravet om at årsregnskapet skal gi opplysninger som er «nødvendige for å bedømme den regnskapspliktiges eller konsernets stilling og resultat og som ikke fremgår av årsregnskapet for øvrig», jf. regnskapsloven $\$ 7-1$ annet ledd.

5 Inntektsføring av visse finansinntekter som tidligere falt under virkeområdet til IAS 18, reguleres nå av IFRS 9 Finansielle instrumenter.

6 For eksempel vil bruk av unntaksregelen for finansielle instrumenter og varederivater i regnskapsloven $\$$ 5-8 annet ledd og bruk av fullført kontrakts metode for anleggskontrakter i regnskapsloven $\$$ 5-12 medføre inntektsføring som avviker fra hovedreglene. 
I IFRS vil inntektsføring være regulert av den enkelte regnskapsstandard og tolkningsuttalelse. Den sentrale inntektsstandarden er likevel IFRS 15 Regnskapsføring av kundekontrakter. Denne angir en femtrinnsmodell for inntektsføring og stiller omfattende notekrav. Denne har som nevnt erstattet tidligere IAS 18 Driftsinntekter og IAS 11 Anleggskontrakter, som hadde færre notekrav. Foretak som velger å utarbeide årsregnskapet etter forenklet IFRS, jf. regnskapsloven $\$$ 3-9 femte ledd og tilhørende forskrift, må bruke IFRS 15 fullt ut.

Vurderingen av om noteopplysninger om inntektsføring holder høy eller lav kvalitet, er ikke først og fremst gjort med utgangspunkt i notekrav nedfelt i lov eller standarder, men med utgangspunkt i hva investorer vil vurdere som nyttig informasjon. Selskap som er notert på uregulerte markeder (slik som Merkur mv.), gjør dette for å få enkel tilgang til risikovillig kapital uten samtidig å måtte forholde seg til alle de kravene som børsnotering på et regulert marked vil innebære. En sentral brukergruppe for regnskapene til disse selskapene er derfor nåværende og potensielle investorer. Disse bruker regnskapsinformasjon til verdsettings- og kontrollformål. Omtalen av inntektsføring i regnskapet bør derfor trolig være mer omfattende enn bare å gi en ren beskrivelse av generelle inntektsføringsprinsipper. For eksempel kan det være relevant å gi informasjon om hvordan inntektene fordeler seg på produkter, tjenester og markeder (en type segmentinformasjon), hvilke sentrale regnskapsestimater som er benyttet for inntektsføring (for eksempel hvis løpende avregningsmetode er benyttet), samt informasjon om vesentlige kontrakter og hvordan inntektsføring skjer for disse (innhold og betingelser, fastsetting og allokering av vederlag og tidspunkt for innregning). Notekrav etter IFRS 15 er motivert av de behovene som nåværende og potensielle investorer har for informasjon om inntekter og inntektsføring. GRS og GRS for små foretak er ikke på samme måte tilpasset disse behovene.

\section{Observasjoner}

De fleste selskapene i utvalget gir en kort beskrivelse av transaksjonsbasert inntekt, men den er ofte generell, lite utfyllende og gir lite selskapsspesifikk informasjon. I mange sammenhenger gjengir den kort omtalen 
av inntektsføringsprinsipper i standarder om inntektsføring. Blant de 43 selskapene som er undersøkt, er 25 selskaper ( 58 prosent) vurdert til ikke å gi en god beskrivelse av inntektsføringsprinsipper. Av disse 25 selskapene er igjen 13 ( 52 prosent) vurdert til å gi svært kort beskrivelse av inntektsføringsprinsipper.

Som nevnt, er selskapene notert på Merkur nærmest notering på et regulert børsmarked (slik som Oslo Børs Hovedlisten og Oslo Axess). Av disse ni selskapene er det seks selskaper (67 prosent) som er vurdert til ikke å gi en god beskrivelse av inntektsføringsprinsipper. To av selskapene gir jevnt gode beskrivelser (det ene rapporterer etter GRS og det andre etter IFRS), mens ett av selskapene er vurdert å gi en god beskrivelse (det rapporterer etter IFRS i konsernregnskapet og GRS i selskapsregnskapet). Blant de 31 selskapene som er notert på NOTC, er det 17 selskaper (47 prosent) som er vurdert til ikke å gi en god beskrivelse av inntektsføringsprinsipper. Samtlige av disse med unntak av ett selskap som utarbeider regnskapet etter forenklet IFRS, utarbeider regnskapet etter GRS eller GRS for små foretak.

De få som rapporterer etter IFRS, stilles overfor mer omfattende krav til noteopplysninger og må også gjennomgående gi mer utfyllende opplysninger om inntektsføring. De som rapporterer etter GRS og GRS for små foretak, er pålagt å gi en nærmere beskrivelse av inntektsføringsprinsipper, jf. regnskapsloven $₫$ 7-2 første punktum og $₫$ 7-35 første ledd første punktum, men det finnes ingen spesifikke krav ut over det. Det at kravene er mindre omfattende og mindre spesifikke, vil naturlig nok påvirke omfanget av de noteopplysninger som blir gitt. Alle IFRS-rapporterende, med unntak av ett selskap, som gir jevnt god beskrivelse, er vurdert til å gi en god beskrivelse av inntektsføringsprinsippene.

\section{Eksempler på mangelfull noter om inntektsføring}

Under følger noen eksempler på korte og mangelfulle notebeskrivelser om inntektsføring som trolig ikke gir tilstrekkelig informasjon vurdert ut fra behovet til investorer.

Et selskap notert på Merkur Market og som rapporterer etter GRS, gir følgende korte beskrivelse av prinsippene for inntektsføring: 
Morselskapets driftsinntekter stammer fra salg av forvaltningstjenester til egne datterselskaper og eksterne kunder. Datterselskapenes driftsinntekter stammer fra utleie av egen eiendom. Konsernets driftsinntekter resultatføres når de er opptjent (opptjeningsprinsippet) (...)

Et annet selskap notert på NOTC og som rapporterer etter forenklet IFRS, gir følgende beskrivelse av prinsipper for inntektsføring:

The Company recognises income in line with the transfer of promised goods and services to customers in an amount that reflects the consideration to which the Company expects to be entitled in exchange for those goods or services. Operating revenue is shown net of discounts, value-added tax and other taxes on gross rates.

Et tredje selskap notert på NOTC og som rapporterer etter IFRS, gir også en kort beskrivelse. Denne synes ikke å være i samsvar med de notekravene som følger av IFRS 15:

Selskapet inntektsfører salg av varer når det foreligger en bindende avtale med kunden, avtalt overlevering av produktet har funnet sted, inntekten er målbar og det vesentligste av risiko og fordeler knyttet til produktet er overført kunden. Driftsinntekter inntegnes ikke dersom det er betydelig usikkerhet knyttet til om forfalte krav vil bli betalt. Selskapet avsetter for garantikostnader, retur etc. basert på historikk eller beste estimat. Fraktkostnader er inkludert som en del av salgsinntekten. Inntekter er vist netto av merverdiavgift, rabatter, garantiavsetninger og konsernelimineringer.

\subsubsection{Forutsetninger om fortsatt drift og balanseføring av utsatt skattefordel \\ Aktuell regulering}

Årsregnskapet skal avlegges under forutsetning om fortsatt drift så lenge det ikke er sannsynlig at virksomheten vil bli avviklet, jf. regnskapsloven $₫$ 4-5 første punktum. Aksjeloven og allmennaksjeloven $₫ 3-4$ stiller krav om at selskapene skal ha en forsvarlig egenkapital og likviditet ut fra 
risikoen ved og omfanget av virksomheten. Dersom dette ikke er tilfellet, vil styrets handleplikt gjelde, jf. aksjeloven og allmennaksjeloven $\$ 3-5$ første ledd.

Selskap som benytter GRS, må omtale fortsatt drift i sin årsberetning, jf. regnskapsloven 3-3a sjuende ledd. Benyttes GRS for små foretak, er det ikke pliktig å utarbeide årsberetning, men selskapet må likevel gi opplysninger i note dersom det er usikkerhet om fortsatt drift, jf. regnskapsloven $₫ 7$-46. Avlegges regnskap etter IFRS, gjelder et tilsvarende opplysningskrav, jf. IAS 1.25 .

Negative finansielle nøkkeltall er, jf. ISA 570 punkt A3, forhold som kan skape tvil om selskapets evne til fortsatt drift. Udekket tap eller annen egenkapital kr o (hvor det er tatt fra overkurs for å utligne udekket tap) kan dermed være en indikator på at en slik usikkerhet foreligger. En usikkerhet knyttet til fortsatt drift kan bety at et selskap ikke kan realisere sine eiendeler og oppfylle sine forpliktelser gjennom den ordinære virksomheten. Når en slik usikkerhet foreligger, kan det ha betydning for verdsettelsen av selskapets eiendeler, og selskapet har da plikt til å vurdere om det foreligger nedskrivningsindikatorer. Dette er spesielt relevant for immaterielle eiendeler.

En utsatt skattefordel representerer en mulig fremtidig skattereduksjon som følge av redusert skattepliktig inntekt. Adgangen til å føre underskudd til fremføring betyr at skattemessig underskudd i dag (eller i tidligere regnskapsår) kan motregnes mot skattemessig overskudd i senere perioder og dermed redusere fremtidig skattepliktig inntekt. Balanseføring av utsatt skattefordel følger de generelle vurderingsreglene. Etter NRS (F) Resultatskatt punkt 2.4 innebærer dette at selskapet må sannsynliggjøre en fremtidig skattepliktig inntekt eller kunne sannsynliggjøre en realistisk skattetilpasning som gjør det mulig å benytte fordelen (eksempel via konsernbidrag). Standarden gir følgende eksempler på forhold som kan indikere at tilstrekkelig fremtidig skattepliktig inntekt ikke kan oppnås: 1) Selskapet har en lang og konsistent historie med negativ inntjening, 2) selskapet forventer tap i de nærmeste årene, eller 3) det foreligger usikre negative forhold for selskapet som ikke er avklart ved avleggelse av årsregnskapet, og som kan medføre negativ inntjening i fremtiden. 
Følgende er eksempler på forhold som kan indikere tilstrekkelig fremtidig skattepliktig inntekt: 1) Eksisterende kontrakter eller sikre ordrereserver som basert på foreliggende priser og kostnadsstruktur, vil generere skattepliktig inntekt, 2) selskapet har en lang og konsistent historie med positiv inntjening hvor et evt. regnskapsmessig underskudd skyldes uvanlige, ikke regelmessige eller ekstraordinære poster, samtidig som det er grunn til å anta at selskapets rammebetingelser ikke vil endre seg innen overskuelig fremtid, eller 3) det foreligger vesentlige merverdier i eiendeler og forpliktelser som ved realisering er tilstrekkelig til å nyttiggjøre seg av skattefordelen.

\section{Observasjoner}

Vi har tatt utgangspunkt i de selskapene som har tapt egenkapital eller har annen egenkapital $\mathrm{kr}$ o. Totalt utgjorde dette 27 av selskapene (63 prosent). Som vist i tabell 1.4 under, har samtlige selskaper med utsatt skattefordel (uavhengig av om den er balanseført eller ikke) opparbeidet seg denne på grunnlag av et skattemessig underskudd. Dersom denne utsatte skattefordelen skal kunne benyttes i fremtiden, må selskapet generere et skattemessig overskudd. Selskapets evne til fortsatt drift og evne til å genere overskudd er en forutsetning for at det skal få utnyttet denne fordelen, og er dermed en forutsetning for at utsatt skattefordel kan balanseføres.

Vi ser $\mathrm{i}$ årsberetningene at styret har lagt forutsetning om fortsatt drift til grunn til tross for at det foreligger flere indikatorer på større usikkerhet på grunn av store underskudd og udekkede tap. Av tabellen under ser vi at samtlige av selskapene som har kombinasjonen udekket tap / annen egenkapital kr o, negativt driftsresultat og balanseført utsatt skattefordel relatert til skattemessig fremførbart underskudd, ikke hadde noen tilleggsinformasjon i note eller årsberetning utover standardtekst om hvilke vurderingsforhold som ligger til grunn for balanseføringen eller forutsetningen om fortsatt drift. Dette tilsier at det neppe er foretatt en nærmere vurdering av de nevnte forhold. 
Tabell 1.4 Negative finansielle nøkkeltall, utsatt skattefordel og ulike markeder

\begin{tabular}{|c|c|c|c|c|}
\hline Økonomisk situasjon 31.12.2018 & $\begin{array}{l}\text { Merkur } \\
\text { Market }\end{array}$ & NOTC & $\begin{array}{l}\text { «Family and } \\
\text { Friends» }\end{array}$ & Totalt \\
\hline Udekket tap eller annen egenkapital = 0 & 6 & 19 & 2 & 27 \\
\hline Negativt driftsresultat & 6 & 18 & 1 & 25 \\
\hline Positivt driftsresultat & 0 & 1 & 1 & 2 \\
\hline $\begin{array}{l}\text { Utsatt skattefordel/utsatt skatt } \\
\text { 31.12.2018 }\end{array}$ & $\begin{array}{l}\text { Merkur } \\
\text { Market }\end{array}$ & NOTC & $\begin{array}{l}\text { «Family and } \\
\text { Friends» }\end{array}$ & Totalt \\
\hline Balanseført utsatt skattefordel & 1 & 6 & 0 & 7 \\
\hline Ikke balanseført utsatt skattefordel & 5 & 12 & 2 & 19 \\
\hline Utsatt skatt eller midlertidige forskjeller $=0$ & 0 & 1 & 0 & 3 \\
\hline Totalt & 6 & 19 & 2 & 27 \\
\hline
\end{tabular}

I vår gjennomgang ser vi at sju av 27 selskaper (30 prosent) balansefører utsatt skattefordel, og ett av selskapene har netto utsatt skatteforpliktelse. 19 av de 27 utvalgte selskapene (7o prosent) balansefører ikke utsatt skattefordel. Dette er en indikasjon på at selskapet ikke finner grunnlag for å balanseføre utsatt skattefordel, og at det dermed ikke er sannsynlig at selskapet i fremtiden vil generere skattemessig overskudd, slik at denne fordelen blir utnyttet. Det foreligger dermed usikkerhet om fortsatt drift. Seks av selskapene (22 prosent) oppgir at netto utsatt skattefordel ikke balanseføres i samsvar med unntaksreglene for små foretak. Fire av selskapene som rapporterer etter IFRS, har begrunnet manglende balanseføring med at de ikke tilfredsstiller kriteriene for balanseføring. Seks av selskapene begrunner manglende balanseføring med usikkerhet om fremtidig utnyttelse av hele eller deler av skattefordelen, og to av selskapene gir ingen forklaring.

\subsubsection{Egenkapitaltransaksjoner}

Egenkapitaltransaksjoner berøres både av selskapsrettslige regler (aksjeloven og allmennaksjeloven) og av regnskapsrettslige regler (IFRS, forenklet IFRS, GRS eller GRS for små foretak). 


\section{Aktuell regulering}

Egenkapitaltransaksjoner skiller seg fra de fleste andre transaksjoner ved at de normalt ikke skjer mellom uavhengige parter siden nåværende aksjonærer eller andre nærstående parter til selskapet er transaksjonsmotpart. Etter GRS skal det gis informasjon «som er nødvendig for å bedømme (...) resultat og stilling», jf. regnskapsloven $\$$ 7-1 annet ledd. Bestemmelsen gjelder både etter GRS og GRS for små foretak. I tillegg vil det etter regnskapsloven $\$ 7$-25 være krav om at det gis ytterligere opplysninger om endringer i egenkapitalen. Det betyr at for eksempel endringer som skyldes egenkapitalemisjoner, herunder gjeldskonvertering, skal spesifiseres i note. Noe tilsvarende krav gjelder ikke etter GRS for små foretak. Samlet sett er det langt mer omfattende notekrav om egenkapitaltransaksjoner etter IFRS enn etter GRS og GRS for små foretak. I transaksjoner med nærstående er det større risiko enn ellers for at aksjonærene ikke likebehandles, eller at selskapets interesser må vike. Det er derfor vesentlig at regnskapsbrukerne får tilstrekkelig informasjon. IFRS stiller krav om at det skal gis informasjon slik at interessenter skal kunne forstå innhold, betingelser, tidspunkt for gjennomføring og usikkerhet i egenkapitaltransaksjoner ved hjelp av den informasjonen som er gitt i regnskapet, jf. eksempelvis IAS 1.79, IFRS 2.44 og IFRS 7.7.

En egenkapitalemisjon som ikke er fondsemisjon, kan gjennomføres som en ren kontantemisjon eller kombineres med en annen transaksjon/hendelse, slik som gjeldskonvertering, aksjeverdibasert betaling og/eller bruk av tegningsretter/aksjeopsjoner. Oppgjørsformen ved en emisjon kan være kontanter, tingsinnskudd eller konvertering av gjeld. Som følge av at konvertering av gjeld til egenkapital er å anse som et tingsinnskudd, må det utarbeides en redegjørelse fra styret, jf. aksjelovene $\$ 2-6$, jf. $₫ 10-2$.

\section{Observasjoner}

Minst aksjonærbeskyttelse og informasjonsplikt har aksjeselskaper (AS) som benytter GRS for små foretak. I vårt utvalg er det seks aksjeselskaper (AS) (14 prosent) som benytter dette regnskapsspråket, i tillegg til ett allmennaksjeselskap (ASA). Informasjonskvaliteten i disse 
regnskapene er vesentlig dårligere enn tilsvarende under IFRS. Det som gjør det ekstra utfordrende, er at disse selskapene i liten grad redegjør for hvilke forenklingsregler som er benyttet ved utarbeidelse av regnskapet.

I vårt utvalg på 43 selskaper har 22 ( 51 prosent) utvidet sin aksjekapital i 2018. Selskapene notert på Merkur Market, er overrepresentert med hensyn til egenkapitalutvidelser. Her har åtte av ni selskaper (89 prosent) foretatt egenkapitaltransaksjoner i 2018, og da i hovedsak som utvidelse av egenkapitalen.

Åtte selskaper i utvalget (16 prosent) hadde konvertibel gjeld. Også her var den relative andelen høyest på Merkur Market med tre av ni selskaper (33 prosent). IFRS krever at sammensatte finansielle instrumenter skal dekomponeres og innregnes i regnskapet hver for seg (jf. IAS 32.32). Etablering av konvertibel gjeld vil kombinere en finanstransaksjon som er opptak av gjeld, med etablering av en konverteringsrett som gjør at utsteder av gjelden på bestemte vilkår kan gjøre den om til aksjer. Tilsvarende dekomponering kreves ikke under GRS. Vi så ingen indikasjoner på at selskapene som benyttet GRS, hadde foretatt en separat innregning i annen innskutt egenkapital for verdien av konverteringsretten. Ut over fanebestemmelsen i regnskapsloven $₫$ 7-1 annet ledd som i visse tilfeller kan pålegge noteopplysninger om konvertibel gjeld, er det ikke pålagt spesifikke notekrav knyttet til slik gjeld under GRS.

En annen komplisert egenkapitaltransaksjon vil være aksjeverdibasert betaling (jf. IFRS 2 og regnskapsloven $\$ 5$-9a og NRS 15a). I transaksjonen skjer det oppgjør for kjøp av varer eller tjenester eller betaling for utført arbeidsinnsats ved at motparten mottar aksjer som vederlag. Vi fant at 10 selskaper (23 prosent) hadde en eller annen form for aksjeverdibasert betaling. Av disse var fem av selskapene (50 prosent) notert på Merkur Market. For ytterligere to selskaper notert på Merkur Market gis det så lite informasjon at vi ikke kunne vurdere eller konkludere på dette. Selskaper som benytter GRS for små foretak, har visse fritak fra hovedregelen i fra regnskapsloven $\$ 5$-9a. En ytterligere utfordring er at notekravene til ledelsens godtgjørelser er begrenset for små foretak, jf. regnskapsloven $₫ 7-44$.

Tabell 1.5 viser en oversikt over ulike egenkapitaltransaksjoner sett opp mot selskapsform og regnskapsspråk. 
Tabell 1.5 Egenkapitaltransaksjoner, selskapsform og ulike regnskapsspråk

\begin{tabular}{llccc}
\hline Selskapsform & Regnskapsspråk & \multicolumn{2}{c}{ Egenkapitaltransaksjoner } \\
\cline { 3 - 5 } & & $\begin{array}{c}\text { Egenkapital- } \\
\text { utvidelser }\end{array}$ & $\begin{array}{c}\text { Gjelds- } \\
\text { konvertering }\end{array}$ & Opsjoner \\
\hline Allmennaksjeselskaper (ASA) & IFRS & 1 & 1 \\
Allmennaksjeselskaper (ASA) & Forenklet IFRS & & \\
Allmennaksjeselskaper (ASA) & GRS & & \\
Allmennaksjeselskaper (ASA) & GRS små foretak & & 6 \\
Aksjeselskaper (AS) & IFRS & 7 & 1 \\
Aksjeselskaper (AS) & Forenklet IFRS & & 5 & 1 \\
Aksjeselskaper (AS) & GRS & 6 & 2 & 2 \\
Aksjeselskaper (AS) & GRS små foretak & 8 & $\mathbf{8}$ \\
\hline Totalt & & $\mathbf{2 2}$ & $\mathbf{1 0}$ \\
\hline
\end{tabular}

I tabell 1.6 vises fordelingen av ulike egenkapitaltransaksjoner fordelt på selskaper notert i de ulike markedene:

Tabell 1.6 Egenkapitaltransaksjoner og ulike markeder

\begin{tabular}{|c|c|c|c|c|c|c|c|}
\hline \multirow[t]{3}{*}{ Marked } & \multirow{3}{*}{$\begin{array}{c}\text { Antall } \\
\text { selskaper }\end{array}$} & \multicolumn{6}{|c|}{ Egenkapitaltransaksjoner } \\
\hline & & \multicolumn{2}{|c|}{ Egenkapitalutvidelser } & \multicolumn{2}{|c|}{ Gjeldskonvertering } & \multicolumn{2}{|c|}{ Opsjoner } \\
\hline & & Antall & Andel \% & Antall & Andel \% & Antall & Andel \% \\
\hline Merkur Market & 9 & 8 & $89 \%$ & 3 & $33 \%$ & 5 & $56 \%$ \\
\hline NOTC & 32 & 13 & $40 \%$ & 5 & $16 \%$ & 4 & $13 \%$ \\
\hline «Family and Friends» & 2 & 1 & $50 \%$ & 0 & $0 \%$ & 1 & $50 \%$ \\
\hline Totalt & 43 & 22 & $51 \%$ & 8 & $19 \%$ & 10 & $23 \%$ \\
\hline
\end{tabular}

Vi har foretatt en vurdering av informasjonskvaliteten på opplysningene knyttet til egenkapitaltransaksjoner som investorene får i årsregnskapet. Når selskapene har valgt å la seg notere, riktignok på et uregulert marked, virker det rimelig å forutsette at nåværende og potensielle investorer får tilstrekkelig informasjon om endringer i egenkapitalen og aksjeverdibasert betaling, herunder aksjeverdibasert avlønning. For at vi skal kunne kategorisere et regnskap som et med høy informasjonsverdi, må det for alle egenkapitaltransaksjoner være opplyst om betingelser og priser. For utestående opsjoner må det være opplyst om antall og innløsningspriser. Transaksjoner med nærstående, slik som med hovedaksjonær og med ledelsen, må oppgis særskilt. 


\section{Eksempler på mangelfulle noter om egenkapitaltransaksjoner}

Ingen av selskapene har omtalt anvendte regnskapsprinsipper ved nyemisjoner, konverteringer av gjeld eller opsjoner. For de fleste av selskapene er det ikke mulig å følge hva som er kontantinnbetalinger i kontantstrømoppstillingen og konverteringer i forbindelse med aksjekapitalutvidelser. Det er kun ett av selskapene som oppgir emisjonskostnader. Vi registrerer at de andre selskapene ikke har oppgitt tilsvarende kostnader, selv om det åpenbart er gjennomført emisjoner.

Under følger noen eksempler på mangelfulle notebeskrivelser om egenkapitaltransaksjoner som trolig ikke gir tilstrekkelig informasjon vurdert ut fra investorers informasjonsbehov. Eksemplene er hentet fra selskaper notert på Merkur Market.

Et selskap oppgir i noten over endringer i egenkapitalen at det har funnet sted kontantemisjon med fordeling på aksjekapital og overkurs, men ut over dette er det ikke ytterligere informasjon. Hvor mange aksjer, til hvilken kurs, øvrige betingelser og til hvem, er det ingen opplysninger om. Dette er kritiske emisjoner for selskapet, enten fordi de er vesentlige, eller fordi selskapet har svært lav egenkapital. I årsberetningen til selskapet står det:

Det har videre blitt arbeidet med å sikre nødvendig finansiering av pågående og planlagte byggeaktiviteter samt også kapital nødvendig for nedbetalinger til bank ihht. låneavtale med (...). I løpet av 2018 ble det hentet inn MNOK 13,25 fordelt på emisjoner i mai og juli 2018.

Det har samtidig også vært gjennomført en rekke samtaler med EPO Aheloy’s bankforbindelse med tanke på opplåning for videre byggearbeid, og det ble $\mathrm{i}$ 2018 innvilget et lån på 3 MEUR med visse forbehold. Det ene forbeholdet har vært knyttet til at enkelte heftelser på eiendommene måtte fjernes før utbetaling noe som har tatt betydelig lengre tid enn forventet.

I noten om konvertible lån er det bare oppgitt: «Konvertible lån er renteberegnet med 10\%.» Hvem som har konverteringsrett, konverteringstid, konverteringskurs og øvrige betingelser er det ingen opplysninger om. 
Et annet selskap som benytter GRS for små foretak, oppgir at det er foretatt egenkapitalutvidelse. Det er oppgitt emisjonskostnader på 12 prosent. I en annen note oppgis det at det er foretatt konverteringer. Selskapet har også utstedt opsjoner i flere omganger, totalt seks ulike ordninger til ulike parter. Til et av opsjonsprogrammene for ledende ansatte fra 2016 er det spesifisert følgende: «Utstedelse av aksjer relatert til opsjonsavtalene forutsetter generalforsamlingens godkjennelse.» Regnskapsmessig behandling i relasjon til regnskapsloven $\$$ 5-9a sies det intet om.

Et tredje selskap oppgir bare kapitalforhøyelse i kroner i note, uten noen form for spesifikasjon med hensyn til hvem og betingelser. Selskapet har heller ikke utarbeidet kontantstrømoppstilling.

\subsubsection{Langsiktig gjeld versus kortsiktig gjeld Aktuell regulering}

Gjeld vil etter regnskapsloven $₫ 5$-1, jf. $₫ 5$-13 første ledd, klassifiseres som langsiktig hvis den forfaller mer enn ett år etter opptakstidspunktet (transaksjonstidspunktet) og den ikke er knyttet til varekretsløpet. Trolig kan ettårsregelen vurderes med utgangspunkt i balansedagen (Schwencke et al., 2020, s. 126). Kortsiktig gjeld er gjeld som ikke kan klassifiseres som langsiktig gjeld. Etter regnskapsloven $₫$ 5-13 tredje ledd kan neste års avdrag på langsiktig gjeld klassifiseres som kortsiktig gjeld.

Etter IFRS vil en del presentasjonsregler følge av de enkelte IFRSstandardene. IAS 1 Presentasjon av finansregnskap nr. 69 flg. har noen generelle regler for klassifisering. Disse er ikke helt sammenfallende med dem som gjelder etter ordinære norske regnskapsregler. Etter IFRS skal neste års avdrag for langsiktig gjeld presenteres som kortsiktig gjeld, jf. IAS 1.72.

Brudd på låneklausuler medfører også omklassifisering etter IFRS. Dette gjelder også om bruddet er ordnet etter balansedagen (men før regnskapsavleggelsen), jf. IAS 1.74. Dette praktiseres ikke like strengt etter GRS (Schwencke et al., 2020, s. 127-128).

\section{Observasjoner}

Det er vanskelig å avgjøre om selskaper i utvalget som rapporterer etter GRS, velger å klassifisere neste års avdrag på langsiktig gjeld 
som kortsiktig gjeld, slik det er adgang til etter regnskapsloven, da de fleste gir for lite informasjon til å avgjøre hvilken klassifisering som er valgt.

Det er få av selskapene som opplyser om at de har låneklausuler, og enda færre som oppgir at selskapet er eller har vært i en situasjon med brudd på låneklausuler. Mange av selskapene har bare kortsiktig gjeld, noe som riktignok er kritisk med tanke på å opprettholde en tilfredsstillende finansiering og likviditet, spesielt når man ser dette i lys av den vanskelige økonomiske situasjonen som mange av disse selskapene er $\mathrm{i}$.

\subsubsection{Tvister}

\section{Aktuell regulering}

Regnskapsmessig vil usikre rettstvister kunne bli behandlet som usikre eller betingede forpliktelser. Under GRS behandles dette i NRS ${ }_{13}$ Usikre forpliktelser og betingede eiendeler. GRS for små foretak har i den andre enden betydelig lettelser, jf. NRS 8 God regnskapsskikk for små foretak punkt 6.1.1.4.1, så lenge tvisten ikke er så vesentlig at den påvirker regnskapets rettvisende bilde. Under IFRS skal de behandles i henhold til IAS 37 Avsetninger, betingede forpliktelser og betingede eiendeler. Notekravene er her vesentlig mer omfattende.

\section{Observasjoner}

Det er vanskelig å finne ut hvilke av selskapene som har pågående tvister, og enda vanskeligere å vurdere kvaliteten på den informasjonen som gis. De kan blant annet være innregnet uten noteopplysninger, eller en kan ha latt være å omtale dem. Av den grunn har vi ikke funnet å kunne lage en tabellarisk oversikt over informasjonskvaliteten.

\section{Eksempler på mangelfulle noter om tvister}

Et selskap notert på Merkur marked oppgir å ha en tvist med en tidligere ansatt. Det oppgis: «Ledelsens vurdering er at den ansattes krav ikke er berettiget og at det ikke er sannsynlig at kravet til føre fram.» 
Et annet selskap notert på Merkur marked oppgir å ha en tvist som gjør at långiver har holdt tilbake utbetaling av et lån. Samtidig opplyser selskapet om at «[d]et er etter styrets oppfatning ingen saker som vil ha vesentlige, negative, økonomiske konsekvenser for konsernet». For en utenforstående leser kan dette virke inkonsekvent og ulogisk.

\subsubsection{Rapporteringstidspunkt Aktuell regulering}

Selskaper notert på Merkur Market, NOTC og «Family and Friends» må fastsette årsregnskapet og årsberetningen senest seks måneder etter regnskapsårets slutt, jf. regnskapsloven $\$$ 3-1 tredje ledd, og sende inn disse til Regnskapsregisteret senest en måned etter fastsettelsestidspunktet, jf. regnskapsloven $\$ 8$-2 første ledd første punktum. Selskaper som er notert i regulerte markeder, må i tillegg overholde plikter etter verdipapirhandelloven. Reglene knyttet til løpende informasjonsplikt og offentliggjøring følger av kapittel 5 og gjelder for utstedere med Norge som hjemstat hvis omsettelige verdipapirer er opptatt til handel på regulert marked, jf. verdipapirhandelloven $₫ 5$-1. Etter verdipapirhandelloven $₫ 5$-5 første ledd andre punktum skal disse selskapene offentliggjøre årsrapporten senest fire måneder etter balansedagen. Det forutsetter i praksis at regnskapet må fastsettes før dette tidspunktet.

\section{Observasjoner}

Vi har valgt å bruke ovennevnte frister som grunnlag for vurderingen av om rapporteringstidspunktet har styrket eller svekket regnskapets informasjonskvalitet. Rapporteringstidspunktet er her satt lik fastsettelsestidspunktet, dvs. det tidligste tidspunktet for når regnskapet vil være offentlig tilgjengelig. Vi gir god vurdering til de selskapene som fastsatte årsregnskapet innenfor fristen for selskaper notert på regulerte markeder, det vil si innenfor fire måneder etter balansedagen. Videre har vi gitt en svak vurdering til de selskapene som fastsetter regnskapet etter denne fristen. Tabell 1.7 viser fordelingen på årets tolv måneder og i de ulike markedene. 
Tabell 1.7 Rapporteringstidspunkt fordelt på måneder og markeder

\begin{tabular}{lcccccccc}
\hline \multirow{2}{*}{$\begin{array}{l}\text { Rapporterings- } \\
\text { måned }\end{array}$} & \multicolumn{2}{l}{ Merkur Market } & \multicolumn{2}{c}{ NOTC } & \multicolumn{2}{c}{ «Family and Friends» } & \multicolumn{2}{c}{ Totalt } \\
\cline { 2 - 10 } & Antall & $\%$ & Antall & $\%$ & Antall & $\%$ & Antall & $\%$ \\
\hline Januar & 0 & $0 \%$ & 0 & $0 \%$ & 0 & $0 \%$ & 0 & $0 \%$ \\
Februar & 0 & $0 \%$ & 1 & $3 \%$ & 0 & $0 \%$ & 1 & $2 \%$ \\
Mars & 1 & $11 \%$ & 9 & $28 \%$ & 0 & $0 \%$ & 10 & $23 \%$ \\
April & 0 & $0 \%$ & 4 & $13 \%$ & 1 & $50 \%$ & 5 & $12 \%$ \\
Mai & 5 & $56 \%$ & 7 & $22 \%$ & 0 & $0 \%$ & 12 & $28 \%$ \\
Juni & 0 & $0 \%$ & 5 & $16 \%$ & 1 & $50 \%$ & 6 & $14 \%$ \\
Juli & 0 & $0 \%$ & 3 & $9 \%$ & 0 & $0 \%$ & 3 & $7 \%$ \\
August & 1 & $11 \%$ & 0 & $0 \%$ & 0 & $0 \%$ & 1 & $2 \%$ \\
September & 1 & $11 \%$ & 1 & $3 \%$ & 0 & $0 \%$ & 2 & $5 \%$ \\
Oktober & 1 & $11 \%$ & 1 & $3 \%$ & 0 & $0 \%$ & 2 & $5 \%$ \\
November & 0 & $0 \%$ & 0 & $0 \%$ & 0 & $0 \%$ & 0 & $0 \%$ \\
Desember & 0 & $0 \%$ & 1 & $3 \%$ & 0 & $0 \%$ & 1 & $2 \%$ \\
\hline Totalt & $\mathbf{9}$ & $\mathbf{1 0 0} \%$ & $\mathbf{3 2}$ & $\mathbf{1 0 0} \%$ & $\mathbf{2}$ & $\mathbf{1 0 0} \%$ & $\mathbf{4 3}$ & $\mathbf{1 0 0} \%$ \\
\hline
\end{tabular}

Vi ser av tabellen at totalt 16 av selskapene (37 prosent) fastsatte regnskapet innenfor årets første fire måneder, noe som styrker informasjonskvaliteten til regnskapet vesentlig sammenlignet med senere fastsettelsestidspunkt. Videre ser vi at 18 selskaper (42 prosent) har fastsatt regnskapet i de to påfølgende månedene frem mot regnskapslovens frist seks måneder etter balansedagen. Avslutningsvis er det ni selskaper ( 21 prosent) som fastsetter regnskapet etter regnskapslovens frist. Totalt er det derfor 27 (63 prosent) som vurderes å ha et fastsettelsestidspunkt som bidrar til å redusere informasjonskvaliteten sammenlignet med om regnskapet ble avlagt innenfor fristen etter verdipapirhandelloven. Igjen er det store forskjeller på markedene. Mens 14 av 32 selskaper på NOTC (43 prosent) rapporterer innen fire måneder etter balansedagen, er det kun ett av ni på Merkur Market (11 prosent) som gjør det.

\subsection{Diskusjon}

Vår kvalitative gjennomgang, i hovedsak basert på forskjellene mellom IFRS og GRS / GRS for små foretak, avdekker flere tilfeller av 
mangelfull og kvalitetsmessig svak regnskapsinformasjon for selskaper notert på Merkur Market, NOTC og «Family and Friends». Generelt kan man si at flere av regnskapene i liten grad tilfredsstiller målet om å gi beslutningsnyttig informasjon til eksterne investorer. Det kan derfor argumenteres for at flere av regnskapene er lite investorvennlige ved at selskapene, riktignok ofte i samsvar med gjeldende regulering, har lagt seg på et minimum av informasjon. Med utgangspunkt i resultatene vil vi diskutere nåværende praksis og vurdere om den manglende oppmerksomheten fra reguleringsmyndighetenes side vedrørende regnskapsplikter for disse selskapene kan betegnes som en svakhet $\mathrm{i}$ regnskapsreguleringen.

En rimelig forventning er at andelen selskaper registrert som allmennaksjeselskap (ASA) på de unoterte markedsplassene, ville øke desto nærmere noteringen lå ordinær børsnotering, jf. «trappetrinnsmodellen». Vi registrerte derimot at kun sju av selskapene (16 prosent) var allmennaksjeselskaper (ASA), og alle disse var notert på NOTC per 31.12.2018. Generelt fremstår det som et lite paradoks at en så stor andel av selskapene notert på de uregulerte markedsplassene, er organisert som aksjeselskaper (AS). Ved notering henvender de seg til det åpne markedet av investorer, samtidig som investorbeskyttelsen som lovgiver gir ved selskapsformen allmennaksjeselskap (ASA), ikke tilbys. Det som kanskje er mest interessant, er at ingen av selskapene (i vårt utvalg) som er notert på Merkur Market, som er trinnet før ordinær børsnotering, er allmennaksjeselskaper (ASA). I «trappetrinnsmodellen» mot ordinær børsnotering ville det vært naturlig å stille krav om omdannelse fra aksjeselskap (AS) til allmennaksjeselskap (ASA) ved notering. Vi er derimot usikre på om dette kravet bør foreligge allerede ved registrering på «Family and Friends»-listen.

Vi registrerer at et flertall av selskapsregnskapene (81 prosent) er avlagt etter GRS, og noen av disse også etter forenklingsreglene for små foretak (16 prosent). Riktignok legger de frivillige rapporteringskravene under NOTC og de obligatoriske på Merkur Market en viss begrensning på anvendelsen av sentrale lempinger for små foretak, eksempelvis fritak fra å utarbeide årsberetning og kontantstrømoppstilling. Likevel er det 
påfallende at fire av ni selskaper på Merkur Market (44 prosent) avlegger selskapsregnskapet etter GRS for små foretak. For konsernregnskapene var fordelingen mellom IFRS (og forenklet IFRS) og GRS (inkl. GSR små foretak) henholdsvis $40 \mathrm{og} 60$ prosent. Vi ser som forventet at valg av GRS generelt, og GRS for små foretak spesielt, gir lavere informasjonskvalitet sammenlignet med regnskapene som er avlagt etter IFRS. Disse funnene er i samsvar med funn fra tidligere litteratur som viser at overgang fra nasjonale regler til IFRS gir regnskaper av høyere kvalitet (Barth et al., 2008; Daske et al., 2008; Christensen et al., 2015). Dette gjelder som nevnt også ved overgang fra GRS til IFRS (Gjerde et al., 2008; Stenheim \& Madsen, 2017). Men til forskjell fra disse studiene, som brukte en kvantitativ metodisk tilnærming, har vi brukt en kvalitativ tilnærming hvor også informasjon i noter, årsberetning og andre forhold av betydning for informasjonskvaliteten har blitt vektlagt.

Beskrivelsen av prinsippene for inntektsføring for de selskapene som avlegger regnskap etter GRS eller GRS for små foretak, er ofte svært generell og gir lite selskapsspesifikk informasjon. Prinsipper for inntektsføring og underliggende inntektsmodell er informasjon som er av særlig interesse for investorene. Alle selskapene avlegger regnskapet under forutsetning om fortsatt drift. Vi finner lite tilleggsinformasjon som viser at det er foretatt vurderinger av situasjonen til tross for negative finansielle nøkkeltall, store fremførbare underskudd og udekkede tap. Vi ser også at flere av selskapene ikke finner grunnlag for å balanseføre den utsatte skattefordelen, eller at de her benytter seg av unntaksreglene for små foretak. Det å ikke balanseføre utsatt skattefordel indikerer at det er usikkert om selskapet får tilstrekkelig inntjening i fremtiden til å kunne utnyttet denne fordelen, noe som videre gir en indikasjon på usikkerhet om fortsatt drift. Forutsetningen om fortsatt drift skal blant annet omtales i selskapets årsberetning i sammenheng med kravet til forsvarlig egenkapital og likviditet, jf. aksjeloven $₫ 3$-4. For selskaper som benytter unntaksreglene for små foretak, skal usikkerhet om fortsatt drift omtales i note. At flere selskaper gir lite tilleggsinformasjon når det foreligger flere indikasjoner på usikkerhet om fortsatt drift, svekker informasjonskvaliteten. Dette er kritikkverdig. 
Omtale av tvister er et av områdene som etter vår mening illustrerer at GRS for små foretak ikke er egnet som regnskapsspråk for selskaper som ønsker å være notert på en markedsplass.

Vurderer vi publiseringstidspunkt opp mot verdsettelsesformålet, må vi anta at investorer ønsker å ha tilgang til informasjonen som er i regnskapet, så tidlig som mulig. Tidligere studier viser en klar sammenheng mellom investors beslutninger og tidsriktig rapportering (for eksempel Chambers \& Penman, 1984). En omfattende litteratur har kartlagt ulike, ofte gjensidig avhengige, årsaker til sen rapportering. Atiase, Bamber og Tse (1989) trekker frem selskapsstørrelse som en vesentlig faktor, der store selskaper i gjennomsnitt rapporterer tidligere enn små. Chambers og Penman (1984) fant blant annet ut at sen rapportering ofte falt sammen med lav, og ofte negativ, uventet avkastning når de sammenlignet med de selskapene som rapporterte tidlig. En annen beslektet observasjon er at selskaper med økonomiske problemer ofte rapporterer sent (Whittred \& Zimmer, 1984). Manglende revisjonsberetning har av ulike årsaker også ofte vist seg å falle sammen med sen levering (Ashton et al., 1987). Siden få selskaper på Merkur Market inngår i vårt utvalg, er det vanskelig å konkludere for denne markedsplassen. Men det er interessant at disse selskapene, som ligger nærmest full børsnotering, i gjennomsnitt fastsetter regnskapet senere enn selskapene som er notert på NOTC. Vi antar riktignok at bildet hadde vært annerledes hvis finansforetakene, som vi ekskluderte på grunn av særregulering, hadde vært med i utvalget. Totalt fastsetter et flertall av selskapene (63 prosent) regnskapet etter firemånedersfristen for avleggelse etter verdipapirhandelloven. I samsvar med argumentasjonen over bør også informasjonen gjøres tilgjengelig for nåværende og potensielle investorer så raskt som mulig. Dette er en vesentlig svakhet. Tabell 1.7 viser at ni av selskapene (21 prosent) avlegger regnskapet etter 1 . juli. Selskaper som velger å ikke avgi årsregnskaper innen fristen i regnskapsloven, burde etter vår mening vært strøket fra notering.

Vi registrerer at mange av selskapene, til tross for mangel på informative og investorvennlige regnskaper, klarer å hente inn ny egenkapital, enten gjennom gjeldskonvertering eller gjennom emisjoner. Vi tror at dette kan ha to årsaker: 1) Selskapene retter seg mot ikke-profesjonelle 
investorer, som ikke i samme grad som de profesjonelle investorene benytter regnskapet som grunnlag for beslutninger. Selskapet, og ledelsen, bruker kanskje også andre informasjonskanaler til å kommunisere sine strategier og mål, noe som gjør at årsregnskap og årsberetning i mange av selskapene utarbeides etter minimumskravene. 2) Mange av selskapene som inngår i vårt utvalg, må kunne karakteriseres som vekstog innovasjonsselskaper. Disse selskapene kjennetegnes av lave inntekter, høye utviklingskostnader og vedvarende underskudd, noe som gjør det vanskelig å benytte tallopplysninger fra regnskapet for fremskriving av fremtidig inntjening og kontantstrøm og dermed som input i en verdsettelsesmodell. Konsekvensen blir at årsregnskapet mister sin relevans som beslutningsgrunnlag for investorene. Likevel mener vi at dette representerer en svakhet i regnskapsreguleringen, og at «trappetrinns»tankegangen frem mot ordinær børsnotering i liten grad er reflektert i øte rapporteringskrav. Vi mener derfor det foreligger et behov for ytterligere regnskapsplikter for disse selskapene. Vår anbefaling er at noterte selskaper skal ha strengere krav til mengden og kvaliteten på den informasjonen som gis i regnskapene. Et minimum er å avvikle adgangen til å bruke GRS for små foretak for selskaper notert på uregulerte markeder. I tillegg kan det også argumenteres for et mer informativt noteverk. En mulighet er gradvis å øke kravene, i samsvar med «trappetrinnsmodellen», ved at GRS tillates som regnskapsspråk for NOTC og «Family and Friends»-registrerte foretak. Når et foretak derimot blir notert på Merkur Market, bør det kunne stilles krav om full IFRS.

\subsection{Konklusjon}

Denne kvalitative gjennomgangen av selskaper notert på Merkur Market, NOTC og «Family and Friends» har avdekket flere interessante forhold. Vi registrerer at få selskaper i vårt utvalg er allmennaksjeselskaper, selv om de inngår i et kvalifiseringsløp mot ordinær børsnotering. Få selskaper har valgt å rapportere i henhold til IFRS, og overraskende mange rapporterer i henhold til GRS for små foretak. Vår gjennomgang av informasjonskvaliteten, basert på sentrale forskjeller mellom IFRS og GRS, avdekker flere eksempler på svak og manglende informasjon. Spesielt 
vårt utvalg av selskaper på Merkur Market utpeker seg negativt, med sentrale avvik og generelt lite investorvennlige årsregnskaper. Vi mener dette er interessant da dette er nivået før ordinær børsnotering på Oslo Børs (hovedlisten) eller Oslo Axess.

Vår konklusjon er derfor at informasjonskvaliteten er lav hos flere av selskapene notert på Merkur Market, NOTC og «Family and Friends». Ifølge våre observasjoner henger dette i stor grad sammen med valg av regnskapsspråk, der flere legger seg på minimumskravene for den aktuelle markedsplassen. Dette manglende investorfokuset kan medføre høyere kapitalkostnader, mindre tilgang på kapital og lavere likviditet på de aktuelle selskapenes aksjer. Vi minner likevel om at funnene må leses som indikasjoner og ikke som presise funn da en vurdering av informasjonskvaliteten innebærer utbredt bruk av faglig skjønn. Grensen mellom god og dårlig informasjon kan ofte være uklar og gjenstand for diskusjon. Men ved bruk av to kontrollører og rullerende fordeling av selskapene mener vi at vi reduserer muligheten for vurderingsavvik. Det er også viktig å bemerke at konklusjonen baserer seg på et begrenset utvalg av selskaper.

Vi mener at manglende krav til disse selskapene må ses som en svakhet i regnskapsreguleringen, og at noterte selskaper på uregulerte markeder i utgangspunktet bør følge de samme regnskapsmessige kravene som selskaper notert på regulerte markeder. Dette innebærer rapportering etter IFRS og tidsriktig fastsetting og publisering av årsregnskap og årsberetning. En løsning kan være å øke kravene jo nærmere man kommer ordinær børsnotering. Men i alle tilfeller bør det ikke være adgang til å velge GRS for små foretak.

Vi mener det er behov for mer forskning på disse markedsplassene. En mulighet kan være å kartlegge ulike rapporteringsstrategier gjennom kvalitative dybdeintervjuer med et utvalg selskaper og deres revisorer. En annen mulighet er å vurdere hvilke effekter publisering av regnskapsinformasjonen har på prising og eventuelt omsetning av aksjene til disse selskapene, for å foreta en kvantitativ vurdering av informasjonskvaliteten på regnskapet. Avslutningsvis kunne det vært interessant å kartlegge eventuelle særtrekk ved selskapene som blir notert på de uregulerte markedene, og andelen som fullfører «trappetrinnsmodellen» og blir notert på Axess eller Oslo Børs (hovedlisten). 


\section{Referanser}

\section{Lover, rettskilder fra EU}

Aksjeloven (1997). Lov om aksjeselskaper

Allmennaksjeloven (1997). Lov om allmennaksjeselskaper

Regnskapsloven (1998). Lov om årsregnskap mv.

Verdipapirhandelloven (2007). Lov om verdipapirhandel

Konsolidert regnskapsdirektiv (EP/Rdir. 2013/34/EU). Brussel: EU

Ot.prp. nr. 42 (1997-98) Om lov om årsregnskap m.v. (regnskapsloven)

\section{Regnskapsstandarder IFRS: (oppdaterte versjoner pr februar 2020)}

IAS 1. Presentasjon av finansregnskap. IASB.

IAS 37. Avsetninger, betingede forpliktelser og betingede eiendeler. IASB.

IFRS 2. Aksjebasert betaling. IASB.

IFRS 7. Finansielle instrumenter - opplysninger. IASB.

IFRS 9. Finansielle instrumenter. IASB.

IFRS 15. Regnskapsføring av kundekontrakter. IASB.

\section{Regnskapsstandarder god regnskapsskikk (regnskapslovens ordinære regler)}

NRS 2. Anleggskontrakter. (Sist oppdatert 2008). Norsk RegnskapsStiftelse.

NRS 8. God regnskapsskikk for små foretak. (Sist oppdatert 2018). Norsk

RegnskapsStiftelse.

NRS 13. Usikre forpliktelser og betingede eiendeler. (Sist oppdatert 2013). Norsk

RegnskapsStiftelse.

NRS 15A. Aksjebasert betaling. (Sist oppdatert 2010). Norsk RegnskapsStiftelse.

NRS 19. Immaterielle eiendeler. (Sist oppdatert 2012). Norsk RegnskapsStiftelse.

NRS (F). Resultatskatt. (Sist oppdatert 2008). Norsk RegnskapsStiftelse.

NRS (V). Regnskapsføring av inntekt. (Sist oppdatert 2010). Norsk Regnskaps-

Stiftelse.

\section{Artikler, bøker mv.}

Ashton, R., Willingham, J. \& Elliott, R. (1987). An empirical analysis of audit delay. Journal of Accounting Research, 25(2), 275-292. 
Atiase, R. K., Bamber, L. S. \& Tse, S. (1989). Timeliness of financial reporting, the firm size effect, and stock price reactions to annual earnings announcements. Contemporary Accounting Research, 5(2), 526-552.

Ball, R. \& Shivakumar, L. (2006). The role of accruals in asymmetrically timely gain and loss recognition. Journal of Accounting Research, 44(2), 207-242.

Barth, M. E. (2018). The future of financial reporting: Insights from research. Abacus, 54(1), s. 66-78.

Barth, M. E., Beaver, William H. \& Landsman, W. R. (2001). The relevance of the value relevance literature for financial accounting standard setting: Another view. Journal of Accounting and Economics, 31(1-3), 77-104.

Barth, M. E., Landsman, W. R. \& Lang, M. H. (2008). International accounting standards and accounting quality. Journal of Accounting Research, 46(3), 467-498.

Basu, S. (1997). The conservatism principle and the asymmetric timeliness of earnings. Journal of Accounting and Economics, 24(1), 3-37.

Beattie, V. (2014). Accounting narratives and the narrative turn in accounting research: Issues, theory, methodology, methods and a research framework. British Accounting Review, 46(2), 111-134.

Beattie, V., McInnes, W. \& Fearnley, S. (2004). A methodology for analysing and evaluating narratives in annual reports: A comprehensive descriptive profile and metrics for disclosure quality attributes. Accounting Forum, 28(3), 205-236

Beyer, A., Cohen, D. A., Lys, T. Z. \& Beverly, W. R. (2010). The financial reporting environment: Review of the recent literature. Journal of Accounting and Economics, 50(2-3), 296-343.

Botosan, C. A. (1997). Disclosure level and the cost of equity capital. The Accounting Review, 72(3), 323-349.

Bråthen, T. (2019). Selskapsrett. Oslo: Gyldendal Akademisk Forlag.

Cascino, S, Clatworthy, M., Garcia, B. O., Gassen, J., Imam, S. \& Jeanjean, T. (2013). The use of information by capital providers - academic literature review. European Financial Reporting Advisory Group.

Chambers, A. \& Penman, S. (1984). Timeliness of reporting and the stock price reaction to earnings announcements. Journal of Accounting Research, 22(1), 21-47.

Christensen, H. B., Lee E., Walker M. \& Zeng C. (2015). Incentives or standards: What determines accounting quality changes around IFRS adoption? European Accounting Review, 24(1), 31-61.

Daske, H., Hail, L., Leuz, C. \& Verdi, R. S. (2008). Mandatory IFRS reporting around the world: Early evidence on the economic consequences. Journal of Accounting Research, 46(5), 1085-1142.

Dechow, P. \& Dichev, I. (2002). The quality of accruals and earnings: The role of accrual estimation errors. The Accounting Review, 77(Supplement), 35-59. 
Dechow, P., Sloan, R. \& Sweeney, A. (1995). Detecting earnings management. The Accounting Review, 7o(2), 193-225.

Elling, J., Kyhnauv-Andersen, C., Kyhnauv-Andersen, H. \& Kyhnauv-Andersen P. (2019). Finansiell rapportering. Teori og regulering. 5. utgave. København: Gjellerup/Gads Forlag.

Elliott, R. \& Jacobson, P. D. (1994). Costs and benefits of business information disclosure. Accounting Horizons, 8(4), 80-96.

Ernst, E., Gassen, J. \& Pellens, B. (2009). Information needs, dividend preferences and voting behavior of German investors: Results of a large-scale survey. Studien des Deutschen Aktieninstituts, Heft 42, Frankfurt am Main.

Gjerde, Ø., Knivsflå, K. H. \& Sættem, F. (2008). The value-relevance of adopting IFRS: Evidence from 145 NGAAP restatements. Journal of International Accounting, Auditing and Taxation, 17(2), 92-112.

Gjesdal, F. (1981). Accounting for stewardship. Journal of Accounting Research, 19(1), 208-231.

Holthausen, R. W. \& Watts, R. L. (2001). The relevance of the value-relevance literature for financial reporting standard setting. Journal of Accounting and Economics, 31(1-3), 3-75.

Hope, O.-K., Thomas, W. B. \& Vyas, D. (2013). Financial reporting quality of U.S. private and public firms. The Accounting Review, 88(5), 1715-1742.

Hope, O.-K., Thomas, W. B. \& Vyas, D. (2016). Stakeholder demand for accounting quality and economic usefulness of accounting in U.S. private firms. Journal of Accounting and Public Policy, 36(1), 1-13.

IASB. (2018). Conceptual Framework for Financial Reporting. IASB.

Kothari, S. P. (2001). Capital markets research in accounting. Journal of Accounting and Economics, 31(1-3), 105-231.

Kothari, S. P., Leone, A. \& Wasley, C. E. (2005). Performance matched discretionary accrual measures. Journal of Accounting and Economics, 39(1), 163-197.

Kothari, S. P., Ramanna, K. \& Skinner, D. J. (2010). Implications for GAAP from an analysis of positive research in accounting. Journal of Accounting and Economics, $50(2-3), 246-286$.

Kumar, A. \& Lee, C. (2006), Retail investor sentiment and return comovements. The Journal of Finance, 61(5), 2451-2486.

Murphy, T., O'Connell, V. \& ÓhÓgartaigh, C. (2013). Discourses surrounding the evolution of the IASB/FASB conceptual framework: What they reveal about the «living law» of accounting. Accounting, Organizations and Society, 38(1), 72-91.

Nelson, M. W. \& Tayler, W. B. (2007). Information pursuit in financial statement analysis: Effects of choice, effort, and reconciliation. The Accounting Review, 82(3), $731-758$. 
NOTC. (2020). Hvordan OTC-systemer fungerer? Hentet 5. juni 2020 fra: https:// www.notc.no/Om-NOTC.

Oslo børs. (2020). Markedsplasser bytter navn i forbindelse med overgangen til Optiq. Hentet 20. august 2020 fra https://www.oslobors.no/Oslo-Boers/Handel/ Delta/Optiq/Markedsplasser-bytter-navn-i-forbindelse-med-overgangen-tilOptiq

Schwencke, H. R., Haugen, D. O., Baksaas, K. M., Stenheim, T. \& Avlesen-Østli, E. (2020). Årsregnskapet i teori og praksis. 21. utgave. Oslo: Gyldendal Akademisk Forlag.

Stenheim, T. \& Madsen, D.-Ø. (2017). The shift of accounting models and accounting quality: the case of Norwegian GAAP. Corporate ownership \& control, 14(4), 289-300.

Watts, R. L. (2003). Conservatism in accounting part I: Explanations and implications. Accounting Horizons, 17(3), 207-221.

Watts, R. L. \& Zimmerman, J. L. (1978). Toward a positive theory of the determination of accounting standards. The Accounting Review, 53(1), 112-134.

Watts, R. L. \& Zimmerman, J. L. (1986). Positive accounting theory. Prentice-Hall contemporary topics in accounting series. Upper Saddle River, NJ: Prentice-Hall.

Watts, R. L. \& Zimmerman, J. L. (1990). Positive accounting theory: A ten year perspective. The Accounting Review, 65(1), 131-156.

Whittred, G. P. \& Zimmer, I. (1984). Timeliness of financial reporting and financial distress. The Accounting Review, 59(2), 287-295

Zeff, S. A. (1978). The rise of economic consequences. The Journal of Accountancy, December, 56-63. 


\section{Vedlegg}

Tabell 1.8.1 Registrerte selskaper hos Merkur Market, NOTC og «Family and Friends» per 31.12.2018 og vurdering knyttet til datagrunnlag

\begin{tabular}{|c|c|c|c|}
\hline & Selskap & Marked & Datagrunnlag \\
\hline 1 & Aasen Sparebank & Merkur Market & Utelukkes pga. særregulering \\
\hline 2 & ADS Crude Carriers Plc & Merkur Market & $\begin{array}{l}\text { Utelukkes pga. hjemmehørende i et annet } \\
\text { land }\end{array}$ \\
\hline 3 & Atlantic Sapphire AS & Merkur Market & Inkludert i utvalg \\
\hline 4 & Baltic Sea Properties AS & Merkur Market & Inkludert i utvalg \\
\hline 5 & Black Sea Property AS & Merkur Market & Inkludert i utvalg \\
\hline 6 & BRAbank & Merkur Market & Utelukkes pga. særregulering \\
\hline 7 & Epic Gas Ltd & Merkur Market & $\begin{array}{l}\text { Utelukkes pga. hjemmehørende i et annet } \\
\text { land }\end{array}$ \\
\hline 8 & Gentian Diagnostics AS & Merkur Market & Inkludert i utvalg \\
\hline 9 & $\begin{array}{l}\text { Golden Energy Offshore } \\
\text { Services AS }\end{array}$ & Merkur Market & Inkludert i utvalg \\
\hline 10 & Grong Sparebank & Merkur Market & Utelukkes pga. særregulering \\
\hline 11 & Induct AS & Merkur Market & Inkludert i utvalg \\
\hline 12 & J. P. Kenny Petroleum Ltd & Merkur Market & $\begin{array}{l}\text { Utelukkes pga. hjemmehørende i et } \\
\text { annet land }\end{array}$ \\
\hline 13 & Lavo.tv & Merkur Market & Inkludert i utvalg \\
\hline 14 & Lifecare AS & Merkur Market & Inkludert i utvalg \\
\hline 15 & Lillestrøm Sparebank & Merkur Market & Utelukkes pga. særregulering \\
\hline 16 & River iGaming plc & Merkur Market & $\begin{array}{l}\text { Utelukkes pga. hjemmehørende i et annet } \\
\text { land }\end{array}$ \\
\hline 17 & Sino Agro Food Inc & Merkur Market & $\begin{array}{l}\text { Utelukkes pga. hjemmehørende i et annet } \\
\text { land }\end{array}$ \\
\hline 18 & SoftOx Solutions AS & Merkur Market & Inkludert i utvalg \\
\hline 19 & Sunndal Sparebank & Merkur Market & Utelukkes pga. særregulering \\
\hline 20 & Surnadal Sparebank & Merkur Market & Utelukkes pga. særregulering \\
\hline 21 & TargetEveryOne $A B$ & Merkur Market & $\begin{array}{l}\text { Utelukkes pga. hjemmehørende i et } \\
\text { annet land }\end{array}$ \\
\hline 22 & Tysnes Sparebank & Merkur Market & Utelukkes pga. særregulering \\
\hline 23 & WR Entertainment & Merkur Market & Utelukkes pga. manglende informasjon \\
\hline 24 & Zenith Energy & Merkur Market & Utelukkes pga. manglende informasjon \\
\hline 25 & 2020 Bulkers LTD & NOTC & $\begin{array}{l}\text { Utelukkes pga. hjemmehørende i et annet } \\
\text { land }\end{array}$ \\
\hline
\end{tabular}

(Fortsatt) 
Tabell 1.8.1 (Fortsatt)

\begin{tabular}{|c|c|c|c|}
\hline & Selskap & Marked & Datagrunnlag \\
\hline 26 & Aprila Bank ASA & NOTC & Utelukkes pga. særregulering \\
\hline 27 & Araca Energy ASA & NOTC & Utelukkes pga. manglende informasjon \\
\hline 28 & Asker og Bærums Budstikke AS & NOTC & Inkludert i utvalg \\
\hline 29 & Atlantica Tender Drilling Ltd & NOTC & $\begin{array}{l}\text { Utelukkes pga. hjemmehørende i et } \\
\text { annet land }\end{array}$ \\
\hline 30 & Avenir LNG Limited & NOTC & $\begin{array}{l}\text { Utelukkes pga. hjemmehørende i et } \\
\text { annet land }\end{array}$ \\
\hline 31 & Avida Holding AB & NOTC & $\begin{array}{l}\text { Utelukkes pga. hjemmehørende i et annet } \\
\text { land }\end{array}$ \\
\hline 32 & Ayfie Group AS & NOTC & Inkludert i utvalg \\
\hline 33 & Bank2 ASA & NOTC & Utelukkes pga. særregulering \\
\hline 34 & Castor Maritime Inc & NOTC & $\begin{array}{l}\text { Utelukkes pga. hjemmehørende i et } \\
\text { annet land }\end{array}$ \\
\hline 35 & DOF Installer ASA & NOTC & Inkludert i utvalg \\
\hline 36 & Dwellop AS & NOTC & Inkludert i utvalg \\
\hline 37 & Easybank ASA & NOTC & Utelukkes pga. særregulering \\
\hline 38 & Eiendomsspar AS & NOTC & Inkludert i utvalg \\
\hline 39 & Eqology AS & NOTC & Inkludert i utvalg \\
\hline 40 & Etman International ASA & NOTC & Inkludert i utvalg \\
\hline 41 & Etrinell AS & NOTC & Inkludert i utvalg \\
\hline 42 & Golar LNG Limited & NOTC & $\begin{array}{l}\text { Utelukkes pga. hjemmehørende i et } \\
\text { annet land }\end{array}$ \\
\hline 43 & $\begin{array}{l}\text { Golden Close Maritime Corp } \\
\text { Ltd }\end{array}$ & NOTC & $\begin{array}{l}\text { Utelukkes pga. hjemmehørende i et annet } \\
\text { land }\end{array}$ \\
\hline 44 & GoodBulk Ltd & NOTC & $\begin{array}{l}\text { Utelukkes pga. hjemmehørende i et annet } \\
\text { land }\end{array}$ \\
\hline 45 & Hafnia Tankers Ltd. & NOTC & $\begin{array}{l}\text { Utelukkes pga. hjemmehørende i et } \\
\text { annet land }\end{array}$ \\
\hline 46 & HitecVision AS & NOTC & Inkludert i utvalg \\
\hline 47 & Huddly AS & NOTC & Inkludert i utvalg \\
\hline 48 & Hval Sjokoladefabrikk ASA & NOTC & Inkludert i utvalg \\
\hline 49 & Ice Group AS & NOTC & Inkludert i utvalg \\
\hline 50 & Independent Oil \& Resources Plc & NOTC & $\begin{array}{l}\text { Utelukkes pga. hjemmehørende i et annet } \\
\text { land }\end{array}$ \\
\hline 51 & $\begin{array}{l}\text { Independent Tankers } \\
\text { Corporation Ltd. }\end{array}$ & NOTC & $\begin{array}{l}\text { Utelukkes pga. hjemmehørende i et annet } \\
\text { land }\end{array}$ \\
\hline 52 & Instabank ASA & NOTC & Utelukkes pga. særregulering \\
\hline 53 & lonero AS & NOTC & Inkludert i utvalg \\
\hline
\end{tabular}




\begin{tabular}{|c|c|c|c|}
\hline & Selskap & Marked & Datagrunnlag \\
\hline 54 & Kahoot! AS & NOTC & Inkludert i utvalg \\
\hline 55 & $\begin{array}{l}\text { Klaveness Combination } \\
\text { Carriers AS }\end{array}$ & NOTC & Inkludert i utvalg \\
\hline 56 & Kraft Bank ASA & NOTC & Utelukkes pga. særregulering \\
\hline 57 & $\begin{array}{l}\text { Maritime \& Merchant Bank } \\
\text { ASA }\end{array}$ & NOTC & Utelukkes pga. særregulering \\
\hline 58 & MyBank ASA & NOTC & Utelukkes pga. særregulering \\
\hline 59 & Navig8 Chemical Tankers Inc & NOTC & $\begin{array}{l}\text { Utelukkes pga. hjemmehørende i et } \\
\text { annet land }\end{array}$ \\
\hline 60 & Net1 International Holdings AS & NOTC & Inkludert i utvalg \\
\hline 61 & NHST Media Group AS & NOTC & Inkludert i utvalg \\
\hline 62 & Noram Drilling Company AS & NOTC & Inkludert i utvalg \\
\hline 63 & Norda ASA & NOTC & Inkludert i utvalg \\
\hline 64 & Nordic Petroleum AS & NOTC & Inkludert i utvalg \\
\hline 65 & Norwegian Crystals AS & NOTC & Inkludert i utvalg \\
\hline 66 & On \& Offshore Holding AS & NOTC & Inkludert i utvalg \\
\hline 67 & Optin Bank ASA & NOTC & Utelukkes pga. særregulering \\
\hline 68 & Oslo Børs VPS Holding ASA & NOTC & Inkludert i utvalg \\
\hline 69 & Otovo AS & NOTC & Inkludert i utvalg \\
\hline 70 & Philly Tankers AS & NOTC & Utelukkes pga. manglende informasjor \\
\hline 71 & Pioneer Marine Inc & NOTC & $\begin{array}{l}\text { Utelukkes pga. hjemmehørende i et } \\
\text { annet land }\end{array}$ \\
\hline 72 & Playsafe Holding AS & NOTC & Inkludert i utvalg \\
\hline 73 & PROPR AS & NOTC & Inkludert i utvalg \\
\hline 74 & Quantafuel AS & NOTC & Inkludert i utvalg \\
\hline 75 & Rosenlund \& Co AS & NOTC & Inkludert i utvalg \\
\hline 76 & Sea Production Ltd & NOTC & Utelukkes pga. selskapstype \\
\hline 77 & $\begin{array}{l}\text { The Containership Company } \\
\text { ASA }\end{array}$ & NOTC & Inkludert i utvalg \\
\hline 78 & Torghatten ASA & NOTC & Inkludert i utvalg \\
\hline 79 & Victoria Eiendom AS & NOTC & Inkludert i utvalg \\
\hline 80 & Western Bulk Chartering AS & NOTC & Inkludert i utvalg \\
\hline 81 & Zenterio $A B$ & NOTC & Utelukkes pga. selskapstype \\
\hline 82 & Fjord Line AS & $\begin{array}{l}\text { «Family and } \\
\text { Friends» }\end{array}$ & Inkludert i utvalg \\
\hline 83 & Norpalm AS & $\begin{array}{l}\text { «Family and } \\
\text { Friends» }\end{array}$ & Inkludert i utvalg \\
\hline
\end{tabular}


Tabell 1.8.2 Kodeskjema 1: Selskapsform, regnskapsspråk og økonomiske forhold

\section{Kodeskjema: Selskapsform, regnskapsspråk og økonomiske forhold}
1) Regnskapsspråk
a) Hvilket regnskapsspråk benyttes i konsernregnskapet?
b) Hvilket regnskapsspråk benyttes i selskapsregnskapet?
c) Hvilke forenklingsregler for små foretak er benyttet, og vurderer vi at disse medfører en dårligere beslutningsnytte?
2) Dato for avleggelse a) Hvilken dato er årsregnskapet avlagt på?
3) Årsrapportens omfang a) Hvor mange sider består årsrapporten av (inkludert (sider) revisjonsberetning)?
4) Driftsresultat
a) Har selskapet positivt eller negativt driftsresultat?
5) Årsresultat
a) Har selskapet positivt eller negativt årsresultat?
6) Egenkapital
a) Har selskapet positiv eller negativ egenkapital?
b) Har selskapet udekket tap?
7) Utsatt skattefordel
a) Har selskapet utsatt skattefordel?
b) Har selskapet balanseført utsatt skattefordel?
c) Er det argumentert for balanseføring / manglende balanseføring?

Tabell 1.8.3 Kodeskjema 2: Sentrale forskjeller IFRS - GRS og forekomst av funn i antall selskaper (av 43 mulige)

\section{Kodeskjema: Sentrale forskjeller IFRS - GRS}

\begin{tabular}{|c|c|c|c|}
\hline Temaer & Sjekkpunkter & Aktuelt & Ikke aktuelt \\
\hline \multirow{3}{*}{$\begin{array}{l}\text { 1) Goodwill - } \\
\text { konsernforhold/ } \\
\text { oppkjøp }\end{array}$} & a) Har selskapet balanseført GWi 2018 eller 2017? & 7 & 36 \\
\hline & $\begin{array}{l}\text { b) Er konsernet endret i 2018, ved tilgang eller } \\
\text { avgang av datterselskaper? }\end{array}$ & 10 & 33 \\
\hline & $\begin{array}{l}\text { c) Mer spesielle transaksjoner rundt } \\
\text { konserneierforhold: trinnvise kjøp eller } \\
\text { etterfølgende kjøp i datterselskap? }\end{array}$ & 3 & 40 \\
\hline \multirow{2}{*}{$\begin{array}{l}\text { 2) Egenkapital/ } \\
\text { utbytte }\end{array}$} & a) Er egenkapitalen utvidet ved nyemisjoner? & 22 & 21 \\
\hline & $\begin{array}{l}\text { b) Er det avsatt utbytte som kortsiktig gjeld i } \\
\text { balansen? }\end{array}$ & 6 & 37 \\
\hline 3) Leieavtaler & a) Har selskapet operasjonelle leieavtaler? & 10 & 33 \\
\hline \multirow{4}{*}{$\begin{array}{l}\text { 4) Finansielle } \\
\text { instrumenter }\end{array}$} & a) Har selskapet konvertibel gjeld? & 8 & 35 \\
\hline & $\begin{array}{l}\text { b) Er EK-andel av konvertibel gjeld skilt og innregnet } \\
\text { separat? }\end{array}$ & 3 & 40 \\
\hline & c) Er det aksjebaserte betalingsavtaler? & 10 & 33 \\
\hline & $\begin{array}{l}\text { d) Herunder, har ledelsen mottatt aksjer eller } \\
\text { opsjoner? }\end{array}$ & 11 & 32 \\
\hline \multirow[t]{2}{*}{ 5) Inntektsføring } & $\begin{array}{l}\text { a) Prinsipper for inntektsføring er godt beskrevet i } \\
\text { note? }\end{array}$ & 43 & 0 \\
\hline & b) Benytter selskapet løpende avregning? & 5 & 38 \\
\hline
\end{tabular}


Kodeskjema: Sentrale forskjeller IFRS - GRS

Temaer

6) Pensjon

7) Presentasjon gjeld

\section{Sjekkpunkter}

a) Har selskapet ytelsesbasert pensjon?

b) Viser noter estimatavvik som ikke er innregnet i balansen?

a) Første års avdrag er presentert som kortsiktig gjeld?

b) Er det indikasjon på brudd på lånebetingelser som eventuelt er reparert etter balansedagen?
Aktuelt lkke aktuelt

$8 \quad 35$

$8 \quad 35$

27

16

6

37 



\title{
IASBs syn på sammenlignbarhet i finansregnskapet
}

\author{
Kjell Ove Røsok
}

Førsteamanuensis, Norges Handelshøyskole

Sammendrag: Sammenlignbarhet er en ønsket kvalitet ved finansregnskapet, og IASB referer hyppig til denne kvaliteten i sitt arbeid med utvikling av IFRS. Men sammenlignbarhet er et vanskelig konsept å forstå (Zeff, 2007), og forskning viser at det er vanskelig å måle (De Franco et al., 2011). I dette kapitlet analyserer jeg IASBs bruk av konseptet. IASB legger stor vekt på konsistens, spesielt for at like ting skal fremstå som like, men IASB søker også å utvikle standarder som er tilstrekkelig robuste til at ulike ting skal fremstå som ulike. Samtidig baserer IASB sin argumentasjon delvis på uuttalte forutsetninger uten å drøfte hva som gjør ting like og ulike. Analysene i kapitlet indikerer at IASB refererer til konseptet vel så mye for å skape inntrykk av kvalitet i standardene som for å gi reell begrunnelse for valgte løsninger.

Nøkkelord: IASB, konsistens, sammenlignbarhet

\subsection{Innledning}

Sammenlignbarhet er en kvalitet ved finansregnskapet som både lovgivere og standardsettere legger stor vekt på i sitt arbeid med regnskapsregulering. IASB (International Accounting Standards Board) utvikler IFRS (International Financial Reporting Standards) for å bidra til internasjonal sammenlignbar finansiell informasjon (IFRS Foundation, 2018). EU har utarbeidet regnskapsdirektiv for å bedre sammenlignbarheten innen unionen (EU, 2013) og vedtok bruk av IFRS for børsnoterte selskap

Sitering av denne artikkelen: Røsok, K. O. (2020). IASBs syn på sammenlignbarhet i finansregnskapet. I T. Stenheim, K. M. Baksaas og E. M. Kulset (Red.), Aktuelle temaer i regnskap og revisjon (Kap. 2, s. 55-81). Oslo: Cappelen Damm Akademisk. https://doi.org/10.23865/noasp.112.ch2

Lisens: CC-BY 4.0. 
med den begrunnelse at sammenlignbare finansregnskap er viktig for et velfungerende kapitalmarked i EU (EC, 2002). I Norge har flere utredninger om regnskapsregulering fremhevet sammenlignbarhet som et viktig mål med finansregnskapet, og internasjonal sammenlignbarhet var et viktig argument da regnskapslovutvalget foreslo å åpne for bruk av IFRS for SMEs (International Financial Reporting Standard for Small and Medium-sized Entities) (NOU 2015: 10).

Mange brukere har nytte av regnskapsinformasjon som er sammenlignbar. Slik informasjon kan hjelpe ledelsen med å utvikle selskapet, den kan hjelpe ansatte med å vurdere arbeidsplassens trygghet, media kan lettere stille kritiske spørsmål, skattemyndighetene kan utføre mer effektive kontroller, politikere kan få oversikter over samlet aktivitet i samfunnet, osv. Mange standardsettere anser imidlertid kapitaltilbyderne, spesielt investorene, som de viktigste brukere av finansregnskapet. Investorer bruker finansregnskap for å vurdere alternative investeringer, og for å kunne vurdere alternativer må de ha tilgang på sammenlignende informasjon (FASB, 1980). Standardsettere utvikler regnskapsstandarder som skal bidra til at finansregnskapet gir finansiell informasjon som er sammenlignbar.

Uniformitet kan ofte fremstå som et mål med standarder (Timmermans \& Epstein, 2010), men ved utvikling av regnskapsstandarder har det lenge vært stor enighet om at sammenlignbarhet ikke er det samme som uniformitet. Konseptet sammenlignbarhet inneholder både en likhets- og en ulikhetsdimensjon (Zeff, 2007; Simmons, 1967; Trueblood, 1966); like ting må fremstå som like, og ulike ting må fremstå som ulike. Men det er uklart når ting er like og ulike (Zeff, 2007). Når er ting tilstrekkelig ulike til at de må fremstå som ulike i finansregnskapet? Og hvordan skal ulikheten fremgå? Må regnskapsreglene åpne for ulike presentasjonsformer? Må regnskapsreglene åpne for ulike målemetoder? Og vil slike åpninger bidra til at like ting ikke fremstilles likt? Regelbaserte standarder kan sikre at like ting behandles likt, men kan også tvinge lik behandling på ulike ting (Schipper, 2003). Motsatt kan prinsippbaserte standarder sikre at ulik ting behandles ulikt (Dennis, 2008), men de kan også innebære skjønnsutøvelse som bidrar til ulik behandling av like ting (De George et al., 2016). 
Sammenlignbarhet er et uklart konsept som det er utfordrende å regulere, og som det er vanskelig å forske på. Forskere har lenge slitt med at det ikke er mulig å måle graden av sammenlignbarhet i finansregnskapene, og det var lenge begrenset med empiriske analyser på sammenlignbarhet. Det siste tiåret har omfanget av slik forskning økt etter at De Franco mfl. (2011) utviklet en proxy for å måle sammenlignbarhet. Mye av denne forskningen konkluderer med at sammenlignbarhet har positive effekter i kapitalmarkedene, men den tar for seg bare spesifikke aspekter av sammenlignbarhet (De George et al., 2016) og ikke sammenlignbarhetskonseptet som sådan (Caban-Garcia \& He, 2013).

Andre forskere tar utgangspunkt i graden av felles regnskapsregler. Først var forskerne mye opptatt av sammenlignbare finansregnskap gjennom harmonisering av regnskapsregler («de jure» sammenlignbarhet) (Gross \& Perotti, 2017). Etter at IFRS ble vanlig i bruk, har forskere fokusert mer på om den faktiske anvendelsen av regnskapsreglene har bidratt til sammenlignbare finansregnskap («de facto» sammenlignbarhet). Felles regnskapsspråk som IFRS vil presumptivt bedre sammenlignbarhet, men forskning gir ikke entydig støtte til denne antakelsen (De George et al., 2016; Brüggemann et al., 2013) og påpeker at selskap kan ha insentiver og land kan implementere og overvåke bruken av IFRS på måter som hindrer ønsket sammenlignbarhet (Kvaal \& Nobes, 2012, 2010; Zeff \& Nobes 2010; Zeff, 2007).

Tross det økende omfanget av forskning på sammenlignbarhet i finansregnskapet, er det bemerkelsesverdig få forskere som utdyper hva de legger i sammenligningskonseptet utover å gjengi at like ting må fremstå som like og ulike ting må fremstå som ulike. På tilsvarende måte som at Regnskapslovutvalget referer til at det er selvinnlysende og ukontroversielt at regnskap må være sammenlignbare (NOU 2015: 10), virker det som mange forskere mener at innholdet i sammenlignbarhetskonseptet er selvinnlysende. Men det er ikke klart når noe er likt og ulikt (Zeff, 2007), og utfordringene med å måle graden av sammenlignbarhet indikerer også at innholdet i konseptet ikke er klart. Denne uklarheten er en utfordring for regnskapsregulering og for forskning, og De George mfl. (2016) etterlyser forskning som kan bedre vår forståelse av konseptet. I dette kapitlet vil jeg bidra til bedre forståelse ved å se på 
hvordan konseptet brukes av IASB. Også IASB har en uklar definisjon av sammenlignbarhet som bare refererer til behovet for å identifisere likheter og ulikheter (IASB, 2018), men IASB er en aktør som har som overordnet mål å bedre sammenlignbarhet i finansregnskapene, og som i sitt arbeid har reflektert mye over konseptet. Kapitlets tekstanalyse av IASBs konseptuelle rammeverk og IFRS-standarder gir derfor innsikt i hva IASB anser som viktig for å oppnå sammenlignbarhet tross en uklar definisjon.

Videre i dette kapitlet studerer jeg først hva forskningslitteraturen sier om sammenlignbarhet, før jeg kort beskriver data og metode som er brukt for kapitlets analyse. Så analyserer jeg hvordan IASB bruker konseptet sammenlignbarhet, før jeg til sist konkluderer.

\subsection{Forskning på sammenlignbarhet}

Sammenlignbarhet har lenge vært en ønsket kvalitet ved finansregnskapet. I USA på 1970-tallet så Accounting Principles Board på sammenlignbarhet som ett av hovedmålene for finansregnskapet (Habib et al., 2017), og American Institute of Certified Public Accountants hevdet at det er en vanlig oppfatning at sammenlignbarhet bør være det overordnede hensyn ved valg mellom metoder (AICPA, 1973). På 1980-tallet hevdet Financial Accounting Standards Board (FASB) i USA at sammenlignbarhet i samspill med relevans og pålitelighet bidrar til nyttig informasjon (FASB, 1980). Denne informasjonen brukes av investorer for økonomiske beslutninger som innebærer evaluering av alternative muligheter, og ifølge FASB (1980) kan slike beslutninger ikke fattes rasjonelt hvis ikke sammenlignende informasjon er tilgjengelig. På 1990-tallet anså International Accounting Standards Committee (IASC) sammenlignbarhet som en hovedkvalitet ved finansregnskapet (IASC, 1989). I løpet av 200o-tallet oppdaterte IASB og FASB i fellesskap sine konseptuelle rammeverk og anser nå relevans og dekkende fremstilling som de primære kvalitetene ved finansregnskapet med sammenlignbarhet som en sekundær kvalitet som forsterker nytteverdien av informasjonen i finansregnskapet (IASB, 2018; IASB, 2010; FASB, 2018; FASB, 2010). I løpet av de siste 50 årene har FASB og IASB altså endret syn på 
sammenlignbarhet fra å være en primærkvalitet ved finansregnskapet til å spille en sekundær rolle som en forsterkende kvalitet. Likevel er sammenlignbarhet fortsatt en svært viktig kvalitet, et syn som deles av standardsettere i mange land.

Regnskapsforskning relaterer viktigheten av sammenlignbarhet både til sammenligning over tid og til sammenligning av selskap. Det første innebærer at man kan sammenligne informasjon fra ulike perioder for samme selskap, mens det andre innebærer at man kan sammenligne informasjon fra flere selskap. Som en følge av den økte globaliseringen har behovet økt for å sammenligne selskap i ulike land (Gross \& Perotti, 2017).

Det er mange brukere av finansregnskapene som kan dra nytte av sammenlignbarhet; for eksempel kan skattemyndigheter lettere identifisere skjønn som brukes for å minimere skatteutbetalinger, og revisorer og ledelse kan lettere identifisere feil (Gross \& Perotti, 2017). Standardsetterne anser imidlertid kapitaltilbydere som de viktigste brukerne av finansregnskapet, og det er nytteverdien for disse brukerne og deres økonomiske beslutninger som er vektlagt mest i regnskapslitteraturen om sammenlignbarhet. Sammenlignbarhet kan redusere kostnadene ved informasjonsinnhenting og redusere informasjonsasymmetri og estimeringsrisiko (Habib et al., 2017; Daske et al., 2008). Slike fordeler i kapitalmarkedene kan bidra til bedre internasjonal integrering av markeder (Felski, 2017). Forskning indikerer at sammenlignbarhet i finansregnskap bidrar til fordeler i kapitalmarkedene som redusert kapitalkostnad (Imhof et al., 2017), økt handelsaktivitet (Kim et al., 2020), økt utenlandsk eierskap (Mita et al., 2018; DeFond et al., 2011; Covrig et al., 2007), redusert mulighet for innsidere til å utnytte privat informasjon (Brochet et al., 2013), økt respons ved resultatmeldinger (Kim et al., 2018; Wang, 2014), redusert regnskapsmanipulering gjennom periodiseringer (Sohn, 2016), redusert behov for kontantbeholdning (Habib et al., 2017) på grunn av redusert usikkerhet for deltakere i gjeldsmarkedet (Kim et al., 2013) og økt effektivitet og nøyaktighet i analytikernes prediksjoner (Neel, 2017; De Franco et al., 2011) og revisors revisjonsarbeid (Zhang, 2018). Kim mfl. (2018) argumenterer for at sofistikerte brukere utnytter sammenlignbarhet mer enn mindre sofistikerte brukere. 
Et av hovedformålene med IFRS er å bidra til økt internasjonal sammenlignbarhet. ${ }^{1}$ Forskning er imidlertid ikke entydig på hvilken effekt IFRS har på sammenlignbarhet. Mens IFRS-forskning i stor grad konkluderer med at IFRS har hatt positive effekter for kapitalmarkedene (Brüggemann et al., 2013), har forskning ikke dokumentert bedret sammenlignbarhet som følge av IFRS (Brüggemann et al., 2013; Cascino \& Gassen, 2015; Barth et al., 2012). IFRS kan bidra til økt sammenlignbarhet gjennom å være et felles regnskapsspråk (De George et al., 2016), men flere forskere påpeker at bruk av IFRS, eller andre regnskapsstandarder, ikke er noen garanti for dette. Det at land krever bruk av IFRS, er i seg selv ikke nok til å sikre mer sammenlignbare finansregnskap (Daske et al., 2008). Land har ulike kulturer og regnskapstradisjoner som påvirker praktiseringen av IFRS (Caban-Garcia \& He, 2013; Zeff, 2007). Selskap har forskjellige rapporteringsincentiver og bruker skjønnsrommet i IFRS-standardene ulikt (Kvaal \& Nobes, 2010). Land kan ta i bruk IFRS som skiller seg fra den IFRS som er vedtatt i andre land på grunn av ulike tidspunkt for implementering, nyanser i oversettelser eller bevisste avvik (Zeff \& Nobes, 2010; Felski, 2017). I mange land vil bare noen få selskap, typisk børsnoterte, gå fra lokale regnskapsregler til IFRS, og bruk av IFRS kan derfor redusere nasjonal sammenlignbarhet (Cascino \& Gassen, 2015; Brüggemann et al., 2013).

Likevel har den økende globaliseringen av kapitalmarkedene ført til etterspørsel etter et felles sett med regnskapsstandarder, og IFRS er tatt i bruk i mange land rundt om i verden (Caban-Garcia \& He, 2013). IASB har per april 2018 identifisert 144 jurisdiksjoner som krever IFRS for børsnoterte selskap, ${ }^{2}$ og mange lokale regnskapsstandarder har blitt påvirket av IFRS (Gordon \& Gallery, 2012). Sammenlignbarhetsargumentet spiller en avgjørende rolle i denne utbredelsen. EUs beslutning om å kreve bruk av IFRS for børsnoterte selskap, er den viktigste hendelsen i spredningen av IFRS. Formålet med beslutningen er å bedre vilkårene i det europeiske kapitalmarkedet ved å øke sammenlignbarheten mellom finansregnskap (Cascino \& Gassen, 2015; Caban-Garcia \& He, 2013;

\footnotetext{
https://www.ifrs.org/about-us/who-we-are/

https://www.ifrs.org/use-around-the-world/use-of-ifrs-standards-by-jurisdiction/\#analysis 
Daske et al., 2008). Mange land utenfor EU tar i bruk eller konvergerer med IFRS og refererer til sammenlignbarhet som et hovedargument, for eksempel Canada (Durocher \& Gendron, 2011). Innflytelsesrike organisasjoner som Securities and Exchange Commission (SEC) og International Organization of Securities Commissions (IOSCO) støtter IFRS med henvisning til fordelene ved økt internasjonal sammenlignbarhet (Cascino \& Gassen, 2015; Durocher \& Gendron, 2011).

Til tross for at sammenlignbarhet er et viktig argument i utviklingen og implementeringen av regnskapsstandarder, er konseptet sammenlignbarhet ikke godt definert (Zeff, 2007). Lærebøker, regulatoriske dokument og forskning refererer til konseptet i generelle vendinger (De Franco et al., 2011; Emmanuel \& Garrod, 2002), og overraskende nok bruker mange forskningsartikler innen regnskap begrepet sammenlignbarhet uten å definere det. De som definerer begrepet, refererer ofte til Truebloods (1966) likhets- og ulikhetsperspektiv hvor «like ting skal se like ut, mens ulike ting skal se ulike ut» (fritt oversatt fra Trueblood, 1966, s. 189). ${ }^{3}$ Zeff (2007) påpeker uklarhetene i denne definisjonen: Det er ikke klart hva som er ting, og når er de henholdsvis like og ulike? Det er heller ikke enkelt å måle graden av sammenlignbarhet. De Franco mfl. (2011) påpeker mangelen på mål for sammenlignbarhet i regnskapsforskningen og konstruerte et mål for sammenlignbarhet i resultatet. Det siste tiåret har bruken av dette og andre konstruerte mål bidratt til økt empirisk forskning som indikerer at sammenlignbarhet har positive effekter (se ovenfor), men har i begrenset grad drøftet selve sammenlignbarhetskonseptet (Caban-Garcia \& He, 2013).

Sammenlignbarhet er med andre ord et uklart konsept, og det er vanskelig å måle graden av det. Likevel fremstår sammenlignbarhet som et viktig argument for valg av og utvikling av regnskapsstandarder, og brukerne av finansregnskapene kan tro at regnskapene er sammenlignbare. Gordon og Gallery (2012) påpeker at dette kan være en dysfunksjonell sammenlignbarhet. De har utviklet et rammeverk som beskriver fire kategorier av sammenlignbarhet (figur 2.1).

3 Trueblood (1966) bruker det engelske ordet «thing», mens IASB bruker andre begrep, for eksempel «item» (se CF, 2.25). Jeg bruker det norske ordet ting ved generell omtale av sammenlignbarhet. 


\begin{tabular}{|l|l|l|l|}
\cline { 3 - 4 } \multicolumn{2}{c|}{} & \multicolumn{2}{c|}{ Økonomisk substans } \\
\cline { 3 - 4 } \multicolumn{2}{c|}{} & Lik & Ulik \\
\hline \multirow{3}{*}{ Regnskapsmetode } & $\begin{array}{l}\text { Likt } \\
\text { (ingen valgmuligheter) }\end{array}$ & $\begin{array}{l}\text { Dyp } \\
\text { sammenlignbarhet }\end{array}$ & $\begin{array}{l}\text { Tilsynelatende } \\
\text { sammenlignbarhet }\end{array}$ \\
\cline { 2 - 4 } & $\begin{array}{l}\text { Ulikt } \\
\text { (valgmuligheter) }\end{array}$ & $\begin{array}{l}\text { Sprikende } \\
\text { sammenlignbarhet }\end{array}$ & $\begin{array}{l}\text { Ulikhets- } \\
\text { sammenlignbarhet }\end{array}$ \\
\hline
\end{tabular}

Figur 2.1 Rammeverk for sammenlignbarhet, tilpasset og oversatt fra Gordon og Gallery (2012).

To av kategoriene reflekterer Truebloods (1966) perspektiver om at like ting skal se like ut (dyp sammenlignbarhet) og ulike ting skal se ulike ut (ulikhetssammenlignbarhet). De to andre kategoriene handler om dysfunksjonell sammenlignbarhet. Ved sprikende sammenlignbarhet er like ting presentert ulikt ved bruk av ulike regnskapsmetoder, og ved tilsynelatende sammenlignbarhet fremstår ulike ting som like ved at samme regnskapsmetode er brukt på ting som er ulike.

\subsection{Metode}

I sitt arbeid med utvikling av regnskapsstandarder har IASB dialog med mange parter og utarbeider mange dokument som sendes ut på høring før de endelige IFRS-standardene vedtas. I tillegg har IASB vedtatt et konseptuelt rammeverk som beskriver kriterier som legges til grunn ved utvikling av standarder. I alle disse dialogene og dokumentene kan IASB gi uttrykk for sitt syn på sammenlignbarhet. Analysene i dette kapitlet tar utgangspunkt i det konseptuelle rammeverket, IFRS-standarder og tilhørende Basis for Conclusions (BC) siden dette er dokument som reflekterer IASBs endelige konklusjoner, og som IASB bruker mye tid på å utforme for å overbevise regnskapsprodusenter, revisorer og andre brukere om de valgte løsningene (Young, 2003).

IASBs konseptuelle rammeverk beskriver sammenlignbarhetens rolle i finansregnskapet. Denne beskrivelsen ble endret i 2010, og kapitlets analyser av IFRS-standarder begrenses til standarder utgitt etter denne oppdaterte vurderingen. Denne avgrensningen faller også sammen med perioden med økt forskning på sammenlignbarhet etter at De Franco mfl. (2011) konstruerte en proxy for måling av sammenlignbarhet. Det 
konseptuelle rammeverket ble oppdatert i 2018 uten at sammenlignbarhetens rolle ble endret, og analysen i dette kapitlet tar utgangspunkt i denne versjonen av rammeverket for å sikre bruk av IASBs mest oppdaterte syn. Dokumentene som analyseres er på engelsk, og sitat fra dokumentene gjengis på engelsk. Tabell 2.1 gir mer detaljer om dataene som er analysert, og hvordan jeg referer til dataene.

Tabell 2.1 Oversikt over dokumentene som er analysert i dette kapitlet. Dokumentene er hentet fra Red Book 2019 Part A (som inneholder standardene) og Part C (som inneholder BC) på eifrs.ifrs.org 5. november 2019. Part B inneholder eksempler o.l. og er ikke brukt i analysen. Dokumentene ble lastet ned i pdf-format, og de ble også lagret i Word-format for å kunne bruke analysefunksjoner i Word. Kapitlet referer til disse dokumentene som følger: CF, x.y henviser til paragraf x.y i det konseptuelle rammeverket, IFRS x.y henviser til paragraf y i IFRS-standard nummer x, BC henviser til «Basis for Conclusions», og SP henviser til kapitlet «Status and Purpose» i det konseptuelle rammeverket.

\begin{tabular}{llc}
\hline Referanse & Tittel & Utgitt \\
\hline IFRS 10 & Konsernregnskap & 2011 \\
IFRS 11 & Felleskontrollerte ordninger & 2011 \\
IFRS 12 & Opplysninger om interesser i andre foretak & 2011 \\
IFRS 13 & Måling av virkelig verdi & 2011 \\
IFRS 14 & Regulatoriske periodiseringsposter & 2014 \\
IFRS 15 & Driftsinntekter fra kontrakter med kunder & 2014 \\
IFRS 16 & Leieavtaler & 2016 \\
IFRS 17 & Forsikringskontrakter & 2017 \\
CF & Konseptuelt rammeverk for finansiell rapportering & 2018 \\
\hline
\end{tabular}

Jeg starter analysen med en frekvensanalyse av ord for de kvalitetene IASB mener et godt finansregnskap skal inneha, for å se etter indikasjoner på at IASB vektlegger enkelte kvaliteter mer enn andre (Weber, 1990). Frekvensanalysen omfatter også IFRS-standardene 1-9 som ble utgitt før 2010, for å se etter indikasjoner på endret vektlegging av kvalitetene etter IASBs oppdatering av det konseptuelle rammeverket i 2010. Som det fremgår av frekvensanalysen, er sammenlignbarhet en av de kvalitetene som nevnes oftest av IASB, men frekvensanalysen teller ord og gjør ingen vurdering av ordets innhold; samme ord kan ha ulike betydninger, og sammenhengen et ord brukes i, kan påvirke ordets betydning. Analysen gir likevel en klar indikasjon på at sammenlignbarhet er et viktig ord som det er verdt å analysere nærmere (Stubbs, 2010). Det gjør jeg ved 
ordsøk i alle dokumentene i tabell 2.1 for deretter å lese gjennom all tekst hvor ord for sammenlignbarhet er brukt. Alle tilfeller hvor ord for sammenlignbarhet er brukt, blir kategorisert for å kunne presentere funnene på en strukturert måte. Kategoriene er utarbeidet med utgangspunkt $\mathrm{i}$ gjennomgang av forskningslitteraturen og ved gjennomlesing av alle de identifiserte tilfellene. Det siste innebærer at nye kategorier utarbeides i løpet av lesingen av teksten, og den leses derfor flere ganger for å sikre en konsistent kategorisering.

IASB kan omtale sammenlignbarhet og de andre kvalitetene som substantiv, verb, adjektiv eller andre ordklasser. Både i den innledende frekvensanalysen og i det etterfølgende ordsøket bruker jeg søkeord som vil dekke flere ordklasser. For sammenlignbarhet bruker jeg søkeordet compar*, som vil finne alle ord som starter med compar, for eksempel comparability, comparison, compare, comparable, comparative og ulike bøyningsformer av disse ordene. Søkeordene for de andre kvalitetene fremgår av tabell 2.2. Søkeordene kan treffe ord som har en annen betydning enn som en kvalitet for finansregnskapet. Denne risikoen fjernes for søkeordet compar ${ }^{\star}$ ved at jeg leser gjennom all tekst hvor søkeordet er brukt, og ekskluderer ord med annen betydning fra videre analyser. Tilsvarende ekskludering blir ikke gjort for de andre søkeordene. Det er imidlertid svært få tilfeller hvor compar* blir brukt i annen betydning enn sammenlignbarhet i finansregnskapene, og en mer nøyaktig frekvensanalyse av de andre kvalitetene vil ikke endre konklusjonene etter frekvensanalysen.

\subsection{IASBs syn på sammenlignbarhet}

I det konseptuelle rammeverket anser IASB relevans og dekkende fremstilling som de primære kvalitetene ved beslutningsnyttig informasjon, mens sammenlignbarhet sammen med verifiserbarhet, tidsriktighet og forståelighet er sekundære kvaliteter som bidrar til å forsterke beslutningsnytten (CF, 2.4).

Tabell 2.2 viser resultatet av frekvensanalysen av ordene for de primære og sekundære kvalitetene. Resultatene vises for det konseptuelle rammeverket og samlet for standardene utgitt henholdsvis før og etter 2010 med unntak av IFRS 9 Finansielle instrumenter, som vises separat 
siden denne standarden er ekstra lang og er utgitt delvis før og delvis etter 2010. Vi ser at de primære kvalitetene nevnes oftere enn de sekundære i det konseptuelle rammeverket. Blant de sekundære kvalitetene fremstår ikke sammenlignbarhet som noen viktigere kvalitet enn de andre. I IFRS-standardene, derimot, er sammenlignbarhet den kvaliteten som nevnes oftest; relevans er den eneste andre kvaliteten som nevnes tilnærmet like ofte. Dette bildet er forholdsvis likt før og etter 2010; rangering av kvalitetene etter frekvens er den samme med unntak av at etter 2010 blir relevans nevnt oftere enn sammenlignbarhet. Men disse to kvalitetene nevnes fortsatt betydelig oftere enn de andre kvalitetene og fremstår som særlig viktige. I det følgende vil jeg analysere sammenlignbarhet nærmere med hovedvekt på analyse av tekst i dokumentene i tabell 2.1.

Tabell 2.2 Antall ganger søkeordene er anvendt i henholdsvis det konseptuelle rammeverket (inklusiv BC) som ble utgitt i 2018, og siste versjon av IFRS-standardene 1 til 17 (inklusiv BC). Søket ble gjort i de engelskspråklige dokumentene som er tilgjengelige på eifrs.ifrs.org. Søket inkludere alle varianter av ordet som starter med bokstavene før * i tabellen. De to siste linjene i tabellen viser samlet størrelse på de nevnte dokumentene

\begin{tabular}{llccccc}
\hline Kvalitet & Søkeord & CF 2018 & IFRS 1-8 & IFRS 9 & IFRS 10-17 & Sum \\
\hline Relevans & Relevan* $^{\star}$ & 188 & 168 & 230 & 406 & 992 \\
Dekkende fremstilling & Faithful* $^{\star}$ & 190 & 40 & 53 & 92 & 375 \\
Sammenlignbarhet & Compar $^{\star}$ & 60 & 274 & 272 & 335 & 941 \\
Verifiserbarhet & Verif* $^{\star}$ & 55 & 8 & 4 & 8 & 75 \\
Tidsriktighet & Timel $^{\star}$ & 25 & 13 & 31 & 14 & 83 \\
Forståelighet & Understand $^{\star}$ & 70 & 147 & 72 & 144 & 433 \\
Totalt antall ord i & & 67147 & 280576 & 251746 & 427635 & 1027104 \\
dokument & & 190 & 696 & 554 & 1070 & 2510 \\
Antall sider i dokument & & & & & &
\end{tabular}

IASB anser det som en av sine viktigste oppgaver å bidra til finansregnskap som er internasjonalt sammenlignbare (CF, SP1.5). Sammenlignbare finansregnskap vil hjelpe brukere, spesielt investorer og andre aktører i verdens kapitalmarkeder, til å ta økonomiske beslutninger (IFRS Foundation 2018). Økonomiske beslutninger er et vidt begrep, men IASB legger mest vekt på beslutninger om kjøp og salg av egenkapital- og gjeldsinstrumenter (CF, 1.2). Sammenlignbar informasjon bidrar til at investorer kan sammenligne alternative investeringer. 
IASB argumenterer med at «comparability will be improved overall by having more entities applying IFRS» (IFRS 14.BC19), og at utvikling av IFRS-standarder som regulerer områder som er vesentlige for selskap, vil få flere til å ta i bruk IFRS fremfor lokale regnskapsregler (IFRS 14.BC20). For å oppnå det overordnede målet om stor utbredelse av IFRS tillater IASB av og til valgmuligheter (IFRS 14.BC35). Dette reduserer sammenlignbarheten, men IASB argumenterer med at felles bruk av IFRS øker sammenlignbarheten på de andre regnskapspostene (IFRS 14.BC71).

Sammenlignbarhetens sekundære rolle innebærer at sammenlignbarhet ikke er tilstrekkelig for at informasjonen skal være nyttig for brukerne. Dersom informasjonen ikke er relevant eller dekkende fremstilt, hjelper det ikke at den er sammenlignbar (CF, BC2.59). Derimot vil nytteverdien av relevant og dekkende fremstilt informasjon bli forsterket av at informasjonen også er sammenlignbar (CF, 2.23). Dette innebærer at informasjon kan være relevant og dekkende fremstilt uten å være sammenlignbar, men IASB forventer at relevans og dekkende fremstilling i seg selv vil bidra til en viss grad av sammenlignbarhet (CF, 2.28). At informasjon kan oppfylle de primære kvalitetene uten å være sammenlignbar, innebærer imidlertid at flere metoder kan gi relevant og dekkende fremstilt informasjon. Dersom flere metoder gir like relevant og dekkende fremstilt informasjon, kan sammenlignbarhet sammen med de andre sekundære kvalitetene brukes for å velge mellom metoder (CF, 2.23).

Som mange andre har også IASB en generell definisjon som følger Truebloods (1966) beskrivelse og reflekterer både likhets- og ulikhetsperspektivet:

Comparability is the qualitative characteristic that enables users to identify and understand similarities in, and differences among, items. (CF, 2.25)

Vi finner igjen begge disse perspektivene som begrunnelse i flere av standardene IASB har utgitt de siste årene. To eksempler er IFRS 11 og IFRS 16. I IFRS 11 argumenterer IASB for at felleskontrollerte driftsordninger og felleskontrollerte virksomheter innebærer ulike typer rettigheter og forpliktelser (IFRS 11.B27), og at slik ordninger skal regnskapsføres etter to forskjellige metoder for å reflektere ulikhetene, samtidig som ordninger med like rettigheter og forpliktelser skal regnskapsføres etter samme 
metode. For IFRS 16 var et av hovedmålene å fjerne skillet mellom finansiell og operasjonell leasing i den eksisterende standarden for leieavtaler, et skille som medførte at transaksjoner som reelt sett var veldig like, kunne bli regnskapsført veldig forskjellig (IFRS 16.BC3). Utgangspunktet i IFRS 16 er at alle leieavtaler skal balanseføres, noe som ikke bare medfører lik regnskapsføring av leieavtaler, men også lik regnskapsføring av leide og eide eiendeler (IFRS 16.BC46).

IASB presiserer at sammenlignbarhet ikke er det samme som konsistens («consistency») eller uniformitet («uniformity»). Konsistens er å bruke samme metode for samme ting over tid eller mellom selskap. Dette er ikke er mål i seg selv, men et virkemiddel for å oppnå sammenlignbarhet (CF, 2.26). Uniformitet er å bruke samme metode uavhengig av om tingene er like. Dette trenger ikke bidra til sammenlignbarhet (CF, 2.27) siden finansregnskapet da kan skjule tingenes ulikheter. I standardene referer IASB stadig til konsistens i sin argumentasjon. IASB er imidlertid ikke konsistent i sin omtale av konsistens i standardene; i noen tilfeller fremstiller IASB konsistens og sammenlignbarhet som to selvstendige kvaliteter ved å argumentere for at løsninger vil bedre både konsistens $o g$ sammenlignbarhet (se f.eks. IFRS 13.72, IFRS 13.BC162, IFRS 15.BC490), mens i andre tilfeller fremstilles konsistens som et virkemiddel i samsvar med det konseptuelle rammeverket (se f.eks. IFRS 13.BC241, IFRS 15.BC444). I sin utvikling av IFRS søker IASB å fjerne eller unngå inkonsistenser. IFRS 13 er et godt eksempel; denne standarden ble utviklet for å få én felles måte å måle virkelig verdi på (IFRS 13.BC6). Før denne standarden ble bruken av virkelig verdi håndtert i de enkelte standardene, noe som resulterte i inkonsistent måling av virkelig verdi (IFRS 13.BC5). IASB innser også at en del standarder har skapt inkonsistens fordi standardene er uklare, og de søker å bedre sammenlignbarhet ved å gjøre dem klarere (for eksempel IFRS 10.BC210 og IFRS 15.BC488). Konsistente regnskapsregler er ett av IASBs viktigste virkemiddel for å bidra til sammenlignbarhet.

IASB vektlegger sammenlignbarhet fordi finansregnskapet skal gi beslutningsnyttig informasjon, og siden beslutninger ofte innebærer valg mellom alternativer, vil beslutningsnytten øke hvis beslutningstaker får informasjon som bidrar til sammenligning av alternativene. 
Da er det aktuelt med sammenligning både over tid og mellom selskap (CF, 2.24).

\subsubsection{Sammenlignbarhet over tid}

Sammenlignbarhet over tid gjør det enklere for brukerne å analysere trender (IAS 8.15), og IASB krever at selskapene bruker samme regnskapsprinsipp gjennom en periode og fra en periode til neste. I noen få tilfeller kan selskap endre regnskapsprinsipp, hovedsakelig når IASB utgir en ny standard som krever bruk av et nytt regnskapsprinsipp (IAS 8.14). For å beholde sammenlignbarhet over tid skal selskapene da implementere endringen retrospektivt (IAS 8.19) og opplyse om effektene på tallene i finansregnskapet (IAS 8.28). Dette innebærer at det ikke bare er transaksjoner etter endringen som skal regnskapsføres etter nytt prinsipp, tidligere perioders regnskapsdata må også omarbeides til nytt prinsipp. Dette kan være en ressurskrevende omarbeiding, og det er vanlig at IASB fastsetter overgangsordninger som tillater forenklinger. Dette vil forringe sammenlignbarheten, men kan forsvares hvis kostnaden ved full retrospektiv implementering overstiger nytteverdien. Overgangsregler med forenklinger har blitt så vanlig at det virker som slike unntak fra hovedreglene har blitt den nye hovedregelen for IASB. IFRS-standardene har egne vedlegg med overgangsregler (Appendix C), og i BC er det egne seksjoner for overgangsregler, endringstidspunkt og kost-nytte-vurderinger. Mens disse delene av standardene IFRS 10-17 utgjør ca. 5 prosent av total lengde (målt i antall ord), inneholder de nesten halvparten av de 335 tilfellene hvor ord for sammenlignbarhet er anvendt (se tabell 2.2). Dette kan indikere at IASB gjør en grundig vurdering av effektene på sammenlignbarhet før forenklinger tillates. Det er fornuftig at slike unntak er basert på grundige vurderinger, men det er likevel bemerkelsesverdig at IASB bruker så mye plass på å argumentere for begrenset nytteverdi av sammenlignbarhet når de samtidig fremstiller dette som en av de viktigste kvalitetene ved finansregnskapet. Dessuten viser nærmere analyse at IASB ofte bruker kost-nytte-argumenter uten å utdype hvordan konklusjonen fremkommer (for eksempel IFRS 10.BCZ201), og noen av kost-nytte-argumentene er standardformuleringer som brukes 
i mange standarder (se for eksempel IFRS 10.BC208, IFRS 11.BC72, IFRS 12.BC124, IFRS 13.BC240). Når IASB først åpner for redusert sammenlignbarhet ut fra kost-nytte-vurderinger, kan dette skape en spiralvirkning som åpner for ytterligere svekkelse av sammenlignbarhet, for eksempel:

They argued that accounting for decreases in non-controlling interests retrospectively imposes compliance costs that are not justifiable, mainly because the requirement to account for increases prospectively reduces comparability anyway. The Board accepted those arguments [...] (IFRS 10.BCZ202)

\subsubsection{Sammenlignbarhet mellom selskap}

IASBs utgangspunkt for vurdering av sammenlignbarhet mellom selskap er at selskapenes finansregnskap skal være sammenlignbare for samme periode. IASB vektlegger ikke tidsdimensjonen i sammenlignbarhet mellom selskap, bare ved sammenlignbarhet innen et selskap:

Users prefer information that is comparable from reporting period to reporting period for an individual entity and between different entities in a particular reporting period (IFRS 10.BC210, se også CF, 2.24).

På den annen side stiller ikke IASB krav til at selskapene må avlegge finansregnskap for samme periode. Ifølge IAS 1.37 skal selskap normalt utarbeide finansregnskap for en ett-års periode, men standarden stiller ingen krav til hvilken del av året dette skal være. Selskap kan følgelig utarbeide finansregnskap for ulike 12-månedersperioder av året. Dette indikerer et behov for å ta hensyn til tidsdimensjonen dersom ulike selskaps finansregnskap skal være sammenlignbare også når de utarbeides på ulike tidspunkt i året. Dessuten er IASB av den oppfatning at bruk av IFRS i seg selv bidrar til sammenlignbarhet mellom selskap, og når hvert selskap er sammenlignbart over tid, inneholder også sammenlignbarheten mellom selskap en sammenlignbarhet over tid.

IASB refererer hyppig til sammenlignbarhet mellom selskap både i strategidokument, i det konseptuelle rammeverket og i de enkelte standardene, men ofte utdypes det ikke hvordan løsningen bidrar til 
sammenlignbarhet. Følgende sitat gir et visst innblikk i IASBs tanker om sammenlignbarhet mellom selskap:

The comprehensive model also improves previous IFRS and US GAAP by [...] improving comparability of revenue recognition practices across entities, industries, jurisdictions and capital markets (IFRS 15.BC3)

Slik det er formulert fremstår de tre siste dimensjonene («industries, jurisdictions and capital markets») i dette sitatet som dimensjoner som kommer i tillegg til mellom-selskap-dimensjonen («across entities»). En slik forståelse fremstår som unaturlig, finansregnskapene som skal sammenlignes, utarbeides på selskapsnivå («entity»), og det antas at når IASB refererer til sammenligning mellom bransjer, land og kapitalmarkeder, er det sammenligning av selskap i ulike bransjer, land og kapitalmarkeder det tenkes på. Med en slik forståelse blir dette referanser til undergrupper av selskap. En slik innsnevring kan være en erkjennelse av at det ikke er et mål at alle selskap skal være sammenlignbare. Eksempelvis kan brukere av finansregnskap fra børsnoterte selskap ha informasjonsbehov som skiller seg fra informasjonsbehovene til andre brukere, slik at det er viktigere med sammenlignbarhet mellom børsnoterte selskap enn mellom børsnoterte og ikke-børsnoterte selskap.

IASB søker å ta hensyn til særtrekk ved bransjer («industries»), både ved å unngå uniformitet som kan skjule særtrekk, og ved å regulere særtrekk og dermed øke sammenlignbarhet mellom selskap i samme bransje, og IASB har flere referanser til sammenlignbarhet både innen og mellom bransjer. Sitatet ovenfor legger vekt på det siste og er uttrykt i samband med utvikling av en modell som skal være tilstrekkelig robust til å håndtere ulikheter mellom bransjer. I andre sammenhenger kommer IASB med løsninger på bransjespesifikke problemstillinger for å øke sammenlignbarhet mellom selskap innen samme bransje, for eksempel for investeringsselskap (IFRS 10.BC302), «rate-regulated entities» (IFRS 14.BC70) og forsikringsselskap (IFRS 17.BC30). En utfordring ved standarder som skal ta hensyn til bransjespesifikke særtrekk, er å formulere standardens virkeområde på en hensiktsmessig måte. IASB søker å avgrense virkeområde ut fra transaksjonenes særtrekk og ikke i forhold til selskapsform. Eksempelvis er IFRS 17 en standard for forsikringskontrakter og ikke for 
forsikringsselskap. Dermed vil regnskapsføring av forsikringskontrakter være sammenlignbar mellom selskap uavhengig av selskapstypen som har utstedt kontraktene (IFRS 17.BC63). Det å fokusere på transaksjonens særtrekk bidrar til sammenlignbarhet for ulike transaksjonstyper med samme særtrekk, for eksempel finansieringselementer i utlån og kundefordringer (IFRS 15.BC244) og i leasinggjeld og annen gjeld (IFRS 16.BC211).

Referansen til sammenlignbarhet over landegrenser («jurisdictions») brukes ofte av IASB også i de enkelte standardene og kan fremstå som et naturlig argument siden dette er et av de overordnede målene med IFRS. Men hvordan kan løsninger i enkeltstandarder bedre sammenlignbarhet over landegrensene? De enkelte standardene kan bedre sammenlignbarhet mellom selskap som bruker standarden, men det er bruken av IFRS som et samlet sett av regnskapsstandarder som bidrar til sammenlignbarhet over landegrensene!

Selv om målet til IASB er å bidra til sammenlignbare finansregnskap ved at selskap verden rundt bruker IFRS som et felles regnskapsspråk, begrunner de også enkelte løsninger med økt sammenlignbarhet med andre regnskapsspråk, særlig US GAAP. I en periode jobbet IASB og FASB med å utarbeide felles standarder. Dette konvergeringsprosjektet strandet etter hvert, men IASB bruker fortsatt økt sammenlignbarhet med US GAAP som argument, for eksempel:

That would also improve comparability with entities applying US GAAP (IFRS

13.BC228)

IASB har blitt kritisert for at IFRS tar for mye hensyn til US GAAP, for eksempel når IASB under finanskrisen endret den tidligere standarden for finansielle instrumenter for å tillate en mulighet som fantes i US GAAP. Men IASB bruker ikke US GAAP ukritisk og har blant annet avvist valgmuligheter i US GAAP med den begrunnelse at valgmuligheter reduserer sammenlignbarheten (IFRS 15.BC302). Valg mellom ulike regnskapsprinsipp var ganske vanlig i de tidligste standardene. I senere standarder har IASB praktisert en strengere linje (IFRS 11.BC8) men tillater fortsatt noen valgmuligheter når dette kan forsvares ut fra en kost-nytte-vurdering. I senere standarder ser vi at valgmuligheter i større grad gis som praktiske 
unntak ("practical expedients») heller enn en generell valgmulighet for alle transaksjoner innenfor standardenes virkeområde (for eksempel IFRS 15.BC437).

For mange selskap vil slike praktiske unntak ikke ha vesentlig betydning for finansregnskapet. For enkelte vil de imidlertid kunne være vesentlige, og sammenlignbarheten blir svekket. IASB erkjenner denne risikoen. Men det virker som IASB forventer selvjustis blant selskapene slik at de ikke bruker unntakene dersom de negative effektene er vesentlige, og dette bruker IASB som argument for å akseptere unntak:

In the IASB's view, the practical expedient will reduce cost and complexity for some lessees, while not creating significant issues of comparability. This is because, in general, a lessee is not expected to adopt the practical expedient for contracts with significant service components because that would significantly increase the lessee's lease liabilities for those contracts. The IASB expects that lessees are likely to adopt this practical expedient only when the non-lease components of a contract are relatively small. (IFRS 16.BC135, se også IFRS 16.BC286)

Som nevnt ovenfor, er det vanlig at IASB tillater forenklinger i overgangen til nytt regnskapsprinsipp. Slik forenkling vil redusere sammenlignbarheten mellom selskap dersom ikke alle selskapene anvender forenklingsreglene. I noen tilfeller velger IASB derfor at alle selskap skal følge forenklingsreglene, for eksempel at endringen ikke skal gjennomføres retrospektivt, men bare prospektivt:

and thus prospective application would be required, would reduce implementation costs and result in greater comparability between entities. (IFRS 10.BCZ201)

Det vanligste er imidlertid at forenklingsreglene er en valgmulighet. Det virker som IASB ikke ønsker å nekte selskap å utarbeide finansregnskap i samsvar med de prinsippene som gir den mest nyttige informasjonen. Når IASB utgir en ny standard, får selskapene ofte noen år på seg før de må ta den i bruk. Men det er også vanlig at IASB tillater tidliganvendelse, noe som reduserer sammenlignbarheten mellom selskap fordi selskapene ikke tar i bruk standarden samtidig (IFRS 15.BC452). 


\subsubsection{Sammenlignbarhet innen et selskap}

I det konseptuelle rammeverket er det tidsdimensjonen som er viktig ved sammenlignbarhet innen et selskap (CF, 2.24). I IFRS-standardene utvider IASB forståelsen av sammenlignbarhet innen et selskap ved å vektlegge at like ting blir regnskapsført likt uavhengig av tidsdimensjonen. I IFRS 15 og IFRS 17 argumenterer IASB med at de nye modellene i standardene vil bidra til at like typer kontrakter blir regnskapsført likt. I IFRS 16 argumenterer IASB med at den nye modellen for leieavtaler vil gjøre at selskap får likere regnskapsføring av eide og leide eiendeler, og at dette øker sammenlignbarheten. I IFRS 13 åpner IASB for tidliganvendelse av standarden for å oppnå konsistent måling og dermed bedret sammenlignbarhet innen selskapet (IFRS 13.BC228) selv om denne valgmuligheten kan svekke sammenlignbarheten mellom selskap.

Det virker rimelig at like ting innen et selskap fremstår som like i finansregnskapet, men sammenholdt med behovet for å sammenligne alternative investeringsmuligheter fremstår det ikke som en kritisk egenskap ved finansregnskapet så lenge det er sammenlignbart over tid og mellom selskap. Eksempelvis er det mange som sier seg enig i at like eiendeler bør regnskapsføres likt uavhengig av om de er kjøpt eller leid, og uavhengig av om de er innenfor eller utenfor definisjonen av finansiell leieavtale. Samtidig er det mange som sier at så lenge alle hadde anvendt den, hadde de klart seg fint med den gamle leiestandarden selv om den ikke sikret samme likebehandling (Kvarsvik \& Hellenes, 2019). Likhet kan være enklere å forstå enn ulikheter, og når IASB legger så stor vekt på sammenlignbarhet innen et selskap, kan det like mye være et bidrag til å bedre forståeligheten som å bedre sammenlignbarheten.

\subsubsection{Virkemiddel for å oppnå sammenlignbarhet}

IASB er altså opptatt av sammenlignbarhet ved at like ting blir håndtert likt i finansregnskapene både innen et selskap, mellom selskap og over tid, og at ulike forhold blir håndtert ulikt. Regnskapsprosessen består av flere steg som innregning, måling og presentasjon. Hvert av stegene kan påvirke sammenlignbarheten. Likevel inngår sammenlignbarhet 
knappest i IASBs drøftelse av rapporteringsenheter (CF, kapittel 3), elementer i finansregnskapet (CF, kapittel 4), innregning og fraregning (CF, kapittel 5) og kapital (CF, kapittel 8).

Når det gjelder presentasjon, er det noe mer drøftelse. Faste oppstillingsformat kan bidra til sammenlignbarhet (CF, 5.2), men kan også skjule ulikheter ved at ulike ting blir presentert likt (CF, 7.8), og IFRS-standardene må balansere behovene for fast struktur og fleksibilitet (CF, 7.4). IASB argumenterer også for at spesifikke opplysningskrav i standardene vil øke sammenlignbarhet ved at flere gir informasjonen (IFRS 12.BC94, IFRS 13.BC192, IFRS 16.BC217). Implisitt i dette argumentet anses sammenlignbarheten å være bedre når alle gir en type informasjon, enn når ingen gir denne informasjonen. For å kunne sammenligne over tid krever IASB at oppstillingene i finansregnskapet skal ha sammenligningstall for minst ett år (CF, 3.5). Dette er en løsning som samsvarer med praksis, men IASB drøfter ikke hvorfor ett år er tilstrekkelig. Behovet for sammenligning over tid knyttes til behovet for å identifisere trender (IAS 8.15). Er det mulig å identifisere trender ved å sammenligne bare to perioder? Rett nok kan brukerne ha tilgang til tidligere perioders finansregnskap og på den måten kunne sammenligne flere år. Men dersom det skulle være argumentet for at det er tilstrekkelig med sammenligningstall for ett år, kan man stille spørsmålet om det er nødvendig med sammenligningstall i det hele. Det er ikke diskutert av IASB.

Naturlig nok finner vi hyppige referanser til sammenlignbarhet i det konseptuelle rammeverkets kapittel 2 om de kvalitative egenskapene ved finansregnskapet, men kapittel 6 om måling har også mange referanser. Frekvensanalysen viser at disse to kapitlene står for ca. 85 prosent av alle tilfellene hvor IASB bruker begrepet sammenlignbarhet i det konseptuelle rammeverket og tilhørende $\mathrm{BC}$. Anvendt målemetode må bidra til relevant og dekkende fremstilt informasjon som i tillegg er sammenlignbar så langt dette er mulig (CF, 6.45). IASB diskuterer hvorvidt dette målet best nås ved bruk av én eller flere målemetoder. Å tillate bare én målemetode vil kunne være enklere å forstå og gi mer meningsfulle summer i finansregnskapet (CF, BC6.5), men IASB konkluderer med at poster i finansregnskapet har ulike karakteristika som best kan reflekteres gjennom bruk av ulike målemetoder (CF, BC6.11). Ulike situasjoner 
kan også kreve ulike målemetoder; samme type eiendel eller gjeld kan bidra til et selskaps inntjening på ulike måter, og det kan være hensiktsmessig å måle dette på ulike måter avhengig av situasjonen (CF, BC6.39). Eksempelvis kan en spesifikk eiendel være en salgsvare, bli leid ut eller inngå i selskapets produksjonsprosess. Bruk av ulike målemetoder støtter opp under ulikhetsperspektivet i definisjonen. Men å tillate bruk av ulike målemetoder for like ting vil imidlertid redusere sammenlignbarhet (CF, 2.29).

I det konseptuelle rammeverket er skillet mellom historisk kost og virkelig verdi viktig i drøftelsen av måling. Etter IASBs syn vil historisk kost redusere sammenlignbarhet når identiske eiendeler måles til ulike verdier fordi de er anskaffet på forskjellig tidspunkt:

Using a historical cost measurement basis, identical assets acquired, or liabilities incurred, at different times can be reported in the financial statements at different amounts. This can reduce comparability, both from period to period for a reporting entity and in a single period across entities. (CF.6.71)

Motsatt vil måling til virkelig verdi bidra til at like eiendeler måles til samme verdi (CF, 6.72). Dette synet forutsetter at lik verdi på like eiendeler gir best sammenlignbarhet, og IASB mener at bruk av markedsverdier vil gi likere verdier enn bruksverdier og andre verdier som kan variere med selskapsspesifikke forhold. Definisjonen av markedsverdi tar utgangspunkt i den verdien som ville blitt oppnådd ved salg (IFRS 13. Appendix A), men verdien skal brukes på eiendeler eller gjeld som ikke er solgt, og er følgelig en hypotetisk verdi (IFRS 13.BC30). IASB er ikke tydelig på hvorfor like verdier basert på hypotetiske verdier gir bedre sammenlignbarhet enn verdier som stammer fra faktiske kjøp eller forventet anvendelse. IASB er heller ikke tydelig på hva som gjør eiendeler eller forpliktelser like. Sitatet ovenfor indikerer at likhet knyttes til egenskaper ved selve eiendelen eller forpliktelse, for eksempel den fysiske tilstanden for et driftsmiddel. Likhetsperspektivet kan imidlertid også knyttes til andre forhold ved eiendelen eller forpliktelsen, for eksempel deres anskaffelseskost. IASB tar sitt syn på likhet for gitt og diskuterer ikke andre syn. 


\subsection{Konklusjon}

I dette kapitlet påpeker jeg at selv om det er stor enighet om at sammenlignbarhet er en viktig kvalitet ved finansregnskapet, er det få som forklarer hva de mener med sammenlignbarhet utover at like ting må fremstå som like og ulike ting må fremstå som ulike. Men det er også uklart hva det vil si at noe er likt eller ulikt (Zeff, 2007), og forskning påpeker at det er vanskelig å måle graden av sammenlignbarhet (De Franco et al., 2011). Dette kapitlet bidrar til bedre innsikt i konseptet sammenlignbarhet ved å analysere hvordan IASB referer til konseptet.

IASB referer ofte til sammenlignbarhet (se tabell 2.2), og i dette kapitlet viser jeg at IASBs vektlegging av konsistens og substans er to viktige virkemiddel for å bidra til sammenlignbarhet. Konsistens vektlegges spesielt for å sikre at like ting behandles likt. Overordnet vil IFRS som et felles regnskapsspråk bidra til konsistent behandling. På standardnivå jobber IASB med konsistens gjennom å begrense valgmuligheter, gjennom konsistent begrepsbruk i de ulike standardene og gjennom klare formuleringer som reduserer risiko for ulik praktisering av standardene. Konsistens kan bidra til dyp sammenlignbarhet (figur 2.1). Men konsistens må ikke forveksles med uniformitet. Uniformitet kan skjule tingenes ulikheter, og IASB søker å bidra til ulikhetssammenlignbarhet (figur 2.1) ved å vektlegge tingenes substans fremfor tingenes form. Av den grunn avviste IASB bruk av én felles målemetode fordi tingenes ulike særtrekk medfører behov for ulike målemetoder. Videre søker IASB å utvikle standarder som er basert på prinsipp som er så robuste at samme transaksjonsart regnskapsføres likt dersom transaksjonene innehar de samme karaktertrekkene, mens de regnskapsføres ulikt dersom transaksjonene har ulike karaktertrekk. Men IASB har også valgt enkelte løsninger som medfører dysfunksjonelle former for sammenlignbarhet (figur 2.1). IASB tillater enkelte valgmuligheter slik at like ting kan fremstå som ulike, og i enkelte tilfeller krever IASB felles metode selv om ulike ting da kan fremstå som like.

Selv om IASB legger stor vekt på virkemidler som kan bidra til bedre sammenlignbarhet, drøfter ikke IASB selve konseptet sammenlignbarhet, det virker som IASB tar for gitt at det er klart når noe er likt og ulikt. Men når er to driftsmidler like? Er det når den fysiske tilstanden er lik, er 
det når formålene med driftsmidlene er like, er det når kjøpsbetingelsene er like, er det når salgsmulighetene er like, eller er det andre forhold eller kombinasjoner av flere forhold? I sin drøftelse av målemetoder argumenterer IASB med at historisk kost kan gi ulik verdi på like eiendeler, dette er en konklusjon som utelukker noen av forholdene foran som grunnlag for likhet, men de drøfter ikke hvilke(t) forhold de legger til grunn og hvorfor. Siden IASB ikke drøfter selve sammenlignbarhetskonseptet, er det ikke mulig å vite hvor nært man er en ideell sammenlignbarhet, selv om man skulle være enig i at IASB gjør mye for å bedre sammenlignbarheten. Jeg oppfordrer forskere til å gå dypere i sammenlignbarhetskonseptet og hva som gjør at ting kan betraktes som like og ulike.

Tross manglende drøftelse av sammenlignbarhet gir IASBs hyppige referanser til konseptet inntrykk av at de vet hva sammenlignbarhet innebærer, og at IFRS bidrar til at finansregnskapene faktisk blir sammenlignbare. Men som nevnt i forrige avsnitt, kan IASBs argumentasjon bygge på uuttalte forutsetninger som gjør det vanskelig å vurdere graden av sammenlignbarhet. Videre erkjenner IASB at standardene inneholder noen løsninger som reduserer sammenlignbarheten, og viser til kost-nyttevurderinger, men uten at disse er utdypet. IASB argumenterer også for bedre sammenlignbarhet uten at det alltid er klart hvordan deres løsninger vil gi denne bedringen. Alle referansene til sammenlignbarhet i IASBs dokument kan være et forsøk på å overbevise publikum om standardenes kvalitet ved å skape en kobling mellom standard og de uttalte målene med IFRS. Nærmere analyser viser imidlertid at sammenhengen mellom standardene og den påståtte bedring av sammenlignbarhet kan være uklar. Eksempelvis introduserer IASB sammenlignbar innen-et-selskap som en tredje dimensjon i tillegg til de to vanlige dimensjonene over-tid og mellom selskap. Jeg stiller spørsmål ved om denne tredje dimensjonen faktisk bidrar til sammenlignbarhet: Dimensjonen kan være nyttig for å bedre forståelsen av finansregnskapet, men den er ikke nødvendig for å kunne sammenligne alternative investeringer. Et annet eksempel er IASBs stadige referanser til bedre sammenlignbarhet over landegrenser. Dette vil være et gyldig argument for å ta i bruk IFRS som et sett av regnskapsstandarder, men er ikke tilsvarende gyldig som argument på standardnivå siden endring i en standard vil påvirke sammenlignbarheten mellom de 
selskapene som anvender standarden uavhengig av landegrenser. Analysene i dette kapitlet indikerer at IASB refererer til sammenlignbarhet vel så mye for å skape inntrykk av kvalitet i standardene som for å gi reell begrunnelse for valgte løsninger.

\section{Referanser}

\section{Regnskapsstandarder IFRS: \\ (oppdaterte versjoner pr november 2019)}

IFRS 10. Konsernregnskap (2011). IASB.

IFRS 11. Felleskontrollerte ordninger (2011). IASB.

IFRS 12. Opplysninger om interesser $i$ andre foretak (2011). IASB.

IFRS 13. Måling av virkelig verdi (2011). IASB.

IFRS 14. Regulatoriske periodiseringsposter (2014). IASB.

IFRS 15. Driftsinntekter fra kontrakter med kunder (2014). IASB.

IFRS 16. Leieavtaler (2016). IASB.

IFRS 17. Forsikringskontrakter (2017). IASB.

\section{Artikler, bøker mv.}

AICPA. (1973). Objectives of financial statements: Report of the study group on the objectives of financial statements. New York: American Institute of Certified Public Accountants.

Barth, M. E., Landsman, W. R., Lang, M. \& Williams, C. (2012). Are IFRS-based and US GAAP-based accounting amounts comparable? Journal of Accounting and Economics, 54(1), 68-93.

Brochet, F., Jagolinzer, A. D. \& Riedl, E. J. (2013). Mandatory IFRS adoption and financial statement comparability. Contemporary Accounting Research, 3o(4), 1373-1400.

Brüggemann, U., Hitz, J.-M. \& Sellhorn, T. (2013). Intended and unintended consequences of mandatory IFRS adoption: A review of extant evidence and suggestions for future research. European Accounting Review, 22(1), 1-37.

Caban-Garcia, M. T. \& He, H. (2013). Comparability of earnings in Scandinavian countries: The impact of mandatory IFRS adoption and stock exchange consolidations. Journal of International Accounting Research, 12(1), 55-76.

Cascino, S. \& Gassen, J. (2015). What drives the comparability of mandatory IFRS adoption? Review of Accounting Studies, 20, 242-282. 
Covrig, V. M., DeFond, M. L. \& Hung, M. (2007). Home bias, foreign mutual fund holdings, and the voluntary adoption of international accounting standards. Journal of Accounting Research, 45(1), 41-70.

Daske, H., Hail, L., Leuz, C. \& Verdi, R. (2008). Mandatory IFRS reporting around the world: Early evidence on the economic consequences. Journal of Accounting Research, 46(5), 1085-1142.

De Franco, G., Kothari, S. P. \& Verdi, R. S. (2011). The benefits of financial statement comparability. Journal of Accounting Research, 49(4), 895-931.

De George, E. T., Li, X. \& Shivakumar, L. (2016). A review of the IFRS adoption literature. Review of Accounting Studies, 21(3), 898-1004.

DeFond, M., Hu, X. \& Hung, M. (2011). The impact of mandatory IFRS adoption on foreign mutual fund ownership: The role of comparability. Journal of Accounting and Economics, 51(3), 240-258.

Dennis, I. (2008). A conceptual enquiry into the concept of a 'principles-based' accounting standard. The British Accounting Review, 40, 260-271.

Durocher, S. \& Gendron, Y. (2011). IFRS: On the docility of sophisticated users in preserving the ideal of comparability. European Accounting Review, 2o(2), 233-262.

EC. (2002). Regulation (EC) No 1606/2002. Regulation (EC) No 1606/2002 of the European Parliament and of the Council of 19 July 2002 on the application of international accounting standards. Hentet fra https://eur-lex.europa.eu

Emmanuel, C. R. \& Garrod, N. (2002). On the relevance and comparability of segmental data. Abacus, 38(2), 215-234.

EU. (2013). Directive 2013/34/EU of the European Parliament and of the Council of 26 June 2013. Hentet fra Official Journal of the European Union: eur-lex.europa.eu

FASB. (1980). Statement of financial accounting concepts no. 2: Qualitative characteristics of accounting information. Norwalk: Financial Accounting Standards Board.

FASB. (2010). Statement of financial accounting concepts No. 8. September 2010. Norwalk: Financial Accounting Standards Board.

FASB. (2018). Statement of Financial Accounting Concepts No. 8. As amended August 2018. Norwalk: Financial Accoutning Standards Board.

Felski, E. (2017). How does local adoption of IFRS for those countries that modified IFRS by design, impair comparability with countries that have not adapted IFRS? Journal of International Accounting Research, 16(3), 59-90.

Gordon, I. \& Gallery, N. (2012). Assessing financial reporting comparability across institutional settings: The case of pension accounting. The British Accounting Review, 44, 11-20.

Gross, C. \& Perotti, P. (2017). Out-based measurement of accounting comparability: A survey of empirical proxies. Journal of Accounting Literature, 39, 1-22. 
Habib, A., Hasan, M. M. \& Al-Hadi, A. (2017). Financial statement comparability and corporate cash holdings. Journal of Contemporary Accounting \& Economics, 13, 304-321.

IASB. (2010). The conceptual framework for financial reporting. London: International Accounting Standards Board.

IASB. (2018). Conceptual framework for financial reporting. London: International Accounting Standards Board.

IASC. (1989). Framework for the preparation and presentation of financial statements. London: International Accounting Standards Committee.

IFRS Foundation. (2018). Constitution. Hentet fra www.ifrs.org: https://www.ifrs. org/-/media/feature/about-us/legal-and-governance/constitution-docs/ifrsfoundation-constitution-2018.pdf

Imhof, M. J., Seavey, S. E. \& Smith, D. B. (2017). Comparability and cost of equity capital. Accounting Horizons, 31(2), 125-138.

Kim, J., Kim, R. \& Kim, S. (2020). Does financial statement comparability mitigate delayed trading volume before earnings announcements? Journal of Business Research, 107, 62-75.

Kim, R., Kim, S. \& Musa, P. M. (2018). When does comparability better enhance relevance? Policy implications from empirical evidence. Journal of Accounting and Public Policy, 37, 436-457.

Kim, S., Kraft, P. \& Ryan, S. G. (2013). Financial statement comparability and credit risk. Review of Accounting Studies, 18(3), 783-823.

Kvaal, E. \& Nobes, C. (2010). International differences in IFRS policy choice: A research note. Accounting and Business Research, 40(2), 173-187.

Kvaal, E. \& Nobes, C. (2012). IFRS policy changes and the continuation of national patterns of IFRS practice. European Accounting Review, 21(2), 343-371.

Kvarsvik, Å. G. \& Hellenes, K. (2019). Analytikeres syn på ny regnskapsstandard for leieavtaler: En kvalitativ studie av aksjeanalytikeres opplevelser av IAS 17 og IFRS 16. Masteroppgave. Bergen: NHH.

Mita, A. F., Utama, S., Fitriany \& Wulandari, E. R. (2018). The adoption of IFRS, comparability of financial statements and foreign investors' ownership. Asian Review of Accounting, 26(3), 391-411.

Neel, M. (2017). Accounting comparability and economic outcomes of mandatory IFRS adoption. Contemporary Accounting Research, 34(1), 658-69o.

NOU 2015: 10. Lov om regnskapsplikt. Hentet fra Høring - Regnskapslovutvalgets utredning om ny lov om regnskapsplikt: www.regjeringen.no

Schipper, K. (2003). Principles-based accounting standards. Accounting Horizons, 17(1), 61-72.

Simmons, J. K. (1967). A concept of comparability in financial reporting. The Accounting Review, 42(4), 680-692. 
Sohn, B. C. (2016). The effect of accounting comparability on the accrual-based and real earnings management. Journal of Accounting and Public Policy, 35(5), 513-539.

Stubbs, M. (2010). Three concepts of keywords. I M. Bondi \& M. Scott (Red.), Keyness in texts (s. 21-42). Amsterdam: John Benjamins.

Timmermans, S. \& Epstein, S. (2010). A world of standards but not a standard world: Toward a sociology of standards and standardization. Annual Review of Sociology, 36, 69-89.

Trueblood, R. M. (1966). Accounting principles: The board and its problems. Journal of Accounting Research, 4(Empirical Research in Accounting: Selected Studies 1966), 183-191.

Wang, C. (2014). Accounting standards harmonization and financial statement comparability: Evidence from transnational information transfer. Journal of Accounting Research, 52(4), 955-992.

Weber, R. P. (1990). Basic content analysis (2. utg.). Newbury Park: Sage.

Young, J. J. (2003). Constructing, persuading and silencing: The rhetoric of accounting standards. Accounting, Organizations and Society, 28, 621-638.

Zeff, S. A. (2007). Some obstacles to global financial reporting comparability and convergence at a high level of quality. The British Accounting Review, 39(4), 290-302.

Zeff, S. A. \& Nobes, C. W. (2010). Commentary: Has Australia (or any other jurisdiction) 'adopted' IFRS? Australian Accounting Review, 20(2), 178-184.

Zhang, J. H. (2018). Accounting comparability, audit effort, and audit outcomes. Contemporary Accounting Research, 35(1), 245-276. 



\section{KAPITTEL 3}

\section{Regnskapsplikten for små foretak med forenklinger i fokus ${ }^{1}$}

Kjell Magne Baksaas

Dosent, Universitetet i Sørøst-Norge

Tonny Stenheim

Professor, Universitetet i Sørøst-Norge

Sammendrag: Ulike regler for finansregnskap og skatteregnskap medfører betydelige administrative byrder for små foretak. Slike byrder bør reduseres, og Finansdepartementet utreder nå muligheten for ytterligere forenklinger ved i større grad å harmonisere regnskaps- og skattereglene (se Schwencke, 2019). Robuste og reelle forenklinger må balansere mellom på den ene siden de formålene som finansregnskapet og skatteregnskapet har, og på den andre siden hva som kan gi størst lettelser.

$\mathrm{Vi}$ argumenterer for at harmonisering av regler for innregning og måling i finansregnskapet og skatteregnskapet kan skje på en rekke områder. Blant annet kan det oppnås stor grad av harmonisering for anleggsmidler, varer og kundefordringer ved at skattereglene i noen grad tilpasses reglene for finansregnskapet. Det skal imidlertid være enkelt å kontrollere etterlevelsen av skattereglene, og dette vil gjerne føre til regler som gir lite rom for bruk av skjønn. Dette kan i noen grad stå i et motsetningsforhold til finansregnskapets formål, som også for små foretak er å gi beslutningsnyttig informasjon. Spesielt viktig er det at finansregnskapet reflekterer urealiserte tap. Hvert foretak må uavhengig av forenklingsreglene se til at finansregnskapet som helhet ikke gir et for positivt bilde av resultat og balanse.

Vi mener det bør innføres en egen foretakskategori for særlig små foretak (mikroforetak), med betydelige forenklinger gjennom å videreutvikle koblingsmodellen, det vil si lempinger ved måling av utsatt skatt, og innføre forenklede krav til oppstillingsplanene. Forenklingsreglene bør velges ved sporvalg.

1 Takk til professor Hans Robert Schwencke ved Handelshøyskolen BI for innspill og kommentarer til et tidligere utkast av kapittelet.

Sitering av denne artikkelen: Baksaas, K. M. \& Stenheim, T. (2020). Regnskapsplikten for små foretak med forenklinger i fokus. I T. Stenheim, K. M. Baksaas og E. M. Kulset (Red.), Aktuelle temaer i regnskap og revisjon (Kap. 3, s. 83-120). Oslo: Cappelen Damm Akademisk. https://doi.org/10.23865/noasp.112.ch3 Lisens: CC-BY 4.o. 
Vi foreslår også at formuesfastsettelsen i langt større grad enn i dag skjer med utgangspunkt i regnskapsmessige verdier. Dette vil gi betydelig forenkling.

Nøkkelord: forenklinger, små foretak, finansregnskap, skatteregnskap

\subsection{Innledning}

Det legges stor vekt på innføring av forenklingsregler for små foretak i både Norge (jf. for eksempel Schwencke, 2019) og EU (jf. for eksempel regnskapsdirektiv 2013: EP/Rdir. 2013/34/EU). Næringslivet er dominert av små foretak, og derfor vil forenklinger for denne gruppen være av vesentlig samfunns$ø$ konomisk betydning. Forenklinger vil redusere utgifter til etterlevelse av administrative pålegg. Målet er et mer konkurransedyktig næringsliv og dermed også høyere skatteproveny. Det er særlig pekt på behovet for å forenkle rapporteringen av økonomisk informasjon, og da spesielt kravene til utarbeidelse av årsregnskapet. Gruppen små foretak er derimot uensartet, og dette gjør at de forenklinger som kan eller bør innrømmes, vil variere innad i denne gruppen. Behovet for forenklinger og adgangen til å innrømme forenklinger vil være størst for de aller minste foretakene (mikroforetakene).

Schwencke (2019) har på oppdrag fra Finansdepartementet utarbeidet rapporten Årsregnskapet og skatteregnskapet muligheter for forenklinger en forstudie. I denne forstudien er det pekt på muligheten til i større grad å harmonisere regnskapsmessige og skattemessige regler om innregning og måling. Andre muligheter for forenkling vil typisk omfatte å lempe på krav til oppstillingsplaner og krav til utarbeidelse av noteopplysninger. Det er ventet at flere av forslagene vil bli utredet videre med etterfølgende politisk behandling. I forkant av forstudien til Schwencke (2019) ble det i to lovutredninger fremmet forslag om forenklinger av regnskapskrav for små foretak, NOU 2015: 10 og NOU 2016: 11. Enkelte av disse forslagene, deriblant forslaget om å innføre «begrenset regnskapsplikt» for visse små foretak og unntak fra plikt til å utarbeide årsberetning for små foretak, ble implementert med virkning fra årsregnskapet 2017. I etterkant av forstudien til Schwencke (2019) er det fremmet andre syn på hvilke forenklinger som bør innføres for små foretak (se for eksempel Kristoffersen, 2019a, 2019b).

Problemstillingen i dette kapittelet er å vurdere og konkretisere forslag til forenklingsregler for innregning og måling i årsregnskapet til små 
foretak. Vurderingen og utformingen av konkrete forenklingsregler skjer med utgangspunkt i forstudien til Schwencke (2019).

Vi vil her vurdere forenklingsreglene med utgangspunkt i regnskapsog skattereglenes ulike formål. Vår vurdering er at vektlegging av deres ulike formål uten at det er lagt vekt på samordning, kan forklare hvorfor regelverkene er ulike. I tillegg vurderer vi forenklingene knyttet til årsregnskapet for små foretak som finnes i EU-regelverket, og dermed det rommet for harmonisering som vi mener finnes i EUs regnskapsdirektiv (EP/Rdir. 2013/34/EU). For at de forslagene som fremmes, skal innebære reelle forenklinger og være mulige å gjennomføre, har vi også sett forslagene i sammenheng med de krav og plikter som følger av merverdiavgiftslovgivningen der hvor dette har vært relevant.

I kapittelet gjør vi bruk av rettsvitenskapelig metode, som dels bygger på den delen av rettsvitenskapen som er å anse som rettsdogmatikk, dvs. drøfting av gjeldende rett, og den delen av rettsvitenskapen som er å anse som rettspolitikk, dvs. drøfting av foretrukket regulering (Graver, 2008; Stenheim, Baksaas \& Haaland, 2019). Bidraget er å komme med forslag til praktiske forenklinger for små foretak gjennom å harmonisere regnskaps- og skatteregler.

\subsection{Oversikt over gjeldende regnskapsregler for små foretak}

\subsubsection{Norske regnskapsregler for små foretak, unntatt begrenset regnskapsplikt}

Små foretak er foretak som faller under to av tre størrelseskriterier, jf. regnskapsloven $₫ 1-6$, og som samtidig ikke faller inn under kategorien store foretak etter regnskapsloven $\$ 1-5 .{ }^{2}$ Størrelseskriteriene for små foretak er mindre enn $\mathrm{kr} 70$ millioner i salgsinntekt, mindre enn $\mathrm{kr} 35$ millioner i balansesum og mindre enn 50 årsverk i gjennomsnitt. ${ }^{3}$ Det er et

2 Store foretak er allmennaksjeselskaper, selskaper som har noterte verdipapirer på regulert markedsplass, eller andre foretak som etter forskrift anses som store foretak.

3 Regnskapsdirektivet (EP/Rdir. 2013/34/EU) artikkel 3 fastsetter grensene til mindre enn 8 millioner euro i salgsinntekt, mindre enn 4 millioner euro i balansesum og mindre enn 50 ansatte i 
$\mathrm{krav}$ at foretaket skal falle under disse to størrelseskriteriene for to etterfølgende balansedager for at det skal kunne klassifiseres som små foretak. Etter norsk målestokk vil imidlertid et foretak med opp mot 70 millioner kroner i salgsinntekter og 50 årsverk i andre sammenhenger normalt bli oppfattet som et relativt stort foretak.

Regnskapsloven angir ulike regnskapsspor. Årsregnskapet kan utarbeides etter regnskapslovens ordinære regler, etter IFRS (International Financial Reporting Standards) ${ }^{4}$ eller forenklet IFRS 5 , jf. regnskapsloven $₫$ 3-9. Små foretak har adgang til å benytte et betydelig antall forenklingsregler i stedet for lovens hovedregler. For en oversikt over alle forenklingsregler for små foretak vises det til NRS 8 God regnskapsskikk for små foretak vedlegg 1 . Den overordnede bestemmelsen om adgangen for små foretak til å velge forenklinger er regnskapsloven $₫$ 3-1 annet ledd, som lyder: «Små foretak kan ved utarbeidelse av årsregnskap og årsberetning følge de unntaksbestemmelser som fremgår av loven.»

Forenklingsreglene for små foretak er implementert som valgadgang, dvs. at små foretak kan velge hovedregler eller unntaksregler. Det betyr at det ikke er nødvendig å velge forenklingsreglene som sporvalg, men man kan i stedet velge hovedregler på ett område og unntaksregler på et annet, jf. NRS 8, punkt 2.1.6 og NOU 2015: 10, s. 371. Dette er en reguleringsform som på mange måter ligner på regulering gjennom markedsløsning, hvor valg av hovedregler, og dermed presumptivt regler som gir høyere beslutningsnytte, kan skje som følge av insentiver hos foretaket og/eller etter påtrykk fra regnskapsbrukere (Watts \& Zimmerman, 1986; Kinserdal, 2005).

I NOU 2015: 10, s. 370-371 pekes det på fordeler og ulemper med dette:

gjennomsnitt. Medlemsstatene kan fastsette høyere grenser opp til 12 millioner euro i salgsinntekt og 6 millioner euro i balansesum.

4 Små foretak som velger å benytte regnskapsspråket IFRS, har adgang til å benytte visse forenklingsregler etter regnskapsloven, jf. regnskapsloven $\$$ 3-1 fjerde ledd. Dette gjelder blant annet notekrav for små foretak som også er pliktige notekrav i regnskapsloven for IFRS-rapporterende foretak.

5 Foretak som velger å benytte reglene for forenklet IFRS, kan ikke benytte notekrav for små foretak, jf. forskrift om forenklet anvendelse av IFRS $\$ 1-2$ annet ledd annet punktum. 
Argumentene for en slik regulering er at tilleggsvalg «oppover» kan ses på som regnskapsmessige forbedringer til glede for regnskapsbrukerne, og at slike valg over tid gjør det enklere for regnskapsprodusentene å tilpasse hele regnskapsavleggelsen til et strengere regime for eksempel som følge av et foretaks vekst eller krav til konsernrapportering. Argumentene mot er hensynet til sammenlignbarhet av regnskapsrapporteringen innenfor samme gruppe av foretak og mulighet til å velge prinsipper som fremstiller virkeligheten på den måten foretaket ønsker (såkalt «cherry-picking»).

Forenkling sett fra den regnskapspliktiges ståsted blir gjerne assosiert med flere valgmuligheter, men hvis dette betraktes fra regnskapsbrukerens ståsted, vil flere valgmuligheter i stedet være kompliserende og representere det motsatte av forenkling. For å kunne gjennomføre en regnskapsanalyse må da regnskapsbrukeren ha oversikt over ordinære regler og forenklingsregler. Han må også ha informasjon om hvilke regler som er benyttet, og hvilken virkning valg av forenklingsregler i stedet for hovedregler har på regnskapet. I praksis mangler det gjerne tilstrekkelige noteopplysninger til at regnskapsbruker kan gjennomføre en slik analyse. Etter IFRS for SMEs $(2015)^{6}$ er forenkling forstått som færre snarere enn flere valg. Det legges da mer vekt på bruk av sporvalg (hovedspor eller forenklingsspor) enn at foretakene kan velge mellom en lang rekke prinsipper, slik de kan etter norsk regulering.

Forenklingsreglene som er angitt i regnskapsloven, er i hovedsak formulert som unntak fra mer eksplisitt angitte hovedregler. For eksempel er forenklingsregler som gjelder årsregnskapets innhold, herunder unntak fra plikt til å utarbeide kontantstrømoppstilling (jf. regnskapsloven $\$$ 3-2 annet ledd), konsernregnskap (jf. regnskapsloven $\$$ 3-2 fjerde ledd første punktum) og årsberetning (jf. regnskapsloven $\$$ 3-1 annet ledd annet punktum) formulert på denne måten. Det samme gjelder unntak fra vurderingsregler (for eksempel et generelt unntak fra sikringsprinsippet, jf. regnskapsloven $\$$ 4-1 annet ledd annet punktum og unntak i regnskapsloven $\$ \$$ 5-10 til 5-12), unntak fra plikt til å utarbeide sammenligningstall (jf. regnskapsloven $\$ 6-6$ annet ledd) og unntak fra plikt til

6 International Financial Reporting Standard for Small and Medium-sized Entities som er et internasjonalt regnskapsspråk utgitt av IASB myntet på små og mellomstore foretak. 
å føre virkning av prinsippendring direkte mot egenkapitalen (jf. regnskapsloven $\$$ 4-3 tredje ledd). Forenklingsreglene for noteopplysninger er tatt inn i loven som selvstendige, komplette regelsett i lovens kapittel 7 (\$\$ 7-1, 7-35 til 7-46).

Forenklingsregler for små foretak følger også av god regnskapsskikk. I lovens kapittel 4 om de grunnleggende regnskapsprinsippene er det gitt adgang til å unnta små foretak fra opptjenings- og sammenstillingsprinsippet, jf. regnskapsloven $\$$ 4-1 første ledd nr. 2 og 3, hvis slike unntak kan begrunnes i god regnskapsskikk for små foretak, jf. regnskapsloven $₫$ 4-1 annet ledd første punktum. I praksis må slike forenklinger fremgå av NRS 8 God regnskapsskikk for små foretak, jf. NOU 2003: 23, s. 113. Eksempler på det siste er adgangen til å kostnadsføre egne utgifter til utvikling av rettigheter, jf. NRS 8, punkt 4.3.1.1, og adgangen til å velge å kostnadsføre varige driftsmidler som har kostnadsramme under $\mathrm{kr} 15$ ooo eller levetid under 3 år, jf. NRS 8, punkt 4.3.2. Begge disse er eksempler på unntak fra sammenstillingsprinsippet.

\subsubsection{Foretak med begrenset regnskapsplikt}

Små foretak som samtidig er enkeltpersonforetak eller ansvarlige selskaper uten deltakere med begrenset ansvar, kan velge å utarbeide årsregnskapet etter bestemmelsen om begrenset regnskapsplikt, jf. regnskapsloven $\$ 3$-2b. Disse foretakene er ikke omfattet av virkeområdet til EUs regnskapsdirektiv. Denne adgangen ble fremmet i NOU 2015: $10 \mathrm{og}$ NOU 2016: 11, men omfattet da en noe større gruppe regnskapspliktige enn slik virkeområdet ble angitt i regnskapsloven $\$ 3-2 b$, jf. Prop $160 \mathrm{~L}$ (2016-2017), punkt 3. Regnskapspliktige som velger å utarbeide årsregnskap etter bestemmelsen om begrenset regnskapsplikt, kan gjøre dette på grunnlag av skatterapporteringen av resultat og balanse med tillegg for noteopplysninger som anses som god regnskapsskikk for slike regnskapspliktige, jf. regnskapsloven $\$ 3$-2b første ledd første punktum. NRS ${ }_{21}$ God regnskapsskikk for foretak med begrenset regnskapsplikt gir veiledning i hvordan et årsregnskap etter $\$ 3-2 b$ skal utarbeides.

Anvendelse av reglene om begrenset regnskapsplikt innebærer med andre ord at regnskapsplikten oppfylles ved rapportering av informasjon 
fra næringsoppgaven, utarbeidet etter skattemessige regler for tidfesting av inntekter og utgifter og måling av eiendeler og forpliktelser, i stedet for særskilt utarbeidet regnskapsinformasjon etter regnskapslovens ordinære regler. Skatterapporteringen er utvidet med enkelte noteopplysninger. Disse foretakene rapporterer dermed skatteregnskapet som sitt årsregnskap.

Det er å bemerke at antall foretak som faller innenfor reglene om begrenset regnskapsplikt, er lavt. For å ikke komplisere regnskapsregimet ytterligere bør regnskapskrav for såkalte særlig små foretak (mikroforetak) etter EUs regnskapsdirektiv trolig samkjøres med reglene for foretak med begrenset regnskapsplikt etter $\$ 3-2 b$, slik at disse faller under samme foretakskategori.

\subsubsection{Regnskapsregler for små foretak i regnskapsdirektivet}

Små foretak som omfattes av virkeområdet til konsolidert regnskapsdirektiv (EP/Rdir. 2013/34/EU), det vil si aksjeselskap eller ansvarlig selskap med en eller flere deltakere med begrenset ansvar, skal utarbeide et årsregnskap som omfatter resultatregnskap, balanse og noter, jf. artikkel 4 nr. 1 første ledd.

Fjerde direktiv (78/66o/EF) og syvende direktiv (83/349/EF) ble i 2013 erstattet med et konsolidert regnskapsdirektiv (EP/Rdir. 2013/34/EU) med implementeringsfrist for EU-landene 20. juli 2015. Direktivet er ennå ikke implementert i norsk rett. En vesentlig forskjell i konsolidert regnskapsdirektiv sammenlignet med tidligere fjerde og syvende direktiv er det nye direktivets plikt og adgang til forenklingsregler for små foretak. I fortalen til direktivet punkt 10 heter det at «[d]irektivet er basert på 'tenk smått først'-prinsippet». Anvendelsen av dette «prinsippet» er spesielt tydelig når det gjelder medlemsstatenes adgang til å pålegge små foretak noteopplysninger. Slik direktivet er utformet, kan medlemsstatene bare pålegge små foretak et visst antall noteopplysninger. Disse fremgår av artikkel 16 nr. 1 og artikkel 19 nr. 3. I tillegg er det i direktivet en medlemsstatsopsjon til å kreve utarbeidelse av inntil fem noter ut over dem som er obligatoriske for små foretak. Disse fem følger av artikkel 16 nr. 2. Det fremgår tydelig 
av artikkel $16 \mathrm{nr} .3$ at medlemsstatene ikke kan kreve noteopplysninger for små foretak ut over dem som er angitt i artikkel $16 \mathrm{nr} .1$ og 2.

Når det gjelder regler for innregning og måling skiller ikke direktivet mellom små foretak og foretak som ikke er små. Imidlertid inneholder direktivet en rekke medlemsstatsopsjoner som gjør det mulig å videreføre og utvide omfanget av forenklingsregler for innregning og måling.

Regnskapsdirektivet inneholder også en egen foretakskategori for særlig små foretak (mikroforetak) (jf. artikkel 36). Medlemsstatene kan velge å utarbeide særlige forenklingsregler for disse. Dette er foretak hvor to av følgende tre kriteriene må være oppfylt på balansedagen (jf. artikkel 3 nr. 1): salgsinntekter ikke over 700 ooo euro, balansesum ikke over 350 ooo euro og gjennomsnittlig antall ansatte ikke over 10. Det er per i dag ikke innført en slik kategori i regnskapsloven, og lovutvalget foreslo heller ikke å innføre en slik kategori, jf. NOU 2015: 10, s. $380-381$ :

Innføringen av en egen foretaksklasse vil komplisere regelverket, og medføre behov for vurdering av om terskelverdiene er overskredet eller ei for regnskapsprodusentene. Etter utvalgets syn er de tilgjengelige forenklingene innenfor noteområdet ikke store nok til å veie opp for ulempene med innføring av ytterligere en foretaksklasse.

Schwencke (2019, s. 14) argumenterer for at den fleksibiliteten som finnes innenfor direktivet for denne typen selskaper, bør utnyttes. Kristoffersen (2019b) foreslår at det opprettes en slik kategori for de minste aksjeselskapene. Vi støtter også en slik foretakskategori ut fra en kost-nytte-vurdering. Det er etter vår mening fornuftig at begrenset regnskapsplikt og den regnskapsplikten som etter direktivet gjelder for særlig små foretak (mikroforetak), samordnes slik at de utgjør en foretakskategori. Dette vil fordre visse justeringer av de plikter og krav som følger av begrenset regnskapsplikt etter gjeldende $\$ 3-2 b$. Samtidig vil det innebære at forenklingsreglene for disse foretakene gjennomføres som sporvalg og ikke ved at det kan velges hovedregler på visse områder og unntaksregler på andre. Langt på vei vil dette tilsvare det Den norske Revisorforening (2009) foreslo, nemlig at mikroforetak skulle utarbeide «[å]rsregnskap etter skattelovens vurderingsregler» og med 
«[k]rav om å gi tilleggsinformasjon dersom de reelle verdiene er vesentlig lavere enn i regnskapet».

\subsection{Begrunnelse for forenklingsregler for små foretak}

\subsubsection{Kost-nytte-vurdering for små foretak}

Kost-nytte-terskelen er gjerne sett på som en generell beskrankning ved utarbeidelse av regnskapsinformasjon (Kvifte \& Johnsen, 2008; Schipper, 2010; Elling et al., 2019; IASB, 2018). Hvis ikke nytten brukerne får ved informasjonen, er større enn kostnaden det rapporterende foretaket har ved å utarbeide den, bør det ikke pålegges foretakene en plikt til å rapportere denne informasjonen. Nytten av informasjonen skal forstås som beslutningsnytten, dvs. den nytten regnskapsbrukerne har av å gjøre bedre og mer informerte beslutninger. Regnskapsbrukernes beslutninger handler ofte om ressursallokering mellom ulike foretak, dvs. å finne en mest mulig optimalt allokering av begrensede ressurser. Dette er kanskje tydeligst når man tenker på beslutninger som involverer allokering av kapital: Skal banken yte lån eller ikke til foretaket, skal en investor delta i emisjonen eller ikke? Bedre ressursallokering vil også komme foretakene til gode gjennom bedre tilgang til og mer riktig prising av ressursene (IASB, 2018, 2.41).

Felles for lovforarbeidene er at forenklingsreglene er begrunnet $\mathrm{i}$ en kost-nytte-vurdering (se for eksempel NOU 1993: 2, punkt 5.1.3). Dette går også klart frem av NRS 8, punkt 1:

Formålet med forenklingene for små foretak er å redusere disse foretakenes utgifter til finansiell rapportering. Nytteverdien av relevant regnskapsinformasjon må vurderes mot de utgifter som påløper og de ressurser som kreves ved utarbeidelse av årsregnskapet. Det er færre eksterne brukergrupper av små foretaks regnskaper sammenlignet med større foretaks regnskaper. I tillegg kan brukernes informasjonsbehov være av en annen karakter enn for øvrige foretak. 
I NOU 1995: 30, punkt 3.6.3 ble det argumentert for at forenklinger må begrunnes ut fra nytte sett opp mot kostnad:

Dersom kostnaden ved å fremskaffe opplysningen er liten, synes det unødvendig å komplisere lovteksten ved å innarbeide et unntak.

Det ble pekt på at det i en del tilfeller ikke var nødvendig med eksplisitte unntak siden forenklingsmulighetene som finnes i regnskapsdirektivene, ofte gjelder spesielle forhold som små foretak normalt ikke har noen befatning med. Samtidig ble det vist til at mer omfattende rapporteringsplikter for norske foretak enn for foretak ellers i Europa kan medføre en konkurranseulempe.

I forbindelse med evalueringen av regnskapsloven ble det pekt spesielt på foretakenes kostnader ved regnskapsrapporteringen (Ot.prp. nr. 39 (2004-2005)). I NOU 2003: 23, punkt 7.5.1 ble det blant annet uttalt:

Formålet med forenklinger for små foretak er å redusere disse foretakenes ressursbruk til utarbeidelse av årsregnskap. Det er således en målsetting at forenklinger tillates innenfor det som er forsvarlig ut fra brukernes informasjonsbehov. Ved en kostnad/nytte vurdering må de kostnader som påløper og de ressurser som kreves ved utarbeidelse av årsregnskapet, vurderes opp mot nytteverdien av relevant regnskapsinformasjon til brukerne. (...) Små foretak vil normalt relativt sett ha større kostnader ved regnskapsproduksjon i forhold til nytteverdien for brukerne enn det øvrige foretak har. Dette tilsier at hensynet til regnskapsprodusentenes kostnader må tillegges mer vekt ved vurdering av regnskapsregler for små foretak.

Kostnaden ved det å fremskaffe informasjonen omfatter direkte og indirekte kostnader. De direkte kostnadene omfatter kostnader ved å samle inn, prosessere, verifisere og bearbeide informasjonen. Dette er kostnader som bæres av den regnskapspliktige. Vurderingen av kost-nytte omfatter mer enn bare de direkte kostnadene som påløper ved utarbeidelse av informasjonen. Ved rapporteringen vil det også påløpe indirekte kostnader. Dette er kostnader som oppstår fordi regnskapet offentliggjør informasjon som det er skadelig å gjøre allment kjent. Spredning av informasjon om en pågående rettsprosess eller informasjon om konkurransefortrinn kan påføre foretaket indirekte kostnader. 
Regnskapsbrukerne vil også kunne pådra seg kostnader ved analyse og fortolkning av regnskapsinformasjonen. Eierne som regnskapsbrukere vil også bære kostnader med redusert utbytte.

I forarbeidene er det pekt på at regnskapsbrukernes behov for informasjon er annerledes i små foretak. I NOU 2003: 23, punkt 7.5.1 ble det blant annet uttalt:

Brukergruppene av små foretaks regnskapsinformasjon er noe annerledes sammensatt enn for øvrige foretak, og brukernes informasjonsbehov kan være av en annen karakter enn for øvrige foretak. Eierne har ofte direkte innsyn i virksomheten i små foretak i motsetning til i større foretak. Styrene består i større grad av arbeidende styremedlemmer. Eierne og ledelsens behov for informasjon i regnskapet kan også være mindre enn for andre foretak som følge av at små foretak ofte er mindre komplekse og mer oversiktlig enn øvrige foretak, slik at behovet for å systematisere informasjon, slik det for eksempel gjøres i regnskapet, er mindre for denne brukergruppen. På den annen side er det mange av de mindre foretakene som setter bort regnskapsutarbeidelsen til andre. Disse eierne kan dermed få et større behov som regnskapsbruker.

I Ot.prp. nr. 42 (1997-98), punkt 4.5 ble det lagt spesielt vekt på at regnskapsbrukernes behov for informasjon generelt er mindre i små foretak enn i foretak som ikke er små:

Etter departementets syn må det imidlertid være forsvarlig å legge til grunn at brukergruppenes behov for informasjon er noe mindre når det gjelder små regnskapspliktige. Eksempelvis vises det til at en rekke mindre foretak har få eiere som ofte har en direkte styring med foretakets drift. I slike tilfeller vil eierne normalt både ha egeninteresse i og anledning til å framskaffe økonomisk informasjon om foretaket. Små foretaks disposisjoner vil videre ofte være enklere enn de som foretas i større foretak med større ressurser når det gjelder finansforvaltningen. I mange tilfeller vil det derfor være enklere å få et bilde av små foretaks stilling selv med et mindre detaljert regnskap. Departementet legger opp til at reduserte behov for informasjon gir rom for reduserte krav til regnskapene. 
Det ble samtidig pekt på at kreditorenes behov for regnskapsinformasjon neppe er mindre i små foretak enn i foretak som ikke er små. Samtidig vil banker og andre finansinstitusjoner, som viktigste kreditor, være i posisjon til å kreve den informasjonen de vil ha for innvilgelse og løpende oppfølging av låneforhold. Informasjonen vil typisk inkludere perioderegnskaper, budsjetter og driftsprognoser. I tillegg vil eier ofte måtte avgi personlige garantier for foretakets lån.

Det er komplisert å beregne kost-nytte, og spesielt nytten. Regulerende myndigheter, lovgiver og regnskapsstandardsetter, vil ved å foreta regulering måtte påta seg oppgaven med å vurdere nytten av reguleringen (Schipper, 2010). Schipper konkluderer med at selv de største standardsetterne, FASB (Financial Accounting Standards Board) og IASB (International Accounting Standards Board), ikke makter å kvantifisere nytten. I stedet gjør de bare en kvalitativ vurdering (s. 320).

Dette ser man også tydelig i forarbeidene til regnskapsloven. Det er gjort forsøk på kost-nytte-vurderinger, men det er normalt ikke gjort noe konkret forsøk på å tallfeste verken nytten eller kostnaden ved å endre reglene. I NOU 1993: 2, punkt 5.1.3 «Særskilt om regnskapets formål i små foretak» heter det: «Arbeidsgruppen er ikke kjent med at slike nyttekostnads analyser har vært utført i tilknytning til regnskapsplikten. En må derfor nøye seg med en drøfting på et noe mer usikkert presisjonsnivå.» I etterkant av at NOU 2016: 11 ble avgitt, høstet regnskapslovutvalget som avgav innstillingen, kritikk fra Regelrådet (2016) for ikke i tilstrekkelig grad å ha vurdert de økonomiske konsekvensene av forslaget til ny regnskapslov?

De samme argumentene som ble løftet frem i tidligere forarbeider, er også gjentatt i NOU 2015: 10, punkt 10.5.3. Oppsummert indikerer dette at forenklingsreglene er begrunnet $i$ at forholdet mellom nytte og kostnad er annerledes for små foretak enn for foretak som ikke er små. Små foretak har forholdsmessig større kostnader ved regnskapsavleggelsen enn øvrige foretak, samtidig som økt nytte av kvalitativt bedre regnskaper er mindre enn for øvrige foretak. Forholdene er mer oversiktlige, og en større

7 Se https://regelradet.no/wp-content/uploads/2016/o9/Uttalelse-fra-Regelradet-til-Regnskapslovutvalgets-utredning-om-regnskapslovens-bestemmelser-om-aarsberetning-med-videre.pdf. 
andel av brukerne er mer involvert i små foretak og er i posisjon til å få tilgang til ikke-lovpålagt informasjon om spesifikke forhold. Det å ikke pålegge små foretak rapporteringsplikter ut over det tilsvarende foretak har i Europa, er også et argument som har vært fremme.

I fortsettelsen vil vi se nærmere på muligheten for ytterligere forenklinger for små foretak, herunder særlig små foretak (mikroforetak). Det vi ønsker å se spesielt på, er mulighetene for i større grad å harmonisere skatteregler og regnskapsregler. Kost-nytte og de rammer som EUs regnskapsdirektiv gir for forenkling, blir sentrale vurderingsmomenter.

\subsection{Harmonisering av skatteregler og regnskapsregler - er det ønskelig og mulig?}

\subsubsection{Innledende diskusjon}

Ved vurdering av om harmonisering av skatteregler og regnskapsregler er ønskelig, er det nødvendig å vurdere formålet med henholdsvis finansregnskapet og skatteregnskapet. Finansregnskapet skal gi beslutningsnyttig informasjon til et bredt sett av regnskapsbrukere og har derfor et bredt informasjonsformål, mens skatteregnskapet i stedet skal danne grunnlag for skattemyndighetenes fastsetting av skyldig skatt. Mens finansregnskapet er et offentlig tilgjengelig dokument, vil skatteregnskapet kun være tilgjengelig for skattemyndighetene.

Begrunnelsen for forenklinger må på samme måte som tidligere skje med utgangspunkt i en avveining mellom det som er nyttig informasjon for regnskapsbrukerne, og den kostnaden som regnskapsbrukerne direkte og indirekte blir påført ved å utarbeide regnskapsinformasjonen. Siden kost-nytte-forholdet er annerledes for små foretak enn for foretak som ikke er små, er det en generell presumpsjon at det bør kunne innrømmes lempninger i regelverket for denne foretakskategorien.

For foretak som faller inn under EUs regnskapsdirektivet (for eksempel aksjeselskaper), vil det ikke være anledning til å innføre lempninger ut over dem som kan gis etter direktivet. For foretak som faller utenfor direktivet, vil Norge derimot stå fritt når det gjelder innhold og omfang i regnskapsplikt, og kan derfor i prinsippet gi vesentlige lempninger (i ytterste fall frita dem helt for regnskapsplikt). Slike ytterligere lempninger 
er allerede gitt. Foretak som faller under bestemmelsen om begrenset regnskapsplikt, er innrømmet lempinger som går lenger enn dem som kan innrømmes etter direktivet, jf. regnskapsloven $₫ 3-2 b$ og NRS 21.

For at lempninger i regnskapsreglene skal medføre reell forenkling, må plikter for utarbeidelse av finansregnskapet etter regnskapsloven ses sammen med andre rapporteringsplikter, for eksempel plikter etter bokføringsloven og plikter etter merverdiavgiftsloven. For små foretak vil normalt overholdelse av bokføringslovens plikter medføre en betydelig kostnad. De krav og plikter som følger av bokføringsloven, er i hovedsak utformet av hensyn til skatte- og avgiftsmyndighetenes kontrollbehov, men skal også sikre godt grunnlag for utarbeidelse av finansregnskapet. Vesentlige forenklinger av regler for utarbeidelse av finansregnskapet vil ikke medføre vesentlige reelle forenklinger hvis ikke dette også ses i sammenheng med hvilke plikter som for eksempel følger av bokføringsloven og merverdiavgiftsloven (om behovet for å regelverk i sammenheng, se blant annet forenklingsforslag fra Den norske Revisorforening, 2018). ${ }^{8}$

Harmonisering av reglene for finansregnskapet og skatteregnskapet kan i utgangspunktet skje på en av tre måter: (1) ved at reglene for finansregnskapet tilpasses skatteregnskapet, (2) ved at reglene for skatteregnskapet tilpasses finansregnskapet, eller (3) ved at begge regelsett tilpasset et nytt felles regelsett.

Schwencke (2019, punkt 4.1) mener at det i Norge trolig har vært lagt for mye vekt på å etablere tydelige skiller mellom finansregnskap og skatteregnskap:

Sammenlignet med andre europeiske land står altså Norge helt i «fremste» rekke når det gjelder omfanget av forskjeller mellom regnskapsmessige og skattemessige måleregler, dvs. omfanget av «midlertidige forskjeller». Fra et regnskapsmessig perspektiv kan dette hevdes å være en fordel, da regnskapsretten kan utvikles uten at det får skattemessige konsekvenser. Samtidig kan et slikt system være unødig komplisert, kostnadskrevende og til dels uforståelig for foretakene. Det er derfor - i tråd med mandatet - naturlig å undersøke om de to sett av regler bør kunnes harmoniseres, dvs. bli likere.

8 Se https://www.revisorforeningen.no/globalassets/fag/selskapsrett/topp-ti-forenklinger-revisorforeningen.pdf 
Ved å gå tilbake til en type koblingsmodell (Schwencke, 2019, punkt 3.3) mellom skatt og regnskap vil det ifølge Schwencke (2019, punkt 3.3) kunne oppnås nærmest full harmonisering av reglene for finansregnskapet og skatteregnskapet. I et formelt rettslig perspektiv vil Norges forpliktelser etter EUs regnskapsdirektiv medføre at det ikke er realistisk med en full harmonisering for foretak som omfattes av regnskapsdirektivet. Kristoffersen (2019a) konkluderer med at «[e]tter min vurdering tilfredsstiller ikke dagens skatteregler kravene til finansiell rapportering som følger av EUs regnskapsdirektiv. En harmonisering av skatte- og regnskapsregler krever derfor at det utformes nye skatteregler som bygger på prinsippene i regnskapsreglene og EUs regnskapsdirektiv». Vi vil argumentere for en posisjon mellom disse to. I praksis vil det allerede i dag i normalsituasjoner kunne oppnås stor grad av harmonisering for de fleste små foretak. Innenfor de rammene som følger av regnskapsdirektivet, vil det også være rom for å gjøre bruk en del sentrale skatteregler som grunnlag for finansregnskapet. Vi kommer nærmere tilbake til dette senere i kapittelet.

\subsubsection{Harmonisering ved at skattereglene tilpasses regnskapsreglene}

Skattereglene er kompliserte, og skattesystemet som trekker rammene for skattereglene, er fastsatt utfra en rekke delvis motstridende hensyn. ${ }^{9}$ Det å endre disse reglene for å sikre harmonisering mellom finansregnskap og skatteregnskap kan derfor bli krevende. Gjeldende skattesystem er et resultat av skattereformen i 1992. Da ble effektivitet og enkelhet prioritert (jf. NOU 1989: 14) ved at hensynet til innkrevingskostnadene i større grad fikk prioritet over andre hensyn. Kristoffersen (2019a, s. 46)

9 Fallan (2011) stiller opp følgende dels kryssende og dels motstridende hensyn: 1) Skattereglene skal innbringe midler til det offentlige, både for å finansiere kollektive goder/velferdsgoder og som virkemiddel i finanspolitikken (provenyformål), 2) de skal legge til rette for effektiv kontroll, fremme forutsigbarhet og i minst mulig grad hindre effektiv ressursutnyttelse, noe som tilsier at reglene bør være enkle å praktisere (kontrollformål), 3) de skal tilpasses skatteyternes evne til å svare skatt av inntekter og formue og bidra til hensiktsmessig omfordeling av inntekter og formue (skatteevneprinsippet), (4) de bør utformes slik at ulike skatteytere stilles likt av rettssikkerhetshensyn (likebehandlingsprinsippet), og (5) de bør helst være i samsvar med andre lands regler (internasjonal skattekonkurranse). Av og til bruker dessuten myndighetene skattesystemet til å favorisere en viss type adferd eller aktivitet (skattefavorisert adferd). 
peker på at «[s]kattereglene bør være næringsnøytrale, enkelt utformet og uten skjønnsmessige vurderinger». Det er særlig to forhold som synes å være spesielt krevende hvis det velges en løsning for harmonisering hvor skattereglene tilpasses regnskapsreglene, og det er hensynet til henholdsvis innkrevingskostnader (kontrollprinsippet) og likebehandling (likebehandlingsprinsippet).

Innkrevingskostnader er summen av de kostnadene skatteetaten har ved å administrere innkrevingen og skatteyter har ved å overholde reglene (Fallan, 2011). En tilpasning av skattereglene slik at det for eksempel i større grad åpnes for fradrag for urealiserte tap, vil medføre forenklinger for skatteyter, men gjøre det mer komplisert å kontrollere etterlevelsen av skattereglene fordi fradragsposter da fastsettes ved mer bruk av skjønn. Dette vil kunne øke risikoen for ulovlig skattemessig tilpasning. Harmoniseringsforslagene bør utformes slik at skatteetaten får en enkel og effektiv kontroll av for eksempel urealiserte tap.

Det andre forholdet som er krevende med tanke på en tilpasning av skattereglene til regnskapsreglene, er hensynet til likebehandling av skatteyterne. For eksempel uttalte Finansdepartementet i 2005 i forbindelse med innføringen av IFRS som pliktig og valgfritt regnskapsspråk i Norge at ulik regnskapsmessig behandling av for eksempel usikre forpliktelser og avsetninger etter ordinære norske regnskapsregler og IFRS burde nøytraliseres skattemessig (Ot.prp. nr. 26 (2005-2006), punkt 6.1.2.1). Hvis det for eksempel søkes en løsning hvor skattereglene tilpasses regnskapsreglene for å oppnå lempninger for små foretak, vil dette kunne medføre at slike foretak er underlagt andre og fradragsmessig gunstigere skatteregler enn foretak som ikke er klassifisert som små. Dette vil forsterke insentiver for skattemessig tilpasning, for eksempel ved at foretak blir splittet for å komme under størrelsesgrensene for små foretak. Ut fra et rettspolitisk synspunkt er det derimot tankevekkende at likebehandlingsprinsippet ikke i samme grad praktiseres for formuesskatt som for inntektsskatt. De personlige aksjonærene betaler formuesskatt av sine aksjer i foretaket, noe institusjonelle, offentlige og utenlandske aksjonærer ikke gjør. Et forslag som også synes å kunne ivareta et likebehandlingsprinsipp, vil være at små foretak der aksjonærene plikter å betale formuesskatt, i et større 
omfang enn i dag kunne få fradrag for urealiserte tap med virkning for skattepliktig inntekt.

Et siste forhold er provenyvirkninger. En tilpasning av skattereglene til regnskapsreglene vil tillate mer fradrag for urealiserte tap enn hva tilfellet er i dag. Større fradrag for urealisert tap vil åpenbart redusere skattegrunnlaget og på den måte få en negativ provenyvirkning for staten. Med forutsetningene som er lagt inn i utredningen til Schwencke (2019), vil det økte fradraget i stor grad gjelde kortsiktige poster. Under normale forhold vil slike avsetninger for urealiserte tap avklares ved realisasjon i etterfølgende periode. Provenytapet inneværende år vil i slike tilfeller kunne reverseres neste år. Størrelsen og betydningen av provenyvirkningen vil naturlig nok variere med innretning, utforming og omfang av slike fradrag.

\subsubsection{Harmonisering ved at regnskapsreglene tilpasses skattereglene}

Harmonisering kan også skje ved at regnskapsreglene tilpasses skattereglene. Slik tilpasning må i så fall skje slik at finansregnskapets formål om å gi beslutningsnyttig informasjon ivaretas, men vurdert ut fra at det her er snakk om små foretak (jf. vurderingen av kost-nytte for små foretak). En full harmonisering der reglene for finansregnskapet i stor grad tilpasses reglene for skatteregnskapet, gir en type regnskap som i mer spesielle situasjoner gir for lite beslutningsnyttig informasjon. For eksempel vil det etter gjeldende skatteregler være svært lite rom for å kunne innregne urealiserte tap. En løsning hvor det ikke er noe klart krav om å innregne urealiserte tap i finansregnskapet, vil trolig heller ikke være i samsvar med krav etter regnskapsdirektivet (jf. krav om nedskrivning av anleggsmidler og omløpsmidler i artikkel 12 nr. 6 bokstav b og artikkel 12 nr. 7.) Et vesentlig punkt i harmoniseringsarbeidet er å operasjonalisere disse mer spesielle situasjonene som i dag medfører at skattereglene ikke kan følges.

Norsk regnskapsregulering kjennetegnes ved at selve regnskapsplikten (hvilke foretak som er regnskapspliktige og det overordnede innholdet i regnskapsplikten) følger av regnskapsloven, som dermed utgjør en 
rammelov. De mer detaljerte reglene vil følge av hva som anses som god regnskapsskikk, jf. regnskapsloven $\$ 4$-6. I tolkningen av bestemmelser i loven vil forarbeider være sentrale. Det gjelder også tolkningen av hva som anses som god regnskapsskikk. Norsk RegnskapsStiftelse har vært en sentral premissleverandør når det gjelder hva som bør anses som god regnskapsskikk gjennom å fastsette norske regnskapsstandarder. Disse regnskapsstandardene må i alle tilfeller ligge innenfor de rammer som til enhver tid følger av regnskapsloven. Forenklingsregler for små foretak kan derfor dels gis som eksplisitte bestemmelser i loven, og dels ved at forenklingsløsningene kan anses som god regnskapsskikk for små foretak.

I praksis vil det trolig også være et visst rom for at små foretak selv kan gjøre ytterligere forenklinger gjennom en vurdering av kost-nytte og vesentlighet. I fortsettelsen vurderer vi konkrete forslag til mer harmonisering mellom regnskapsregler og skatteregler.

\subsubsection{Anleggsmidler}

Anleggsmidler skal etter gjeldende regnskapslov avskrives over økonomisk levetid etter en fornuftig avskrivningsplan, jf. regnskapsloven $₫$ 5-3 annet ledd. Periodisering av avskrivbart beløp (anskaffelseskost redusert for eventuell restverdi) over økonomisk levetid blir derfor et sentralt spørsmål ved regnskapsmessig behandling av anleggsmidler. Avskrivningsplanen innebærer en vurdering av avskrivningsmetode, dvs. en fastsetting av profilen eller forløpet for verdifallet som følge av forbruk og elde og en vurdering av økonomisk levetid. I praksis benyttes lineære avskrivninger i stor grad, men det benyttes ofte for kort økonomisk levetid, noe som fører til at anleggsmiddelet kan være helt avskrevet selv om det fortsatt bidrar med økonomiske fordeler i foretaket. Dette vil redusere informasjonsverdien til finansregnskapet (Schwencke et al., 202O, s. 291). Etter regnskapsdirektivet er det krav om at anleggsmidler skal avskrives planmessig hvis anleggsmiddelet har begrenset økonomisk levetid, jf. artikkel 12 nr. 5 . Av den grunn synes det ikke å være noe i veien for å tilpasse avskrivningene i finansregnskapet til skattemessige avskrivninger, som i all hovedsak følger saldoprinsippet (jf. skatteloven $\$ \$ 14-40$ til 14-48). 
Det er derimot noe mer krevende å få til full harmonisering gjennom tilpasning av regnskapsreglene til skattereglene på andre områder. Det gjelder spesielt behandling av salg eller annen realisasjon av anleggsmidler og plikt til å nedskrive anleggsmidler ved verdifall. På disse områdene må det markeres når regnskapsmessige spesialbestemmelser må følges. Under beskriver vi hovedtrekkene i vårt forslag til tilpasning for anleggsmidler:

\section{Bruk av skattemessige avskrivninger i finansregnskapet - endring av regnskapsreglene}

Små foretak bør kunne bruke skattemessige avskrivninger, herunder avskrivninger etter saldoprinsippet, som avskrivninger også i finansregnskapet (se også Schwencke, 2019, s. 20). I gjeldende regnskapslov $\$ 5-3$ annet ledd er det vist til krav om fornuftige avskrivninger. Etter NRS 8, punkt 4.3.2.1 er det adgang til å benytte skattemessige avskrivninger hvis disse oppfyller krav til fornuftige avskrivninger. Avskrivninger etter saldoprinsippet vil i mange tilfeller gi vel så korrekte, i betydningen fornuftige, bedriftsøkonomiske avskrivninger som lineære avskrivninger. Det er derfor ikke strengt tatt nødvendig å endre bestemmelsen i $\$$ 5-3 annet ledd for at små foretak kan benytte saldoavskrivningene som regnskapsmessige avskrivninger. En omtale i forarbeider vil imidlertid være formålstjenlig slik at tilpasningen kan gjennomføres i god regnskapsskikk for små foretak med henvisning til disse. Skattemessig er avskrivningsprosentene maksimalsatser (jf. skatteloven $\$ 14-43$ ), og det må forutsettes at man ikke avviker vesentlig fra disse. Hvis skattemessige avskrivninger skal kunne brukes ubetinget, må det derimot gjøres endringer i lovbestemmelsen.

For tidsbegrensede rettigheter (en undermengde av immaterielle eiendeler) skal det benyttes lineære avskrivninger over levetiden som skattemessige avskrivninger, jf. skatteloven 14-50. Dette er en avskrivningsplan som synes å være sammenfallende med den som normalt brukes i finansregnskapet.

For saldogruppe b «ervervet goodwill» (jf. skatteloven $\$ 14-41$ første ledd bokstav b) er det derimot ikke mulig å tilpasse regnskapsreglene til skattereglene fullt ut, men denne bestemmelsen er i minimal bruk for 
små foretak. Etter EU-direktivet artikkel $12 \mathrm{nr}$. 11 skal goodwill avskrives over økonomisk levetid, men i unntakstilfeller der den økonomiske levetiden ikke kan fastsettes pålitelig, skal goodwill avskrives over et maksimalt antall år fastsatt av medlemsstaten. Denne maksimumsperioden skal være på minst fem år og høyst ti år.

\section{Kapitalvarer på egne saldoer - endring av skattereglene}

Som omtalt tidligere, bør flere regelverk ses i sammenheng hvis det skal sikres reelle forenklinger for små foretak. Etter merverdiavgiftsloven kapittel 9 er det særlige regler knyttet til behandling av inngående merverdiavgift på såkalte kapitalvarer (omtalt som justeringsregler). Kapitalvarer omfatter blant annet maskiner, inventar og andre driftsmidler med kostpris inklusiv merverdiavgift som er høyere enn kr 250 ooo, jf. merverdiavgiftsloven $\$$ 9-2 annet ledd bokstav a. Dette er eiendeler som i alle tilfeller må føres på egne kontorer i regnskapssystemet, uavhengig av regnskaps- og skatteregler, for at foretaket skal overholde reglene om justeringsplikt. Kristoffersen (2019a) foreslår en «[e]gen saldogruppe for vesentlige transportmidler, personbiler mv. som er godkjent for kjøring på offentlig veg». Vi mener en slik avgrensing til vesentlige kjøretøy og transportmidler ikke vil være til særlig hjelp. Derimot mener vi at egne skattemessige saldoer for de enkelte kapitalvarene vil redusere den mengden eiendeler som gjenstår ført på samlesaldoer, saldogruppe a til d og eventuelt $\mathrm{j}$, i så stor grad at føringen av disse i skatteregnskapet også kan gjøres i finansregnskapet. Når det gjelder kapitalvarer knyttet til fast eiendom, vil disse allerede være ført på egne skattemessige saldoer, jf. skatteloven $₫ 14-41$.

\section{Bruk av andre deler av det skattemessige saldosystemet}

Det skattemessige saldosystemet omfatter skattemessige avskrivninger (saldoavskrivninger) og skattemessig behandling av gevinst og tap ved salg og annen realisasjon av anleggsmidler. Det er utfordrende å gi full virkning for finansregnskapet av skattemessig behandling av gevinster og tap. Saldosystemet er lagt opp slik at gevinster og tap ved salg av varige driftsmidler og immaterielle eiendeler periodiseres over tid. 
For å oppnå reell forenkling må i utgangspunktet resten av saldosystemet også tas i bruk. Dette betinger imidlertid at endringen vi foreslo i forrige avsnitt om at kapitalvarer skal få egne saldoer, innføres. Saldosystemet gir mulighet til å utsette beskatningen av gevinster, samtidig som det er plikt til å utsette fradrag for tap. For saldogruppe a til d og j skal den delen av salgssummen som ikke inntektsføres umiddelbart, føres til fradrag i saldoverdien. Hvis salgssummen føres til fradrag, vil dette gi lavere fremtidige skattemessige fradrag i form av avskrivninger, noe som innebærer at salgssummen kommer til beskatning i tiden fremover som følge av skattemessige mindreavskrivninger. Hvis salgssummen gjør at vi får en tom negativ saldo, skal det inntektsføres fra denne med minst avskrivningssatsen.

Ved at vesentlige driftsmidler føres på egne saldoer, oppnår vi at restbeløpet på samlesaldoene består av relativt små driftsmidler som i de aller fleste tilfeller ikke vil medføre vesentlige gevinster og tap ved realisering. Vi mener derfor at det kan forsvares å bruke saldosystemet fullt ut på disse samlesaldoene. Et unntak må være i spesielle situasjoner der foretak har en vesentlig tom positiv saldo i saldogruppe a til d og j (jf. skatteloven $\$$ 14-44 annet ledd), dvs. saldoer som ikke lenger inneholder driftsmidler, men hvor det fortsatt står en verdi som skal avskrives skattemessig fremover. Vesentlige tom positiv samlesaldo må kostnadsføres umiddelbart i finansregnskapet, selv om skattereglene kun gir fradrag over tid.

Ved salg av driftsmidler knyttet til enkeltsaldoer har saldosystemet også en type gevinst- og tapsberegning. Etter at salgssummen har redusert gjenværende saldo, vil gevinst eller tap fremstå som restsaldoen. Denne skal overføres til en felles gevinst- og tapskonto (jf. skatteloven $\$ 14-44$ tredje ledd). Netto gevinst fra gevinst- og tapskontoen inntektsføres hvert år med minimum 20 prosent, mens netto tap fradragsføres med maksimalt 20 prosent hvert år. Netto gevinst vil fremstå som en positiv saldo på gevinst- og tapskontoen. Vi foreslår at den presenteres som ubeskattet egenkapital i finansregnskapet. Se vårt forslag om innføring av koblingsmodellen senere i kapittelet.

En negativ saldo på gevinst- og tapskontoen vil representere et tap og ikke være en regnskapsmessig eiendel. Tapet vil være det samme som en 
tom positiv saldo, som må kostnadsføres umiddelbart i finansregnskapet. Det må også presiseres at saldosystemet ikke kan følges dersom hele eller deler av salgssummen inntektsføres knyttet til disse saldogruppene (jf. skatteloven $\$ 14-44$ første ledd).

Saldosystemets behandling av gevinster og tap vil stride mot hvordan man regnskapsmessig normalt innregner gevinster og tap som er knyttet til transaksjoner. Ved bruk av saldosystemet må man kompensere for dette med noteopplysninger om transaksjoner ført på saldoer uten at postene vises i resultatregnskapet.

\section{Regnskapsmessig nedskrivning uten skattemessig fradrag}

Plikt til å nedskrive anleggsmidler ved ikke-forgående verdifall følger av regnskapsloven $\S_{5-3}$ tredje ledd. Tilsvarende nedskrivningsplikt følger også av regnskapsdirektivet, jf. artikkel 12 nr. 6. I god regnskapsskikk for små foretak er nedskrivningstesten operasjonalisert som test av balanseført verdi for eiendelen (mer generelt: vurderingsenheten) mot gjenvinnbart beløp for eiendelen, definert som høyeste verdi av netto salgsverdi og bruksverdien til eiendelen, jf. NRS 8, punkt 4.3.2.2. I praksis er det sjelden at det er behov for nedskrivninger, men i særlige situasjoner vil regnskapet lide av vesentlig mangler om nedskrivning ikke foretas. Det å unnlate nedskrivning i slike tilfeller vil også kunne stride mot regnskapsdirektivet. Kristoffersen (2019a) henviser til vurdering av forsvarlig egenkapital og likviditet (jf. aksjeloven $\$ 3-4$ ) og peker på viktigheten av å regne inn urealiserte tap slik at egenkapitalen ikke blir overvurdert. Vi er enig i at man må unngå at regnskapsreglene legitimerer vesentlig overvurderte verdier og dermed vesentlig høyere egenkapital enn det som er reelt.

Schwencke (2019, s. 20) argumenterer for at nedskrivningsreglene bør gjennomgås på nytt med tanke på å oppnå større forenklinger for små foretak. Vi mener at selve kravet om nedskrivning uten skattemessig fradrag (skattereduserende midlertidig forskjell) ikke kan avskaffes helt. På dette området vil det ikke være mulig med full harmonisering. Forenklingene må da i stedet skje ved å forenkle selve nedskrivningsinstituttet. En forenkling kan være å legge opp til bruk av mer aggregerte indikatorer for verdifall, for eksempel indikatorer på foretaksnivå, slik at det blir 
tydeligere at foretaket er i en nedskrivningssituasjon. Dette vil trolig også medføre sjeldnere behov for nedskrivningstesting.

Det andre er å forenkle selve nedskrivningstesten. Kravene i NRS 8 er omfattende og vil på mange måter ligge nær de kravene som følger av full IFRS og IAS 36 Verdifall på eiendeler. I de aller fleste tilfeller vil små foretak ha bare én kontantgenererende enhet som grunnlag for testingen. Vi mener derfor at det bør innføres en generell adgang til å definere hele foretaket som vurderingsenhet ved nedskrivningstest. Det å estimere bruksverdi vil i de fleste tilfeller være komplisert hvis denne estimeringen skal holde faglig god kvalitet. En forenkling vil være å tillate små foretak å innhente takst på foretaket som helhet og benytte denne som estimat på gjenvinnbart beløp.

En presisering vil være at hvis et foretak velger å inntektsføre hele eller deler av salgssummen for saldogruppene (jf. skatteloven $\$ 14$-44 første ledd), vil dette være en indikator på at saldoen bør nedskrives med virkning for finansregnskapet.

\section{Presisering angående forskning og utvikling - endring av skattereglene}

I skatteretten er grensen mellom aktivering og fradragsføring av FOU-utgifter regulert i skatteloven $\$ 6$-25. Der heter det at «kostnader til egen forskning og utvikling knyttet til konkrete prosjekter som kan bli eller er blitt til driftsmidler, skal behandles som del av kostprisen for vedkommende driftsmiddel.» Her foreslår Schwencke (2019, s. 24) at den skattemessige bestemmelsen tilpasses skillet mellom balanseføring og kostnadsføring etter regnskapsretten, jf. regnskapsloven $₫ 5$-6. Dette vil innebære at utgifter til egen forskning og utvikling kan fradragsføres skattemessig. Vi støtter dette forslaget.

\section{Krav til anleggsregister?}

De fleste foretak har et anleggsregister. Bakgrunnen kan være bokføringslovens regler om dokumentasjon av balansen (jf. bokføringsloven $\$ 11)$, som i praksis er tolket som et krav om å registrere og oppdatere et anleggsregister for alle balanseførte eiendeler. Kaaby (2015, s. 360-361) kommenterer dokumentasjon av varige driftsmidler og henviser til at 
Skattedirektoratet var opptatt av dokumentasjon gjennom anleggsregister i høringsrunden til bokføringsloven. I gjennomgangen av plikter etter bokføringsloven nevner imidlertid ikke Kaaby noen plikt om anleggsregister. Vi mener at det fremstår noe underlig at det er nettopp skattemyndighetene som er opptatt av anleggsregister. De forvalter jo saldosystemet, der samlesaldoer ikke gir grunnlag for å spesifisere hver enkelt eiendel. Vi vil mene at større krav om bruk av enkeltsaldoer vil utgjøre en tilstrekkelig dokumentasjon (og fungere som en type anleggsregister). Tidligere har vi foreslått krav om å føre såkalte kapitalvarer på egne kontoer i regnskapssystemet som følge av justeringsplikt etter merverdiavgiftsloven. Vi mener videre at det ikke skal stilles opp et krav om at driftsmidlene som da er igjen på samlesaldoene, skal registreres særskilt i et anleggsregister.

Oppsummert vil det etter vår vurdering ikke være mulig med full harmonisering for driftsmidler, men å legge til rette for harmonisering i normale driftsperioder vil representere en betydelig forenkling.

\subsubsection{Varelager}

Varer vurderes til laveste verdi av anskaffelseskost og virkelig verdi, jf. regnskapsloven $\$ 5$-2, hvor virkelig verdi fastsettes som netto salgsverdi, jf. NRS 8, punkt 4.4.1.1. Ved kjøp skal anskaffelseskost fastsettes som kjøpspris med tillegg for kjøpsutgifter, mens ved tilvirkning blir anskaffelseskost faste og variable tilvirkningskostnader, jf. regnskapsloven \$ 5-4 første ledd. Små foretak kan velge å innregne bare variable tilvirkningskostnader, jf. regnskapsloven $\$ 5-4$ annet ledd. Etter skatteloven omfatter tilvirkningskost (der omtalt med begrepet tilvirkningsverdi) direkte variable kostnader slik som «råstoff, halvfabrikata, hjelpestoff og produksjonslønn», jf. skatteloven $\$ 14-5$ annet ledd bokstav a. Tilvirkningskostnad i skatteloven omfatter altså ikke indirekte variable kostnader. I regnskapsdirektivet er det bare krav om at tilvirkningskost inkluderer direkte kostnader (trolig tolket som direkte variable kostnader), jf. artikkel 2 nr. 7. Av den grunn synes det ikke å være noe som er til hinder for å kunne la skattelovens bestemmelse også få virkning for finansregnskapet. 
Anskaffelseskost skal enten fastsettes ved spesifikk tilordning eller etter FIFU-prinsippet (først-in-først-ut) eller gjennomsnittlig anskaffelseskost, jf. regnskapsloven $\$ 5-5$. Etter skatteloven er hovedregelen også spesifikk tilordning, men hvis slik tilordning ikke er mulig, skal tilordningen skje ved bruk av FIFU-prinsippet, jf. skatteloven $₫ 14-5$ annet ledd bokstav b. Ludvigsen og Baksaas (2012) påviser at FIFU-prinsippet er nærmest umulig å praktisere, og selv i systemer hvor det hevdes at FIFU-prinsippet etterleves, benyttes i realiteten gjennomsnittlig anskaffelseskost. For å sikre større mulighet for praktisk harmonisering, bør skattereglene endres slik at det er adgang til å kunne bruke gjennomsnittlig anskaffelseskost (som et alternativ til FIFU-prinsippet).

Varelager skal måles til laveste verdis prinsipp etter regnskapsdirektivet, jf. artikkel 12 nr. 7. Dette innebærer at skattelovens bestemmelse om at det ikke skal tas hensyn til opp- eller nedskrivning av verdien av varebeholdning ved fastsettelse av inntekt, ikke kan legges til grunn for utarbeidelse av finansregnskapet. I stedet vil verdifall på varer først få skattemessig virkning når varene er realisert, jf. skatteloven $₫ 9$-2. Det betyr at med mindre skattereglene endres, vil det måtte bli midlertidige forskjeller mellom finansregnskap og skatteregnskap når det gjelder varer.

Schwencke (2019, s. 30-31) foreslår endringer i skattereglene slik at den regnskapsmessige behandlingen av verdifall på varer er bestemmende for den skattemessige behandlingen. I de tilfeller der det er grunnlag for nedskrivning, foreslås det altså at skattereglene endres slik at nedskrivningene også kan få skattemessig virkning, men med den forutsetning at nedskrivningen kan dokumenteres (jf. kontrollhensynet). Schwencke (2019) foreslår at fradrag skal dokumenteres ved salgspriser eller inngåtte salgskontrakter. Vi vil hevde at det må kunne innrømmes skattemessig fradrag for verdifall i varelageret også i andre situasjoner. Det er bare for enkelte ukurante varer det er mulig å stille opp en slik dokumentasjon som Schwencke viser til. Vi mener at det også bør kunne innrømmes skattemessig fradrag når disse varene er fysisk skilt ut fra øvrig varelager og salg fra dette varelageret blir særskilt registrert. Det er viktig å påpeke at et fradrag som er større enn hva det skulle vært grunnlag for, bare vil få en kortvarig effekt på skatteprovenyet siden varer normalt har forholdsvis stor omløpshastighet. 
Ved salg av disse varene vil det som eventuelt er nedskrevet for mye, bli effektivt reversert. Av hensyn til skatteprovenyet er det mulig at det bør fastsettes maksimale grenser for nedskrivning for ukurans på for eksempel to prosent av total anskaffelseskost for varelageret og/eller for eksempel 2 prosent av salgsinntekter. En slik regel med sjablongmessig nedskrivning bør baseres på erfaringstall.

Forslaget om å kunne innrømme skattemessig fradrag ut over de tilfeller hvor dette kan dokumenteres gjennom salgspriser eller inngåtte salgskontrakter, vil også passe godt inn i et bærekraftsperspektiv (jf. også FNs bærekraftsmål). I et bærekraftsperspektiv er det dårlig samfunnsøkonomisk løsning å gi skattemessig fradrag først ved kassering av varer. I overgang til sirkulær økonomi må naturressurser resirkuleres og forvaltes bedre.

I praksis er det bare et fåtall små foretak som har et tilfredsstillende godt vareregistreringssystem. Typisk har de fleste skybaserte regnskapssystemer ikke ordre-lager-fakturering-innkjøp (såkalt OLFI-moduler). Noe av kompleksiteten på dette området er derfor å finne praktikable løsninger.

\subsubsection{Kundefordringer}

Kundefordringer vurderes til laveste verdi av anskaffelseskost og virkelig verdi, jf. regnskapsloven $₫ 5-2$, hvor virkelig verdi fastsettes som forventet innbetaling på fordringen (eventuelt justert for renteeffekt), jf. NRS 8 , punkt 4.4.3. Det betyr at konstaterte og forventede tap må føres til fradrag for at man skal komme frem til virkelig verdi på fordringene. Det er to problemstillinger her. Det ene er å vurdere harmonisering av regnskapsregler og skatteregler når det gjelder vurdering av når en fordring er konstatert tapt, eller i skatterettslige termer, når tapet anses realisert. Her bør det også gjøres en vurdering av om merverdiavgiftsreglenes vilkår for konstaterte tap kan samordnes med reglene i regnskapsretten og i skatteretten, slik at ett felles sett av vilkår kan gjelde for alle tre regelsett. Det andre er å vurdere harmonisering av reglene for nedskrivning av urealiserte tap i kundefordringer. Vår antagelse er at et betydelig antall små foretak i dag har skattereduserende midlertidige forskjeller knyttet 
til kundefordringer. Dette er derfor et område der behovet for harmonisering og forenkling er betydelig.

\section{Konstatert tap}

Etter god regnskapsskikk vil det foreligge et konstatert tap når det er overveiende sannsynlig at fordringen helt eller delvis ikke vil bli betalt. Fordringen skal nedskrives når den anses som uerholdelig, eksempelvis etter gjentatte purringer uten at fordringen er innfridd, ved forgjeves inkasso eller ved åpning av gjeldsforhandlinger eller konkurs hos debitor, jf. NRS 8, punkt 4.4.3. Etter skatteretten er det først når tapet anses realisert, at det innrømmes fradrag, jf. skatteloven 6-2. I forskrift til skatteloven \$ 6-2-1 er det gitt nærmere regler for når et tap anses endelig konstatert. Schwencke (2019, s. 25-29) har gitt en grundig omtale av dette regelverket og har også kommet med forslag til endringer i skattereglene som gjør at disse kan samordnes med finansregnskapet. Vi støtter disse forslagene.

Det bør også foretas en samordning av reglene for konstatert tap i skatteloven og merverdiavgiftsloven (merverdiavgiftsloven $\$ 4-7$ og merverdiavgiftsforskriften $₫ 4-7-1$ ). Dette vil være vesentlig forenklende. Begge regelsettene har det samme grunnleggende formålet.

\section{Avsetning/nedskrivning av urealisert tap}

I utgangspunktet åpner ikke skatteloven for fradrag for urealiserte tap på fordringer, men det gjøres et unntak for kundefordringer, jf. skatteloven $\$ 14-5$ fjerde ledd. Her kan det benyttes en sjablongmessig nedskrivning som tar utgangspunkt i gjennomsnittlig skattemessig tapsprosent siste to år beregnet som konstaterte skattemessige tap siste to år dividert på kredittsalget siste to år. Denne tapsprosenten multipliseres med faktortallet fire, og produktet av dette igjen multipliseres med utestående kundefordringer. Avsetningen blir dermed gjennomsnittlig skattemessig tap siste to år multiplisert med fire. I utgangspunktet lyder dette som en raus fradragsordning, men i praksis har foretakene ofte større regnskapsmessige nedskrivninger enn dette. Årsaken er at det ofte tar lang tid å få avklart om en fordring må anses som tapt. Tidsfaktoren vil jo inkludere purrerutiner, rettslig pågang og forhandlinger ved uenighet om beløpets størrelse. Derfor vil det oftest være flere usikre fordringer i 
kundefordringsmassen enn det som reflekteres av den gjennomsnittlige skattemessige tapsprosenten. En mulig løsning for samordning vil være å øke faktoren fra fire til et faktortall som i større grad reflekterer det forventede tapet. Dette faktortallet bør i så fall settes med utgangspunkt i et bredt erfaringsmateriale, og av kontrollhensyn bør det fastsettes et felles faktortall (for eksempel et faktortall på åtte eller ti). Et høyere faktortall kan suppleres med at avsetningen ikke kan overstige utestående fordringer på balansedagen som ikke er betalt ved regnskapsavleggelsen. En illojal tilpasning vil da la seg lett identifisere ved se på innbetalinger av fordringer etter balansedagen.

I mange situasjoner vil en sjablongmessig nedskrivning (med et noe høyere faktortall enn gjeldende faktortall fire) kunne gi en tilfredsstillende løsning også for finansregnskapet, men i særlige situasjoner kan kundefordringene kreve separat vurdering pga. stor usikkerhet om vesentlige nedskrivninger. Det vil oppfylle regnskapsdirektivets krav om bruk av laveste verdis prinsipp for fordringer, jf. artikkel $12 \mathrm{nr} .7$.

\subsubsection{Uopptjent inntekt}

Opptjeningsprinsippet, jf. regnskapsloven $₫$ 4-1 første ledd nr. 2, stiller krav om at bare den delen av inntekten som anses opptjent, skal innregnes som inntekt. Det innebærer at salgsavtaler som består av separable ytelser, må periodiseres hvis opptjeningen (ytelsene) skjer på ulike tidspunkt, jf. NRS (V) Regnskapsføring av inntekt, punkt 5.1. Et klassisk eksempel på dette er salg av en bil med garanti og hvor inntekten fra salget av selve bilen skjer når den leveres kunden, mens garantiinntekten først opptjenes etter hvert som garantiperioden løper. Små foretak kan derimot følge en forenklingsregel, jf. NRS 8, punkt 6.2.1.8.5, som sier at de som et alternativ kan innregne salgsbeløpet i sin helhet og i stedet foreta en kostnadsavsetning. I eksempelet med bil med tilhørende garanti betyr dette at hele salgssummen for bil og garanti innregnes på leveringstidspunktet for bilen, og at det samtidig foretas en kostnadsavsetning for forventede utgifter knyttet til garantiytelser. På de fleste områder vil ikke anvendelse av forenklingsregler medføre at det oppstår nye midlertidige forskjeller mellom finansregnskap og skatteregnskap. Men her vil 
det være unntak. Den skattemessige tidfestingen av inntekten vil være når ytelsen er levert (jf. også omtale i Skatte- $A B C$ 2019/20, punkt 4.1). Vi mener at små foretak som utnytter denne regnskapsmessig forenklingen i NRS, 8, punkt 6.2.1.8.5, også bør få skattemessig fradrag for den regnskapsmessig avsetningen.

\subsubsection{Permanente resultatforskjeller må resultatføres}

Permanente resultatforskjeller må kostnadsføres eller inntektsføres i finansregnskapet. En måte å håndtere dette på er å anvende en type koblingsmodell som kobler skattemessig resultat og regnskapsmessig resultat med en gruppe poster bestående av de permanente resultatforskjellene. Det er for eksempel helt utenkelig at en stor representasjonskostnad ikke skal kostnadsføres i finansregnskapet som følge av at foretaket ikke får skattemessig fradrag for utgiften. Ved valg av en koblingsmodell må det gjøres en vurdering av om regnskapsdirektivets krav til oppstillingsplaner er oppfylt. I nesten avsnitt diskuteres disse kravene mer i detalj.

\subsubsection{Utsatt skatt-modellen og koblingsmodellen}

Utsatt skatt-modellen håndterer skatt knyttet til skatteøkende midlertidige forskjeller (grunnlag for utsatt skatt) og skattereduserende midlertidige forskjeller (grunnlag for utsatt skattefordel) ved at utsatt skatt eller utsatt skattefordel innregnes i balansen. Etter regnskapsdirektivet er det bare i konsernregnskapet man plikter å bruke denne modellen, jf. artikkel 24 nr. 13 annet ledd (se også tolkning av regnskapslovutvalget i NOU 2015: 10, s. 136). Det kan synes overraskende at regnskapsdirektivet ikke har andre bestemmelser om behandling av midlertidige forskjeller enn dette. En mulig forklaring kan ifølge Schwencke (2019, s. 12) være at «[i] de fleste andre land er det mer vanlig enn det har vært i Norge å bygge skatteretten på regnskapet». Ettersom det ikke er plikt til å anvende utsatt skatt-modellen andre steder enn i konsernregnskapet, vil det kunne være rom for å tenke andre løsninger for håndtering av midlertidige forskjeller mellom regnskap og skatt i selskapsregnskapet, spesielt for små foretak. 
Schwencke (2019, s. 34) foreslår at det for små foretak innføres en koblingsmodell tilsvarende den som fantes før skattereformen av 1992. En tilsvarende modell er innført for foretak med begrenset regnskapsplikt, jf. regnskapsloven $\$ 3-2 b$ og NRS 21. Bruk av en koblingsmodell vil innebære at deler av egenkapitalen i balansen er ubeskattet. Den ubeskattede delen av egenkapitalen bør i så fall presenteres for seg som en egen post under egenkapitalen, noe som kan medføre utfordringer med hensyn til krav til oppstillingsplaner etter regnskapsdirektivet vedlegg III og IV. Det er derimot mer lempelige krav til oppstillingsplaner for særlig små foretak (mikroforetak). Disse kan etter artikkel 36 nr. 2 utarbeide en såkalt sammendratt balanse, så sant denne adgangen tillates av medlemsstaten. Etter denne balansen er det ikke plikt til å spesifisere egenkapitalen. Kristoffersen (2019b, s. 295) foreslår at «[m]ikroselskap fritas for krav om å bruke utsatt skatt-modellen, men kan i stedet ta i bruk koblingsmodellen». Vi mener på samme måte som Kristoffersen at adgangen til å benytte koblingsmodellen bør begrenses til en kategori særlig små foretak (mikroforetak) pga. de konsekvensene anvendelsen av koblingsmodellen har på finansregnskapets informasjonsverdi.

Innføring av en eventuell koblingsmodell kan ha selskapsrettslige konsekvenser. En mulig løsning foreslått av Schwencke (2019, s. 34), og som vi støtter, er at egenkapitaldelen ( 78 prosent) av ubeskattet egenkapital fortolkes å inngå i begrepet «netto eiendeler», jf. aksjeloven $₫$ 8-1 første ledd.

\subsubsection{Forenkling av den skattemessige formuesfastsettelsen}

Skattemessig verdsetting av formue for ikke-børsnoterte foretak ${ }^{10}$ skjer med utgangspunkt i et sett av egne regler i skattelovens kapittel 4. I praksis er dette regler som er kompliserte å følge. Bortsett fra verdsettelse av næringseiendommer har reglene antagelig liten eller helt minimal provenyvirkning. En vesentlig forenkling ville derfor vært at formuesverdiene som i dag ligger i skattemeldingen side 4 , ble erstattet av formuesfastsettelsen bygd på de regnskapsmessige verdiene i næringsoppgaven. Den

10 Heleide datterforetak av børsnoterte foretak er også unntatt, jf. skatteforskriften $\$$ 4-12-5. 
særskilte formuesfastsettelsen av næringseiendommer bør trolig videreføres. Et annet område er formuesfastsettelsen av aksjer i andre foretak. Her bør man trolig også opprettholde at denne bygger på formuesverdien i disse foretakene i stedet for regnskapsmessig verdi.

\subsection{Oversikt over forenklingsforslag i vurderingsreglene for små foretak}

En overordnet analyse av forskjellene mellom finansregnskapet og skatteregnskapet kan ta utgangspunkt i RF-1217 Forskjeller mellom regnskapsmessige og skattemessige verdier, som vedlegges skattemeldingen. I oversikten under har vi oppsummert de sentrale forslagene over og i tillegg gjort en kort kvalitativ vurdering av en del andre harmoniseringsposter som ikke er omtalt over:

\begin{tabular}{lll}
\hline Post i RF-1217 & $\begin{array}{l}\text { Regnskapsmessige } \\
\text { vurderingsregler }\end{array}$ & Skattemessige vurderingsregler \\
\hline $\begin{array}{l}\text { Anleggsmidler } \\
\text { (materielle og }\end{array}$ & $\begin{array}{l}\text { Skattemessige } \\
\text { avskrivninger kan brukes } \\
\text { som regnskapsmessige } \\
\text { avskrivninger }\end{array}$ & $\begin{array}{l}\text { Harmonisering av regnskapsmessig } \\
\text { og skattemessig behandling av } \\
\text { gevinst og tap (salg og annen } \\
\text { realisasjon) er vanskelig uten å endre } \\
\text { skattereglene }\end{array}$ \\
\hline Varer & Harmonisering av regnskapsmessig \\
& og skattemessig behandling av varer \\
& fordrer at skattereglene i noen grad \\
& tilpasses regnskapsreglene. Det \\
& gjelder blant annet adgang til å føre \\
& nedskrivninger til skattemessig fradrag, \\
& mulighet til å samordne variabel \\
& tilvirkningskostnad regnskapsmessig \\
& og skattemessig og adgang til å bruke \\
& gjennomsnittkostnad skattemessig ved \\
tilordning av anskaffelseskost for varer.
\end{tabular}


(Fortsatt)

\begin{tabular}{|c|c|c|}
\hline Post i RF-1217 & $\begin{array}{l}\text { Regnskapsmessige } \\
\text { vurderingsregler }\end{array}$ & Skattemessige vurderingsregler \\
\hline $\begin{array}{l}\text { Tilvirkningskontrakt } \\
\text { som ikke er fullført ved } \\
\text { årsslutt }\end{array}$ & \multicolumn{2}{|c|}{$\begin{array}{l}\text { Regnskapsmessig forenkling finnes allerede, og harmonisering kan } \\
\text { foretas. }\end{array}$} \\
\hline $\begin{array}{l}\text { Langsiktige fordringer } \\
\text { og gjeld i utenlandsk } \\
\text { valuta }\end{array}$ & \multicolumn{2}{|c|}{$\begin{array}{l}\text { Ikke noe til hinder for skattemessig inntektsføring av urealiserte } \\
\text { valutagevinster. Harmonisering kan foretas. }\end{array}$} \\
\hline Balanseførte leieavtaler & \multicolumn{2}{|c|}{$\begin{array}{l}\text { Regnskapsmessig forenkling finnes allerede, og harmonisering kan } \\
\text { foretas. Vi anser at området er lite aktuelt for små foretak. }\end{array}$} \\
\hline $\begin{array}{l}\text { Regnskapsmessig } \\
\text { avsetning til tap på } \\
\text { kontrakter mv. }\end{array}$ & $\begin{array}{l}\text { Bortsett fra } \\
\text { garantiavsetning anser vi } \\
\text { området som lite aktuelt for } \\
\text { små foretak. }\end{array}$ & $\begin{array}{l}\text { Vi støtter forslagene til Schwencke } \\
\text { (2019, punkt 6.5) om endringer i } \\
\text { skattereglene. }\end{array}$ \\
\hline $\begin{array}{l}\text { Pensjonsforpliktelser/- } \\
\text { midler, avsetning til } \\
\text { premiefond }\end{array}$ & $\begin{array}{l}\text { Regnskapsmessig forenkling } \\
\text { finnes allerede, og } \\
\text { harmonisering kan foretas }\end{array}$ & \\
\hline $\begin{array}{l}\text { Andre poster ved kjøp } \\
\text { av virksomhet/ fusjon/ } \\
\text { fisjon / omdanning / } \\
\text { konserninterne } \\
\text { transaksjoner / } \\
\text { fordringer og gjeld etter } \\
\text { fordrings-modellen }\end{array}$ & \multicolumn{2}{|c|}{$\begin{array}{l}\text { Vi anser at dette ikke er normale poster for små foretak. Små } \\
\text { foretak har allerede regnskapsmessig adgang til forenkling ved } \\
\text { å benytte kontinuitet ved fusjon og fisjon. Dette er kompliserte } \\
\text { transaksjoner som må håndteres særskilt når de oppstår. }\end{array}$} \\
\hline $\begin{array}{l}\text { Aksjer og andre } \\
\text { finansielle } \\
\text { instrumenter/ } \\
\text { andeler i selskap med } \\
\text { deltakerfastsetting. }\end{array}$ & \multicolumn{2}{|l|}{$\begin{array}{l}\text { Dette er poster som } \\
\text { omfattes av fritaksmetoden. } \\
\text { Små foretak kan benytte } \\
\text { forenklingsregler for } \\
\text { markedsbaserte aksjer. }\end{array}$} \\
\hline $\begin{array}{l}\text { Akkumulert fremførbart } \\
\text { skattemessig } \\
\text { underskudd/ avskåret } \\
\text { rentefradrag til } \\
\text { fremføring }\end{array}$ & \multicolumn{2}{|l|}{$\begin{array}{l}\text { Den midlertidige forskjellen } \\
\text { må videreføres. }\end{array}$} \\
\hline
\end{tabular}

Som oversikten viser, er det en lang rekke vurderingsregler som lett lar seg harmonisere. I et forenklingsperspektiv er det viktig å fremheve at det er de mest vanlige regnskapspostene, slik som varige driftsmidler, varer, og kundefordringer, som har minst harmoniserte regler.

\section{Avslutning}

I dette kapittelet bidrar vi inn i en pågående faglige debatt om hvilke forenklingsregler som kan etableres for små foretak. Et sentralt utgangspunkt har vært å se på muligheten til å harmonisere regler for finansregnskapet 
og skatteregnskapet. Slik harmonisering kan i utgangspunktet skje på tre måter: (1) ved at reglene for finansregnskapet tilpasses skatteregnskapet, (2) ved at reglene for skatteregnskapet tilpasses finansregnskapet, eller (3) ved at begge regelsett tilpasset et nytt felles regelsett ved at det skjer endringer i begge regelsettene. Det er særlig harmonisering etter 1) og 2) som har vært vurdert her.

Kapittelet bidrar til en prinsipiell gjennomtenkning av at harmonisering av disse to regelsettene må ta hensyn til finansregnskapets formål og skatteregnskapets formål. Mens finansregnskapet har som formål å gi beslutningsnyttig informasjon innenfor en kost-nytte-beskrankning, har skatteregnskapet som formål å danne grunnlag for å fastsette skyldig skatt. I det siste tilfellet vil sentrale prinsipper som likebehandlingsprinsippet, skatteevneprinsippet, kontrollprinsippet osv. være styrende for utformingen av reglene. I tillegg vil endring av skattereglene kunne ha vesentlige provenyeffekter. På mange måter synes det enklere å tilpasse reglene for finansregnskapet til reglene for skatteregnskapet, men da vil en kunne ende med et finansregnskap som gir mindre beslutningsnytte. Samtidig vil regnskapsdirektivet sette visse grenser for i hvor stor grad reglene for finansregnskapet kan tilpasses skattereglene, i alle fall for de foretakene som omfattes av dette direktivet.

Vi har spesielt undersøkt tre områder inngående i denne studien, og det er regler for anleggsmidler (materielle og immaterielle), for varer og for kundefordringer. Dette er områder hvor det kan oppnås betydelig harmonisering og dermed forenkling, men hvor det ikke er mulig med full harmonisering dels av hensyn til at finansregnskapet skal gi beslutningsnyttig informasjon og dels av hensyn til krav i regnskapsdirektivet. Likevel vil vi påstå at det er mulig å oppnå store forenklingsgevinster gjennom de forslagene som er fremmet.

Ut over dette er det også fremmet andre forenklingsforslag. For eksempel er det foreslått større grad av harmonisering mellom merverdiavgiftsreglene og regnskaps- og skattereglene, og det er forslått enklere regler for formuesfastsettelsen.

Forslaget vårt innebærer også at det etableres en egen foretakskategori bestående av særlig små foretak (mikroforetak). Det foreslås at disse inngår i samme kategori som dem som omfattes av bestemmelsen om 
begrenset regnskapsplikt, jf. regnskapsloven $\$ 3-2 b$, noe som vil fordre mindre justeringer av regnskapskravene. Forenklingene vil kunne velges som sporvalg slik som etter $\$ 3$-2b i dag.

Samlet sett vil forslagene over kunne gi betydelige lettelser for små foretak og dermed frigjøre betydelige ressurser til andre formål. Dette gjøres uten at forslagene vil svekke ivaretakelsen av de formålene og de hensynene som ligger bak regnskaps- og skattereglene. Den praktiske implikasjonen av studien er at den kan bidra til fortgang $\mathrm{i}$ arbeidet med å utvikle konkrete, praktiske forenklingsregler.

En studie av størrelsen på de ulike midlertidige forskjellene til små foretak og av kost-nytte-vurderingen for små foretak vil kunne gi ytterligere bidrag inn i diskusjonen og konkretiseringen av forenklingsregler.

\section{Referanser}

\section{Lover, rettskilder fra EU og lovforarbeider}

Regnskapsloven (1998) Lov om årsregnskap m.v. LOV-1998-07-17-56.

Skatteloven (1999) Lov om skatt av formue og inntekt (skatteloven) LOV-1999-0326-14.

Bokføringsloven (2004) Lov om bokføring. LOV-2004-11-19-73.

IFRS-forordning (2002). Forordning nr. 1606/2002/EF om anvendelse av internasjonale regnskapsstandarder. (1606/2002/EF).

EF: Fjerde direktiv (1978) Regnskapsdirektivet. Rådets fjerde selskapsdirektiv. $(78 / 660 / \mathrm{EF})$.

EF: Syvende direktiv. (1983) Konserndirektivet. Rådets syvende selskapsdirektiv. $(83 / 349 / \mathrm{EF})$.

EU: Konsolidert regnskapsdirektiv (2013) Europaparlamentet og Rådets konsoliderte regnskapsdirektiv. (EP/Rdir. 2013/34/EU).

NOU 1989: 14. Bedrifts- og kapitalbeskatningen - en skisse til reform.

NOU 1993: 2. Differensierte krav til årsoppgjør, konsernoppgjør og revisjonsplikt.

NOU 1995: 30. Ny regnskapslov.

NOU 2003: 23. Evaluering av regnskapsloven.

NOU 2015: 10. Lov om regnskapsplikt.

NOU 2016: 11. Regnskapslovens bestemmelser om årsberetning $m v$.

Ot.prp. nr. 42 (1997-98). Om lov om årsregnskap m.v. (regnskapsloven). 
Ot.prp. nr. 39 (2004-2005). Om lov om endringer i lov 17. juli $1998 \mathrm{nr} .56$ om årsregnskap m.v. (regnskapsloven) og enkelte andre lover (evaluering av regnskapsloven).

Ot.prp. nr. 26 (2005-2006) Om lov om endringer i skatte- og avgiftslovgivningen (endret skatte- og avgiftsopplegg $2006 \mathrm{mv}$.)

Prop. 160 L (2016-2017). Endringer i regnskapsloven $m v$. (forenklinger).

\section{Regnskapsstandarder}

NRS 8. God regnskapsskikk for små foretak. (Sist oppdatert 2018). Norsk RegnskapsStiftelse.

NRS 21. God regnskapsskikk for foretak med begrenset regnskapsplikt. (Sist oppdatert 2019). Norsk RegnskapsStiftelse.

NRS (V). Regnskapsføring av inntekt. (Sist oppdatert 2010). Norsk RegnskapsStiftelse. NRS(F). Resultatskatt. (Sist oppdatert 2008). Norsk RegnskapsStiftelse.

IAS 36. Verdifall på eiendeler. (Sist oppdatert 2014). Internasjonal regnskapsstandard. IFRS. IASB.

\section{Bøker, artikler mv.}

Den norske Revisorforening. (2009). Reelle forenklinger for de minste selskapene. Forslaget er blant annet omtalt av Knudsen, E. \& Husaas, T. (2009). Forenklinger i aksje- og regnskapslovgivningen for små selskaper. Revisjon og regnskap, nr. 4/2009, s. 17-20.

Den norske Revisorforening. (2018). Ti prioriterte forenklingsforslag. Brev til Nærings- og fiskeridepartementet. Hentet 22.5.20 fra https://www. revisorforeningen.no/globalassets/fag/selskapsrett/topp-ti-forenklingerrevisorforeningen.pdf

Elling, J. O., Kyhnauv-Andersen, C., Kyhnauv-Andersen, H. \& Kyhnauv-Andersen, P. (2019). Finansiell rapportering. Teori og regulering. 5. utgave. Gjellerup/Gads Forlag.

Fallan, L. (2011). Økonomistyring, skatter og verdsettelse - et kontraktsperspektiv. Gyldendal Akademisk.

Graver, H. P. (2008). Vanlig juridisk metode? Om rettsdogmatikken som juridisk sjanger. Tidsskrift for Rettsvitenskap, 121(2), 149-178.

IASB. (2018). Conceptual framework for financial reporting. London: International Accounting Standards Board.

IFRS for SMEs. (2015). International financial reporting standard (IFRS) for small and medium-sized entities (SMEs). International Accounting Standard Board (IASB). 
Kaaby, J. T. (2015). Bokføringsloven. Med kommentarer til lov, forskrifter og god bokføringsskikk. 2. utg. Fagbokforlaget.

Kinserdal, A. (2005). Finansiell rapportering og analyse. Cappelen Akademisk Forlag.

Kristoffersen, T. (2019a). Norsk regnskapslovgivning: Skatteregler som regnskapsregler. Revisjon og regnskap, 7.

Kristoffersen, T. (2019b). Norsk regnskapslovgivning: Alternativer til regnskapsføring av utsatt skatt i små aksjeselskap. Praktisk økonomi og finans, 4 , 293-308

Kvifte, S. S. \& Brandsås, H. (2010). God regnskapsskikk i 25 år - fra «skatteregnskap» til IFRS. Praktisk økonomi og finans, 3, 45-59.

Kvifte, S. S. \& Johnsen, A. (2008). Konseptuelle rammeverk for regnskap. DnR-forlaget.

Ludvigsen, E. \& Baksaas, K. M. (2012). Skattemessig varekostnad - om rekkevidden av plikten til å vite prisen på den først anskaffede av de vareenhetene som ved hver varerealisasjon fortsatt er «på lager». Skatterett, 31(4), 360-387.

Regelrådet. (2016). Regnskapslovutvalgets utredning om regnskapslovens bestemmelser om årsberetning med videre. Uttalelse til Finansdepartementet. Hentet 22.5.20 fra https://www.regelradet.no/2016/og/21/regnskapslovutvalgets-utredning-omregnskapslovens-bestemmelser-om-arsberetning-med-videre/

Schipper, K. (2010). How can we measure the costs and benefits of changes in financial reporting standards? Accounting and Business Research, 40(3), 309-327.

Schwencke, H. R. (2019). Årsregnskapet og skatteregnskapet muligheter for forenklinger - en forstudie. Rapport til Finansdepartementet datert 15.05.2019.

Schwencke, H. R., Haugen, D. O., Baksaas, K. M., Stenheim, T. \& Avlesen-Østli, E. (2020). Årsregnskapet i teori og praksis 2019. Oslo: Gyldendal Norsk Forlag.

Scott, W. R. \& O’Brien, P. C. (2019). Financial accounting theory (8. utg.). Pearson Canada Inc.

Skatteetaten. (2019). Skatte-ABC 2019/20.

Stenheim, T., Baksaas K. M. \& Haaland, G. (2019). Masteroppgaver i regnskap og revisjon. Magma, 1, 17-20.

Watts, R. L. \& Zimmerman, J. L. (1986). Positive accounting theory. Prentice-Hall contemporary topics in accounting series. Upper Saddle River, NJ: Pearson. 


\section{Vedlegg - Tabell små foretak}

Vi har valgt å ta med en analyse av foretak som har levert årsregnskap for 2018, basert på tall fra Bisnodes database per 3.1.2020. Det er ikke mulig på en enkel måte å beregne eksakt antall foretak som oppfyller kriteriene for små foretak, jf. regnskapsloven $\$ 1$-6. En praktisk tilnærming er å anse foretak med under 50 ansatte og under 70 millioner kroner i salgsinntekter som små foretak. Det utgjør ca. 319 ooo foretak eller 96 prosent av alle foretak som har levert årsregnskap. ${ }^{11}$ Antagelig er prosenten enda litt høyere.

\begin{tabular}{|c|c|c|c|c|c|c|}
\hline & \multirow{2}{*}{$\begin{array}{l}\text { Totalt } \\
\text { antall }\end{array}$} & & \multirow{2}{*}{$\begin{array}{l}\text { Antatt } \\
\text { små }\end{array}$} & \multicolumn{3}{|c|}{ Herav } \\
\hline & & & & $\begin{array}{l}\text { Sovende/ } \\
\text { holding }\end{array}$ & $\begin{array}{l}\text { Aktive } \\
\text { mikro }\end{array}$ & Rest små \\
\hline & & $\%$ & $\begin{array}{c}\text { Ansatte } \\
<50\end{array}$ & $\begin{array}{c}\text { Antall } \\
\text { ansatte }=0\end{array}$ & $\begin{array}{c}\text { Antall } \\
\text { ansatte }<10\end{array}$ & $\begin{array}{l}10-49 \\
\text { ansatte }\end{array}$ \\
\hline & & & $\begin{array}{l}\text { Salgsinnt. } \\
<70 \text { mill }\end{array}$ & $\begin{array}{c}\text { Salgsinnt } \\
<1000\end{array}$ & $\begin{array}{l}\text { Salgsinnt. } \\
1000-7 \text { mill }\end{array}$ & $\begin{array}{l}\text { Salgsinnt. } \\
\text { 7-70 mill }\end{array}$ \\
\hline Levert regnskap 2018 & 330379 & & 319027 & 133211 & 129579 & 56237 \\
\hline $\begin{array}{l}\text { Bokført utsatt skatt } \\
>\text { kr } 1000\end{array}$ & 57756 & $17 \%$ & 53892 & 15812 & 24163 & 13917 \\
\hline $\begin{array}{l}\text { Bokført utsatt } \\
\text { skattefordel >kr } 1000\end{array}$ & 60579 & $18 \%$ & 54602 & 16257 & 13873 & 24472 \\
\hline Betalbar skatt & & & 104871 & 25416 & 52437 & 27018 \\
\hline $\begin{array}{l}\text { Betalbar skatt }>1 \text {, utsatt } \\
\text { skatt }<0\end{array}$ & & & 69647 & 16766 & 35668 & 17213 \\
\hline $\begin{array}{l}\text { \% foretak som har } \\
\text { betalbar skatt, men ikke } \\
\text { utsatt skatt }\end{array}$ & & & $66 \%$ & $66 \%$ & $68 \%$ & $64 \%$ \\
\hline
\end{tabular}

Det er mange små foretak som velger å ikke benytte forenklingsreglene for små foretak. En indikasjon er at 54 ooo foretak har balanseført utsatt skattefordel (summen av de tre kolonnene med spesifisering av små foretak).

11 Vi har vurdert at dette gir best uttrykk for antall små foretak fordi antall med under 35 millioner kroner i sum eiendeler og enten under 70 millioner kroner i salgsinntekter eller under 50 ansatte er lavere, begge ca. 297000. 
En analyse av skatteforpliktelse er videre interessant. I det store bildet viser dette at bare 32 prosent $^{12}$ av årsregnskapene har betalbar skatt på over $1000 \mathrm{kr}$ som gjeldspost. Av disse igjen er det 66 prosent som ikke har noe utsatt skatt som avsetningsforpliktelse. Vår tolkning av dette er at av foretak som betaler skatt, er det $2 / 3$ som beskatter inntjeningen samtidig eller før den rapporteres som regnskapsmessig overskudd. Disse foretakene har med andre ord netto negative midlertidige forskjeller eller netto skattereduserende midlertidig forskjeller (jf. NRS(F) Resultatskatt).

En nærmere statistisk analyse av forskjellene mellom regnskap og skatt bør ta utgangspunkt i foretakenes rapportering til Skatteetaten på $R F-1217$ Forskjeller mellom regnskapsmessige og skattemessige verdier, som skal vedlegges skattemeldingen. Vi har ikke en slik statistikk tilgjengelig. 


\title{
KAPITTEL 4
}

\section{Fisjon under IFRS ${ }^{1}$ - mulige regnskapsmessige løsninger ${ }^{2}$}

\author{
Tonny Stenheim \\ Professor, Universitetet i Sørøst-Norge
}

Sammendrag: I dette kapittelet diskuteres mulige regnskapsmessige løsninger for fisjon etter IFRS (International Financial Reporting Standards). I motsetning til god regnskapsskikk finnes det ikke en enkelt standard eller tolkningsuttalelse under IFRS som er spesifikt innrettet mot å regulere regnskapsføring av fisjon. Derimot vil reguleringen være spredt mellom standarder og tolkningsuttalelser. I dette kapittelet diskuteres først regnskapsføring av fisjon i overtakende foretak og deretter i overdragende foretak. I de tilfeller hvor det som overtas ved fisjonen, er å anse som virksomhet, vil IFRS 3 og overtakelsesmetoden gjelde, dvs. regnskapsføring til virkelig verdi. Forutsetningen er at fisjonen ikke skjer under samme kontroll, dvs. fisjoner som verken skjer mellom selskaper innad i et konsern eller mellom selskaper under kontroll av en enkelt eier/eiergruppering. Hvis det som overtas, ikke er å anse som virksomhet, må fisjonen anses som overtakelse av eiendeler og forpliktelser (ikke virksomhet) med vederlag i aksjer. I overdragende foretak vil IFRIC 17 kunne få anvendelse. Det innebærer at utfisjoneringen skjer til virkelig verdi. Forutsetningen er at eierne likebehandles, og at fisjonen ikke skjer under samme kontroll. Hvis det ikke skjer en likebehandling, argumenteres det for at en analog anvendelse av IFRIC 17-bestemmelsene, dvs. regnskapsføring til virkelig verdi, vil gi relevant og pålitelig informasjon og dermed være en foretrukket løsning. Hvis fisjonen derimot

1 Kapittelet vil ha tilsvarende relevans for regnskapspliktige som utarbeider årsregnskap etter forskrift om forenklet anvendelse av IFRS, jf. regnskapsloven $\$$ 3-9 femte ledd. Forskriften har ingen særregler for regnskapsføring av fisjon ut over at det gis unntak fra vurderingsreglene i IFRS 5 hvis forskriften brukes i selskapsregnskapet, jf. forskriften $\$$ 3-1 første ledd nr. 2.

2 Takk til professor Hans Robert Schwencke og Jan Aastveit for kommentarer. Alle vurderinger og konklusjoner i dette kapittelet står for forfatterens egen regning. Artikkelen er delvis basert på forelesningsmateriell brukt på temaet fisjon og omorganiseringer i konsern ved Handelshøyskolen BI (Kvaal \& Stenheim, 2018; Stenheim, 2019).

Sitering av denne artikkelen: Stenheim, T. (2020). Fisjon under IFRS - mulige regnskapsmessige løsninger. I T. Stenheim, K. M. Baksaas og E. M. Kulset (Red.), Aktuelle temaer i regnskap og revisjon (Kap. 4, s. 121-141). Oslo: Cappelen Damm Akademisk. https://doi.org/10.23865/noasp.112.ch4

Lisens: CC-BY 4.0. 
skjer under samme kontroll, må de regnskapsmessige løsningene utledes. Her kan også løsninger etter de norske regnskapsstandardene ha relevans, slik som NRS

(F) Fisjon og NRS 9 Fusjon, men da som en av flere kilder i kildehierarkiet.

Nøkkelord: fisjon, IFRS, virksomhetskjøp, samme kontroll

\subsection{Innledning}

En fisjon innebærer at et selskap blir delt. Dette kan skje på flere måter. For eksempel kan selskapet deles i to eller flere selskaper (fisjon ved oppløsning) slik at det opprinnelige selskapet opphører å eksistere. Alternativt kan det opprinnelige selskapet beholde en del av eiendeler og forpliktelser selv (fisjon med kapitalnedsettelse), mens andre deler overføres til et eller flere andre selskaper. Det selskapet som overtar eiendeler og forpliktelser, kan enten være stiftet ved fisjonen (fisjon ved nystiftelse) eller være et eksisterende selskap (fisjonsfusjon) (Aamelfot et al., 2015; Aarbakke et al., 2017).

Regnskapsmessig behandling av fisjoner under GRS er regulert av transaksjonsprinsippet og den rettslige standarden god regnskapsskikk, herunder regnskapsstandardene NRS (F) Fisjon og NRS 9 Fusjon (det siste gjelder for fisjonsfusjon). I de internasjonale regnskapsstandardene, IFRS, finnes det derimot ikke en eksplisitt regulering av fisjoner, noe som har ført til usikkerhet om hvilke regnskapsmessige løsninger som gjelder (se eksempelvis Blegeberg \& Haraldseth, 2016). Det betyr imidlertid ikke at fisjon er uregulert under IFRS (Kvaal, 2004). Den litteraturen som finnes om regnskapsmessig behandling av fisjoner under IFRS, gjelder typisk fisjoner under samme kontroll (se for eksempel Strandvold \& Juul, 2020; EY, 2020; PwC, 202ob; KPMG, 2019; Deloitte, 2019; Grant Thornton, 2018). Dette er fisjoner som skjer mellom selskaper innad i et konsern eller mellom selskaper under kontroll av en enkelt eier (eller eiergruppering som virker som en eier) (se for eksempel IFRS 3 Virksomhetssammenslutninger, appendiks B).

Derimot er det langt vanskeligere å finne litteratur som omhandler regnskapsføring av fisjoner under IFRS når disse ikke skjer under samme kontroll. Slike fisjonene er likevel ikke uvanlige, spesielt i Norge som følge av gunstige skatteregler, noe som grunngir behovet for en avklaring 
av hvilke regnskapsmessige løsninger som kan gjelde for slike fisjoner. Kapittelet vil ha relevans for alle som er involvert i utarbeidelse av regnskaper etter IFRS, de som kontrollerer slike regnskaper (revisorer og kontrollmyndigheter), og de som bruker slike regnskaper som grunnlag for beslutninger (investorer, kreditorer osv.). Kapittelet kan også ses som et forsiktig innspill inn i utviklingen av en mer eksplisitt regulering av fisjoner under IFRS.

I kapittelet konkluderes det med at IFRS 3 Virksomhetssammenslutninger vil være relevant regnskapsstandard i overtakende foretak for alle fisjoner som ikke skjer under samme kontroll, og hvor det som overdras ved fisjonen, er virksomhet etter definisjonen i IFRS 3 . Hvis det som overdras ikke kan anses som virksomhet, vil relevante enkeltstandarder kunne få anvendelse, slik som IFRS 2 Aksjebasert betaling, IAS 16 Eiendom, anlegg og utstyr, IAS 38 Immaterielle eiendeler, osv. Hvis fisjonen skjer under samme kontroll, finnes det ingen rettledning i regnskapsstandard eller tolkningsuttalelse, og den regnskapspliktige er dermed hensatt til å utlede løsningen ved bruk av kildehierarkiet (jf. IAS 1 og IAS 8).

I overdragende foretak vil IFRIC 17 Utdeling av ikke-kontante eiendeler til eierne være relevant, så sant det skjer en likebehandling av eierne og fisjonen ikke skjer under samme kontroll. Jeg har tolket krav om likebehandling slik at fisjoner som skjer ved skjevdeling (eierne deltar ikke i samme forhold før og etter fisjonen), faller utenfor virkeområdet til IFRIC 17. Likevel argumenterer jeg for at IFRIC 17 bør få gyldighet også i slike tilfeller gjennom en analog tolkning og anvendelse av IFRIC 17-bestemmelsene. IFRS 5 Anleggsmidler holdt for salg og avviklet virksomhet mener jeg derimot kan ha relevans ved regnskapsføring av alle fisjoner i overdragende foretak.

Fisjoner under samme kontroll vil verken være regulert av IFRS 3 eller IFRIC 17. Her må de regnskapsmessige løsningene utledes av kildehierarkiet (jf. IAS 1 og IAS 8). Som en del av dette kildehierarkiet skal det blant annet gjøres bruk av balanseorienterte definisjoner og innregningskriterier i det konseptuelle rammeverket til IFRS for utledning av regnskapsmessige løsninger. Jeg velger likevel å argumentere for at løsninger som er utledet av transaksjonsprinsippet i regnskapsloven, herunder 
NRS (F) Fisjon og NRS 9 Fusjon, ikke kan diskvalifiseres med henvisning til at norsk regnskapsrett er basert på resultatorienterte regnskapsprinsipper. Transaksjonsprinsippet, som har dannet grunnlag for disse standardene, er verken utpreget resultat- eller balanseorientert. Dessuten finnes det spor av tilsvarende transaksjonsprinsipp en rekke steder $\mathrm{i}$ IFRS-regelverket.

I kapittelet gjør jeg bruk av rettsvitenskapelig metode og da den delen som handler om rettsdogmatikk, dvs. drøfting av gjeldende rett (Graver, 2008). Formålet med dette kapittelet er å vurdere hvilke regnskapsmessige løsninger som synes å gjelde for fisjon under IFRS med utgangspunkt i relevante IFRS-standarder og -tolkningsuttalelser. I tillegg skal jeg vurdere i hvilken grad løsninger etter norske regnskapsstandarder for fisjon og fusjon har relevans som rettskilder.

Kapittelet er strukturert på følgende måte: I første del omtales kort fisjonsinstituttet med utgangspunkt i reguleringen av fisjon i selskapsretten i Norge. I annen del gis det en introduksjon til regnskapsmessig behandling av fisjoner under IFRS. Deretter diskuteres ulike regnskapsstandarder og tolkningsuttalelser under IFRS som kan ha relevans ved regnskapsmessig behandling av fisjon. I nest siste del sammenholdes norske løsninger for regnskapsmessig behandling av fisjon med mulige IFRS-løsninger, før kapittelet oppsummeres med noen avsluttende betraktninger om fisjon under IFRS.

\subsection{Kort om fisjonsinstituttet}

En fisjon innebærer deling av foretak og vil på mange måter være motstykket til en fusjon, som innebærer sammenslåing av foretak. Selv om fisjon kan ses på som motstykket til fusjon, har fisjon og fusjon mange likhetstrekk, ${ }^{3}$ og det er i stor grad de samme selskapsrettslige reglene som gjelder for fusjon og fisjon, jf. aksjeloven og allmennaksjeloven kapittel

3 Det er mulig å fremstille fusjon som en spesialvariant av fisjon som innebærer full overdragelse (i motsetning til delvis overdragelse) av et overdragende foretak til ett overtakende foretak (Kvaal \& Johnsen, 2000). 
13 og $14 .{ }^{4}$ Det stilles ikke spesielle krav til det som skal utfisjoneres: Dette kan være enkelteiendeler eller virksomhet.

Etter aksjelovgivningen innebærer fisjon at et foretak (det overdragende foretaket) deles slik at alle eller en del av foretakets eiendeler og forpliktelser skilles ut til ett eller flere foretak (det eller de overtakende foretakene), jf. aksjeloven og allmennaksjeloven $\$$ 14-2 første ledd. Eierne i det overdragende foretaket skal i utgangspunktet bli kompensert gjennom aksjer i det overtakende foretaket. Inntil 20 prosent av det samlede fisjonsvederlaget kan imidlertid være i en annen form enn aksjer (omtalt som tilleggsvederlag). Det overtakende foretaket kan være et foretak som stiftes i forbindelse med fisjonen (omtalt som ren fisjon), eller det kan være et eksisterende foretak (omtalt som fisjonsfusjon). I det sistnevnte tilfellet er fisjonen samtidig en fusjon i det overtakende foretaket (Kvaal \& Johnsen 2000; Aarbakke et al., 2017).

Fisjon kan også gjennomføres ved at alle eiendeler og alle forpliktelser i det overdragende foretaket overføres til ett eller flere overtakende foretak, samtidig som det overdragende foretaket oppløses ved fisjonen, jf. aksjeloven og allmennaksjeloven $\$ 14-2$ annet ledd. En variant av dette er en fisjon hvor eiendeler og forpliktelser i det overdragende foretaket fordeles direkte til eierne. Forutsetningen er at disse eierne er selskaper som til sammen eier samtlige aksjer i det overdragende foretaket før fisjonen, jf. IFRS 3 aksjeloven og allmennaksjeloven $\$ 14-11 b$.

Endelig kan fisjoner gjennomføres som såkalt konsernfisjon. Hvis det overtakende foretaket inngår i et konsern, kan en fisjon gjennomføres ved at eierne i det overdragende foretaket får aksjer i et annet konsernselskap enn i det overtakende foretaket, jf. aksjeloven og allmennaksjeloven $\$ 14$-2 tredje ledd. Det er en forutsetning at ett eller flere av konsernforetakene samlet har mer enn 90 prosent av både aksjene og stemmene på generalforsamlingen i det overtakende foretaket. I så fall kan vederlaget i aksjer være aksjer i morforetaket (trekantfisjon) eller aksjer i et annet datterforetak hvor morforetaket alene eller gjennom datterforetak har mer enn 90 prosent av både aksjene og stemmene på generalforsamlingen (firkantfisjon).

4 Fisjon av andre foretaksformer enn aksjeselskap og allmennaksjeselskap behandles ikke her. 
I dette kapittelet vil det være ren fisjon og fisjonsfusjon som står i fokus, dvs. fisjoner hvor overtakende foretak enten er et foretak som stiftes ved fisjonen, eller et eksisterende foretak. Der hvor det er hensiktsmessig, vil det også gjøres bruk av begrepene jevndeling og skjevdeling. I en fisjon med jevndeling skjer det ingen endring (eller kun marginal endring) i eiersammensetningen før og etter fisjonen, mens i en fisjon med skjevdeling skjer det derimot en endring i eiersammensetningen ved at eierne ikke deltar i samme forhold før og etter fisjonen.

I den norske fisjonsstandarden NRS (F) Fisjon er skillet mellom ren fisjon og fisjonsfusjon og mellom jevndeling- og skjevdelingsfisjon sentralt for å avgjøre hvilken regnskapsmessig løsning som skal anvendes for fisjonen (jf. særlig NRS (F) Fisjon, punkt 22 flg.). Disse skillelinjene bidrar til å kategorisere fisjoner ut fra ulike kjennetegn eller egenskaper som er relevante for vurderingen av om fisjonen skal regnskapsføres som transaksjon (dvs. til virkelig verdi) eller til kontinuitet med utgangspunkt i regnskapslovens transaksjonsprinsipp.

Skillet mellom ren fisjon og fisjonsfusjon og mellom jevndelings- og skjevdelingsfisjon har ikke noen selvstendig rolle ved tolkning av regnskapsmessige løsninger under IFRS. Men for å kunne sammenholde mulige regnskapsmessige løsninger etter IFRS med dem som gjelder etter GRS, er det hensiktsmessig å følge den norske regnskapsstandardens systematikk. Dette gir følgende 2 x 2-matrise for ulike fisjonstyper som diskuteres i dette kapittelet:

Tabell 4.1 Ulike fisjonstyper

\begin{tabular}{ll}
\hline Ren fisjon & Fisjonsfusjon \\
\hline Jevndeling & Jevndeling \\
Skjevdeling & Skjevdeling \\
\hline
\end{tabular}

\subsection{Fisjon under IFRS}

Regnskapsmessig behandling av fisjon er ikke eksplisitt regulert etter IFRS. Det finnes for eksempel ikke en spesifikk regnskapsstandard eller tolkningsuttalelse under IFRS som regulerer fisjon. Det betyr imidlertid ikke at regnskapsmessig behandling av fisjon er uregulert under IFRS 
(Kvaal, 2004). I de situasjoner hvor det ikke finnes eksplisitt regulering i regnskapsstandard eller tolkningsuttalelse som gjelder den regnskapsmessige problemstillingen, vil kildehierarkiet ${ }^{5}$ under IAS 8 komme til anvendelse. Dette kildehierarkiet består av følgende trinn:

1) Hvis det foreligger regnskapsstandarder eller tolkningsuttalelser som regulerer den regnskapsmessige problemstillingen, skal denne regnskapsstandarden eller tolkningsuttalelsen anvendes (jf. IAS 8.7-9).

2) Hvis det $\underline{\mathrm{ikke}}$ foreligger regnskapsstandarder eller tolkningsuttalelser som regulerer den regnskapsmessige problemstillingen, skal ledelsen ved bruk av skjønn utarbeide og anvende regnskapsprinsipper som gir relevant og pålitelig ${ }^{6}$ regnskapsinformasjon (jf. IAS 8.10).

3) Ved bruk av skjønn under punkt 2 over skal det tas hensyn til:

i) krav i standarder eller tolkningsuttalelser som omhandler lignende eller tilknyttede spørsmål (jf. IAS 8.11a) og

ii) definisjoner, innregningskriterier og måleprinsipper for eiendeler, forpliktelser, inntekter og kostnader i det konseptuelle rammeverket (jf. IAS 8.11b).

4) Ved bruk av skjønn under punkt 2 og 3 over kan det også tas hensyn til uttalelser fra andre regnskapsstandardsettere som benytter lignende konseptuelt rammeverk som IFRS til utarbeidelse av regnskapsstandarder, i tillegg til annen regnskapslitteratur og bransjepraksis, så sant dette ikke strider med det som følger av punkt 3 over (jf. IAS 8.12).

Mens IAS 8.7 til 8.11 angir obligatoriske trinn i kildehierarkiet, vil IAS 8.12 være et valgbart trinn. Det betyr at man kan avslutte kildehierarkiet

5 Dette systemet omtales av og til som «veiledningshierarkiet» eller «tolkningshierarkiet» (se for eksempel Kvifte \& Johnsen, 2008, s. 48). I dette kapittelet brukes derimot «kildehierarkiet» som begrep.

6 I nytt konseptuelt rammeverk fra IASB (2018) er det grunnleggende kvalitetskravet "pålitelig» erstattet med «faithful representation». «Faithful representation» er oversatt med «tro gjengivelse» eller «troverdighet» på norsk (jf. uoffisiell norsk oversettelse av IFRS for SMEs). Regnskapsstandarder og tolkningsuttalelser som bruker begrepet «pålitelig», er derimot ikke endret (per februar 2020) som følge av endringen i rammeverket. 
ved 8.11. I en del situasjoner vil det ikke være regnskapsstandarder eller tolkningsuttalelser som omhandler lignende eller tilknyttede spørsmål, og da er man henvist til å bruke det konseptuelle rammeverket til IASB. Inntil 2018 bestod det konseptuelle rammeverket under IFRS av en del (kapittel 1 og 2) som ble vedtatt i 2010, og en del som var videreført fra det opprinnelige rammeverket fastsatt av International Accounting Standards Committee (IASC; forløperen til IASB) i 1989. Dette rammeverket var spesielt fattig når det gjaldt problematisering av valg av målegrunnlag og måleprinsipper. I nytt konseptuelt rammeverk fra $2018 \mathrm{er} \mathrm{det} \mathrm{gitt}$ mer veiledning med hensyn til måling. Likefullt kan det være krevende å anvende det konseptuelle rammeverket til å utlede konkrete løsninger på regnskapsmessige problemer slik som fisjon. Årsaken er at også det nye rammeverket bygger på abstrakte begreper og sammenhenger som sjelden leder frem til en klar regnskapsmessig løsning. Av den grunn vil det ofte være hensiktsmessig å se hen til regnskapsmessig regulering hos andre regnskapsstandardsettere (jf. IAS 8.12). I IFRS sitt tilfelle vil US GAAP være en åpenbar kilde, dels fordi IFRS og US GAAP (US Generally Accepted Accounting Principles) er forsøkt harmonisert de siste 15 årene, dels fordi US GAAP anses som en autorativ kilde, og dels fordi IFRS og US GAAP bygger på konseptuelle rammeverk som i stor grad er sammenfallende (Kvifte, 2003; Kvifte \& Johnsen, 2008). Under US GAAP finnes det ikke en regnskapsstandard som eksplisitt regulerer fisjoner, men det finnes en regnskapsstandard som regulerer såkalte «spin-offs» og andre tilsvarende omorganiseringer, jf. ASC 845 Accounting for Nonmonetary Transactions. Denne foreskriver bruk av regnskapsmessig kontinuitet?

Et spørsmål som melder seg, og som vil bli grundigere diskutert senere i kapittelet, er om norsk regnskapsregulering kan være relevant som kilde under IFRS. Norske regnskapsstandarder er utviklet med utgangspunkt i resultatorienterte regnskapsprinsipper som bryter med de balanseorienterte regnskapsprinsippene i det konseptuelle rammeverket til IFRS (Johnsen \& Kvaal, 1999; Schwencke et al., 2020). Samtidig er god

7 Regnskapsmessig kontinuitet skal også i visse tilfeller legges til grunn etter IFRS når det etableres et nytt morselskap på toppen av en allerede eksisterende konsernstruktur (jf. IAS 27.13). Ut over dette er det sjelden IFRS-regelverket eksplisitt foreskriver kontinuitetsløsning. 
regnskapsskikk i noen grad tilpasset IFRS, blant annet som følge av at Norsk RegnskapsStiftelse i lang tid har hatt som del av sin strategi å tilpasse norske regnskapsstandarder til IFRS (jf. Norsk RegnskapsStiftelses' strategi fra 2008 og 2012).

I tillegg til at de regnskapsmessige løsningene som fastsettes ved hjelp av kildehierarkiet skal gi relevant og pålitelig informasjon, er det også nødvendig at disse ivaretar det overordnede kravet om dekkende fremstilling av foretakets finansielle stilling, finansielle inntjening og kontantstrømmer i IAS 1.15 (Kvifte \& Johnsen, 2008).

For å utlede mulige regnskapsmessige løsninger for fisjon vil det ifølge kildehierarkiet først være relevant å vurdere om det finnes spesifikke regnskapsstandarder eller tolkningsuttalelser som regulerer fisjon. Det er allerede konstatert at så ikke er tilfellet. Det fører oss til neste trinn i kildehierarkiet, som vil være å vurdere om det foreligger regnskapsstandarder eller tolkningsuttalelser som omhandler lignende eller tilknyttede spørsmål (jf. IAS 8.11a). I fortsettelsen vil det bli pekt på spesifikke regnskapsstandarder og tolkningsuttalelser som kan være relevante å anvende.

\subsection{Regnskapsføring av fisjon i overtakende foretak $^{8}$}

\subsubsection{IFRS 3 Virksomhetssammenslutninger}

Regnskapsmessig behandling av fisjon i overtakende foretak vil i noen grad være regulert av IFRS 3 . En virksomhetssammenslutning er definert som «[e]n transaksjon eller annen hendelse der et overtakende foretak oppnår kontroll over en eller flere virksomheter», jf. IFRS 3, appendiks A. En virksomhet er videre definert som «[e]t integrert sett av aktiviteter og eiendeler som utføres og styres med henblikk på å frembringe en avkastning i form av utbytte, lavere utgifter eller andre økonomiske fordeler direkte til investorer eller andre eiere, medlemmer eller deltakere», jf. appendiks A med ytterligere veiledning i appendiks B5 til B12. Det betyr at fisjoner hvor det som overføres ved fisjonen kan anses som virksomhet,

8 Hvis ikke annet er spesielt nevnt, vil dette være å forstå som reelt overtakende foretak (som ikke nødvendigvis sammenfaller med formelt overtakende foretak). 
normalt vil kunne regnskapsføres i overtakende foretak etter overtakelsesmetoden i IFRS 3. Det betyr at alle identifiserbare eiendeler og forpliktelser som fisjoneres ut av overtakende foretak, måles til virkelig verdi på tidspunktet for når disse overtas av overtakende foretak (i fortsettelsen omtalt som fisjonstidspunktet), jf. IFRS $3.18 \mathrm{flg}$.

IFRS 3 vil trolig også gjelde der hvor det ved fisjonen etableres et nytt foretak, jf. tolkning av B6 bokstav c og B18, men det må gjøres en vurdering av om det nye foretaket er overtakende foretak eller ikke etter standarden, dvs. om det kan foreligge en såkalt omvendt overtakelse. Det er derfor ikke nødvendig at overtakende foretak eksisterer på fisjonstidspunktet så lenge dette foretaket blir stiftet senest på dette tidspunktet. Det betyr at IFRS 3 i utgangspunktet må kunne få anvendelse både for rene fisjoner og for fisjonsfusjoner ved regnskapsføring av fisjonen i overtakende foretak, så lenge det som overføres ved fisjonen, oppfyller definisjonen av virksomhet etter IFRS 3. Før 2009 ble virksomhetssammenslutning definert som «sammenslåing av separate foretak eller virksomheter til ett regnskapspliktig foretak», jf. IFRS 3 (2004), appendiks A. Fisjonsfusjoner hvor det som overdras var virksomhet, ville da normalt falle inn under denne definisjonen, mens rene fisjoner hvor overdragende foretak er nystiftet, trolig falt utenfor (Kvaal, 2004). Dette synes ikke lenger å være tilfellet etter at definisjonen av virksomhetssammenslutning ble endret i 2009. Både rene fisjoner og fisjonsfusjoner kan etter den nye definisjonen være å anse som virksomhetssammenslutning.

\subsubsection{Utenfor virkeområdet til IFRS 3 \\ Sammenslutning av foretak eller virksomheter under samme kontroll}

Virkeområdet til IFRS 3 utelukker virksomhetssammenslutninger mellom foretak eller virksomheter under samme kontroll, jf. IFRS 3.2c. I appendiks B til standarden er det gitt veiledning i å identifisere virksomhetssammenslutninger under samme kontroll. Samme kontroll defineres her som kontroll som innehas av samme øverste part (eller parter) både før og etter virksomhetssammenslutningen, og hvor denne kontrollen ikke er midlertidig. Denne kontrollen kan ligge hos et foretak, en enkeltperson eller en 
gruppe enkeltpersoner forutsatt at disse opptrer samlet etter en kontraktsregulert ordning, jf. B2 og B3. Fisjoner som skjer under samme kontroll, vil ikke være regulert av en spesifikk regnskapsstandard eller tolkningsuttalelse, og dette krever anvendelse av kildehierarkiet. Det er i hovedsak pekt på to regnskapsmessige løsninger: analog anvendelse av IFRS 3 , noe som innebærer at alle identifiserbare eiendeler og forpliktelser måles til virkelig verdi, eller regnskapsføring til kontinuitet (se for eksempel EY, 2020; PwC, 2020a; KPMG, 2019; Deloitte, 2019). Analog anvendelse av løsninger i standarder og tolkningsuttalelser på regnskapsmessige problemstillinger som er utelatt fra virkeområdet, er kontroversielt (Kvaal, 2004; Kvifte \& Johnsen, 2008). Jeg argumenterer imidlertid for at det ikke er noe i veien for analog anvendelse av løsninger i en regnskapsstandard eller tolkningsuttalelse på problemstillinger som faller utenfor virkeområdet, så sant dette vil gi en regnskapsmessig løsning som gir relevant og pålitelig informasjon, og en løsning som er i samsvar med definisjoner, innregningskriterier og måleprinsipper i det konseptuelle rammeverket, jf. også IAS 8.10 og 8.11. IFRS 3 vil derfor etter min mening ikke være utelukket fra analog anvendelse på virksomhetssammenslutninger under samme kontroll, men slik anvendelse må begrunnes i kildehierarkiet. I denne sammenhengen vil det også være relevant å vurdere om andre regnskapsregimer kan gi veiledning, herunder om den norske fisjonsstandarden, NRS (F) Fisjon (2006), eventuelt NRS 9 Fusjon (gjelder fisjonsfusjon), kan være relevant. Det siste spørsmålet diskuteres nærmere senere i kapittelet.

Virksomhetssammenslutninger under samme kontroll er for øvrig et område hvor det eksisterer ulik praksis, og IASB har som målsetting å regulere slike virksomhetssammenslutninger. Det er antydet fra IASBs side at det vil bli publisert et diskusjonsnotat om «Business Combinations under Common Control» i siste halvår 2020.

\section{Overføring av enkelteiendeler $\mathrm{mv}$.}

Virkeområdet til IFRS 3 utelukker også transaksjoner eller hendelser som medfører overdragelse av annet enn det som oppfyller definisjonen av virksomhet. Det betyr at fisjoner hvor det som overdras ved fisjonen ikke anses som virksomhet, i alle tilfeller vil falle utenfor virkeområdet til IFRS 3. I slike tilfeller må dette anses som overtakelse av 
enkelteiendeler og -forpliktelser med oppgjør i aksjer i overtakende foretak. I så fall vil de enkelte regnskapsstandardene og tolkningsuttalelsene som er relevante, komme til anvendelse ved innregning og måling av disse i balansen til overtakende foretak. For eksempel vil overtakelse av varer bli regnskapsført etter IAS 2, overtakelse av eiendom, anlegg og utstyr bli regnskapsført etter IAS 16, immaterielle eiendeler etter IAS 38 , investeringseiendom etter IAS 40, biologiske eiendeler etter IAS 41, usikre forpliktelser etter IAS 37 og finansielle eiendeler og forpliktelser etter IFRS 9 og IAS 32. Disse standardene unntar ikke transaksjoner som skjer under samme kontroll, noe som gjør at de får anvendelse på fisjoner under samme kontroll når det som overføres ved fisjonen, ikke representerer virksomhet etter IFRS 3. IFRS 2 Aksjebasert betaling vil kunne få anvendelse ved måling av vederlagsaksjer i fisjonen så sant fisjonen faller inn under virkeområdet til standarden. Se nærmere omtale senere i kapittelet.

\subsubsection{IAS 32 Finansielle instrumenter - presentasjon}

Fisjoner kjennetegnes ved at formelt overtakende foretak (som ikke nødvendigvis sammenfaller med reelt overtakende foretak) utsteder vederlagsaksjer. Utstedelse av slike vederlagsaksjer vil være regulert av IAS 32 Finansielle instrumenter - presentasjon. Av IAS 32.35 og 37 følger det at slike kapitalutvidelser skal regnskapsføres netto. I IAS 32.35 heter det blant annet at « $[\mathrm{t}]$ ransaksjonsutgifter for en egenkapitaltransaksjon skal regnskapsføres som et fradrag i egenkapitalen».

\subsubsection{IFRS 2 Aksjebasert betaling}

IFRS 2 vil i utgangspunktet gjelde ved regnskapsføring av alle transaksjoner hvor et foretak mottar varer eller tjenester mot et vederlag i foretakets aksjer. Den kan derfor få anvendelse ved regnskapsføring av fisjon i overtakende foretak selv om IFRS 2 ikke synes å være spesielt innrettet mot fisjoner. I standarden defineres «varer» svært vidt: «Varer omfatter 
beholdninger, forbruksvarer, eiendom, anlegg og utstyr, immaterielle eiendeler og ikke-finansielle eiendeler», jf. IFRS 2.5.

Det som derimot er klart, er at IFRS 2 ikke vil få anvendelse hvis fisjonen innebærer overføring av virksomhet etter IFRS 3 . Det følger av IFRS 2.5: «Et foretak skal imidlertid ikke anvende denne IFRS på transaksjoner der foretaket anskaffer varer som den del av de nettoeiendelene som overtas ved en virksomhetssammenslutning i IFRS 3.» Det samme gjelder hvis fisjonen skjer under samme kontroll, jf. IFRS 2.5.

\subsection{Regnskapsføring av fisjon i overdragende foretak $^{9}$}

\subsubsection{IFRIC 17 Utdelinger av ikke-kontante eiendeler til eierne}

Fisjoner som faller inn under virkeområdet til IFRIC 17, vil bli regnskapsført til virkelig verdi i overdragende foretak. På vedtakstidspunktet føres det som er vedtatt utdelt (utfisjonert del) som en forpliktelse målt til virkelig verdi, jf. IFRIC 17.11. Denne forpliktelsen skal måles på ny for hvert balansetidspunkt, jf. IFRIC 17.13. Når fisjonen skjer (utdelingen skjer), vil en eventuell forskjell mellom balanseført verdi på forpliktelsen og balanseført verdi på eiendelene som deles ut, bli resultatført (normalt som gevinst), jf. IFRIC 17.14. Tolkningsuttalelsen omhandler bare regnskapsføringen hos overdragende foretak, ikke regnskapsføring hos overtakende foretak, jf. IFRIC 17.8.

For at en fisjon skal falle inn under virkeområdet til IFRIC 17, jf. IFRIC 17.3 til 17.8, må den representere en ensidig utdeling, og utdelingen må gjelde eiendeler som ikke er kontanter, eller utdelinger hvor det kan gjøres et valg mellom å motta kontanter eller ikke-kontanter. Alle eierne innenfor samme klasse må likebehandles, og de ikke-kontante eiendelene kan ikke kontrolleres av samme part (parter) før og etter utdelingen.

9 Hvis ikke annet er spesielt nevnt, vil dette være å forstå som reelt overdragende foretak (som ikke nødvendigvis sammenfaller med formelt overdragende foretak). 
IFRIC 17 omfatter ikke utdelinger som innebærer forskjellsbehandling mellom eiere i samme klasse. Slik forskjellbehandling kan tyde på at mottakende eier har gitt fra seg noe til foretaket eller til de andre eierne, dvs. at det har skjedd en byttetransaksjon (Aamelfot et al., 2015, s. 350). Det kan derfor diskuteres om krav om likebehandling kan være til hinder for at IFRIC 17 kan anvendes på fisjoner hvor det skjer skjevdeling.

I fisjoner med skjevdeling skjer det endring i eiersammensetningen ved at eierne ikke deltar i samme forhold før og etter fisjonen, noen velger kanskje også full innløsning av sin aksjesits. Det innebærer samtidig at vederlaget ved fisjonen blir forskjellig mellom eierne, i betydningen at vederlagsaksjene og tilleggsvederlag ved fisjonen ikke tilfaller eierne $\mathrm{i}$ samme forhold som de eide aksjer i det overdragende foretaket før fisjonen. En fisjon med skjevdeling har derfor trekk av å være en byttetransaksjon ved at enkelte eiere helt eller delvis innløses. I NRS (F) Fisjon, punkt 26 heter det blant annet: «I en skjevdeling har aksjonærene motstridende interesser. (...) Skjevdeling har derfor alltid trekk av transaksjon.» Dette reflekteres også i det sterke minoritetsvernet som reglene i aksjelovene gir i forbindelse med slike fisjoner. Det kreves enstemmighet blant stemmene og aksjekapitalen som er representert på generalforsamlingen, for å vedta en fisjon med skjevdeling, jf. aksjeloven og allmennaksjeloven $\$ 14-6$ tredje ledd. Årsaken er at slike fisjoner i utgangspunktet strider mot det generelle aksjerettslige likebehandlingsprinsippet, jf. Aamelfot mfl. (2015, s. 42).

Fisjon med skjevdeling innebærer imidlertid ikke at den enkelte eier får et fisjonsvederlag, i form av aksjer og/eller tilleggsvederlag, som avviker i verdi fra vedkommendes forholdsmessige andel av de underliggende verdiene i overdragende foretak før fisjonen (Aamelfot et al., 2015, s. 40). Det skjer med andre ord ingen overføring av verdier mellom eierne verken ved jevndelings- eller skjevdelingsfisjon. Til tross for dette er det argumenter for at skjevdelingsfisjoner ikke kan anses å innebære likebehandling av eierne, noe som gjør at de tilsynelatende faller utenfor virkeområdet for IFRIC 17. Som omtalt over, er slike skjevdelingsfisjoner i strid med det generelle aksjerettslige likebehandlingsprinsippet, jf. krav om enstemmighet, og det skjer en endring av kontroll og risiko hos eierne når deres deltakelse i det fisjonerte foretaket endres ved fisjonen. 
Skjevdelingsfisjoner synes derfor ikke å være omfattet av virkeområdet til IFRIC 17. Likefullt kan det argumenteres for at en analog anvendelse av IFRIC 17-bestemmelsene på skjevdelingsfisjoner vil gi regnskapsbrukerne relevant og pålitelig informasjon. Et spørsmål som da melder seg, er om noe som synes utelatt fra virkeområdet, likevel kan brukes som grunnlag for analog tolkning. Jeg mener at det ikke er noe i veien for analog anvendelse av løsninger i en regnskapsstandard eller tolkningsuttalelse på problemstillinger som faller utenfor virkeområdet, så sant disse løsningene vil gi relevant og pålitelig informasjon og er i samsvar med definisjoner, innregningskriterier og måleprinsipper i det konseptuelle rammeverket, jf. også IAS 8.10 og 8.11. Av den grunn mener jeg at utfisjonerte eiendeler og forpliktelser i overdragende foretak bør regnskapsføres til virkelig verdi etter IFRS uavhengig av om fisjonen har trekk av jevndelings- eller skjevdelingsfisjon.

\subsubsection{IFRS 5 Anleggsmidler holdt for salg og avviklet virksomhet}

Når et overdragende foretak har et en utdelingsforpliktelse ved fisjon, vil ikke lenger balanseført verdi på de eiendelene som skal utfisjoneres, (i hovedsak) bli gjenvunnet ved bruk, og IFRS 5 vil komme til anvendelse, jf. IFRS 5.6. Det betyr at eiendeler klassifisert som holdt for utdeling til eiere, skal klassifiseres, presenteres og måles etter IFRS 5 så lenge vilkårene for å falle inn under virkeområdet til standarden er oppfylt. Det er dessuten viktig å poengtere at IFRS 5 kan komme til anvendelse ved fisjon også når IFRIC 17 ikke gjelder.

IFRS 5 skal anvendes fra det tidspunktet foretaket har forpliktet seg til utdeling. Eiendelene må da være tilgjengelige for utdeling i sin nåværende tilstand, og utdelingen må være svært sannsynlig, jf. IFRS 5.7. For at utdelingen skal være svært sannsynlig, må den oppfylle de samme vilkårene som gjelder for klassifisering som holdt for salg. Siden IFRS 5 stiller krav om svært sannsynlig, men ikke at det foreligger et absolutt vedtak, vil omklassifisering som holdt for utdeling, i mange tilfeller måtte skje før generalforsamlingen vedtar fisjonen.

Eiendeler som er klassifisert som holdt for utdeling, skal måles til laveste verdis prinsipp, dvs. laveste verdi av balanseført verdi og virkelig 
verdi fratrukket utdelingsutgifter, jf. IFRS 5.15A. Disse eiendelene skal presenteres separat i balansen, jf. IFRS 5.38 .

\subsection{Regnskapsmessig behandling av fisjoner under GRS og IFRS - en oversikt}

Til forskjell fra IFRS er det under GRS en egen fisjonsstandard, NRS (F) Fisjon. Ved vurdering av regnskapsmessig behandling av fisjon etter denne standarden skilles det mellom rene fisjoner (fisjon ved nystiftelse) og fisjonsfusjonen hvor det overtakende foretaket eksisterer før fisjonen. I tillegg skilles det mellom fisjon med skjevdeling og jevndeling.

I tabellen under er ulike regnskapsmessige løsninger for fisjoner presentert etter inndelingen av typetilfeller av fisjoner i NRS (F) Fisjon. Deretter er den regnskapsmessige løsningen under GRS og NRS (F) Fisjon sammenholdt med mulig løsning etter IFRS.

Tabell 4.2 Regnskapsmessige løsninger for fisjon under GRS og IFRS

\begin{tabular}{|c|c|c|c|c|c|}
\hline \multirow[b]{2}{*}{ Fisjonstype } & \multirow{2}{*}{$\begin{array}{l}\text { Regnskaps- } \\
\text { språk }\end{array}$} & \multicolumn{2}{|c|}{ GRS } & \multicolumn{2}{|c|}{ IFRS } \\
\hline & & $\begin{array}{l}\text { Overdragende } \\
\text { foretak }\end{array}$ & $\begin{array}{l}\text { Overtakende } \\
\text { foretak }\end{array}$ & $\begin{array}{l}\text { Overdragende } \\
\text { foretak }\end{array}$ & $\begin{array}{l}\text { Overtakende } \\
\text { foretak }\end{array}$ \\
\hline \multirow{2}{*}{ Ren fisjon } & Jevndeling & Kontinuitet & Kontinuitet & $\begin{array}{l}\text { IFRIC 17: virkelig } \\
\text { verdi med } \\
\text { gevinst og tap } \\
\text { IFRS 5: holdt for } \\
\text { utdeling }\end{array}$ & $\begin{array}{l}\text { IFRS 3: } \\
\text { overtakelses- } \\
\text { metoden hvis } \\
\text { virksomhet } \\
\text { IFRS } 2 \text { og andre } \\
\text { enkeltstandarder } \\
\text { hvis ikke } \\
\text { virksomhet }\end{array}$ \\
\hline & Skjevdeling & $\begin{array}{l}\text { Virkelig verdi } \\
\text { med gevinst } \\
\text { og tap }\end{array}$ & Virkelig verdi & $\begin{array}{l}\text { IFRIC } 17 \text { gjelder } \\
\text { ikke, men kan } \\
\text { trolig brukes } \\
\text { analogt, jf. IAS } \\
8.11 \\
\text { IFRS 5: holdt for } \\
\text { utdeling }\end{array}$ & $\begin{array}{l}\text { IFRS 3: } \\
\text { overtakelses- } \\
\text { metoden hvis } \\
\text { virksomhet } \\
\text { IFRS } 2 \text { og andre } \\
\text { enkeltstandarder } \\
\text { hvis ikke } \\
\text { virksomhet }\end{array}$ \\
\hline
\end{tabular}




\begin{tabular}{|c|c|c|c|c|c|}
\hline \multirow[b]{2}{*}{ Fisjonstype } & \multirow{2}{*}{$\begin{array}{l}\text { Regnskaps- } \\
\text { språk }\end{array}$} & \multicolumn{2}{|c|}{ GRS } & \multicolumn{2}{|c|}{ IFRS } \\
\hline & & $\begin{array}{l}\text { Overdragende } \\
\text { foretak }\end{array}$ & $\begin{array}{l}\text { Overtakende } \\
\text { foretak }\end{array}$ & $\begin{array}{l}\text { Overdragende } \\
\text { foretak }\end{array}$ & $\begin{array}{l}\text { Overtakende } \\
\text { foretak }\end{array}$ \\
\hline \multirow{2}{*}{ Fisjonsfusjon } & Jevndeling & $\begin{array}{l}\text { Virkelig verdi } \\
\text { med gevinst } \\
\text { og tap }\end{array}$ & $\begin{array}{l}\text { Virkelig verdi } \\
\text { Kontinuitet } \\
\text { ved uendret } \\
\text { eierskap }\end{array}$ & $\begin{array}{l}\text { IFRIC 17: virkelig } \\
\text { verdi med } \\
\text { gevinst og tap, jf. } \\
\text { IAS } 8.11 \\
\text { IFRS 5: holdt for } \\
\text { utdeling }\end{array}$ & $\begin{array}{l}\text { IFRS 3: } \\
\text { overtakelses- } \\
\text { metoden hvis } \\
\text { virksomhet } \\
\text { IFRS } 2 \text { og andre } \\
\text { enkeltstandarder } \\
\text { hvis ikke } \\
\text { virksomhet }\end{array}$ \\
\hline & Skjevdeling & $\begin{array}{l}\text { Virkelig verdi } \\
\text { med gevinst } \\
\text { og tap }\end{array}$ & Virkelig verdi & $\begin{array}{l}\text { IFRIC } 17 \text { gjelder } \\
\text { ikke, men kan } \\
\text { trolig brukes } \\
\text { analogt, jf. IAS } \\
8.11 \\
\text { IFRS 5: holdt for } \\
\text { utdeling }\end{array}$ & $\begin{array}{l}\text { IFRS 3: } \\
\text { overtakelses- } \\
\text { metoden hvis } \\
\text { virksomhet } \\
\text { IFRS } 2 \text { og andre } \\
\text { enkeltstandarder } \\
\text { hvis ikke } \\
\text { virksomhet }\end{array}$ \\
\hline
\end{tabular}

\subsection{Avsluttende betraktninger}

Jeg har i dette kapittelet forsøkt å klargjøre hvilke regnskapsmessige løsninger som kan gjelde for fisjoner under IFRS. Under IFRS finnes det ikke en eksplisitt regulering av regnskapsmessig behandling av fisjoner, og dette har ført til en uensartet praksis og dermed også et behov for klargjøring. Hensikten med dette kapittelet er å gi en slik klargjøring. Det betyr imidlertid ikke at kapittelet løser eller besvarer alle spørsmål som gjelder regnskapsmessig behandling av fisjoner under IFRS. Det er heller ikke sikkert at alle er enige i de forslagene som presenteres, men de tjener likevel som innspill til de diskusjonene som i praksis oppstår når fisjoner skal regnskapsføres etter IFRS.

IFRS har ikke en egen regnskapsstandard eller tolkningsuttalelse som direkte regulerer regnskapsmessig behandling av fisjon. Likefullt finnes det en rekke standarder mv. som berører problemstillinger som er knyttet til fisjon. Disse vil være relevante kilder for å avgjøre hvordan fisjoner skal regnskapsføres etter IFRS. Ved regnskapsføring av fisjon i overtakende 
foretak argumenteres det for at IFRS 3 får anvendelse hvis det som overtas i forbindelse med fisjonen, oppfyller definisjonen av virksomhet og fisjonen ikke skjer under samme kontroll, dvs. fisjoner som verken skjer mellom selskaper innad i et konsern eller mellom selskaper under kontroll av en enkelt eier/eiergruppering. Hvis det som overtas ikke er virksomhet, vil eiendeler og forpliktelser bli regnskapsført etter relevant regnskapsstandard (eksempelvis IAS 2, IAS 16, IAS 38 osv.). IFRS 2 vil være relevant ved måling av vederlaget (med noen unntak).

Ved regnskapsføring av fisjon i overdragende foretak argumenterer jeg for at IFRIC 17 vil ha relevans, så lenge eierne likebehandles og fisjonen ikke skjer under samme kontroll. IFRIC 17 vil imidlertid gjelde både når det overføres virksomhet ved fisjonen og ikke. Krav om likebehandling gjør at IFRIC 17 ikke uten videre gjelder ved skjevdelingsfisjoner, men en tilsvarende løsning som den som følger av IFRIC 17, vil kunne gi relevant og pålitelig informasjon. Dette er også en løsning som er sammenfallende med den norske løsningen etter NRS(F) Fisjon. Det kan derfor argumenteres med referanse til kildehierarkiet at en løsning tilsvarende IFRIC 17 vil kunne benyttes for skjevdelingsfisjoner. IFRS 5 vil kunne få anvendelse i overdragende foretak ved alle fisjoner.

Fisjoner under samme kontroll faller utenfor virkeområdet til IFRS 3 og IFRIC 17. Det innebærer at kildehierarkiet må anvendes (jf. IAS 8.11 og IAS 8.12). Det kan argumenteres for analog anvendelse av IFRS 3 og IFRIC 17 og dermed regnskapsføring etter overtakelsesmetoden også i slike fisjoner, men det kan også argumenteres for bruk av kontinuitetsmetoden. Hvis det legges vekt på det som skjer på selskapsnivå, vil man raskt kunne argumentere for at langt de fleste fisjoner (og fusjoner) innebærer endringer i de underliggende økonomiske realitetene i foretakene som deltar i fisjonen (endringer i risiko- og kontantstrømprofil). Dette tilsier bruk av overtakelsesmetoden også for fisjoner under samme kontroll. På eiernivå er derimot de økonomiske realitetene uendret, noe som tilsier bruk av kontinuitetsløsning.

Det kan være relevant å trekke inn norsk regulering siden krav om lignende konseptuelt rammeverk, jf. IAS 8.12, ikke synes å ramme fisjoner (eller fusjoner). De regnskapsmessige løsningene som er nedfelt i NRS (F) Fisjon og NRS 9 Fusjon (relevant ved fisjonsfusjon) er utledet 
av transaksjonsprinsippet i regnskapsloven $₫$ 4-1 første ledd nr. 1. Man kan finne mange eksempler på et tilsvarende transaksjonsprinsipp i regnskapsstandarder og tolkningsuttalelser etter IFRS. Det at god regnskapsskikk i tillegg til transaksjonsprinsippet bygger på resultatorienterte prinsipper slik som opptjenings- og sammenstillingsprinsippet, vil ikke i seg selv være diskvalifiserende (Kvifte \& Johnsen, 2008). I tillegg kan det fremholdes at norske regnskapsstandarder i lang tid er forsøkt tilpasset IFRS, jf. Norsk RegnskapsStiftelses strategi (2008 og 2012).

Som omtalt over, er kapittelet ment som et innspill til diskusjonen om hvilke regnskapsmessige løsninger som gjelder for fisjon under IFRS, men det gir imidlertid ikke svar på alle spørsmål, og det er heller ikke sikkert at de løsningene som skisseres her, er noe som alle er enig i. Som en forlengelse av dette arbeidet kunne det vært interessant å gjennomført en kartlegging av hvilke løsninger som er anvendt i praksis, og hvorfor løsningene er valgt. En slik undersøkelse kunne vært rettet mot foretak som rapporterer etter IFRS, eller mot revisorer som reviderer regnskaper avlagt etter IFRS. En mer spisset innretning på en slik undersøkelse kunne vært å intervjue representanter fra fagavdelingene i regnskap i de store revisjonsselskapene. De spørsmålene som er berørt i dette kapittelet, er heller ikke avgrenset til Norge, men har også internasjonal relevans. Det kunne derfor vært interessant å gjøre tilsvarende undersøkelse rettet mot et internasjonalt utvalg av for eksempel revisorer.

\section{Referanser}

\section{Rettskilder mv.}

Aksjeloven (1997). Lov om aksjeselskaper.

Allmennaksjeloven (1997). Lov om allmennaksjeselskaper.

ASC 845. Accounting for Nonmonetary Transactions. FASB.

IAS 1. Presentasjon av finansregnskap. IASB.

IAS 2. Beholdninger. IASB.

IAS 8. Regnskapsprinsipper, endringer i regnskapsmessige estimater og feil. IASB.

IAS 16. Eiendom, anlegg og utstyr. IASB.

IAS 27. Separat finansregnskap. IASB.

IAS 32. Finansielle instrumenter - Presentasjon. IASB.

IAS 37. Usikre forpliktelser og betingede eiendeler. IASB. 
IAS 38. Immaterielle eiendeler. IASB.

IAS 40. Investeringseiendom. IASB.

IAS 41. Landbruk. IASB.

IASB (2018). Conceptual Framework for Financial Reporting. IASB.

IFRIC 17. Utdelinger av ikke-kontante eiendeler til eierne.

IFRS 2. Aksjebasert betaling. IASB.

IFRS 3. Virksomhetsammenslutninger. IASB.

IFRS 7. Finansielle instrumenter - opplysninger. IASB.

IFRS 9. Finansielle instrumenter. IASB.

IFRS 15. Regnskapsforing av kundekontrakter. IASB.

NRS 9. Fusjon. Norsk RegnskapsStiftelse.

NRS (F). Fisjon. Norsk RegnskapsStiftelse.

\section{Artikler, bøker mv.}

Berner, P. \& Aastveit, J. (2011). Utdelinger i IFRS. Revisjon og Regnskap, 81(5), 22-26.

Blegeberg, J. \& Haraldseth, M. (2016). Omorganiseringer i konsern etter GRS og IFRS. Masteroppgave i regnskap og revisjon. BI.

Deloitte. (2019). Deloitte international IFRS pack 2019.

EY. (2020). International GAAP. Wiley.

Grant Thornton. (2018). IFRS viewpoint: Common control business combinations. https://www.grantthornton.global/globalassets/1.-member-firms/global/insights/ article-pdfs/ifrs/ifrs-viewpoint-4---common-control-business-combinations.pdf

Graver, H. P. (2011). Rettsforskningens oppgaver og rettsvitenskapens autonomi. Tidsskrift for Rettsvitenskap, 124(2), 230-249.

IASB. (2020). Business combinations under common control. https://www.ifrs.org/ projects/work-plan/business-combinations-under-common-control/

Johnsen, A. \& Kvaal, E. (1999). Regnskapsloven. Kommentarer til lov av 17.7.1998 nr. 56 om årsregnskap m.v. Oslo: Cappelen Akademiske Forlag.

KPMG. (2019). Insights into IFRS: KPMG's practical guide to international financial reporting standards.

Kvifte, S. S. (2003). The usefulness of the asset-liability view: An analysis of conceptual frameworks and the implications for Norwegian accounting regulation. Doktorgradsavhandling. NHH.

Kvifte, S. S. (2008). Regnskapsføring av omorganiseringer - et regulatorisk vakuum. Praktisk økonomi \& finans.

Kvifte, S. S. \& Johnsen, A. (2008). Konseptuelle rammeverk. Oslo: DnR-forlaget.

Kvaal, E. (2004). Fisjon i skjæringspunktet mellom IFRS og norsk lovgivning. Revisjon og regnskap, 74(8), 24-30. 
Kvaal, E. \& Johnsen, A. (2000). Fusjon og fisjon - en eksersis i

transaksjonsprinsippet. I E. Mamelund (Red.), Festskrift til Finn Berg Jacobsen: 6o-årsdag. Oslo: J. W. Cappelen Forlag.

Kvaal, E. \& Stenheim, T. (2018). Forelesningsfoiler i fisjon og omorganiseringer i konsern brukt ved master i regnskap og revisjon ved BI.

PwC. (2020a). Common control transaction guidance (2020). Hentet fra https://www. pwc.com/us/en/services/audit-assurance/accounting-advisory/common-controltransactions.html

PwC. (2020b). Manual of accounting - IFRS.

Norsk RegnskapsStiftelse. (2008). Strateginotat. Hentet fra https://www. regnskapsstiftelsen.no/wp-content/uploads/2015/04/Strateginotat-2008-vedtatt.pdf

Norsk RegnskapsStiftelse. (2012). Endring av strategi. Hentet fra https://www. regnskapsstiftelsen.no/om-nrs/strategi/

Schwencke, H. R., Haugen, D. O., Baksaas, K. M., Stenheim, T. \& Avlesen-Østli, E. (2020). Årsregnskapet i teori og praksis. 21. utgave. Oslo: Gyldendal Akademisk Forlag.

Stenheim, T. (2019). Forelesningsfoiler på omorganisering under samme kontroll brukt ved master i regnskap og revisjon ved BI.

Strandvold, A. A. \& Juul, M. A. (2020). Samme kontroll - fusjoner og fisjoner under IFRS. Magma, 23(1), 25-33.

Aamelfot, T. H., Bjørken, S. I., Bjørnslett S., Jacobsen K. L., Løfsgaard E. S, Johansen, O. E. \& Wilter G. N. (2015). Fusjon og fisjon: skatt, regnskap og selskapsrett. Oslo: Fagbokforlaget.

Aarbakke, M., Skåre, J., Aarbakke, A., Knudsen, G. \& Ofstad, T. (2017). Aksjeloven og allmennaksjeloven Lovkommentar. Oslo: Universitetsforlaget. 



\title{
Standardisert elektronisk regnskapsrapportering i Norge: bruk av XBRL
}

\author{
Ellen M. Kulset
}

Førsteamanuensis, Universitetet i Sørøst-Norge og Norges Handelshøyskole

Kjell Magne Baksaas

Dosent, Universitetet i Sørøst-Norge

Sammendrag: Elektronisk utveksling av finansiell informasjon skjer i stadig større grad ved hjelp av rapporteringsformatet XBRL (eXtensible Business Reporting Language), som sies å gi både regnskapsprodusenter og regnskapsbrukere fordeler, blant annet i form av effektivitet og mer sammenlignbar informasjon. Fra og med 01.01.2020 stilles det for eksempel krav om at børsnoterte foretak i EU må benytte en form for XBRL-rapportering i sine konsernregnskap. Samtidig stilles det spørsmål ved om informasjonen som kommuniseres ved hjelp av denne typen formater, vil være mindre beslutningsnyttig, og om ikke dette er spesielt problematisk dersom man befinner seg i et prinsippbasert regnskapsregime som IFRS. I dette kapittelet undersøker vi først (1) hvilke former for elektronisk rapportering av finansiell informasjon som benyttes i Norge. I forbindelse med implementering av XBRL i EU er det interessant å kunne bygge på erfaringer fra bruk av XBRL-formatet i USA, og vi oppsummerer derfor tidligere forskning for å svare på følgende spørsmål: (2) I hvilken grad preges XBRL-regnskap av rapporteringsfeil? (3) Når benytter selskap egentilpassede rapporteringselementer? (4) Hvilken betydning har bruk av egentilpassede rapporteringselementer for regnskapsbrukerne? (5) Blir finansregnskap mer sammenlignbare etter implementering av XBRL? Vår oppsummering konkluderer med at forskningen på dette området $\mathrm{i}$ liten grad gir klare svar på disse spørsmålene, og det bør oppmuntres til ytterligere forskning.

Nøkkelord: elektronisk regnskapsrapportering, elektronisk rapportering av finansiell informasjon, ESEF, XBRL

Sitering av denne artikkelen: Kulset, E. M. \& Baksaas, K. M. (2020). Standardisert elektronisk regnskapsrapportering i Norge: bruk av XBRL. I T. Stenheim, K. M. Baksaas og E. M. Kulset (Red.), Aktuelle temaer i regnskap og revisjon (Kap. 5, s. 143-165). Oslo: Cappelen Damm Akademisk. https://doi.org/10.23865/ noasp.112.ch5

Lisens: CC-BY 4.0. 


\subsection{Innledning}

I en stadig mer digitalisert verden vil naturligvis elektronisk utveksling av regnskapsinformasjon kunne gi en rekke fordeler for både regnskapsbrukere og regnskapsprodusenter. XBRL er et eksempel på et slikt utvekslingsformat, og det hevdes gjerne å gi mange fordeler i forbindelse med informasjonsutveksling både internt og mellom selskaper (bedret informasjonsutveksling i kunde-leverandør-forhold). Allikevel har det vært omfattende diskusjoner knyttet til obligatorisk innføring med tanke på valg av format og på hvilke selskaper som skal omfattes av eventuelle krav, og det var først i 2017 at de første norske selskapene ble omfattet av regulering som innebærer obligatorisk XBRL-rapportering.

I forbindelse med diskusjoner om hvilke selskaper som skulle omfattes av obligatorisk XBRL-rapportering av årsregnskap i USA, ble det for eksempel hevdet at det ikke var nødvendig å inkludere mindre børsnoterte selskaper ettersom de som investerer i slike selskaper, ikke har noen interesse av å få regnskapet i maskinlesbar form (Cong et al., 2018). Cong mfl. (2018) studerer hvordan regnskapene i 880 mindre selskaper som er omfattet av reglene om obligatorisk XBRL-rapportering, ble hentet ut av EDGAR-databasen i perioden 3. kvartal 2012 til 1. kvartal 2015, og finner at det ikke stemmer med liten interesse for XBRL-rapportering: 61 prosent av brukerne går inn i XBRL-filene, mens de resterende 39 prosent går inn i de tradisjonelle regnskapene.

I Norge benyttes XBRL-formatet i relativt liten grad i dag ved standardisert elektronisk rapportering av regnskapsinformasjon, men det benyttes $\mathrm{i}$ noen grad i forbindelse med annen rapportering til offentlige myndigheter. Det første formålet med dette kapittelet er å skaffe en oversikt over hvilke former for standardisert elektronisk rapportering av finansiell informasjon som benyttes i Norge. Vi stiller altså følgende spørsmål:

1) Hvilke former for elektronisk rapportering av finansiell informasjon benyttes i Norge i dag?

Dette spørsmålet er ikke behandlet i tidligere forskning.

EU pålegger børsnoterte foretak en form for XBRL-rapportering i sine konsernregnskap fra regnskapsåret som starter 01.01.2020. Etter at 
EU-direktivet er implementert i Norge, vil dette medføre at også norske børsselskaper må rapportere etter denne malen. IFRS (International Financial Reporting Standards) er et prinsippbasert regnskapsspråk der det overordnede kravet om «dekkende fremstilling» spiller en viktig rolle. Av denne grunn hevdes det gjerne at standardisert elektronisk rapportering er problematisk med sin iboende vekt på standardisering og sammenlignbarhet. Regnskapsloven er også et slikt prinsippbasert regnskapsspråk.

Det andre formålet med dette kapittelet er derfor å undersøke nærmere hvilke konsekvenser det er grunn til å tro at implementeringen av XBRL i EU vil få på noen viktige områder. Dette gjøres ved å gjennomgå og oppsummere funn fra internasjonale studier som behandler spørsmål om implementering og betydning av XBRL. Vi stiller følgende spørsmål:

2) I hvilken grad preges XBRL-regnskap av rapporteringsfeil?

3) Når benytter selskaper egentilpassede rapporteringselementer?

4) Hvilken betydning har bruk av egentilpassede rapporteringselementer for regnskapsbrukerne?

5) Blir finansregnskap mer sammenlignbare etter implementering av XBRL?

Disse spørsmålene er tidligere behandlet i studier publisert i internasjonale tidsskrift, og vi fremskaffer således ny kunnskap ved å sammenfatte tidligere forskning og diskutere internasjonale studier i en norsk kontekst samt ved å komme med forslag til ny forskning. Perdana mfl. (2015) summerer opp tidligere internasjonal XBRL-relatert forskning i en litteraturstudie. Vår litteraturstudie skiller seg fra denne studien hovedsakelig på to måter: (1) Der Perdana mfl. (2015) søker å skaffe en oversikt over all publisert litteratur innenfor temaet XBRL, har vi et snevrere siktemål ved at vi bare ser på studier som er relevante for forskningsspørsmålene 2 til 5 som vi stiller over, og går i dybden på disse. (2) Vi inkluderer forskning som er publisert etter at Perdana mfl. (2015) publiserte sin studie.

Så langt forfatterne av dette kapittelet er kjent med, er det ikke tidligere gjennomført noen akademiske studier der det fokuseres på XBRL i Norge. Kapittelet vil således bidra med innsikt som kan være interessant, både for reguleringsmyndigheter, for selskaper som skal gjennom denne 
prosessen i relativt nær fremtid, og for selskaper som vurderer frivillig å implementere XBRL-rapportering enten til ekstern eller intern bruk.

Vi vil i delkapittel 2 presentere generell informasjon om XBRL, og deretter vil vi i delkapittel 3 presentere vår metode og datainnsamling før vi presenterer våre funn i delkapittel 4. Avslutningsvis vil vi oppsummere funn og implikasjoner av disse.

\subsection{Bakgrunn}

\subsubsection{Generelt om XBRL}

XBRL (eXtensible Business Reporting Language) er en XML-basert standard for elektronisk kommunikasjon av finansielle data (www.xbrl.org), dvs. «et språk for elektronisk kommunikasjon av forretnings- og regnskapsinformasjon» (Tystad, 2005). Finansielle data struktureres og standardiseres etter en fast mal, gjerne kalt en taksonomi. XBRL-filer kan enten inkludere detaljerte transaksjonsdata (Global Ledger) eller aggregert rapportering på regnskapslinjenivå (Financial Statements / Financial Reporting), eventuelt på kontonivå som en mellomvariant. Nøkkelpunktet er at en autorativ instans bestemmer en taksonomi som rapporteringen skal benytte. XBRL-taksonomien er et «ordforråd» eller en «ordbok» (Microsoft, 2020). Dette vil si regler for hvilke elementer (tagger) som er tillatt, og hva hvert element skal bety. De rapporteringspliktige tagger rapportert informasjon opp mot taksonomien. Mottaker eller bruker kan da nøyaktig og spesifikt fastslå hva slags post rapportert informasjon omhandler. Regnskapsinformasjon rapportert ved hjelp av XBRL er så spesifikk og entydig at analyseprogrammer kan benytte XML-kodingen til å foreta videre analyser uten noe ytterligere tolking. Dette kan blant annet bidra til at regnskapsbrukerne får en ny innsikt i tallene som presenteres, ved at de på en enkel måte kan lese XBRL-merkelappene og se tilhørende regnskapsstandard mens de gjennomgår tallene.

Med fremveksten av internett så vi på slutten av forrige årtusen at finansiell informasjon i stadig økende grad ble presentert i elektronisk form enten i HTML- eller pdf-format. Disse formatene kunne imidlertid ikke leses/analyseres direkte av maskiner. XBRL er derimot et maskinlesbart format for rapportering av finansiell informasjon. Det betyr at 146 
informasjonen direkte kan inngå som input i regnskapsbrukeres analysemodeller uten at tallene må tastes inn på nytt.

XBRL har en historie tilbake til 1997, da Charlie Hoffman, en amerikansk CPA, leste en bok om XML og begynte arbeidet med å finne ut hvordan dette kunne benyttes i sammenheng med finansiell rapportering. Rundt årtusenskiftet hadde AICPA (American Institute of Certified Public Accountants) koblet seg på arbeidet, og en prototype kalt XFRML, senere omdøpt XBRL, ble utviklet (UB Partner). Hensikten med arbeidet var å gjøre det enklere å utveksle finansiell informasjon (Perdana et al., 2015) med vekt på effektivitet (efficiency), men XBRL kan også bidra med informasjon som kan utgjøre en forskjell i beslutningssammenheng (effectiveness), se for eksempel Robb mfl. (2016). Ifølge Beerbaum mfl. (2017) innebærer XBRL fire sentrale fordeler: redusert informasjonsasymmetri, $ø$ kt effektivitet, reduserte rapporteringskostnader og bedret sammenlignbarhet gjennom standardisering.

XBRL brukes per i dag i en rekke land i forbindelse med rapportering av finansiell informasjon på ulike måter. Mens man i land som Nederland og Australia har valgt et «multiagency-focus», det vil si en løsning der man har tilrettelagt for XBRL-rapportering til ulike instanser i samme tekniske løsning (skatt, finansregnskap, rapportering til bruk i ulike statistikker osv.) i den hensikt å gi effektivitetsgevinster i forbindelse med rapportering, har man for eksempel i USA flere ulike XBRL-løsninger for ulike typer rapportering (Robb et al., 2016). I norsk sammenheng svarte Hallstein Husand, avdelingsdirektør i Altinn, slik på spørsmålet «Hva med XBRL - den globale XML-baserte standarden for finansiell rapportering?» i 2005:

Vi har sett på den, men foreløpig er det ikke noen i Norge som har tatt den i bruk. Uansett kan ikke Altinn gå i spissen når det gjelder XBRL. Det må i så fall være etatene, Norges Bank, Børsen, VPS og andre som bruker økonomisk statistikk. Mange som bruker økonomisk statistikk vil være tjent med en form som er lik over alt. (Asklund 2005)

Mens noen land har valgt at XBRL skal være en obligatorisk løsning for finansiell rapportering for store selskaper (for eksempel USA), har andre land valgt at XBRL skal benyttes i forbindelse med obligatorisk rapportering også av små/mellomstore selskaper (for eksempel Italia), 
og i noen land er XBRL en frivillig rapporteringsløsning (Australia). Ettersom XBRL-implementering skjer via regnskapssystemet, vil frivillig XBRL-implementering i Norge bare være mulig ved bruk av IFRS inntil det eventuelt er utarbeidet en egen norsk -taksonomi basert på GRS God regnskapsskikk) som kan innarbeides i eksisterende regnskapssystemer.

XBRL-rapportering ble obligatorisk i USA fra 2009 for alle innenlandske selskaper som på dette tidspunktet var pliktig til å rapportere regnskapsinformasjon til Securities and Exchange Commission (SEC, 2009). Hensikten med kravet var å gjøre det enklere for investorer å analysere regnskapsinformasjon, automatisere rapporteringsprosessen samt sørge for raskere og nøyaktigere utveksling av regnskapsinformasjon (SEC, 2016). For å sikre rapporteringsfleksibilitet valgte SEC en rapporteringsløsning der regnskapsprodusenten har mulighet til å inkludere egenutviklede elementer («extension elements») i tilfeller der XBRLtaksonomien ikke inneholder passende/nødvendige elementer.

\subsubsection{Elektronisk årsregnskap for børsnoterte foretak i EU}

I dette kapittelet fokuserer vi særlig på nye krav for foretak som er børsnotert på regulert marked og tar spesifikt for oss ESEF Regulation (European Single Electronic Format) fastsatt av ESMA (The European Securities and Markets Authority) og vedtatt av EU. Bakgrunnen og hjemmelen er rapporteringsdirektivet for omsettelige verdipapirer, Europaparlaments- og rådsdirektiv 2013/50/EU av 22. oktober 2013 om endring av direktiv 2004/109/EF artikkel 4. I Norge ble endringsdirektivet utredet i NOU 2016: 2 og var på høring våren/sommeren 2016. Bestemmelsene i verdipapirhandelloven er i skrivende stund fremdeles under behandling i Finansdepartementet.

Etter direktivets artikkel 21a skal det etableres en elektronisk publiseringsportal. I EU er det videre vedtatt at årsrapportene til alle børsnoterte foretak fra og med 1. januar 2020 må være utarbeidet i XHMTL-format. Dette er en rapportform som kombinerer optisk lesbar HTML og digital XBRL-koding. I første omgang, for årsregnskapet for 2020, er det konsernregnskapet som skal rapporteres med XBRL-koding i samsvar med ESEFs 
XBRL-taksonomi, som bygger på IFRS-regelverkets XBRL-taksonomi fra IASB (Ernst \& Young, 2018). Deretter er det planlagt at også noter for 2021 skal inneholde XBRL-koding. Det er i skrivende stund uavklart når dette vedtaket vil tre i kraft for norske børsnoterte selskaper. Enkelte norske selskaper rapporterer allerede i XBRL-format, for eksempel på grunn av krav som stilles av SEC. Disse kravene gjelder blant annet Equinor, som har rapportert årsregnskapet sitt i XBRL-format siden 2017 (Kvelvane, 2019).

IASB har i flere år arbeidet med en taksonomi for XBRL. Taksonomien er å regne som en ordbok som gjør det mulig for regnskapsprodusentene å levere et digitalt regnskap basert på IFRS (IFRS), men så vidt oss bekjent, har denne hatt beskjeden utbredelse inntil IFRS-taksonomien ble tillatt benyttet av SEC. Prosessen bak arbeidet med IFRS-taksonomien beskrives i Troshani mfl. (2019), som blant annet fokuserer på arbeidet som er utført for å utvikle taksonomien gitt den iboende konflikten som finnes mellom det prinsippbaserte IFRS-språket og en detaljorientert IT-basert taksonomi (Troshani et al., 2019).

\subsubsection{Generelt om tidligere XBRL-relatert forskning}

XBRL er så vidt vi er kjent med, i liten grad tidligere behandlet i norsk forskning og er heller ikke mye omtalt i norsk profesjonslitteratur. Søk i Oria 13/02/20 gir for eksempel treff på bare én artikkel i Magma, og denne er redaksjonelt vurdert. Søk i Revisjon og Regnskap (profesjonstidsskrift) 13/o2/20 gir bare fire treff på XBRL hvorav tre av omtalene fant sted i 2005/2006 og en i 2019 .

Internasjonalt er det imidlertid publisert en rekke forskningsstudier, særlig i tidsskriftene International Journal of Accounting Information Systems og Journal of Information Systems. Søk i databasen «Business Source Elite» på «XBRL» gir 613 treff i kategorien fagfellevurderte artikler (søk utført 13/o2/20). Litteraturen er i all hovedsak oppsummert i en relativt ny litteraturstudie foretatt av Perdana mfl. (2015). Ettersom forskningsfeltet er relativt nytt, er det imidlertid en rekke studier som er så nye at de ikke er en del av oppsummeringen i Perdana mfl. (2015).

Perdana mfl. (2015) deler inn tidligere XBRL-forskning i fire kategorier. Det er studier som ser på: (1) forretningsmessige konsekvenser, 
(2) implementering, (3) teknisk utvikling og (4) utdanning. Perdana mfl. (2015) summerer opp XBRL-forskning utført i 2014 og tidligere, og studien lister opp en rekke forretningsmessige konsekvenser av XBRL, for eksempel enklere utveksling av informasjon, nyttigere regnskapsinformasjon, reduserte kostnader knyttet til produksjon og bruk av regnskapsinformasjon, høyere regnskapskvalitet målt ved hjelp av faktorer som integritet, relevans, transparens, troverdighet og sammenlignbarhet, osv.

Effendi mfl. (2016) studerer for eksempel den frivillige implementeringen av XBRL i USA (det vil si XBRL-rapportering til SEC før det ble obligatorisk i 2009) og finner at XBRL-formatet bidrar med ny informasjon som investorer er interessert $\mathrm{i}$ å benytte. Bhattacharya mfl. (2018) finner at innføring av XBRL har ført til mindre informasjonsasymmetri mellom store og små institusjonelle investorer, mens Henderson (2015) i en eksperimentelt basert studie finner at XBRL gjør det enklere å lykkes med investeringer for ikke-profesjonelle aktører, slik at XBRL-formatet er spesielt «bra» for ikke-profesjonelle aktører.

Ifølge Beerbaum mfl. (2017) fører nasjonale standardsetteres fokusering på innføring av elektronisk rapportering til at finansregnskapene blir mer regelbasert, og de ser derfor nærmere på konflikten mellom elektronisk rapportering og prinsippbasert regnskapsføring. Studien finner at denne konflikten i liten grad har vært påaktet i tidligere forskning, men forskerne konkluderer med at selv om det finnes en konseptuell konflikt mellom et prinsippbasert regnskapsspråk som IFRS og XBRL-basert rapportering, er hovedutfordringen per i dag i praksis at IFRS-taksonomien ikke er tilstrekkelig utviklet. Vår litteraturstudie behandler den samme underliggende problematikken som Beerbaum mfl. (2017), men skiller seg fra denne studien ved at vi oppsummerer nyere empirisk forskning som er relevant i forbindelse med implementering av XBRL i EU, og som ikke omtales i Beerbaum mfl. (2017).

\subsection{Metode og data}

Vi undersøker først hvilke former for XBRL-rapportering som er i bruk i forbindelse med standardisert rapportering av finansiell informasjon i Norge. For å svare på dette spørsmålet benytter vi skriftlig informasjon 
som finnes om XBRL i en norsk sammenheng i profesjonslitteraturen samt blant annet på ulike offentlige nettsteder.

Videre foretar vi en gjennomgang av tidligere internasjonal forskning for å finne svar på resten av forskningsspørsmålene vi stilte innledningsvis. Vi vil begrense oss til å se på forskning knyttet til bruk av XBRLtaksonomiene til US-GAAP og IFRS. Ettersom forskningsspørsmålene vi stiller omhandler elektronisk rapportering på regnskapslinjenivå, vil vi bare presentere internasjonal forskning som fokuserer på dette temaet. Videre vil vi primært fokusere på empiriske forskningsstudier. For å finne ut hva tidligere forskning kan gi oss av svar på spørsmålene vi stiller, gjennomfører vi en litteraturgjennomgang med «usystematiske trekk» (engelsk «narrative literature review», se blant annet Paré et al., 2015, og Bell et al., 2019), der hensikten ikke er å identifisere, beskrive og analysere alle forskningsartikler som omhandler XBRL eller spørsmålene vi stiller, men å identifisere et mindre antall artikler publisert i velrenommerte tidsskrift som i størst mulig grad belyser forskningsspørsmålene våre. Sett $\mathrm{i}$ lys av hensikten med litteraturstudien, kombinert med det høye antallet treff søk i både Google Scholar (for eksempel over 4000 treff på søket «XBRL and filing errors») og EBSCO (over 600 treff på «XBRL») gir, samt det faktum at det allerede eksisterer en større systematisk litteraturstudie om XBRL (Perdana et al., 2015), har vi valgt en mer usystematisk metode for litteratursøk enn den som benyttes i en systematisk litteraturstudie (se for eksempel Paré et al., 2015, for en gjennomgang av trekk ved ulike typer litteraturstudier).

For å identifisere relevante artikler tok vi utgangspunkt i litteraturstudien til Perdana mfl. (2015) og identifiserte der en håndfull artikler som ut fra beskrivelsen av disse syntes relevante. Vi leste gjennom disse artiklene og sorterte ut dem som faktisk omhandlet spørsmålene vi stiller. Deretter brukte vi beskrivelsen av tidligere litteratur i disse artiklene for å identifisere artikler bakover i tid. Deretter arbeidet vi oss fremover i tid ved å bruke referanseverktøyet i Google Scholar til å identifisere artikler som er skrevet i etterkant av allerede identifiserte artikler om temaene vi er interessert i. Identifiserte studier som ikke er publisert i tidsskrifter som er rangert i Academic Journal Guide (CABS, 2018), ble med noen unntak sortert ut. Avslutningsvis gjennomførte vi søk i databasen «Business Source Elite» 
med søkeordene «XBRL and reporting error», "XBRL and extension elements» og «XBRL and comparability» for å identifisere eventuelt ytterligere publiserte artikler som kunne belyse forskningsspørsmålene vi stiller.

\subsection{Funn og diskusjon knyttet til standardisert elektronisk rapportering av finansiell informasjon i Norge (forskningsspørsmål 1)}

\subsubsection{Dagens bruk i Norge av XBRL til myndighetskontroll - etterlevelse og analyse}

I Norge gjennomføres per i dag rapportering med bruk av XBRL til tilsynsmyndigheter for spesielle bransjer med detaljerte og spesifikke krav. Dette gjelder rapportering til Finanstilsynet for finans-, forsikrings- og pensjonsforetak som er underlagt CRD IV og Solvens II (Finans Norge, 2015; Finanstilsynet, 2017 og 2019). Disse reglene er i stor grad EU-styrt. Rapportering ved hjelp av Excel-maler ble erstattet med obligatorisk rapportering ved hjelp av XBRL fra 1. kvartal 2018 for disse foretakene og fra 1.1.2020 for krisetiltaksplaner, jf. finansforetaksloven $₫ 20-6$.

Skatteetaten har med hjemmel i bokføringsforskriften $₫$ 7-8 rett til å kreve SAF-T Regnskap (Standard Audit File - Tax) fra 1.1.2020. Dette er en form for XBRL- transaksjonsrapportering av kontospesifikasjon, kundespesifikasjon og leverandørspesifikasjon. Det er ventet at regnskapsfiler fra SAF-T kan være nyttige for rapportering og analyse også for andre regnskapsbrukere enn Skatteetaten, for eksempel ekstern revisor, men foreløpig er ikke bruken kommet i gang. Sentrale kilder i bransjeorganisasjonene synes å rope et varsko om at selv enkelte standard IT-systemer ikke vil klare å levere rapportene som forutsatt, og at foretakene må være forberedt på til dels omfattende og kompliserte innkjøringsutfordringer (Dyrnes et al., 2019). Det er ikke lagt opp til at regnskapsfilene fra SAF-T skal være offentlig tilgjengelige, men foretakene kan velge å dele filene med de samarbeidspartnerne de ønsker. Mulige andre anvendelsesområder enn dem som gjelder for Skatteetaten, er mer effektiv eksport og import av historiske data ved bytte av regnskapssystem og for revisor/ regnskapsfører ved kontroll og analyse av regnskapene. 


\subsubsection{Standardisert elektronisk rapportering av eksternt årsregnskap i Norge}

Regnskapsloven kapittel 6 har et standardisert format for resultat og balanse. Alle regnskapspliktige må elektronisk sende inn årsregnskap til Regnskapsregistereret ${ }^{1}$ via Altinn-portalen, jf. regnskapsloven $₫ 8$ 8-2. Årsregnskapene må rapporteres digitalt etter en standardmal som samsvarer med kravene i regnskapslovens kapittel 6. Det benyttes ikke XBRLformat, men en fast rapportmal i XML-format. Baksaas (2015) har foretatt en kritisk analyse av denne formen for standardisering. Han finner at regnskapsloven gir anvisning om at regnskapsprodusenten skal tilpasse layout og innhold til regnskapspresentasjonene. Regnskapsregisteret standardiserer informasjonen til lovens oppstillingsplaner. Det er denne standardiserte informasjonen for eksempel kredittrankingsselskapene benytter. To konkrete eksempler er at en egen regnskapslinje med særlige poster i resultatregnskapet eller betegnelsen andre immaterielle eiendeler i balansen standardiseres bort. Malen i regnskapsloven er spesifikk og med et begrenset antall linjer. Det er så langt ikke kjent at Regnskapsregisteret utreder bruk av XBRL på årsregnskap for ikke-børsnoterte selskaper. Regnskapsregisteret administrerer en database der alle innsendte regnskap rapporteres i standardlinjene etter oppstillingsplanene i regnskapsloven. Dermed er det overflødig å innføre en merking (tagging) av hvilke regnskapslinjer som hører til hvilke linjer i malen. Statistisk sentralbyrå ønsker også at det innføres maler på standardnoter, (NOU 2015: 10, vedlegg 2), slik at samme system som regnskapsmaler for oppstillingsplaner i størst mulig grad kan benyttes. Standardisering er en betingelse for elektronisk publisering med den konsekvens at det kan begrense muligheten regnskapsprodusentene har til å inkludere frivillig rapportering i sine årsregnskap, avhengig av hvilke løsninger man velger for egentilpassede elementer.

Tilgang til dataene i Regnskapsregisteret i elektronisk form er dyrt for brukere ved at tilgang i maskinlesbar form er en betalingstjeneste.

1 En del av Brønnøysundregistrene 
Tilgang til enkeltregnskap i pdf-format er gratis. ${ }^{2}$ Dette vanskeliggjør bruk av dataene for eksempel til analyser for andre regnskapsbrukere slik som nåværende/fremtidige investorer, leverandører og forskere.

Som tidligere nevnt er enkelte norske selskap, for eksempel Equinor ASA, omfattet av XBRL-rapporteringsplikt til SEC. Når det gjelder kravet til norske selskaper om rapporteringsplikt på grunn av EU-lovgivning, oppgir Finanstilsynet i november 2019 at det ikke vil komme endringer som innebærer krav om bruk av ESEF før 1.1.2020, og dermed vil det være frivillig for 2020. Det oppgis at det sannsynligvis blir rapporteringsplikt fra 2021 (Finanstilsynet, 2019).

\subsection{Funn og diskusjon knyttet til XBRL-relatert forskning (forskningsspørsmål 2-5)}

\subsubsection{I hvilken grad preges XBRL-regnskap av rapporteringsfeil?}

For å svare på dette spørsmålet ser vi nærmere på enkelte studier av både frivillig og obligatorisk rapportering av finansregnskap til SEC. Implementering av et nytt rapporteringssystem må forventes å innebære en del innkjøringsproblemer, og slik er det også med XBRL. Boritz og No (2008) studerer frivillig XBRL-rapportering til SEC fra oppstart til 2007 og ser i sitt materiale overraskende tendenser til at andelen feil i datamaterialet synes å øke over tid. Debreceny mfl. (2010) studerer de første obligatoriske rapporteringene til SEC og finner at en firedel av de første rapporteringene til SEC i 2009 inneholder rene beregningsfeil, det vil si feil som det i utgangspunktet skal være relativt lett både å oppdage og dermed også unngå ved bruk av XBRL. Dette i motsetning til hva som ville vært tilfelle ved rapportering ved hjelp av pdf og HTML, der denne typen feil ikke direkte kan oppdages ved hjelp av automatiserte analyser. Du mfl. (2013) studerer fenomenet videre ved å se på XBRL-rapporteringsfeil i et utvalg bestående av 4260 rapporteringsfeil fordelt på 4532 rapporteringer

2 Det er også noen kjøpere av hele datasett med årsregnskap som velger å offentliggjøre enkeltregnskaper gratis på egne nettsider, for eksempel www.Proff.no. 
i perioden juni 2009 til desember 2010 og dokumenterer at det finnes en læringskurve i dette datamaterialet både ved at det enkelte selskap lærer av egen rapportering, og ved at det lærer av andres rapporteringer.

Vi har ikke funnet nyere studier som kan si noe mer om omfanget av feil i senere år. Dette synes å være et spørsmål som kan være aktuelt for videre forskning. Basert på funnene vi oppsummerer, synes det ikke helt unaturlig å forvente at også XBRL-implementeringen i EU må forventes å gi feilrapporteringer, i det minste i en innkjøringsperiode. Dette tilsier videre at det bør benyttes gode kontrollrutiner for å begrense mengden feil mest mulig.

\subsubsection{Når benytter rapporteringspliktige selskaper egentilpassede rapporteringselementer?}

XBRL-implementering innebærer håndtering av et vanskelig dilemma: På den ene siden er selve grunnideen med standardisert rapportering at standardisering skal sikre sammenlignbar informasjon både over tid og mellom selskap, og det er derfor viktig at det ikke er for mange muligheter til å rapportere uten å følge fastsatt oppsett. Egentilpassede elementer $\mathrm{i}$ forbindelse med rapportering innebærer videre ekstrakostnader for regnskapsbrukerne ettersom disse elementene ikke kan leses maskinelt. På den andre siden kan standardisering som innebærer begrenset/manglende mulighet til å rapportere selskapsspesifikk informasjon $\mathrm{i}$ ikke-standardisert form, ha betydning for hvor nyttig informasjonen er for regnskapsbrukerne.

SEC har valgt en løsning der det tillates at selskaper som ved tagging av egen finansiell informasjon finner at de predefinerte XBRL-elementene i taksonomien ikke passer for egen rapportering, kan lage egne tilpassede elementer og bruke disse i XBRL-rapporteringen for å sikre rapporteringsfleksibilitet (Securities and Exchange Commission (SEC), 2009).

Debreceny mfl. (2011) studerer monetære egentilpassede elementer i amerikanske XBRL-regnskap i selskaper som var omfattet av obligatorisk rapportering til SEC i perioden april 2009 til juni 2010. I denne perioden var 12 prosent av de monetære elementene egentilpassede elementer. De ser deretter nærmere på egentilpassede elementer i et utvalg 
selskap bestående av 67 rapporteringer og finner at 40 prosent av de egentilpassede elementene er unødvendige (det finnes allerede passende elementer i taksonomien), 30 prosent dreier seg om selskapsnødvendige tilpasninger, 21 prosent dreier seg om aggregering eller disaggregering av allerede eksisterende elementer, og 9 prosent er andre typer tilpasninger. Scherr og Ditter (2017) ser nærmere på årsakene til at selskap ikke rapporterer i samsvar med US-GAAP taksonomien, og skiller mellom (1) nødvendige avvik, (2) feilaktige avvik (ikke-intensjonelle) og (3) strategiske avvik (intensjonelle). Basert på en analyse av i overkant av 16.00o rapporteringer med bruk av omtrent 2,7 millioner standard XBRLtagger/-elementer i perioden 2009 til 2013, finner de at selskaper som har regnskap som avviker betydelig fra hva som er vanlig blant sammenlignbare selskaper, samt selskaper med stor grad av ikke-obligatorisk tilleggsinformasjon i regnskapene, i større grad benytter egentilpassede elementer enn selskaper med vanlige regnskap og mindre grad av frivillig tilleggsinformasjon. Selskaper med lite XBRL-erfaring (målt ved hjelp av antall XBRL-rapporteringer) og liten grad av involvering i rapporteringen (målt ved hjelp av software-type som benyttes i forbindelse med rapporteringen) benytter også i større grad egentilpassede elementer. Studien finner imidlertid ikke støtte for en hypotese om at egentilpassede elementer benyttes strategisk for å redusere «transparens», ettersom selskaper med lav regnskapskvalitet (målt ved hjelp av «discretionary accruals») ikke har flere egentilpassede elementer enn selskaper med høyere regnskapskvalitet.

Huang mfl. (2019) studerer et utvalg bestående av 16.130 XBRLrapporteringer fra perioden 2009 til 2015 for å finne ut om selskap benytter egentilpassede elementer i forbindelse med XBRL-rapportering strategisk for å påvirke regnskapsbrukerne. Ved å ta utgangspunkt i hvorvidt selskapene har en kompleks XBRL-rapportering, målt som forholdstallet egentilpassede XBRL-elementer / totalt antall elementer, finner de at dette forholdstallet samvarierer negativt med inntjening («earnings») etter å ha kontrollert for en rekke ulike variabler som har betydning for firm performance. Videre finner forskerne at selskaper med lite vedvarende positiv inntjening («less persistent earnings») har mer kompleks XBRL-rapportering. Denne studien finner altså støtte for en hypotese om 
at egentilpasset XBRL-rapportering benyttes strategisk i den hensikt å øke selskapets rapporteringskompleksitet.

Basert på forskningen referert over, ser vi at spørsmålet om strategisk bruk av XBRL er uavklart. Det bør oppmuntres til ytterligere forskning som kan bidra mer til å avklare eventuelt omfang og betydning av egentilpassede elementer i XBRL-rapportering der hensikten er å gjøre regnskapsinformasjon mindre tilgjengelig for brukerne.

Ettersom så vidt mange av de egentilpassede elementene ifølge tidligere forskning på US-GAAP XBRL-taksonomien er nødvendige (Debreceny et al., 2011, se over), indikeres et behov for å utvide denne ytterligere. I forbindelse med implementeringen av XBRL i EU er et interessant spørsmål hvorvidt denne taksonomien er tilstrekkelig utviklet.

Beerbaum mfl. (2019) ser nærmere på denne problematikken og studerer XBRL-årsregnskapene for 2017, slik disse fremkommer i EDGARdatabasen per oktober 2018, for 1112 ikke-amerikanske selskaper som er notert på NYSE, og som følger IFRS. For disse selskapene ble det innført tvungen XBRL-rapportering fra og med regnskapsåret 2018 (Securities and Exchange Commission (SEC), 2017), og SEC besluttet at disse selskapene kunne bruke IFRS-taksonomien for å rapportere IFRS-baserte regnskap til SEC (SEC, 2017). Studien finner at de innsendte regnskapene i stor grad avviker fra IFRS-taksonomien, det vil si at de inneholder egentilpassede elementer. Dette gjelder spesielt banksektoren, der man finner avvik fra taksonomien i 50 prosent av selskapene som studeres. Ifølge forskerne indikerer funnene at den IFRS-baserte XBRL-taksonomien ikke er godt nok utviklet, særlig innenfor spesifikke bransjer, og det etterspørres mer forskning særlig knyttet til XBRL-rapportering av noteopplysninger. 3 Den mangelfulle taksonomien begrenser naturligvis regnskapenes sammenlignbarhet, og samtidig fremhever forskerne at det også synes å være en grunnleggende konflikt mellom en standardisert taksonomi og prinsippbasert regnskapsføring.

3 Det vil sannsynligvis bli krav til XBRL-mapping av noter i EU fra årsregnskapene for 2021 (Løvik, 2019). 


\subsubsection{Hvilken betydning har bruk av egentilpassede rapporteringselementer for regnskapsbrukerne?}

For å kunne si noe mer om konflikten mellom standardisering og rapportering av beslutningsnyttig informasjon, ser Li og Nwaeze (2015) nærmere på sammenhengen mellom selskapers bruk av egentilpassede elementer og i hvilken grad deres finansielle informasjon reflekteres i ulike finansielle mål ("financial information environment»), med andre ord om den informasjonen som investorer har tilgjengelig, er nyttig. De finansielle måltallene måles ved hjelp av proksiene «event return volatility», «information efficiency», "change in return volatility around extension filing dates» og «bid-ask spread». Utvalget som studeres, består av 29.180 rapporteringer fra perioden juni 2009 til desember 2012, og studien finner at ikke-forventede egenutviklede elementer samvarierer negativt med de finansielle måltallene i de første periodene etter innføring av XBRL, mens de samvarierer positivt i den siste delen av perioden. Dette indikerer at de egentilpassede elementene over tid tilfører informasjon som er nyttig for regnskapsbrukerne.

Li og Nwaeze (2018) studerer også betydningen av egenutviklede elementer og finner i et utvalg i samme periode som hos Li og Nwaeze (2015) og på omtrent samme størrelse som i studien fra 2015 at abnormal bruk av egenutviklede elementer (egenutviklede elementer utover det som forventes basert på bruk av egenutviklede elementer i andre, tilsvarende selskaper) er positivt assosiert med både antall analytikere som følger selskapet, og hvor nøyaktige analytikerprognosene («forecast») er, og negativt assosiert med prognosenes spredning («forecast dispersion»). Assosiasjonene blir sterkere over tid, og funnene tilsier at bruk av egenutviklede elementer er positivt ved at de bidrar med nyttig informasjon.

Felo mfl. (2018) studerer betydningen av egenutviklede elementer spesifikt i forbindelse med noteopplysninger, det vil si et noe snevrere begrep enn egenutviklede elementer slik det benyttes av Li og Nwaeze (2018), i noenlunde samme tidsperiode og med en lignende modell som Li og Nwaeze (2018), men funnene deres er motstridende. Felo mfl. (2018) finner for det første at XBRL-tagging av noteopplysninger gir mindre analytikerfeil $\mathrm{i}$ forbindelse med utarbeiding av analytikerprognoser sammenlignet med ingen slik tagging, men der Li og Nwaeze (2018) 158 
finner at egentilpasset tagging også bidrar til at analytikernes prognoser er mindre feilaktige, finner Felo mfl. (2018) at bruk av egentilpassede elementer i forbindelse med noter innebærer at effekten av XBRL blir mindre enn den hadde vært dersom det hadde vært benyttet bare standard XBRL-elementer. De to artiklene synes å være utarbeidet parallelt og referer derfor dessverre i liten grad til hverandre. Som en konsekvens av sine funn konkluderer Felo mfl. (2018) med at bruk av egenutviklede elementer bør begrenses, mens Li og Nwaeze (2018) konkluderer med at egenutviklede elementer inneholder informasjon som er nyttig for regnskapsbrukerne.

Basert på den nyeste tilgjengelige forskningen på området egenutviklede rapporteringselementer ser vi altså motstridende funn, noe som bør være en spore til videre forskning også på dette området.

\subsubsection{Blir finansregnskap mer sammenlignbare etter implementering av XBRL?}

Også for å svare på dette spørsmålet vil vi skjele til studier gjennomført på amerikanske data. Standardisering ved hjelp av XBRL bør forventes å medføre mer sammenlignbar informasjon, i hvert fall når man har kvittet seg med typiske «implementeringsfeil», jf. for eksempel Du mfl. (2013). Årsaken til dette kan for eksempel være at endringer fra én regnskapsperiode til en annen for samme foretak kan bli tydeligere. En annen effekt kan være at med mer detaljerte regler og revisjon av disse kan etterlevelsen av standarder øke. Videre kan manglende etterlevelse bli lettere å oppdage for ettersynsmyndigheter med bruk av spesialiserte analysemodeller. På den annen side vil bruk av egenutviklede rapporteringselementer kunne redusere sammenlignbarhet (Dhole et al., 2015).

Vasarhelyi mfl. (2012) studerer konsekvensene av XBRL-standardisering for regnskapsdata i USA i en analytisk/argumenterende studie (en ikke-empirisk studie) og peker blant annet på at standardiseringen vil løse enkelte tidligere identifiserte problemer ved at det ikke lenger vil være mulig å forlede regnskapsbrukerne gjennom ulike valg av ord for å beskrive økonomisk sett samme situasjon. To selskaper som i realiteten rapporterer nærmest like hendelser, men som 
velger så ulik innpakning at brukerne har vanskelig for å se likheten, vil nå fremkomme som like ettersom de vil bli tagget med samme XBRL-merkelapp.

Dhole mfl. (2015) er den eneste empiriske studien vi har identifisert som spesifikt ser på XBRL-rapportering og sammenlignbar informasjon. Dhole mfl. (2015) har som utgangspunkt at det at regnskap rapporteres ved hjelp av XBRL, har betydning for sammenlignbarhet ettersom hver enkelt linje i regnskapet blir unikt identifisert samtidig som taggingen også klart viser hvilke metodevalg som er foretatt. Videre kan det oppnås forbedret sammenlignbarhet ved at regnskapene er maskinlesbare og sammenligning dermed enklere kan foretas. På tross av dette finner Dhole mfl. (2015) at amerikanske regnskaper de første årene etter at XBRL ble implementert, faktisk ble mindre sammenlignbare, målt ved hjelp av et inntjeningsbasert-mål (se De Franco et al., 2011), og peker også på at bruk av egentilpassede elementer i rapporteringen kan bidra til forverret sammenlignbarhet.

Det lille antallet studier som er gjennomført på dette området, kombinert med at funnene stammer fra rapporteringer foretatt de første årene etter at XBRL-rapportering til SEC ble obligatorisk, tilsier at det bør utføres ytterligere forskning, gjerne med alternative mål for sammenlignbarhet for å undersøke nærmere hvilke effekter XBRL-implementeringen faktisk har hatt.

Med tanke på den nær forestående XBRL-implementeringen i EU ser vi også at man ikke nødvendigvis kan forvente bedret sammenlignbarhet på kort sikt. Hva som skjer på noe lengre sikt, er et spørsmål for videre forskning.

\subsection{Oppsummering og implikasjoner}

Vi viser i dette kapittelet at XBRL foreløpig brukes lite i Norge i forbindelse med regnskapsrapportering, men bruken vil bli mer utstrakt når norske selskap som benytter IFRS som regnskapsspråk, etter hvert blir pålagt å rapportere elektronisk. Ettersom det ikke finnes en egen norsk taksonomi, tilsier dette at XBRL i mindre grad vil være aktuelt i bruk for mellomstore og små selskap. 
Vi har her fokusert på potensielle implikasjoner av XBRL-implementering i Norge, og funnene våre viser følgende: Basert på tidligere forskning utført på amerikanske data, finner vi at det i forbindelse med implementering av obligatorisk bruk av XBRL i EU i startfasen er grunn til å forvente en god del feil i regnskapene som rapporteres, og det er dermed behov for gode kontrollrutiner for i størst mulig grad å begrense dette. Både regnskapsprodusentene og reguleringsmyndighetene bør fokusere på dette. Basert på tidligere forskning finner vi også at det er grunn til å forvente at regnskapsprodusentene må bruke egenutviklede elementer i forbindelse med rapporteringen, se for eksempel Beerbaum mfl. (2019). Hvor stort behovet blir, vil naturligvis avhenge av hvilket arbeid som utføres med den IFRS-baserte XBRL-taksonomien fremover for å gjøre behovet for egenutviklede elementer minst mulig. Det synes å være en iboende konflikt mellom det IFRS-baserte grunnlaget om «dekkende fremstilling» og standardisert rapportering. Når det gjelder effekten av slike egenutviklede rapporteringselementer på brukerne, har man i de studiene vi beskriver, vært særlig opptatt av analytikerfeil. Funnene i disse studiene er motstridende: Mens Li og Nwaze (2018) finner at de egenutviklede rapporteringselementene bidrar med beslutningsnyttig informasjon, finner Felo mfl. (2018) at det ville vært bedre for finansanalytikergruppen dersom alle regnskaper ble utarbeidet i tråd med en standard XBRL taksonomi. Nå det gjelder effekten av XBRL på regnskapers sammenlignbarhet, er det teoretiske utgangspunktet at XBRL vil bedre denne, men i en studie basert på amerikanske selskaper finner likevel Dhole mfl. (2015) at dette ikke har vært tilfellet.

Vi har gått i dybden på et utvalg interessante studier i dette kapittelet, og vår metode innebærer en begrensing med tanke på mulighet til å opparbeide oss en komplett oversikt over alle studier som er gjennomført. Funnene vi presenter her, er basert på bare et lite utvalg studier foretatt innenfor temaparaplyen XBRL, og de er til dels motstridende. Videre forskning vil således kunne ta tak i forskningsspørsmålene vi stiller i dette kapittelet, for å fremskaffe nye funn, både basert på XBRLregnskap som utarbeides med utgangspunkt i IFRS-taksonomien, og basert på nyere datasett enn dem som hittil er studert basert på amerikanske data. Tidligere forskning basert på amerikanske data når det gjelder 
effektene av egenutviklede rapporteringselementer på regnskapsbrukerne, rapporterer svært ulike funn. Dette vil være et spesielt interessant forskningsspørsmål i en IFRS-basert setting der behovet for egenutviklede elementer muligens vil være betydelig større enn i en US-GAAPbasert setting, og forskning på dette området bør oppmuntres. Det samme gjelder spørsmålet om betydningen av XBRL-baserte regnskap for ønsker om mer sammenlignbare regnskap. Også her er det foretatt lite internasjonal forskning, og mer forskning kan være av interesse.

\section{Referanser}

\section{Lover, rettskilder fra EU}

Bokføringsloven (2004). Lov om bokføring. LOV-2004-11-19-73.

Bokføringsforskriften (2004). Forskrift om bokføring. FOR-2004-12-01-1558.

Finansforetaksloven (2005). Lov om finansforetak og finanskonsern. LOV-2015-0410-17.

Regnskapsloven (1998). Lov om årsregnskap m.v. LOV-1998-07-17-56.

Verdipapirhandelloven (2007). Lov om verdipapirhandel. LOV-2007-06-29-75.

Europaparlaments- og rådsdirektiv 2013/50/EU av 22. oktober 2013 om endring av rapporteringsdirektiv 2004/109/EF artikkel 4.

NOU 2015: 10. Lov om regnskapsplikt.

NOU 2016: 2. Endringer $i$ verdipapirhandelloven - flagging og periodisk rapportering. Gjennomføring av endringer i rapporteringsdirektivet.

\section{Artikler, bøker mv.}

Asklund, A. (2005). Altinn - veien videre. Revisjon og Regnskap, 1, 9-10.

Baksaas, K. M. (2015). Forbedret presentasjon av årsregnskapet. Praktisk økonomi \& finans, 31(4), 319-342.

Beerbaum, D., Piechocki, M. \& Weber, C. (2017). Is there a conflict between principles-based standard setting and structured electronic reporting with XBRL? European Financial and Accounting Journal, 12(3), 33-52.

Beerbaum, D., Piechocki, M. \& Mindlin, V. (2019). The annual reports becoming digital - an initial field analysis of the NYSE listed IFRS-filers. Hentet 14.02.20 fra https://papers.ssrn.com/sol3/papers.cfm?abstract_id=3336109

Bell, E., Bryman, A. \& Harley, B. (2019). Business research methods. Oxford University Press. 
Bhattacharya, N., Cho, Y. J. \& Kim, J. B. (2018). Leveling the playing field between large and small institutions: Evidence from the SEC's XBRL mandate. The Accounting Review, 93(5), 51-71.

Boritz, J. E. \& No, W. G. (2008). The SEC's XBRL voluntary filing program on EDGAR: A case for quality assurance. Current Issues in Auditing, 2(2), A36-A50.

CABS. (2018). Academic Journal Guide. Hentet 01.05.20 fra https://charteredabs.org/ academic-journal-guide-2018/

Cong, Y., Du, H. \& Vasarhelyi, M. A. (2018). Are XBRL files being accessed? Evidence from EDGAR log file dataset. Journal of Information Systems, 32, 23-29.

Debreceny, R., Farewell, S., Piechocki, M., Felden, C. \& Gräning, A. (2010). Does it add up? Early evidence on the data quality of XBRL filings to the SEC. Journal of Accounting Public Policy, 29, 296-306.

Debreceny, R., Farewell, S., Piechocki, M., Felden, C., Gräning, A. \& d'Eri, A. (2011). Flex or break? Extensions in XBRL disclosures to the SEC. Accounting Horizons, $25,631-657$.

De Franco, G. S. P. Kothari \& Verdi, R. S. (2011). The benefits of financial statement comparability. Journal of Accounting Research, 49(4), 895-931.

Dhole, S., Lobo, G. J., Mishra, S. \& Pal, A. M. (2015). Effects of the SEC's XBRL mandate on financial reporting comparability. International Journal of Accounting Information System, 9, 29-44.

Du, H., Vasarhelyi, M. A. \& Zheng, X. (2013). XBRL mandate: Thousands of filing errors and so what? Journal of Information Systems, 27, 61-78.

Dunne, T., Helliar, C., Lymer, A. \& Mousa, R. (2013). Stakeholder engagement in internet financial reporting: The diffusion of XBRL in the UK. The British Accounting Review, 45, 167-182.

Dyrnes, C., Østlie, G. J., Ellefsen, H. C. \& Bjerketveit, R. (2019). Er dere klare? SAF-T Regnskap. Revisjon og Regnskap, 8, 20-21.

Effendi, J., Park, J. D. \& Subramaniam, C. (2016). Does the XBRL reporting format provide incremental information value? A study using XBRL disclosures during the voluntary filing program. Abacus, 52(2), 259-285.

Ernst \& Young. (2018). Regnskapsnyheter Juni 2018. Hentet 14.02.20 fra https://www. ey.com/no/no/services/assurance/ey-regnskapsnyheter-2018-juni

Felo, A. J., Kim, J. W. \& Lim, J. (2018). Can XBRL detailed tagging of footnotes improve financial analysts' information environment? International Journal of Accounting Information Systems, 28, 45-58.

Finans Norge. (2015). Finanstilsynet varsler obligatorisk overgang til XBRLrapportering i 2017. Hentet 14.02.20 fra https://www.finansnorge.no/aktuelt/ nyheter/2015/o9/finanstilsynet-varsler-obligatorisk-overgang-til-xbrlrapportering-i-2017/ 
Finanstilsynet. (2017). CRD IV Teknisk løsning. Hentet 14.02.20 fra https://www. finanstilsynet.no/rapportering/fellesrapporteringer/crd-iv-teknisk-losning/

Finanstilsynet. (2019). Seminar om krav til finansiell rapportering og løpende informasjonsplikt. Hentet fra https://vimeo.com/372825738/519cc28a4b

Henderson, D., Sheetz, S. D. \& Trinkle, B. S. (2012). The determinants of interorganizational and internal in-house adoption of XBRL: A structural equation model. International Journal of Accounting Information Systems, 13, 109-140.

Henderson, C., Huerta, E. \& Glandon, T. (2015). Standardizing the presentation of financial data: Does XBRL's taxonomy affect the investment performance of nonprofessional investors? The International Journal of Digital Accounting Research, 15, 127-153.

Huang, F., No, W. G. \& Vasarhelyi, M. A. (2019). Do managers use extension elements strategically in the SEC's tagged data for financial statements? Evidence from XBRL complexity. Journal of Information Systems, 33(3), 61-74.

IFRS. IFRS Taxonomy. Hentet 14.02.20 fra https://www.ifrs.org/issued-standards/ ifrs-taxonomy/

Janvrin, D. J., Pinsker, R. E. \& Mascha, M. F. (2013). XBRL-enabled, spreadsheet, or PDF? Factors influencing exclusive user choice of reporting technology. Journal of Information Systems, 27(2), 35-49.

Kim, J. W., Lim, J. \& No, W. (2012). The effect of first waves mandatory XBRL reporting across the financial information environment. Journal of Information Systems, 26(1), 127-153.

Kvelvane, Ø. (2019). Kan XBRL sammenlignes med overgangen fra analogt til digitalt kamera? Magma, 1, 14-16.

Li, S. \& Nwaeze, E. T. (2015). The association between extensions in XBRL disclosures and financial information environment. Journal of Information Systems, 29(3), 73-99.

Li, S. \& Nwaze, E. T. (2018). Impact of extensions in XBRL disclosure on analysts' forecast behavior. Accounting Horizons, 32(2), 57-79.

Løvik, Å. (2019). European single electronic format. Revisjon og Regnskap, 3, 24-27.

Microsoft. (2020). Opprette rapporter med XBRL. Hentet 14.02.20 fra https://docs. microsoft.com/nb-no/dynamics365/business-central/bi-create-reports-with-xbrl

Paré, G., Trudel, M., Jaana, M. \& Kitsiou, S. (2015). Synthesizing information systems knowledge: A typology of literature reviews. Information \& Management, 52, 183-199.

Perdana, A., Robb, A. \& Rohde, F. (2015). An integrative review and synthesis of XBRL research in academic journals. Journal of Information Systems, 29(1), $115-153$.

Pinsker, R. \& Wheeler, P. (2009). Nonprofessional investors' perceptions of the efficiency and effectiveness of XBRL-enabled financial statement analysis and of 
firms providing XBRL-formatted information. International Journal of Disclosure and Governance, 6(3), 241-261.

Robb, D. A., Rohde, F. H. \& Green, P. F. (2016). Standard business reporting in Australia: Effiviency, effectiveness, or both? Accounting and Finance, 56, 509-544.

Scherr, E. \& Ditter, D. (2017). Customization versus standardization in electronic financial reporting: Early evidence from the SEC XBRL mandate. Journal of Information Systems, 31(2), 125-148.

Securities and Exchange Commission (SEC). (2009). Interactive data to improve financial reporting.

Securities and Exchange Commission (SEC). (2016). What is structured data? Hentet 14.02.20 fra https://www.sec.gov/structureddata/what-is-structured-data

Securities and Exchange Commission (SEC). (2017). IFRS Taxonomy for foreign private issuers that prepare their financial statements in accordance with international financial reporting standards as issued by the international accounting standards board. US SEC, Washington, DC, Release Nos 33-10320; 34-80128. Hentet 14.02.20 fra www.sec.gov/rules/other/2017/33-10320.pdf

Troshani, I., Locke, J. \& Rowbottom, N. (2019). Transformation of accounting through digital standardisation. Accounting, Auditing and Accountability Journal, 32(1), 133-162.

Tystad, R. (2005). XBRL i Europa. Revisjon og Regnskap, 1, 10-1.

UB Partner. Short XBRL History. Hentet 14.02.20 fra https://www.ubpartner.com/ company/XBRL_history.html

Vasarhelyi, M. A., Chan, D. Y. \& Krahel, J. P. (2012). Consequences of XBRL standardization on financial statement data. Journal of Information Systems, 26(1), $155-167$. 



\title{
KAPITTEL 6
}

\section{Regnskapsestimater - når er dårlige vurderinger straffbare?}

\author{
Ellen M. Kulset
}

Førsteamanuensis, Universitetet i Sørøst-Norge og Norges Handelshøyskole

\section{Eivind Ludvigsen}

Advokat, CeMa Advokat

\section{Kjell Magne Baksaas}

\section{Dosent, Universitetet i Sørøst-Norge}

\begin{abstract}
Sammendrag: Regnskapslovens straffebestemmelse i § 8-5 og straffeloven $₫ 392$ gir ingen klar angivelse av når et feil regnskapsestimat blir straffbart. Revisor har ved sin gjennomgang et avklart vesentlighetsprinsipp å forholde seg til. Noe tilsvarende finnes ikke uttrykt i regnskapsloven, men teori og reelle hensyn tilsier at noe tilsvarende finnes også i regnskapsretten. Ut fra de nevnte bestemmelsenes ordlyd og forarbeider vil imidlertid ethvert avvik fra beste estimat kunne straffeforfølges, og den begrensede rettspraksisen som foreligger, gir ikke noe grunnlag for å konkludere med det motsatte. Påtalemyndighetene synes i sin praksis å legge inn en nedre grense for hva som faktisk blir straffeforfulgt, men dette belyser ikke selve straffbarheten i særlig grad og bidrar ikke til forutsigbarhet. Det er heller ingen påviselig forankring for å si at den nedre grensen som praktiseres av påtalemyndigheten, er bygget på, eller forutsetter, noe regnskapsrettslig vesentlighetsprinsipp. Det synes å være et rettssikkerhetsproblem at lovteksten favner for vidt og/eller gir for svak forutsigbarhet, samt angir straff på forhold som ikke vil bli straffeforfulgt. Rettspolitisk burde det vært inkludert et vesentlighetsbegrep i straffebestemmelsen.
\end{abstract}

Nøkkelord: regnskapsestimat, regnskapsloven $₫ 8$ 8, regnskapsovertredelse, straffeloven $₫ \$ 392-394$, vesentlighet

Sitering av denne artikkelen: Kulset, E. M., Ludvigsen, E. \& Baksaas, K. M. (2020). Regnskapsestimater når er dårlige vurderinger straffbare? I T. Stenheim, K. M. Baksaas og E. M. Kulset (Red.), Aktuelle temaer i regnskap og revisjon (Kap. 6, s. 167-195). Oslo: Cappelen Damm Akademisk. https://doi.org/10.23865/ noasp.112.ch6

Lisens: CC-BY 4.0. 


\subsection{Innledning}

Bestemmelsene om straff knyttet til overtredelser av regnskapsreglene har over tid gjennomgått betydelige endringer med hensyn til ordlyd og plassering sammenlignet med de opprinnelige bestemmelsene i regnskapsloven (1977) og straffeloven (1902). Mens det i ordlyden til regnskapsloven (1977) og straffeloven (1902) ble stilt krav til at overtredelser måtte innebære en vesentlig tilsidesettelse av kravene i loven for at de skulle være straffbare, er etter gjeldende rett enhver overtredelse av bestemmelsene i regnskapsloven (regnskapsovertredelse) straffbar (uten et eksplisitt vesentlighetskrav), jf. straffeloven (2005) $\$ \$ 392-393$, jf. straffeloven $\$ 23$ så sant andre straffbarhetsvilkår er oppfylt, for eksempel lovgivingens krav til uaktsomhet. ${ }^{1}$ Denne utviklingen samsvarer med en generell samfunnstendens der stadig flere handlinger kriminaliseres (Kvam, 2014).

Larsen (2005) gjennomførte en grundig gjennomgang av regnskapsloven (1998) \$ 8-5 og straffeloven (1902) \$286 og konkluderte med at disse straffebudene ikke var i samsvar med legalitetsprinsippet når det gjelder krav til klarhet og forutsigbarhet. Et tema som ikke berøres verken i NOU 1995: 30, andre relevante lovforarbeider eller Larsens utredning, er hvordan man skal forstå begrepet regnskapsovertredelse i forbindelse med regnskapsposter som må estimeres. Vi mener dette er et rettssikkerhetsproblem. En rekke av bestemmelsene i regnskapsloven omhandler slike usikre størrelser, og disse skal behandles i henhold til den rettslige standarden «god regnskapsskikk» (jf. regnskapsloven $₫ 4-6$ ). Dette innebærer at det vanligvis ikke finnes fasitsvar ex-ante for hvordan disse postene skal vurderes, og det er således problematisk å vurdere hvorvidt bestemmelsene er overtrådt. Bestemmelsene om straffbarhet i lovtekst og forarbeider definerer ikke begrepet regnskapsovertredelse utover det som følger av ordvalget i seg selv, og skiller ikke mellom ulike typer regnskapsovertredelser. Vi er ikke kjent med andre studier som fokuserer på straffebestemmelsene for regnskapsovertredelser knyttet til regnskapsestimater, og dette er således et interessant tema for videre forskning.

1 Straffbarhet for uvesentlige regnskapsovertredelser kunne tidligere følge av aksjeloven, jf. 6.2.4 nedenfor. 
Hensikten med dette kapittelet er todelt: For det første ønsker vi å bidra til en bedre forståelse av regnskapsprodusentenes strafferettslige ansvar knyttet til den regnskapsmessige behandlingen av skjønnsbaserte regnskapsposter ved å foreta en rettsdogmatisk juridisk fortolkning (de lege lata-vurdering) av de kravene som stilles for at en «dårlig» vurdering av en skjønnsmessig regnskapspost er straffbar. Vi fokuserer her særlig på begrepet «regnskapsovertredelse». Den andre hensikten med kapittelet er å drøfte på grunnlag av et rettspolitisk perspektiv (de lege ferendavurdering) om bestemmelsen er hensiktsmessig utformet ut fra et informasjonsmessig og pedagogisk hensyn.

Som metodisk innfallsvinkel vil vi derfor både benytte oss av rettsdogmatikk og rettspolitikk, som er de to sentrale metodiske retningene innen juridisk forskningsmetode (Graver, 2008, og Graver, 2011).

Kapittelet er i overveiende grad begrenset til spørsmål som dreier seg om regnskapsestimater. Det bidrar med kunnskap som bør være av interesse for både lovgiver og regnskapspraktikere så vel som bedriftsledere og styremedlemmer.

Vi vil først beskrive det strafferettslige utgangspunktet, beskrive vår begrepsbruk og kortfattet gjennomgå den historiske utviklingen av lovreguleringen på området. Deretter vil vi se nærmere på hvordan vi skal forstå begrepene regnskapsovertredelse og uaktsomhet i tilfeller der det stilles krav til utøvelse av skjønn ved avleggelse av regnskapet, og hvilken betydning dette har for spørsmålet om hva som skal til for at for eksempel en feilaktig vurdering av goodwill eller andre usikre regnskapsstørrelser er straffbar. Vi foretar en gjennomgang av rettspraksis og påtalemyndighetenes omtale for å se nærmere på denne når det gjelder regnskapsovertredelse i forbindelse med skjønnsmessige poster. Avslutningsvis foretar vi en vurdering av hvordan straffebestemmelsen burde utformes.

\subsection{Bakgrunn}

\subsubsection{Strafferettslig utgangspunkt}

Legalitetsprinsippet, at ingen kan dømmes uten et autorativt rettsgrunnlag, er et av de viktige grunnlagene for rettssikkerheten. Til 
rettssikkerheten hører også at straffebestemmelsen skal være forutsigbar. Borgerne skal ut fra loven kunne forutsi konsekvensen ved en handling.

I strafferetten er legalitetsprinsippet og rettssikkerheten derfor essensiell. Dette medfører at tolkning av lovtekst er viktigere som rettskilde her enn på andre rettsområder (Andenæs, 1997, s. 176). Det er åpenbart at en straffedom krever formelt grunnlag i en lovtekst, og en straffedom som utelukkende er basert på skjønn, vil kunne være i strid med grunnloven ${ }^{2}$ (Andenæs, 2016, s. 104-105). Andre rettskilder som vil vektlegges, vil i samsvar med de alminnelige rettskildeprinsippene være de relevante lovforarbeidene, høyesterettspraksis om dette finnes, samt reelle hensyn.

Det er generelt fire straffbarhetsvilkår som alle må være oppfylt for å kunne idømme straff: For det første må det foreligge en handling eller unnlatelse som dekkes av et straffebud som er nedfelt i lov. Dette objektive straffbarhetsvilkåret - altså spørsmålet om hvilke uriktige regnskapsestimater som dekkes av straffebudet om regnskapsovertredelser - står sentralt i dette bokkapittelet. For det annet må det ikke foreligge noen straffrihetsgrunn (som nødverge, nødrett, samtykke, handling i den fornærmedes interesse, militær ordre, osv.). ${ }^{3}$ Det går vi ikke nærmere inn på her. For det tredje må det foreligge subjektiv skyld i henhold til lovens krav. En side ved dette subjektive straffbarhetsvilkåret - nærmere bestemt spørsmålet om hva som ligger i uaktsomhetsnormen for uriktige regnskapsestimater - er også sentralt for vårt tema. For det fjerde må det foreligge tilregnelighet hos den tiltalte, hvilket ikke er tema her.

\subsubsection{Begrepsbruk - skjønnsmessige regnskapsposter og regnskapsestimater}

Ved regnskapsavleggelsen vil det være knyttet usikkerhet til mange av regnskapspostene. Ved enhver usikkerhet må regnskapsprodusenten utøve skjønn knyttet til hvilken påvirkning denne usikkerheten kan ha på regnskapet. Dette skjønnet munner ut i et regnskapsestimat som legges til grunn for årsregnskapet. Eksempler på estimater er verdien av

2 Grunnlovens $₫ 96$ «Ingen kan dømmast utan etter lov ...»

3 Merk at dette er noe annet enn en straff-fritaksgrunn. 
regnskapsposter som ukurans på varer, avskrivninger og avsetning til tap på fordringer (se for eksempel Schwencke et al. 2020, s. 145).

Regnskapsloven pålegger at regnskapsestimater skal baseres på beste estimat, jf. regnskapsloven $\$$ 4-2. «Prinsippet om beste estimat innebærer at en skal bruke all tilgjengelig informasjon for å komme fram til et best mulig estimat i de tilfeller hvor det foreligger måleusikkerhet» (Schwencke et al., 2020, s. 119). Tilsvarende krever også det internasjonale regnskapsspråket IFRS (International Reporting Financial Standards) at skjønnsmessige poster skal baseres på beste estimat (se for eksempel IAS 36.33 og IAS 37.36). Beste estimat vil være et punktestimat, det vil si den beste verdien som ett bestemt beløp (se for eksempel NRS(F) Nedskrivning av anleggsmidler, punkt 5.3.2).

I ettertid kan det vise seg at et skjønn ble feil ved at regnskapsposten viste seg å være over- eller undervurdert. En slik endring av en skjønnsmessig post regnes inn som et ordinært resultatelement i resultatregnskapet (se for eksempel Schwencke et al., 2020). En regnskapsbruker vil derfor ikke normalt få innsyn i tidligere perioders feilaktige skjønn.

Noen enkle eksempler illustrerer en slik skjønnsmessig vurdering:

Illustrasjonseksempel 1: Hagemiljø AS har per 31.12.x1 500 trendy utesofagrupper til en innkjøpspris på kr 10 ooo på lager. På grunn av uheldige omstendigheter kom disse varene inn på lager helt på slutten av sesongen. Normal utsalgspris er kr 15 ooo. På grunn av det store antallet og fordi dette tydelig er en fjorårsmodell, mener ledelsen i Hagemiljø AS at sofagruppene må selges med betydelig rabatt. Rabatter som medfører at fortjenestemarginen blir mindre, vil ikke resultere i regnskapsmessig nedskrivning (unntatt når «fortjenestemarginen» blir negativ). Ledelsen må estimere hva som er forventet utsalgspris, jf. NRS 1 Varer. Dersom ledelsen for eksempel vurderer at de må selges med 50 prosent avslag av normal utsalgspris, vil forventet utsalgspris ligge kr 2500 under kostpris per sofagruppe. Varelageret må nedskrives med kr 1250 ooo (2500 * 500). Det sier seg selv at det er usikkert hvilken pris Hagemiljø AS får for et stort parti med fjorårets modell.

Illustrasjonseksempel 2: Verksted AS utførte høsten x1 et betydelig reparasjonsarbeid som følge av vannlekkasje på en to år gammel spesialbygget bobil og fakturerte eieren i oktober x1 kr 1500 ooo. Eieren av bobilen, som er et ANS, mente at deler av reparasjonen måtte være garantiarbeid og har på 
dette grunnlaget avvist å betale fakturaen. Men selgeren av bobilen da den var ny, har avvist noe garantioppgjør. Selv om dokumentasjonen er svak, er det bobileieren som har bestilt reparasjonen. Også eierens forsikringsselskap har av ulike grunner nektet å dekke skaden. Status per 31.12.x1 er at Verksted AS har stevnet bobil-eieren for retten for å få oppgjør av fordringen. Det har også kommet fram at eieren av bobilen sliter økonomisk, og det er usikkert om vedkommende har evne til å gjøre opp fordringen.

Regnskapsmessig må Verksted AS foreta en skjønnsmessig vurdering av fordringen per 31.12.x1. Da må både vilje (utfallet av rettssaken), og evne til å betale (skyldnerens økonomiske stilling) vurderes. Rent teoretisk kan man tenke en forventningsverdi basert på mulige utfall og tilhørende sannsynligheter (NRS 13, punkt 4.3.1). I praksis er slike estimater vanskelig, for ikke å si umulig å kvantifisere. Ledelsen kan på den ene siden være svært optimistisk anlagt og vurdere at skyldneren vil dekke fordringen, renter og alle påløpte kostnader. På den annen side kan ledelsen være svært pessimistisk anlagt og hevde at store deler av fordringen er tapt, basert på at en rettssak vil være dyrt, og fordi dommeren kan forventes å favorisere bobileieren siden vedkommende fort vil oppfattes som den svake part. I tillegg er skyldnerens evne til å gjøre opp fordringen høyst usikker. En regress mot ANS-deltakerne kan være en dyr og langvarig affære. Ledelsens rom for skjønn er betydelig og vil lett kunne bli farget at en opportunistisk tankegang i forhold til situasjonen for øvrig. Dersom Verksted AS har en svak drift med betydelig underskudd og egenkapital nær kroner null, kan ledelsen ha insitament til å vurdere fordringen mer optimistisk enn et objektivt beste estimat.

Vi kan videreføre eksempelet over i år x2. Verksted AS går konkurs i august år x2. Fordringen mot bobileieren ble av ledelsen per 31.12.x1 estimert til kr 1250 ooo. Det vil si at det i regnskapet for x1 ble foretatt en nedskrivning på kr 250 ooo. Konkursboet velger å ikke videreføre rettsprosessen og inngår forlik med en innbetaling på kr 300 ooo fra bobileieren. Bobestyreren spør seg om ledelsen bør straffeforfølges basert på regnskapsovertredelse ved at det synes å ikke være brukt beste estimat per 31.12. x1. Strafferettslig skal det vurderes ut fra tilgjengelig informasjon da estimatet ble foretatt 31.12.x1 og ikke fremstå som etterpåklokskap. Samtidig er dette også vanskelig fordi tilgjengelig informasjon vil fremstå i et annet lys 
når man kjenner til hvordan situasjonen har utviklet seg i ettertid. En opplysning som fremstår som en mindre detalj da estimeringen ble foretatt, vil i ettertid kunne fremstå som vesentlig for estimeringen.

\subsubsection{Vesentlighetsprinsipp}

Trolig finnes det implisitt et grunnleggende vesentlighetsprinsipp i regnskapsloven: «Regnskapslovutvalget 1990 ga uttrykk for at vesentlighetsprinsippet gjelder for utarbeidelse av årsregnskapet uten uttrykkelig kodifisering, og dette utvalget er i og for seg enig i det» (NOU 2015: 10, s. 99). Utvalget og også Finanstilsynet foreslo at et vesentlighetsprinsipp skulle tas inn i regnskapsloven med følgende formulering: «Bestemmelsene i kapittel 4 til 7 kan fravikes dersom virkningen av fravikelsen er uvesentlig» (Finanstilsynet 2019, forslag til \$ 4-7). Bakgrunnen synes å ha vært lojal direktivimplementering 4 snarere enn å gjøre regnskapsloven klarere eller mer presis. Forslagene er fremdeles til utredning i Finansdepartementet med tanke på en lovproposisjon for implementering av EUs regnskapsdirektiv (EP/Rdir.2013/34/EU).

Under IFRS er vesentlighetsprinsippet hjemlet i IAS 8.8. Regnskapsprinsippene «er ikke nødvendig å anvende [...] når anvendelsen av dem har en uvesentlig virkning». Selskapet står dermed friere med hensyn til hvordan uvesentlige beløp behandles. Det er presisert i samme bestemmelse at vesentlighetsprinsippet ikke kan benyttes «for å oppnå en bestemt framstilling av et foretaks finansielle stilling, finansielle inntjening eller kontantstrømmer».

\subsubsection{Regnskap og straff - en historisk gjennomgang}

Regnskapsloven (1977) og aksjeloven (1976) hjemlet straff for den som forsettlig eller uaktsomt vesentlig tilsidesetter «bestemmelser gitt i eller $\mathrm{i}$ medhold av denne lov (...)», jf. regnskapsloven $\$ 23$ eller «bestemmelsene i kapittel 11», jf. aksjeloven (1976) \$17-1, der kapittel 11 inneholder bestemmelser om årsoppgjør og konsernoppgjør. I straffeloven (1902) finner vi den parallelle bestemmelsen $\$ 286$ :

4 Implementering av konsolidert regnskapsdirektiv (EP/Rdir.2013/34/EU). 
Den som forsettlig eller uaktsomt vesentlig tilsidesetter bestemmelser om bokføring og dokumentasjon av regnskapsopplysninger, årsregnskap, årsberetning eller regnskapsoppbevaring som er fastsatt i lov eller forskrift i medhold av lov, straffes med bøter eller fengsel inntil 1 år eller begge deler. Foreligger særlig skjerpende omstendigheter, kan fengsel inntil 3 år anvendes.

Aksjeloven (1976) \$ 17-1 tredje ledd hjemlet også straff for forhold som ikke er vesentlige, omtalt i Ot.prp. nr. 42 (1997-98) som «mindre vesentlige forhold».

Regnskapsloven $₫ 23$ ble foreslått videreført i forslag til ny regnskapslov, NOU 1995: 30, som $\$ 10-2$, men utvalget påpekte på side 204 at det «ikke har foretatt noen prinsipiell vurdering av spørsmål om straff for overtredelser av regnskapslovgivningen», og påpekte videre at «en slik vurdering bør foretas samlet for brudd på bestemmelser som har tilknytning til hhv. bokføringsplikten og årsregnskapsplikten» (NOU 1995: 30, s. 204).

Da regnskapsloven (1998) ble vedtatt, var lovteksten endret til å omfatte også brudd som ikke er «vesentlige», og kriteriene for at regnskapsovertredelser skulle være straffbare, var formulert slik i regnskapsloven $₫ 8$-5 (våre uthevinger):

Første ledd: Den som forsettlig eller uaktsomt vesentlig overtrer denne lov eller forskrift ...

Annet ledd (lavere strafferamme): Den som for øvrig forsettlig eller uaktsomt overtrer denne lov eller forskrift ...

Dermed var alle overtredelser (vesentlige eller ikke) straffbare direkte, også de som dreier seg om bestemmelser knyttet til årsoppgjør inklusiv de grunnleggende prinsippene. Bestemmelsen ble endret i 1999 og i 2004 uten at det ble rokket ved det ovennevnte. Fra 2015 ble hele $\$ 8-5$ konsentrert ned til én setning, nå med et vesentlighetsbegrep inkludert $\mathrm{i}$ bestemmelsen (vår utheving):

Den som betydelig overtrer bestemmelser om bokføring eller regnskap, straffes etter straffeloven $\$ \$ 392-394$.

Tilsvarende endring ble gjort i bokføringsloven $₫ 15$. Lovendringene hadde sammenheng med ikrafttredelsen av den nye straffeloven, og de bestemmelsene i straffeloven som regnskapsloven $₫ 8$-5 henviser til, ble 
vedtatt i 2009, men trådte i kraft sammen med resten av den nye straffeloven (2005) i 2015.

Etter ordlyden i regnskapsloven $\$ 8-5$ isolert sett kunne man da oppfatte det slik at det var innført en høyere terskel for straffbarhet etter den nye bestemmelsen. Imidlertid ville det ha liten interesse som følge av utformingen av de bestemmelsene i straffeloven som regnskapsloven $\$ 8$-5 viser videre til (Handeland et al. 2019: note 744). Regnskapslovens straffebestemmelse synes først og fremst å ha et pedagogisk formål fordi selve straffebestemmelsene følger av straffeloven: «Det synes tvilsomt om ordlyden i regnskapsloven kan innskrenke det straffansvaret som følger av straffeloven.» (Prop. 120 L (2017-2018) pkt. 3.4 «Til regnskapsloven»). De aktuelle bestemmelsene i straffeloven fra 2015 lyder slik (vår utheving):

\section{$\$ 392$. Regnskapsovertredelse}

Med bot eller fengsel inntil 2 år straffes den som overtrer bestemmelser om bokføring og dokumentasjon av regnskapsopplysninger, årsregnskap, årsberetning eller regnskapsoppbevaring som er fastsatt i lov eller forskrift i medhold av lov.

\section{$\$$ 393. Grov regnskapsovertredelse}

Grov regnskapsovertredelse straffes med fengsel inntil 6 år. Ved avgjørelsen av om regnskapsovertredelsen er grov skal det særlig legges vekt på om

a) det er brukt uriktig eller villedende informasjon eller et uriktig dokument,

b) den er begått over lang tid,

c) den er begått av noen ved brudd på den særlige tillit som følger med hans stilling eller virksomhet,

d) den har gitt betydelig økonomisk fordel,

e) det forelå risiko for betydelig skade av økonomisk eller annen art, eller

f) den har gjort det vanskelig å kontrollere virksomheten.

\section{\$394. Uaktsom regnskapsovertredelse}

Uaktsom regnskapsovertredelse straffes med bot eller fengsel inntil 1 år.

Bestemmelsene i straffeloven stiller ikke noe krav til at overtredelsen skal være vesentlig eller betydelig slik at fra og med ikrafttredelsen av den nye straffeloven er det hjemmel, direkte i straffeloven, for å straffe regnskapsovertredelser uten hensyn til om de er vesentlige eller betydelige. Forarbeidene tyder på at dette er bevisst valgt. Straffelovkommisjonen foreslo å 
avkriminalisere enkelte regnskapsovertredelser, herunder «vanlig uaktsomhet», men fikk ikke gehør for dette hos departementet. (Ot.prp. nr. 22 (2008-2009), kap. 11.12). Uttalelser i forarbeidene tyder også på at departementet nærmest så det slik at man nå «opphevet» regnskapsloven $₫ 8-5$ fordi man ønsket å samle straffebestemmelsene i straffeloven, men at man lot det stå igjen en henvisning av «informasjonshensyn». Ordet «betydelig» i regnskapsloven $₫ 8-5$ og bokføringsloven $\$ 15$ var uten betydning for selve straffbarheten og «kom inn ved en inkurie» før det ble fjernet igjen i 2018 (Prop. 120 L (2017-2018), punkt 3.4 «Til regnskapsloven»).

\subsection{Hva er en «regnskapsovertredelse» etter loven? Det objektive straffbarhetsvilkåret for uriktige regnskapsestimater}

Vi vil i dette delkapittelet presentere ulike tolkningsmomenter som er relevante for å forstå straffebestemmelsene knyttet til regnskapsovertredelser. Vi vil først fokusere på bestemmelsens ordlyd og innholdet i lovens forarbeider samt kommentere foreliggende rettspraksis, og deretter vil vi behandle problemstillingen fra et regnskapsfaglig ståsted.

\subsubsection{Etter ordlyden med forarbeider oppfyller enhver regnskapsovertredelse det objektive straffbarhetsvilkåret}

For at man skal kunne straffes for brudd på regnskapslovgivningen, må det ha funnet sted en regnskapsovertredelse. Som det fremgår av presentasjonen over, inneholder ordlyden ikke noe krav om at overtredelsen skal være vesentlig eller betydelig. Matningsdal (2019, note 2455) påpeker at «[v]ed regnskapsovertredelse gjør allmennpreventive hensyn seg sterkt gjeldende». Det fremgår av Ot.prp. 22 (2008-2009), side 473 at «med 'regnskapsovertredelse' menes overtredelse av enhver bestemmelse om regnskapsplikt, bokføring, krav til årsregnskap, årsberetning og regnskapsoppbevaring osv.». Vi merker oss at det dreier seg om overtredelse av enhver bestemmelse: Ordlyden skiller altså rent prinsipielt ikke mellom 
ulike typer overtredelser. I kommentarutgaven til regnskapsloven (Handeland \& Schwencke, 2011, s. 281) påpekes det at «[b]estemmelsen i 8-5 er gitt en generell utforming; det er ikke spesifisert hvilke konkrete brudd på regnskapslovgivningen som er straffebelagt». Videre uttales det i forarbeidene til lovendringen i 2015 at (våre uthevinger):

Som i dag er enhver overtredelse av regelverket straffbar. Det er opp til påtalemyndigheten å ta stilling til hvilke overtredelser som bør bli gjenstand for strafforfølgning. Dette kan blant annet avhenge av om regelbruddet fører til at regnskapet gir et misvisende bilde at selskapets økonomiske stilling, om feilen vanskeliggjør kontrollmyndighetenes arbeid eller om bokføringsregler er fraveket med det formål å unndra skatt og avgifter eller føre andre bak lyset. Tidsforløpet vil også ha betydning for vurderingen, dvs. om reglene om bokføring er systematisk fraveket eller fraveket over noe tid. Departementet antar at det som i dag normalt ikke vil være grunnlag for å forfølge mer bagatellmessige lovbrudd, som for eksempel at en regnskapspliktig ikke har angitt hvem en bevertning omfatter, jf. forskrift om bokføring 1. desember $2004 \mathrm{nr} .1558$ \$ 5-10. Skulle bagatellmessige lovbrudd likevel bli iretteført, kan retten anvende straffutmålingsutsettelse etter straffeloven $2005 \$ 60$ eller straffutmålingsfrafall etter $\$ 61$ (Ot.prp. nr. 22 (2008-2009), pkt. 16.11).

Uttalelsen påpeker at alle overtredelser er straffbare. Samtidig signaliseres det at det kan unnlates straffeforfølgelse blant annet ut fra at regnskapet eventuelt ikke gir et misvisende bilde (dvs. så lenge regnskapet ikke inneholder vesentlige feil), men dette er noe helt annet. Det er verdt å merke seg at i den grad påtalemyndigheten ikke benytter seg av sin adgang til å la være å straffeforfølge et bagatellmessig lovbrudd, så vil domstolene stå igjen med bare reaksjonsformen for å bøte på dette. De vil ikke kunne snu selve skyldspørsmålet. Det er ellers verdt å merke seg at bokføring og regnskap nevnes i samme «åndedrag». Lovgivningen på disse to områdene er imidlertid svært ulik, fra mange detaljerte formalkrav i bokføringsloven med forskrifter til prinsippbaserte vurderingsregler i regnskapsloven. Ut fra eksemplene som gis, viser departementet at deres oppmerksomhet er rettet mot bokføringen som grunnlag for skatt og avgift. Med bagatellmessige lovbrudd blir det i denne sammenhengen 
ment manglende overholdelse av de detaljerte formalkravene med hjemmel i bokføringsloven.

Videre har Høyesterett ansett avleggelse av årsregnskapet som «fullbyrdelse» av lovbrudd på regnskapsrettens område, også inkludert overtredelser av bokføringsbestemmelser (HR-1999-3-B - Rt-1999-36). Dermed blir lovbrudd mot bokføringsloven også lovbrudd mot regnskapsloven.

Vi viser også til den omtalen av forarbeidene, særlig forarbeidene til selve straffeloven, som er gitt i punkt 6.2.4 ovenfor, inkludert lovteksten i straffeloven $\$ \$ 392-394$.

Etter loven og forarbeidene vil altså enhver feil oppfylle det objektive straffbarhetsvilkåret hvis den først utgjør en overtredelse.

\subsubsection{Kort om meningsytringer på utrednings- og høringsstadiet}

Meningsytringer på utrednings- og høringsstadiet kan, i den grad de ikke fikk gehør i det videre lovarbeidet, ikke rokke ved det som er sagt ovenfor. Enkelte slike merknader tas likevel med for oversiktens skyld.

Medlemmet Arnholm i lovutvalget til regnskapsloven (1998) anførte i en egen merknad i NOU 1995: 30 at det ikke var nødvendig å ha med vesentlig i lovteksten ettersom (vår utheving):

Vesentlighet er et grunnleggende regnskapsprinsipp. Det innebærer bl. a. at uvesentlige forhold ikke tillegges materiell betydning for årsregnskapet. Et årsregnskap vil med andre ord kunne være korrekt (og lovlig utarbeidet) selv om det inneholder feil som ikke er vesentlige for årsregnskapet som helhet eller eventuelt den enkelte post. Tatt i betraktning at vesentlighetsprinsippet alltid vil ligge til grunn for praktisering av loven, synes det unødvendig og kompliserende å ta et slikt krav inn i straffebestemmelsen. Uavhengig av dette mener dette medlem at det ikke er grunn til at straffbarhet skal være betinget av at overtredelsen er kvalifisert (her «vesentlig»). Dersom det foreligger et lovbrudd bør dette også være straffesanksjonert.

Merknaden påpeker altså at årsregnskapet, etter medlemmets mening, kan være lovlig selv om det inneholder feil, men at feil alltid bør være straffbare hvis de først er overtredelser. Merknaden spesifiserer imidlertid ikke nærmere hva dette innebærer med tanke på forståelse av begrepet 
«overtredelse», men kommentaren om at «vesentlighetsprinsippet alltid vil ligge til grunn for praktisering av loven», kan indikere at det aktuelle utvalgsmedlemmet ikke så det som naturlig å snakke om regnskapsovertredelser i forbindelse med skjønnsmessige poster før disse overtredelsene er vesentlige. I så fall kunne dette indikert et behov for en nærmere spesifikasjon av hvordan man skal forstå begrepet «regnskapsovertredelse», ettersom usikkerhet rundt dette ellers kunne bli problematisk med tanke på regnskapsprodusentenes rettssikkerhet (prinsippet om at man skal ha mulighet til i forkant å avgjøre om man gjør noe straffbart).

Underutvalget til utredningen Bestemmelser om regnskapsføring påpekte også at det i moderne lovgiving gjerne listes opp hvilke forhold som er straffbare, men påpeker videre at dette ikke er en farbar vei når det gjelder overtredelser av bestemmelser knyttet til regnskap, jf. Ot. prp. nr 42 (199798) kap. 13. Dette forhindrer jo ikke at det hadde vært mulig å lage noen grove kategoriseringer av hvilke forhold som er straffbare. Underutvalget foreslo videre at det skulle skilles mellom mindre vesentlige overtredelser, vesentlige overtredelser og grove overtredelser, og at det må tas hensyn til at det tidvis eksisterer skjerpende omstendigheter, som helt unnlatt regnskapsføring, grove tilsidesettelser av oppbevaringsplikten, vesentlig uriktig eller villedende informasjon, vesentlig for sen informasjon, vesentlige $ø$ konomiske interesser involvert, vanskeliggjøring av kontroll/innsyn, herunder for offentlige myndigheter, og bruk av uriktige dokumenter. ${ }^{5}$

Når det gjelder høringskommentarer av betydning, var Økokrim opptatt av at det ikke syntes mulig å gi en grundig oppramsing av hvilke brudd på lovgivingen som burde straffesanksjoneres, mens NHO i sin høringsuttalelse foreslo at brudd på de grunnleggende regnskapsprinsippene ikke i seg selv skulle være straffbare av hensyn til rettssikkerheten. Økokrim var opptatt av at vesentlighetsbegrepet i regnskapsloven ikke skal samsvare med revisors vesentlighetsbegrep, ettersom

Regnskapsfeil som ikke slår ut i balansen, og derfor ikke er vesentlig fra revisors synsvinkel, kan likevel være strafferettslig vesentlige. Typisk gjelder dette falske bilag eller bilag med uriktig innhold, som er ført i regnskapet til tross for at de er virksomheten uvedkommende (Ot. prp. 42:1997-98, kap. 13.3) 
Kredittilsynet ba i sine merknader om at vesentlighetsbegrepet ville bli presisert av departementet.

Videre la Økokrim, Kredittilsynet og Kommunal- og arbeidsdepartementet i sine høringsuttalelser til grunn at også mindre vesentlige overtredelser burde være straffbare. Dette er i samsvar med hva underutvalget foreslo (merk imidlertid at dette underutvalget ble nedsatt for å se nærmere på «bestemmelser om regnskapsføring»). Senere er som kjent disse reglene inkludert i den egne bokføringsloven. I forarbeidene til regnskapsloven (NOU 1995:30, Ot.prp. 42: 1997-98) ble det ikke foretatt noen konkret vurdering av hvorvidt brudd på noen av reglene i regnskapsloven i realiteten ikke er å forstå som brudd for eksempel på grunn av iboende utfordringer knyttet til regnskapsføring av usikre størrelser.

\subsubsection{Rettspraksis}

Rettspraksis viser at det har funnet sted domfellelse etter ulike brudd på regnskapslovgivningen.

Vi vil i denne delen av kapittelet gjennomgå rettspraksis knyttet til brudd på regnskapsloven som vedrører skjønnsmessige beregninger. Dommer som kun omhandler manglende bokføring osv., inkluderes ikke.

Høyesterett har henvist til straffebestemmelsen i regnskapsloven $₫ 8$-5 i 59 saker. Vi har undersøkt hvilke andre sentrale bestemmelser disse dommene viser til, se tabell 6.1 under:

Tabell 6.1 Oversikt over hvilke andre paragrafer det vises til i høyesterettsdommer knyttet til regnskapsloven §8-5 (Kilde: hentet fra lovdata.no, domsregister til hver §)

\begin{tabular}{|c|c|c|c|c|c|c|}
\hline § 8-5 & $\begin{array}{c}\text { Antall dommer } \\
\qquad 8-5\end{array}$ & $\begin{array}{c}\S 3-2 a \\
\operatorname{mot} \$ 8-5\end{array}$ & $\begin{array}{c}\$ 4-6 \text { mot } \\
\$ 8-5\end{array}$ & $\begin{array}{c}\text { Strl } \\
\$ 392\end{array}$ & $\begin{array}{l}\text { Strl } \$ 393 \\
\text { Grov }\end{array}$ & $\begin{array}{l}\text { Strl \$394 } \\
\text { Uaktsom }\end{array}$ \\
\hline A-dom/avgjørelse & 36 & 2 & 8 & 1 & 1 & \\
\hline Erstatning etter frifinnelse & 1 & & & & & \\
\hline U-ankeutvalg & 22 & 2 & 3 & 1 & 1 & \\
\hline Ingen henvisning til § 8-5 & & & & 2 & 1 & 2 \\
\hline Sum antall HR & 59 & 4 & 11 & 4 & 3 & 2 \\
\hline
\end{tabular}

Det er altså bare i to domsavgjørelser fra Høyesterett hvor det vises til $\$ 3$-2a om rettvisende bilde. I åtte Høyesterettsdommer henvises det til $\$ 4$-6 god regnskapsskikk. 
Ikke i noen av sakene for Høyesterett blir spørsmålet om hva som er en regnskapsovertredelse i forhold til regnskapsestimater behandlet og avgjort. Vi omtaler kort noen dommer som vi anser som de mest relevante for dette kapittelet.

HR-2019-2O2-U og HR-2019-831-A henviser til regnskapslovens straffebestemmelse i $\$ 8$-5 og rettvisende bilde i $\$ 3$-2a. Dette er imidlertid tiltalepunkter i tingrettsdommen som ikke er anket, og Høyesterett tar dermed ikke stilling.

HR-2007-1995-A - Rt-2007-1677 (en del av Finance Credit-saken) omhandlet anke over tilståelsesrabatt. Selve saken for tingretten vedrørte i tillegg til dokumentforfalskning også overtredelse av regnskapsloven ved at, jf. punkt 13 og 14 :

a) En «rekke posteringer av vesentlig betydning for regnskapene ble gitt ufullstendig eller ingen beskrivelse av transaksjonens underliggende realiteter.»

b) «Det var heller ikke noen klar forbindelse mellom bilag og presentasjonen i regnskapene.»

c) Regnskap var «i tillegg [...] forfalsket etter at det var avgitt revisjonsberetning».

HR-2008-1150-A - Rt-2008-996 (KPMG i Finance Credit-saken) handlet om foretaksstraff for revisjonsselskapet. Ansvarlig revisor var i tillegg til brudd på revisjonsloven dømt «for uaktsom medvirkning til overtredelse av regnskapsloven. Domfellelsen gjelder Cs manglende revisjon av nærståendetransaksjoner og godkjennelse av to noter til årsregnskapet til Finance Credit Norge ASA for 1999 og 2000 som ga et ufullstendig bilde av transaksjoner med nærstående selskaper. Også på dette punkt er handlingen av tingretten karakterisert som grovt uaktsom» (punkt 19), med henvisning til regnskapsloven $₫ 7$-1. Med hensyn til vesentlighet uttaler Høyesterett: «Transaksjoner og fordringer knyttet til nærstående selskaper var med andre ord svært omfattende og utgjorde en vesentlig del av selskapets aktivaside. Det var således av grunnleggende betydning for holdbarheten av selskapets resultat og balanse at det var substans i transaksjonene og fordringene» (punkt 17). 
HR-2010-1855-A - Rt-2010-1328 (sentral revisormedarbeider i Finance Credit-saken) handlet om straff etter revisorloven utelukket straff etter regnskapsloven, altså idealkonkurrens mellom revisorloven og regnskapsloven. ${ }^{6}$ Høyesterett konkluderte med at «[d]e to lovene ivaretar ulike sider for å kunne nå dette målet. ${ }^{7}$ A kan derfor dømmes etter tiltalens post I og post II i idealkonkurrens». Høyesterett la vekt på at revisjon i større selskaper ikke ble utført etter at styret avgav årsregnskapet, men revisjonen skjedde i en løpende prosess og kommunikasjon med selskapet. Revisors signaler om at det ville bli avgitt «ren revisjonsberetning», medførte at revisormedarbeideren medvirket til brudd etter regnskapsloven. En del av tiltalepunktet var estimering av avskrivninger og nedskrivning av balanseførte verdier. Partene fremførte ikke ankeprosedyre på disse punktene, og Høyesterett gikk dermed ikke inn i denne delen av saken.

I Finance Credit-saken fremstår dommene mot ansvarlig revisor og revisormedarbeider som strenge ved domfellelse etter regnskapsloven, spesielt gjelder det ved vurdering av medvirkning.

Høyesteretts dom mot regnskapsføreren til «drosjeeiere i Oslo» omhandlet straffeutmåling. «Dette er Norges hittil mest omfattende sak om skattesvik som også gjelder graverende brudd på regnskapsloven» (HR-2008-601-A - Rt-2008-468 pkt 17). Saken gjaldt i tillegg til skattesvik «medvirkning til destruksjon av en mengde regnskaper og regnskapsbilag for 1999, 2000 og 2001 og for å ha besørget at regnskaper for årene 1998, 2000 og 2001 har vist en for lav inntekt for en rekke klienter» (punkt 13).

HR-2009-65-A - Rt-2009-14 («pilotsak» for «drosjeeiere i Oslo») gjaldt straffeutmåling. «Overtredelsen av regnskapsloven - lovens $\$ 8$-5 første ledd andre straffalternativ - gjelder først og fremst at han i årene 2000 og 2001 forsettlig og under særlig skjerpende omstendigheter unnlot å sørge for regnskapsføring av alle inntekter og kostnader han hadde som drosjeeier. For de to årene var det til sammen 9,25 millioner kroner som ikke ble regnskapsført» (punkt 7).

\footnotetext{
6 Idealkonkurrens: i strafferetten det forhold at noen ved en og samme handling begår flere lovbrudd.

7 Nemlig å «sikre regnskapsbrukerne korrekt regnskapsinformasjon».
} 
I HR-2016-590-A (Fast-saken) behandlet Høyesterett straff i form av inndragning av utbytte. Uriktige regnskap hadde medført økning av børskurs. Høyesterett tok ikke stilling til regnskapsovertredelsen, og konklusjon i dommen var ingen inndragning basert på at det ikke forelå noe reell berikelse. Den straffedømte anket også utmålingen av fengselsstraff, men trakk anken før den ble behandlet. Dermed har Høyesterett ikke behandlet straffeutmålingen i relasjon til økonomisk ingen reell berikelse.

Høyesterett har, slik vi har sett over, ikke behandlet innhold og omfang av regnskapsovertredelser.

Etter vår gjennomgang finner vi ingen eksempler på at domstolene setter seg opp mot lovteksten og forarbeidene ved å innfortolke noe vesentlighetsprinsipp som vilkår for straff hvis de først har konstatert en overtredelse. Tiltalepunktene har også vært for betydningsfulle til at dette har vært nødvendig å vurdere. At en feil trolig kan være så uvesentlig at den ikke utgjør en overtredelse av de materielle regnskapsreglene, er noe annet. Dette kan ikke ses å ha blitt satt på spissen i rettspraksis. At klart vesentlige virkninger av en feil benyttes som tilleggsargument ved domfellelser for overtredelse, særlig ved grove (og dermed forsettlige) overtredelser, er også noe annet.

\subsubsection{Rom for skjønn ved fastsetting av regnskapsestimater}

Regnskapsføring av regnskapsestimater reguleres av regnskapsloven $\$$ 4-2, der det slås fast at «ved usikkerhet skal det brukes beste estimat, på bakgrunn av den informasjon som er tilgjengelig når årsregnskapet avlegges». Lovens ordlyd peker på «beste estimat» som et punktestimat, den beste verdien. Praksis og økonomisk teori tilsier et skjønnsintervall (Mamelund, 2008a, 2008b, 2008c). Med utgangspunkt i paragrafens ordlyd synes rettstilstanden klar: Hvis regnskapsprodusenten ikke benytter beste estimat, er dette å anse som en overtredelse. Bestemmelsen om den rettslige standarden god regnskapsskikk (regnskapsloven $\$ 4$-6) vil gi innhold til hvordan dette beløpet bør beregnes på ulike områder, men synes ikke å endre innholdet i beste estimat. Finanstilsynet (2016, punkt 4.7) 
gir for eksempel uttrykk for at regnskapsstandarden for nedskrivning av anleggsmidler ${ }^{8}$ krever fastsetting av punktestimat.

I dette kapittelet fokuserer vi på brudd på bestemmelsene om «krav til regnskapsestimater» i regnskapsloven, og spørsmålet vi drøfter, er når det eksisterer brudd på disse bestemmelsene (en regnskapsovertredelse). Problemstillingen kan illustreres ved hjelp av følgende eksempel: Anta at et selskap har en rekke balanseførte fordringer, og ved årsslutt må selskapet derfor foreta en konkret vurdering av hvilket beløp som skal avsettes til delkredere/avsetning for tap på krav. Avsetningen er en usikker størrelse som i henhold til regnskapsloven $₫$ 4-2 skal føres i samsvar med prinsippet om beste estimat. Basert på sin bransjekjennskap og ikke minst konkrete kjennskap til egne kunder anslår selskapet at avsetningen skal foretas med samme prosentsats som tidligere år, på tross av at de økonomiske utsiktene fremover er mer usikre enn tidligere. Revisor er imidlertid uenig i denne vurderingen og mener at det er behov for en større avsetning. Beløpet selskapet og revisor er uenige om, er ikke vesentlig, så det får ingen konsekvenser for revisjonsberetningen. Hva skal i denne situasjonen til for at selskapets vurdering innebærer en regnskapsovertredelse? I teorien synes det regnskapsrettslige avklart, men i praksis er det en komplisert, skjønnsmessig og usikker oppgave å fastslå hvilket beløp som representerer dette beste estimatet: Er det selskapet som har rett? Er det revisor? Er det et helt annet beløp som representerer det faktisk beste estimatet? Når har vi da i praksis en regnskapsovertredelse?

Revisor skal vurdere om årsregnskapet er utarbeidet og fastsatt $\mathrm{i}$ samsvar med lov og forskrifter, og om den revisjonspliktiges ledelse har oppfylt sin plikt til å sørge for ordentlig og oversiktlig registrering og dokumentasjon av regnskapsopplysninger i samsvar med lov og forskrifter, jf. revisorloven $\$ 5-1$, og for at det anvendes god revisjonsskikk i arbeidet (revisorloven $\$$ 5-2 annet ledd). Imidlertid skal revisor i samsvar med revisorloven $\$$ 5-2 første ledd (vår utheving)

... påse at vedkommende har tilstrekkelig grunnlag til å vurdere om det foreligger brudd på lover og forskrifter av vesentlig betydning for årsregnskapet. 
Dette innebærer at revisor gjør bruk av en vesentlighetsgrense når han både planlegger, utfører og konkluderer på sitt arbeid (ISA 320), og revisor har ikke noe ansvar for å uttale seg om brudd på regnskapslovgivningen som ikke er vesentlige. Vurderingen vil foregå i to trinn: a) Revisor vil anse at utført skjønn må ligge utenfor et pålitelighetsintervall for å bli betegnet som en feil, og b) beløpsfeilen må være større enn vesentlighetsgrensen før revisor foretar seg noe med tanke på revisjonsberetningen.

Straffelovens ordlyd (enhver regnskapsovertredelse er straffbar) inklusiv beskrivelsen i forarbeidene tyder på at kravet til beste estimat skal forstås absolutt (dvs. uten slingringsmonn) også i forbindelse med skjønnsmessige poster. En slik forståelse av regelverket vil imidlertid innebære at feil som revisor vurderer som ikke vesentlige, og som dermed ikke kommuniseres til offentligheten i revisors beretning, i strafferettslig forstand er å anse som en regnskapsovertredelse og dermed er straffbar (gitt at kravet om uaktsomhet er til stede, og at revisors vurdering av hva som er beste estimat, er korrekt). I tidligere høringsuttalelser har vi også sett det fremhevet som viktig at også mindre overtredelser skal være straffbare, men eksemplene som har blitt benyttet, har dreiet seg om bokføring. Med tanke på skjønnsbaserte regnskapsposter synes dette å være en lite praktisk forståelse av regelverket. Det hevdes også tidvis at det implisitt finnes et vesentlighetsprinsipp i regnskapsloven. Spørsmålet blir altså om disse og eventuelt andre reelle hensyn tilsier at det regnskapsrettslig, og dermed strafferettslig, skal tolkes inn et vesentlighetsprinsipp for å avgjøre når det eksisterer en regnskapsovertredelse i forbindelse med vurdering av regnskapsestimater. Som det fremgår ovenfor, er det altså ikke noe ytterligere strafferettslig slingringsmonn i det objektive straffbarhetsvilkåret hvis det først foreligger en overtredelse. Foreligger det først en overtredelse, er den straffbar uansett hvor liten den er. Rommet for skjønn må altså knytte seg til om estimatet autoritativt kan kategoriseres som en feil (i motsetning til et diskutabelt resultat), og/eller til om estimatet er en feil som er lovlig etter regnskapslovens materielle regler (deriblant et eventuelt regnskapsrettslig vesentlighetsprinsipp) og som derfor ikke er en overtredelse.

Et estimat er per definisjon basert på utøvelse av skjønn, og det finnes, i hvert fall ikke på det tidspunktet man avlegger regnskapet, en fasit som 
kan fortelle oss hva som er korrekt regnskapsføring (hva som er «beste estimat»). Et viktig spørsmål blir da om man skal forstå kravet om «beste» estimat som et krav om at det skal benyttes et bestemt punktestimat, eller om det er tilstrekkelig at det regnskapsførte estimatet er omsluttet av et estimert intervall, dvs. inkludert et rom for utøvelse av skjønn. Ettersom et estimat er et beløp som representerer en usikker størrelse, kan dette tale for at regnskapslovens krav til beste estimat ikke er overtrådt (i indirekte strafferettslig forstand) hvis det regnskapsførte beløpet befinner seg innenfor et akseptabelt estimert intervall, selv om det i regnskapsrettslig forstand ellers synes klart at man skal benytte et punktestimat. Dette vil i så fall innebære at man i forbindelse med estimater ikke kan snakke om en regnskapsovertredelse så lenge regnskapsprodusenten regnskapsfører et beløp som er innenfor et passende intervall, for eksempel tilsvarende dette revisor gjerne utarbeider som en del av sine revisjonshandlinger.

Revisor vil, dersom benyttet estimat er utenfor akseptabelt skjønnsintervall, gi uttrykk for dette ved forbehold i revisjonsberetningen. Med de anførsler vi har ovenfor, synes det å forholde seg slik at det foretas regnskapsovertredelser i lovens forstand i det minste i alle de selskapene der revisor ikke avgir normalberetning.

Et subsidiært spørsmål vil også være om forsiktighetsprinsippet regnskapsrettslig innebærer en lovlighet av konservativ, forsiktig vurdering. Vi behandler ikke denne problemstillingen her, men konstaterer bare at i teorien skal ikke forsiktighetsprinsippet være noen overstyring av beste estimat (se for eksempel Stenheim \& Madsen, 2014). Regnskapsstandardene pålegger likevel: «Ved utøvelse av skjønn må det utvises aktsomhet slik at inntekter og eiendeler ikke blir overvurdert, og kostnader og forpliktelser ikke blir undervurdert» (NRS 13, punkt 4.3.1). I praksis vil en slik kobling mellom forsiktighet og beste estimat være utbredt. Med en slik «forsiktig» overstyring av beste estimat vil skjønnsrommet for undervurdering av eiendeler og overvurdering av gjeld være betydelig større enn omvendt.

Videre vil det, etter lovendring i 2004, være naturlig å trekke inn regnskapslovens faneparagraf 3-2a om rettvisende bilde, som legger til grunn at «[å]rsregnskapet skal gi et rettvisende bilde av den regnskapspliktiges og konsernets eiendeler og gjeld, finansielle stilling og resultat». 
Lovendringen var resultat av en mer tydelig implementering av EU-direktivet og var ikke ment å innebære en realitetsendring (Ot.prp. nr. 89 (2003-2004), punkt 5.6). Et slikt krav lå allerede i bestemmelsen om at årsregnskapet skulle følge god regnskapsskikk. Straffebestemmelsen ble ikke drøftet i relasjon til innføring av egen bestemmelse om rettvisende bilde.

Slik gjeldende lov fremstår, er det rettspolitisk logisk at regnskapsovertredelse når det gjelder regnskapsestimater, knyttes opp til at regnskapet ikke gir et rettvisende bilde. Dersom regnskapet gir et rettvisende bilde på tross av at det ikke er benyttet «beste estimat», kan dette rettspolitisk tale for at vi i slike tilfeller ikke burde se det som et straffbart brudd på regnskapsloven (litt avhengig av hva som er grunnen til at regnskapet gir et rettvisende bilde til tross for at det ikke er benyttet beste estimat).

Regnskapsmessig estimering kan innebære kompliserte vurderinger. Fra et regnskapsrettslig ståsted innebærer lovens krav om beste estimat at det mest riktige punktestimatet skal benyttes. Dette tilsier at en mulig tolkning av gjeldende regnskapslov er at ethvert avvik fra det objektivt beste estimatet er en regnskapsovertredelse. Hvis dette først er tilfellet, vil avviket oppfylle det objektive straffbarhetsvilkåret, uavhengig av hvor lite det er. At påtalemyndigheten bør, og trolig vil, praktisere tilbakeholdenhet med å påtale mindre avvik, er noe annet. Dette vil vi komme tilbake til.

\subsection{Hva ligger i uaktsomhetskravet for uriktige regnskapsestimater? Det subjektive straffbarhetsvilkåret}

Straffelovens utgangspunkt når det gjelder kravet til subjektiv skyld, er at det alltid kreves forsett hvis ikke noe annet er bestemt (jf. straffeloven $\$ 21)$. Når det har funnet sted en regnskapsovertredelse, skiller straffeloven mellom overtredelser som er henholdsvis grove (\$393), vanlige/ikkegrove (\$ 392) og uaktsomme (\$ 394). For de to førstnevnte er det ikke fastsatt noe annet krav til subjektiv skyld. Disse krever dermed forsett. For den sistnevnte sier loven at det er nok med uaktsomhet. Det er altså 
ikke noe som heter uaktsom grov regnskapsovertredelse. For å avgjøre om en regnskapsovertredelse skal anses som grov, stilles det i $₫ 393$ opp en rekke momenter som det skal legges vekt på i en eventuell vurdering. I vår sammenheng er det mest interessant hvilke momenter som er avgjørende for om en overtredelse er å regne som uaktsom, ettersom dette er et minstekrav for at en overtredelse skal være straffbar.

Ifølge straffeloven $₫ 393$ skal det

ved avgjørelsen av om regnskapsovertredelsen er grov skal det særlig legges vekt på om

a) det er brukt uriktig eller villedende informasjon eller et uriktig dokument,

b) den er begått over lang tid,

c) den er begått av noen ved brudd på den særlige tillit som følger med hans stilling eller virksomhet,

d) den har gitt betydelig økonomisk fordel,

e) det forelå risiko for betydelig skade av økonomisk eller annen art, eller

f) den har gjort det vanskelig å kontrollere virksomheten

Fastsetting av regnskapsestimater er et avansert og sammensatt faglig skjønn, basert på faktisk informasjon som kan fremstå i et endret lys når den i ettertid har blitt supplert med annen informasjon. Kravene til regnskapsprodusentenes vurderingsevne ligger nær realismens yttergrense, og det er av stor interesse for dem å forstå når de kan bli straffedømt for ikke å ha strukket til på jobben.

Som det fremgår av 6.3 ovenfor, er både klarhet og nåde vanskelig å utlede av det objektive straffbarhetsvilkåret. Blir man beskyldt for å ha fastsatt et estimat som er feil, kan man argumentere med at estimatet bare er diskutabelt, og ikke feil, selv om eksempelvis bostyrer, Økokrim eller Finanstilsynet har en annen oppfatning av hva estimatet skulle vært. Men denne grensen mellom feil og ikke-feil er nærmest fullstendig uforutsigbar fordi den ikke har noen klare kilder eller omforent forankring. Dernest vil man (eventuelt subsidiært) kunne argumentere med at materiell regnskapsrett har et implisitt vesentlighetsprinsipp som innebærer at noen feil ikke er overtredelser, og at den aktuelle feilen er i denne kategorien. Den samme uforutsigbarheten vil gjelde her. 
Når det gjelder det subjektive straffbarhetsvilkåret, er dette annerledes. Her er forutsigbarheten større og slår i forskjellige retninger for de tre forskjellige straffebudene.

For «vanlige» og grove regnskapsovertredelser etter $\$ \$ 392$ og 393 kreves det forsett. Etter disse straffebudene risikerer man ikke å bli dømt for å ha gjort en subtil feil i en avansert og sammensatt skjønnsmessig vurdering der man har forsøkt å gjøre så godt man kan, og heller ikke for å ha «kommet på mindretallssiden» i en akademisk uenighet i fagmiljøet. Egentlig er det kanskje riktigere å formulere dette motsatt vei: En regnskapsprodusent som har benyttet noe annet enn beste estimat fordi han ønsket å bruke noe annet enn beste estimat, bør alltid kunne straffes. Dette har ingen ting med de faglige vanskelighetene å gjøre og er også forutsigbart. ${ }^{9}$

For uaktsom regnskapsovertredelse er dette motsatt, i den forstand at argumentene om at forholdet ikke er en definitiv feil, eller eventuelt en feil som etter materiell regnskapsrett ikke er en overtredelse, nå er relevante i ny skikkelse.

Begrepet «uaktsom regnskapsovertredelse» må forstås ut fra straffeloven $\$ 23$ : «den som handler i strid med kravet til forsvarlig opptreden på et område, og som ut fra sine personlige forutsetninger kan bebreides, er uaktsom». Aktsomhetsnormen kan trolig være streng på regnskapsområdet. Likevel vil alle de momentene som belyser hvor vanskelig det er å fastsette regnskapsestimater, og hvor lett det er å bli uenig om et regnskapsestimat, være relevante i en konkret helhetsvurdering av skyldkravet i det enkelte tilfellet. Uaktsomheten må dekke hele handlingen og følgene av den. Vi gjør ikke noe forsøk på å trekke opp generelle prinsipper for denne helhetsvurderingen her, men en undersøkelse av om det er mulig, ville være et interessant tema for videre forskning. Vi nøyer oss med å påpeke at det vil være denne vurderingen av uaktsomhetskravet som i mange tilfeller må sikre at man kommer frem til et rimelig resultat, fordi det objektive straffbarhetsvilkåret enten er for vidtfavnende eller er for uforutsigbart til å sørge for dette.

9 Det vil kunne foreligge en uforutsigbarhet i den skyldiges favør ved at det er vanskelig for påtalemyndigheten å bevise forsettet, men det er noe annet. 


\subsection{Kort om påtalemyndighetenes praksis}

Et utvalg har på oppdrag fra regjeringen nylig utarbeidet nasjonale standarder for påtalepraksis i konkurssaker. Utvalget gjennomførte en spørreundersøkelse om påtalepraksis i konkurssaker hos samtlige av landets $ø$ koteam. Ifølge Riksadvokaten vitner tilbakemeldingene om «en svært sprikende påtalepraksis i relativt standardiserte saker, hvilket illustrerer behovet for en nasjonal standard» (Riksadvokaten, 2017). Et område som trekkes frem, er manglende innsending av årsregnskap og vurdering av om Regnskapsregisterets gebyr ivaretar behovet for en reaksjon. Dette området faller utenfor temaet i dette kapittelet, men illustrer at en uklar straffebestemmelse lett fører til urimelig forskjellsbehandling.

Et annet område som trekkes frem og tillegges vekt av påtalemyndighetene, er at noen har lidt et økonomisk tap som følge av regnskapsovertredelsen. Her pekes det på en form for «vesentlighetsvurdering» ved å henvise til at «[d]en sivilrettslige rettspraksis om styreansvar kan gi veiledning om hvilke overtredelser det er verdt å bruke politiets ressurser på» (Riksadvokaten, 2017, punkt 3.5).

Forut for en eventuell påtalebeslutning vil i praksis ofte bostyrernes innberetning være praktisk viktige for om en person straffeforfølges. Konkursrådet har som oppgave å gi anbefalinger og veiledninger for effektiv og harmonisert insolvensbehandling, blant annet bostyrers vurderinger. Vi behandler derfor kort Konkursrådets anbefalinger. Først er det interessant å merke at Konkursrådet har en egen anbefaling om straffbare forhold som ikke skal anmeldes (Konkursrådet, u.d.). Det som betegnes «bagatellmessig regnskapsovertredelse» som ikke skal anmeldes, er unnlatt bokføring i driftsperiode på inntil 6 måneder, med omsetning under 1 million kroner der bilagene i det vesentlige er til stede. Når det gjelder oppbud, anbefales det «at bostyrer i normaltilfellene ikke skal anmelde overtredelse av oppbudsplikten med mindre den tapsbringende virksomheten har pågått i mer enn 8 måneder». Videre har Konkursrådet (2018) skrevet en anbefaling om behandling av straffbare forhold begått i forbindelse med konkurs som i punkt 2.1.9 omhandler regnskapsovertredelser etter straffeloven $\$ \$ 392-394$. Det mest interessante for dette kapittelet er denne anbefalingens omtale av begrepet «god regnskapsskikk». Vi siterer: 
Årsregnskapet skal utarbeides i samsvar med fem lovfestede grunnleggende regnskapsprinsipper, jf. regnskapsloven $₫ 4-1$. «God regnskapsskikk» antas å være en overordnet norm for regnskapsføringen, uten hensyn til om regnskapspliktene kommer klart til uttrykk i lov eller forskrift. Kravet supplerer de mer konkrete pålegg og plikter, der disse ikke gir noen klar løsning. Ved fastleggelse av det nærmere innhold i kravet til «god regnskapsskikk», må flere momenter tillegges vekt. Dette gjelder krav til: Orden, Pålitelighet, Klarhet, Fullstendighet, Kontinuitet, Forsiktighet.

Av andre momenter som ofte skal tillegges vekt ved vurderingen av «god regnskapsskikk», nevnes praksis i bransjen da "god regnskapsskikk» forutsetter at det foreligger en noenlunde fast og presis praksis som kvalitativt holder en akseptabel faglig standard. Videre skal hensyntas yrkesfaglige anbefalinger, eksempelvis nevnes uttalelsene fra NRS (Norsk Regnskapsstiftelse). (...) En typisk overtredelse av regnskapsloven i konkurssammenheng vil være unnlatelse av å utarbeide årsregnskap og årsberetning, jf. regnskapsloven $₫ 3-1$.

Fra et regnskapsfaglig ståsted vil vi hevde at denne omtalen fremstår noe unyansert ved at regnskapsstandardene fra NRS synes å tillegges mindre vekt enn hva Schwencke (2015) kommer frem til at domstolene gjør.

Man kan altså gjerne velge å si det slik at Konkursrådet og påtalemyndighetene legger til grunn et "vesentlighetsprinsipp» i sine råd og veiledninger (og presumptivt da også i det meste av sin praksis). Det ville imidlertid være en uegnet terminologi i forhold til vårt tema, som er hva som skal til for at et forhold er straffbart. Hva det er verdt å bruke politiets ressurser på, er noe helt annet og må ikke blandes sammen med dette.

\subsection{Oppsummering og rettspolitisk vurdering}

Det objektive vilkåret for straffbarhet etter straffeloven $\$ 392 \mathrm{er}$ at det foreligger overtredelse. Hvis det foreligger en overtredelse, behøver altså ikke overtredelsen å være vesentlig. Når det gjelder regnskapsestimater, vil det kunne oppstå situasjoner der det kan føres vanskelige diskusjoner om hvorvidt det foreligger en feil etter materiell regnskapsrett. Hvis det foreligger en feil, kan det diskuteres om det foreligger et implisitt vesentlighetsprinsipp i den materielle regnskapsretten (enten generelt eller bare 
i tilfeller der det får straff som konsekvens), og i så fall om dette fører til at feilen ikke er en overtredelse. Det objektive straffbarhetsvilkåret vil dermed favne veldig vidt og/eller gi svak forutsigbarhet i lys av vanskelighetsgraden av de vurderingene det knytter seg til. Dette er uheldig. Problemet dempes av at temaene som knytter seg til tvilen og vanskelighetsgraden, kommer inn i vurderingen av det subjektive straffbarhetsvilkåret, men vi mener likevel at situasjonen er uheldig. Å hvile seg på at påtalemyndigheten kan la være å påtale en del forhold som oppfyller straffbarhetsvilkårene, er etter vår mening ikke riktig vei å gå. Dette kan føre til forskjellsbehandling og vil ikke kunne etablere en forutsigbarhet. Prinsipielt mener vi også at det ville være svært uheldig i et demokratisk samfunn om man bevisst skulle velge å utforme straffebudene for vidt, i den hensikt å overlate til påtalemyndigheten å velge hvor langt de skulle følges. Det ville flytte makt bort fra både den folkevalgte lovgiver og de uavhengige domstoler og over til den utøvende statsmakten.

Ut fra dette, og legalitets- og rettssikkerhetsprinsippet generelt, og i lys av at allmennpreventive hensyn i mindre grad slår til som begrunnelse for straffbarhet for uaktsomme uvesentlige regnskapsovertredelser, bør det etter vår mening foretas en ny vurdering av om straffebestemmelsen i straffeloven $\$ 392$ bør få et eksplisitt vesentlighetskrav til selve overtredelsen. Enten generelt eller bare for feil i regnskapsestimater som medfører en vesentlig virkning på årsregnskapet. En slik vurdering vil i sin tur kunne tjene på å være godt koblet sammen med en annen vurdering som vi mener fortsatt bør foretas, nemlig vurderingen av å lovfeste et vesentlighetsprinsipp i den materielle regnskapsretten. En lojal direktivimplementering av EUs regnskapsdirektiv (EP/Rdir.2013/34/EU) tilsier etter vår oppfatning at de grunnleggende regnskapsprinsippene i regnskapsloven kapittel 4 utvides med et nytt grunnleggende vesentlighetsprinsipp. Dersom dette blir gjort, og implementeringen etablerer et vesentlighetsprinsipp som er tilstrekkelig klart også for regnskapsestimater, vil det kunne redusere, eller i ytterste konsekvens fjerne, behovet for et eksplisitt krav i straffeloven $\$ 392$ om at selve overtredelsen må være vesentlig (og omvendt). En slik fremgangsmåte vil kunne redusere dagens uklarheter om når et estimatavvik faktisk er en regnskapsovertredelse, og om når en slik regnskapsovertredelse skal være straffbar. 


\section{Referanser}

\section{Lover og lovforarbeider}

Grunnloven. (1814). Kongeriket Noregs grunnlov LOV-1814-05-17.

Straffeloven (1902). Almindelig borgerlig Straffelov (Straffeloven). LOV-1902-05-2210 (Opphevet).

Aksjeloven (1976). Lov om aksjeselskaper. LOV-1976-06-04-59 (Opphevet).

Regnskapsloven (1977). Lov om regnskapsplikt m.v. (regnskapsloven). LOV-1977-0513-35 (Opphevet).

Regnskapsloven (1998) Lov om årsregnskap m.v. LOV-1998-07-17-56.

Revisorloven (1999). Lov om revisjon og revisorer (revisorloven) LOV-1999-01-15-2.

Bokføringsloven (2004) Lov om bokføring. LOV-2004-11-19-73.

Straffeloven (2005) Lov om straff. LOV-2005-05-20-28.

NOU 1995: 30. Ny regnskapslov.

NOU 2015: 10. Lov om regnskapsplikt.

Ot. prp. nr. 42 (1997-98). Om lov om årsregnskap m.v. (regnskapsloven).

Ot. prp. nr. 89 (2003-2004). Om lov om endringer i lov 17. juli $1998 \mathrm{nr} .56$ om årsregnskap m.v. (regnskapsloven) og enkelte andre lover (gjennomføring av EØS-regler om anvendelse av internasjonale regnskapsstandarder m.m.).

Ot. prp. nr. 22 (2008-09). Om lov om endringer i straffeloven 20. mai 2005 nr. 28.

Prop. 120 L (2017-2018). Endringer i rettshjelploven $m v$.

\section{Dommer}

Rt. 1993 s. 980, jf. også Rt. 1986 s. 260 og Rt. 1994 s. 713.

HR-2019-202-U og HR-2019-831-A.

HR-2007-1995-A - Rt-2007-1677 (en del av Finance Credit-saken).

HR-2008-1150-A - Rt-2008-996 (KPMG i Finance Credit-saken).

HR-2010-1855-A - Rt-2010-1328 (sentral revisormedarbeider i Finance Credit-saken).

HR-2008-601-A - Rt-2008-468 (regnskapsføreren til «drosjeeiere i Oslo»).

HR-2009-65-A - Rt-2009-14 («pilotsak» for «drosjeeiere i Oslo»).

HR-2016-590-A (Fast-saken).

\section{Regnskaps- og revisjonsstandarder}

IAS 8. Regnskapsprinsipper, endringer i regnskapsmessige estimater og feil. Sist oppdatert 2013. Internasjonal regnskapsstandard. IFRS. IASB.

IAS 36. Verdifall på eiendeler. Sist oppdatert 2014. Internasjonal regnskapsstandard. IFRS. IASB. 
IAS 37. Avsetninger, betingede forpliktelser og betingede eiendeler. Sist oppdatert 2013. Internasjonal regnskapsstandard. IFRS. IASB.

ISA 320. Vesentlighet ved planlegging og gjennomføring av en revisjon. Norsk utgave av internasjonal revisjonsstandard 320. The International Auditing and Assurance Standards Board / Den norske Revisorforening. 2010. New York, NY: The International Federation of Accountants (IFAC).

NRS 13. Usikre forpliktelser og betingede eiendeler. Sist oppdatert 2013. Norsk RegnskapsStiftelse.

NRS(F). Nedskrivning av anleggsmidler. Sist oppdatert 2009. Norsk RegnskapsStiftelse.

\section{Artikler, bøker, forarbeider m.m}

Andenæs, J. (1997). Statsforfatningen i Norge. 8. utgave.

Andenæs, J. (2016). Alminnelig strafferett. 6. utgave ved Georg Fredrik Rieber-Mohn Knut Erik Sæther. Oslo: Universitetsforlaget.

Finanstilsynet. (2016). Nedskrivningsvurderinger etter IAS 36 Verdifall på eiendeler. En oppsummering.

Finanstilsynet. (2019). Brev til Finansdepartementet Gjennomføring av regnskapsdirektivet i norsk rett. Datert 22.03.2019.

Graver, H. P. (2008) Vanlig juridisk metode? Om rettsdogmatikken som juridisk sjanger. Tidsskrift for Rettsvitenskap, 121(2), 149-178.

Graver, H. P. (2011). Rettsforskningens oppgaver og rettsvitenskapens autonomi. Tidsskrift for Rettsvitenskap, 124(2), 230-249.

Handeland, Ø. \& Schwencke, H. R. (2011). Regnskapsloven med kommentarer. Oslo: Gyldendal akademisk.

Handeland, Ø., Schwencke, H. R., Stenheim, T. \& Baksaas, K. M. (2019). Noter til Regnskapsloven (1998) \$ 8-5. Norsk lovkommentar. Oslo: Gyldendal rettsdata. Konkursrådet. (2018). Behandling av straffbare forhold begått i forbindelse med konkurs. Hentet 27.12.2019 fra http://www.konkursradet.no/behandling-avstraffbare-forhold-begaatt-i-forbindelse-med-konkurs.308090.no.html\#_ Toc510601664

Konkursrådet. (u.d.). Anbefaling om anmeldelse av straffbare forhold. Hentet 27.12.2019 fra http://www.konkursradet.no/anbefaling-om-anmeldelse-avstraffbare-forhold.308018.no.html

Kvam, B. (2014). ABC i alminnelig strafferett. Skal gjerningspersonen straffes? Oslo: Cappelen Damm Akademisk.

Larsen, M. V. (2005). Straffbare brudd på opplysningsplikten. En analyse av regnskapsloven $\$ 8-5$ og straffeloven $\$ 286$. UiO Det juridiske fakultet. Masteroppgave. 
Mamelund, E. (2008a). Virkelig verdi og andre usikre regnskapsestimater i IFRS: Profesjonell skjønnsutøvelse. Revisjon og Regnskap, 4, 20-25.

Mamelund, E. (2008b). Virkelig verdi og andre usikre regnskapsestimater i IFRS: Profesjonell skjønnsutøvelse. Revisjon og Regnskap, 5, 17-22.

Mamelund, E. (2008c). Virkelig verdi og andre usikre regnskapsestimater i IFRS: Profesjonell skjønnsutøvelse. Revisjon og Regnskap, 6, 21-34.

Matningsdal, M. (2019). Noter til Straffeloven (2005) \$\$ 392-394. Norsk lovkommentar. Gyldendal rettsdata.

Riksadvokaten. (2017). RA-2014-1510 Nasjonal standard for påtalepraksis og etterforsking i mindre økonomiske straffesaker, nr. 1. Hentet 27.12.2019 fra https:// www.riksadvokaten.no/wp-content/uploads/2019/03/Nasjonal-standard-foretterforsking-og-påtalepraksis-i-mindre-økonomiske-straffesaker-1.pdf

Schwencke, H. R. (2015). Norske domstolers tolkning av god regnskapsskikk. NOU 2015: 10. Lov om regnskapsplikt. Vedlegg 1.

Schwencke, H. R., Haugen, D. O., Baksaas, K. M., Stenheim, T. \& Avlesen-Østli, E. (2020). Årsregnskapet i teori og praksis 2019. Oslo: Gyldendal Norsk Forlag.

Stenheim, T. \& Madsen, D. (2014). Forsiktig regnskapsrapportering - hva og hvorfor? Praktisk økonomi \& Finans, 30(4), 356-366. 



\title{
Hva påvirker adopsjon av digitaliseringsverktøy i revisjonsbransjen i Norge?
}

\author{
Tom Erik Wiklund \\ Ph.d.-stipendiat, Høgskolen i Innlandet
}

Sjur Annexstad

Siviløkonom

\section{Even Fallan}

Førsteamanuensis, Høgskolen i Innlandet ${ }^{1}$

Sammendrag: Revisjon er en viktig del av prosessen med å produsere brukernyttig finansiell rapportering. Digitalisering av revisjonstjenester kan påvirke blant annet revisjons- og dermed regnskapskvalitet samt inntekts- og kostnadssiden ved revisjon og tilliggende tjenester. Denne studien undersøker hva som påvirker beslutninger om adopsjon (valg av adopsjon eller ikke-adopsjon) av digitaliseringsverktøy blant aktører i revisjonsbransjen i Norge i 2018.

Digitalisering og digitaliseringsverktøy betraktes i studien som innovasjoner. Hva som påvirker de aktuelle revisorenes adopsjon av innovasjonene - bruk av og holdning til digitaliseringsverktøy - er analysert både utfra en modell for rasjonelle valg (adopsjonsteori) og utfra alternativ motivasjon (fad). Adopsjonsteori er et klassisk rammeverk basert på at revisjonsselskapers, -kontorers eller -teams beslutninger om adopsjon av digitaliseringsverktøy blir påvirket av deres oppfatninger av fem egenskaper/attributter ved innovasjonene: kompatibilitet, kompleksitet, prøvbarhet, observerbarhet og relativ fordel.

De empiriske funnene er basert på intervjuer med partnere i sju norske revisjonsselskaper av ulik størrelse og ved kontorer utenfor Oslo.

1 Vi vil takke Stein Antonsen, Høgskolen i Innlandet, som har bidratt i egenskap av å være en av to veiledere for masteroppgaven som lå til grunn for dette kapitlet. (Even Fallan var den andre.)

Sitering av denne artikkelen: Wiklund, T. E., Annexstad, S. \& Fallan, E. (2020). Hva påvirker adopsjon av digitaliseringsverktøy i revisjonsbransjen i Norge? I T. Stenheim, K. M. Baksaas og E. M. Kulset (Red.), Aktuelle temaer i regnskap og revisjon (Kap. 7, s. 197-222). Oslo: Cappelen Damm Akademisk. https://doi. org/10.23865/noasp.112.ch7

Lisens: CC-BY 4.o. 
Studien finner at det bare er en av informantene som til en viss grad har tatt i bruk avanserte digitaliseringsverktøy. Fem av informantene signaliserer at de forventer å ta i bruk slike verktøy når tida er mer moden, mens en inntil videre ikke har planer om dette. Lave adopsjonsrater i 2018 synes å ha sammenheng med oppfattet manglende kompatibilitet og relativ fordel samt høy kompleksitet og synlighet av dårlige resultater ved prøving og bruk. Vente-og-se-holdningen er også kjennetegnet ved at man imiterer andre aktører i samme eller konkurrerende foretak (fad). Analysen indikerer at manglende standardisering av rapporteringsdata er et viktig underliggende forhold som påvirker alle de fem attributtene negativt. Det forventes endringer i oppfatningen av attributtene når det standardiserte rapporteringsformatet SAF-T (standard audit file - tax) innføres.

Nøkkelord: digitalisering, SAF-T, revisor, Rogers, Abrahamson, adopsjon

\subsection{Innledning}

Digitalisering innenfor revisjonsbransjen har de siste årene blitt et hett tema, både i praksis og i forskning (e.g. Appelbaum et al., 2017; Baksaas, 2019; Fløtre et al., 2019; Gustavsen \& Baksaas, 2019; Opsahl \& Nygård, 2019; Stephansen \& Bardal, 2019; Tiberius \& Hirth, 2019). I metastudien til Kaarbøe mfl. (2018) skisseres ulike forskningsretninger innen temaet. Litteraturgjennomgangen viser imidlertid at få studier forklarer årsaker til adopsjon eller ikke-adopsjon av digitaliseringsverktøy (Annexstad \& Wiklund, 2019). Denne studien søker å bidra til å fylle det kunnskapshullet.

Utgangspunktet for å adoptere innovasjoner er anerkjennelsen av et problem eller et behov (Rogers, 2003). Revisjonsbransjen utrykker et ønske om økt effektivisering/måloppnåelse (Fjørtoft, 2018; Kinserdal, 2017; Nordstrøm \& Sælensminde, 2018). Dette kan kalles et rasjonelt («efficient choice») perspektiv (Abrahamson, 1991). Forskningslitteraturen har ofte vært lite presis i sin beskrivelse av hvordan digitaliseringen faktisk skal påvirke effektiviseringen hos revisorene (Fjørtoft, 2018; Nordstrøm \& Sælensminde, 2018). Kinserdal (2014) og Tiberius og Hirth (2019) antyder hvordan revisjonen gjennomføres i dag, og hvordan den kan se ut i framtida. Det etterlyses likevel studier om hvordan digitaliseringsverktøy kan påvirke effektivitet (måloppnåelse) og produktivitet. Enda større er kunnskapshullet om adopsjon (bruk) og effektiviteten av digitale løsninger om vi beveger oss utenfor de store revisjonsselskapenes norske hovedkontor i 
Oslo eller i deres kontorer i internasjonale metropoler. Verden (inkludert kundemassen) kan se annerledes ut i mindre miljøer.

Klare målformuleringer, kompetente vurderinger om hvordan digitaliseringsverktøyene skal bidra til å nå målene i den angitte situasjon og virksomhet, håndtering av risiko, mv. ligger til grunn for gode, rasjonelle valg. Rasjonell atferd tilsier at innovasjoner eller teknologi som blir oppfattet å bidra til den beste måloppnåelsen for bedriften, vil bli adoptert. På samme måte vil bedriftene forkaste innovasjoner som ikke bidrar til positive resultater (Abrahamson, 1991). I en situasjon hvor revisjonsbransjen ønsker å forbedre sin konkurransekraft (Fjørtoft, 2018), er det naturlig at enkelte revisjonsselskaper, -kontorer eller -team søker mer effektive løsninger. Rogers (2003) har utviklet en modell som skisserer viktige forhold som må vurderes når man forsøker å foreta rasjonelle adopsjonsbeslutninger.

Ofte er det imidlertid stor usikkerhet om mål og virkemidler samt begrensede ressurser for å foreta opplyste vurderinger av om tilgjengelige digitaliseringsløsninger er hensiktsmessige. Prosesser er mer preget av begrenset rasjonalitet (Abrahamson, 1991; March, 1978). Av og til har man heller ikke et valg, ettersom myndigheters reguleringer eller andre rammebetingelser tvinger fram bestemte løsninger. Abrahamson (1991) skisserer «fad», «fashion» og «forced selection» som alternative forklaringer på adopsjon.

Studiens problemstilling er: Hva påvirker adopsjon eller ikke-adopsjon av digitaliseringsverktøy blant aktører $i$ revisjonsbransjen i Norge? Problemstillingen vil bli undersøkt og analysert både i lys av Rogers' (2003) rammeverk for adopsjon av innovasjoner, som er basert på (forsøk på) rasjonell beslutningsatferd, og Abrahamsons (1991) fad-konsept (imitasjon av andres valg), som er basert på alternativ motivasjon.

Vi har foretatt intervjuer med partnere i revisjonsselskaper av ulik størrelse, men hvor alle har tilhold i mindre miljøer utenfor Oslo.

\subsection{Digitalisering}

Begrepet digitalisering må ikke forveksles med elektronisk. Elektronisk ansees som vridningen fra papir til data, mens digitalisering handler om bruken av datateknologi i den hensikt å effektivisere og erstatte oppgaver som tidligere har måttet utføres av mennesker (Yoo et al., 2010). 
Ifølge Unruh og Kiron (2017) og Șerban (2017) kan man betrakte digitalisering som en endringsprosess som går over tid, hvor nivåene blir stadig mer sofistikerte.

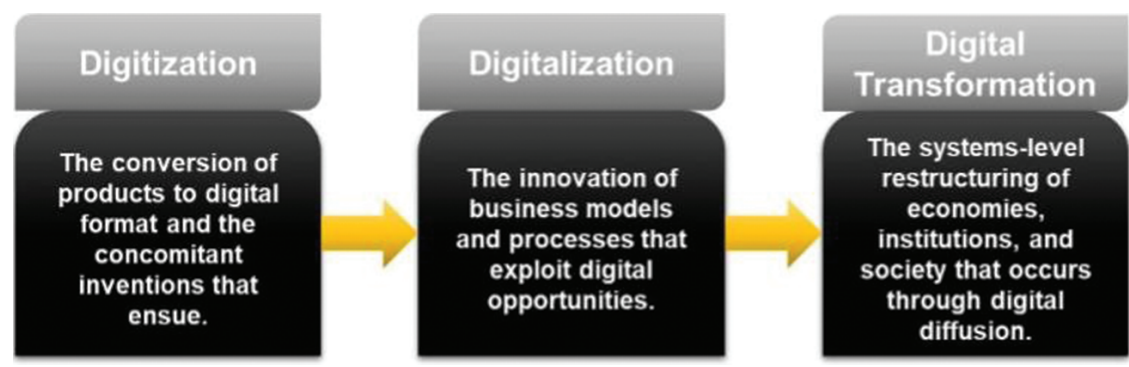

Figur 7.1 Digitaliseringens stadier. Figur hentet fra (Șerban, 2017, s. 184; Unruh \& Kiron, 2017)

Stadium 1 omhandler overgangen til digitale data og de tilhørende innovasjonene som følger med. Omkoding av analog informasjon til digital informasjon kan medføre ytterligere kontroll og verdiskaping (MartínPeña et al., 2018). Stadium 2 gjelder den videre innvirkningen stadium 1 har på forretningsmodeller, mens stadium 3 omtaler den digitale transformasjonen som skjer når nye digitale modeller og prosesser restrukturerer økonomier, institusjoner og samfunn.

Når datamengden øker, vil analysen av denne kreve maskinkapasitet, nye verktøy og nye metoder gjennom automatisering og stordatabehandling (Dai \& Vasarhelyi, 2017; Kinserdal, 2017). Dette innebærer digitalisering som et verktøy som håndterer avstemmingsoppgaver i regnskapet, og som kan teste hele utvalg i en populasjon og følgelig erstatte utvalgstestingen. Disse dataene analyseres i den hensikt å avdekke avvik, som deretter undersøkes nærmere (Kinserdal, 2017). Dai og Vasarhelyi (2017), Issa mfl. (2016) og Oldhouser (2016) påpeker at adopsjon av digitalisering i revisjon henger etter utviklingen i andre bransjer, hvilket kan forsinke eller vanskeliggjøre endring av forretningsmodeller (stadium 2) (Martín-Peña et al., 2018). Det er usikkerhet rundt diffusjon av digitalisering og digitalisingsløsninger i revisjonsbransjen, for eksempel sett utfra Serbans (2017) og Unruh og Kirons (2017) rammeverk. Uavhengig av hvor langt eller kort utviklingen har kommet, vil kunnskap om 
enkeltaktørers adopsjonsbeslutninger gi viktig informasjon om årsaker til utviklingen.

\subsection{Teori}

I denne studien blir digitalisering betraktet som en innovasjon i revisjonsbransjen. En innovasjon er «an idea, practice, or object that is perceived as new by an individual or other unit of adoption» (Rogers, 2003, side 12). Denne vide, generelle definisjonen er konsistent med Schumpeters (2017) syn på introduksjon av nye produksjonsmetoder som også kan relateres til revisjon: «Den nye produksjonsmetoden behøver ikke være basert på en forskningsmessig nyvinning, og kan eksistere som en ny måte å forvalte en vare eller tjeneste kommersielt.»

Innovasjonsteori, nærmere bestemt adopsjonsteori, er et velprøvd rammeverk i samfunnsvitenskapen generelt (Rogers, 2003) og for regnskap spesielt (Fallan, 2015). Den kan også bli benyttet for å analysere revisjonsselskapers, revisjonskontorers eller revisjonsteams beslutninger om å adoptere eller ikke adoptere digitaliseringsinnovasjoner (Annexstad \& Wiklund, 2019).

Adopsjon er «... a decision to make full use of an innovation as best course of action available» (Rogers, 2003, s. 21). Beslutning om å adoptere en innovasjon er et valg mellom flere alternativer (inkludert status quo), hvor den potensielle adoptøren søker den innovasjonen som kan føre til den beste måloppnåelsen. Dette forutsetter at adoptøren opptrer rasjonelt og står fritt til å velge det beste alternativet (efficient choice). Ifølge Rogers (2003) kan adoptørens oppfatning av fem attributter ved innovasjonen forklare opptil 87 prosent av variansen i adopsjonbeslutninger. Disse attributtene (kompatibilitet, kompleksistet, prøvbarhet, observerbarhet og relativ fordel) kan derfor representere et rammeverk for å forklare adopsjon av digitaliseringsverktøy på individuelt nivå og blir presentert kort i kapittel 7.3.1 til 7.3.5. De ulike attributtene vil ofte kunne forsterke (eventuelt motvirke) hverandre (Fallan, 2015).

Beslutninger trenger imidlertid ikke være basert på rasjonelle valg. Abrahamson (1991) utviklet et rammeverk for å forklare diffusjon av innovasjoner, hvor efficient choice kun utgjør en av fire forklaringsfaktorer. 
Rogers' (2003) fem attributter ved innovasjoner vil i Abrahamsons (1991) rammeverk høre hjemme innenfor efficient choice. De tre andre forklaringsfaktorene til Abrahamson var forced selection, fad og fashion. Forced selection innebærer at myndigheter, andre aktører eller andre forhold i realiteten tvinger en aktør til å adoptere en innovasjon. Myndighetskrav til innføring av SAF-T (standard audit file - tax) er eksempel på et slikt krav som på flere måter kan få stor betydning for digitalisering $\mathrm{i}$ revisjonsbransjen. I dette kapitlet vil vi imidlertid i hovedsak diskutere SAF-T gjennom efficient choice-perspektivet. Fad vil si at aktøren selv tar beslutninger om adopsjon basert på imitasjon av andre aktører, mens fashion vil si at utenforstående foretar adopsjonsbeslutninger for en aktør basert på imitasjon av andre aktører.

I denne studien ser vi særskilt på efficient choice og fad.

\subsubsection{Oppfattet kompatibilitet}

En innovasjons kompatibilitet gjelder i hvilken grad den ansees som konsistent med eksisterende normer, verdier, ideer, erfaringer, eksisterende metoder og behov hos potensielle adoptører og deres sosiale nettverk / samfunnet (Rogers, 2003). Kompatibilitet knyttet til digitalisering kan for eksempel gjelde metodebruk og konsekvenser for kvalitet, arbeidskraft osv. Høy grad av kompatibilitet vil fremme adopsjon gjennom å redusere usikkerheten innovasjonen representerer. Det finnes ulike typer kompatibilitet hvis konsekvenser bør vurderes i en rasjonell beslutningsprosess (Aldrich \& Reuf 2006; Fallan, 2015, 2016; Fallan \& Fallan, 2019; Suchman, 1995). Revisjonsbransjen er underlagt reguleringer i lover og standarder, og digitaliseringsverktøys kompatibilitet er avhengig av at de bidrar til å oppfylle disse kravene. Denne formen for kompatibilitet kalles regulatorisk kompatibilitet. Moralsk kompatibilitet vurderes mot moralske heller enn lovmessige standarder, mens den høyeste graden av kognitiv legitimitet eksisterer dersom en løsning, metode eller annet er så vanlig/selvsagt at den blir tatt for gitt. En fjerde type er pragmatisk kompatibilitet, som innebærer at innovasjonen oppfattes som nyttig/fordelaktig av adoptørens interessenter. 


\subsubsection{Oppfattet kompleksitet}

Dersom en innovasjon er vanskelig å forstå, vanskelig å bruke eller oppfattes som for kompleks, vil det, ifølge Rogers (2003), redusere sannsynligheten for adopsjon. Eksempler på dette kan være at det stilles høye krav til IT-teknisk kompetanse hos brukerne av digitaliseringsverktøy, eller at bruken betinger at man stadig må spesialtilpasse verktøyet til ulike datagrunnlag. Graden av kompleksitet i implementering og bruk for både revisor og kunde kan ha praktiske, økonomiske og andre ressursmessige konsekvenser som en rasjonell vurdering må ta hensyn til.

\subsubsection{Oppfattet prøvbarhet}

Adopsjon blir fremmet om det er enkelt å prøve ut innovasjonen, i liten skala, med enkle midler, få ressurser eller lignende (Rogers, 2003). Muligheten til å høste erfaringer gjennom andres prøving kan også oppfylle slike behov. Prøvbarheten øker dersom man ikke er bundet til å teste ut eller ta i bruk alle digitaliseringsverktøyenes funksjonaliteter, men bare de som er mest relevante for den potensielle adoptøren. Prøvbarhet og kompleksitet bør ofte sees i sammenheng. Dersom digitaliseringsvertkøyene oppleves som komplekse, vil muligheten til å teste ut bli desto viktigere. Det kan være nødvendig å prøve ut både implementering og senere bruk, både hos revisor og revisorens kunder/ interessenter.

\subsubsection{Oppfattet observerbarhet}

Noen innovasjoner kan være svært synlige og lette å kommunisere, mens andre er vanskeligere både å observere og beskrive. Ifølge Rogers (2003) eksisterer det en positiv sammenheng mellom innovasjonens synlighet og adopsjon. Observerbarhet kan videre deles inn i to, hvor den ene siden handler om synligheten til selve innovasjonen og den andre siden om synligheten av innovasjonens resultater (Fallan, 2015; Moore \& Benbasat, 1991). Bruk av revisjonsroboter kan i seg selv være et salgsargument overfor kunder, og slik sett kan digitaliseringsverktøy ha en direkte synlighet. Revisjonsbransjen må imidlertid også kunne se og måle effektene 
av hvordan digitaliseringen av arbeidsprosessene opptrer. Det er usikkerhet knyttet til å ta i bruk nye metoder og prosesser før man har vurdert hvordan disse påvirker den etablerte arbeidsmetodikken (effektivitet og produktivitet). Det vil samtidig være vanskelig å vurdere alternativer opp mot hverandre dersom de ikke kan observeres (Rogers, 2003).

\subsubsection{Oppfattet relativ fordel}

Ifølge Rogers (2003) er det en positiv sammenheng mellom innovasjonens relative fordel og adopsjon. Dette handler om i hvilken grad nye digitaliseringsvektøy tilfører en fordel i forhold til dagens praksis eller alternative verktøy og metoder. Innovasjonen trenger ikke erstatte eksisterende metoder eller verktøy fullt ut, men kan tilføre verdi som et supplement (Rogers, 2003). Relativ fordel kan for eksempel knyttes til endringer i inntekter, kostnader, produktivitet, risiko, kvalitet, image osv. (Fallan, 2015), noe som åpenbart hører hjemme i grunnlaget for rasjonelle beslutninger. For revisjonsbransjen vil det være et krav om at nye metoder må være minst like gode som tidligere praksis (Kinserdal, 2017).

\subsection{Metode}

Det foreligger lite forskning om hvordan standardisering påvirker adopsjon av digitaliseringsverktøy i revisjonsbransjen. Det er derfor valgt et eksplorativt forskningsdesign med semistrukturerte intervjuer til den initielle studien. Målet er ikke å generalisere resultater. I stedet er målet å la aktører identifisere relevante forhold knyttet til digitalisering i revisjonsbransjen utfra sin hverdag og sine vurderinger. Analyse av disse betraktningene i et velprøvd teoretisk rammeverk kan gi innspill på vei mot teoretisk generalisering.

De valgte informantene befinner seg i situasjoner hvor de benytter teknologi eller kan ta valg om å benytte seg av teknologi. Vi har stilt som krav at informantene skulle ha flere års formell og praktisk revisjonskompetanse, slik at de hadde god forståelse og innsikt i revisjonsbransjen. Valget av informanter er basert på intensitetsprinsippet (Esaiasson et al., 2007). Informantene har gjennom sin posisjon den nødvendige kunnskapen 
for å belyse problemstillingen. Oppsummert fant vi det hensiktsmessig å velge revisjonspartnere.

Det er videre foretatt et bevisst valg om å snakke med informanter som ikke sokner til de fire-fem store revisjonsselskapenes hovedkontor i Oslo. I stedet er informantene fra sju ulike revisjonsselskaper, både små og store. Geografisk er informantene fra middels store steder med et omland av små steder. En stor del av deres kunder er små og mellomstore foretak. Dette er en vinkling som eksisterende litteratur i liten grad har fanget opp, og hvor vår empiri gir et bidrag.

Under følger en oversikt over antall informanter, størrelse på revisjonsselskap, lengden på intervjuene og hvor intervjuet fant sted. Alle intervjuene ble foretatt i 2018.

Tabell 7.1 Informasjon om intervjuer

\begin{tabular}{llll}
\hline Respondent & $\begin{array}{l}\text { Størrelse på } \\
\text { revisjonsselskap }\end{array}$ & $\begin{array}{l}\text { Tidsforbruk } \\
\text { intervju }\end{array}$ & Sted for gjennomføring \\
\hline R1 & Stort & 80 minutter & På respondentens kontorsted \\
R2 & Stort & 72 minutter & På respondentens kontorsted \\
R3 & Mindre & 57 minutter & På respondentens kontorsted \\
R4 & Mindre & 61 minutter & På respondentens kontorsted \\
R5 & Stort & 80 minutter & På respondentens kontorsted \\
R6 & Stort & 61 minutter & På respondentens kontorsted \\
R7 & Mindre & 93 minutter & På respondentens kontorsted \\
\hline
\end{tabular}

Artikkelen er en spisset versjon av deler av en masteroppgave (Annexstad \& Wiklund, 2019).

\subsection{Resultat}

\subsubsection{Definisjon av eller tilnærming til digitalisering}

For å illustrere kompleksiteten i begrepet digitalisering og for å kunne tolke informantenes svar, er det viktig å ha en forståelse av hvordan informantene selv definerer begrepet.

Vi vurderer informantenes egne definisjoner opp mot de tre stadiene i modellen skissert av Unruh og Kiron (2017) og Șerban (2017). Dette kan 
også gi en indikasjon på hvor langt digitalisering i revisjonsbransjen har kommet. Informantene definerer digitalisering ulikt.

Informant R2 tilbyr et perspektiv som tangerer stadium-3-modellen, altså «digital transformation». Dette harmonerer med Kinserdals (2017) modell for framtidig revisjon. R2 fremhever at noen av kontrolloppgavene kan automatiseres, og antyder samtidig en mulig framtid der revisorens vurderinger av risiko også kan bli overtatt av roboter og algoritmer.

Definisjonen av digitalisering hos fem av informantene kan plasseres $\mathrm{i}$ stadium 2 («digitalization»). Den siste informanten $\left(\mathrm{R}_{3}\right)$ svarer imidlertid på en måte som ikke kan plasseres innenfor de tre stadiene. Definisjonen passer mer med en kategori som kan klassifiseres som «fra papir til data», det vil si elektroniske og maskinleselige data (Wahlster, 2017).

\subsubsection{Efficient choice}

Vi forutsetter i denne studien at effektivitet (måloppnåelse) er et sentralt mål for revisorer og revisjonsbransjen. Begrepet er hensiktsmessig i generell bruk siden det åpner for et hvilket som helst mål. Det kan være lønnsomhet, produktivitet, å oppfylle kravene til revisjon i lov og standarder, kvalitet i revisjon, kvalitet/nytte for kundene av både revisjon og rådgivning, attraktive arbeidsoppgaver for ansatte, jobbsikkerhet osv. Rasjonelle valg (efficient choice) handler om å nå disse målene, altså oppnå effektivitet.

De fleste informantene nevner effektivisering som et av motivene for å adoptere digitaliseringsteknologi, og samtlige informanter fremhever bruken av Microsoft Excel som fordelaktig i denne sammenhengen. Under gjennomføringen av intervjuene kom det tydelig frem at Excel bidrar til å behandle store datamengder på en effektiv måte, der man slipper å bla i hovedboka for å lete frem bilagsnummer.

Informantene antyder i ulik grad at digitaliseringsverktøy skal kunne gjøre uttrekk fra bilag og foreta testing automatisk. Dersom dataene er standardiserte, skal arbeidsoppgavene kunne gjennomføres automatisk av digitaliseringsverktøy. Dette underbygges av R5:

Jobben vår er å fremskaffe revisjonsbevis. ... Da er det jo mye statistiske stikkprøver, utvalgsmetodikk osv., og så er det ganske mye jobb å beregne de 
utvalgene, hente inn informasjon, sjekke den informasjonen som en del av den revisjonen. Altså mye manuelt arbeid. Selv om vi bruker Excel, er det fortsatt mye manuelt arbeid. Hele den digitaliseringsbiten vil jo kunne effektivisere dette.

Vi fortolker dette som at det foreligger en forventning hos informantene om at digitaliseringsverktøyene skal kunne utføre mer komplekse oppgaver sammenliknet med Excel. Vi oppfatter dette som at det refereres til adopsjon av mer avanserte digitaliseringsverktøy, hvilket er i tråd med bransjens overordnede ambisjon (Kinserdal, 2017).

Ifølge $\mathrm{R}_{3}$ setter kundene større pris på god rådgivning fremfor at revisjonsselskapet leverer bedre analyser gjennom bruk av digitaliseringsverktøy.

Jeg ønsker ikke denne utviklingen fullt ut, fordi jeg mener at det å møte kunden, møte ledelsen. ... Hva andre gjør, bryr vi oss ingen ting om. ... For mange er revisjon et nødvendig onde. Det er ikke det de legger vekt på ved å ha kontakt med oss. Men kanskje først og fremst den rådgivingen som de får. At vi er orientert mot hva kundene har behov for.

Vi fortolker dette som at ikke alle revisorer vurderer å adoptere digitaliseringsverktøy for at de selv skal bli mer effektive, men er avventende fordi de ikke ser et behov.

For å avdekke om det kun er effektivitetshensyn som utgjør motivasjonen for valg om adopsjon av digitaliseringsverktøy, er det viktig å finne ut av om informantene blir påvirket på andre måter. Flere av informantene er åpne på at de følger med på hva de øvrige konkurrentene tilbyr av løsninger, og gir et klart utrykk for at dette bidrar til å presse frem adopsjon av digitaliseringsverktøy.

I høyeste grad. Vi ser jo selvfølgelig hen til hva de rundt oss ... for vi er også nødt til å kunne tilby på en eller annen måte.

Dette utsagnet kommer fra $\mathrm{R} 7$, og vi tolker det som at valget om adopsjon av digitaliseringsverktøy ikke alltid er fritt for ytre påvirkning.

En forutsetning for å plassere en adoptør i efficient choice-perspektivet er et rasjonelt valg, samtidig som man ikke er særlig påvirket av andre aktører eller tvang (Abrahamson, 1991). For at en aktør skal kunne ta et 
rasjonelt valg, må aktøren betrakte digitalisering gjennom Rogers (2003) fem attributter.

\section{Kompatibilitet}

Flere av informantene gir utrykk for at regulatorisk kompatibilitet er sentralt når de vurderer adopsjon av digitaliseringsverktøy. R1 utrykker seg slik:

... vi [har ikke] et standard dataformat i Norge som gjør at vi enkelt kan hente inn data og analysere det uten at vi må gjøre en god del arbeid med det. Men nå har jo skattemyndighetene iverksatt dette SAF-T-formatet og det tror jeg vil hjelpe oss på det der.

Fram til nå har det ikke vært krav i lov e.l. om standardisert dataformat. Men fra 01.01.2020 er SAF-T innført som en obligatorisk standard for utveksling av regnskapsinformasjon (Ellefsen, 2017). Skattetaten (2014) antyder at denne standarden vil imøtekomme revisorenes ønske om standardisering. Det obligatoriske brukskravet medfører en regulatorisk kompatibilitetsrisiko ved manglende samsvar og med dette økt sannsynligheten for adopsjon av SAF-T og digitale løsninger.

SAF-T vil omfatte alle bedrifter som er bokføringspliktige etter bokføringsforskriften $\$ 7-7$ (Skattetaten, 2014, s. 32). Denne forskriften sier at alle bokføringspliktige med en brutto omsetning på 5 millioner kroner skal rapportere på denne standarden. Likevel blir i praksis samtlige bedrifter som oppbevarer regnskapsinformasjon digitalt, påvirket av innføringen av standarden:

Bokføringspliktige som skal ha bokførte opplysninger elektronisk tilgjengelig etter bokføringsloven $\$ 13 \mathrm{~b}$, skal kunne gjengi bokførte opplysninger i standardisert form. Kravet gjelder også for bokføringspliktige som omfattes av unntakene i $₫$ 7-7 tredje ledd, men som likevel har bokførte opplysninger elektronisk tilgjengelig. (Bokføringsforskriften $₫ 7-8$ )

Jo flere bedrifter som er underlagt standarden, desto større vil den regulatoriske kompatibilitetseffekten være.

Når det gjelder pragmatisk kompatibilitet, oppgir R2 at selskapet benytter digitaliseringsverktøy i stor grad, og etterlater liten tvil om at 
dette er måten å jobbe på fremover. Det forutsetter riktignok, i likhet med hva R1 sier, at datagrunnlaget er standardisert, men ikke minst også at kundene selv velger å levere data på et digitalt format som revisor enkelt kan håndtere fordi det gagner dem selv:
Altså [vårt kontor] er vel på, i noe særlig omfang, på andre året i bruk av roboter. Jeg har ikke hørt at noen andre bruker det enda. Og vi bruker det jo i sammenhenger der hvor vi kan ha mange kunder på en lik teknologisk platt- form, hvor den gjentakende effekten er stor. Så det kan være små revisjoner, men som kan gjennomføres likt. ... kundene som skjønner at hvis vi får lov til å jobbe smart med digital behandling av data, så stiller vi jo ofte mange færre spørsmål.

Som vi har sett tidligere, mener dog $\mathrm{R}_{3}$ at firmaets kunder har andre behov enn det R2 skisserer for sine kunder. Vi vil også se senere at flere informanters kunder foretrekker andre dataformater (som papir).

Informantenes svar indikerer ikke at den kognitive kompatibiliteten knyttet til bruk av digitaliseringsverktøy og forutsetningene for dette er relativt lav. Felles for de fleste informantene er fraværet av digitale data (på en enkel form) å jobbe med. R1 utrykker dette på følgende måte:

... det hjelper ikke at vi er langt fremme på digitalisering hvis omverden ikke er det.

Verken revisjonsselskaper eller kunder tar det for gitt at det skal benyttes digitale løsninger. Denne forståelsen og holdningen kan endre seg over tid. SAF-T kan bidra, men også forhold som Revisorforeningens digitaliseringsakademi (som flere nevner), tilbud av nye revisjonsroboter/softwareløsninger, kunnskap om at det kan gi billigere og bedre revisjon og analyse, og den generelle oppmerksomheten rundt digitalisering i media og andre steder.

Moralsk kompatibilitet er relevant i den grad at digitalisering medfører at bedrifter tvinges til å legge ned, at arbeidsplasser forsvinner, eller eventuelt utvikling mot et storebror -ser -deg-samfunn (økt overvåkning). Flere informanter kommenterer betydningen for arbeidsplasser, som vi vil se senere. Likevel vil vi ikke framheve moralsk kompatibilitet som den mest sentrale forklaringsfaktoren utfra informantenes svar. 


\section{Kompleksitet}

Alle informantene svarer bekreftende på at det foreligger en stor heterogenitet og kompleksitet i datagrunnlagene.

Det utvikles nye verktøy, men kundene har jo ulike systemer ... det er veldig vanskelig å trekke ut data fra et vilkårlig system, og få det på en kvalitet og et format som gjør at det er til nytte for oss, inn i våre verktøy. Nå vi snakker om mer avanserte ting enn Excel-massasje av data. Det er den store barrieren så langt føler jeg. ... Selskapet globalt og nasjonalt utvikler masse verktøy ... men enn så lenge er det for lite som vi lokalt ser nytten av. Vi har ikke gått over den terskelen enda, hvor ting er så enkelt og generisk at det kommer raskt til nytte for oss lokalt, som også jobber med mindre oppdrag som ikke har mulighet til å investere titalls timer i å ta i bruk et verktøy på en lokal, mindre kunde. (R5)

Dermed kan det være utfordrende å få digitaliseringsverktøy til å fungere godt.

Robotiseringen passer best på rutineoppgaver, og vi har jo ingen saker som er like her. ... Slik som de store børsnoterte selskapene har de en helt annen datamengde. Derfor vil det være forskjellige vurderinger mellom disse selskapene og de vi holder på med, det er naturlig. Man har et stort gap der. (R3)

R1 svarer riktignok ikke direkte på om kompleksiteten representerer en utfordring, men lister opp en stor mengde systemers interaksjon med hverandre, og at de har mange egenutviklede systemer, nettopp som følge av denne kompleksiteten. R2 er mer konkret når det gjelder å illustrere kompleksiteten, og viser til at det kan være stor variasjon bare innad i ett enkelt regnskapssystem. $R_{3}$ poengterer $i$ likhet med $R_{2}$ at ingen regnskap er like, og at det er en betydelig forskjell i kompleksitet mellom mindre og store selskaper. Denne regnskapsheterogeniteten og kompleksiteten gjelder kundenes regnskaper, men dermed også ressurs- og kompetansemessige krav til revisjonsselskaper som vil ta i bruk digitalisering. R5 henviser også til at IT-kompetanse representerer et forhold som gjør at man i mindre grad er i stand til å utnytte digitaliseringsverktøy.

Det koster så mye å lære seg det, og ta det i bruk, og vi klarer ikke å hente ut noen gevinster av det på våre relativt små kunder. Barrieren for å ta det i bruk er for stor. Det er kanskje ikke teknisk mulig heller. (R5) 
Internasjonal, nasjonal eller eventuelt bransjemessig standardisering av rapporterings- og filformater, inkludert kontoplaner, spesifikasjoner osv., kan redusere heterogenitet og kompleksitet og dermed øke sannsynligheten for adopsjon av digitaliseringsverktøy.

Jeg ser for meg at før vi kommer til SAF-T regimet, det er først da jeg mener vi kommer til den store flodbølgen av dataanalyse og muligheter rundt dette. ... Det utvikles nye verktøy, men kundene har jo ulike systemer ... Det er veldig vanskelig å trekke ut data fra et vilkårlig system, og få det på en kvalitet og et format som gjør at det er til nytte for oss, inn i våre verktøy. (R5)

\section{Prøvbarhet}

Alle informantene tilkjennegir at det er mulig å prøve ut digitaliseringsverktøy i liten skala. Flere informanter har også testet slike verktøy. Det er også enighet om at ulikt regnskapsmateriale er en utfordring for verktøyene. R4 og $\mathrm{R}_{7}$ har testet det samme verktøyet og uttrykker at funksjonaliteten er dårlig. R1, R4 og R7 peker på at mangel på standardisering skaper utfordringer for bruken av verktøyene. Vi må altså skille mellom mulighet for utprøving (som er til stede) og resultatene av utprøvingen.

Det finnes imidlertid også barrierer for utprøving. R1 har erfart tid som en praktisk utfordring:

Så fort går dette, at vi har jo ikke tid eller råd til å gjennomprøve på forhånd, samtidig så er det en risiko for at du har oversolgt deg, og lanserer noe for tidlig og får en kunde med bakgrunn i det.

Videre opplever informantene at det er kostnader forbundet ved utvikling av kompetansen som behøves for å utnytte muligheten de nye verktøyene gir. Den kompetansen er ikke nødvendig bare for implementering og bruk, men også for reell utprøving i liten skala.

Informantene har gitt utrykk for at standardisering av utveksling av regnskapsinformasjon kan bidra både til å øke oppfattet prøvbarhet og til å redusere kompleksiteten ved bruk. Standardiseringsprosjekter som SAF-T kan dermed være en løsning som medfører at begge attributtene bidrar til økte adopsjonsrater. 


\section{Observerbarhet}

Alle informantene er enige $i$ at digitalisering eller bruk av digitaliseringsverktøy er synlige innovasjoner. De ser og hører om digitalisering i Revisorforeningens nyhetsbrev, fagtidsskrift og digitaliseringsakademi, fra kunder, regnskapsførere og andre revisorer internt og eksternt, gjennom tilbud om roboter/programvare, gjennom egen programvare, gjennom innføringen av SAF-T, osv. Det foregår også en løpende diskusjon om temaet i bransjen. Et eksempel på synligheten av digitaliseringsverktøy blir illustrert av informant R4, som tester ut et digitaliseringsverktøy fra en ekstern leverandør:

Det kommer inn noen verktøy for oss små revisjonsselskaper nå, type xxxx, som er en ny robot som blir lansert nå i desember. Og den skal vi holde oss oppdatert på. ... Den er utviklet i samarbeid med Revisorforeningen og en del av de små og mellomstore selskapene.

Informant $\mathrm{R}_{3}$, som selv ikke har personlig erfaring med det vedkommende oppfatter som digitaliseringsverktøy, er imidlertid mer nyansert enn de andre når det gjelder den reelle synligheten (utover ren prat):

Vi hadde en kunde som hadde innhentet anbud på revisjonstjenester, der den ene tilbyderen hadde solgt inn at de brukte slike løsninger, men etter et år med erfaringer med dette revisjonsselskapet, så var måten man jobbet på akkurat lik.

Synligheten av resultatene av bruk av digitaliseringsverktøy er også en viktig faktor ved observerbarhet. Det inkluderer både resultater fra egen bruk og kunnskap om andres erfaringer. I dette tilfellet er resultatene synlige. Utfordringen er i større grad hvorvidt de synlige resultatene er positive eller negative. Her er oppfatningene mer delte. Flere observerer fordelene ved enkle verktøy som gjerne har vært i bruk en god stund allerede. Vi har ovenfor, og senere i kapitlet, skrevet om positive erfaringer med effektivisering ved bruk av Excel, slik som enkle analyser og ikke minst muligheten til å gjøre søk i hovedboka. De fleste informantene har også en positiv, teoretisk holdning til hvilke resultater de vil se av dette i framtida. R1 gir uttrykk for at effekten av digitaliseringsverktøy vil være lette å se: 
En robot kan sammenligne de to tallene og se at de er like. Og hvis de tallene er like, så er det kanskje ikke noe store problemer.

R5 uttrykker samme oppfatning:

Hele den digitaliseringsbiten vil jo kunne effektivisere dette. For det første vil vi kunne dekke, i stedet for at vi skal revidere populasjonen ved å ta noen statistiske signifikante stikkprøver, kan vi nå revidere hele populasjonen ... alt ... gjerne på kortere tid.

Imidlertid er oppfatningene at resultatene av adopsjon (bruk eller prøving) av mer avanserte digitaliseringsverktøy i dag, med ett unntak, er negative / lite overbevisende eller i beste fall uklare. Dette skyldes ikke minst manglende standardisering av data siden det ikke er mulig å skreddersy løsninger eller manuelt tilrettelegge data innenfor tidsrammene for små oppdrag. R7 fortalte følgende om sine erfaringer:

Har fått presentert programmer som ikke funker ennå, blant annet. Men jeg er veldig spent på hva det blir om to-tre år ...

Unntaket er R2, som mener at de positive effektene er lett synlige. Denne aktøren tilbyr kunder større grad av digital revisjon mot at de leverer data på angitt format.

... er på andre året i bruk av roboter. ... Poenget er jo at en robot gjør ting likt, og det koster litt å lage roboten. Så hvis du skal klare å tjene penger på den, så må du ha et gitt antall gjentakelser. ... I denne ene casen har vi sikkert en standard mellom 5-7000 gjentakelser. Så da begynner det å hjelpe på. ... Og de verktøyene som har kommet nå, er såpass enkle å bruke at det er veldig kjapt å se nytten av det.

\section{Relativ fordel}

De fleste informantene ser store potensielle relative fordeler ved bruk av digitaliseringsverktøy, knyttet både til økt produktivitet (spart tid, flere kontroller, behov for mindre manuell arbeidskraft, osv.) og til økt effektivitet (økt revisjonskvalitet med mindre tidsbruk) og gjennom dette endrede kostnader, samt at det eventuelt kan gi nye typer tjenesteleveranser. 
Analyse av data. Det kan automatiseres veldig. En hovedbok på 3000 sider kan en robot eller datamaskin mye enklere stupe gjennom på null komma niks, basert på den input vi legger inn. (R4)

Jeg håper og tror at ved å få på plass gode verktøy, så vil vi kunne gjøre bedre revisjon også. ... Som vi kan bruke mye mindre tid på, så kan vi heller bruke mer tid på det som presumtivt ikke er riktig. (R5)

I mitt hode er det ikke noe tvil om at behovet for manuell arbeidskraft reduseres da. Men det betyr ikke at det totale behovet for arbeidskraft behøver å bli noe mindre. ... Du får et større behov ... for seniorfolk som kan analysere og ta tak i de dataene som verktøyene fremskaffer, og bruke til de til noe fornuftig. (R5)

Samtidig uttrykker alle, så nær som R2, at slike fordeler ligger fram i tid siden data ofte ikke er i digitalt format, ikke er standardisert, programvare ikke er god nok ennå, det krever høy IT-kompetanse, og lignende.

... når vi om noen år forhåpentligvis er over på en automatisering, robotiseringsløsning ... (R5).

Vi hopper på den digitale bølgen så lenge det er effektivt for oss. ... Kanskje ikke nødvendigvis bare i dag, men kanskje ser vi at den prosessen vi setter i gang i dag, kan ha effekt om 1-2 år. ... Men i forhold til de store har vi dårligere IT kompetanse. ... Regnskapsførere og kunder er ikke veldig på ballen i forhold til elektroniske verktøy enda. ... Fortsatt veldig mange som kommer med permene sine. Så lenge det er permer der, så er det vanskelig for oss, altså. (R4)

Det er verdt å merke seg kommentaren om at små selskaper ikke har samme IT-kompetanse/ressurser som de store til å gjøre digitalisering til en relativ fordel i dagens kontekst. Dette kan nok ha betydning. Samtidig poengterte $\mathrm{R} 2$ at det særlig var en ressursperson hos dem som stod i bresjen for den tekniske utviklingen, og at det var dels tilfeldig at ressurspersonen havnet der/viste seg å ha de egenskapene.

Informantene i denne studien går i liten grad inn i mulighetene for at standardisering kan pressene prisene nedover, slik for eksempel Tiberius og Hirth (2019) finner i sin tyske studie. Vi har imidlertid sett at $\mathrm{R}_{3}$ er skeptisk til en utvikling hvor digitalisering kan redusere eller fjerne fysiske møter med kundene, som vedkommende opplever som avgjørende 
for muligheten til å identifisere og levere tjenester av verdi for kunden og dermed for revisor (altså utover standardproduktet). R3 stiller seg avventende til digitaliseringsløsninger:

Vi mener jo selv at vi har et veldig bra fortrinn ved at vi har relativt enkle systemer.

R2, som er en "early adopter» av digitaliseringsverktøy, er som R4 og R5 opptatt av kompetansen som kreves for å utnytte de relative fordelene som ligger i digitalisering, og ikke kun IT-kompetanse:

Altså teknologien er jo bare muliggjøreren. Du må jo da skjønne denne typen bransje eller virksomhet først, for å vite hva som er relevant. Ofte kan du fortelle 100000 ting med basis i dataanalyse, selv for en liten virksomhet ... med unntak av 50 punkter kanskje til slutt, er egentlig uinteressante. ... Så da er det å trekke fram de punktene som er relevante, og som den kunden bør ta tak i og jobbe mer med, som er interessant. ... Det som er paradokset, er jo at vi trenger fortsatt dypt regnskap og skatte- og avgiftskompetanse, som er ganske teknisk kompetanse som tradisjonelt sett revisoren har hatt.

\subsection{Diskusjon}

Det er store forskjeller på hvor langt de ulike informantene hadde kommet med hensyn til digitalisering (digitaliseringsnivået) i 2018. En aktør stod bevisst passivt på sidelinja $\left(\mathrm{R}_{3}\right)$ og så på digitaliseringsverktøy verken som nær forestående eller som noe kundene ønsket. Aktøren R2 mobiliserte og spredde digitaliseringsverktøy i stor skala internt på sitt kontor (og i sitt selskap) og arbeidet bevisst for å få sine kunder til å se fordelene for dem selv av å hjelpe revisor med en økt bruk av digitalisering. De øvige informantene hadde inntatt en vente-og-se-holdning, flere av dem etter å ha prøvd ut digitaliseringsverktøy i liten skala med dårlige erfaringer (for eksempel revisjonsroboten Smartbob). Disse mente også at de må være med på denne utviklingen, men avventet mer hensiktsmessig løsninger i kjølvannet av en kommende økt standardisering (for eksempel SAF-T). Adopsjonsraten for digitaliseringsverktøy blant de sju revisorene i denne studien var med andre ord relativt lav ennå. 
Abrahamson (1991) beskriver fire faktorer som kan forklare diffusjon ${ }^{2}$ (eller her: manglende diffusjon) av innovasjoner, hvorav vi har valgt å rette søkelyset mot perspektivene efficient choice og fad. Vi starter med å diskutere adopsjonsbeslutninger som rasjonelle valg, basert på de fem relevante attributtene ved innovasjoner identifisert av Rogers (2003).

Digitalisering og digitaliseringsløsninger hadde nok relativt lav kompatibilitet i revisjonsbransjen i 2018. Media hadde flere store oppslag om (forsknings)rapporter som viste at digitalisering ville erstatte en stor andel av arbeidsoppgavene i regnskapsbransjen. Det kan ha påvirket moralsk kompatibilitet negativt. Regulatorisk kompatibilitet var forventet å øke i framtida for revisor med innføringen av SAF-T, men krav om SAF-T skulle egentlig bli innført først fra 2020. Samtidig var det usikkerhet om hvorvidt digitale løsninger ville oppfylle krav i revisorloven og revisjonsstandarder, noe som var egnet til å redusere regulatorisk kompatibilitet. Informantene fortalte også at kundene i liten grad så fordelene med og etterspurte digital revisjon, på grunn av problemer med konvertering av dataformater osv. Dermed var også pragmatisk kompatibilitet lav. R2 skilte seg imidlertid ut ved å arbeide systematisk for å bevisstgjøre kunder om hvilke fordeler det ville ha for dem (lavere pris o.l.) ved å tilrettelegge regnskapsdataene på filformater som revisor kan bruke digitalt. Blant disse kundene var dermed pragmatisk kompatibilitet høyere. Oppsummert virker det som oppfattet kompatibilitet var lav i 2018 (med mulig unntak for R2), noe som bidro til at det var mindre rasjonelt å adoptere digitaliseringsverktøy (med mulig unntak for R2). Samtidig var det forventet at digitaliseringsverktøys regulatoriske kompatibilitet ville bli viktigere for både revisorer og kunder over tid (SAF-T). Dette vil dermed sannsynligvis også øke pragmatisk kompatibilitet siden fordelene for kunder ved digitalisering vil øke når SAF-T er pålagt, samt at terskelen for bruk av digitaliseringsløsninger reduseres. ${ }^{3}$ Dette taler for $ø k t$ adopsjonsrate framover.

2 Diffusjon av digitaliseringsverktøy i revisjonsbransjen er den akkumulerte effekten av alle revisorers adopsjonsbeslutninger. Det er dermed relevant å studere hva som påvirker adopsjonsbeslutninger.

3 Dette illustrer også at det er et samspill mellom ulike typer kompatibilitet, kompleksitet, prøvbarhet, observerbarhet og relativ fordel. Det er ikke anledning til å gå dypere inn på dette her. 
De fleste informantene oppfattet også implementering og bruk av digitaliseringsverktøy som kompleks, på grunn av heterogene regnskapsdata, filformater, et stort antall ulike systemer, varierende kompetanse osv. Høy oppfattet kompleksitet i 2018 reduserer sannsynligheten for adopsjon av digitaliseringsverktøy. Også her skilte R2 seg ut ved å hevde at dette var overkommelige utfordringer, og vedkommende oppfattet dermed kompleksiteten som lavere med dertil økt sannsynlighet for adopsjon.

Flere av informantene hadde prøvd digitaliseringsverktøy, i liten skala. Noen hadde for eksempel testet ut revisjonsroboten Smartbob på noen få kunder. Andre informanter virket mer reservert til å prøve, fordi de oppfattet at det var en teknologisk og ressursmessig (blant annet tidsmessig) barriere. De var imidlertid interessert i å lære via andres erfaringer. Det at det faktisk var reell prøvbarhet, direkte eller indirekte, er isolert sett positivt for sannsynligheten for adopsjon. Oppfattet prøvbarhet, og derav prøving, kan også øke kunnskapen om kompleksiteten i implementering og bruk av digitaliseringsverktøy. Prøving kan videre gi læring om bruk som reduserer oppfattet kompleksitet. Samspillet mellom disse attributtene kan dermed også påvirke sannsynligheten for adopsjon.

Det er liten tvil om at digitaliseringsverktøy var synlige for informantene. Alle hadde et forhold til temaet og hadde hørt om ulike løsninger. Blant annet hadde Revisorforeningen presentert slike løsninger på samlinger/kurs de hadde arrangert. Også resultater av egen og/eller andres tester og bruk av digitaliseringsverktøy var godt kjent (observerbare) blant informantene. Isolert sett medfører høy observerbarhet både for innovasjonen i seg selv og for innovasjonens resultater økt sannsynlighet for adopsjon.

Ifølge Rogers (2003) var relativ fordel en særlig viktig forklaringsfaktor for adopsjon. Gjennom studien observerte vi at digitaliseringsverktøy både har en viss prøvbarhet og ikke minst observerbarhet. Prøvbarhet og observerbarhet hjelper imidlertid sannsynligvis lite når de synlige resultatene av utprøvingen og bruken av digitaliseringsverktøyene var nedslående. De fleste informantene (delvis unntatt R2) oppfattet at bruken var kompleks, tids- og kompetansemessig og økonomisk ressurskrevende (lav relativ fordel), ulønnsom for revisor (lav relativ fordel), ulønnsom for kundene (lav 
pragmatisk kompatibilitet), osv. ${ }^{4}$ Når seks av sju informanter oppfatter at den relative fordelen ved innovasjonen er negativ (på kort sikt), reduserer det sannsynligheten for adopsjon blant disse. R2 oppfattet en høyere relativ fordel enn de andre på kort sikt. Samme informant mente også at det var viktig å investere i læring av bruk (adopsjon) på kort sikt for å stå bedre rustet for framtida, altså en vurdering av (akkumulert) langsiktig relativ fordel.

Tiberius og Hirth (2019) påpeker et annet forhold som er relevant for oppfattet relativ fordel. Potensiell effektivisering av revisjon ved adopsjon av digitaliseringsverktøy medfører at kunder ønsker å betale et lavere revisjonshonorar. Lavere relativ fordel vil redusere insentivene til å adoptere digitaliseringsverktøy.

En analyse av Rogers' (2003) fem attributter ved innovasjoner viser at for seks av de sju informantene vil lav kompatibilitet, høy kompleksitet og lav relativ fordel redusere sannsynligheten for adopsjon. Selv om prøvbarhet og observerbarhet isolert sett virker i motsatt retning, innebar resultatene av disse reelt sett en synliggjøring av kompleksiteten og negativ relativ fordel. Basert på informantenes oppfatninger av attributtene ved digitaliseringsverktøy var det ikke rasjonelt å adoptere innovasjonen i 2018. Rogers' rammeverk bidrar også til å forklare hvorfor R2 oppfattet adopsjon som mer rasjonelt (hadde høyere sannsynlighet for adopsjon) enn de andre. R2 opplevde høyere pragmatisk kompatibilitet, lavere kompleksitet ved bruk (fordi vedkommende fikk kundene til å levere data på ønsket format) og høyere relativ fordel.

De fleste informantenes oppfatninger av bruken av digitaliseringsverktøy indikerer at det ikke var rasjonelt å adoptere slike innovasjoner, samtidig som den informanten som hadde mest erfaring med bruken, var mer positiv. I tillegg til ulik(e) erfaring(er), ressurser, interesse, kompetanse osv. med hensyn til digitalisering fant Annexstad og Wiklund (2019) at informantenes forståelse av begrepene digitalisering og digitaliseringsverktøy var uklare, usikre og ulike. Det var med andre ord usikkerhet, per se, knyttet til denne typen verktøy og deres effekter (måloppnåelse), noe som igjen underminerer attributtene og kan gjøre det vanskelig å

4 Dette illustrerer igjen et samspill mellom attributtene prøvbarhet, observerbarhet, kompleksitet, relativ fordel og kompatibilitet. 
foreta rasjonelle valg. I lys av dette er det relevant å diskutere om alternative forklaringsperspektiver til efficient choice kan være relevante. Vi velger her å diskutere Abrahamsons fad-perspektiv.

Fad går ut på at aktører prøver å redusere sin egen usikkerhet ved å imitere aktører det er naturlig å sammenligne seg med, som synes å være suksessfulle, som generelt har et godt renomme innad i sin sosiokulturelle gruppe, som er sikre på sine mål og virkemidler, og som synes å ta rasjonelle valg. For revisorer (både personer, team, kontorer eller selskaper) vil det være naturlig å se til andre aktører i revisjonsbransjen. De observerte aktørenes bruk av digitaliseringsverktøy og erfaring med disse med kan påvirke hvorvidt den som observerer, adopterer eller avviser tilsvarende digitale løsninger. En potensiell adoptør kan benytte omgivelser og andres empiri som et kompass og imitere deres handlinger. Usikkerhet kombinert med at enkelte av informantene (særlig de mindre revisjonsselskapene) medgir at de ikke har kompetanse eller ressurser til å bruke mye tid på digitaliseringsverktøy, eksponerer aktørene for påvirkning fra eksterne krefter i tråd med det Abrahamsons (1991) rammeverk.

$\mathrm{R}_{4}$ og $\mathrm{R}_{7}$ er bekymret for eventuelle framtidige negative konsekvenser dersom man velger ikke å ta i bruk digitaliseringsverktøy. De gir uttrykk for usikkerhet knyttet til effektene av digitalisering (ikke bare for enkeltoppdrag, men for bransjen mer generelt). R5 og R7 gir utrykk for at digitalisering i revisjon er en nødvendighet på sikt, at det tvinger seg fram, og at «man ikke skal bli stående igjen på stasjonen». Man kan kanskje overleve noen år til med tradisjonelle metoder, men på et tidspunkt må man ta i bruk digitaliseringsverktøy.

Usikkerheten knyttet til effektene av digitalisering per i dag versus nødvendigheten av digitale løsninger for å overleve i framtida gir et press for å følge med på hva andre gjør. Det er vanskelig å vite om digitaliseringsstrategier gi konkurransefortrinn eller -ulemper i dag og på lengre sikt. Imitasjon av andres digitaliseringsstrategi vedrørende adopsjon av verktøy medfører iallfall at man ikke kommer vesentlig dårligere ut enn dem man imiterer.

R2 og R3 er tydelige på at de ikke imiterer andre, og altså ikke bruker en fad-strategi. R2 framstår som en innovatør eller tidlig adoptør av digitaliseringsløsninger, mens $\mathrm{R}_{3}$ bevisst $ø$ nker å være en sen adoptør. Begge mener 
de vil tjene på sin strategi (økt relativ fordel), og det er fullt mulig for begge å gjøre det samtidig. R2s selskap er allerede beskrevet som å ha kommet relativt langt innen automatisering. Selskapet bruker digitaliseringsverktøy vel vitende om at det på kort sikt ikke bidrar til effektivisering og økt relativ fordel i alle tilfeller. De anerkjenner at man utvikler egen kompetanse. I et lengre perspektiv virker R2 sikker på målsetninger og på hvordan digitaliseringsverktøy bidrar til at selskapet når målene. Ut ifra R2s utsagn gir strategien betydelig effekt i output, og i henhold til Abrahamson (1991) indikerer dette at R2 opererer i efficient choice-perspektivet.

\subsection{Konklusjon}

Vi har i denne studien sett på hva som påvirket adopsjon eller ikke-adopsjon av digitaliseringsverktøy blant aktører i revisjonsbransjen i Norge i 2018. Problemstillingen er undersøkt i lys av Rogers' (2003) rammeverk for adopsjon av innovasjoner og Abrahamsons (1991) fad-konsept (imitasjon av andres valg).

De fleste informantene hadde i liten grad tatt i bruk avanserte digitaliseringsverktøy i 2018. Årsaken synes å være at bruk av slike verktøy var oppfattet å ha lav regulatorisk, pragmatisk, og til dels moralsk, kompatibilitet, høy kompleksitet og lav relativ fordel. Dette hemmer adopsjon av innovasjoner. Virkningen av disse attributtene var øyensynlig sterkere enn rimelig grad av prøvbarhet og høy observerbarhet, som egentlig bare medførte synliggjøring av utfordringene med de eksisterende digitaliseringsverktøyene.

En av informantene hadde i større grad adoptert digitaliseringsløsninger i sin revisjon og syntes å være en innovatør eller tidlig adoptør. Informanten virket å ha ressurser (inkludert intern kompetanse), besluttsomhet og hensiktsmessige pionerkunder til allerede i 2018 å overvinne en del hindringer knyttet til kompleksitet og regulatorisk og moralsk kompatibilitet. Digitalisering ble indikert å skape synlige positive relative fordeler for revisor og positiv pragmatisk kompatibilitet for kunder (og kanskje til og med ansatte).

Stor usikkerhet knyttet til hva digitalisering er og kan bli, og til hvordan digitalisering best kan utnyttes i revisjon, kan medføre at 
adopsjonsbeslutninger ikke kun blir basert på rasjonelle valg. En løsning er å se hen til hva andre gjør. Imitasjon av andre lignende aktører ville i 2018 medføre at en avventende holdning til adopsjon bredde om seg. Den tidlige adoptøren hadde en del utypiske trekk blant disse revisorene og var nok ikke den første til å bli imitert. Selv om imitasjon i et fad-perspektiv (begrenset rasjonalitet) er relevant, kan informasjon om hva andre aktører velger, også være input i rasjonelle valg.

En viktig implikasjon av studien er behovet for standardisering av data/dataformat/programvare osv. i revisjon og regnskap, noe som kan $ø$ ke regulatorisk kompatibilitet, redusere kompleksitet, øke relativ fordel for revisor og øke pragmatisk kompatibilitet for kunder. De fleste informantene påpekte at de var klare til å adoptere digitaliseringsverktøy dersom gode og enkle løsninger kom på markedet. Den lovpålagte bruken av SAF-T fra 2020 ble sett som en mulig standardiseringsmilepæl i så måte. Det anbefales derfor å foreta studier av hvordan innføringen av SAF-T påvirker adopsjon av digitale løsninger i revisjon og regnskap.

\section{Referanser}

Abrahamson, E. (1991). Managerial fads and fashions: The diffusion and rejection of innovations. Academy of management review, 16(3), 586-612.

Aldrich, H. \& Ruef, M. (2006). Organizations evolving. London: Sage Publications.

Annexstad, S. \& Wiklund, T. E. (2019). Digitalisering i revisjonsbransjen: Hva påvirker adopsjon av digitialiseringsverktøy blant revisorer i Norge? Masteroppgave, master i $ø$ konomi og ledelse med spesialisering i økonomistyring, Høgskolen i Innlandet.

Bokføringsforskriften. Forskrift om bokføring, FOR-2004-12-01-1558. Hentet fra https://lovdata.no/dokument/SF/forskrift/2004-12-01-1558\#KAPITTEL_7

Dai, J. \& Vasarhelyi, M. A. (2017). Toward blockchain-based accounting and assurance. Journal of Information Systems, 31(3), 5-21.

Ellefsen, H. (2017). Smart anvendelse av SAF-T-filen. Regnskap Norge.

Esaiasson, P., Gilljam, M., Oscarsson, H. \& Wängnerud, L. (2007). Metodpraktikan. Konsten att studera samhälle, individ och marknad, 3(1).

Fallan, E. (2015). Explaining the variation in adoption rates of the information content of environmental disclosure. Journal of Accounting \& Organizational Change, 11(2), 247-268.

Fallan, E. (2016). Environmental reporting regulations and reporting practices. Social and Environmental Accountability Journal, 36(1), 34-55. 
Fallan, E. \& Fallan, L. (2019). Corporate tax behaviour and environmental disclosure: Strategic trade-offs across elements of CSR? Scandinavian Journal of Management, 35(3).

Fjørtoft, L. E. \& PwC, P. (2018). Digitalisering og disrupsjon i revisjonsbransjen. Revisjon og regnskap, 1, 24-26.

Issa, H., Sun, T. \& Vasarhelyi, M. A. (2016). Research ideas for artificial intelligence in auditing: The formalization of audit and workforce supplementation. Journal of Emerging Technologies in Accounting, 13(2), 1-20.

Kinserdal, F. (2014). Hvordan manipulere med regnskapet. Magma, 1.

Kinserdal, F. (2017). NHH skal forske på digitalisering i revisjonsbransjen. Magma, 2o(6), 79-86.

March, J. G. (1978). Bounded rationality, ambiguity, and the engineering of choice. The Bell Journal of Economics, 587-608.

Martín-Peña, M. L., Díaz-Garrido, E. \& Sánchez-López, J. M. (2018). The digitalization and servitization of manufacturing: A review on digital business models. Strategic Change, 27(2), 91-99.

Moore, G. C. \& Benbasat, I. (1991). Development of an instrument to measure the perceptions of adopting an information technology innovation. Information Systems Research, 2(1), 192-222.

Nordstrøm, M. K. \& Sælensminde, B. V. (2018). Digitalisering i revisjon: Teknologiens innvirkning på revisjon og revisors rolle. Universitetet i Agder.

Oldhouser, M. C. (2016). The effects of emerging technologies on data in auditing. Rogers, E. M. (2003). Diffusion of innovations. Simon and Schuster.

Schumpeter, J. A. (2017). Theory of economic development. Routledge.

Șerban, R.-A. (2017). The impact of big data, sustainability, and digitalization on company performance. Studies in Business and Economics, 12(3), 181-189.

Skattetaten. (2014). Standard audit file - tax standard dataformat for utlevering av regnskapsopplysninger til skatteetaten ved virksomhetskontroll (bokettersyn). Hentet fra https://www.skatteetaten.no/globalassets/bedrift-og-organisasjon/ starte-og-drive/rutiner-regnskap-og-kassasystem/saf-t-regnskap/saf-trapport 2014finansdepartementet.zip

Suchman, M. C. (1995). Managing legitimacy: Strategic and institutional approaches. The Academy of Management Review, 20(3), 571-610.

Tiberius, V. \& Hirth, S. (2019). Impacts of digitization on auditing: A Delphi study for Germany. Journal of International Accounting, Auditing and Taxation, 100288.

Unruh, G. \& Kiron, D. (2017). Digital transformation on purpose. MIT Sloan Management Review, 6th November.

Yoo, Y., Lyytinen, K. J., Boland, R. J. \& Berente, N. (2010). The next wave of digital innovation: Opportunities and challenges: A report on the research workshop 'digital challenges in innovation research'. Available at SSRN 1622170. 


\title{
Bruker norske revisorer konsistente og tilstrekkelige stikkprøvestørrelser når de tester ukentlig forekommende interne kontroller? En teoretisk analyse ${ }^{1}$
}

\author{
Ellen M. Kulset
}

Førsteamanuensis, Universitetet i Sørøst-Norge og Norges Handelshøyskole

\begin{abstract}
Sammendrag: Tidligere forskning viser at revisorer gjerne bruker tommelfingerregler foreslått av American Institute of Certified Public Accountants (AICPA) når de skal bestemme seg for stikkprøvestørrelser til bruk i forbindelse med test av ikke-frekvente interne kontroller. I Norge har Den norske Revisorforening (DnR) forslått bruk av tilsvarende stikkprøvestørrelser. Jacoby og Hitzig (2011) kritiserer de amerikanske tommelfingerreglene for å bidra til utilstrekkelige og inkonsistente stikkprøvestørrelser. I dette kapittelet analyseres stikkprøvestørrelsene som benyttes av norske revisorer når de tester ukentlig forkommende kontroller. Basert på data innsamlet av Finanstilsynet i et tematilsyn i 2016, finner vi at praksis med tanke på stikkprøvestørrelser synes svært ulik i de ulike revisjonsselskapene. Videre finner vi at stikkprøvepraksisen bare tidvis tilsier at det isolert sett hentes inn tilstrekkelig bevis fra stikkprøvene, og at stikkprøvestørrelsene synes inkonsistente når de sammenlignes med praksis knyttet til test av frekvente kontroller. Videre finner vi at omstendighetene stikkprøven gjennomføres i, tidvis kan tilsi at dagens praksis innebærer tilstrekkelige stikkprøvestørrelser.
\end{abstract}

Nøkkelord: stikkprøve, stikkprøvestørrelser, ukentlig forekommende interne kontroller, ISA 530

\footnotetext{
$1 \quad$ Forfatteren takker Jostein Lillestøl, Aasmund Eilifsen og William Messier for nyttige kommentarer knyttet til tidligere versjoner av dette kapittelet.
}

Sitering av denne artikkelen: Kulset, E. M. (2020). Bruker norske revisorer konsistente og tilstrekkelige stikkprøvestørrelser når de tester ukentlig forekommende interne kontroller? En teoretisk analyse. I T. Stenheim, K. M. Baksaas og E. M. Kulset (Red.), Aktuelle temaer i regnskap og revisjon (Kap. 8, s. 223-242). Oslo: Cappelen Damm Akademisk. https://doi.org/10.23865/noasp.112.ch8

Lisens: CC-BY 4.o. 


\subsection{Innledning}

American Institute of Certified Public Accountants (AICPA) foreslår i Audit Sampling (2014) ulike tommelfingerregler revisor kan benytte for å velge stikkprøvestørrelse ved revisjon av ikke-frekvente interne kontroller (kontroller som utføres ukentlig eller sjeldnere). I forbindelse med ukentlig forekommende kontroller foreslås for eksempel en stikkprøvestørrelse i intervallet 5 til 9. Den norske Revisorforening (DnR) foreslår at det kan benyttes stikkprøvestørrelser i intervallet 5 til 10 (Revisorforeningen, 2010). Elder mfl. (2013) oppsummerer tidligere forskning på området revisors stikkprøvepraksis og foreslår at det bør utføres ytterligere forskning knyttet til stikkprøvepraksis i både store og små selskaper og i ulike kontekster. Christensen mfl. (2015) responderer på dette forslaget ved å gjennomføre en studie på amerikanske data og finner blant annet at stikkprøvestørrelser i intervallet 5 til 9 benyttes av amerikanske revisorer når de reviderer ukentlig forekommende kontroller. Kulset (2019) analyserer norske revisorers stikkprøvepraksis i forbindelse med frekvente kontroller, men vi er ikke kjent med annen forskning som analyserer stikkprøvestørrelser benyttet i mindre selskaper eller i andre land enn USA.

Jacoby og Hitzig (2011) kritiserer tommelfingerreglene som foreslås av AICPA for å føre til stikkprøvestørrelser som er både utilstrekkelige og inkonsistente, og foreslår isteden bruk av stikkprøvestørrelser i intervallet 12 til 19 når det revideres ukentlig forekommende kontroller. Hensikten med dette kapittelet er å gjennomføre en teoretisk analyse av stikkprøvestørrelsene som benyttes av norske revisorer når de reviderer ukentlig forekommende kontroller, for å klargjøre når dagens praksis er passende.

Vi stiller følgende forskningsspørsmål: (1) Hvor mye bevis hentes inn ved hjelp av de stikkprøvestørrelsene som benyttes av norske revisorer i forbindelse med test av ukentlig forekommende kontroller? (2) Hvilke forutsetninger må være på plass for at denne stikkprøvepraksisen skal resultere i konsistente og tilstrekkelige stikkprøvestørrelser?

For å besvare spørsmålene benytter vi data samlet inn av Finanstilsynet i deres tematilsyn Stikkprøver i revisjon (2016). Svar på spørsmålene vil være av interesse for både revisjonspraktikere, forskere og regulerende myndigheter ved at det kan identifiseres behov for ny 
revisjonspraksis, behov for bedre beslutningsstøtte og behov for ytterligere forskning.

I resten av kapittelet presenterer vi først relevant bakgrunnsinformasjon i delkapittel 8.2. Vår forskningsmetode presenteres i delkapittel 8.3 før vi presenterer studiens funn i delkapittel 8.4. I delkapittel 8.5 konkluderer vi samt diskuterer studies implikasjoner, bidrag og begrensninger.

\subsection{Bakgrunn}

\subsubsection{Bruk av stikkprøver ved test av frekvente interne kontroller}

Stikkprøver defineres i ISA 530 (International Standard on Auditing 530), pkt. 5a som:

Anvendelsen av revisjonshandlinger på mindre enn $100 \%$ av enhetene i en populasjon som er relevant for revisjonen, under forutsetning av at alle enhetene har en mulighet til å bli valgt ut, for å skaffe revisor et betryggende grunnlag for å kunne trekke konklusjoner om hele populasjonen.

Helt siden den industrielle revolusjon har stikkprøver vært et viktig verktøy i revisors verktøykasse (Johansen, 2015). Men selv om moderne ITbasert teknologi i stadig større grad muliggjør testing av hele populasjoner, er det ikke grunn til å tro at revisors behov for å benytte stikkprøver vil forsvinne helt, i det minste ikke i den nærmeste fremtid (se blant annet Eilifsen et al., 2014, s. 259).

En av stikkprøvemetodene som revisor gjerne benytter, er attributtstikkprøver der man «søker å anslå andelen avvik fra en foreskrevet kontrollprosedyre i forhold til de tilfeller der kontrollen skal brukes» (Lillestøl, 1996, s. 17).

Når vi tester en intern kontroll, har vi fra et matematisk ståsted følgende situasjon: Vi har en populasjon som består av N enheter (antall ganger kontrollen skulle ha vært utført). I denne populasjonen er M enheter spesielle (antall ganger kontrollen ikke har blitt utført som intendert). Hvis revisor nå ønsker å bruke en stikkprøvebasert metodikk for å estimere M, kan han trekke en tilfeldig stikkprøve bestående av n enheter. La oss 
anta at han finner Y spesielle enheter i stikkprøven. Basert på disse forutsetningene vet vi nå at $\mathrm{Y}$ er hypergeometrisk fordelt med parametrene $(\mathrm{N}, \mathrm{M}, \mathrm{n})$. Passende stikkprøvestørrelse $\mathrm{n}$ avhenger av hvor presist man ønsker at estimatet skal være (ønsket konfidensintervall), og ønsket konfidensnivå, se Kulset og Lillestøl (2020) for en nærmere fremstilling av faktorene som stikkprøvestørrelsen $\mathrm{n}$ avhenger av.

For å bestemme hva som er en passende stikkprøvestørrelse, kan revisor bruke statistiske tabeller, Excel eller ulike former for revisjonsprogramvare, for eksempel ACL eller IDEA. AICPAs tabeller A-1 og A-2 (2014) er eksempler på slike tabeller, og i disse tabellene finner vi stikkprøvestørrelsen som en funksjon av valgt konfidensnivå og presisjon, tabulert ved hjelp av tolererbar avviksrate (den høyeste populasjonsavviksraten revisor finner akseptabel hvis han skal konkludere med at kontrollen fungerer) og forventet avviksrate (avviksraten revisor forventer i populasjonen). I disse tabellene skal vi forstå begrepet konfidensnivå på følgende måte: Et konfidensnivå på for eksempel 95 prosent betyr at ved gjentatt bruk av metoden vil den faktiske avviksraten i populasjonen 95 av 100 ganger være lavere enn beregnet øvre grense (øvre konfidensgrense). Risikoen for feilaktig å akseptere en kontroll som fungerende når den faktisk ikke er det, kaller vi gjerne for beta-risiko. AICPAs tabeller A1 og A2 er konstruert slik at det valgte konfidensnivåt i tabellene er lik 1 minus beta-risikoen. I resten av dette kapittelet vil vi definere konfidensnivå på denne måten. Vi tar altså ikke eksplisitt hensyn til alfarisikoen ved valg av stikkprøvestørrelse (risikoen for feilaktig å forkaste en kontroll som ikke-fungerende når den faktisk fungerer). Implisitt tar tabellverket allikevel noe hensyn til alfa-risikoen via faktoren forventet avviksrate, se Kulset og Lillestøl (2020).

Vi ser av tabell 8.1 at dersom revisor forventer en avviksrate på null, tolererer en avviksrate på 10 prosent og ønsker et konfidensnivå på 90 prosent, så bør han/hun benytte en stikkprøvestørrelse på 22. Med de samme forutsetningene om forventet og tolererbar avviksrate, men med et ønsket konfidensnivå på 95 prosent, ser vi i tabell 8.2 at en passende stikkprøvestørrelse vil være 29. Hvis revisor tolererer en avviksrate på 20 prosent, vil en passende stikkprøvestørrelse være 11 med et konfidensnivå på 90 prosent og 14 med et konfidensnivå på 95 prosent. Tabell $8.1 \mathrm{og}$ 
8.2 er utarbeidet med hjelp av binomisk fordeling, og stikkprøvestørrelsene avhenger ikke av populasjonsstørrelsen. For små populasjoner ville eksakt beregning av stikkprøvestørrelsene ved hjelp av den hypergeometriske fordelingen gitt en noe mindre stikkprøvestørrelse enn de som beregnes med utgangspunkt i den binomiske fordelingen.

Tabell 8.1 Stikkprøvestørrelse som en funksjon av tolererbar og forventet avvikshyppighet ved et ønsket konfidensnivå på 90 prosent (hentet fra AICPA tabell A-2, 2014)

\begin{tabular}{lcccccccccc}
\hline $\begin{array}{l}\text { Forventet } \\
\text { avvikshyppighet } \\
\text { i populasjonen }\end{array}$ & $\mathbf{3} \%$ & $\mathbf{4} \%$ & $\mathbf{5 \%}$ & $\mathbf{6 \%}$ & $\mathbf{7} \%$ & $\mathbf{8} \%$ & $\mathbf{9 \%}$ & $\mathbf{1 0} \%$ & $\mathbf{1 5} \%$ & $\mathbf{2 0} \%$ \\
\hline $0,00 \%$ & 76 & 57 & 45 & 38 & 32 & 28 & 25 & 22 & 15 & 11 \\
$0,25 \%$ & 129 & 96 & 77 & 64 & 55 & 48 & 42 & 38 & 25 & 18 \\
$0,50 \%$ & 129 & 96 & 77 & 64 & 55 & 48 & 42 & 38 & 25 & 18 \\
$0,75 \%$ & 129 & 96 & 77 & 64 & 55 & 48 & 42 & 38 & 25 & 18 \\
$1,00 \%$ & 176 & 96 & 77 & 64 & 55 & 48 & 42 & 38 & 25 & 18 \\
$1,25 \%$ & 221 & 132 & 77 & 64 & 55 & 48 & 42 & 38 & 25 & 18 \\
\hline
\end{tabular}

Tabell 8.2 Stikkprøvestørrelse som en funksjon av tolererbar og forventet avvikshyppighet ved et ønsket konfidensnivå på 95 prosent (hentet fra AICPA tabell A-1, 2014)

\begin{tabular}{lcccccccccc}
\hline $\begin{array}{l}\text { Forventet } \\
\text { avvikshyppighet } \\
\text { i populasjonen }\end{array}$ & $\mathbf{3} \%$ & $\mathbf{4} \%$ & $\mathbf{5} \%$ & $\mathbf{6} \%$ & $\mathbf{7} \%$ & $\mathbf{8} \%$ & $\mathbf{9 \%}$ & $\mathbf{1 0} \%$ & $\mathbf{1 5} \mathbf{\%}$ & $\mathbf{2 0} \%$ \\
\hline $0,00 \%$ & 99 & 74 & 59 & 49 & 42 & 36 & 32 & 29 & 19 & 14 \\
$0,25 \%$ & 157 & 117 & 93 & 78 & 66 & 58 & 51 & 46 & 30 & 22 \\
$0,50 \%$ & 157 & 117 & 93 & 78 & 66 & 58 & 51 & 46 & 30 & 22 \\
$0,75 \%$ & 208 & 117 & 93 & 78 & 66 & 58 & 51 & 46 & 30 & 22 \\
$1,00 \%$ & $*$ & 156 & 93 & 78 & 66 & 58 & 51 & 46 & 30 & 22 \\
$1,25 \%$ & $*$ & 156 & 77 & 78 & 66 & 58 & 51 & 46 & 30 & 22 \\
\hline
\end{tabular}

* For stor til å være effektiv

Alternativet til at revisor benytter en stikkprøvestørrelse basert på statistisk teori, er at han/hun benytter sitt profesjonelle skjønn for å bestemme stikkprøvestørrelsen, jf. ISA 530, pkt. A4, men stikkprøvestørrelsen skal ikke avhenge av hvorvidt revisor benytter statistikk eller skjønn, jf. ISA 530, pkt. A11. 


\subsubsection{Bruk av stikkprøver i små populasjoner}

Når revisor benytter stikkprøver for å teste kontroller i små populasjoner, dvs. kontroller som utføres ukentlig eller sjeldnere, har AICPA utviklet en egen tabell (AICPA 2014, tabell 3-5), se tabell 8.3, som revisor kan benytte. Ved testing av ukentlig forekommende kontroller foreslås for eksempel bruk av en stikkprøvestørrelse fra 5 til 9. DnR foreslår i sin Veiledning: Dokumentasjon ved revisjon av små foretak (2010) en stikkprøvestørrelse fra 5 til 10 for ukentlig forekommende kontroller.

Tabell 8.3 AICPA tabell 3-5 «Stikkprøvestørrelser i små populasjoner (Testing operating effectiveness of small populations)»

\begin{tabular}{lc}
\hline Kontrollfrekvens og populasjonsstørrelse & Stikkprøvestørrelse \\
\hline Kvartalsvis (4) & 2 \\
Månedlig (12) & $2-4$ \\
To ganger i måneden (24) & $3-8$ \\
Ukentlig (52) & $5-9$ \\
\hline
\end{tabular}

Christensen mfl. (2015) undersøker stikkprøvepraksisen i seks internasjonale amerikanske revisjonsselskaper (de fire store samt ytterlige to internasjonale selskaper) og finner blant annet at halvparten av disse selskapene oppgir at de bruker tabellen over, se tabell 8.3, for å fastsette stikkprøvestørrelser i forbindelse med test av ikke-frekvente kontroller. Stikkprøvestørrelsene som benyttes av de resterende selskapene, er også i samsvar med denne tabellen, selv om det ikke eksplisitt oppgis at tabellen benyttes.

Hvis vi benytter den hypergeometriske fordelingen til å beregne passende stikkprøvestørrelse for en populasjon på 52, finner vi for eksempel at med en tolererbar avviksrate på 10 prosent (5/52), ingen forventede avvik og en stikkprøvestørrelse på 5 , gir dette et implisitt konfidensnivå på 41 prosent, ${ }^{2}$ mens en stikkprøvestørrelse på 9 gitt de samme forutsetningene gir et implisitt konfidensnivå på 63 prosent. Sagt på en annen måte: Hvis vi planla med et konfidensnivå på 63 prosent, forutsatte ingen forventede

2 Implisitt konfidensnivå er beregnet ved hjelp av Excel-formelen HYPGEOM.DIST. Implisitt konfidensnivå, $\mathrm{x}$, er gitt som den største $\mathrm{x}$ slik at $\mathrm{x} \leq 1-$ CHyp (Y, n, M, N), hvor CHyp er kumulativ hypergeometrisk sannsynlighet. For $\mathrm{Y}=\mathrm{o}, \mathrm{n}=\mathrm{o}, \mathrm{M}=5, \mathrm{~N}=52$ har vi da et implisitt konfidensnivå på o,41. 
feil og satte den tolererbare avviksraten til 10 prosent, ville 9 være en passende stikkprøvestørrelse, se tabell 8.4. ${ }^{3}$ Vi ser altså at stikkprøvestørrelser i intervallet 5 til 9 isolert sett gir liten sikkerhet. Hvis vi tolererer høyere avviksrater, for eksempel 19 prosent (10/52), vil vi oppnå høyere sikkerhet med et implisitt konfidensnivå fra 67 til 88 prosent, se tabell 8.4, men vi har fremdeles ikke oppnådd «høy grad av sikkerhet» slik dette defineres av AICPA som et konfidensnivå på 90 prosent eller høyere (AICPA, 2014, pkt. 3.42). Med utgangspunkt i forutsetninger om stikkprøvestørrelser i intervallet 5 til 9 og ingen forventede avvik vil vi ikke oppnå et så høyt implisitt konfidensnivå før vi har en tolererbar avviksrate på 20 prosent eller høyere, se tabell 8.4. En stikkprøvestørrelse på 10 vil akkurat gi et implisitt konfidensnivå på 90 prosent gitt nevnte forutsetninger.

Tabell 8.4 Implisitt konfidensnivå i en populasjon på 52 (1000 i de to kolonnene til høyre med en forventet avviksrate på null)*

\begin{tabular}{lcccccccc}
\hline & \multicolumn{8}{c}{ Stikkprøvestørrelse } \\
\hline Tolererbar avviksrate & $\mathbf{1}$ & $\mathbf{2}$ & $\mathbf{5}$ & $\mathbf{8}$ & $\mathbf{1 0}$ & $\mathbf{2 0}$ & $\mathbf{1 5}$ & $\mathbf{6 0}$ \\
\hline $6 \%$ & $6 \%$ & $11 \%$ & $27 \%$ & $40 \%$ & $48 \%$ & $78 \%$ & $60 \%$ & $98 \%$ \\
$10 \%$ & $12 \%$ & $18 \%$ & $41 \%$ & $58 \%$ & $67 \%$ & $92 \%$ & $79 \%$ & $\approx 100 \%$ \\
$19 \%$ & $21 \%$ & $35 \%$ & $67 \%$ & $84 \%$ & $90 \%$ & $\approx 100 \%$ & $96 \%$ & $\approx 100 \%$ \\
\hline
\end{tabular}

* Beregningene er utført ved hjelp av den hypergeometriske fordelingen, se fotnote 2. På grunn av denne fordelingens egenskaper er det rapportert tilnærmede konfidensnivåer.

Jacoby og Hitzig (2011) kritiserer stikkprøvestørrelsene i tabell 8.3, dvs. AICPAs tommelfingerregler, for å være utilstrekkelige og inkonsistente («deficient and inconsistent») (se s. 34) ettersom så små stikkprøvestørrelser medfører høy risiko for å ikke avdekke avvik samtidig som stikkprøvepraksisen blir inkonsistent ettersom sikkerhetsnivået man benytter i forbindelse med stikkprøver for frekvente og ikke-frekvente kontroller, avhenger av kontrollfrekvensen.

Amerikanske revisorer bruker gjerne et konfidensnivå på 90 prosent når de tester frekvente kontroller (Christensen et al., 2015), og Jacoby og

3 Implisitt konfidensnivå = 1- CHyp $(0,9,5,52)=0,63$, hvor CHyp er kumulativ hypergeometrisk sannsynlighet $(0,37)$. 
Hitzig (2011) foreslår at revisorer bør benytte de samme forutsetningene om ønsket konfidensnivå og forventet og tolererbar avviksrate uavhengig av frekvensen på kontrollene som testes, det vil si for eksempel planlegge med en tolererbar avviksrate på 10 prosent, en forventet avviksrate på null og et konfidensnivå på 90 prosent uavhengig av kontrollfrekvens. Dette tilsier at revisor bør benytte stikkprøvestørrelser i intervallet 12 til 19 i forbindelse med test av ukentlig forekommende kontroller. Stikkprøvestørrelser i dette intervallet innebærer at revisors beta-risiko («the auditors' risk of failure to detect any deviation») vil være fra 25 til 9 prosent, som gir implisitte konfidensnivåer i intervallet fra 75 til 91 prosent.

Avhengig av situasjon kan imidlertid en stikkprøve som er lavere enn den som foreslåes av Jacoby og Hitzig (2011), være passende.

\subsection{Metode og data}

Finanstilsynet gjennomfører ulike typer tilsyn hos norske revisjonsselskaper, blant annet «kontroll av at revisjonsselskapene virker på hensiktsmessig og betryggende måte i samsvar med lovgivningen» (Finanstilsynet, 2017a). I forbindelse med tilsyn er revisjonsselskapene pliktige å gi alle de opplysninger tilsynet krever. Hvert år utfører Finanstilsynet blant annet tematilsyn der de «kartlegger hvordan en problemstilling faktisk blir håndtert av revisjonsbransjen, for deretter å vurdere om Finanstilsynet mener det er behov for endringer» (Finanstilsynet, 2017b). Basert på avdekkede svakheter i tidligere tilsyn knyttet til revisors etterlevelse av ISA 530, gjennomførte Finanstilsynet i 2016 et tematilsyn om bruk av stikkprøver for å skaffe «bredere bilde av hvordan ISA 530 er innarbeidet i revisjonsselskapenes metodikk og hvordan den etterleves» (Finanstilsynet, 2016). For å svare på forskningsspørsmålene bruker vi data knyttet til valg av stikkprøvestørrelser som Finanstilsynet samlet inn som en del av dette tematilsynet. Data om stikkprøvepraksisen til 65 norske revisjonsselskaper ble samlet inn, dette inkluderer de fem største revisjonsselskapene (Big 4 pluss BDO). De 60 resterende revisjonsselskapene ble tilfeldig valgt blant de små og mellomstore selskapene.

I undersøkelsen inkluderer Finanstilsynet blant annet et eksempel der revisjonsselskapene blir bedt om å angi hvilken stikkprøvestørrelse de 
vil benytte dersom de har «konstatert at en nøkkelkontroll i det reviderte foretaket er fornuftig utformet, at kontrollen er implementert, at revisor planlegger å bygge på kontrollen og derfor skal teste om den har fungert effektivt» (Finanstilsynet, 2016, s. 5). Nøkkelkontrollen blir utført henholdsvis (a) flere ganger daglig (det vil si ca. 2000 ganger i året), (b) én gang per dag (ca. 250 ganger i året) eller (c) én gang $i$ uken (ca. 50 ganger $i$ året). Finanstilsynet legger videre til grunn at det er ønskelig med moderat risiko/sikkerhet, uten at dette begrepet tallfestes.

For å svare på forskningsspørsmålene våre foretar vi en teoretisk analyse av de stikkprøvestørrelsene norske revisorer oppgir til Finanstilsynet at de benytter. Med teoretisk analyse vil vi i dette kapittelet forstå en analyse der vi benytter statistisk teori for å foreta nødvendige beregninger, samtidig som vi benytter to begreper (konsistent og tilstrekkelig) som sammenligningsgrunnlag i analysene vi utfører.

For å finne ut hvor mye bevis som hentes inn ved hjelp av stikkprøvestørrelsene som benyttes, bruker vi statistisk teori for å beregne hvor mye bevis (målt ved hjelp av implisitt konfidensnivå) norske revisorer henter inn med de stikkprøvestørrelsene som benyttes ved revisjon av ukentlig forekommende kontroller. Beregningene legger til grunn at det er ønskelig med en tolererbar avviksrate i intervallet 6 til 19 prosent og en forventet avviksrate på null. ${ }^{4}$

Når vi vurderer om norske revisorers stikkprøvepraksis knyttet til ukentlig forkommende kontroller er konsistent og tilstrekkelig, benytter vi samme definisjon på konsistent stikkprøvepraksis som Hitzig og Jacoby (2011). Et revisjonsselskaps stikkprøvepraksis er med dette konsistent dersom selskapet lar sine valg av forutsetninger om tolererbar og forventet avviksrate samt ønsket konfidensnivå være uavhengig av kontrollfrekvens. For å vurdere om stikkprøvepraksisen er konsistent, sammenligner vi den sikkerheten som norske revisorer implisitt planlegger stikkprøvene med for henholdsvis store og små populasjoner. For at en stikkprøvestørrelse skal gi tilstrekkelig bevis, må den enten være av en størrelse som gjør at det hentes inn tilstrekkelig bevis fra stikkprøven

4 Anekdotiske bevis tilsier at norske revisorer stort sett planlegger test av kontroll med en forventning om ingen avvik i populasjonen. 
isolert sett, eller det må finnes omstendigheter som gjør at en stikkprøve som i seg selv ikke er tilstrekkelig til at revisor kan konkludere på en påstand, allikevel er å regne som passende. Dersom en stikkprøvestørrelse for passende forutsetninger om forventet og tolererbar avviksrate tilsier et implisitt konfidensnivå på 90 prosent eller høyere, vil vi legge til grunn at dette isolert sett er en tilstrekkelig strikkprøvestørrelse. For å svare på siste del av forskningsspørsmålet vil vi derfor se på hvilke selskaper som har en slik praksis, og videre diskutere i hvilke situasjoner norske revisorer på tross av eventuell lav stikkprøvestørrelse allikevel kan sies å ha benyttet et utvalg som er tilstrekkelig stort.

\subsection{Funn og diskusjon}

\subsubsection{Valg av stikkprøvestørrelse med tilhørende sikkerhetsnivåer}

Funnene i Finanstilsynets tematilsyn knyttet til stikkprøvestørrelser fremkommer i tabell 8.5 under. Vi ser at norske revisorer oppgir at de benytter svært ulik stikkprøvestørrelse når de reviderer ukentlig forekommende kontroller, med angitte stikkprøvestørrelser i intervallet fra 1 til 50, avhengig av revisjonsselskap og ønsket sikkerhetsnivå, se tabell 8.5.

Tabell 8.5 Norske revisorers stikkprøvestørrelser ved kontrolltesting ${ }^{\star}$

\begin{tabular}{lcccc}
\hline & \multicolumn{2}{c}{ 5 store } & \multicolumn{2}{c}{ Øvrige } \\
\hline Sikkerhet & Moderat $^{5}$ & Høy & Moderat & Høy \\
\hline Kontrollfrekvens & & & & \\
Ca. 2000 ganger i året & $14-25$ & $25-60$ & $8-50$ & $8-80$ \\
Ca. 250 ganger i året & $10-25$ & $15-25$ & $5-42$ & $10-60$ \\
Ca. 50 ganger i året & $2-5$ & $5-8$ & $1-30$ & $1-50$ \\
\hline
\end{tabular}

* Innholdet er hentet fra tabell 3 i Finanstilsynets rapport Stikkprøver i revisjon. Tematilsyn 2016 (2016).

Finanstilsynet ba i utgangspunktet selskapene legge til grunn at det var ønskelig med moderat sikkerhet.

5 De fem store revisjonsselskapene oppga i sine svar hvilke stikkprøvestørrelser de benytter ved ønske om både høyt og moderat sikkerhetsnivå. For de mindre selskapene har Finanstilsynet tolket de innsamlede dataene slik at dersom det er oppgitt et stikkprøveintervall, benyttes den laveste stikkprøvestørrelsen ved ønske om moderat sikkerhet og den høyeste oppgitte størrelsen ved ønske om høy sikkerhet. Dette er ikke nødvendigvis en korrekt fortolkning ettersom det kan tenkes at alle eller noen av disse selskapene bruker en stikkprøvestørrelse som er høyere enn det oppgitte intervallet når de ønsker høy sikkerhet. 
De fem største revisjonsselskapene bruker en stikkprøvestørrelse i intervallet fem til åtte hvis de ønsker høy grad av sikkerhet, og en stikkprøvestørrelse fra to til fem hvis de ønsker moderat grad av sikkerhet. Alle disse stikkprøvestørrelsene er lavere enn størrelsen som foreslås av Jacoby og Hitzig (2011). Stikkprøvestørrelsen på to er også lavere enn den som foreslås av både AICPA og DnR.

Avhengig av hvilke forutsetninger vi legger til grunn knyttet til forventet og tolererbar avviksrate, vil stikkprøvestørrelser fra fem til åtte kunne føre til implisitte konfidensnivåer fra 27 til 84 prosent, se tabell 8.4. Som vi har vist tidligere, er disse oppnådde sikkerhetsnivåene ikke i samsvar med høy grad av sikkerhet slik dette defineres av AICPA, som legger til grunn at høy grad av sikkerhet først oppnås ved konfidensnivåer på 90 prosent eller høyere.

Hvis det spørres etter bare moderat grad av sikkerhet, benytter et av de store norske revisjonsselskapene en stikkprøvestørrelse på to. Hvis det i denne situasjonen tolereres tre avvik i populasjonen (det vil si at det opereres med en tolererbar avviksrate på 6 prosent), ser vi fra tabell 8.4 at disse forutsetningene fører til et implisitt konfidensnivå på 11 prosent. Hvis vi tolererer ti avvik (det vil si en tolererbar avviksrate på 19 prosent), gir forutsetningene et implisitt konfidensnivå på 35 prosent. Disse konfidensnivåene synes ikke kompatible med et moderat sikkerhetsnivå.

De mindre revisjonsselskapene oppgir at de bruker både mindre og større stikkprøvestørrelser enn de større revisjonsselskapene, se tabell 8.5. Mindre revisjonsselskaper synes å ha en svært variabel praksis: Der ett av selskapene oppgir at det benyttes en stikkprøvestørrelse på én ved test av ukentlig forekommende kontroller, benyttes det for eksempel også stikkprøvestørrelser på 30 og 50 (det vil si at svært store deler av populasjonen på 52 testes, og det er grunn til å tro at spørsmålet enten er misforstått, eller at selskapet over-reviderer i slike situasjoner).

To av de små selskapene oppgir at det kan benyttes en stikkprøvestørrelse på så mye som 20, dvs. en stikkprøvestørrelse som er i overkant av intervallet som foreslås av Jacoby og Hitzig (2011). Denne stikkprøvestørrelsen impliserer at det planlegges med konfidensnivåer i intervallet 78 til tilnærmet 100 prosent, og den er i samsvar med AICPAs krav til høy 
sikkerhet dersom det forutsettes en tolererbar avviksrate på 10 prosent eller høyere, se tabell 8.4. 23 av de små revisjonsselskapene oppgir at de tidvis benytter en stikkprøvestørrelse på 10 (implisitt konfidensnivå fra 48 til 90 prosent). Bruk av denne stikkprøvestørrelsen er ikke overraskende tatt i betraktning DnRs forslag fra 2010. De resterende små revisjonsselskapene i undersøkelsen har en stikkprøvepraksis som enten er i samsvar med praksis i de store revisjonsselskapene, eller som innebærer lavere stikkprøvestørrelser enn i de store selskapene.

Tabell 8.6 Maksimal stikkprøvestørrelse - ukentlig forekommende kontroller*

\begin{tabular}{lcc}
\hline & Maksimal stikkprøvestørrelse & Antall \\
\hline Store revisjonsselskap & 8 & 2 \\
Små revisjonsselskap & 5 & 3 \\
& 20 & 2 \\
& 10 & 23 \\
& 8 & 4 \\
\hline
\end{tabular}

${ }^{\star}$ Totalt antall revisjonsselskap i tabellen er 59. Totalt antall revisjonsselskap i Finanstilsynets unders økelse er 65. De 6 små revisjonsselskapene som ikke er inkludert i tabellen svarte «test hele populasjonen» (1), «bruker profesjonelt skjønn» (2), foreslo bruk av større stikkprøvestørrelse når populasjonen ble mindre (det vil hadde trolig misforstått spørsmålet) (2) eller svarte ikke (1).

\subsubsection{Konsistente stikkprøvestørrelser}

I denne delen av kapittelet, har vi først fokusert på de store revisjonsselskapenes stikkprøvepraksis når det er ønskelig med høy grad av sikkerhet. I slike situasjoner benytter de store norske revisjonsselskapene en stikkprøvestørrelse fra fem til åtte. Det følger fra tidligere utregninger at dette, avhengig av forutsetninger knyttet til forventede og tolererbare avvik, gir implisitte konfidensnivåer på fra 27 til 84 prosent, se tabell 8.4 .

Ifølge Finanstilsynet (2016) benytter norske revisorer i de samme revisjonsselskapene stikkprøvestørrelser fra 15 til 60 når de reviderer frekvente kontroller (det vil si når den interne kontrollen utføres én eller flere ganger per dag) dersom de ønsker en høy grad av sikkerhet, det vil 
si at de planlegger med et konfidensnivå fra omtrent 60 (hvis vi antar ingen forventede avvik, tolererbare avvik på 6 prosent og n lik 15) til nær 100 prosent (hvis vi antar ingen forventede avvik, tolererbare feil på 19 prosent og n lik 60). Vi ser altså at med de samme forutsetningene knyttet til forventede og tolererbare feil, vil en stikkprøvestørrelse fra fem til åtte for ukentlig forekommende kontroller og en stikkprøvestørrelse på 15 til 60 for frekvente kontroller tilsi at det planlegges med et lavere konfidensnivå når man reviderer ukentlig forekommende kontroller enn når man reviderer frekvente kontroller. Dette impliserer en inkonsistent stikkprøvepraksis ettersom man systematisk henter inn mer bevis ved testing av frekvente kontroller enn ved tester av ukentlig forekommende kontroller.

Når det gjelder de mindre revisjonsselskapene, oppgir 23 at de kan benytte en stikkprøvestørrelse på 10 når de reviderer ukentlig forekommende kontroller. Dette impliserer et planlagt konfidensnivå på fra 48 til 90 prosent gitt forventede avvik lik null og tolererbare avvik i intervallet 6 til 19 prosent, jf. tabell 8.4. Den laveste stikkprøvestørrelsen som benyttes av disse selskapene når det testes frekvente interne kontroller, er 25, noe som impliserer et konfidensnivå i intervallet 78 til 99,5 prosent $^{6}$ gitt samme forutsetninger om forventede og tolererbare feil som i tilfellet med ukentlig forekommende kontroller. Et selskap benytter en stikkprøvestørrelse på 20 for ukentlige kontroller (implisitt konfidensnivå på 78 til tilnærmet 100 prosent) og 50 for frekvente kontroller (implisitt konfidensnivå i intervallet 95 til tilnærmet 100 prosent). Vi ser at heller ikke disse revisjonsselskapene har en konsistent stikkprøvepraksis.

Resten av de små revisjonsselskapene i undersøkelsen benytter stikkprøvestørrelser i intervallet én til åtte. Vi ser fra tabell 8.4 at dette gir implisitte konfidensnivåer i intervallet 6 til 84 prosent. Den laveste stikkprøvestørrelsen som benyttes av disse selskapene ved test av frekvente kontroller, er 15, noe som gir implisitte konfidensnivåer i intervallet 60 til 96 prosent.

6 Ikke tabulert. 
Tabell 8.7 Stikkprøvestørrelse som en funksjon av konfidensnivå og tolererbar avviksrate og en forventet avviksrate på null*

\begin{tabular}{lccc}
\hline \multicolumn{1}{c}{$\mathbf{N}=\mathbf{5 2}$} & \multicolumn{3}{c}{ Konfidensnivå } \\
\hline Tolererbar avviksrate & $\mathbf{5 0} \%$ & $\mathbf{7 0} \%$ & $\mathbf{9 0} \%$ \\
$6 \%$ & 10 & 17 & 28 \\
$10 \%$ & 5 & 9 & 16 \\
$19 \%$ & 3 & 5 & 10 \\
\hline \multicolumn{1}{r}{$\mathbf{N}=\mathbf{1 0 0 0}$} & & Konfidensnivå & \\
\hline Tolererbar avviksrate & $\mathbf{5 0} \%$ & $\mathbf{7 0} \%$ & $\mathbf{9 0} \%$ \\
$6 \%$ & 12 & 20 & 37 \\
$10 \%$ & 7 & 12 & 22 \\
$19 \%$ & 4 & 6 & 11 \\
\hline
\end{tabular}

*Beregningene er basert på den hypergeometriske fordelingen.

For å oppsummere ser vi at ingen av revisjonsselskapene har en konsistent revisjonspraksis slik vi definerer begrepet i dette kapittelet. Vi ser i tabell 8.7 at en slik konsistent praksis vil innebære at stikkprøvestørrelsen som benyttes i forbindelse med test av ukentlig forekommende kontroller, kan være noe lavere enn ved test av frekvente kontroller, men ikke så mye som den forskjellen som forekommer i praksis.

\subsubsection{Når vil dagens stikkprøvestørrelser medføre/bidra til tilstrekkelig bevis?}

Funnene i Finanstilsynets tematilsyn om norske revisorers stikkprøvepraksis viser at det er klare forskjeller mellom stikkprøvestørrelsene som benyttes i de mindre revisjonsselskapene og dem som benyttes i de store revisjonsselskapene. Men mens det ikke er noen av de store selskapene som benytter stikkprøvestørrelser med implisitte konfidensnivåer på 90 prosent eller høyere, er det 23 av de små selskapene som tidvis opererer med implisitte konfidensnivåer på 90 prosent eller høyere.

Lav stikkprøvestørrelse innebærer rent generelt at det isolert sett hentes inn lite bevis fra testen, og som det fremheves i Audit Sampling Guide er stikkprøvestørrelsene i tabell 8.3 ikke passende «if the internal control test is the sole source of evidence regarding this control» (AICPA, 2014, s. 43). 
Stikkprøvestørrelsene som foreslås av AICPA, dvs. i intervallet fem til ni, kan imidlertid være passende i ulike situasjoner, og vi vil i det følgende presentere noen slike. (Husk at vi har sett at det øvre intervallet i DnRs tommelfingerregler, det vil si en stikkprøvestørrelse på 10, gir et konfidensnivå som tilsier at en slik test ikke nødvendigvis må kombineres med ytterligere bevis.)

For det første, og som nevnt i kapittelets innledning, kan revisor benytte profesjonelt skjønn når det foretas avgjørelser knyttet til stikkprøvestørrelser, jf. ISA 530, pkt. A4, men stikkprøvestørrelsen skal ikke avhenge av om det benyttes skjønn eller statistikkbaserte metoder, jf. ISA 530, pkt. A11. Det følger av dette at en stikkprøvestørrelse på åtte kan være passende hvis revisor ikke forventer noen avvik, tolererer omtrent 10 prosent avvik i populasjonen og ikke ønsker et høyere konfidensnivå enn ca. 60 prosent. For å hente inn tilstrekkelig bevis knyttet til den konkrete påstanden som revideres, må nå revisor bruke revisjonsrisikomodellen og kombinere de innhentede bevisene fra internkontrolltesten med bevis hentet inn ved hjelp av andre revisjonshandlinger. Vi fokuserer i denne studien ikke på i hvilken grad norske revisorer faktisk henter inn slikt tilstrekkelig revisjonsbevis ved å se bevis innhentet fra test av kontroller og andre typer tester i sammenheng. Dette spørsmålet overlater vi til senere forskning.

For det andre kan det som diskutert i Jacoby og Hitzig (2011), være slik at ikke-frekvente kontroller har andre egenskaper enn mer frekvente kontroller, og dette kan ha betydning for hvilke stikkprøvestørrelser det er passende å benytte ved test av disse kontrollene. Dersom internkontrollene er akkumulerende av natur, kan det for eksempel være tilstrekkelig å teste bare den siste gangen kontrollen utføres i løpet av året. Dette vil blant annet kunne gjelde kvartalsvise kontroller. Stikkprøvestørrelsene som foreslåes i tabell 8.3, kan da faktisk være større enn det egentlig er behov for, og eventuelt større stikkprøvestørrelse vil kunne ha mer preg av å være kundeservice enn av å være nødvendig for å hente inn tilstrekkelige bevis. Hvorvidt den interne kontrollen er automatisert eller manuell, vil naturligvis også ha betydning for valg av stikkprøvestørrelse. Ved automatiserte kontroller vil det normalt være tilstrekkelig å teste kontrollene én eller noen få ganger ettersom slike kontroller vil fungere på samme måte hver gang dersom de er korrekt satt opp. Slik redusert testing krever 
imidlertid at det er foretatt tilstrekkelig testing ved første gangs implementering, jf. ISA 330, pkt. A129. Dersom de generelle IT-kontrollene i et selskap ikke vurderes som tilfredsstillende, må imidlertid automatiserte kontroller testes som om de skulle være manuelle.

For det tredje vil en del interne kontroller i et selskap gjerne være ganske like eller helt like over en lengre tidsperiode. Dette tilsier at vi fra et statistisk ståsted kan argumentere for at det, med en ukentlig forekommende kontroll, ikke er nødvendig å ta utgangspunkt i en populasjon på 52, men i en populasjon som består av utførte kontroller over en lengre tidsperiode, for eksempel tre år, noe som vil gi en populasjonsstørrelse på ca. 150. Med en populasjon bestående av 156 enheter (tre år kombinert), et konfidensnivå på 90 prosent, ingen forventede avvik og en tolererbar avviksrate på 10 prosent er 22 en passende stikkprøvestørrelse, se tabell 8.1. Dette gir en gjennomsnittlig årlig stikkprøvestørrelse på 7, dvs. i midten av intervallet som foreslås av AICPA, jf. tabell 8.3. Følgende må være på plass dersom man skal gjennomføre en stikkprøve på denne måten med et konfidensnivå på 90 prosent: (1) Kontrollen i stikkprøven må være den samme, og den må utføres på samme måte i hele tidsperioden som populasjonen det trekkes fra, omfatter. (2) For at man skal bygge på egenskapene til den hypergeometriske fordelingen, må stikkprøven som trekkes være tilfeldig. Årsaken til at vi fremhever at stikkprøven vi benytter skal være trukket tilfeldig, er at de matematiske teoremene som ligger til grunn for stikkprøvestørrelsene i tabell 8.1 og 8.2, bare vil gjelde i tilfeldige utvalg. (3) Ettersom revisor utsteder sin revisjonsberetning på årlig basis, må revisor foreta nødvendige tilpasninger i revisjonsplanen slik at han/hun henter inn tilstrekkelig revisjonsbevis i år 1 og 2 ettersom han/hun i disse årene ikke kan bygge på revisjonsbevis innhentet i senere perioder (en stikkprøvestørrelse på $7^{7}$ er ikke kompatibelt med et konfidensnivå på 90 prosent). (4) Revisjonsplanen må være i samsvar med ISA 330, pkt. 13 og 14 om bruk av revisjonsbevis innhentet i tidligere perioder.

For å trekke et slikt tilfeldig utvalg på 21 i en populasjon som består av alle ukentlig forekommende kontroller av en bestemt type over en

7 En stikkprøvestørrelse på 7 gir et implisitt konfidensnivå på 50 prosent hvis forventet avviksrate er lik null og tolererbar avviksrate er lik 10 prosent. 
periode på tre år, kan vi benytte en tilfeldig-nummer generator til å generere 21 tall fra 1 til 156, der hvert tall representerer en gang kontrollen skulle ha vært utført. For å oppnå ønsket konfidensnivå også i år 2 og år 3, kan vi gjøre som følger: Etter å ha generert 21 tall genererer vi tall fra 1 til 104 inntil vi har en stikkprøvestørrelse på 21 også i år 2, og til slutt genererer vi tall fra 1 til 52 inntil vi har oppnådd en stikkprøvestørrelse på 21 også i dette intervallet. I praksis har vi følgende problem med en slik stikkprøvepraksis: ISA 330 synes å begrense antall perioder som kan sees i sammenheng til tre, og hvordan skal vi da trekke en stikkprøve i periode fire som ikke ødelegger de tilfeldige egenskapene til stikkprøven?

\subsection{Konklusjon, implikasjoner, bidrag og begrensninger}

I dette kapittelet finner vi at små norske revisjonsselskaper synes å ha en mer uensartet stikkprøvepraksis enn større revisjonsselskaper når de reviderer ukentlig forekommende kontroller. Mens de store revisjonsselskapene oppgir at de anvender stikkprøvestørrelser fra to til åtte, oppgir et av de små revisjonsselskapene at de benytter en stikkprøvestørrelse på én, mens et annet av de små selskapene oppgir at det benytter en stikkprøvestørrelse på 50, noe som resulterer i at det hentes inn helt ulik mengde bevis fra disse testene i de ulike revisjonsselskapene. Implisitte konfidensnivåer vil som en konsekvens variere mye. Noen av stikkprøvestørrelsene som benyttes, synes å være i minste laget, for eksempel et av de store selskapenes bruk av en stikkprøvestørrelse på to når det ønskes moderat sikkerhet. Mens ingen av stikkprøvestørrelsene som benyttes av de store revisjonsselskapene, isolert sett synes å være tilstrekkelige, benytter en stor andel av de små revisjonsselskapene tidvis stikkprøvestørrelser som isolert sett kan sies å være tilstrekkelige (stikkprøvestørrelser på ti eller høyere). Videre finner vi at stikkprøvestørrelsene som benyttes av både små og store revisjonsselskaper, er inkonsistente ettersom det hentes inn mer bevis fra stikkprøver når disse benyttes i forbindelse med testing av frekvente interne kontroller, enn når de brukes ved testing av ukentlig forekommende kontroller. Hvorvidt stikkprøvestørrelsene bør være konsistente, er et spørsmål vi ikke konkluderer på. 
En stikkprøvestørrelse i intervallet fem til åtte når man tester ukentlig forekommende kontroller, bidrar altså med lite bevisverdi isolert sett knyttet til påstanden som revideres. Stikkprøvestørrelser i dette intervallet kan allikevel benyttes når revisor er klar over hvilken grad av sikkerhet testen bidrar til, kombinert med at én eller flere av følgende omstendigheter er på plass: (1) Bevisene som hentes inn fra testen, kombineres med bevis som innhentes ved hjelp av en eller flere andre tester. (2) Kontrollen som testes, har spesielle egenskaper som tilsier at et lavere sikkerhetsnivå er tilstrekkelig, den er f.eks. en automatisert kontroll, den er akkumulerende i sin natur, osv. (3) Stikkprøven er en del av en større utvalgsbasert plan hvor kontroller utført over en lengre periode enn ett år slås sammen slik at de til sammen utgjør en større populasjon. Det følger av diskusjonene i dette kapittelet at stikkprøvestørrelsene som anvendes av norske revisorer når de tester ukentlig forekommende kontroller, kan gi revisor tilstrekkelig bevis for de aktuelle påstandene som testes, men ettersom stikkprøvestørrelser som anvendes ofte er relativt små, vil mer beslutningsstøtte kunne gi en mer passende stikkprøvepraksis.

De viktigste bidragene fra dette kapittelet er som følger: Dataene som analyseres, kommer fra både små og store revisjonsselskaper og er hentet inn i et annet land enn USA. De kompletterer på denne måten funnene i Christensen mfl. (2015). Videre viser analysene som utføres, at norske revisorer tidvis benytter stikkprøvestørrelser som er i laveste laget når de tester ukentlig forekommende kontroller. Dette er funn som er av interesse for norske revisjons-selskap så vel som for reguleringsmyndighetene ettersom det indikeres at norske revisorer tidvis kan ha behov for tilgang til ytterligere beslutningsstøtte for å bedre sin bruk av stikkprøver. Mens Jacoby og Hitzig (2011) kritiserer nåværende revisjonspraksis (det vil si bruk av stikkprøvestørrelser i intervallet 5 til 9) for å være både ikke-tilstrekkelig og inkonsistent, har denne studien også sett på situasjoner der dette kan være en god praksis. Denne innfallsvinkelen er i liten grad benyttet i tidligere forskning.

Analysene som utføres i dette kapittelet, er basert på hva norske revisjonsselskap har oppgitt til Finanstilsynet om egen praksis, det vil si hva som er nedfelt i de ulike revisjonsselskapenes manualer når det gjelder stikkprøvebasert testing av ukentlig forekommende kontroller. I praksis 
vil den enkelte revisor i stor grad måtte foreta egne valg knyttet til hvorvidt en identifisert kontroll skal testes, og, dersom kontrollen skal testes, hvilket sikkerhetsnivå som er ønskelig (for eksempel høyt eller moderat). I noen revisjonsselskaper kan revisor etter å ha valgt sikkerhetsnivå i tillegg velge stikkprøvestørrelse fra et spesifisert intervall. Den enkelte revisor må altså i stor grad benytte eget profesjonelt skjønn. Dette innebærer at en rekke spørsmål er av interesse for videre forskning: Hvilke valg tar revisor i praksis knyttet til revisjonskundenes ukentlige utførte kontroller, og hvilke faktorer har innvirkning på disse valgene? Velger revisor å teste ukentlige kontroller i det hele tatt? I den grad revisjonsselskapet revisor jobber i, skiller mellom moderat og høy sikkerhet: Hvilket sikkerhetsnivå velger revisor å legge til grunn? I den grad revisor kan velge mellom ulike stikkprøvestørrelser innenfor et intervall: legger han/hun seg høyt eller lavt i dette intervallet? Vi overlater disse spørsmålene til senere forskning. Videre vil det være interessant å undersøke nærmere revisors praksis når det gjelder mulighetene til å benytte bevis innhentet i forbindelse med kontrolltesting i tidligere år, sammen med bevis innhentet i inneværende år.

Samtidig som den enkelte revisor tar egne valg, viser både funnene i Finanstilsynets rapport (2016) og tidligere forskning (Christensen et al., 2015) at stikkprøvestørrelsene som benyttes i den ulike revisjonsselskapene, varierer relativt mye når det gjelder revisjon av ukentlig forekommende kontroller. Dersom revisorer i revisjonsselskaper som systematisk benytter lavere stikkprøvestørrelser i forbindelse med kontrolltesting, ikke systematisk innhenter mer bevis fra andre typer tester enn revisorer som systematisk benytter høyere stikkprøvestørrelser, vil dette kunne innebære at revisjonsrisikoen på tvers av revisjonsselskap kan bli ulik. Hvordan revisor i praksis kombinerer bevis fra kontrolltesting og substanstesting både internt i det enkelte revisjonsselskap og på tvers av ulike revisjonsselskap, er dermed også et område som vil være av interesse for videre forskning.

\section{Referanser}

AICPA (American Institute of Certified Public Accountants). (2014). Audit sampling. New York: AICPA.

Christensen, B. E., Elder, R. J. \& Glover, S. M. (2015). Behind the numbers: Insights into large audit firms sampling policies. Accounting Horizons, 29(1), 61-81. 
Eilifsen, A., Messier, W. F., Glover, S. M. \& Prawitt, D. F. (2014). Auditing and assurance services. Berkshire: McGraw Hill Education.

Elder, R. J., Akresh, A. D., Glover, S. M., Higgs, J. L. \& Liljegren, J. (2013). Audit sampling research: A synthesis and implications for future research. Auditing: A Journal of Practice \& Theory, 32, Suppl. 1, 99-129.

Finanstilsynet. (2016). Stikkprøver i revisjon. Tematilsyn 2016. Hentet fra https://www. finanstilsynet.no/contentassets/d3e9938d72314f4f84db450629766128/stikkprover_ -revisjon_tematilsyn_2016.pdf

Finanstilsynet. (2017a). Tilsyn revisor. Hentet 28.04.2020o fra https://www. finanstilsynet.no/tilsyn/revisor/

Finanstilsynet. (2017b). Ulike tilsynsmetoder revisorer og revisjonsselskaper. Hentet 28.4. 2020 fra https:// www.finanstilsynet.no/tilsyn/arkiv-fellessider-tilsyn/uliketilsynsmetoder-revisorer-og-revisjonsselskaper/

Jacoby, J. E. \& N. B. Hitzig (2011). Auditing internal controls in small populations. The CPA Journal, December, 34-36.

Johansen, Ø. K. (2015). Verdien av tillit. Revisjonens historie. Oslo: Kagge Forlag.

Kulset, E. (2019). Revisors bruk av profesjonelt skjønn i forbindelse med stikkprøvebasert testing av frekvente interne kontroller. I L. Gårseth-Nesbakk, K. M. Baksaas \& T. Gustavsen (Red.), Trender og utfordringer i regnskap og revisjon. Bergen: Fagbokforlaget.

Kulset, E. \& Lillestøl, J. (2020). Test av internkontroll ved hjelp av en stikkprøve: Kan revisor stole på kunders interne kontroller? Regnskap og Revisjon, 1, 42-49.

Lillestøl, J. (1996). Statistiske metoder i revisjon. Oslo: Cappelen Akademisk Forlag.

Den norske Revisorforening, (2010). Veiledning: Dokumentasjon ved revisjon av små foretak.

Sullivan, J. (1992). Litigation risk broadly considered. I Auditing symposium XI: Proceedings of the 1992 Deloitte and Touche/University of Kansas symposium on auditing problems: 49-59. Lawrence, KS: The University of Kansas School of Business.

The International Auditing and Assurance Standards Board / Den norske Revisorforening. (2009). ISA 530 Stikkprøver i revisjon. Norsk utgave av internasjonal revisjonsstandard 530. New York, NY: The International Federation of Accountants (IFAC).

The International Auditing and Assurance Standards Board / Den norske Revisorforening. (2010). ISA 330 Revisors håndtering av anslåtte risikoer. Norsk utgave av internasjonal revisjonsstandard 330. New York, NY: The International Federation of Accountants (IFAC). 


\title{
KAPITTEL 9
}

\section{Bruk av informasjon fra foretaks miljørapportering til ressursallokerings- og kontrollformål}

\section{Even Fallan}

\author{
Førsteamanuensis, Høgskolen i Innlandet
}

Sammendrag: Formålet med studien er å undersøke ulike norske interessentgruppers etterspørsel etter og bruk av foretaks miljørapportering. ${ }^{1}$ På grunn av de miljøutfordringer samfunnet står overfor, er slik kunnskap viktig i seg selv. Generelt kan studier av etterspørsel etter miljørapportering si noe om i hvilken grad dagens miljørapporteringspraksis blir oppfattet å være vesentlig og nyttig. Dette er ekstra relevant siden det er dokumentert at den generelle kvaliteten på foretaks miljørapportering er svært lav. På sikt kan kunnskap om etterspørsel og bruk bidra til å identifisere og eventuelt tette forventningsgap mellom tilbud og etterspørsel etter foretaks miljørapportering. ${ }^{2}$

De tradisjonelle formålene med regnskap blir benyttet som rammeverk for å analysere bruken av rapporteringen. Miljørapportering har imidlertid noen naturlige særtrekk som utvider grensene sammenlignet med finansregnskapet, slik som eksterne effekter og ikke-finansielle målsettinger. Det er derfor utviklet et rammeverk som spesifiserer fire typer bruk av (og etterspørsel etter) informasjon. Ressursallokeringsformålet deles i verdsettingsformål og andre ressursallokeringsformål. Kontrollformålet deles i bruk av informasjon ex-ante og ex-post.

1 Behov for «bruk av rapportering» blir i denne studien ansett å være en (viktig) delmengde av og årsak til «etterspørsel etter rapportering».

2 En mulighet er at gapet blir tettet ved at det er tilnærmet null etterspørsel etter slik rapportering, enten fordi informasjonen er uvesentlig, eller fordi behovet blir dekket av andre og mer hensiktsmessige informasjonskilder.

Sitering av denne artikkelen: Fallan, E. (2020). Bruk av informasjon fra foretaks miljørapportering til ressursallokerings- og kontrollformål. I T. Stenheim, K. M. Baksaas og E. M. Kulset (Red.), Aktuelle temaer i regnskap og revisjon (Kap. 9, s. 243-275). Oslo: Cappelen Damm Akademisk. https://doi. org/10.23865/noasp.112.ch 9

Lisens: CC-BY 4.o. 
Feltstudiens empiri stammer fra intervjuer med og/eller dokumentstudier knyttet til 23 interessenter fra ulike interessentgrupper (investorer, kreditorer, kunder/innkjøpere, NGO-er, og ulike myndigheter). Både privat og offentlig sektor og enheter med profitt- og ideelt/sektorpolitisk formål er inkludert.

Nøkkelord: bruk av og etterspørsel etter miljørapportering, samfunnsansvarsrapportering, formål med regnskap, ressursallokering, kontroll, interessenter

\subsection{Innledning}

«Since financial statements are not usually thought of as consumption goods, asking for the reason they are in demand is not trivial» (Gjesdal, 1981, s. 208). Det samme gjelder for foretaks offentlige rapportering om sosiale og miljømessige forhold (samfunnsansvarsrapportering ${ }^{3}$ ), dog slik at det for denne typen rapportering også må stilles spørsmål ved i hvilken grad den i hele tatt blir etterspurt og brukt. Kunnskap om interessenters etterspørsel etter og bruk av samfunnsansvarsrapportering kan bidra til å vise om temaer knyttet til samfunnsansvar, og informasjon om slike temaer, blir oppfattet som vesentlige. Gitt at informasjon om temaene er vesentlig, kan forståelse av interessentbehov også avklare hvilken informasjon interessentene etterspør og bruker, relevante informasjonskilder og om rapporteringspraksis er hensiktsmessig. ${ }^{4}$ Denne feltstudien ser derfor på aspekter ved interessenters bruk av og etterspørsel etter foretaks samfunnsansvarsrapportering, nærmere definert til slutt i innledningen.

Etter at det på 1960- og 70-tallet begynte å komme oppmerksomhet rundt de sosiale og miljømessige forholdene ved bedrifters aktivitet, har det blitt vanlig at store foretak over hele verden rapporterer offentlig

3 Rapportering om sosiale og miljømessige (inkludert økonomiske) forhold har mange navn og samlebetegnelser (sosial rapportering, miljørapportering, samfunnsansvarsrapportering, bærekraftsrapportering og integrert rapportering mv.). I praksis er forståelsen av begrepene diffus, bruken av betegnelsene overlapper hverandre, og flere begreper er sterkt kritisert. Les mer om det i Buhr, Gray og Milne (2014) og Fallan og Granrud (2020). I denne artikkelen bruker jeg samfunnsansvar som samlebetegnelse for sosiale, miljømessige og (tilhørende, relevante) økonomiske forhold, mens jeg bruker miljørapportering om rapportering om det ytre miljø (inkludert bedrifts- og samfunnsøkonomiske forhold knyttet til dette).

4 Foretak kan få hjelp til å identifisere etterspurt informasjon. Offentlig kjennskap til etterspørselen øker foretaks incentiv til å imøtekomme interessentenes informasjonsbehov, samtidig som kunnskap om etterspørsel bevisstgjør interessenter (inkludert myndigheter og standardsettere) om hvilken informasjon de må sikre tilbud av. 
om disse sidene (Buhr et al., 2014; Gray et al., 2014). Ifølge KPMG (2017) hadde 93 prosent av de 250 største selskapene i verden en eller annen form for slik rapportering for $2015 / 16^{5}$, mens 72 prosent av de 100 største selskapene i hvert av 49 land (altså 4900 selskaper) hadde det samme. Andelen blant store og/eller børsnoterte selskaper i Norge har lenge vært høy (Fallan, 2015, 2016a, 2016b; Fallan \& Fallan, 2007, 2009, 2017; The Governance Group, 2019; Melting \& Tungen, 2012; PwC, 2017; Vormedal \& Ruud, 2009).

I Norge var det høyst sannsynlig også vanlig at en høy andel av små og mellomstore foretak hadde en eller annen form for samfunnsansvarsrapportering for regnskapsårene 1989 til og med 2016, rett og slett fordi det i den perioden var påbudt for alle regnskapspliktige foretak ${ }^{6}$ (Fallan \& Fallan, 2009). Hvordan situasjonen er for små foretak etter bortfallet av kravet om årsberetningen med virkning fra regnskapsåret 2017 er usikkert.? Internasjonalt er utbredelsen sannsynligvis langt lavere blant små foretak enn blant store, men det finnes relativt lite forskning på små foretak også der (Corazza, 2017; Dias et al., 2019).

Eksistens av samfunnsansvarsrapportering kan være et tegn på at temaet og rapporteringen blir oppfattet som relevant (og vesentlig), og at informasjon blir etterspurt og brukt. Forskning viser imidlertid at generell rapporteringspraksis har svært lav kvalitet, både internasjonalt og i Norge $^{8}$ (Adams, 2004; Garcia-Torea et al., 2019; Patten, 20059). I Norge har det for eksempel vært svært vanlig at rapporteringen vedrørende ytre

5 Publikasjonen sier ikke hvilket år de undersøkte rapportene vedrører, men siden den årlige undersøkelsen synes å være gjennomført i første del av 2017 må det antas at den gjelder rapporteringsåret 2015 og/eller 2016.

6 Små foretak skulle følge regnskapsloven \$3-3 og NRS 8 God regnskapsskikk for små foretak, mens andre foretak skulle følge regnskapsloven $\$ 3-3$ a og NRS 16 Årsberetningen, samt at store foretak fra 2013 også skal følge regnskapsloven $\$ 3$-3c.

7 Det finnes imidlertid svært få fagfellevurderte studier av små og mellomstore foretaks rapportering om sosiale og miljømessige forhold i Norge. Se referanser i vedlegg.

8 Dette innebærer for eksempel at informasjonen er positiv heller enn negativ, generell heller enn spesifikk, tekstlig/narrativ heller enn kvantitativ / eventuelt monetær, eksempelbasert heller enn systematiske og fullstendige oppstillinger, ikke inkluderer sammenligningstall over tid og med andre foretak/bransjetall, ikke inkluderer redegjørelse for rapporteringsprinsipper, vurderingsregler og begrepsavklaringer, ikke er verifisert, osv. Videre er det typisk liten systematikk i rapportering av tematisk innhold som målsettinger, tiltak og måloppnåelse, status ved periodens begynnelse og slutt, perioderesultater osv.

Andre relevante referanser inkluderer referanser lagt i eget vedlegg. 
miljø bestod i bare en setning som dette: «Selskapet påvirker ikke det ytre miljø utover det som er vanlig i bransjen.» Selv om rapporteringspraksis kan variere mellom foretak, blir det stilt spørsmål ved i hvilken grad rapporteringen innehar de kvalitative egenskaper ved brukernyttig regnskapsinformasjon som er egnet til å oppfylle de tradisjonelle formålene med regnskap, ressursallokering og kontroll (Gjesdal, 1981; IASB, 2018; Ijiri, 1975; Snavely, 1967). ${ }^{10}$ En stor mengde studier av rapporteringspraksis konkluderer med at den lave kvaliteten tilsier at rapporteringen ikke kan være utarbeidet for kontrollformål, men i stedet på bakgrunn av ulike typer strategisk egeninteresse (legitimitet og lignende) (for eksempel Patten \& Crampton, 2003; Patten, Ren \& Zhao, 2015). Forskning på etterspørsel etter og bruk av informasjon om samfunnsansvarstemaer kan bidra til å utforske konsekvensene av rapporteringspraksisen mer direkte: i hvilken grad temaet er vesentlig, hvorvidt informasjonen er nyttig for interessentenes formål, og hvilken informasjon de eventuelt behøver.

Samfunnsansvarsrapportering er blant de største forskningsområdene innen regnskap internasjonalt (Fallan, 2013b; Fifka, 2013), men det er forskning på tilbudssiden (rapporteringspraksis) som dominerer. Det er gjennomført få studier av etterspørselssiden (Campbell \& Slack, 2008; Deegan \& Rankin, 1997; Fallan, 2013a; Ho \& Wong, 2004; Solomon \& Solomon, 2006), og de som finnes, har i stor grad fokusert på investorer (bredt definert) og NGO-er ${ }^{11}$ (O’Dwyer \& Unerman, 2010, 2016 $6^{12}$ ). De fleste etterspørselsside-studiene har i tillegg undersøkt bare én interessentgruppe, selv om foretak må forholde seg til en rekke interessenter og at «the interaction between them and the incentives they face in determining the information environment» har betydning (Beyer et al., 2010). I litteraturen blir det foretatt en rekke observasjoner og beskrivelser av interessenters konkrete etterspørsel etter (bruk av, lesing av, søk etter, nedlastning av, ønske om osv.), opptreden i forbindelse med eller holdninger til samfunnsansvarsrapportering (De Villiers \& Van Staden,

\footnotetext{
10 Det kan for begge formål være relevans, kompletthet, nøytralitet, feilfrihet, verifiserbarhet, sammenlignbarhet og forståelighet (IASB, 2018), og det kan for kontrollformål være harde/objektive data (verifiserbare, velspesifiserte og få målekriterier) (Ijiri, 1975).

11 I tillegg har studier av forhold mellom foretak og ansatte/fagforeninger/lokalsamfunn vært en nisje, jf. referanser i vedlegg.

12 Andre relevante referanser finnes i vedlegg.
} 
2010; Deegan \& Rankin, 1997). Fra starten av har studiene ofte ikke vært like eksplisitt teoribaserte som studier fra tilbudssiden, utover grunnleggende interessentteoretiske perspektiver. ${ }^{13}$ Funnene har likevel bidratt til teoribygging. Etter hvert har analyser og teoretisering ofte, implisitt eller eksplisitt, blitt knyttet til enkeltstående kvalitative egenskaper ved brukernyttig regnskapsinformasjon, for eksempel vesentlighet (Campbell \& Slack, 2008), eller aspekter ved regnskapets tradisjonelle kontrollformål (accountability/stewardship) diskutert i en bredere interessentkontekst (Deegan \& Rankin, 1997; O’Dwyer \& Unerman, 2010, 2016; Tilt, 1994). En videreutvikling av disse tilnærmingene har kommet i studier som direkte tar utgangspunkt i begge de tradisjonelle formålene med regnskap, ressursallokering og kontroll, og benytter disse mer systematisk som et helhetlig teoretisk rammeverk (De Villiers \& Van Staden, 2010; Fallan, 2013a; McInnes et al., 2007; Munroe \& Shrives, 2017). ${ }^{14}$ Den underliggende forutsetningen for denne teoretiseringen er uansett at de tradisjonelle formålene med finansregnskap / finansiell rapportering også er relevante for samfunnsansvarsrapportering. Det er imidlertid behov for å videreutvikle rammeverket ved å skille mellom flere typer ressursallokerings- og kontrollformål samt å belyse dette empirisk. Det kan gi ytterligere kunnskap om etterspørsel etter og bruk av samfunnsansvarsrapportering og er de viktigste teoretiske og empiriske bidragene i denne studien.

Denne studien bidrar til forskningsfronten ved å foreta en feltstudie av flere interessentgruppers etterspørsel etter og bruk av foretaks offentlige samfunnsansvarsrapportering. Det inkluderer både interessentgrupper som er ofte og mer sjeldent studert, inspirert av McInnes mfl. (2007). I tillegg til å skille mellom tradisjonelle interessentgrupper blir det også bevisst inkludert interessenter fra både privat og offentlig sektor og interessenter med profittformål og med ideelt eller sektorpolitisk formål. Undersøkelse av etterspørsel blir i studien avgrenset til bruk av foretaks rapportering, og bruken blir analysert ut fra to typer ressursallokeringsformål og to aspekter ved kontrollformålet. Som tema er samfunnsansvar

13 Dierkes og Antal (1985) utviklet et eget rammeverk, men dette synes ikke å ha blitt brukt.

14 Siden særskilte kvalitative egenskaper ved informasjon er nødvendig for at rapportering skal bidra til å oppfylle formålene med regnskap (IASB, 2018; Ijiri, 1975), vil tilnærmingene utfylle hverandre. 
et svært bredt område. De miljømessige, sosiale og økonomiske forholdene inkluderer for eksempel FNs 17 bærekraftsmål (United Nations, 2019). Denne studien er derfor begrenset til å fokusere på forhold knyttet til ytre miljø og foretaks miljørapportering.

Norge skiller seg fra andre land ved at det omtrent ikke finnes forskning på samfunnsansvarsrapportering (Fallan \& Fallan, 2019; Utgård, 2019), og etterspørselssiden er knapt nok undersøkt i publiserte, fagfellevurderte studier. ${ }^{15}$ Potensielle forskjeller mellom land tilsier at det bør etableres kunnskap også om norske forhold. Hvilke temaer innenfor samfunnsansvar som er mest utfordrende eller blir oppfattet som mest vesentlig, hvilke interessenter som dermed har størst innflytelse, og interessenters behov for informasjon gjennom foretaks egen offentlige rapportering kan variere mellom land. Velstandsnivå, avhengighet av miljøsensitive bransjer/produkter (for eksempel olje og gass), tillit til foretaks atferd, myndighetenes systemer for regulering og håndheving, pressens rolle samt alternative informasjonskilder kan være spesifikt for den norske konteksten. Det er behov for økt kunnskap om etterspørsel etter og bruk av samfunnsansvarsrapportering, inkludert miljørapportering, i Norge. Feltstudien er empirisk basert på norske forhold. Den inkluderer dokumentstudier og/eller intervjuer med 23 interessenter fra, grovt sagt, seks interessentgrupper: egenkapitalinvestorer (inkludert rådgivere), långivere, kunder/innkjøpere, miljømyndigheter, myndigheter som regulerer rapporteringen og NGO-er. Investorer og kunder er ytterligere delt mellom interessenter fra offentlig og privat sektor.

Studien har samme hovedproblemstilling som Fallan (2013a): Hvordan (til hvilke formål) bruker ulike interessenter foretaks offentlige miljørapportering? Problemstillingen fanger opp både hvorvidt rapportering blir brukt, inkludert om rapporteringen blir lest, og eventuelt hvilke typer ressursallokerings- og kontrollformål den blir brukt til. Denne studien er en videreutvikling av Fallan (2013a), basert på de samme dataene. Til forskjell fra Fallan (2013a) er det teoretiske rammeverket utvidet fra å identifisere én til to ulike typer ressursallokeringsformål. Mens

15 Dersom reguleringer (krav og forventninger i lover, standarder osv.) ekskluderes fra etterspørselsbegrepet. 
hovedproblemstillingen generelt besvares mer utfyllende i Fallan (2013a), er bidraget i denne studien en ekstra vekt på forskningsspørsmålet: Hvordan bruker ulike interessenter (foretaks) miljørapportering til ressursallokeringsformål? Det videreutviklede teoretiske rammeverket for å besvare dette spørsmålet blir nærmere definert i delkapittel 9.2.

\subsection{Teoretisk rammeverk}

De tradisjonelle formålene med finansregnskap ${ }^{16}$ er å bidra med brukernyttig informasjon for ressursallokering og kontroll (Gjesdal, 1981; IASB, 2018; Ijiri, 1975; Snavely, 1967). Det blir i denne artikkelen argumentert for at disse formålene er like relevante for miljørapportering og samfunnsansvarsrapportering.

Formålene i seg selv er langt eldre enn det moderne finansregnskapet, som i hovedsak ble utviklet på 1800- og særlig 1900-tallet. Behovet for informasjon til kontrollformål (stewardship/accountability ${ }^{17}$ ) var årsaken til at regnskap ble oppfunnet for 10 ooo år siden, 5 ooo år før de første skriftspråkene (Baksaas \& Stenheim, 2015; Nordstrøm, 2009). Informasjonsbehovet i forbindelse med beslutninger om ressursallokering har utviklet seg over flere hundre år. Konkret sett vokste det fram i takt med for eksempel behov for (hjemmeværende) investorer ved finansiering av langveisfarende handelsskuter, børser og den industrielle revolusjon. Konseptuelt sett har det sammenheng med økt kapitalbehov, separering av eierskap og kontroll/styring, arbeidsdeling, spesialisering, koordinering og koordineringsmekanismer (markeder og organisasjoner) ${ }^{18}$ (Baksaas \& Stenheim, 2015; L. Fallan, 2016; Nordstrøm, 2009).

En diskusjon om hvorvidt formålene med finansregnskapet er hensiktsmessige også for samfunnsansvarsrapportering (inkludert miljørapportering), kan ta utgangspunkt i likheter og forskjeller mellom rapporteringstypene. Et helt grunnleggende spørsmål er hva regnskap er.

\footnotetext{
16 Dette gjelder formål på etterspørselssiden. Gjesdal (1981) åpner for at regnskapet har andre formål sett fra tilbudssiden (produsentsiden) (s. 208, fotnote 1).

17 Stewardship og accountability er like, men ikke nødvendigvis identiske begreper (PAAinE, 2007).

Disse elementene påvirker samtidig kontrollbehovet (Birnberg, 1980).
} 
Gjesdal (1981) skriver ytre sett om finansregnskap. Likevel presiserer han at analysene i realiteten gjelder produksjon av informasjon (for formålene) (Gjesdal, 1981, s. 225). Regnskap er bare en systematisk måte å organisere eller frambringe informasjon på. Slik sett er det irrelevant om regnskapet skal gi informasjon om et foretaks økonomiske prestasjon i perioden og $ø$ konomiske status ved periodens begynnelse og slutt, eller om det i stedet gjelder foretakets miljømessige prestasjon og status. I tillegg overlapper finansregnskap og miljørapportering hverandre. Foretaks aktiviteter for å tjene penger påvirker miljøet, og miljøforhold kan påvirke foretaks lønnsomhet. Finansregnskapet inkluderer miljørelaterte transaksjoner, eiendeler og forpliktelser (selv om disse sjelden blir identifisert og rapportert separat), samt at det må redegjøre for vesentlig miljømessig risiko (og muligheter). Regnskapsloven krever også blant annet noteopplysninger om framtidige utgifter til disponering og opprydding etter petroleumsog kraftproduksjon og gruvedrift. ${ }^{19}$ Både finansielle og ikke-finansielle aspekter ved miljøforhold kan potensielt påvirke verdsetting av foretak gjennom kapitalkostnad og estimater for framtidige kontantstrømmer eller andre typer vurderinger av foretaket. I flere tiår har regnskapsloven krevd (ikke-finansiell) informasjon om miljøforhold og andre typer samfunnsansvar i årsberetningen. ${ }^{20}$ Prinsippene som ligger til grunn for finansregnskapet, er til og med ansett å være viktige rammebetingelser og på visse områder også rettesnor i arbeidet med samfunnsansvarsrapportering (Garcia-Torea et al., 2019; O'Dwyer \& Unerman, 2016).

Det er også vesentlige forskjeller mellom finansregnskap og miljørapportering, blant annet knyttet til grensesetting. Finansregnskapet forsøker å måle prestasjon og status for foretaket isolert sett. ${ }^{21}$ Når det gjelder foretaks samfunnsansvar, gir det imidlertid liten mening å ekskludere eksterne effekter av foretakets aktiviteter siden dette er en del av kjernen i begrepet. EU har definert samfunnsansvar (corporate social

19 Regnskapsloven $\$ 7-34$.

20 Per nå gjelder dette regnskapsloven $\$ \$ 3-3 \mathrm{a} \mathrm{og} \mathrm{3-3c.} \mathrm{\$ 3-3c} \mathrm{er} \mathrm{ikke} \mathrm{begrenset} \mathrm{bare} \mathrm{til} \mathrm{årsberetnin-}$ gen. Den endelige regnskapsstandarden NRS 16. Årsberetningen presiserer/konkretiserer regnskapslovens bestemmelser gjennom skal-krav og bør-anbefalinger.

21 Eksterne forhold er dog relevante også i forbindelse med finansregnskap og vurdering av foretakets prestasjon og stilling. For eksempel synes Gjesdal (1981) å anerkjenne betydningen av eksterne virkninger, selv om det er definert utenfor rammene for hans studie (s. 208, fotnote 1). 
responsibility) som «the responsibility of enterprises for their impact on society» (EU, 2019). Samfunnsansvar, for eksempel for miljøforhold, handler e om virkninger både i foretaket og for andre enn foretaket selv. Finansregnskapet er også begrenset til å måle virkninger i penger. Bruk av bare én måleenhet er heller ikke hensiktsmessig for samfunnsansvar, som kan omhandle svært mange tema og perspektiver. Samfunnsansvar inkluderer altså både interne, eksterne, økonomiske og ikkeøkonomiske virkninger. Satt på spissen kan finansregnskapet sies å være en delmengde av samfunnsansvarsrapportering, ${ }^{22}$ selv om det nok i praksis ikke blir oppfattet slik per nå. ${ }^{23}$ Det følger av dette at samfunnsansvarsrapportering potensielt kan ha flere eller andre typer interessenter enn finansregnskapet.

De primære målgruppene for finansregnskapet er investorer, långivere og andre kreditorer (Baksaas \& Stenheim, 2015; Gjesdal, 1981; IASB, 2010, 2018). Et teoretisk rammeverk for etterspørsel etter og bruk av samfunnsansvarsrapportering må være relevant for flere interessentgrupper. Finansregnskapsstandardsetterne IASB (International Accounting Standards Board) og FASB (Financial Accounting Standards Board) (2006) identifiserer sju potensielle brukergrupper: egenkapitalinvestorer, kreditorer, leverandører, ansatte, kunder, myndigheter og deres etater og reguleringsorganer og allmennheten og deres representanter. Allmenhetens representanter inkluderer sannsynligvis fagforeninger, næringsforeninger, forbrukerorganisasjoner og (andre) NGO-er. IASB (2018) nøyer seg med å nevne regulerings- eller tilsynsmyndigheter/-organer og allmennheten, i tillegg til de primære brukerne. Trueblood-rapporten til American Institute of Certified Public Accountants (AICPA) fra 1973 har en litt annerledes tilnærming. Ifølge den skal finansregnskapet primært dekke behovene til brukere med begrenset makt, evne eller ressurser til å skaffe seg informasjon (Murphy et al., 2013). The Government Accounting Standards Board, som utarbeider regnskapsstandarder for

\footnotetext{
22 Men finansregnskapet er ikke en delmengde av miljørapportering (snevert definert) siden miljø utgjør bare en liten del av samfunnsansvarsbegrepet. Finansregnskap og miljørapportering vil være delvis overlappende, og samtidig vil (eller bør) begge begreper ha særskilte delmengder.

23 Fenomenet «integrert rapportering» peker i den retning. I realiteten har Norge lenge hatt en primitiv form for integrert rapportering, jf. regnskapslovens krav til årsberetningen.
} 
offentlig sektor, vektlegger innbyggerne, lovgivende-/regulerings- og tilsynsmyndigheter/-organer, investorer og kreditorer (GASB, 1987). ${ }^{24}$ Selv om det er visse forskjeller, viser oversikten fra ulike kilder at et teoretisk rammeverk basert på de tradisjonelle formålene med regnskap er vurdert å være relevante for mange interessentgrupper.

Utgangspunktet var at regnskap er systematisering av informasjon som er ment å være nyttig for potensielle brukere. «Financial reporting is not an end in itself. It is a means of communicating to the users» (IASB \& FASB, 2006, s. 19). Når formålene med regnskap ses i et slik informasjonperspektiv, virker det sannsynlig, ex ante, at et teoretisk rammeverk som bygger på dem, også er relevant for å forklare etterspørsel etter og bruk av samfunnsansvarsrapportering (og miljørapportering). Men rammeverket, som er et potensielt viktig bidrag i denne artikkelen, trenger å bli nærmere beskrevet og utprøvd.

\subsubsection{Ressursallokeringsformål}

I dette teoretiske rammeverket blir ressursallokering delt $\mathrm{i}$ to typer: verdsettingsformål og andre ressursallokeringsformål. Denne oppsplittingen er en videreutvikling av bruken av begrepet i forbindelse med samfunnsansvarsrapportering i De Villiers og Van Staden (2010), Fallan (2013a), McInnes mfl. (2007) og Munroe og Shrives (2017). Etterspørsel etter informasjon for ressursallokeringsformål gjelder uansett bruk av informasjon ex post (bruk av informasjon etter at den er rapportert).

\section{Verdsettingsformål}

Informasjon for ressursallokering kan være relevant for investorer og kreditorer som søker maksimering av formue eller profitt gjennom pengemessig avkastning på investeringen. Dette er her kalt verdsettingsformålet, men mange andre navn er benyttet i litteraturen: investerings-,

24 I offentlig sektor settes altså innbyggerne først, mens i privat sektor listes de opp til slutt. Kontrollformålet, herunder pengeforvaltningskontroll (demokratisk kontroll med offentlige midler), budsjettkontroll og betalingskontroll, er også relativt sett viktigere enn ressursallokeringsformålet i offentlig sektor, særlig for stats- og kommuneforvaltningens regnskaper (Jensen \& Monsen, 2009). 
prognose-, ressurs- eller kapitaltilgangs- og ressursallokerings-beslutningsnytteformålet (Baksaas \& Stenheim, 2015; Gjesdal, 1981; IASB, 2010, 2018; PAAinE, 2007). Gjesdal (1981, s. 208) kaller det også beslutningstakingsetterspørsel og foreslår at informasjon kan være etterspurt på grunn av dens «value to investors (in a broad sense) making investment decisions». Dette kan være informasjon som gir bedre estimater for beløp, tidfesting og usikkerhet knyttet til beregning av framtidige netto kontantstrømmer (Christensen, 2010; IASB, 2018; IASB \& FASB, 2006).

Det er mulig å tenke seg mange eksempler knyttet til miljøforhold. Enkelte foretak er avhengige av utslippstillatelser fra miljømyndighetene for å kunne drive. Informasjon om overholdelse og eventuelle sanksjoner knyttet til nåværende konsesjoner eller forventede endringer av vilkår i kommende konsesjoner, vil kunne påvirke investorers og kreditorers forventninger om framtidige kontantstrømmer. Dersom store innkjøpere (offentlig sektor og store foretak) fastsetter nye og vesentlig endrede miljøkrav som kvalifikasjonskriterier for å få delta i anskaffelsesprosesser og miljøkrav til selve anskaffelsen (produktet), kan det påvirke foretaks muligheter til å delta eller vinne konkurranser. Det kan endre forventninger om framtidige netto kontantstrømmer. I flere år fra 2006/2007 var det krise i Chiles lakseoppdrettsindustri. Miljøforhold medførte at produksjonen til verdens neste største produsent ble redusert med 85 prosent. ${ }^{25}$ Dette medførte at foretak engasjert i Chile, som Cermaq, tapte store summer. Samtidig medførte krisen at lakseprisene på verdensmarkedet steg kraftig, og at foretak med produksjon andre steder tjente godt. Gitt at informasjon om diskutabel forvaltningspraksis fra myndighetene og uforsvarlig drift fra foretak kunne sannsynliggjort slike fiskehelse-/ miljøproblemer, ville det vært relevant for (potensielle) investorer og kreditorer både i foretak i og utenfor Chile og for lakseoppdrettsnæringen. Miljøinformasjon kan være verdirelevant.

25 https://www.nrk.no/urix/mener-kongen-har-latt-seg-bruke-i-chile-1. 14498405 (Lenke kontrollert: 10.02.2020.) 


\section{Andre ressursallokeringsformål}

Verdsettingsformålet gjelder maksimering av pengeverdi på formue eller avkastning (for eierne). Ulike aktørers beslutninger om ressursallokering (eiere, bevilgende myndigheter, tilskuddsgivere, kreditorer osv.) er imidlertid ikke nødvendigvis motivert av slike mål. Aktørene kan ha andre eller flere samtidige mål, for eksempel ideelle eller sektorpolitiske. Milton Friedman (1970) presiserte at det er eiernes (prinsipalens) ønsker som skal være avgjørende for hvilke mål som foretaket og foretaksledelsen (agenten) skal jobbe mot, uavhengig av hva målene er. ${ }^{26}$ Han eksemplifiserte dette med ideelle organisasjoners drift av sykehus eller skoler, hvor målet er leveranse av (gode og kostnadseffektive) tjenester, ikke profitt. Et relevant eksempel i konteksten for denne artikkelen kan være myndigheter, NGO-er og miljøengasjerte privatpersoner som allokerer ressurser basert på vurderinger av miljøprestasjoner: Hvilke tiltak skal vi støtte, igangsette eller investere i for å oppnå størst mulig miljøgevinst (per krone brukt av prinsipalens midler)?

En annen mulighet Friedman (1970) peker på, er at agenten (foretaksledelsen) kan fremme for eksempel foretakets miljøprestasjoner (grønn profilering) på bekostning av eiernes ønske om størst mulig pengemessig avkastning eller verdi. Slik opportunistisk atferd ${ }^{27}$ kan også høre hjemme under andre ressursallokeringsformål.

Hvorvidt etterspørsel etter eller bruk av miljørapportering for ressursallokeringsformål er knyttet til verdsettingsformål eller andre ressursallokeringsformål, kan ha betydning for hvilken type informasjon som behøves.

\subsubsection{Kontrollformål}

Kontrollformålet (stewardship/accountability) er nær knyttet til agentteori. Det gjelder transaksjoner mellom en oppdragsgiver (prinsipal) og en forvalter ${ }^{28}$ (agent) som skal foreta beslutninger og/eller handlinger på

\footnotetext{
26 Innenfor lovlige rammer.

27 Opportunistisk overfor prinsipalen «eierne», ikke nødvendigvis overfor prinsipalen «samfunnet».

28 Valget av begrepet forvalter er bevisst for å illustrere båndene mellom agentteori (forhold mellom prinsipal og agent) og stewardshipteori (forhold mellom master og steward). Steward
} 
vegne av prinsipalen (L. Fallan, 2016). I et rapporteringsperspektiv er forholdet mellom eiere, styret og foretaksledelsen sentralt, samt formelle og uformelle forhold mellom foretaket og diverse interessenter (inkludert myndigheter, NGO-er, kunder og långivere). Agentteori bygger generelt på at det i slike relasjoner er begrenset og asymmetrisk informasjon mellom prinsipal og agent, og at partene potensielt kan ha motstridende mål/interesser (L. Fallan, 2016; Gjesdal, 1981; O'Connell, 2007; PAAinE, 2007). Kombinasjonen av disse forholdene åpner for opportunistisk atferd, både i form av det Arrow (1985) kaller skjult informasjon før en formell eller uformell kontrakt er inngått (ex ante), og i form av skjult handling etter at partene er enige om en transaksjon (ex post) (L. Fallan, 2016).

Ifølge Gjesdal (1981, s. 208) oppstår det etterspørsel etter informasjon for kontrollformål fordi «[i]nvestors usually delegate decision-making to managers. Then there may be a demand for information about the actions that are taken for the purpose of controlling them». Rosenfield (1974) uttrykker det litt mer generelt (gjengitt i Gjesdal, 1981, s. 209): «An objective of financial statements is to report on the control and use of resources by those accountable for their control and use to those to whom they are accountable.» Interessenter (prinsipalen) vil ønske at foretaket skal rapportere informasjon for å redusere informasjonsasymmetrien fordi det kan øke sannsynligheten for å oppdage skjult informasjon (ex ante) og redusere sannsynligheten for skjult handling (ex post). I et kontrollperspektiv er rapportering ikke et mål i seg selv, men et redskap for å redusere agentproblemer knyttet til delegering av beslutningstaking fra prinsipal til agent (L. Fallan, 2016; Gjesdal, 1981).

Innholdet i kontrollformålet har utviklet seg i løpet av 10 ooo år til å inkludere mer komplekse oppgaver i form av mindre struktur og økt usikkerhet (Birnberg, 1980). Det har gått fra at agenten skal passe på eiendeler for prinsipalen («safekeeping»), noe som krever operasjonell kontroll, til produktivitet og effektivitet i utnyttelsen av prinsipalens ressurser, noe som krever ledelseskontroll, og strategisk videreutvikling av

kan oversettes med forvalter. Ifølge Gjesdal (1981, s. 213) er agentforhold karakteristisk ved «stewardship»-begrepet slik det blir brukt i regnskapslitteraturen. 
ressursene for framtiden, noe som krever strategisk kontroll (Birnberg, 1980; Gjesdal, 1981; Ijiri, 1975; Zeff, 2012). Dermed er også kravene til relevant informasjon endret fra balanseoppstillinger til prestasjonsmåling og både tilbake- og framoverskuende informasjon (Birnberg, 1980; Eierle \& Schultze, 2013; Ijiri, 1975; PAAinE, 2007). Kontrollformålet inkluderer dermed både kontroll og evaluering av historiske handlinger og prestasjoner og vurderinger av framtidige muligheter og risiko (PAAinE, 2007). Slik sett kan likheten i informasjonsbehov mellom kontrollformålet og ressursallokeringsformålet ha økt over tid.

Ansvar utover egeninteresse og smale økonomiske vurderinger er felles kjennetegn både ved miljøhensyn, miljørapportering og forvalteransvar (stewardship). Kontrollformålet (stewardship/accountability) er derfor like relevant for miljørapportering som for tradisjonell finansiell rapportering (O'Connell, 2007). Chen (1975) hevder at det historiske stewardship-begrepet innebærer et todelt ansvar, overfor både eiere og samfunnet, noe som anerkjenner at ens egen atferd (for eksempel bruk av ressurser) påvirker andre. Stewardship impliserer moralske forpliktelser og ansvar (Jeavons, 1994; Murphy et al., 2013) og rettferdighet (Coy et al., 2001) og vektlegger dermed «company performance as a whole» (PAAinE, 2007). Ifølge Grimsey og Lewis (2002) har «accountability also [...] broader economic and social purposes and objectives [than investors' resource allocation] because of the many other groups that have a legitimate interest in knowing about the activities and operations». Mange forhold og interessenter, både eksplisitte og implisitte kontrakter mellom foretak og interessenter (Ramanna 2013), bør tas hensyn til. Regnskapets kontrollformål er særlig viktig innen rapportering om sosiale og miljømessige forhold (Murphy et al., 2013; O’Connell, 2007), og «[a]s changes occur in our concepts and focus of accountability for the environment, demands for different flows of information, accounting and otherwise, are also likely to grow» (Hopwood, 2009, s. 433). De Villiers og Van Staden (2010, s. 237) fant at etterspørsel etter rapportering ut fra kontrollformålet «implies both responsible environmental management and giving an account of the environmental management actions taken». Det er sannsynlig at informasjon om hvordan foretak håndterer og styrer miljøforhold, vil være relevant for et bredt spekter av interessenter. Delegering 
av forvalteransvar for miljøet fra befolkningen til oljeselskap er et eksempel på en (implisitt) prinsipal-agent-kontrakt.

Ressursallokeringsformålet gjaldt etterspørsel etter og bruk av informasjon etter at den er rapportert (ex post). I tråd med Fallan (2013a) og Munroe og Shrives (2017) ${ }^{29}$ er det hensiktsmessig å dele kontrollformålet i bruk av informasjon ex post og ex ante.

\section{Kontrollformål -bruk av informasjon ex post}

Etterspørsel etter informasjon for kontrollformål ex post oppstår fordi interessenter kan bruke rapporteringens innhold til å kontrollere og evaluere foretakets/foretaksledelsens valgte handlinger (Christensen, 2010). Bruk av rapportering ex post kan øke sannsynligheten for å oppdage skjult informasjon ${ }^{30}$ (ex ante) og skjult handling (ex post).

Kontroll og evaluering av foretaks(ledelsers) prestasjoner, for eksempel (strategier for) lønnsomhet eller miljøpåvirkning, setter interessenter i stand til å fatte beslutninger av diverse slag: endre eller skifte ut ledelsen og identifisere og prioritere nye kandidater (Gjesdal, 1981; PAAinE, 2007), krav om endret foretaksatferd, (fremme krav om) nye/endrede reguleringer, identifisering av foretak som objekter for miljøkampanjer, valg av arbeidsgiver, samarbeidspartnere, leverandører eller kunder, medias identifisering av saker av allmenn interesse, osv.

\section{Kontrollformål -bruk av informasjon ex ante (incentiver)}

Etterspørsel etter informasjon for kontrollformål ex ante innebærer bruk av informasjon før den er rapportert. Det er mulig gjennom bruk av en incentivmekanisme. Når foretaksledelsen vet at de må rapportere til interessentene, og at interessentene kan bruke rapporteringen (ex post) til å kontrollere og evaluere ledelsens handlinger, har ledelsen et incentiv til å handle mer i overensstemmelse med interessentenes ønsker slik at rapporteringen vil vise positive resultater.

\footnotetext{
29 Munroe og Shrives (2017) er basert på rammeverket utviklet i Fallan (2013a).

30 Dette kan for eksempel være at man bruker rapportering fra en ny lederkandidats tidligere arbeidsgivere samt kontrollerer vitnemål og foretar referansesjekker for å evaluere vedkommende kompetanse og egnethet før vedkommende blir ansatt.
} 
Fallan (2013a) og senere Munroe og Shrives (2017) introduserte bruk av informasjon ex ante til kontrollformål som en del av et teoretisk rammeverk for å analysere etterspørsel etter og bruk av samfunnsansvarsog miljørapportering. Ideen er basert på Gjesdals (1981, s. 226) resultat om at det i desentraliserte organisasjoner ${ }^{31}$ vil være etterspørsel etter rapportering for kontrollformål fordi slik rapportering er «ex-ante efficient». Incentivmekanismen ved bruk av rapportering ex ante har en motivasjons- eller håndhevingseffekt. Interessenter gir foretaket/foretaksledelsen incentiv til å opptre i overensstemmelse med interessentenes interesser (Gjesdal, 1981; Christensen, 2010). Bruk av rapportering ex ante er dermed et egnet virkemiddel for å redusere sannsynligheten for skjult handling (ex post), altså opportunistisk atferd. Incentivmekanismen var en viktig del av grunnlaget for innføring av lovkrav om miljørapportering i Norge, myndighetenes forventninger til statseide foretaks rapportering og for standarder om internasjonal rapportering (Adams et al., 2020; Fallan, 2013a; Meld. St. 13 (2010-2011); St.meld. nr. 10 (2008-2009)).

Incentivmekanismen betyr at interessenter kan etterspørre rapportering for kontrollformål uavhengig av om de faktisk leser eller har tenkt å lese informasjonen etter at den er rapportert (ex post). Man skal imidlertid være oppmerksom på at incentiveffekten blir redusert eller forsvinner hvis kontrollen ikke er troverdig, for eksempel hvis agenten skjønner at informasjonen ikke blir brukt (Gjesdal, 1981). Dette stiller også spørsmål ved incentiveffekten ved rapportering av så lav kvalitet at det er vanskelig å bruke den til kontrollformål, noe som er relevant for den generelle samfunnsansvars- og miljørapporteringspraksisen. Konsekvensene av funnene til Cormier mfl. (2004) peker også i samme retning. De konkluderer med at foretaksledere reagerer på interessenters etterspørsel, men at dette er en evolusjonær prosess. Ledere tilpasser og endrer atferd over tid etter sin oppfatning av hvilke forhold eller hvilken type informasjon interessenter mener er vesentlig, og hvilke interessenter som er viktigst i ulike kontekster.

31 Organisasjoner med skille mellom eierskap og kontroll/styring. 


\subsubsection{Særtrekk ved interessenter fra offentlig sektor}

Det er en nær sammenheng mellom begrepet forvalteransvar (stewardship) og offentlig sektors rolle. Politikere er valg av befolkningen, og offentlig sektor eksisterer for å forvalte fellesgoder og velferdsgoder på vegne av samfunnet. Naturmiljøet er på mange måter et fellesgode. Politikere er ansvarlige for de virkningene beslutningene deres har på miljøet. De må sørge for at offentlig sektor handler i tråd med sitt særlige forvalteransvar, samt påvirke andres atferd gjennom reguleringer, incentivmekanismer og ved å være rollemodell. Dette er et prinsipal-agent-forhold styrt av både formelle og sosiale kontrakter. Miljøansvar gir behov for informasjon om miljøforhold, både på makronivå (samfunn/økosystem/ planet) og på mikronivå (bedrifter/personer). Kontrollformålet medfører etterspørsel etter miljøinformasjon og potensielt også miljørapportering.

Når miljøhensyn medfører netto kostnader (inkludert alternativkostnader), for en selv og andre, vil forvalteransvar overfor miljøet kreve en altruistisk dimensjon. ${ }^{32}$ Dette gjør det enklere å knytte forvalteransvaret for miljøet til offentlig sektor og ideelt/sektorpolitisk formål enn privat profittformål. Ansvaret til foretak (eller personer) med profittformål kan bli ansett å være og følge reglene i samfunnet, både de som er gitt i lov, og etiske normer (Friedman, 1970). Markedsøkonomien i seg selv er ikke egnet til å løse vesentlige miljøproblemer, ${ }^{33}$ det behøves reguleringer av offentlig sektor (og overnasjonale avtaler). Dette er reflektert i den tradisjonelle forståelsen av formålene med finansiell rapportering. Financial Accounting Standards Board (FASB) etablerte Governmental Accounting Standards Board (GASB) for å skille ansvaret for regnskapsstandarder for amerikanske statlige og lokale myndigheter fra ansvaret for foretak med profittformål. Begrunnelsen var at «the duty to be publicly accountable is more significant in governmental financial reporting than in business enterprise financial reporting» (Coy et al., 2001, s. 4). GASB (1987) anerkjenner dette:

Inkludert byrden det innebærer (for eksempel for gjenvalg) å ta ansvar gjennom at overliggende myndighet setter krav til (inkludert gir incentiver til) organisasjoners og personers atferd. 
The Board believes that financial reporting plays a major role in fulfilling government's duty to be publicly accountable in a democratic society. Public accountability is based on the belief that the taxpayer has a «right to know», a right to receive openly declared facts that may lead to public debate by the citizens and their elected representatives.

Dette forvalteransvaret (kontrollformålet) er framtredende i primær bruk av finansielle rapporter:

... compare actual financial results with the legally adopted budget; to assess financial condition and results of operations; to assist in determining compliance with finance-related laws, rules, and regulations; and to assist in evaluating efficiency and effectiveness. (GASB, 1987)

Dette gjelder ikke i mindre grad i Norge (Jensen \& Monsen, 2009). Mens GASB oppfatter kontrollformålet «to be the paramount objective from which all other objectives must flow» i finansiell rapportering i offentlig forvaltning (Coy et al., 2001, s. 4), har FASB (1978, 1980), IASB og FASB (2006) og IASB (2018) fastsatt at ressursallokeringsformålet er (vel så) viktig for private foretak. Denne forskjellen reflekteres også i valget av primære interessenter. FASB $(1978,1980)$ og IASB (2018) vektlegger i hovedsak behovene til investorer og kreditorer, mens GASB (1987) har valgt «the citizenry, legislative and oversight bodies, and investors and creditors» (hvor befolkningen bevisst er satt først). GASB framholder at offentlig sektors «decision-making encompasses social and political decisions in addition to economic decisions» (Coy et al., 2001, s. 4).

Selv om kontrollformålet har en mer framtredende rolle i offentlig forvaltning, er det viktig også å anerkjenne at offentlig forvaltnings rolle ikke er begrenset til kontroll. Offentlig forvaltning fordeler tilskudd/ bevilgninger og foretar innkjøp av varer og tjenester for store samlede beløp. Dette innebærer også ressursallokering, men en ressursallokering som ofte har andre formål enn profitt, som god skole, godt helsetilbud, god eldreomsorg og/eller godt naturmiljø. Det samme kan gjelde valg knyttet til ressursallokering for ideelle organisasjoner (på miljøområdet).

Basert på dette er det sannsynlig at etterspørsel og bruk av miljørapportering blant interessenter som må oppebære offentlig sektors forvalteransvar overfor naturmiljøet, i utgangspunktet (før eventuell eksistensen 
av gjennomgripende reguleringer) skiller seg fra etterspørsel og bruk fra private bedrifter med profittformål. Den samme logikken kan også skille organisasjoner med ideelt/sektorpolitisk formål fra dem med profittformål.

\subsubsection{Oppsummering av teoretisk rammeverk}

Det teoretiske rammeverket etablert i denne artikkelen er en videreutvikling av rammeverket i Fallan (2013a), Gjesdal (1981) og Munro og Shrives (2017) gjennom å identifisere fire underkategorier under de to tradisjonelle (etterspørselsbaserte) formålene med regnskap. Rammeverket kan brukes til å analysere etterspørsel etter og bruk av miljørapportering fra ulike interessenter. Denne studien vil undersøke bruken av rapportering til enkelte utvalgte informanter fra ulike interessentgrupper. Det inkluderer et skille mellom interessenter fra henholdsvis privat og offentlig sektor og mellom profitt- og ideelt/sektorpolitisk formål.

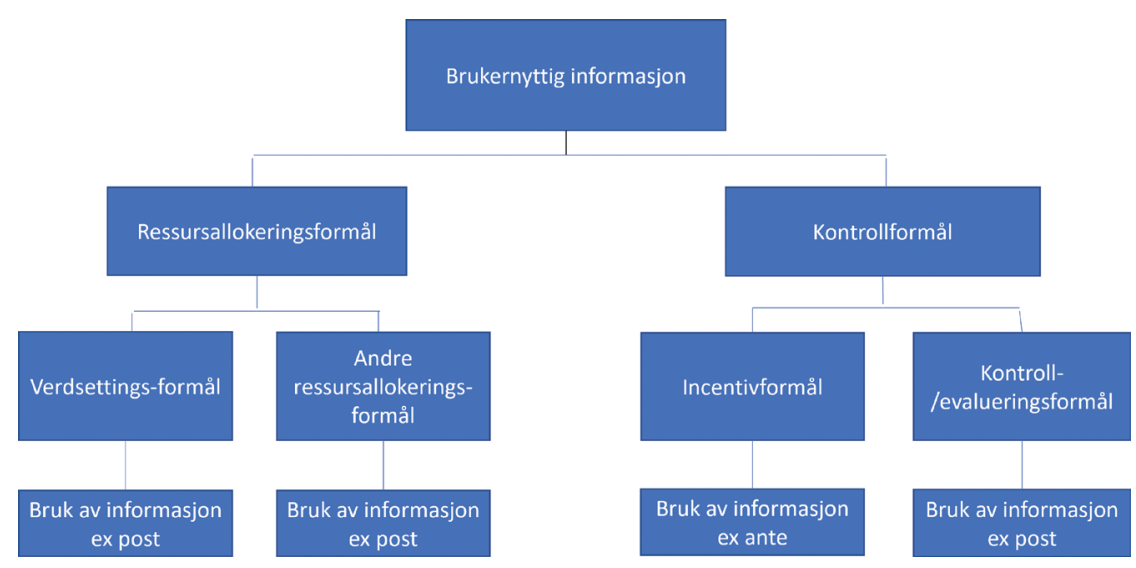

Figur 9.1 Teoretisk rammeverk for analyse av etterspørsel etter og bruk av samfunnsansvarsrapportering

\subsection{Metode}

Etterspørselssiden av miljørapportering er kompleks og relativt lite studert sammenlignet med tilbudssiden. I Norge er det nesten ikke gjennomført studier av denne typen. Derfor er det hensiktsmessig å starte 
utforskingen gjennom en kvalitativ feltstudie, basert på intervjuer og dokumentstudier, for å søke dypere teoribasert forståelse gjennom tilgang til nødvendige interessentgrupper (Atkinson \& Shaffir, 1998; Keating, 1995; Lukka \& Kasanen, 1995). Ideelt sett skal valget av informanter fremme forståelsen av temaet «because it is believed that understanding them will lead to better understanding, and perhaps better theorizing, about a still larger collection of cases» (Stake, 2005; s. 446). Antall informanter, interessenter og interessentgrupper (pluss de organisasjoner og den kompetansen de representerer) innebærer at dette er en relativt omfattende feltstudie som kan bidra til å gi en første indikasjon med hensyn til det teoretiske rammeverkets hensiktsmessighet.

Valg av interessentgrupper er basert på problemstillingen, det teoretiske rammeverket og tidligere studier og inspirert av feltstudien til McInnes mfl. (2007). Det er nødvendig å ha med investorer og kreditorer siden disse er de primære interessentene for finansregnskap (Baksaas \& Stenheim, 2015; IASB, 2018). I tillegg til investorer er NGO-er mest studert i forskningslitteraturen (Munroe \& Shrives, 2017; O'Dwyer et al., 2005; Tilt, 1994). Store, profesjonelle kunder/innkjøpere er valgt siden miljøkrav ved innkjøp potensielt kan ha stor betydning for samfunnets miljøinnsats, samt at interessentgruppen er lite studert og derfor har kunnskapsverdi isolert sett. Miljømyndigheter har mulighet til å stille krav og sanksjonere foretak, og dermed påvirke atferd, men det er samtidig gjort få undersøkelser av dette. Reguleringer av rapportering (myndigheter) er valgt på grunn av at Norge har hatt særegne rapporteringskrav, og fordi formålet med innføringen av reglene var bruk av informasjonen både ex post og ex ante. Reguleringer er et stort forskningsområde innen miljørapportering (Bebbington et al., 2012; Luque Vilchez \& Larrinaga, 2016), men de er i liten grad undersøkt i en slik etterspørselskontekst.

Fifkas (2013) metastudie viser at organisasjoners synlighet (størrelse og bransje/miljøsensitivitet) er en viktig forklaringsfaktor på tilbudssiden. Innenfor interessentgruppene er det derfor valgt informanter fra store og/eller velkjente organisasjoner i Norge eller informanter med særlig kompetanse. Organisasjonene er valgt fra bransjer med relativt stor miljøpåvirkning, og for investorer og kreditorer er det lagt vekt på at deres fokusområde/spesialisering gjelder slikebransjer. Frainteressentgruppene 
investorer og kunder/innkjøpere er det valgt informanter fra organisasjoner i både privat og offentlig sektor, siden det potensielt kan være forskjeller mellom sektorer og foretak med ulike formål.

Intervjuene var inspirert av designet til Campbell og Slack (2011) og McInnes mfl. (2007). Det ble forsøkt å ha et konkret referansepunkt for samtalen (et foretak, eventuelt en bransje eller et par situasjoner) slik at interessentrollen skulle bli tydelig (prinsipal-agent-roller) og svarene mer konkrete. Det ble gjennomført semistrukturerte intervjuer ansikt til ansikt med en informant fra 19 organisasjoner/funksjoner høsten $2011 \mathrm{og}$ våren 2012. Det ble dessuten foretatt to intervjuer med informant 11 fordi den avsatte timen til intervjuet ikke strakk til. Tre supplerende intervjuer ble foretatt per telefon senere i 2012. Intervjuene tok fra 10 til 70 minutter, og de fleste varte en time. De ble tatt opp og transkribert.

Det ble også foretatt dokumentstudier knyttet til interessentene, både i utvalgsfasen, i forberedelse til intervjuer og etterpå. Interessent 23 (regulering av rapportering) er utelukkende representert gjennom dokumentstudie, basert på brev, lovproposisjoner osv.

En oversikt over interessentene/informantene finnes i tabell 9.1.

\subsection{Resultater og diskusjon}

Utforskningen av informantenes bruk av foretaks offentlige miljørapportering er oppsummert i tabell 9.1. Tabellen har en kolonne for hver av de fire delene av det teoretiske rammeverket. I tillegg har den en kolonne som rett og slett viser hvorvidt interessentene leser det/de relevante foretaks miljørapportering. Én kolonne viser hvorvidt informantenes organisasjon tilhører offentlig eller privat sektor, og en annen hvilken bransje deres organisasjon tilhører (og for investorer og långivere: deres kunders eller spesialområdes bransje). Tabellen er organisert etter interessentgruppe, med én rad per interessent/informant.

Se vedlegg 1 Tabell 9.1. (Indikasjoner på) bruk av foretaks miljørapportering, organisert etter formål med regnskapet.

Studien er ikke egnet til å generalisere resultater. Likevel er det av interesse å se hvordan bruken av rapporteringen var blant disse informantene/interessentene. Det var bare seks av 22 aktuelle informanter 
som i hele tatt leser den offentlige miljørapporteringen til foretak de har et interessentforhold til. Av disse var fire fra offentlig sektor, hvorav alle de tre investorene og én fra miljømyndigheter. De to informantene fra privat sektor som leste slik rapportering, var begge långivere fra banker. Det er ingen investorer fra privat sektor som leser rapporteringen, og ingen innkjøpere verken fra offentlig eller privat sektor.

For å bruke rapporteringen ex post, er man nødt til å lese den. Det er dermed få som bruker foretaks miljørapportering til ressursallokeringsformål og kontrollformål ex post (tre av de fire formålene i rammeverket). Til tross for at få leser rapporteringen, ønsker likevel mange informanter i studien at foretak skal rapportere slik informasjon. Disse informantene etterspør foretaks miljørapportering, og bruk av rapportering ex ante er en viktig årsak til dette. Hele 16 av de 23 interessentene bruker rapportering ex ante, for to er svaret usikkert, mens for de fem siste synes kontrollformålets incentivmekanisme å være uinteressant. En nærmere beskrivelse av disse resultatene, med sitater fra intervjuer og dokumenter, er gitt i Fallan (2013a).

Nyhetsverdien i denne artikkelen, sammenlignet med De Villiers og Van Staden (2010), Fallan (2013a), McInnes mfl. (2007) og Munroe og Shrives (2017), både teoretisk og empirisk, ligger i at ressursallokeringsformålet er delt i verdsettingsformål og andre ressursallokeringsformål. Ved å sammenligne tabell 9.1 med tilsvarende tabell uten oppsplitting av ressursallokeringsformålet i Fallan (2013a) synes dette skillet å ha verdi for å kunne beskrive bruk av rapportering. Informantene $14 \mathrm{og} 20 \mathrm{sin}$ bruk av rapportering til ressursallokeringsformål gjelder utelukkende andre ressursallokeringsformål enn verdsetting. Informant 13 bruker foretaks rapportering til ressursallokeringsformål, men det gjelder i hovedsak til verdsettingsformål og bare unntaksvis, i noen få enkelttilfeller, til andre ressursallokeringsformål. Dette er også illustrert i teksten i Fallan (2013a). Et lignende resultat som hos informant 13 finner vi teoretisk sett også hos informantene 18 og 19. Merk at regnskapsloven (med tilhørende standarder), jf. interessent 23, etterspør rapportering (av informasjon som er relevant) også for andre ressursallokeringsformål. Igjen er det altså hos investorer fra offentlig sektor, långivere og myndigheter vi finner forskjeller. Det er ikke overraskende siden Fallan 
(2013a) viste at det bare var disse som leste rapporteringen, og dermed kan bruke den ex post.

De informantene som leser foretaks miljørapportering, begrenser sjelden sitt informasjonssøk til denne kilden. Det er også flere informanter enn disse som leser/bruker miljøinformasjon ex post fra andre kilder. I tabell 9.1 er dette forsøkt vist med stjernemarkeringer for informantene 12 (en investor fra privat sektor) og 21 og 22 (miljø- og naturbaserte ideelle organisasjoner (NGO-er)). ${ }^{34}$ Informasjon fra andre kilder er i utgangspunktet ekskludert fra denne studien. Det er imidlertid relevant for denne studien at det også for informant 21 og 22 (NGO-ene) er et skille i bruk av informasjon til ressursallokeringsformål mellom verdsettingsformålet og andre ressursallokeringsformål.

Blant informantene i denne studien synes det å skille mellom verdsettingsformål og andre ressursallokeringsformål å kunne gi relevant tilleggsinformasjon om bruk av informasjon for flere investorer fra offentlig sektor, långivere og NGO-er. Studien indikerer at miljøinformasjon til dette formålet kan være vesentlig for enkelte interessenter. Samtidig er det er naturlig at slik miljøinformasjon ikke er like relevant for alle interessenter.

\subsection{Konklusjon}

Denne studien er en videreutvikling av Fallan (2013a) basert på de samme dataene. Studiens utgangspunkt gjelder hvordan (om og til hvilke formål) ulike interessenter bruker foretaks offentlige miljørapportering. Som vist i Fallan (2013a), er den vanligste bruken av foretaks miljørapportering bruk av informasjon ex ante til kontrollformål.

Det nye forskningsspørsmålet i denne studien er hvordan ulike interessenter bruker (foretaks) miljørapportering til ressursallokeringsformål. Blant (de få) informantene som bruker miljørapportering på den måten, synes hovedvekten for de fleste å ligge på enten verdsettingsformål eller andre ressursallokeringsformål. Det varierer hvilket av de to formålene 
vekten ligger på. Dermed kan det være relevant å skille mellom disse formålene i studier av etterspørsel etter og bruk av (foretaks) miljørapportering. I denne studien gjelder dette for flere investorer fra offentlig sektor og långivere i bedriftsmarkedet innen miljøsensitive bransjer. Dersom vi utvider fra foretaks miljørapportering til miljøinformasjon mer generelt, synes skillet, blant informantene i denne studien, relevant også for NGO-er.

Dataene i denne studien er fra $2011 \mathrm{og}$ 2012. Det vil være nyttig å foreta en lignende studie i dag for å vurdere utviklingen i interessentenes oppfatninger. Selv om miljøspørsmål har vært viktige lenge, og kanskje nå er viktigere enn noensinne vedrørende klima, plast og naturmangfold, betyr ikke det at studiens funn om at det bør skilles mellom miljøinformasjon og miljørapportering, er aktuelt. Det er nemlig lite som tyder på at kvaliteten i den generelle miljørapporteringspraksisen har bedret seg vesentlig det siste tiåret.

\section{Referanser}

Adams, C. A. (2004). The ethical, social and environmental reporting-performance portrayal gap. Accounting, Auditing \& Accountability Journal, 17(5), 731-757.

Adams, C. A., Druckman, P. B. \& Picot, R. C. (2020). Sustainable development goals disclosure (SDGD) recommendations.

Arrow, J. K. (1985). The economics of agency. I Pratt \& Zeckhauser (Red.), Principals and agents: The structure of business (s. 37-51). Boston: Harvard Business School Press.

Atkinson, A. A. \& Shaffir, W. (1998). Standards for field research in management accounting. Journal of Management Accounting Research, 10.

Baksaas, K. M. \& Stenheim, T. (2015). Regnskapsteori. Oslo: Cappelen Damm Akademisk.

Bebbington, J., Kirk, E. A. \& Larrinaga, C. (2012). The production of normativity: A comparison of reporting regimes in Spain and the UK. Accounting, Organizations and Society, 37, 78-94.

Beyer, A., Cohen, D. A., Lys, T. Z. \& Walther, B. R. (2010). The financial reporting environment: Review of the recent literature. Journal of Accounting and Economics, 50, 296-343.

Birnberg, J. G. (1980). The role of accounting in financial disclosure. Accounting, Organizations \& Society, 5, 71-80.

Buhr, N., Gray, R. \& Milne, M. J. (2014). Histories, rationales, voluntary standards and future prospects for sustainability reporting. CSR, GRI, IIRC and beyond. 
I Bebbington, Unerman \& O’Dwyer (Red.), Sustainability accounting and accountability (2. utg.) London og New York: Routledge.

Campbell, D. \& Slack, R. (2008). Narrative reporting: Analysts' perceptions of its value and relevance. ACCA, Research report 104.

Campbell, D. \& Slack, R. (2011). Environmental disclosure and environmental risk: Sceptical attitudes of UK sell-side bank analysts. The British Accounting Review, $43,54-64$.

Chen, R. S. (1975). Social and financial stewardship. The Accounting Review, 50, 533-543.

Christensen, J. (2010). Conceptual frameworks of accounting from an informational perspective. Accounting and Business Research, 40, 237-299.

Corazza, L. (2017). The standardization of downstreamed small business social responsibility (SBSR): SMEs and their sustainability reporting practices. Information Resources Management Journal, 30(4).

Cormier, D., Gordon, I. M. \& Magnan, M. (2004). Corporate environmental disclosure: Contrasting management's perceptions with reality. Journal of Business Ethics, 49, 143-165.

Coy, D., Fischer, M. \& Gordon, T. (2001). Public accountability: A new paradigm for college and university annual reports. Critical Perspectives on Accounting, 12, 1-31.

De Villiers, C. \& Van Staden, C. J. (2010). Shareholders' requirements for corporate environmental disclosures: A cross country comparison. The British Accounting Review, Vol. 42, s. 227-240.

Deegan, C. \& Rankin, M. (1997). The materiality of environmental information to users of annual reports. Accounting, Auditing \& Accountability Journal,10, 562-583.

Dias, A., Rodrigues, L. L., Craig, R. \& Neves, M. E. (2019). Corporate social responsibility disclosure in small and medium-sized entities and large companies. Social responsibility journal, 15(2), 137-154.

Dierkes, M. \& Antal, A. B. (1985). The usefulness and use of social reporting information. Accounting, Organizations \& Society, 10, 29-24.

Eierle, B. \& Schultze, W. (2013). The role of management as a user of accounting information: Implications for standard setting. Journal of Accounting and Managment Information Systems, 12, 155-189.

EU. (2019). Commission staff working document. Corporate social responsibility, responsible business conduct, and business \& human rights: Overview of progress. Brussels, 20.3.2019. SWD (2019) 143 final. European Commission.

Fallan, E. (2013a). Exploration of resource allocation decision making demand and stewardship demand for environmental disclosure. I E. Fallan (Red.), Issues on supply and demand for environmental accounting information. PhD Series 41-2013, LIMAC PhD School, Department of Accounting and Auditing, Copenhagen Business School. 
Fallan, E. (2013b). The representativeness of the annual report as data source in CSR reporting research. I E. Fallan (Red.), Issues on supply and demand for environmental accounting information. PhD Series 41-2013, LIMAC PhD School, Department of Accounting and Auditing, Copenhagen Business School.

Fallan, E. (2015). Explaining the variation in adoption rates of the information content of environmental disclosure. Journal of Accounting \& Organizational Change, 11(2), 247-268.

Fallan, E. (2016a). Environmental reporting regulations and reporting practices. Social and Environmental Accountability Journal, 36(1), 34-55.

Fallan, E. (2016b). Miljørapportering i offentlig sektor: en studie av kontroll- og tillitsbasert styring. I Høyer, Kasa \& Tranøy (Red.), Tillit, styring, kontroll. (Kapittel 10). Oslo: Universitetsforlaget.

Fallan, E. \& Fallan, L. (2007). A longitudinal and cross-sectional analysis of volume and content of corporate environmental disclosure in Norwegian companies: A research note on innovativeness and adoption. ТØH-serien 2007:5, Trondheim Business School.

Fallan, E. \& Fallan, L. (2009). Voluntarism versus regulation: Lessons from public disclosure of environmental performance information in Norwegian companies. Journal of Accounting \& Organizational Change, 5, 472-489.

Fallan, E. \& Fallan, L. (2017). Er regnskapsreguleringer avgjørende for kvaliteten på miljøinformasjon i årsrapporten? I Busch, Olaussen \& Pettersen (Red.), Bred og spiss! NTNU Handelshøyskolen 50 år. Bergen: Fagbokforlaget.

Fallan, E. \& Fallan, L. (2019). Corporate tax behaviour and environmental disclosure: Strategic trade-offs across elements of CSR? Scandinavian Journal of Management, 35(3).

Fallan, E. \& Granrud, H. R. (2020). Attestasjon av rapportering om sosiale, miljømessige og økonomiske forhold (miljø, samfunnsansvars- og bærekraftsrapportering). I Stenvold \& Degerstrøm (Red.), Revisjonshandlinger $i$ praksis (Kapittel 36). Bergen: Fagbokforlaget.

Fallan, L. (2016). Del 1 Grunnlaget for og kjernen i faget bedriftsøkonomi (kapittel 1, 2 og 3). Del 2 Noen bedrifsøkonomiske teorier (kapittel 4, 5 og 6). Kapittel 10 Likheter og forskjeller mellom de bedriftsøkonomiske tilnærmingene. I Fallan \& Pettersen (Red.), Bedriftsøkonomiske atferdsteorier. Endrede perspektiver på atferd, koordinering og organisering. Bergen: Fagbokforlaget.

FASB. (1978). Statement of financial accounting concepts no. 1. Objectives of financial reporting by business enterprises. Norwalk: Financial Accounting Standards Board.

FASB. (1980). Statement of financial accounting concepts no. 2. Qualitative charateristics of accounting information. Norwalk: Financial Accounting Standards Board.

Fifka, M. S. (2013). Corporate responsibility reporting and its determinants in comparative perspective - a review of the empirical literature and a metaanalysis. Business Strategy and the Environment, 22, 1-35. 
Friedman, A. L. \& Miles, S. (2001). Socially responsible investment and corporate social and environmental reporting in the UK: An exploratory study. British Accounting Review, 33, 523-548.

Friedman, M. (1970, 13. september). The social responsibility of business is to increase its profits. The New York Times Magazine.

Garcia-Torea, N., Fernandez-Feijoo, B. \& De La Cuesta, M. (2019). CSR reporting communication: Defective reporting models or misapplication? Corporate Social Responsibility and Environmental Management, 1-17.

GASB. (1987). Concept statement no. 1. Government Accounting Standards Board.

Gjesdal, F. (1981). Accounting for stewardship. Journal of Accounting Research, 19, 208-231.

Gray, R., Adams, C. A. \& Owen, D. (2014). Accountability, social responsibility and sustainability. Accounting for society and the environment. Harlow: Pearson Education Limited.

Grimsey, D. \& Lewis, M. K. (2002). Accounting for public private partnerships. Accounting Forum, 26, 245-270.

Ho, S. S. M. \& Wong, K. S. (2004). Investment analysts' usage and perceived usefulness of corporate annual reports. Corporate Ownership and Control, 1, 61-71.

Hopwood, A. G. (2009). Accounting and the environment. Accounting, Organizations \& Society, 34, 433-439.

IASB. (2010). The conceptual framework for financial reporting. IFRS Foundation and International Accounting Standards Board.

IASB. (2018). IFRS conceptual framework for financial reporting. International Accounting Standards Board.

IASB og FASB. (2006). Preliminary views on an improved conceptual framework for financial reporting. Discussion paper.

Ijiri, Y. (1975). Theory of accounting measurement, Sarasota, FL: American Accounting Assosiation.

Jeavons, T. H. (1994). Stewardship revisited: Secular and sacred views of governance and management. Nonprofit and Voluntary Sector Quarterly, 23, 107-122.

Jensen, B. \& Monsen, N. (2009). Regnskap i stat og kommuner. Om dagens regnskaper og et alternativ. Høgskolen i Hedmark, rapport 7/2009.

Keating, P. J. (1995). A framework for classifying and evaluating the theoretical contributions of case research in management accounting. Journal of Management Accounting Research, 7.

KPMG. (2017). The road ahead. The KPMG survey of corporate responsibility reporting 2017.

Lukka, K. \& Kasanen, E. (1995). Methodological themes. The problem of generalizability: Anecdotes and evidence in accounting research. Accounting, Auditing \& Accountability Journal, 8(5), 71-90. 
Luque-Vilchez, M. \& Larrinaga, C. (2016). Reporting models do not translate well: Failing to regulate CSR reporting in Spain. Social and Environmental Accountability Journal, 36(1), 56-75.

McInnes, B., Beattie, V. \& Pierpoint, J. (2007). Communications between management and stakeholders: A case study. London: Centre for business performance.

Meld. St. 13 (2010-2011). Aktivt eierskap - norsk statlig eierskap i en global økonomi. Nærings- og handelsdepartementet.

Melting, E. \& Tungen, Ø. (2012). Miljørapportering og lovverk: har rapporteringspraksis utviklet seg etter endelig innføring av Norsk RegnskapsStandard 16 i 20o7? Masteroppgave i økonomi og administrasjon, Trondheim Økonomiske Høgskole.

Munroe, K. \& Shrives, P. (2017). The use of environmental reporting - a story of stewardship from the perspective of NGO's. Conference paper, European Accounting Association Conference (EAA), Milano, 2018.

Murphy, T., O’Connell, V. \& Ó Hógartaigh, C. (2013). Discourses surrounding the evolution of the IASB/FASB conceptual framework: What they reveal about the 'living law' of accounting. Accounting, Organizations \& Society, 38, 72-91.

Nordstrøm, C. J. (2009). Bedriftsøkonomiens historie. Glimt og portretter. Bergen: Fagbokforlaget.

O'Connell, V. (2007). Reflections on stewardship reporting. Accouting Horizons, 21, 215-227.

O’Dwyer, B. \& Unerman, J. (2010). Enhancing the role of accountability in promoting the rights of beneficiaries of development NGOs. Accounting and Business Research, 40(5), 451-471.

O’Dwyer, B. \& Unerman, J. (2016). Fostering rigour in accounting for social sustainability. Accounting, Organizations and Society, 49, 32-40.

O'Dwyer, B., Unerman, J. \& Bradley, J. (2005). Perceptions on the emergence and future development of corporate social disclosure in Ireland: Engaging the voices of non-governmental organisations. Accounting, Auditing \& Accountability Journal, 18, 14-43.

PAAinE. (2007). Stewardship/accountability as an objective of financial reporting: A comment on the IASB/FASB conceptual framework project. Proactive Accounting Activies in Europe (PAAinE).

Patten, D. M. (2005). The accuracy of financial report projections of future environmental capital expenditures: A research note. Accounting, Organizations \& Society, 30(5), 457-468.

Patten, D. M. \& Crampton, W. (2003). Legitimacy and the internet: An examination of corporate web page environmental disclosures. Advances in Environmental Accounting and Management, 2, 31-57. 
Patten, D. M., Ren, Y. \& Zhao, N. (2015). Standalone corporate social responsibility reporting in China: An exploratory analysis of its relation to legitimation. Social and Environmental Accountability Journal, 35(1), 17-31.

PWC. (2017). PwC boerekraft 10o. Rapportering for framtiden.

Ramanna, K. (2013). A framework for research on corporate accountability reporting. Accounting Horizons, 27, 409-432.

Rosenfield, P. (1974). Stewardship. Objectives of financial statements, selected papers. New York: AICPA.

Solomon, J. F. \& Solomon, A. (2006). Private social, ethical and environmental disclosure. Accounting, Auditing \& Accountability Journal, 19, 564-591.

Snavely, H. J. (1967). Accounting information criteria. The Accounting Review, 42(2), 223-232.

Stake, R. E. (2005). Qualitative case studies. I N. K. Denzin \& Y. S. Lincolm (Red.), The Sage handbook of qualitative research (3. utg.). Sage.

St.meld. nr. 10 (2008-2009). Noringslivets samfunnsansvar i en global økonomi. Det kongelige utenriksdepartement.

The Governance Group. (2019). Borekraft på børs 2019. En analyse av borekraftsrapporteringen til de 100 største selskapene på Oslo Børs.

Tilt, C. A. (1994). The influence of external pressure groups on corporate social disclosure: Some empirical evidence. Accounting, Auditing \& Accountability Journal, 7, 47-72.

United Nations. (2019). The sustainable development goals report 2019. New York: United Nations.

Utgård, J. (2019). Regulering for bærekraft? Magma, 5, 45-50.

Vormedal, I. \& Ruud, A. (2009). Sustainability reporting in Norway - an assessment of performance in the context of legal demands and socio-political drivers. Business Strategy and the Environment, 18, 207-222.

Zeff, S. A. (2012). The objectives of financial reporting: A historical analysis. ICAEW's Information for Better Markets Conference, November 28, 2012 draft 2012 London. 


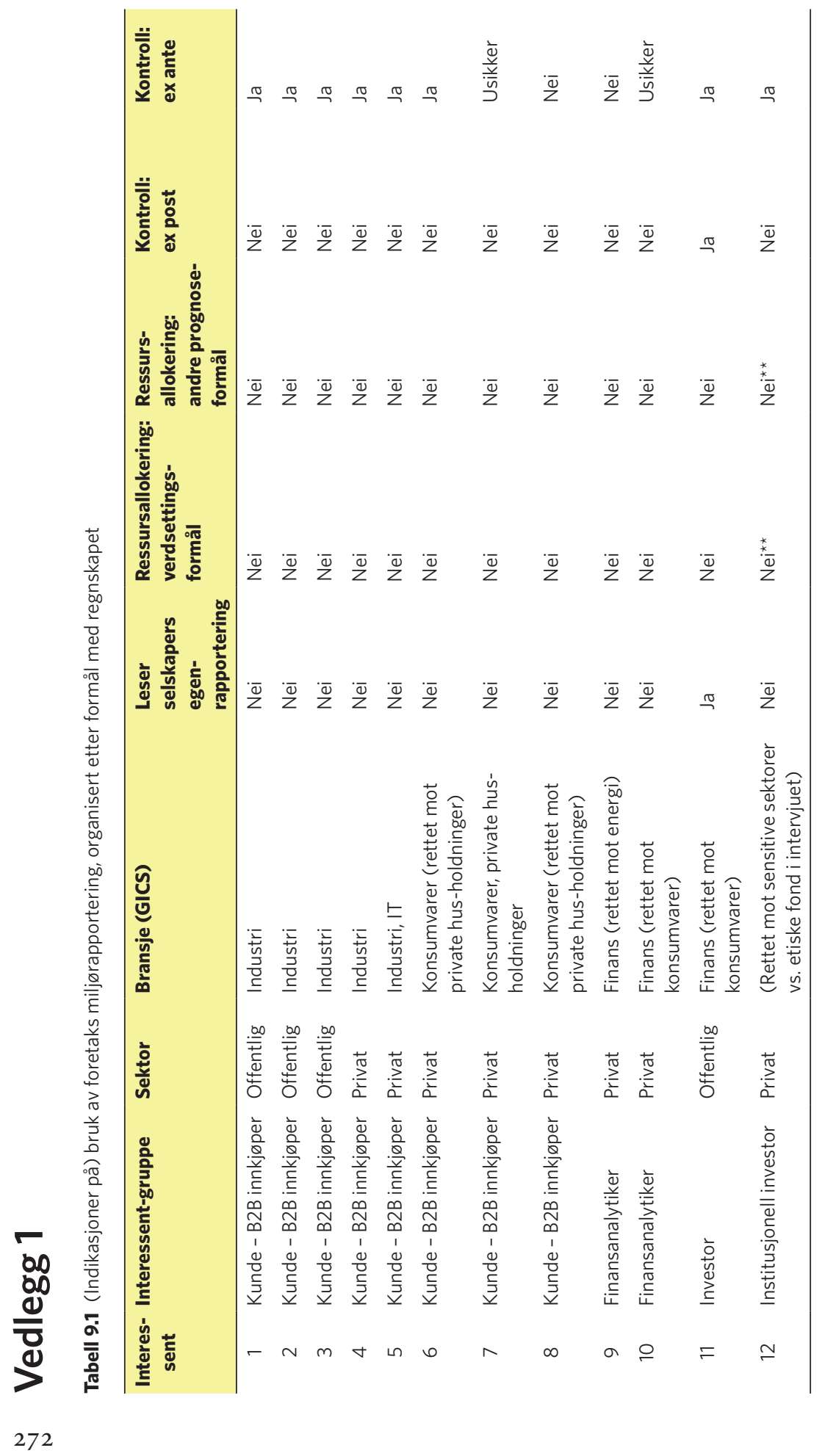




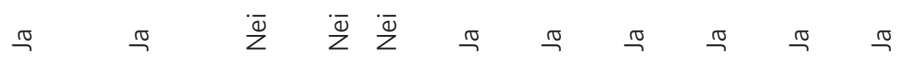

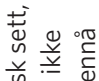

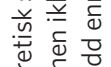

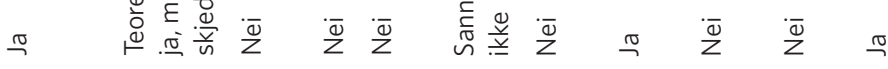

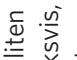

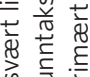

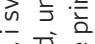

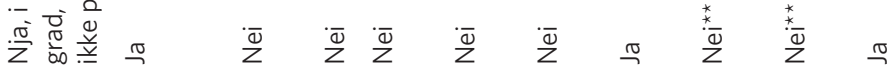

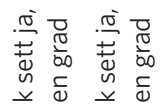
美离离窇离

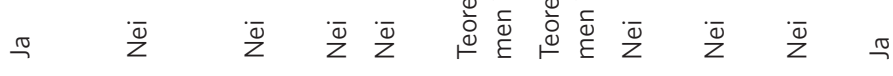

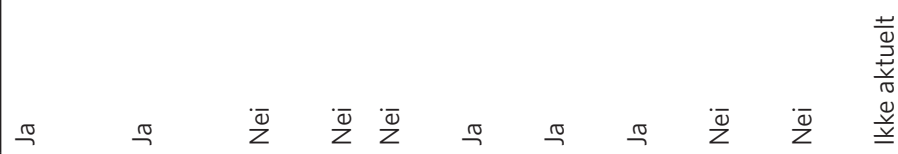

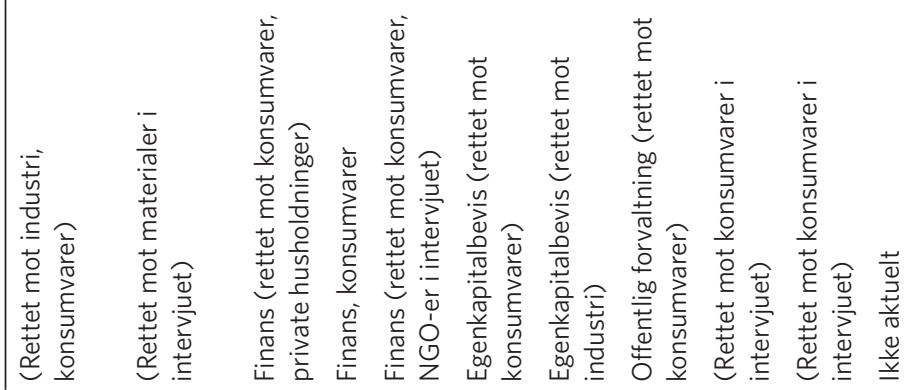

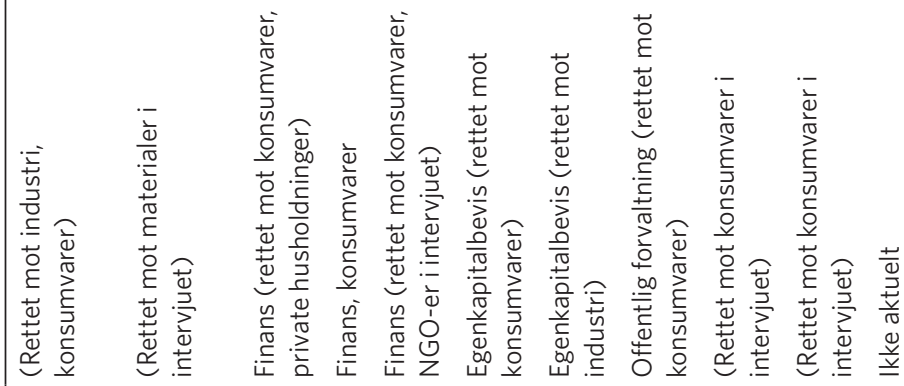

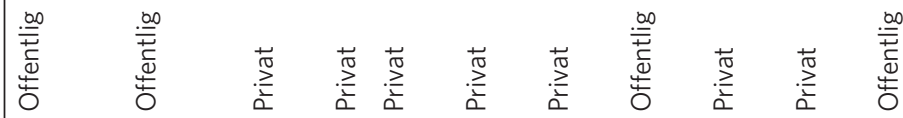

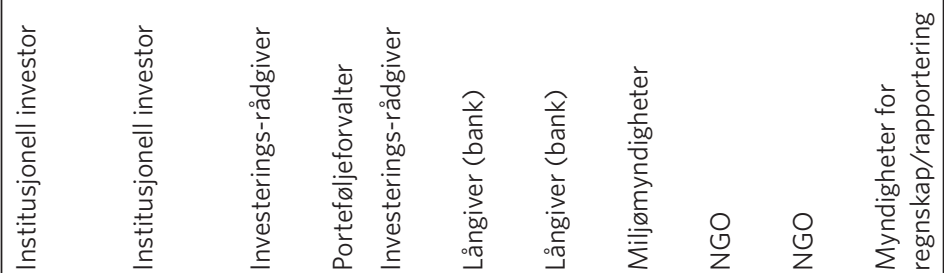

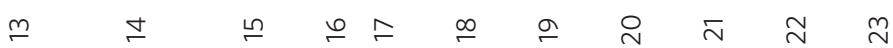




\section{Vedlegg 2}

\section{Referanseliste tilleggsreferanser}

Følgende referanser utdyper andre referanser brukt i teksten, og angir relevante resultater og aktuell videre lesning. Relevante artikler i ordinær referanseliste er ikke ført opp her.

Beattie, V. og Pratt, K. (2002). Voluntary Annual Report Disclosures: What Users Want. The Institute of Chartered Accountants of Scotland, Edinburgh.

Beck, A. C., Campbell, D. og Shrives, P. J. (2010). Content analysis in environmental reporting research: Enrichment and rehersal of the method in a British-German context. The British Accounting Review, Vol. 42, s. 207-222.

Bouten, L., Everaert, P., Liedekerke, L. V., Moord, L. D. og Christiaens, J. (2011). Corporate social responsibility reporting: A comprehensive picture? Accounting Forum, 35, s. 187-204.

Cho, C., Laine, M. Roberts, R. W. og Rodrigue, M. (2015). Organized hypocrisy, organizational façades, and sustainability reporting. Accounting, Organizations and Society, 40, s. 78-94.

Cooper, D., og Essex, S. (1977). Accounting information and employee decision making. Accounting, Organizations and Society, 2(3), s. 201-217.

Deegan, C. og Rankin, M. (1996). Do Australian companies report environmental news objectively?: An analysis of environmental disclosures by firms prosecuted successfully by the Environmental Protection Authority. Accounting, Auditing \& Accountability Journal, Vol. 9, s. 50-67.

Deegan, C. og Rankin, M. (1999). The environmental reporting expectations gap: Australian evidence. The British Accounting Review, Vol. 31, s. 313-346.

Deegan, C., Rankin, M. og Voght, P. (200o). Firms' disclosure reactions to major social incidents: Australian evidence. Accounting Forum, 24(1), s. 101-130.

Ditlev-Simonsen, C. (2016). Rapportering om samfunnsansvar i små foretak. I Anderssen og Bråthen (red.), Moderne forretningsjus III. Bergen: Fagbokforlaget.

Habek, P. og Wolkniak, R. (2016). Assessing the quality of corporate social responsibility reports: the case of reporting practices in selected European Union member states. Quality \& Quantity, 50, s. 399-420.

Harte, G., og Owen, D. (1987). Fighting de-industrialisation: the role of local government social audits. Accounting, Organizations and Society, 12(2), s. 123-142.

Islam, M. A. og Deegan, C. (2010). Media pressures and corporate disclosure of social responsibility performance information: a study of two global clothing and sports retail companies. Accounting and Business Research, Vol. 40, s. 131-148.

Johansen, T. R. (2008a). «Blaming oneself»: Examining the dual accountability role of employees. Critical Perspectives on Accounting, 19, s. 544-571. 
Johansen, T. R. (2008b). Employees and the Operation of Accountability. Journal of Business Ethics, 83, s. 247-263.

Johansen, T. R. (2010). Employees, Non-financial Reports and Institutional Arrangements: A Study of Accounts in the Workplace. European Accounting Review, Vol. 19, s. 97-130.

Larrinaga, C., Carrasco, F., Correa, C., Llena, F. og Moneva, J. M. (2002). Accountability and accounting regulation: the case of the Spanish environmental disclosure standard. The European Accounting Review, Vol. 11, s. 723-740.

Matuszak, L. og Rozanska, E. (2017). CSR Disclosure in Polish-Listed Companies in the Light of Directive 2014/95/EU Requirements: Empirical Evidence. Sustainability, 9.

McBarnet, D., Weston, S., og Whelan, C. (1993). Adversary accounting: strategic uses of financial information by capital and labour. Accounting, Organizations and Society, 18(1), s. 81-100.

Niskanen, J. og Nieminen, T. (2001). The objectivity of corporate environmental reporting: a study of Finnish listed firms`environmental disclosures. Business Strategy and the Environment, Vol. 10, s. 29-37.

O’Dwyer, B., Unerman, J. og Hession, E. (2005). User Needs in Sustainability Reporting: Perspectives of Stakeholders in Ireland. European Accounting Review, Vol. 14, s. 759-787.

Owen, D. L., og Lloyd, A. J. (1985). The use of financial information by trade union negotiators in plant level collective bargaining. Accounting, Organizations and Society, 10(3), s. 329-350.

Patten, D. M. og Zhao, N. (2014). Standalone CSR reporting by U.S. retail companies. Accounting Forum, 38(2), 132-144. 



\title{
Attestasjon av rapportering om sosiale og miljømessige forhold $i$ Norge og internasjonalt - kort blikk på historie, standarder og praksis
}

\author{
Even Fallan
}

\author{
Førsteamanuensis, Høgskolen i Innlandet ${ }^{1}$
}

Sammendrag: Attestasjon av samfunnsansvarsrapportering kan bidra til å øke rapporteringens kvalitet og redusere informasjonsasymmetrien mellom foretak og interessenter. Forskning tyder imidlertid på at dette forutsetter attestasjon av høy kvalitet. ${ }^{2}$ Samtidig øker bruken av slik attestasjon internasjonalt. Det finnes lite forskning på dette aktuelle området i Norge. I lys av det, er formålet med denne artikkelen å bidra med en første kartlegging og beskrivelse av praksis knyttet til bruk av attestasjon av samfunnsansvarsrapportering i Norge, både historisk og i dag, og sette dette i et internasjonalt perspektiv. Gjennom å skissere utfordringer i internasjonal attestasjonspraksis skissert i forskningslitteraturen, samt peke på den heterogene (kommunikasjonen av) attestasjonspraksis (i attestasjonsberetningene) som synes å eksistere også i Norge, kan studier som denne på sikt bidra til økt bevissthet rundt myndigheters/standardsetteres krav til, foretaks bestilling av, leverandører av attestasjonstjenesters gjennomføring og kommunikasjon av attestasjonsoppdrag og -resultat og regnskapsbrukeres forståelse av attestasjoners betydning for rapporteringskvaliteten. Studien er blant annet basert på samtaler med noen relevante aktører i Norge og gjennomgang av forskningsstudier og foretaks attestasjonsberetninger.

Nøkkelord: verifisering; attestasjon av miljørapportering, samfunnsansvarsrapportering og bærekraftsrapportering; attestasjonspraksis; attestasjonsstandard ISAE 3000 og AA1000; rapporteringskvalitet

1 Dette kapitlet representerer en ny vinkling, utvidelse av data-, kilde- og teorigrunnlag og videre bearbeiding av deler av Fallan og Granrud (2020).

2 Høy sikkerhet, relevant innretning og omfang (scope) på oppdraget, visse typer attestasjonshandlinger, tydelig kommunikasjon av hva attestasjonen omfatter og ikke, osv.

Sitering av denne artikkelen: Fallan, E. (2020). Attestasjon av rapportering om sosiale og miljømessige forhold i Norge og internasjonalt - kort blikk på historie, standarder og praksis. I T. Stenheim, K. M. Baksaas og E. M. Kulset (Red.), Aktuelle temaer i regnskap og revisjon (Kap. 10, s. 277-319). Oslo: Cappelen Damm Akademisk. https://doi.org/10.23865/noasp.112.ch10 Lisens: CC-BY 4.0. 


\subsection{Innledning}

De tradisjonelle formålene med regnskap, sett fra etterspørselssiden, er å gi brukernyttig informasjon for ressursallokering og kontroll (Gjesdal, 1981). Formålene er også relevante for samfunnsansvarsrapportering (Fallan, 2013a, 2020). For at regnskap eller rapportering skal bidra til dette, må informasjonen oppfylle visse kvalitative egenskaper (FASB, 1980; IASB, 2018; Ijiri, 1975; Snavely, 1967), slik som relevans, nøytral, feilfri og komplett informasjon, sammenlignbarhet, verifiserbarhet osv. Rapportering av høy kvalitet, som bidrar til å oppfylle formålene med regnskap/rapportering, setter investorer i stand til å ta hensyn til sosiale og miljømessige forhold relevante for investeringsbeslutninger og setter interessenter generelt i stand til å stille foretak til ansvar for sine valg og handlinger knyttet til samfunnsansvar. Brukernyttig rapportering av informasjon om miljømessige, sosiale og økonomiske forhold ved foretak, inkludert eksterne effekter, er altså regnskapets bidrag til å skape en bedre verden. Accounting can help save the world!

Den generelle kvaliteten på foretaks rapportering om sosiale og miljømessige forhold ${ }^{3} \mathrm{er}$ imidlertid lav: Informasjonen utfordrer ofte kvalitetskrav som for eksempel komplett, nøytral, feilfri, sammenlignbar, hard/ objektiv, vesentlig, prediksjonsverdi og bekreftelsesverdi (Boiral \& Henri, 2017; Garcia-Torea et al., 2019; Larrinaga et al., 20184). I tillegg viser studier entydig at en stor andel av foretak ikke (fullt ut) følger rapporteringskrav om sosiale og miljømessige forhold i lover og standarder, verken internasjonalt eller i Norge (Chauvey et al., 2015; Fallan, 2015a, 2016; Fallan \& Fallan, 2009, 2017, 2019; Luque Vilchez \& Larrinaga, 2016; Moe-Helgesen, 2019; $\mathrm{PwC}, 2017^{5}$ ). Dette er krav som er ment å sikre en viss informasjon (av en viss kvalitet). Forskning stiller dermed kritiske spørsmål ved verdien av den generelle rapporteringspraksisen for interessentenes ressursallokerings- og kontrollformål.

3 I denne artikkelen blir begrepene «rapportering om sosiale og miljømessige forhold» og «samfunnsansvarsrapportering» brukt om rapportering om sosiale og miljømessige forhold (inkludert økonomiske/finansielle og foretaksstyringsmessige aspekter ved disse forholdene), og disse begrepene blir her betraktet som synonymer med bærekraftsrapportering, ESG-rapportering, integrert rapportering, tredelt bunnlinje osv. Omtale av slike begreper er gitt i Fallan og Granrud (2020).

4 Andre relevante referanser fra et lengre tidsspenn er lagt i vedlegg.

5 Andre relevante referanser fra et lengre tidsspenn er lagt i vedlegg. 
Attestasjon av rapporteringen - verifisering av innholdet av en uavhengig part som for eksempel en revisor ${ }^{6}$ - er et forhold som kan bidra til bedre kvalitet gjennom økt pålitelighet og relevans for formålene (ACCA, 2004; Helfaya et al., 2018; Hodge et al., 2009; Kolk \& Perego, 2010). Det er bred enighet om at verifiserbarhet er en nødvendig kvalitativ egenskap ved brukernyttig informasjon (FASB, 1980; IASB, 2018; Ijiri, 1975; Snavely, 1967). Videre tilsier agentteori at ekstern verifikasjon (attestasjon) vil redusere informasjonsasymmetrien mellom interessenter og foretak, og dermed også sannsynligheten for opportunistisk atferd (Fallan et al., 2018). Fuhrman mfl. (2017) finner empirisk støtte for at enkelte typer attestasjon av samfunnsansvarsrapportering, men ikke alle, reduserer informasjonsasymmetri. Birkey mfl. (2016) finner også at attestasjon bedrer omgivelsenes syn på foretaks miljøimage.

Attestasjonsprosesser trenger ikke være av verdi for rapporteringen bare det angjeldende året. De kan også bidra til å forbedre senere års rapportering. ? Den som gjennomfører attestasjonen, kan gi råd. Med attestasjonsstandardarden AA10oo skal slike forbedringsforslag til og med inkluderes $i$ attestasjonsberetningen. Foretakets egen oppmerksomhet på rapporteringsprosessen kan også bli styrket av at de vet de skal bli sett i kortene av eksterne. ${ }^{8}$ Sammen med blant annet regulering, standarder og forhåpentligvis etter hvert utdanning er oppbygging av attestasjonstjenester, -praksis og -regelverk også med på å bygge en infrastruktur som kan gjøre samfunnsansvarsrapportering bedre over tid (Gray et al., 2014). Å sette attestasjon (og rapportering) på agendaen kan også øke foretaks fokus på ledelse av og prestasjonsforbedringer knyttet til underliggende sosiale og miljømessige forhold, policyer, forpliktelser og risiko (Zadek et al., 2004), åpenhet om påvirkning og resultater, sikkerhet for etterlevelse av relevante standarder og bedre score på eksterne rangeringer (Thornam, 2019), bidra til stabilitet i markeder (Kend, 2015), osv.

\footnotetext{
6 Attestasjon er forklart nærmere i kapittel 10.3.1.

7 Det er særlig relevant for foretak hvor rapporteringen har lav kvalitet. Samtidig er gjerne ikke disse foretakene de første til å kjøpe attestasjonstjenester.

8 Jf. for eksempel incentivmekanismen skissert i Fallan (2013a, 2020) og Gjesdal (1981).
} 
Imidlertid er det ikke likegyldig hvordan attestasjon(sprosess)en er $^{9}$ (Fuhrman et al., 2017). Reduksjon av informasjonsasymmetri (økning av rapporteringens relevans og pålitelighet) avhenger av sikkerhet for uttalelsen, hvilke attestasjonshandlinger som foretas, hvor stor del eller hvilke deler av foretakets sosiale og miljømessige forhold attestasjonen skal omhandle, osv. I den sammenheng er det nødvendig å sikre at foretak i rapporteringsprosessen innhenter og imøtekommer informasjonsbehovene til et bredere sett av interessenter enn kun de med størst makt (Adams \& Evans, 2004; Cooper \& Owen, 2014; Gray et al., 2014; Hodge et al., 2009; Kolk \& Perego, 2010). Dette innebærer også problematisering av innholdet $i$ attestasjonsstandarder og attestasjonspraksis.

Når attestasjon kan påvirke oppfatninger av foretaks image (Birkey et al., 2016), kan attestasjon også benyttes som et legitimeringsverktøy for foretaksledelsen. Foretak kan imitere andres bruk av attestasjon for å ha ryggen fri, uten at attestasjon i seg selv bedrer de attesterte forholdene. Hummel mfl. (2019) fant til og med en negativ sammenheng mellom foretaks prestasjoner på sosiale og miljømessige forhold og attestasjon av samfunnsansvarsrapportering. Dette blir tolket som at attestasjon kan bli brukt til kamuflering, særlig når attestasjonen har lav sikkerhet og bare dekker et begrenset område (høy attestasjonsrisiko samlet sett). Legitimeringshensyn kan til og med påvirke revisors arbeid. Michelon mfl. (2019) indikerer at leverandører av attestasjonstjenester påpeker uvesentlige feil for å legitimere behovet for tjenestene og skape et marked.

Omfanget av attestasjon og dens potensielle og reelle rolle gjør attestasjon til et betydningsfullt tema, både i praksis og forskningsmessig. Attestasjon av samfunnsansvarsrapportering har økt vesentlig blant de største foretakene i verden og i ulike land de siste 20 årene (KPMG, 2017). Utviklingen har imidlertid vært forbeholdt store foretak (Cooper \& Owen, 2014). Norske foretak har også hengt etter (Fuhrman et al., 2017). Attestasjon kan bidra til å øke rapporteringens kvalitet og redusere informasjonsasymmetri mellom foretak og interessenter, samtidig som forskning indikerer at attestasjon også kan gi rapportering et skinn

9 Egenskaper ved attestasjonen, attestasjonsoppdraget, attestasjonsberetningen/-rapporten og attestasjonsprosessen. 
av pålitelighet og kvalitet som ikke stemmer med virkeligheten (Adams et al., 2020; Adams \& Evans, 2004; Cooper \& Owen, 2014; Gray et al., 2014; Larrinaga et al., 2018; Michelon et al., 2019). Siden rapportering av informasjon som oppfyller formålene med regnskap kan bidra til bedre beslutningsgrunnlag og økt ansvarliggjøring med hensyn til samfunnsansvarsforhold, er det viktig å øke bevisstheten om attestasjon, dens rolle og praksis, både historisk og i dag..$^{10}$ Det gjelder både myndigheter/standardsettere, foretak som bestiller attestasjonstjenester, leverandører av attestasjonstjenester og regnskapsbrukere, internasjonalt og i Norge. Forskning på attestasjon av rapportering av sosiale og miljømessige forhold er nesten ikke-eksisterende i Norge. I første omgang er det dermed behov for grunnleggende, beskrivende studier av attestasjon av samfunnsansvarsrapportering her til lands, hvor internasjonal praksis, standarder og forskning er referanseramme. Problemstillingen for denne artikkelen er derfor: Hvordan er attestasjonspraksis for samfunnsansvarsrapportering blant norske foretak, historisk og i dag, sett opp mot attestasjonsstandarder og internasjonale erfaringer?

Etter Fallan og Granrud (2020), er dette en av de første fagfellevurderte kartlegginger av slik attestasjonspraksis i Norge.

\subsection{Metode}

Dette er en kvalitativ studie, basert på en kombinasjon av mange ulike typer data og datakilder.

Fallan og Granrud (2020) var et første, lite og ressursmessig avgrenset forsøk på å beskrive attestasjonspraksis og rammebetingelser for attestasjon av samfunnsansvarsrapportering i Norge. Arbeidet med den studien viste at data, informasjon og kunnskap om dette er fragmentert, fordelt på mange skriftlige og særlig muntlige kilder av varierende tilgjengelighet. Det finnes lite systematisert kunnskap om temaet i

10 For eksempel hvilke foretak som skal attestere sin rapportering, hvilken sikkerhet for uttalelsen attestasjonen skal ha, hvilke deler av foretakets sosiale og miljømessige forhold samt foretakets rapportering som attestasjonen skal omfatte, hvem som skal være adressat for attestasjonen, hvilke attestasjonshandlinger som skal gjennomføres, hva som skal stå i attestasjonsberetningen, osv. 
forskningspublikasjoner. Denne studien er derfor starten på en mer systematisk tilnærming til data- og informasjonsinnhenting. En selvstendig motivasjon for studien er å få oversikt over ressurspersoner, datakilder osv. Slik sett må denne studien, med hensyn til datainnhenting, sies å være av eksplorativ karakter. Et design basert på diverse datakilder, som dette, har imidlertid også styrker. Denne studien kan bidra til at kildematerialet knyttet til norsk attestasjonspraksis over tid blir lettere tilgjengelig for alle, og det blir enklere å lage renere forskningsdesign.

Datakilder i studien inkluderer:

- Forskningslitteratur. Søk tok utgangspunkt i oppsummerende bokkapitler i utenlandske «lærebøker»/fagbøker samt i ordinære forskningsdatabaser.

- Andre studier av attestasjonspraksis i Norge. Dette ble søkt etter på nett samt etterspurt fra enkelte informanter opplistet nedenfor.

- Foredrag med Moe-Helgesen (2019) og Thornam (2019) på Revisorforeningens DNR-dagen, 6. juni 2019, på Thon Hotel Opera i Oslo. I fraværet av et rikt utvalg av offentlig tilgjengelige skriftlige kilder om norsk attestasjonspraksis er det kjærkomment med offentlig tilgjengelige foredrag på film fra attestasjonsbransjen selv.

- Attestasjonsberetninger for norske foretak fra 2009 og 2018. Identifisering av slike foretak har skjedd gjennom samtaler (inkludert med informantene opplistet nedenfor), søk på internett, oversikt fra tilbydere av attestasjonstjenester, databaser mv. Beretninger vedrørende 2018 ble valgt fordi det var de nyeste tilgjengelige rapportene. Året 2009 ble valgt som en avveining mellom et tidspunkt så tidlig at etterfølgende utvikling $\mathrm{i}$ attestasjonspraksis burde forventes, og behovet for at det skulle finnes flere selskaper som hadde fått foretatt slik attestasjon. Ytterligere informasjon om utvalgsprosessen er gitt i kapittel 10.5.2.

- Intervjuer med relevante ressurspersoner i Norge. Det blir gitt ytterligere informasjon om disse i tabell 10.1. Alle samtalene ble foretatt våren 2020, med unntak av R7..1

11 Ingen av samtalene inngikk som del av datagrunnlaget for Fallan og Granrud (2020). 
Tabell 10.1 Oversikt over informanter

\begin{tabular}{|c|c|c|c|c|}
\hline Informant & $\begin{array}{l}\text { Foretak } \\
\text { (samtale i } \\
\text { hovedsak } \\
\text { omhandlet) }\end{array}$ & Rolle / årsak til inkludering & Type datainnhenting & $\begin{array}{l}\text { Varighet } \\
\text { samtale }\end{array}$ \\
\hline R1 & $A$ & $\begin{array}{l}\text { Rapporterende foretak, i dag } \\
\text { og/eller tidligere }\end{array}$ & $\begin{array}{l}\text { Telefon og div. } \\
\text { e-poster etterpå }\end{array}$ & Ca. $45 \mathrm{~min}$. \\
\hline R2 & B & $\begin{array}{l}\text { Rapporterende foretak, i dag } \\
\text { og/eller tidligere }\end{array}$ & $\begin{array}{l}\text { Telefon og } \\
\text { oppfølgende e-post }\end{array}$ & Ca. 5 min. \\
\hline R3 & $\mathrm{A} / \mathrm{B} / \mathrm{C} /$ flere & $\begin{array}{l}\text { Tilbyder av attestasjonstjenester, } \\
\text { i dag og/eller tidligere }\end{array}$ & Telefonsamtale & Ca. 70 min. \\
\hline R4 & D/flere & $\begin{array}{l}\text { Tilbyder av attestasjonstjenester, } \\
\text { i dag og/eller tidligere }\end{array}$ & Telefonsamtale & Ca. 25 min. \\
\hline R5 & E/flere & $\begin{array}{l}\text { Tilbyder av attestasjonstjenester, } \\
\text { i dag og/eller tidligere }\end{array}$ & $\begin{array}{l}\text { Telefonsamtale og } \\
\text { oppfølgende e-poster }\end{array}$ & Ca. $20 \mathrm{~min}$. \\
\hline R6 & F/flere & $\begin{array}{l}\text { Tilbyder av attestasjonstjenester, } \\
\text { i dag og/eller tidligere }\end{array}$ & $\begin{array}{l}\text { Møte, telefonsamtale } \\
\text { og div. e-poster }\end{array}$ & Ca. 60 min. \\
\hline R7 & G & Regulering & Telefonsamtale & Ca. $45 \mathrm{~min}$. \\
\hline
\end{tabular}

\subsection{Hva er attestasjon av rapportering om sosiale og miljømessige forhold?}

\subsubsection{Generelt om attestasjon av samfunnsansvarsrapportering}

Attestasjon av rapportering vil si at en uavhengig part (tjenesteleverandøren) verifiserer et saksforhold ${ }^{12}$ fra den ansvarlige part (foretaket) utfra identifiserte kriterier og med en konklusjon med angitt sikkerhet slik at usikkerheten reduseres for en tredjepart (interessenten) (Tvedt, 2018).

Attestasjon (verifisering) kan gjelde et hvilket som helst forhold, også foretaks rapportering om sosiale, miljømessige og tilliggende økonomiske forhold (samfunnsansvarsrapportering). Informasjon om slike

12 Historiske, finansielle resultater og finansiell stilling, ikke-økonomiske resultater/prestasjoner, fysiske karakteristika, systemer og prosesser, atferd og annet. 
forhold finnes både i finansregnskapet, ${ }^{13} \mathrm{i}$ årsberetningen, ${ }^{14}$ ellers i årsrapporten, i separate rapporter, på nettsiden og andre steder. Informasjonen i finansregnskapet er en del av den ordinære revisjonen. Det er ikke tema i denne artikkelen. Attestasjon av annen samfunnsansvarsrapportering er frivillig. Det er for eksempel ikke et krav i den ordinære revisjonen at samfunnsansvarsrapportering $\mathrm{i}$ årsberetningen ${ }^{15}$ blir vurdert mot virkeligheten. Det kan inngå i en attestasjon. Hva slike attestasjonsoppdrag omfatter, blir bestemt og avgrenset i hvert tilfelle. Det kan være en rapport som attesteres, deler av en rapport, et eller flere nøkkeltall, osv. Attestasjonen kan ha ulik grad av sikkerhet. Selv om attestasjon ikke er obligatorisk, er det anbefalt av rapporteringsstandarder som Global Reporting Initiative (GRI). GRI markerte i mange år selskaper med attestert rapportering med et eget suffiks $(+)$ som vedheng til deres rapporteringsnivå (Knebel \& Seele, 2015).

Tjenesteleverandører av attestasjon av samfunnsansvarsrapportering er i dag revisjonsselskaper (inkludert alle de store), andre konsulent- og/ eller sertifiseringsselskaper ${ }^{16}$ og enkelte NGO-er (jf. blant annet informant $\mathrm{R}_{1}, \mathrm{R}_{3}, \mathrm{R}_{4}$ og $\mathrm{R}_{5}$ ).

\subsubsection{Attestasjonsstandarder}

De to viktigste attestasjonsstandardene for samfunnsansvarsrapportering i dag er ISAE 3000 og AA100o ${ }^{17}$ (Adams \& Evans, 2004; Cooper \&

13 Finansregnskapet kan potensielt inneholde en rekke transaksjoner, inntekter, kostnader, eiendeler og forpliktelser som direkte eller indirekte gjelder slike forhold. Ifølge regnskapsloven $\$ 7$-34 skal det opplyses i note om fjernings- og oppryddingsforpliktelser ved olje- og gassproduksjon, kraftproduksjon og gruvedrift. Men det er også snakk om regnskapsføring av eller opplysninger om for eksempel utgifter og inntekter i forbindelse med renseanlegg, utgifter for sikkerhetstiltak for ansatte, bøter for ulovlig lakserømming, utgifter i forbindelse med rettsak etter alvorlig personskade på arbeidsplassen, utgifter til miljøsertifisering av bedrift eller produkt, varemerkeverdi knyttet til grønn profil eller rett og slett utgifter til rapportering og attestasjon av samfunnsansvarsrapportering.

14 Jf. også krav i regnskapsloven.

15 Regnskapsloven $\$ \$ 3-3 a$ og 3-3c og NRS 16 Årsberetning (Norsk RegnskapsStiftelse, 1999/2019).

16 For eksempel The Governance Group, Lloyds og DNV GL (tidligere Det norske veritas).

17 Det finnes også nasjonale standarder i enkelte land (for eksempel Sverige) som blir hyppig brukt, gjerne i kombinasjon med ISAE 3000 og/eller AA10oo. 
Owen, 2014; Fuhrman et al., 2017; Gray et al., 2014; Helfaya \& Kotb, 2016; Larrinaga et al., 2018; Michelon et al., 2019).

Den internasjonale revisjonsstandarden ISAE 3000 omhandler «attestasjonsoppdrag som ikke er revisjon eller forenklet kontroll av finansiell informasjon». Standarden blir utarbeidet av IAASB, ${ }^{18}$ som er underlagt International Federation of Accountants (IFAC). Den første utgaven av ISAE 3000 ble godkjent i 2003. Det har kommet oppdaterte versjoner senere. Standarden er per i dag den dominerende standarden i Norge for attestasjon av samfunnsansvarsrapportering. Den viktigste årsaken til det er at revisorer, som har de fleste attestasjonsoppdragene i Norge, krever å benytte den, ifølge informant R1, R3 og R6. 16 av verdens 50 største selskaper ( 32 prosent) får foretatt attestasjon av samfunnsansvarsrapportering i henhold til ISAE 3000 (Jagd, 2015).

Attestasjonsstandarden AA10ooAS inngår i en serie standarder knyttet til samfunnsansvar utgitt av AccountAbility (AccountAbility, 2018a, 2018b). De har også utgitt standarder siden rundt årtusenskiftet og har varslet en ny versjon av attestasjonsstandarden i 2020. Standarden er brukt ved attestasjon av samfunnsansvarsrapporteringen hos 10 av verdens 50 største selskaper (20 prosent) (Jagd, 2015). I Norge har for eksempel Norsk Hydro tidligere brukt denne standarden.

Det gis ikke en grundig beskrivelse av ISAE 3000 og AA10oo her. Nærmere presentasjoner er for eksempel gitt i Fallan og Granrud (2020) og Jagd (2015). Både Fuhrman mfl. (2017) og Larrinaga mfl. (2018) gir i appendiks en punkt-for-punkt-sammenligning av de to standardene. Analyser og/eller sammenligninger er også foretatt blant annet i Adams og Evans (2004), Cooper og Owen (2014) og Gray mfl. (2014). Noen momenter om standardene bør likevel nevnes her av hensyn til kapitlets videre diskusjon.

Et viktig og felles trekk er at standardene skiller mellom «betryggende sikkerhet» (reasonable assurance) og "moderat sikkerhet» (limited assurance) når det gjelder attestasjoners konklusjon. De nødvendige attestasjonshandlinger avhenger av hvilken grad av sikkerhet som skal gis. Konklusjon med betryggende sikkerhet skal uttrykkes i positiv form. 
Dette innebærer at revisor går god for at rapportert informasjon «i det alt vesentlige» er korrekt, at rapporter «i det alt vesentlige» er utarbeidet i samsvar med aktuelle kriterier, osv. Moderat sikkerhet innebærer en konklusjon på negativ form, altså hvorvidt revisor gjennom sitt arbeid har blitt oppmerksom på et eller flere forhold som indikerer at påstander og informasjon som skal attesteres, inneholder vesentlig feilinformasjon. Det er mulig at konklusjon med både høy og moderat sikkerhet benyttes for ulike deler av attestasjonsoppdraget hos ett og samme selskap, i ett og samme år. Ifølge Jagd (2015) har 87 prosent av ISAE 3000- og 90 prosent av AA10oo-attestasjoner av samfunnsansvarsrapporteringen blant verdens 50 største selskaper moderat (lav) sikkerhet. Det vil si hos tilsammen 23 selskaper. Bare to av ISAE 300o-selskapene og ett AA10oo-selskap hadde attestasjon med betryggende sikkerhet. (Resten av selskapene hadde ikke attestasjon av rapporteringen.) Senere i kapitlet vil vi se at vi har samme tendens i Norge.

En overordnet forskjell mellom standardene er at ISAE 3000 er basert på den velprøvde logikken i revisjonsstandarder for det tradisjonelle finansregnskapet, mens AA10oo i større grad er ment å fokusere på identifikasjon og ivaretakelse av interessenters (også andre enn eieres) behov for informasjon (Adams \& Evans, 2004; Cooper \& Owen, 2014; Gray et al., 2014; Larrinaga et al., 2018). Skillet kommer også til uttrykk i selve attestasjonsberetningen. ISAE 3000 skiller i stor grad mellom ren beretning og ikke, slik tradisjonelle revisjonsberetninger gjør. Avdekkede forhold kommuniseres til foretaket privat og er ikke offentlig tilgjengelig. Beretningen etter AA10oo er ment å kommunisere med en bredere gruppe interessenter enn kun foretaksledelsen. Det er for eksempel meningen at beretningen skal gi detaljert informasjon om forhold som er identifisert i forbindelse med attestasjonen, inkludert sterke og svake sider, forslag til forbedringer, osv. (Jagd, 2015). Anbefalingen om attestasjon i Adams mfl. (2020) virker å orientere seg mot perspektiver fra både ISAE 3000 og AA10oo.

Forskningslitteraturen stiller kritiske spørsmål til i hvilken grad attestasjonsstandardene og attestasjonspraksis bidrar til økt brukernytte for ulike interessenter. Noen konkrete eksempler på dette blir beskrevet senere i kapitlet. Men generelt omhandler det valgfrihet i standardene 
(hva som skal attesteres, med hvilken sikkerhet, hvilke metoder som brukes, osv.), hvem attestasjonen er til for (foretaksledelse versus flere interessentgrupper), inkludert attestasjonsleverandørens rolle, bestillingsprosessen (oppdragets art), hvilke forhold attestasjonen og attestasjonsberetningen uttaler seg om (inkludert prosesser versus resultater), osv. (Adams \& Evans, 2004; Cho et al., 2014; Cooper \& Owen, 2014; Gray et al., 2014; Segui-Mas et al., 2018).

\subsection{Utbredelse av attestasjon av samfunnsansvarsrapportering}

\subsubsection{Tidlige spor av attestasjon av samfunnsansvarsrapportering}

Rapportering om sosiale og miljømessige forhold kom selvsagt før attestasjon av rapporteringen. Internasjonalt er det dokumentert tilfeller av rapportering av informasjon om sosiale og miljømessige forhold (inkludert forhold knyttet til ansatte og lokalsamfunn) tilbake til 180o-tallet, men selve oppstarten av moderne samfunnsansvarsrapportering regnes å være på 1960- og 70-tallet (Buhr et al., 2014; Crowther \& Aras, 2008; Gray et al., 2014). Norge fikk verdens første allmenne ${ }^{19}$ lovkrav til foretaks offentlige miljørapportering (ytre miljø) i årsberetningen fra 1989. På det tidspunktet hadde Norge allerede krav om rapportering om arbeidsmiljø. Men det var heller ikke uvanlig med miljørapportering i årsrapporten før 1989 (Fallan, 2013b; Fallan \& Fallan, 2007, 2009). Om vi ser utover årsrapporten, var Norsk Hydros miljørapport for 1989 var blant verdens første separate miljørapporter (Lober et al., 1997). Internasjonalt var det flere selskaper som utga slike rapporter for 1989, mens den tidligste rapporten Lober mfl. (1997) har identifisert, virker å være Polaroids rapport for 1988. Det kan legges til at Norsk Hydros miljørapportering på tidlig 1990-tall ble regnet for å være verdensledende og satte en standard som få selskaper senere har oppnådd, ifølge Buhr mfl. (2014, s. 54). Norske Skog var et annet selskap som lå langt framme på det tidspunktet. 
Det er vanskelig å vite sikkert hva som er de første eksemplene på verifisering/attestasjon av samfunnsansvarsrapportering. Lober mfl. (1997) gir en oversikt over 14 amerikanske selskaper som har fått utført slik attestasjon. På grunn av tidsforskyvning i publisering både av miljørapporter og forskningsartikler må disse gjelde for regnskapsåret 1995 eller tidligere. Ball mfl. (2000) gir eksempler fra blant annet Dow Europes attestasjon for 1994 samt Caird Group for 1991 og 1992. Det er imidlertid noe uklart om sistnevnte er verifisering av rapportering og/eller bare verifisering av miljøforhold (altså mer type miljørevisjon). Ifølge informant R1 var Norsk Hydros britiske datterselskap etter sigende svært tidlig ute (i verdensmålestokk) med attestering av sin miljørapport. Det skjedde en gang mellom 1989 og 1996 og ble foretatt av Lloyds. Tidspunktet har forfatteren ikke klart å bringe på det rene ennå.

Tidsperspektivet for tidlige attestasjoner av samfunnsansvarsrapportering kan også belyses ved hjelp av Preben J. Sørensens historie. Han er nestor innen attestasjon av samfunnsansvarsrapportering i verdenssammenheng. I forbindelse med sin partnerkvalifisering i Deloitte i Danmark skrev han i 1992 et idenotat om miljøregnskap som forslag til potensielle nye forretningsområder. Det var starten på hans arbeid på området. ${ }^{20}$

Ball mfl. (2000) og Beets og Souther (1999) viser til EMAS (EUs forordning for miljøstyring og miljørevisjon) og ISO14001 som sertifiseringsordninger som kunne motivere attestasjon. I motsetning til andre sertifiseringsordninger, som ISO14001, hadde EMAS krav til miljørapportering og verifisering av denne (jf. informant R4). EMAS trådte offisielt i kraft i EU i april 1995, men både ISO14001 og EMAS’ foreløpige standardtekster er fra ca. 1992.

Siden det ikke har vært særlig forskning på området i Norge, er det ikke enkelt å etablere når de første attestasjonene ble foretatt. Selskaper som ble sertifisert i henhold til EMAS, var tidlig ute. For eksempel fikk kontorstolprodusenten $H A ̊ G$ på Røros verifisert sin miljørapport (integrert i årsrapporten) for 1996. Verifiseringen ble foretatt av Dovre Sertifisering. Årsaken til at Norske Skog startet med attestasjon av miljørapporteringen, 
er etter sigende at attestasjon ble trukket fram i begrunnelsen da SAS vant en nordisk pris for god miljørapportering (jf. informant R3). Norske Skog fikk verifisert sin miljørapport for 1997 av Deloitte \& Touche, signert av danske Preben J. Sørensen. Selskapet fikk tre fabrikker EMAS-godkjent i 1997. Ifølge årsrapportene for 1995 og 1996 hadde de imidlertid fått en fabrikk godkjent i 1996. Det er derfor sannsynlig at deres første verifisering av miljørapportering skjedde i $1996 .{ }^{21}$ EMAS fikk imidlertid ikke noe særlig gjennomslag i Norge, så det er sannsynligvis ikke et stort antall selskaper dette gjelder for. Norsk Hydro fikk attestert sin konsernrapportering første gang i 1997, gjennomført av Deloitte \& Touche. Ifølge informant $\mathrm{R}_{3}$ ble rapporten signert av Ingebret $\mathrm{G}$. Hisdal som var partner for det ordinære revisjonsoppdraget, men danske Preben J. Sørensen hadde ansvar for planleggingen av attestasjonen og Frank Dahl hadde en sentral rolle i gjennomføringen. ${ }^{22}$

\subsubsection{Utbredelse av attestasjon av foretaks samfunnsansvarsrapportering}

Utviklingen over tid viser en klar økning i uavhengig attestasjon av samfunnsansvarsrapportering blant de største selskapene internasjonalt. Andelen av verdens 250 største selskaper (G250) som attesterer rapporteringen har økt fra 19 prosent i 1999 til 29 prosent i 2002, 30 prosent i 2005, 46 prosent i 2011 og 67 prosent i 2017 (Buhr et al., 2014; KPMG, 2017). Blant de 100 største selskapene i hvert av mange land (N100) var samme tall i gjennomsnitt 18 prosent i 1999, 27 prosent i 2002, 33 prosent i 2005, 38 prosent i 2011 og 45 prosent i $2017 .{ }^{23}$ Det er imidlertid store variasjoner mellom land (Cooper \& Owen, 2014; Fuhrman et al., 2017; Kolk \& Perego, 2010; Larrinaga et al., 2018; Simnett et al., 2009).

21 Forfatteren har ikke fått tak i miljørapporten for 1996 eller fått informasjon om dette fra selskapet. Det ble ikke foretatt attestasjon i 1994 eller 1995 (dvs., det ikke ble vist (til) attestasjonsberetning i rapporteringen).

22 Jeg trekker fram disse navnene her fordi de dukker opp igjen i kapittel 10.5.2.

23 I 2017 gjelder dette gjennomsnittstallene for de 100 største selskapene i 49 land, mens det for eksempel i 2002 gjaldt de 100 største selskapene i 19 land. Mange land som var inkludert i undersøkelsen tidlig, ligger gjerne på et høyere nivå enn en del av dem som er inkludert nylig. Slik sett er prosenttallene over tid ikke helt sammenlignbare. 
Studier indikerer at foretaks størrelse, bransje, børsnotering og lønnsomhet har sammenheng med adopsjonsraten for attestasjon (Branco et al., 2014; Peters \& Romi, 2015; Salterbaxter-Context, 2005; Sierra-García et al., 2018; Simnett et al., 2009). En sammenligning av gjennomsnittstallene for G250 og N10o (hvor størrelsen på N10oselskapene i gjennomsnitt er langt lavere enn for G250-selskapene) indikerer at størrelse er en relevant forklaringsfaktor for utbredelsen av denne typen uavhengige attestasjonstjenester. Larrinaga mfl. (2018) angir at 50 prosent av alle italienske selskaper og 70 prosent av alle amerikanske selskaper som har publisert attestasjonsberetninger, ${ }^{24} \mathrm{er}$ børsnoterte. ${ }^{25}$ Thornam (2019) indikerer det samme i Norge. Mange forhold tilsier at det sannsynligvis er få selskaper som kjøper attestasjon av samfunnsansvarsrapportering når vi beveger oss en god del under de topp 100 største selskapene, men det er ønskelig med flere studier som viser dette i Norge.

Ifølge Fuhrman mfl. (2017) hadde Norge nest laveste andel selskaper med attestasjon av 17 europeiske land (20 prosent) i 2008 og 2009. 40 prosent av de 100 største selskapene kjøpte ekstern attestasjon av samfunnsansvarsrapporteringen i 2014 ( $\mathrm{PwC}, 2015)$, et tall som var redusert til 30 prosent for $2016(\mathrm{PwC}, 2017)$. Andelen i Norge for dette året lå dermed langt under gjennomsnittet blant de 100 største selskapene i hvert av 49 land ( 45 prosent) vist ovenfor. I PwCs norske topp 10o-undersøkelse fra 2019 er det ikke lagt inn tall for attestasjon ( $\mathrm{PwC}$, 2019). I kommunikasjon har de imidlertid formidlet at det var 24 av de 100 største selskapene som hadde slik attestasjon (jf. informant $\mathrm{R}_{5}$ ). Da er vi omtrent nede på nivået Fuhrman mfl. (2017) fant at Norge var på i $2008 / 2009$.

Blant de 100 største selskapene i Norge hadde 45 prosent av de 33 allmennaksjeselskapene (ASA) slik ekstern verifikasjon for 2014, mot 37 prosent blant de øvrige selskapene ( $\mathrm{PwC}, 2015)$. I rapporteringen

\footnotetext{
24 Ifølge GRIs database.

25 Det framgår dog ikke eksplisitt at de børsnoterte selskapene er større enn ikke-børsnoterte.
} 
for 2016 hadde imidlertid 50 prosent av 38 ASA attestert samfunnsansvarsrapportering mot kun 18 prosent for andre selskaper ( $\left.\mathrm{PwC}_{\mathrm{w}}, 2017\right)$. Forskjellen var enda større blant de 100 største selskapene dersom vi skiller mellom de med og uten statlig eierskap. 63 prosent av de 16 selskapene med statlig eierskap hadde attestasjon mot 24 prosent blant de 84 selskapene uten statlig eierskap ( $\mathrm{PwC}$, 2017). Dette er i tråd med de særskilte forventningene staten har uttrykt til samfunnsansvarsrapportering (og dermed attestasjon) for selskaper de har eierandel i (Meld. St. 13 (2010-2011)). Uten at vi kjenner grunnlagstallene for $\mathrm{PwC}$ (2015, 2017), er sannsynligvis mange av de statlig eide selskapene (Equinor, Hydro, Telenor, DnB osv.) også blant de største selskapene. Størrelse er tradisjonelt en viktig forklaringsfaktor med hensyn til rapportering, noe også forskjellen i tallene ovenfor mellom de 250 største selskapene i verden og gjennomsnittet av de 100 største i hvert av 49 land (som er langt mindre selskaper) viser.

Tiltross for tallene ovenfor blir det hevdet fra flere aktører i revisjonsbransjen at aktiviteten (etterspørselen etter) og økonomien i hele spekteret av tjenester knyttet til samfunnsansvarsrapportering og attestering har bedret seg vesentlig de siste par årene (se for eksempel Thornem, 2019). Det kan skyldes at omfanget av hvert attestasjonsoppdrag har økt. I tillegg vil ikke rådgivning og «trail»-audits komme med i tallene ovenfor. Historisk har ofte økonomien i attestasjon av samfunnsansvarsrapportering vært begrenset. Det har vært knyttet både til antall oppdrag og til størrelsen på honorarer. En tidlig svensk studie fant at attestasjonshonorarer knyttet til rapportering om sosiale og miljømessige forhold typisk utgjorde 4 til 6 prosent av revisjonshonoraret for den ordinære revisjonen (Park \& Brorson, 2005). En litt nyere studie blant selskaper notert på London-børsen (FTSE) fant at tilsvarende tall typisk var under 10 prosent (Cooper \& Owen, 2014).

EY forventet å være 13 ansatte som jobbet med slike tjenester i Norge høsten 2019, og de hadde da blant annet kunder som DnB, DOF, Equinor, Posten og Tine (Thornam, 2019). PwC attesterer blant annet Storebrand, Lerøy, KLP, Lundin, SAS (PwC Sverige) og Sparebankı Østlandet. De har nå slike samfunnsansvarsmiljøer i Oslo og Bergen og planlegger opplæring av medarbeidere også andre steder i landet (informant R5). 


\subsection{Attestasjonspraksis}

\subsubsection{Forskningsstudiers kritiske blikk på internasjonal attestasjonspraksis}

Det er i ferd med å vokse fram en omfattende forskningslitteratur som undersøker attestasjonspraksis for samfunnsansvarsrapportering. Det er ikke mulig å gi en uttømmende oversikt over litteraturen i dette kapitlet, men jeg vil peke på noen trekk.

\section{Attestasjonspraksis på 1990-og tidlig 2000-tall - behov for nye standarder}

På 1990-tallet ble det oppfattet å være vesentlige utfordringer knyttet til attestasjonspraksis for miljørapportering (Adams \& Evans, 2004; Cooper \& Owen, 2014; Gray et al., 2014). Studier pekte på lav brukernytte på grunn av manglende systematikk, manglende konsistens knyttet til hvilke temaer som ble adressert, omfang og innretning på oppdragene, formål med attestasjonen, attestasjonskriterier og -handlinger, nivå av sikkerhet som attestasjonene ga, attestasjonsarbeidets grundighet, måten attestasjonsberetningene ble utformet/formulert på og attestasjonsleverandørenes uavhengighet. Foretaksledelsen ble ansett å ha stor grad av kontroll over hele attestasjonsprosessen (Adams \& Evans, 2004). Når attestasjonen i tillegg ofte fokuserte på ledelsessystemer i stedet for resultater, kunne det være egnet til å redusere åpenhet og ansvar overfor eksterne interessenter (Cooper \& Owen, 2014). Det oppstod et forventningsgap mellom interessentenes behov for verifikasjon og attestasjonenes innhold (Adams \& Evans, 2004; Kamp-Roelands, 1999).

Attestasjon av rapportering om samfunnsansvar og samfunnsansvarsforhold er også i utgangspunktet ${ }^{26}$ langt mer komplekst enn for eksempel revisjon av finansregnskapet. Årsaken er at de underliggende forholdene som skal attesteres, er mer komplekse: eksterne effekter, mange potensielt relevante måleenheter, uklarhet i målekriterier og manglende kunnskap om komplekse sammenhenger i for eksempel naturen stiller store krav til avgrensning, gjennomføring av kommunisering av oppdrag og resultater

26 Dog avhengig av oppdragets art. 
for attestasjon. Den generelt lave rapporteringskvaliteten gjør ikke saken enklere (se for eksempel Adams \& Evans, 2004).

Oppsummert synliggjorde mangelen på brukernytte behov for blant annet større grad av standardisering av attestasjon (Cooper \& Owen, 2014; Gray et al., 2014) og eventuelt lovkrav knyttet til slik attestasjon (Adams \& Evans, 2004). Dette lå til grunn for utvikling og bruk av (nye) attestasjonsstandarder som AA10oo og ISAE 3000 (Adams \& Evans, 2004; Cooper \& Owen, 2014; Gray et al., 2014). Flere land har også utviklet nasjonale standarder. ${ }^{27}$ Diffusjon av brukernyttig attestasjon gjennom «forced selection» (Abrahamson, 1991), lovkrav om attestasjon av samfunnsansvarsrapportering, har imidlertid ikke fått særlig gjennomslag, verken for spesifikke standardarder eller generelt. Vi skal se på noen resultater om hvordan de nye standardene påvirker attestasjonspraksis knyttet til brukernytte, slik som behov for sammenlignbarhet (ensartethet og konsistens), hensiktsmessig omfang, innretning og sikkerhet og standardisering.

\section{Utvikling utover 2000-tallet - valgfrihet innenfor standardene og standardisering av attestasjonspraksis}

Det er stor valgfrihet innenfor de nye attestasjonsstandardene. Dette gir mulighet til å skreddersy løsninger for ulike foretak og situasjoner, samtidig som det kan medføre utfordringer knyttet til bruk og rom for opportunisme / strategisk bruk av attestasjon. Et eksempel er valget mellom betryggende/høy og moderat/lav attestasjonssikkerhet. Jagd (2015) fant at 90 prosent av AA10oo-attestasjoner og 87 prosent av ISAE 300o-attestasjoner blant verdens 50 største selskaper hadde lav sikkerhet for uttalelsen, som skissert ovenfor. Beskrivelser av forskjellene på attestasjon med betryggende versus moderat/lav sikkerhet illustrerer hvordan denne attestasjonspraksisen kan redusere samfunnsansvarsrapporteringens brukernytte (Adams \& Evans, 2004; Cooper \& Owen, 2014; Gray et al., 2014; Jagd, 2015).

En annen type valgfrihet er attestasjonsoppdragets omfang og innretning. Dette handler om hvor mye og hva som skal attesteres, og har

27 Vi skal se et eksempel på bruk av en slik hos SAS i kapittel 10.5.2. 
også vesentlig (negativ) innvirkning på brukernytten (Adams \& Evans, 2004; Boiral \& Henri, 2017; Borial \& Heras Saizarbitoria, 2019; Cooper \& Owen, 2014; Gray et al., 2014). Temaene knyttet til valgfrihet blir illustrert nærmere i forbindelse med eksemplene fra norsk attestasjonspraksis i kapittel 10.5.2.

De nye attestasjonsstandardene har likevel medført økt standardisering, for eksempel av ordleggingen i attestasjonsberetningen (Cooper \& Owen, 2014). Larrinaga mfl. (2018) fant stor grad av slik standardisering over tid i Italia, mens det i USA var langt større variasjon. Normene for og graden av institusjonalisering av attestasjon av samfunnsansvarsrapportering i Italia samsvarte med langt høyere adopsjonsrater for attestasjon enn i USA. Men selv om standardisering har noen fordeler for gjennomføring, utbredelse og bruk av attestasjon, finner Larrinaga mfl. (2018) at den mer varierte amerikanske praksisen bidrar til minst like stor åpenhet blant de (færre) selskapene som har attestasjon. De konkluderer med at den generelle praksisen som har spredd seg i Italia med en svært begrenset versjon av attestering, ikke øker åpenheten. I stedet antyder de at praksisen er motivert av hensyn til foretaksledelsen og ikke åpenhet og ansvar for interessentenes behov. ${ }^{28}$ Brukernytten er relativt lav. Studien viser til tilsvarende funn i O’Dwyer og Owen (2007) og Perego (2009). Den italienske praksisen kan være i tråd med funnet av at motivasjonen for samfunnsansvarsattestasjon hos foretaksledelsen i utvalgte britiske selskaper i hovedsak var av foretaksintern karakter (rapporteringsprosesser osv.), og ikke brukernytte for eksterne interessenter (Owen et al., 2009). Standardisering alene er ikke tilstrekkelig. Innholdet i de standardiserte løsningene er viktige.

I studien knyttes forskjellene mellom Italia og USA også til at de fire store revisjonsselskapene har en stor del av attestasjonsmarkedet i Italia, mens andre typer attestasjonstilbydere fortsatt dominerer markedet i USA. Revisjonsselskaper bruker i hovedsak revisjonsstandarden ISAE 3000 som dermed er dominerende i Italia (Larrinaga et al., 2018). Implisitt synes det som om bruken av andre standarder er mer utbredt i USA, hvor de store revisjonsselskapene ikke har samme markedsandel. 
Michelon mfl. (2019) indikerer også at revisjonsselskaper i hovedsak benytter IASE 3000, mens andre typer attestasjonsleverandører i større grad benytter AA10ooAS. Vi har sett ovenfor at ISAE 3000 og AA1000AS har ulike krav til innholdet $\mathrm{i}$ attestasjonsberetningene. Forskjellene i innhold $\mathrm{i}$ attestasjonsberetningene mellom Italia og USA stemmer dermed med ulik utbredelse av de to standardene i de to landene (Larrinaga et al., 2018). Omlag to tredeler av attestasjonene av samfunnsansvarsrapportering ble foretatt av de store revisjonsselskapene, både blant verdens 250 største selskaper og i gjennomsnitt blant de 100 største selskapene i hvert av en stor mengde land (KPMG, 2015). Også på dette området er det varierende resultater. Ogando $\mathrm{mfl}$. (2018) fant at verken bruken av internasjonale standarder eller den profesjonelle bakgrunnen til leverandøren av attestasjonstjenestene påvirker oppfatningen av attestasjonsprosessen eller -kvaliteten.

\section{Attestasjonspraksis med nye standarder utover 2000-tallet - opportunistisk motivasjon?}

Michelon mfl. (2019) finner indikasjoner på opportunistisk atferd fra amerikanske leverandører av attestasjonstjenester. Innen revisjonslitteraturen er det vanlig å anta at attestasjon bidrar til å oppdage feil i regnskapet før rapportering, slik at antall korrigeringer i avgitte regnskaper er lavere for reviderte selskaper enn for andre. Det er en indikasjon på at revisjon av finansregnskapet bidrar til økt regnskapskvalitet. Når det gjelder samfunnsansvarsrapportering, finner imidlertid Michelon mfl. (2019) at attestasjon øker antall korrigeringer i rapporteringen. Funnet fra USA gjelder både korrigeringer av direkte feil og på grunn av metodeendringer, og det gjelder både vesentlige og uvesentlige korrigeringer utfra en kvantitativ vesentlighetsgrense. Når det gjelder funn for metodeendringer og uvesentlige feil, er disse signifikante bare for andre attestasjonsleverandører enn revisjonsselskaper. Resultatene for samfunnsansvarsforhold er i overensstemmelse med funn hos KPMG (2011, 2013). Michelon mfl. (2019) konkluderer med at korrigeringer for samfunnsansvarsrapportering avviker fra finansregnskapskorrigeringer. Selv om «samfunnsansvarskorrigeringer» potensielt kan indikere bedre rapportering, mener de det kan være en markedsstrategi for 
attestasjonsleverandører for å øke synligheten og den oppfattede verdien av deres tjenester. Slike strategier kan anses nødvendige siden få selskaper i USA har attestasjon av samfunnsansvarsrapportering, samt at attestasjonshonorarene har vært lave sammenlignet med dem for revisjon av finansregnskapet.

Strategisk egennytte kan også ligge til grunn for kjøp av attestasjonstjenester. Selv om attestasjonspraksis for samfunnsansvarsrapportering blir kritisert for å ha lav brukernytte, har utbredelsen av slik attestasjon $ø$ kt vesentlig blant verdens største selskaper. Spørsmålet er da om det skyldes at attestasjon er av verdi for interessentene, at den er av verdi for foretaket/foretaksledelsen, eller at den er av verdi for alle parter. Relativt entydige resultater fra forskningslitteraturen tilsier at foretak bruker samfunnsansvarsrapportering strategisk for å legitimere sin virksomhet (Patten \& Crampton, 2003; Patten \& Zhao, 2014). Det samme kan skje for attestasjon (Hummel et al., 2019; Owen et al., 2009). Birkey mfl. (2016) viser at attestasjon kan påvirke oppfatninger av foretaks miljøimage, dermed kan attestasjon også benyttes som et legitimeringsverktøy for foretaksledelsen. Foretak kan imitere andres bruk av attestasjon for å ha ryggen fri, uten at attestasjon i seg selv bedrer de attesterte forholdene. Attestasjon er kun «managerial capture» (Segui-Mas et al., 2018). Hummel mfl. (2019) fant til og med en negativ sammenheng mellom foretaks prestasjoner på sosiale og miljømessige forhold og attestasjon av samfunnsansvarsrapportering. Boiral (2013) fant at 90 prosent av faktiske negative hendelser ikke var omtalt i rapporteringen blant foretak på de høyeste applikasjonsnivåene hos GRI (A og A+), hvor nesten samtlige av disse foretakene hadde attestasjon $(\mathrm{A}+)$. Attestasjonstjenester kan gi et skinn av ansvarlighet og transparens, selv om rapporteringens og attestasjonens kvalitet ikke reelt sett er egnet til å redusere informasjonsasymmetrien mellom foretak og interessenter og sette interessentene i stand til å holde foretaket til ansvar. Dette er særlig relevant når attestasjonen har lav sikkerhet og kun dekker et begrenset område (høy attestasjonsrisiko samlet sett). Andre foretak kan strategisk ønske attestasjon av høy kvalitet for å vise fram sine samfunnsansvarsresultater.

Når det gjelder den mer direkte økonomiske verdien av attestasjon, viser forskning ennå få entydige funn. For eksempel fant Cho mfl. (2014) 
ingen sammenheng mellom attestasjon og markedets verdsetting av foretak i USA, mens Caglio mfl. (2019) fant at en positiv effekt (ved ellers svak rapportering) i Sør-Afrika.

En alternativ forklaring til økt diffusjon av attestasjonstjenester kan være knyttet til at sammenhenger mellom foretakets økonomiske situasjon og ulike samfunnsansvarsforhold er så komplekse at mål og virkemiddelbruk blir uklare. Som et alternativ til rasjonelle valg kan det i slike situasjoner oppfattes trygt å imitere valg som lignende organisasjoner har foretatt. Da har også ledelsen ryggen fri. I dette tilfellet kan slik imitasjon, eller «fad», (Abrahamson, 1991) innebære økt bruk av attestasjon og også påvirke hvilken kvalitet på attestasjonstjenestene som blir valgt. Sistnevnte aspekt kan sørge for at trenden blant andre Jagd (2015) skisserer, med lav sikkerhet (og avgrenset omfang/innretning), fortsetter, selv om andre valg egentlig er mer rasjonelle. (Imitasjon/fad er atskilt fra rasjonelle valg i Abrahamsons (1991) diffusjonsperspektiv.)

\subsubsection{Eksempler på innholdet i norske attestasjoner}

Attestasjonsberetninger gir informasjon om attestasjonsoppdragene. Flere av studiene referert ovenfor er direkte basert på systematiske undersøkelser av disse. Enkelte har også gjengitt eksempler på beretninger (Beets \& Souther, 1999). I tabell 10.2 (se appendiks) er flere typer informasjon fra norske attestasjonsberetninger angitt. Eksemplene gjelder store, norske selskaper notert på Oslo Børs for regnskapsårene 2009 og 2018. Det er lagt vekt på å velge selskaper fra ulike bransjer og selskaper hvis rapportering er attestert av ulike revisjons-/attestasjonsselskaper. Eksemplene er ment som en illustrasjon. Det er ikke et mål å gi en uttømmende oversikt over variasjonen i attestasjonsoppdrag eller gi vurderinger av om teksten representerer særskilt gode eller dårlige eksempler.

\section{Bruk av ISAE 3000 versus andre standarder}

ISAE 3000 er nesten enerådende som standard i disse eksemplene for 2018. Det kommer nok av at alle revisjonsselskaper krever å bruke den (jf. informant R1, R3 og R6). SAS bruker de svenske standardene RevR 
6 og RevR 12 i tillegg til ISAE 300o, henholdsvis i 2009 og i 2018. Hydro benyttet AA10oo i tillegg til ISAE 3000 i en del år, inkludert 2009. Informant R1 indikerer at AA10oo har blitt mindre relevant over tid. Det skjer dels fordi revisjonsselskaper uansett krever bruk av ISAE 3000, men også fordi det har virket som organisasjonen som står bak AA10oo i økende grad har lagt vekt på salg av konsulenttjenester og egne økonomiske forhold. AA10oo vil bli utgitt i en ny, oppdatert versjon i et forsøk på å øke standardens relevans. Vi får se om det vil påvirke utbredelsen i Norge.

\section{Redegjørelse i attestasjonsberetningen for hvordan rappor- tering $m v$. kan forbedres}

En konsekvens av ISAE-bruken er at beretningene ikke inneholder kommentarer fra leverandøren av attestasjonstjenesten (revisor e.l.) om hvordan rapporteringen, rapporteringsprosessen og måloppnåelsen kan forbedres (tjenesteleverandøren), slik AA10oo-standarden har krevd. Den ekstra transparensen som slik rapportering innebærer, er positivt for interessentene og kan bidra til å redusere informasjonsasymmetrien. Informant $\mathrm{R}_{3}$ mente at den ordningen i AA1ooo i praksis ikke fungerte så godt. Studier ovenfor har også indikert at rapporteringen ofte kunne bli ullen. Revisor kan komme i en vanskelig situasjon hvor det av og til er best eller iallfall enklere å løfte vanskelige spørsmål internt. Slik rapportering setter uansett hensynet til eksterne interessenter på spissen. Revisor skal jo være samfunnets ombudsperson, ikke et redskap for ledelsen. Det er på grunn av denne åpenheten i AA10oo-beretninger at enkelte av forskningsstudiene nevnt ovenfor kunne gjennomføres.

\section{Attestasjonsrisiko}

Alle attestasjonsoppdragene, unntatt SAS 2018, innebærer uttalelse med moderat sikkerhet. SAS skiller seg ut ved at de for deler av oppdraget gir betryggende sikkerhet. Equinor kunne også vært brukt som eksempel på dette. Den generelle praksisen med moderat sikkerhet er en utfordring for brukernytten av attestasjonen, dvs. evnen til å redusere informasjonsasymmetri (Fuhrman et al., 2017). Bortsett fra hos SAS har bruken av betryggende sikkerhet for uttalelsen altså ikke endret seg fra 2009 til 2018. 
Nå er det ikke kun sikkerheten som påvirker attestasjonsrisikoen. Et annet element er oppdragets omfang (og innretning). Hos Norsk Hydro og SAS synes oppdraget i 2018 å innebære attestasjon av omtrent hele samfunnsansvarsrapporten, altså et omfattende oppdrag. Hos andre selskaper i utvalget virker omfanget langt mindre, noe som også påvirker i hvilken grad attestasjonen påvirker informasjonsasymmetrien. Storebrand er et eksempel på at oppdraget synes å ha blitt større over tid (fra 2009 til 2018), selv om det er vanskelig å si hvor mye større. ${ }^{29}$ Andre selskaper har sluttet med ekstern verifisering i perioden. Et eksempel er Norske Skog, som i mange år var svært langt framme på miljørapportering i internasjonal målestokk. Rapporteringen for 2018 holdt ikke gammelt nivå, etter artikkelforfatterens mening. Det skal sies at de store økonomiske utfordringene i Norske Skog kan ha påvirket dette. Vi får håpe de kommer tilbake.

Det er med andre ord variasjon mellom selskaper og år. Generelt, utover disse eksemplene, kan det sies at noen selskaper kun vil ha en vurdering av interne forhold eller påvirkninger, mens andre ønsker å inkludere eksterne effekter. Enkelte selskaper vil ha en vurdering av prosesser, mens andre også vil ha verifikasjon av resultater, måloppnåelse osv. Dette viser også aspekter knyttet til (manglende) standardisering. Den store variasjonen i hva attestasjon innebærer fra tilfelle til tilfelle (sikkerhet, omfang og innretning), eventuelt at sikkerhet og omfang ofte er lave, er viktige elementer i kritikken mot attestasjonspraksis (Gray et al., 2014). Det blir vanskelig for interessenter å forstå hva attestasjonsrisikoen er, og det blir vanskeligere å sammenligne foretak og holde dem til ansvar.

\section{Andre forhold knyttet til informasjonsasymmetri}

Den samme virkningen som vi omtalte i forrige avsnitt, kan også oppstå fordi flere av beskrivelsene i attestasjonsberetningene er uklare, slik at det er vanskelig for interessentene å forstå sikkerheten, omfanget og innretningen på oppdraget. Det bidrar i liten grad til å redusere informasjonsasymmetri, og gir foretaksledelsen et strategisk spillerom. 
De utførte attestasjonshandlingene og beskrivelsene av dem varierer også en god del: fra svært konkrete handlinger og beskrivelser til overordnede analyser og beskrivelser. Et positivt trekk er at flere selskaper synes å ha attestasjon av kvantitativt tallmateriale, noe Fuhrman mfl. (2017) fant var et viktig element for å redusere informasjonsasymmetri. For andre selskaper gir beretningen leseren liten mulighet til å forstå hva som er gjort rent konkret. Mangelen på standardisering av oppdrag og handlinger, samt forståelig beskrivelse av dem og risiko, gjør det vanskelig for interessenter å forstå i hvilken grad attestasjoner øker rapporteringens pålitelighet.

\section{Andre observasjoner}

Selv om grunnlaget er svært tynt, er det grunn til å spørre om det har blitt mer vanlig at revisor for den ordinære revisjonen også signerer beretningen for attestasjonen av samfunnsansvarsrapporteringen. Det kan i såfall tyde på en sterkere integrering av oppgaver og stab.

Det framgår av eksemplene ovenfor at det ikke bare er tradisjonelle revisjonsselskaper som kan gjennomføre og avlegge attestasjon for samfunnsansvarsrapportering. Vi har tidligere sett at Lloyds og Dovre Sertifisering har attestert rapporter. DNV GL har attestert Telenors samfunnsansvarsrapport for 2018. ISAE 3000 er lagt til grunn også for den attestasjonen. Det synes forøvrig ikke å være angitt en ansvarlig person for DNV GLs oppdrag. Telenor skiller seg også ut ved at det ikke er samme firma som har både finansiell revisjon og attestasjon av samfunnsansvarsrapporteringen. Informantene i denne studien forteller at det er vanlig at attestasjonen ligger innenfor samme oppdragsutlysning som den finansielle revisjonen. Disse egenpålagte restriksjonene gjør at mange selskaper ikke står fritt til å velge hvilken attestasjonsleverandør som skal foreta attestasjon av samfunnsansvarsrapporteringen. I den grad økonomiske forhold som er relevant for den tradisjonelle revisjonen av finansregnskapet henger sammen med relevante forhold for samfunnsansvarsrapporteringen (integrert rapportering), kan en slik kobling være forståelig. Samtidig er rammene for samfunnsansvar(srapportering) videre og mer komplekse enn for årsregnskapet. Attestasjonsoppdrag kan også variere sterkt, fra samlet rapportering til enkeltstående forhold. Tidvis vil det ikke være nødvendig med en kobling mot den finansielle 
revisjonen og tidvis kan slik attestasjon kreve kompetanse som revisjonsselskapene per i dag ikke innehar.

\subsection{Avslutning}

Problemstillingen for denne studien var å beskrive attestasjonspraksis blant norske foretak, både over tid, ut fra bruk av standarder og sammenlignet med internasjonale forhold.

Det er relativt få norske selskaper som kjøper attestasjon av samfunnsansvarsrapportering. Vi har tall bare for store, børsnoterte foretak, men andelen er lavere enn gjennomsnittet for flere titalls andre land. Andelen ser heller ikke ut til å stige jevnt og trutt fra år til år. Tvert imot sank de sist år. Innhentet datamateriale viser heller ikke at tallene for 2019 er særlig høyere enn nivået for 2008/2009. På den annen side melder attestasjonsleverandørene om økt oppdragsmengde. De tilbyr imidlertid flere tjenester enn bare attestasjon.

I Norge virker det som bruken av attestasjonsstandarden ISAE 3000 er dominerende. Andelen i Norge som bruker den, synes å være høyere enn for store foretak i verden generelt og i USA spesielt. Årsaken synes å ligge i at revisorer utfører de fleste attestasjonsoppdragene, et forhold som tilsvarer situasjonen for eksempel i Italia.

Når det gjelder kvaliteten på attestasjonene, attestasjonsrisikoen og bidraget til å redusere informasjonsasymmetri, virker observasjonene fra noen utvalgte norske eksempler å ligne på internasjonale funn. De fleste foretak velger moderat sikkerhet, omfanget og innretningen på attestasjonsoppdragene varierer sterkt mellom foretak og år, og det samme gjør attestasjonshandlingene. På dette området virker det imidlertid som om utviklingen jevnt over ikke har vært negativ fra 2009 til 2018, iallfall ikke for de selskapene i studien som hadde attestasjon begge år.

Basert på denne studien er det vanskelig å uttale seg om hvorvidt attestasjon bidrar til å oppfylle formålene med samfunnsansvarsrapporteringen (ressursallokering og kontroll). Det behøves grundigere studier av norske forhold for å få kunnskap om det. Bidraget til dette kapitlet er å bidra til å starte en systematiseringsprosess knyttet til data og kunnskap om dette feltet i Norge. 
Den generelle oppmerksomheten rundt samfunnsansvarsspørsmål, og næringslivets tilsynelatende oppslutning rundt rapporterings- og attestasjonsanbefalingen til Adams mfl. (2020), peker forhåpentligvis i riktig retning. Hovedforfatteren bak Adams mfl. (2020), Carol Adams, har vært involvert $\mathrm{i}$ en rekke kritiske analyser av rapporterings- og attestasjonspraksis og -standarder siden 1990-tallet (se referanselista og vedlegg). Der gir hun anbefalinger som kan øke rapporterings- og attestasjonskvalitet. Spørsmålet er i hvilken grad hun får gjennomslag for dette i kommende standarder, og om standarder og attestasjonspraksis vil bli bedre over tid. Det vil forskning vise.

\section{Referanser}

Abrahamson, E. (1991). Managerial fads and fashions: The diffusion and rejection of innovations. The Academy of Management Review, 16(3), 586-612.

ACCA. (2004). Towards transparency: Progress on global sustainability reporting 2004. ACCA og CorporateRegister.com. London: ACCA.

AccountAbility. (2018a). AA10oo assurance standard (AA10ooAS, 2008) with 2018 addendum. September 2018.

Accountability. (2018b). AA10oo Accounting principles 2018.

Adams, C. A., Druckman, P. B. \& Picot, R. C. (2020). Sustainable development goals disclosure (SDGD) recommendations.

Adams, C. A. \& Evans, R. (2004). Accountability, completeness, credibility and the audit expectations gap. The Journal of Corporate Citizenship, 14, 97-115.

Ball, A., Owen, D. \& Gray, R. (200o). External transparency or internal capture? The role of third-party statements in adding value to corporate environmental reports. Business Strategy and the Environment, 9, 1-23.

Beets, S. D. \& Souther, C. C. (1999). Corporate environmental reports: The need for standards and an environmental assurance service. Accounting Horizons, 13(2), 129-145.

Birkey, R. N., Michelon, G., Patten, D. M. \& Sankara, J. (2016). Does assurance on CSR reporting enhance environmental reputation? An examination in the U.S. context. Accounting Forum, 40(3), 143-152.

Boiral, O. (2013). Sustainability reports as simulacra? A counter-account of A and A 1 GRI reports. Accounting, Auditing \& Accountability Journal, 26(7), 1036-1071.

Boiral, O. \& Henri, J.-F. (2017). Is sustainability performance comparable? A study of GRI reports of mining organizations. Business \& Society, 56(2) 283-317. 
Boiral, O. \& Heras Saizarbitoria, I. (2019). Sustainability reporting assurance: Creating stakeholder accountability through hyperreality? Journal of Cleaner Production.

Branco, M. C., Delgado, C., Gomes, S. F. \& Eugenio, T. C. P. (2014). Factors influencing the assurance of sustainability reports in the context of the economic crisis in Portugal. Managerial Auditing Journal, 29(3), 237-252.

Buhr, N., Gray, R. \& Milne, M. J. (2014). Histories, rationales, voluntary standards and future prospects for sustainability reporting. CSR, GRI, IIRC and beyond. I Bebbington, Unerman \& O'Dwyer (Red.), Sustainability accounting and accountability. 2. utg. London og New York: Routledge.

Caglio, A., Melloni, G. \& Perego, P. (2019). Informational content and assurance of textual disclosures: Evidence on integrated reporting. European Accounting Review. https://doi.org/10.1080/09638180.2019.1677486

Chauvey, J.-N., Giordano-Spring, S., Cho, C. H. \& Patten, D. M. (2015). The normativity and legitimacy of CSR disclosure: Evidence from France. Journal of Business Ethics, 130, 789-803.

Cho, C. H., Michelon, G., Patten, D. M. \& Roberts, R. W. (2014). CSR report assurance in the USA: An empirical investigation of determinants and effects. Sustainability Accounting, Management and Policy Journal, 5(2), 130-148.

Cooper, S. \& Owen, D. (2014). Independent assurance of sustainability reports. I Bebbington, Unerman \& O’Dwyer (Red.), Sustainability accounting and accountability. 2. utg. London og New York: Routledge.

Crowther, D. \& Aras, G. (2008). Corporate social responsibility. Ventus Publishing.

Fallan, E. (2013a). Exploration of resource allocation decision making demand and stewardship demand for environmental disclosure. I E. Fallan (Red.), Issues on supply and demand for environmental accounting information. PhD Series 41-2013, LIMAC PhD School, Department of Accounting and Auditing, Copenhagen Business School.

Fallan, E. (2013b). The representativeness of the annual report as data source in CSR reporting research. I E. Fallan (Red.), Issues on supply and demand for environmental accounting information. PhD Series 41:2013. Copenhagen Business School.

Fallan, E. (2015a). Explaining the variation in adoption rates of the information content of environmental disclosure: An exploration of innovation adoption theory. Journal of Accounting and Organizational Change, 11 (2), 47-268.

Fallan, E. (2016). Environmental reporting regulations and reporting practices. Social and Environmental Accountability Journal, 36(1), 34-55.

Fallan, E. (2020). Bruk av informasjon fra foretaks miljørapportering til ressursallokerings- og kontrollformål. I T. Stenheim, K. M. Baksaas \& E. Kulset (Red.), Aktuelle temaer i regnskap og revisjon (Kap. 9). Oslo: Cappelen Damm Akademisk. 
Fallan, E., Antonsen, S., Fallan, L. \& Olsen, T.-E. (2018). Abolition of statutory audit obligation of small limited liability companies in Norway. Should tax evasion Inclined industries be excepted? International Journal of Accounting and Taxation, 6(1), 18-30.

Fallan, E. \& Fallan, L. (2007). A longitudinal and cross-sectional analysis of volume and content of corporate environmental disclosure in Norwegian companies: A research note on innovativeness and adoption. ТØH-serien 2007:5, Trondheim Business School.

Fallan, E. \& Fallan, L. (2009). Voluntarism versus regulation: Lessons from public disclosure of environmental performance information in Norwegian companies. Journal of Accounting \& Organizational Change, 5, 472-489.

Fallan, E. \& Fallan, L. (2017). Er regnskapsreguleringer avgjørende for kvaliteten på miljøinformasjon i årsrapporten? I Busch, Olaussen \& Pettersen (Red.), Bred og spiss! NTNU Handelshøyskolen 50 år. Bergen: Fagbokforlaget.

Fallan, E. \& Fallan, L. (2019). Corporate tax behaviour and environmental disclosure: Strategic trade-offs across elements of CSR? Scandinavian Journal of Management, 35(3).

Fallan, E. \& Granrud, H. R. (2020). Attestasjon av rapportering om sosiale, miljømessige og økonomiske forhold (miljø, samfunnsansvars- og bærekraftsrapportering). I Stenvold \& Degerstrøm (Red.), Revisjonshandlinger $i$ praksis (Kapittel 36). Bergen: Fagbokforlaget.

FASB. (1980). Statement of financial accounting concepts no. 2. Qualitative characteristics of accounting information. Financial Accounting Standards Board.

Fuhrman, S. Ott, C., Looks, E. \& Guenther, T. W. (2017). The contents of assurance statements for sustainability reports and information asymmetry. Accounting and Business Research, 47(4), 369-400.

Garcia-Torea, N., Fernandez-Feijoo, B. \& De La Cuesta, M. (2019). CSR reporting communication: Defective reporting models or misapplication? Corporate Social Responsibility and Environmental Management, 1-17.

Gjesdal, F. (1981). Accounting for stewardship. Journal of Accounting Research, 19, 208-231.

Gray, R., Adams, C. A. \& Owen, D. (2014). Accountability, social responsibility and sustainability. Accounting for society and the environment. Harlow: Pearson Education Limited.

Helfaya, A. \& Kotb, A. (2016). Environmental reporting quality: An analysis of global credibility initiatives. I I. Ahmed (Red.), Handbook of research on green economic development: Initiatives and strategies (s. 628-657). IGI global book.

Helfaya, A., Whittington, M. \& Alawattage, C. (2018). Exploring the quality of corporate environmental reporting: Surveying preparers' and users' perceptions. Accounting, Auditing \& Accountability Journal. 
Hodge, K., Subramaniam, N. \& Stewart, J. (2009). Assurance of sustainability reports: Impact on report users' confidence and perceptions of information credibility. Australian Accounting Review, 19(3), 178-194.

Hummel, K., Schlick, C. \& Fifka, M. (2019). The role of sustainability performance and accounting assurors in sustainability assurance engagements. Journal of Business Ethics, 154, 733-757.

IASB. (2018). IFRS conceptual framework for financial reporting. International Accounting Standards Board.

Ijiri, Y. (1975). Theory of accounting measurement, Sarasota, FL: American Accounting Assosiation.

Jagd, J. T. (2015). Investor oriented corporate social responsibility reporting. London and New York: Routledge.

Kamp-Roelands, N. (1999). Audits of environmental reports: Are we witnessing the emergence of another expectation gap? Koninklijk Nederlands Instituut van Registeraccountants.

Kend, M. (2015). Governance, firm-level characteristics and their impact on the client's voluntary sustainability disclosures and assurance decisions. Sustainability Accounting, Management and Policy Journal, 6(1), 54-78.

Knebel, S. \& Seele, P. (2015). Quo vadis GRI? A (critical) assessment of GRI 3.1 $\mathrm{A}+$ non-financial reports and implications for credibility and standardization. Corporate Communications: An International Journal, 2o(2), 196-212.

Kolk, A. \& Perego, P. (2010). Determinants of the adoption of sustainability assurance statements: An international investigation. Business Strategy and the Environment, 19(3), 182-198.

KPMG. (2011). KPMG international survey of corporate responsibility reporting 2011.

KPMG. (2013). The KPMG survey of corporate responsibility reporting 2013.

KPMG. (2015). Currents of change. The KPMG survey of corporate responsibility reporting 2015.

KPMG. (2017). The road ahead. The KPMG survey of corporate responsibility reporting 2017.

Larrinaga, C., Rossi, A., Luque-Vilchez, M. \& Núñez-Nickel, M. (2018). Institutionalization of the contents of sustainability assurance services: A comparison between Italy and United States. Journal of Business Ethics.

Lober, D. J., Bynum, D., Campbell, E. \& Jaques, M. (1997). The 100 plus corporate environmental report study: A survey of an evolving environmental mangament tool. Business Strategy and the Environment, 6, 57-73.

Luque-Vilchez, M. \& Larrinaga, C. (2016). Reporting models do not translate well: Failing to regulate CSR reporting in Spain. Social and Environmental Accountability Journal, 36(1), 56-75. 
Meld. St. 13 (2010-2011). Aktivt eierskap - norsk statlig eierskap i en global økonomi. Nærings- og handelsdepartementet.

Michelon, G., Patten, D. M. \& Romi, A. (2019). Creating legitimacy for sustainability assurance practices: Evidence from sustainability restatements. European Accounting Review, 28(2), 395-422.

Moe-Helgesen, E. (2019). Hvordan rapporterer norske bedrifter om borekraftsmålene? Innlegg på Den norske revisorforeningens DNR-dag, 6. Juni 2019, Thon Hotel Opera. Film og PDF av presentasjonen er tilgjengelig på Revisorforeningens hjemmeside. (Moe-Helgesen holdt foredraget i egenskap av å være partner med ansvar for bærekraft i PWC.)

Norsk RegnskapsStiftelse. (1999/2019). Norsk RegnskapsStandard nummer 16 årsberetning (NRS 16).

O’Dwyer, B. \& Owen, D. (2007). Seeking stakeholder-centric sustainability assurance. Journal of Corporate Citizenship, 25, 77-94.

Ogando, N. V., Ruiz Blanco, S. \& Fernandez-Feijoo, B. (2018). A provider's approach to the assurance market of sustainability reports in Spain. Administrative Sciences, $8,28$.

Owen, D., Chapple, W. \& Urzola, A. P. (2009). Key issues in sustainability assurance. ACCA Research report 115.

Park, J. \& Brorson, T. (2005). Experiences of and views on third-party assurance of corporate environmental and sustainability reporting. Journal of Cleaner Production, 13, 1095-1106.

Patten, D. M. \& Crampton, W. (2003). Legitimacy and the internet: An examination of corporate web page environmental disclosures. Advances in Environmental Accounting and Management, 2, 31-57.

Patten, D. M. \& Zhao, N. (2014). Standalone CSR reporting by U.S. retail companies. Accounting Forum, 38(2), 132-144.

Perego, P. (2009). Causes and consequences of choosing different assurance providers: An international study of sustainability reporting. International Journal of Management, 26(3), 412-425.

Peters, G. F. \& Romi, A. M. (2015). The association between sustainability governance characteristics and the assurance of corporate sustainability reports. AUDITING: A Journal of Practice \& Theory, 34(1), 163-198.

PwC. (2015). PwC Samfunnsansvar 100. 2015: Reisen har begynt.

PwC. (2017). PwC Bæerekraft 10o. Rapportering for framtiden.

PwC. (2019). PwC Borekraft 100.

Salterbaxter-Context. (2005). Trends in CSR reporting 2003-2004. London: Salterbaxter-Context. 
Seguí-Mas, E., Bollas-Araya, H.-M. \& Polo-Garrido, F. (2018). Assurance on corporate governance reports in Spain: Towards an enhanced accountability or a new form of public relations? Administrative Sciences, 8, 32.

Sierra-García, L., Garcia-Benau, M. \& Bollas-Araya, H. (2018). Empirical analysis of non-financial reporting by Spanish companies. Administrative Sciences, 8, 29.

Simnett, R., Vanstraelen, A. \& Chua, W. F. (2009) Assurance on sustainability reports: An international comparison. The Accounting Review, 84(3), 937-967.

Snavely, H. J. (1967). Accounting information criteria. The Accounting Review, 42(2), 223-232.

Thornam, H. (2019). Hvordan bidrar vi til borekraftmålene? Innlegg på Den norske revisorforeningens DNR-dag, 6. Juni 2019, Thon Hotel Opera. Film og PDF av presentasjonen er tilgjengelig på Revisorforeningens hjemmeside. (Thornem holdt foredraget i egenskap av å være leder for bærekrafttjenester i EY.)

Tvedt, T. (2018). Verdifulle bidrag eller meningsløs formalisme? Revisors attestasjoner. Revisjon og regnskap, 3-2018.

Zadek, S., Raynard, P., Forstater, M. \& Oelschlaegel, J. (2004). The future of sustainability assurance. London: ACCA. 


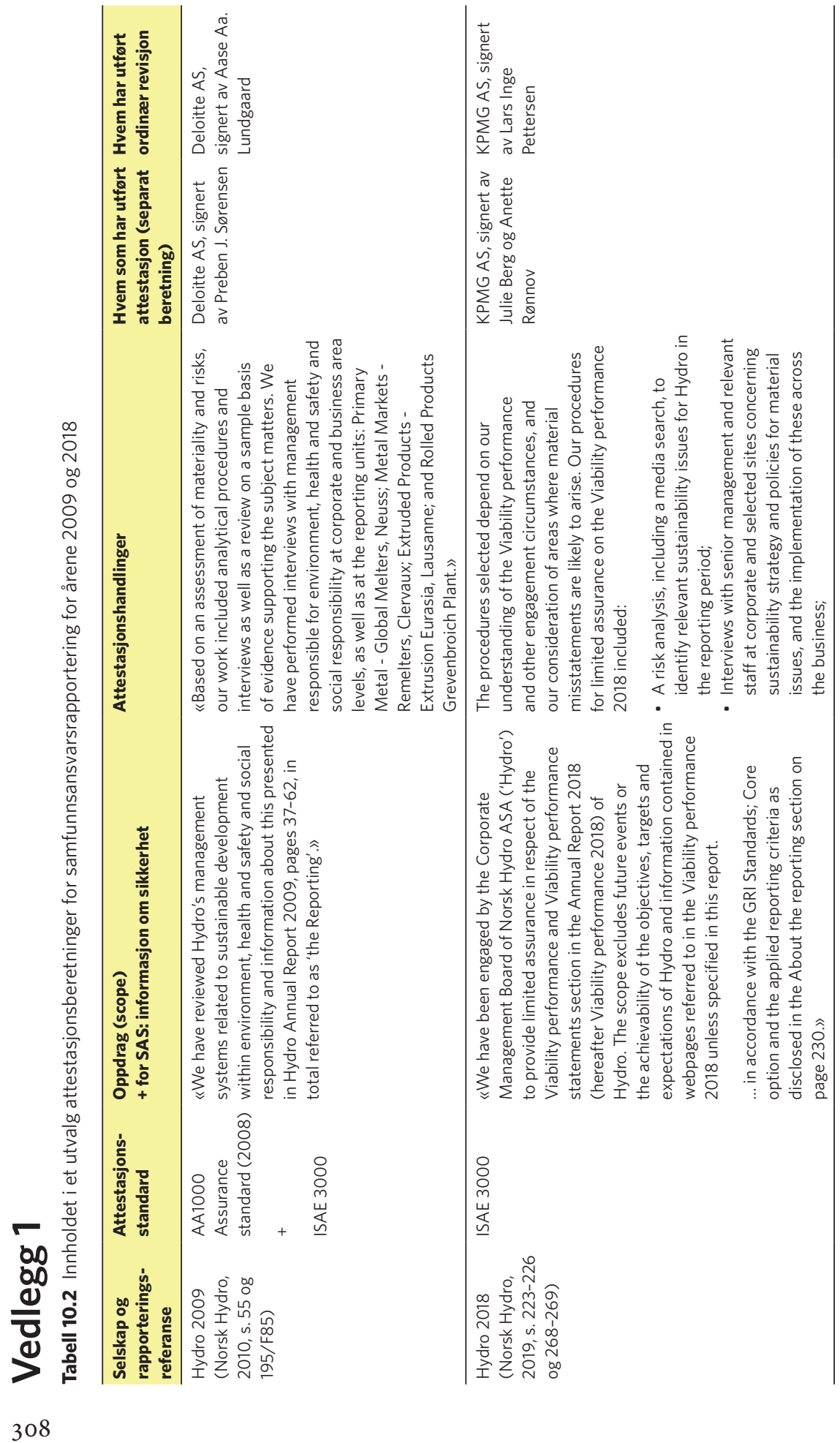




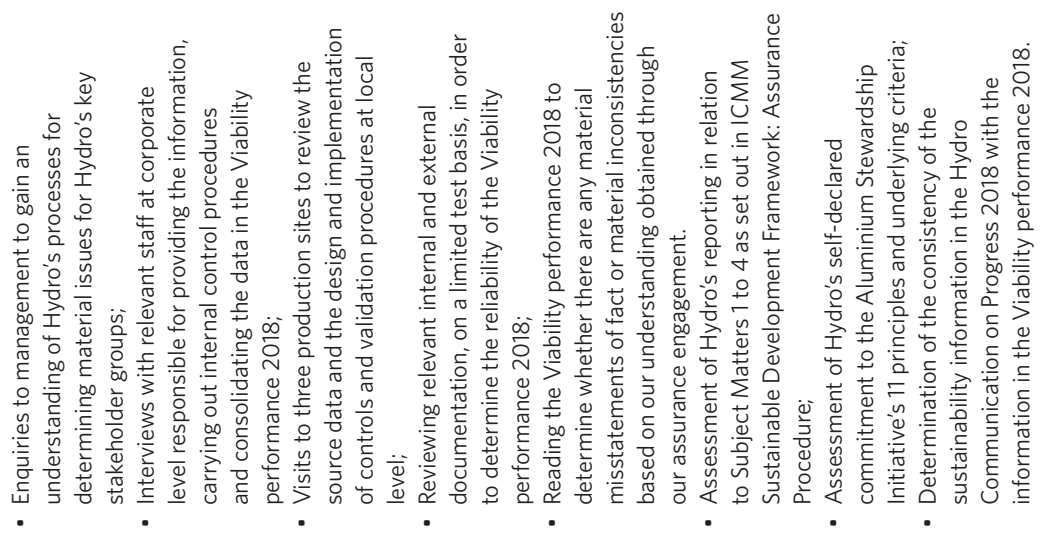




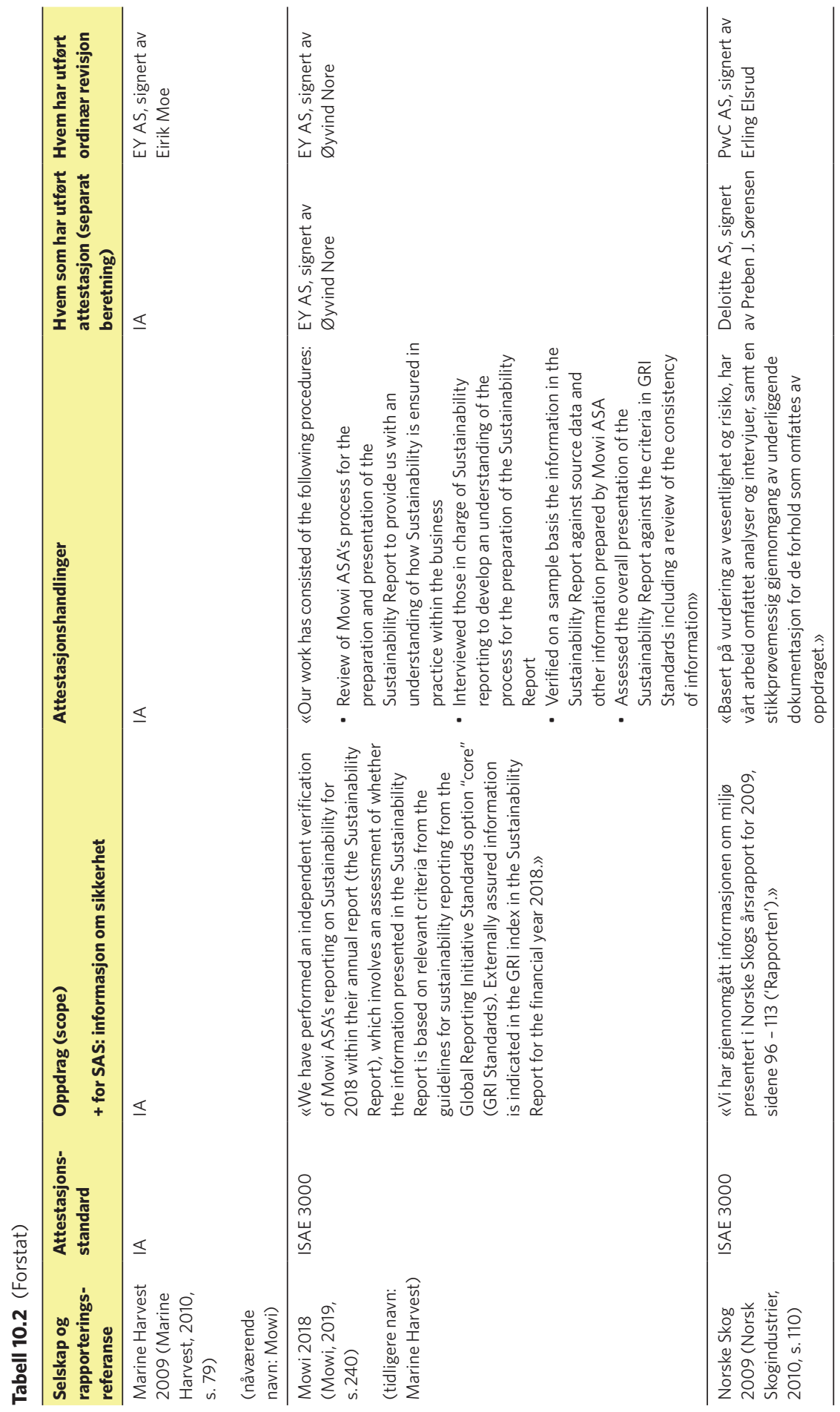




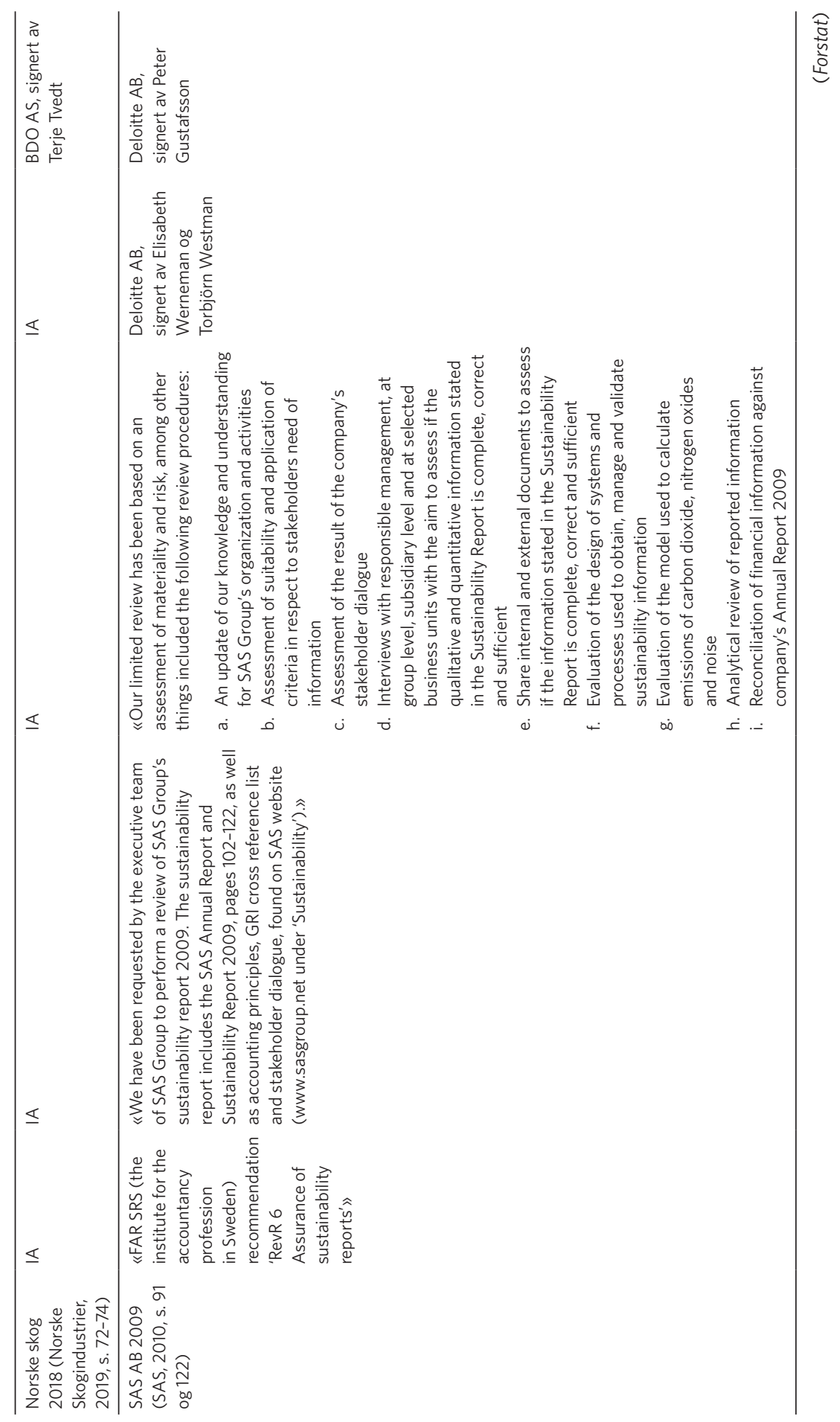




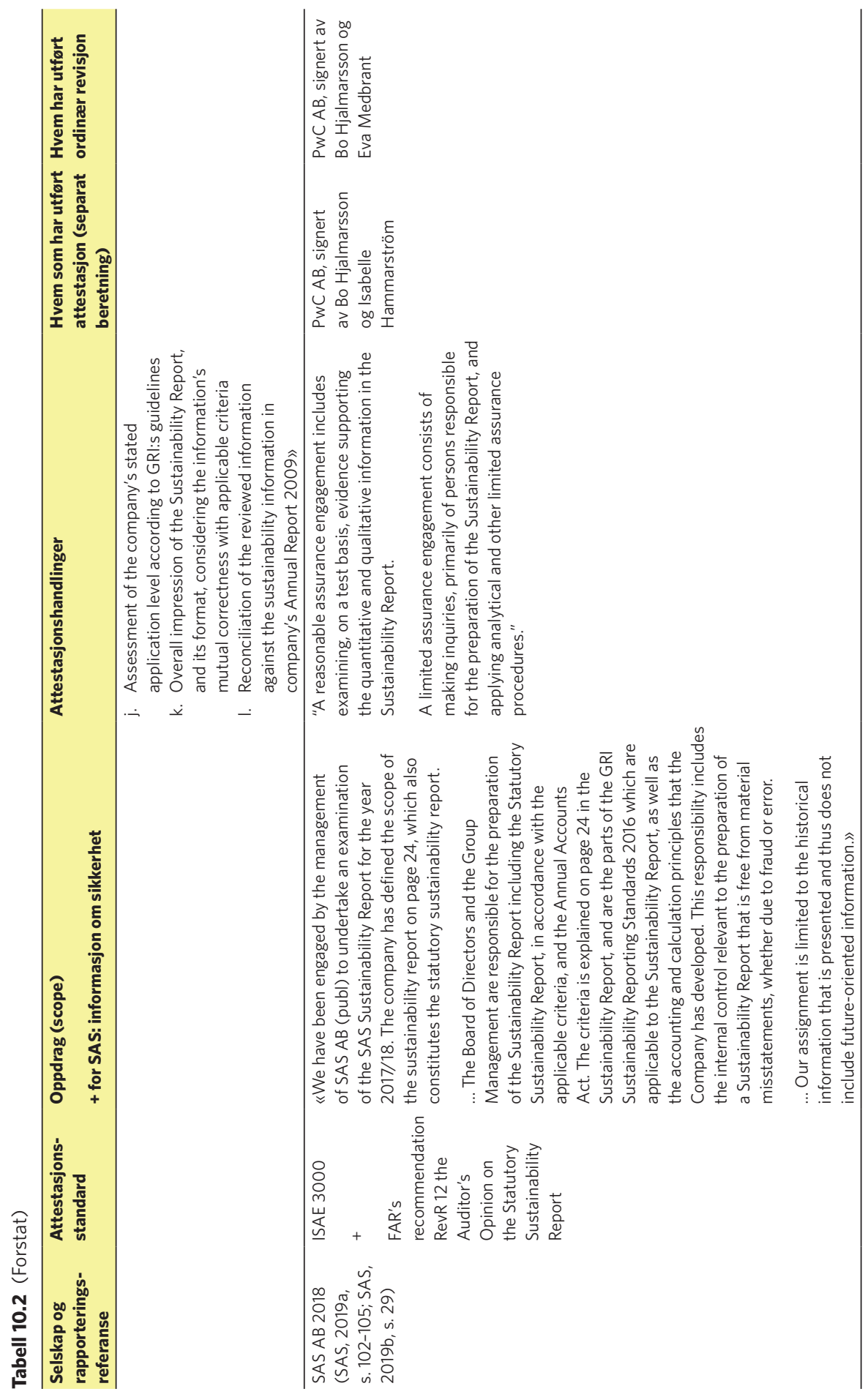




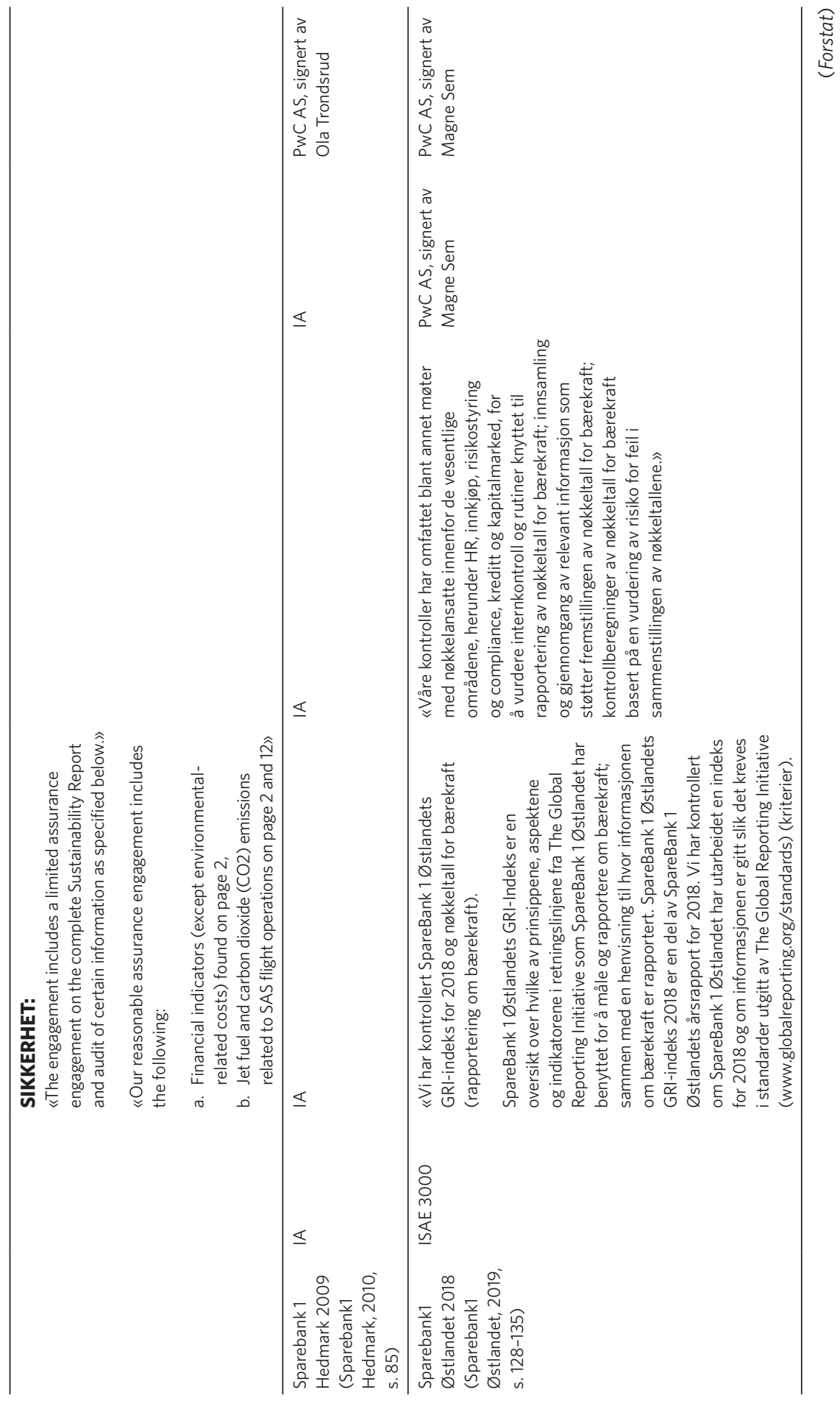




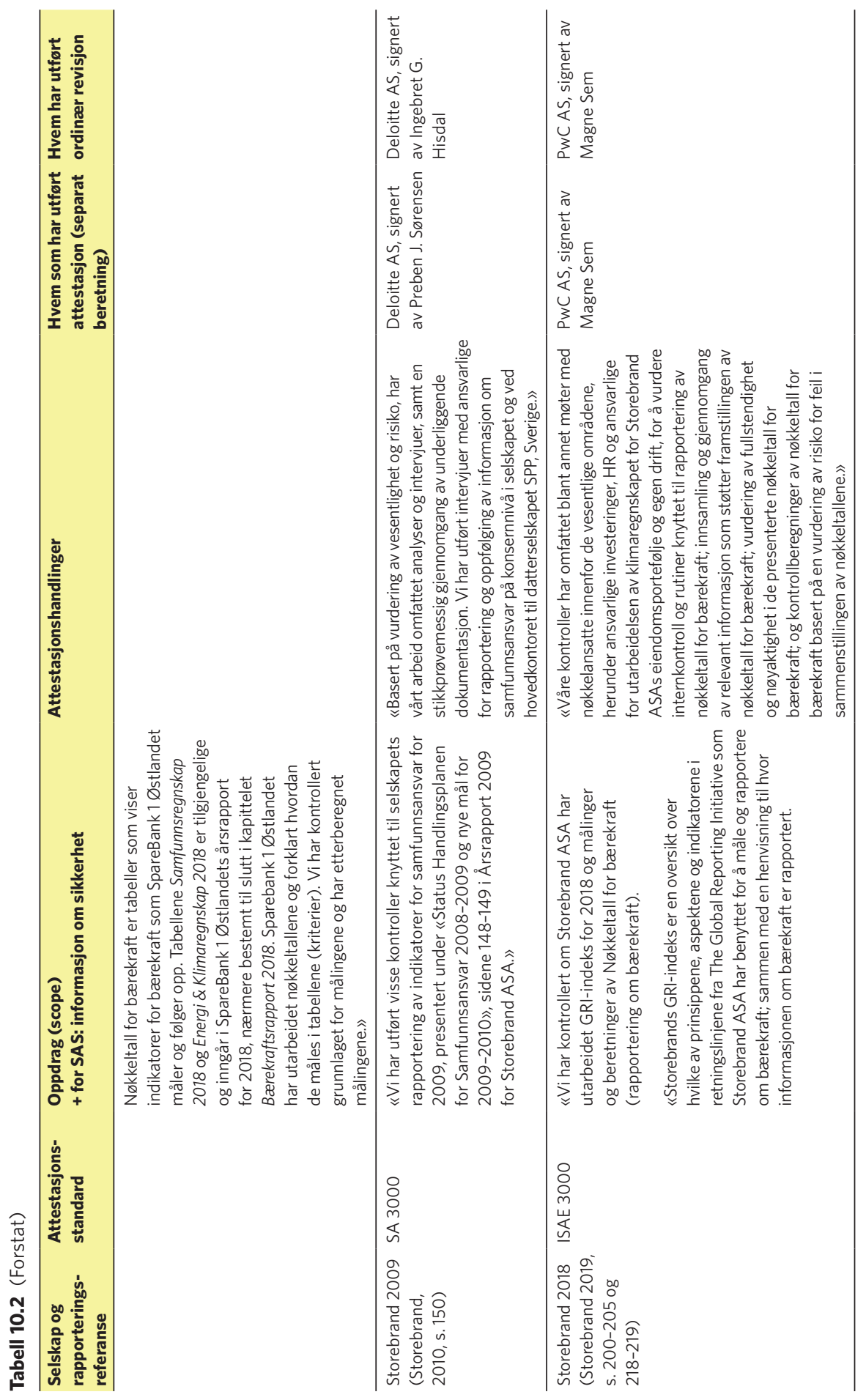




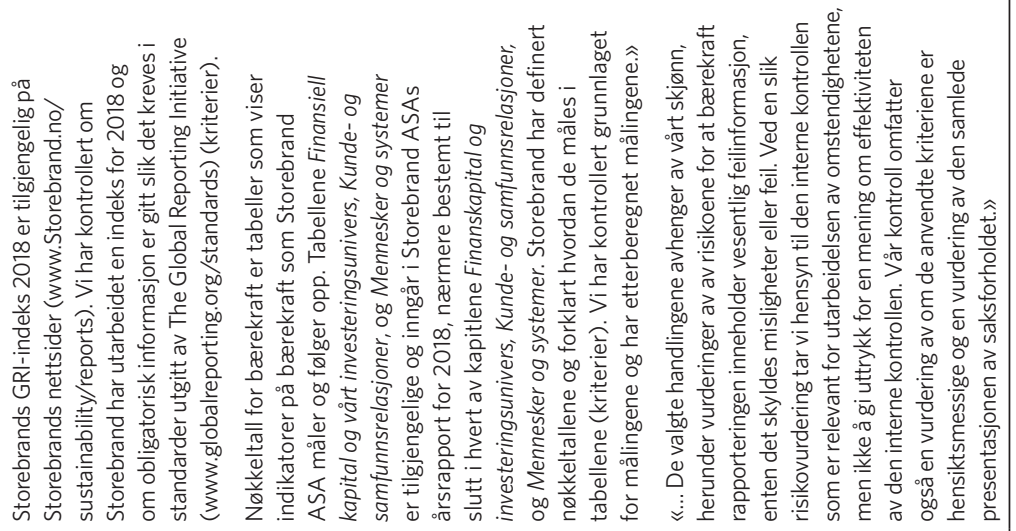




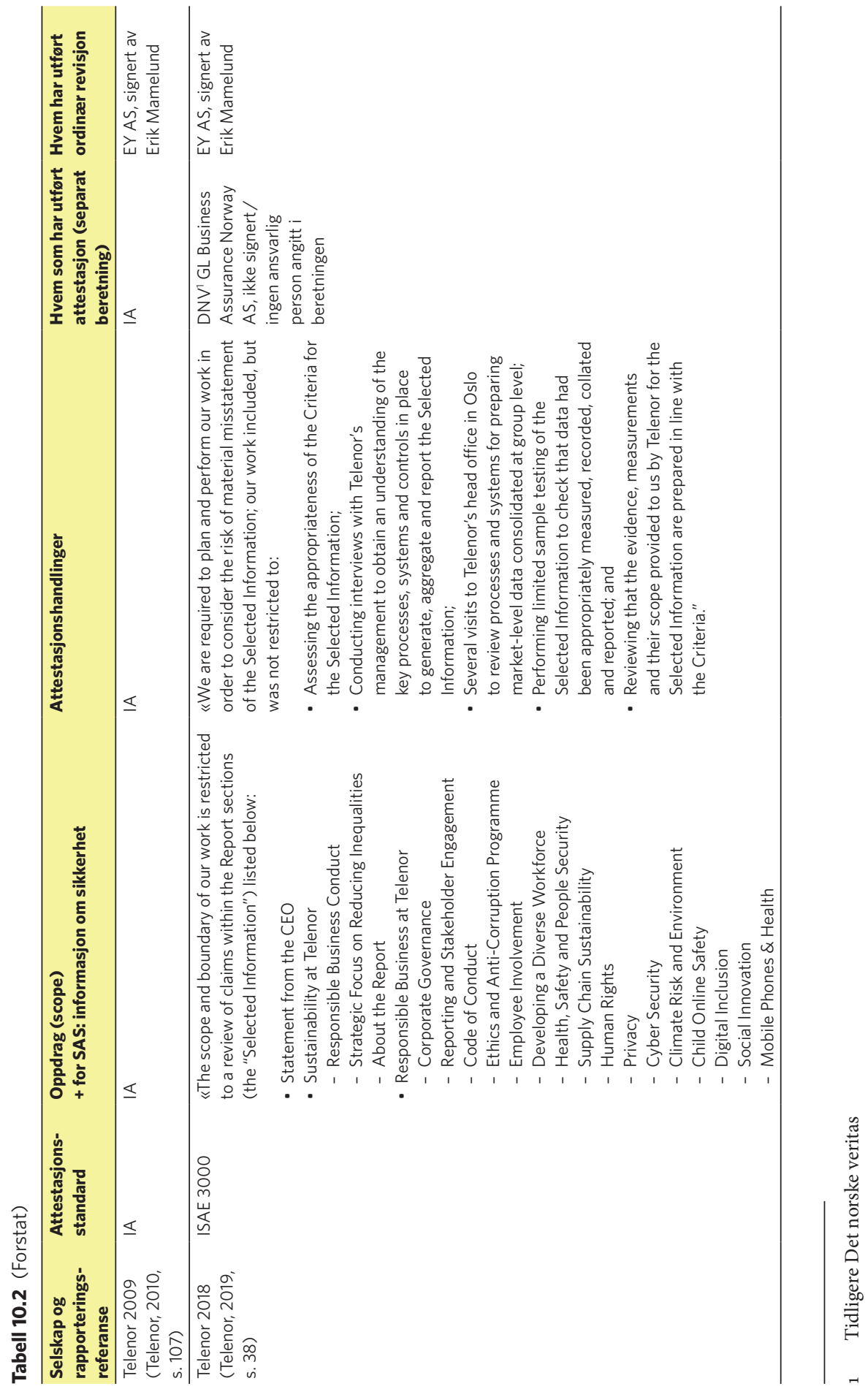



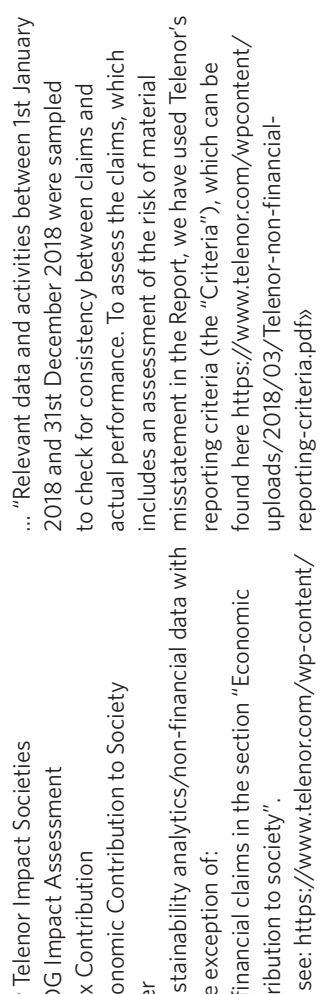

凹

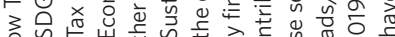

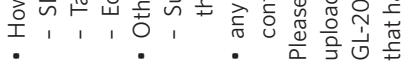

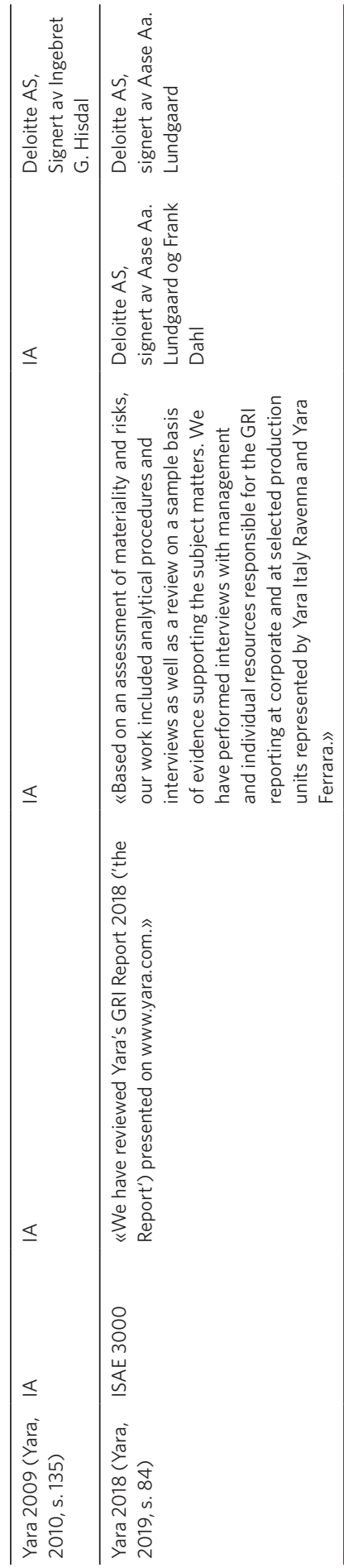




\section{Vedlegg 2}

\section{Referanseliste tilleggsreferanser}

Følgende referanser utdyper andre referanser brukt i teksten og angir relevante resultater og aktuell videre lesing. Relevante artikler i ordinær referanseliste er ikke ført opp her.

Adams, C. A., Coutts, A. \& Harte, G. (1995). Corporate equal opportunities (non-) disclosure. British Accounting Review, 27, 87-108.

Adams, C. A. (2004). The ethical, social and environmental reporting-performance portrayal gap. Accounting, Auditing \& Accountability Journal, 17(5), 731-757.

Adams, C. A. \& Whelan, G. (2009). Conceptualising future change in corporate sustainability reporting. Accounting, Auditing \& Accountability Journal, 22(1), 118-143.

Bebbington, J., Kirk, E. A. \& Larrinaga, C. (2012). The production of normativity: A comparison of reporting regimes in Spain and the UK. Accounting, Organizations and Society, 37, 78-94.

Beck, C., Campbell, D. \& Shrives, P. J. (2010). Content analysis in environmental reporting research: Enrichment and rehearsal of the method in a British-German context. The British Accounting Review, 42, 207-222.

Bouten, L., Everaert, P., Liedekerke, L. V., Moord, L. D. \& Christiaens, J. (2011). Corporate social responsibility reporting: A comprehensive picture? Accounting Forum, 35, 187-204.

Cho, C., Laine, M. Roberts, R. W. \& Rodrigue, M. (2015). Organized hypocrisy, organizational façades, and sustainability reporting. Accounting, Organizations and Society, 40, 78-94.

Criado-Jiménez, I., Fernández-Chulián, M., Husillos-Carqués, F. J. \& LarrinagaGonzález, C. (2008). Compliance with mandatory environmental reporting in financial statements: The case of Spain (2001-2003). Journal of Business Ethics, 79, 245-262.

Deegan, C. \& Rankin, M. (1996). Do Australian companies report environmental news objectively? An analysis of environmental disclosures by firms prosecuted successfully by the Environmental Protection Authority. Accounting, Auditing \& Accountability Journal, 9, 50-67.

Deegan, C. \& Rankin, M. (1999). The environmental reporting expectations gap: Australian evidence. The British Accounting Review, 31, 313-346.

Deegan, C., Rankin, M. \& Voght, P. (200o). Firms' disclosure reactions to major social incidents: Australian evidence. Accounting Forum, 24(1), 101-130.

Fallan, E. (2015b). Corporate social responsibility and tax aggressiveness: A test of legitimacy theory. Social and Environmental Accountability Journal, 35(3), 198-200. 
The Governance Group. (2019). Boerekraft på børs 2019. En analyse av borekraftsrapporteringen til de 100 største selskapene på Oslo Børs.

Habek, P. \& Wolniak, R. (2016). Assessing the quality of corporate social responsibility reports: The case of reporting practices in selected European Union member states. Quality \& Quantity, 50, 399-420.

Hopwood, A. G. (2009). Accounting and the environment. Accounting, Organizations and Society, 34, 433-439.

Islam, M. A. \& Deegan, C. (2010). Media pressures and corporate disclosure of social responsibility performance information: a study of two global clothing and sports retail companies. Accounting and Business Research, 40, 131-148.

Larrinaga, C., Carrasco, F., Correa, C., Llena, F. \& Moneva, J. M. (2002). Accountability and accounting regulation: The case of the Spanish environmental disclosure standard. The European Accounting Review, 11, 723-740.

Matuszak, L. \& Rozanska, E. (2017). CSR disclosure in Polish-listed companies in the light of directive 2014/95/EU requirements: Empirical evidence. Sustainability, 9.

Melting, E. \& Tungen, Ø. (2012). Miljørapportering og lovverk: har rapporteringspraksis utviklet seg etter endelig innføring av Norsk RegnskapsStandard 16 i 2007? Masteroppgave i økonomi og administrasjon, Trondheim Økonomiske Høgskole.

Niskanen, J. \& Nieminen, T. (2001). The objectivity of corporate environmental reporting: A study of Finnish listed firms' environmental disclosures. Business Strategy and the Environment, 10, 29-37.

Patten, D. M. (2005). The accuracy of financial report projections of future environmental capital expenditures: A research note. Accounting, Organizations \& Society, 30(5), 457-468.

Solomon, J. F. \& Solomon, A. (2006). Private social, ethical and environmental disclosure. Accounting, Auditing \& Accountability Journal, 19, 564-591.

Vormedal, I. \& Ruud, A. (2009). Sustainability reporting in Norway - an assessment of performance in the context of legal demands and socio-political drivers. Business Strategy and the Environment, 18, 207-222. 



\title{
EUs nye retningslinjer for foretaksrapportering av klimarelaterte opplysninger - byggverk på utrygg grunn?
}

Anders Berg Olsen

Førstelektor, Norges teknisk-naturvitenskapelige universitet

\section{Per Ståle Knardal}

Førsteamanuensis, Norges teknisk naturvitenskapelige universitet

\begin{abstract}
Sammendrag: I de siste årene har det i økende grad blitt fokusert på klima og bærekraft. Dette er en utvikling som også har fătt økt oppmerksomhet i virksomheters rapportering, og en rekke aktører tar i bruk nye kriterier knyttet til bærekraft i sine retningslinjer og modeller for økonomiske beslutninger. Med utgangspunkt i regnskapsdirektivet har EU-kommisjonen utgitt retningslinjer for rapportering fra store foretak om ikke-finansiell informasjon. I dette kapittelet bygger vi på kunnskap fra utviklingen av finansiell rapportering og kriterier som har blitt utviklet for å forbedre og understøtte denne, og vurderer fundamentet for retningslinjer for rapportering av klimarelaterte opplysninger. Kapittelet bygger på en dokumentanalyse for å belyse grunnleggende forutsetninger om rapporteringsenhet, rapporteringens formål og kvalitetskriterier for ikke-finansiell foretaksrapportering. Dokumentanalysens resultat indikerer at kravene til ikke-finansiell rapportering kan videreutvikles med hensyn til systematikk og konsistens tilsvarende det som er utviklet for finansiell rapportering. Grunnlaget for rapportering av ikke-finansiell informasjon fremstår som uklart med hensyn til rapporteringsenhet, rapporteringens formål og sentrale kvalitetskriterier. Med bakgrunn i analysen foreslås det at det bør utvikles kvalitetskriterier for ikke-finansiell informasjon basert på kvalitetskrav til informasjon IFRS konseptuelt rammeverk for finansiell rapportering. Det er også behov for økt forskning innen ikke-finansiell rapportering.
\end{abstract}

Nøkkelord: bærekraft, ikke-finansiell rapportering, miljørapportering, regnskapsdirektivet

Sitering av denne artikkelen: Olsen, A. B. \& Knardal, P. S. (2020). EUs nye retningslinjer for foretaksrapportering av klimarelaterte opplysninger - byggverk på utrygg grunn? I T. Stenheim, K. M. Baksaas og E. M. Kulset (Red.), Aktuelle temaer i regnskap og revisjon (Kap. 11, s. 321-344). Oslo: Cappelen Damm Akademisk. https://doi.org/10.23865/noasp.112.ch11

Lisens: CC-BY 4.o. 


\subsection{Introduksjon}

Klodens klimautfordringer er betydelige. EU og mange andre mener at foretak må synliggjøre og rapportere mer klimarelatert informasjon, dersom målene for blant annet klimagassutslipp skal nås. Parisavtalen (UN, 2015) definerer et mål om at global temperaturstigning må begrenses til 2 grader over før-industrielt nivå. Parisavtalen og rapporter fra FNs klimapanel (IPPC) er brukt som begrunnelse for utgivelse av EUs retningslinjer for rapportering fra store foretak om klimarelatert informasjon, som ble utgitt i juni 2019. En forutgående høringsrunde ble gjennomført mellom 20. februar og 20. mars 2019. Disse retningslinjene er et tillegg til retningslinjer om ikke-finansiell rapportering utgitt i 2017.

EUs retningslinjer har forankring i regnskapsdirektivet (2013/34/EU), etter at det ble endret av direktiv 2014/95/EU vedrørende bestemmelser om visse store foretaks og konserners offentliggjøring av ikke-finansielle opplysninger. Endringsdirektivet krever at store foretak skal gi informasjon om miljøspørsmål, sosiale og personalmessige forhold, status for menneskerettigheter og bekjempelse av korrupsjon og bestikkelser, i den grad det er nødvendig for å forstå foretakets utvikling, resultater, stilling og virkningen av foretakets aktiviteter. Motivet bak bestemmelser gitt i direktiv 2014/95/EU, er beskrevet i fortalen til direktivet:

Offentliggjøring av ikke-økonomisk informasjon er et avgjørende skritt for å styre overgangen til en bærekraftig global økonomi ved å kombinere langsiktig lønnsomhet med sosial rettferdighet og miljøvern. I denne sammenhengen bidrar offentliggjøring av ikke-økonomisk informasjon til å måle, overvåke og styre virksomhetsaktiviteter og deres innvirkning på samfunnet.

En rekke næringslivsaktører, herunder investorer og banker, bygger inn nye kriterier knyttet til bærekraft i sine retningslinjer og modeller for økonomiske beslutninger. For å understøtte denne utviklingen og for å legge til rette for ansvarliggjøring av foretak, styrer og ledere, legger myndigheter og private standardsettere innsats i å utvikle nye regler, standarder og anbefalinger for utarbeidelse av rapportering fra foretak om ulike aspekter ved bærekraft, herunder klima og miljø. Det legges også større vekt på koblingen mellom ikke-finansiell og finansiell rapportering nå enn tidligere. Den økende interessen har likhetstrekk med 
et fremvoksende behov for ekstern finansiell rapportering som gjorde seg gjeldende utover på 1900-tallet.

Det har over flere år kommet frem initiativer fra en rekke ikke-statlige organisasjoner (på engelsk NGO-er) og andre for å fremme mer ikkefinansiell rapportering. Eksempler er standardene fra Global Reporting Initiative (GRI), AA10oo-serien fra AccountAbility og Communication on Progress (COP) fra FN Global Compact, og det finnes også mange andre (Venturelli et al., 2019; Brandsås, 2019). Det å kommunisere til en bredere gruppe interessenter og informasjonsbrukere enn dem finansiell rapportering har vært rettet mot, har stått i fokus.

Det er innbakt stor fleksibilitet i kravene i regnskapsdirektivet. EU-kommisjonens begrunnelse for at rapporteringskrav bør ha stor fleksibilitet og frivillighet, er at virksomheters samfunnsansvar (CSR) har en flerdimensjonal natur, og at det er stort mangfold med hensyn til hvilke CSR-politikker som gjennomføres av foretak (Fortalen til direktiv 2014/95/EU). Den ikke-finansielle rapporteringen er i stor utstrekning frivillig og kan gjennomføres innenfor rammer som gir mange valgmuligheter for hvert enkelt rapporterende foretak. Aerts og Cormier (2009) hevder at foretakenes miljørapportering først og fremst har vært en form for strategisk kommunikasjon, som et middel for å styre oppfatningen om foretaket, og for å legitimere virksomhetens aktiviteter og prestasjoner.

Accountancy Europe har i 2019 tatt til orde for mer forpliktende regulering av ikke-finansiell rapportering og har i et diskusjonsnotat (Accoutancy Europe, 2019) poengtert at finansiell informasjon alene ikke gir et fullstendig bilde av foretakenes virksomhet. Den norske revisorforening (2019) har uttalt at diskusjonsnotatet gir håp om en global løsning for integrering av finansiell og ikke-finansiell informasjon. På den annen side finnes det også en rekke holdepunkter for at store deler av næringslivet trenger strengere krav og incentiver for å produsere pålitelig og relevant ikke-finansiell informasjon som er koblet til den finansielle rapporteringen. Sannsynligvis kan regulering bidra til bedre kvalitet på rapporteringen enn når dette skjer på frivillig grunnlag (Venturelli et al., 2019).

Krav til systemer, rutiner og kontroller, samt form, innhold og informasjonskvalitet, for finansiell foretaksrapportering er utviklet over 
mange år. Vi har antatt at kunnskap fra utvikling av finansiell foretaksrapportering er et relevant grunnlag å bygge på når retningslinjer for ikke-finansiell foretaksrapportering skal utformes og innføres. I denne studien har vi derfor tatt utgangspunkt i grunnleggende forutsetninger om rapporteringsenhet, brukere av foretaksrapportering og kvalitetskriterier for informasjon, som ligger til grunn for regler og standarder for finansiell rapportering, og undersøkt om det er gjort tilsvarende forutsetninger når EU har stilt krav til og gitt retningslinjer for ikke-finansiell rapportering, med forankring i regnskapsdirektivet.

Metoden vi har brukt, er dokumentanalyse, herunder har vi gjort en analyse av høringsinnspill innhentet av EU forut for at retningslinjene for rapportering om klimarelatert informasjon er publisert. Hensikten er å vise at utvikling av kravene til og veiledning om ikke-finansiell rapportering møter tilsvarende utfordringer som har gjort seg gjeldende ved utvikling av forutsetninger for og krav til finansiell foretaksrapportering.

Gjennom dette bidrar vi med ny innsikt i hvordan utvikling av regelverk, standarder og retningslinjer for ikke-finansiell rapportering møter tilsvarende utfordringer som har vist seg å være krevende ved utarbeidelse av lovgivning og standardsetting for finansiell rapportering.

Nedenfor redegjør vi først for rapporteringskrav for foretak. Deretter benytter vi vitenskapelig litteratur til å synliggjøre hvilke grunnleggende hensyn som ligger bak krav til foretaksrapportering, og hvilke fundamentale utfordringer som foretaksrapporteringen tar sikte på å løse. Etter gjennomgang av metoden for analysen viser vi funnene. Funnene analyseres og diskuteres deretter i lys av kvalitetskrav til foretaksrapportering utviklet for finansiell rapportering. Avslutningsvis gir vi noen kommentarer samt anbefalinger om videre forskning som kan bidra til å informere myndigheter og standardsettere som utvikler rammer og krav til ikkefinansiell foretaksrapportering og koblinger til finansiell rapportering.

\subsection{Krav til foretaksrapportering}

Krav om finansiell rapportering fra foretak er utviklet over en årrekke og er underlagt omfattende regulering. Krav til systemer, rutiner og intern kontroll følger av selskapsrettslig lovgivning og av bokføringsloven. 
Andre land har tilsvarende regulatoriske krav. Det vil si at regnskapsrapportering i samsvar med regnskapslovens bestemmelser og i samsvar med IFRS (International Financial Reporting Standards) bygger på systematikk og logikk med hensyn hvordan transaksjoner bokføres og summeres, og krav til systemer og kontroll. Rapporteringskravene følger av regler som utledes av lover, forskrifter og regnskapsstandarder. Disse er i stor utstrekning utviklet på basis av prinsipper som er utviklet gjennom 100 år, og er uttrykt gjennom teori, rammeverk og standarder.

Ikke-finansiell foretaksrapportering er av nyere dato, og rammebetingelser og krav er under utvikling. Mange av kravene til kvalitativ informasjon har tidligere vært rettet mot å forklare, utdype og presisere informasjon gitt i regnskapsoppstillinger. Det nye er at rapporteringsformålet utvides, og at etterspørselen etter foretaksrapportering omfatter mer enn det som faller inn under en naturlig forståelse av begrepene regnskap og finansiell rapportering.

I Norge kom $\$ 3-3 \mathrm{C}$ inn i regnskapsloven i 2013, med krav om redegjørelse for samfunnsansvar. Det er hovedsakelig børsnoterte selskaper og banker som må følge $\$ 3-3 c$, jf. regnskapsloven $\$ 1-5$. I 2019 fikk Finanstilsynet i oppdrag å utrede behovet for minimumsoppdatering av regnskapsloven for å sikre tilpasning til EU-reglene. På området ikkefinansiell rapportering ble $\$ 3-3 c$ oppdatert ved at det fra 01.01.2020 skal inkluderes informasjon om hva foretaket gjør for å integrere hensynet til likestilling og ikke-diskriminering. Bestemmelsene i $\$ 3-3 \mathrm{c}$ gir betydelige muligheter for valgfrihet (det vil si frivillighet) for foretakene med hensyn til rapportering om samfunnsansvar. Det er ikke eksplisitte krav i regnskapsloven om redegjørelse for sammenhenger mellom rapporteringselementer vedrørende samfunnsansvar og finansiell rapportering.

I motsetning til rammebetingelsene for finansiell rapportering er kravene til ikke-finansiell rapportering mindre forpliktende. Et foretak som har valgt å unnlate å ha retningslinjer for samfunnsansvar, trenger ikke opplyse om annet enn at foretaket ikke har retningslinjer, prinsipper, prosedyrer og standarder for å integrere hensynet til menneskerettigheter, arbeidstakerrettigheter, likestilling og ikke-diskriminering, sosiale forhold, det ytre miljø og bekjempelse av korrupsjon i sine 
forretningsstrategier, i sin daglige drift og i forholdet til sine interessenter., jf. regnskapsloven $\$ 3-3 \mathrm{c}$ andre ledd.

Før innføringen av $\$ 3-3 \mathrm{C}$ var det krav til norske regnskapspliktige foretak om å gi opplysninger i årsberetningen om arbeidsmiljøet, likestilling, antidiskriminering og om forhold ved virksomheten som kunne medføre en ikke ubetydelig påvirkning på det ytre miljø. Praksis var ofte at rapportering ble gjort i form av standardiserte og knappe formuleringer. Med $\$ 3-3 c$ har kravene blitt noe skjerpet for store foretak, mens forenklingshensyn har gitt reduserte rapporteringskrav for små foretak. For foretak som ikke regnes som små foretak, skal styret utarbeide årsberetning. De tidligere kravene er i stor grad videreført og til dels utvidet. $\$ 3$-3a krever at styret skal gi opplysninger om forhold ved virksomheten som kan medføre en ikke ubetydelig påvirkning av det ytre miljøet, og om hvilke miljøvirkninger de enkelte forholdene gir eller kan gi, samt om tiltak for å forhindre eller redusere negative miljøvirkninger.

Verken etter EU-reglene eller etter norske regler er det obligatoriske krav til å følge en bestemt standard for rapportering av ikke-finansielle opplysninger. Flere foretak velger imidlertid frivillig å gå langt i rapporteringen av ikke-finansiell informasjon og rapporterer mer enn det som kreves. Likevel har mange norske foretak forbedringsmuligheter (Brandsås, 2019). Forpliktende krav til ikke-finansiell foretaksrapportering er så langt begrenset til store foretak, både i EU og i Norge, men det er i stor utstrekning opp til foretakene å avgjøre omfang av og detaljeringsgrad i rapporteringen. Det er også valgfritt om foretaket vil ha ekstern uavhengig attestasjon av hele eller deler av rapporteringen.

\subsection{Foretaksrapporteringens formål, brukere og kvalitetskriterier}

Etter 1900 økte omfanget av handel på børs, og det ble flere foretak med finansiering fra andre enn dem som var direkte involvert i styring og ledelse. Dette skapte agentproblemer (Berle \& Means, 1932), og behovet for profesjonalisering av finansiell rapportering ble etter hvert mer synlig. Viktige momenter i utviklingen av regnskapet ble poengtert av Paton (1922) tidlig på 1920-tallet, at underliggende generelle forutsetninger for 
regnskap ikke eksisterer, ikke lar seg bevise fullt ut og også medfører begrensninger for regnskapet. Finansiell rapportering må derfor bygge på et sett med valgte, konstruerte forutsetninger. Dette har vært viktig i utviklingen av regnskapet, både i praksis og for regnskap som forskningsområde. Samtidig anerkjente Paton også en viss pragmatisme: "Accounting is a highly purposive field and any assumptions, principle, or procedure is accordingly justified if it adequately serves the end in view - assuming the end to be reasonable, all things considered» (Paton, 1922, s. 472).

For å kunne identifisere utfordringer knyttet til ikke-finansiell foretaksrapportering trengs det kunnskap om regnskapsteori og regnskapsforskning. Gitt regnskapets underliggende begrensinger, har diskusjonen om regnskapets fundamentale problem vært sentral i utviklingen av regnskapet og regnskapsdebatten. Dette problemet har sitt utgangspunkt i at regnskapet er ment å skulle ivareta informasjonsbehovet til ulike interessentgrupper, noe som er relevant for både finansiell og ikke-finansiell rapportering. Ulike grupperinger har ulike behov, og det er vanskelig, om ikke umulig, å imøtekomme alle interessenters behov fullt ut, med én standardisert rapport.

Teoretisk har det fundamentale problemet blitt belyst gjennom en prinsipal-agent-tilnærming. Dette innebærer at det skilles mellom adverse selection og moralsk hasard og hvordan dette har implikasjoner for hvordan man tenker om sentrale konsepter innen regnskapet. Adverse selection er en type informasjonsasymmetri hvor én eller flere aktører i en transaksjon har en informasjonsfordel. Dette kan gjelde innsideinformasjon om karakteristikker eller hendelser som kan påvirke selskapet i kapitalmarkedet. Dersom denne typen informasjon finnes, vil det innebære en begrensing i kapitalmarkedets funksjon. Moralsk hasard er en annen type informasjonasymmetri der én eller flere aktører i et kontraktsforhold kan observere hvordan kontrakten blir overholdt, mens andre aktører ikke har denne muligheten. Et eksempel er hvordan ledelsen i et selskap jobber på vegne av investorene, og at investorer ikke har muligheten til fullt ut å kontrollere hvordan dette ansvaret forvaltes. Med bakgrunn i prinsipal-agent-tilnærmingen er det dermed grunnleggende for regnskapsdebatten at informasjon som skal informere investorer og kreditorer som ønsker å anslå fremtidig utvikling for selskapet (adverse 
selection), ikke nødvendigvis er den samme informasjonen som er egnet for evaluering og oppfølging av selskapets ledelse (moralsk hasard). Dette ble påpekt av Gjesdal i 1981 (Gjesdal, 1981).

Selv om det er veletablert at objektivt sanne regnskapsstørrelser ikke eksisterer, er det en utbredt enighet om at regnskapet bør være nyttig og ha iboende kvaliteter som kan hjelpe regnskapsbrukeren med å ta gode beslutninger. Dette er beskrevet som beslutningsnytte og tar utgangspunkt i at dersom teoretisk korrekte regnskaper ikke kan utformes, bør man prøve å gjøre dem mer nyttige. For at regnskapet skal være nyttig, ligger det med utgangspunkt i beslutningsnytteperspektivet noen sentrale kvalitetskrav til grunn (Baksaas \& Stenheim, 2015). Regnskapet må være utformet slik at rimelig kompetente brukere skal kunne forstå og gjøre seg nytte av innholdet. Videre legges det vekt på sammenlignbarhet som et kvalitetskrav. Optimal og rasjonell beslutningstaking hviler på muligheten til å kunne sammenligne informasjon. Til slutt ligger det en vurdering av kostnad opp mot nytte. For at produksjon av regnskapet skal kunne forsvares, må nytten av regnskapet overstige kostnaden det har å produsere det.

Selv om regnskapet oppfyller sentrale kvalitetskrav, løser ikke dette nødvendigvis det fundamentale problemet om hvem som er den faktiske regnskapsbrukeren, og hvilke beslutningsproblemer de ulike brukerne har. Produksjon av regnskapsrapporter for eksterne brukere følger regler bygd på forutsetninger om brukeren og dennes anvendelse av regnskapsinformasjonen. Utarbeidelse av regnskap i samsvar med IFRS tar utgangspunkt $i$ en tenkt primærbruker av regnskapet, og i IFRS-rammeverket fra 2010 (IASB, 2010) trekkes det å gi informasjon som er relevant for verdsetting frem som eneste formål, altså satte rammeverket investor i fokus. Det å forhindre adverse selection ble prioritert foran moralsk hasard. Ved oppdatering av IFRS-rammeverket i 2018 (IASB, 2018) ble det imidlertid lagt mer vekt på at informasjonen også skal kunne nyttiggjøres mer for å evaluere ledelsens prestasjoner. Dette kan på mange måter fremstå som fornuftig, men det er i teorien holdepunkter for at dekning av begge behov, verdirelevans og evaluering av og kontroll med ledelsen, ikke lett lar seg kombinere med felles målsettinger og prinsipper for hvordan regnskapet skal utarbeides (se blant annet Gjesdal, 1981). 
IFRS’ konseptuelle rammeverk (IASB, 2018) har på overordnet nivå forsøkt å løse problemet med ulike brukerbehov ved å definere investorer og kreditorer som de primære interessentene, men selv om dette er klargjort i rammeverket, kan andre hensyn bli gjort gjeldende når det gjelder å utarbeide konkrete løsninger i standarder. Ulike brukergrupper og behov er også drøftet i forarbeider til den norske regnskapsloven (NOU 1995:30), hvor loven fra 1998 ble basert på tankegods og prinsipper fra historisk kost og ideen om at en viktig oppgave for regnskapet er å gi et bilde av sammenstilte inntekter og kostnader, en idé som kan spores tilbake til Paton og Litleton (1940).

I og med at nytte for investor har vært fremholdt som det primære formålet med regnskapet, har det vokst frem forskning som har tatt på seg å undersøke om regnskapsinformasjon faktisk har relevans i markeder for verdipapirer. Noe av kritikken mot IFRS og det konseptuelle rammeverkets holdning til nytten av regnskapsinformasjon er at det er basert på påstander om relevans heller en faktisk og etterprøvbar relevans (Lee, 2015). Forskningen som retter seg inn mot relevansen av regnskapet, hviler på en antagelse om at for at regnskapet skal være relevant, må det være en signifikant statistisk sammenheng mellom endringer i aksjepris og regnskapsinformasjon. Denne typen sammenheng ble testet så tidlig som på 196o-tallet. Ball og Brown (1968) undersøkte informasjonsinnholdet eller nytten av regnskapstall, mer spesifikt resultatet, ved å teste om markedet responderte i det aktuelle tidsvinduet for annonsering av resultatet. Ball og Brown (1968) fant positive sammenhenger, altså at markedet responderte på regnskapsinformasjonen, og regnskapsinformasjon kunne dermed anses å ha verdirelevans. Likevel var det identifisert små endringer i aksjekurs, og Ball og Brown (1968) estimerte at 85 til 90 prosent av informasjonen allerede var integrert $\mathrm{i}$ aksjeprisen ved annonsering av resultatet.

Denne måten å måle relevans av regnskapet på har imidlertid vært kritisert og debattert. For eksempel mener Holthausen og Watts (2001) at Ball og Brown (1968) og lignende studier, som for eksempel Francis og Schipper (1999), ikke tilstrekkelig reflekterer faktiske sammenhenger mellom finansiell informasjon og verdirelevans. Holthausen og Watts argumenterer for at resultatene av verdirelevansforskningen beskriver 
statistiske sammenhenger mellom relevante variabler heller enn kausalsammenhenger. Konklusjonen er uansett at funnene er uklare med tanke på verdirelevansen av finansiell rapportering. Leuz og Wysocki (2016) konkluderer også i sin studie av den empiriske litteraturen om økonomiske konsekvenser av rapportering og regulering med at det fortsatt mangler bevis for markedseffekter, andre faktiske effekter av rapportering og effekter av regulering av foretaksrapporteringen.

Det har de siste årene vært et økt volum av ikke-finansiell informasjon i selskapers rapporter. Dette har ført til økt interesse, både blant selskaper, forskere, regulerende myndigheter og andre interessenter. Det kan hevdes at denne interessen hviler på en gjennomgående trend om økt forventning til transparens i et mer globalisert og komplekst finansmarked, noe som gjerne leder til argumenter om at investorer trenger mer og annen informasjon for å vurdere verdien på verdipapirer. Ut av denne økte oppmerksomheten på andre typer informasjon har det vokst frem en rekke initiativer som ofte ønskes velkommen fordi det finnes en tro på at denne typen transparens og rapportering vil ha en form for verdirelevans. Debatten rundt ikke-finansiell informasjon har pågått en del år, men forskningsbasen vedrørende effektene av ikkefinansiell informasjon er ikke konsistent med tanke på dette. For eksempel tar Sutopo mfl. (2018) utgangspunkt i verdirelevansbegrepet fra Ball og Brown (1968) og undersøker om det er en sammenheng mellom relevansen av finansiell rapportering og om selskapene har vunnet pris for sin bærekraftrapportering. Resultatene i denne studien indikerer at det er en positiv sammenheng, altså at informasjon om å ha vunnet pris for bærekraftrapportering har en påvirkning på verdien av selskapets finansielle rapportering.

Andre initiativer som har vært studert, er integrert rapportering. Konklusjoner fra noen av disse studiene er at det ikke er tilstrekkelig med bevis for å kunne påstå at integrert rapportering har nytteverdi for markedet (se for eksempel Baboukardos \& Rimmel, 2016; Zenkina, 2018; Flower, 2015; Zhou et al., 2017). Litteraturen peker på flere grunner til at det kan være vanskelig å fastslå nytten av ikke-finansiell informasjon. Rapportering av ikke-finansiell informasjon innebærer større kompleksitet enn rapportering av finansiell informasjon. Når det i tillegg er vage og 
uklare standarder kombinert med stor valgfrihet i hva som skal rapporteres og hvordan (Flower, 2015), skaper dette vanskeligheter for brukere av informasjonen både fordi påliteligheten blir begrenset og fordi mulighetsrommet for hva som er rimelige fortolkninger, blir stort.

Litteraturen og 100 års utvikling av prinsipper, teori, regler og kunnskap om finansiell rapportering indikerer at det er krevende å etablere krav til foretaksrapportering, både finansiell og ikke-finansiell, som imøtekommer ulike brukeres behov samtidig. Dette har vi også vist nedenfor, i oppsummering av våre funn, med hensyn til rapporteringsenhet, rapporteringens formål og tiltenkte brukernytte samt kvalitetskriterier for rapportert ikke-finansiell informasjon.

\subsection{Metode}

Hensikten med dette kapittelet er å bidra med innsikt i diskusjonen om hvordan utvikling av regler og standarder for ikke-finansiell rapportering støter på tilsvarende utfordringer som ved utarbeidelse av lovgivning og standardsetting for finansiell rapportering. Studien er en dokumentstudie og er basert på følgende dokumenter:

- Regnskapsdirektivets bestemmelser om ikke-finansiell rapportering, etter endring i 2014.

- EUs retningslinjer for rapportering av ikke-finansiell informasjon (2017)

- Høringsdokumenter vedrørende EUs retningslinjer for klimarelatert informasjon (2019)

- Publiserte retningslinjer fra EU, juni 2019

Dokumentstudier av denne typen er en veletablert forskningsmetode, spesielt benyttet i kvalitative studier som for eksempel case-studier, og har vist seg å være spesielt hensiktsmessige for å gi en rik og dyp beskrivelse av enkeltfenomener (Bowen, 2009; Otley \& Berry, 1994). Smith (2019) hevder at dokumentanalyser gir en mulighet til å hente inn bevis fra en rekke ulike kilder, noe som igjen gir et spenn i typen analyser man har mulighet til å gjennomføre, fra fundamentale analyser av enkelte 
regnskapstall og parametere til kritisk innholdsanalyse av tekst og narrativer. Potensielt er det dermed en krevende metode siden den stiller en rekke krav til forskerens vurderinger. Viktige vurderinger som må gjøres, er ulike klassifiseringer av data, om det er noe innhold som skal vurderes som mer primært enn annet materiale. Andre vurderinger er knyttet til om data passer til formålet, om dataene er ny nok, om de er av god nok kvalitet med tanke på gjengivelse. Det finnes ikke absolutter når det gjelder disse kravene, og det stiller derfor ekstra krav til forskernes tilnærming til data i en sånn prosess (Smith, 2019).

For å ivareta de metodiske kravene i denne dokumentanalysen, har forfatterne, etter først uavhengig av hverandre å ha identifisert mulig relevante dokumenter, gått gjennom dokumentene. Basert på gjennomgangen har hver forfatter identifisert problemstillinger samt synspunkter fremkommet i høringsuttalelsene til Targeted Consultation on the Update of the Non-Binding Guidelines on Non-Financial Reporting (20 February20 March 2019). For utvalgte temaer og problemstillinger har vi også gjort enkelte oppslag i regler, standarder og dokumenter som det er henvist til i høringsuttalelser. Dette for å klargjøre betydningen av påpekninger og kommentarer gitt i nevnte dokumenter.

Deretter har vi i fellesskap diskutert våre funn: Har vi identifisert de samme problemstillinger og standpunkter, har vi forstått dokumentene på samme måte, og har vi resonnert på samme måte med hensyn til å identifisere og beskrive gap mellom fundamentet for retningslinjer for ikke-finansiell rapportering og fundamentet for finansiell rapportering? Basert på at vi har kommet til samme forståelse, har vi nedenfor gjort rede for funn i dokumenter og høringsuttalelser begrenset til disse temaene:

- rapporteringsenhet

- rapporteringens formål og tiltenkte brukernytte

- kvalitetskriterier for rapportert informasjon

Denne måten å gjennomføre analysen på har vært praktisk hensiktsmessig og gir etter vår oppfatning et forsvarlig grunnlag for våre funn og diskusjonen nedenfor. 


\subsection{Funn i dokumenter og høringsuttalelser}

Som pekt på tidligere, ligger det noen sentrale kvalitetskrav til grunn for at finansiell foretaksrapportering skal være nyttig: at regnskapet skal være forståelig for rimelig kompetente brukere, at det skal være relevant og troverdig, og at det skal være mulig å sammenligne informasjon. Våre funn fra analyse av dokumenter, som vi oppsummerer nedenfor, viser at dette er utfordrende innen rapportering av klimarelaterte opplysninger fra foretak.

\subsubsection{Rapporteringsenhet}

Paton (1922) slo fast at regnskapsrapportering forutsetter en identifiserbar, gjenkjennelig og distinkt forretningsenhet, og at dette ikke nødvendigvis beror på juridisk form eller identifikasjon med eiere. Kompleksitet og mangfold i måter å organisere økonomisk aktivitet på, med ulike kombinasjoner av formelle selskapsstrukturer, reelle styringsstrukturer og ulike former for kontrakter, gjør at det i dag ofte kan være krevende å definere rapporteringsenheten. Mens Paton så det slik at rapporteringsenheten var naturlig definert og identifisert av den som utarbeider regnskapet, ut fra at de fleste forretningsvirksomheter den gang var lett identifiserbare, har IFRS' konseptuelle rammeverk (2018) punkt 3.10 et annerledes utgangspunkt og definerer en rapporteringsenhet som en enhet som har plikt eller frivillig har valgt å utarbeide regnskapsrapporter. I punkt 3.13 klargjøres det at utgangspunktet er en juridisk enhet eller et konsern i juridisk forstand, men dette er ikke alltid tilstrekkelig for å identifisere og avgrense rapporteringsenheten. I punkt 3.14 gis det anvisning på at det i så fall skal være informasjonsbehovet til primærbrukerne av regnskapsrapportene som avgjør, og dette konkretiseres ved at informasjonen i rapporter skal gi et sannferdig bilde av det rapportene har til hensikt å gi et bilde av. Det vil at rapporteringsenhetens grenser ikke skal være villedende for investorer og kreditorer.

Artikkel 19a i regnskapsdirektivet, om ikke-finansiell redegjørelse fra store virksomheter, og artikkel 29a om konsolidert ikke-finansiell redegjørelse for store konsern er utgangspunktet for retningslinjene om 
ikke-finansiell rapportering (2017) og retningslinjene om klima-relaterte opplysninger (2019). Regnskapsdirektivet legger til grunn at årsregnskap utarbeides for juridisk enhet, og at konsernregnskap utarbeides for morforetak og datterforetak som om disse var en økonomisk enhet.

De nye bestemmelsene som ble tilføyd i 2014 om ikke-finansiell rapportering, har ikke egne bestemmelser som definerer rapporteringsenhet, men det er unntak fra rapporteringsplikt dersom opplysninger er rapportert av morselskap for konsernet.

I retningslinjene er det gitt konkrete anbefalinger med hensyn til rapportering om utslipp av klimagasser. Det anbefales å beregne utslipp av klimagasser i samsvar med GHG-protokollens metode eller ISO 14064. GHG-protokollen (2004) synes å være mye brukt av store foretak som rapporterer utslipp. Den åpner for alternative definisjoner av rapporteringsenhet og skiller mellom «equity share approach» og «control approach». Innenfor «control approach» skilles det mellom operasjonell kontroll og finansiell kontroll. Definisjonene er ikke avstemt mot eksempelvis IFRS eller nasjonale regnskapsregler. GHG-protokollen gir flere eksempler på forskjellene mellom å rapportere etter det ene eller det andre prinsippet. Et eksempel viser at andelen av utslipp fra et datterselskap kan inngå i konsernets rapportering av utslipp med 41,5 prosent, o prosent eller 50 prosent, avhengig av hvilken definisjon av rapporteringsenhet som anvendes (GHG-protokollen, 2004, s. 23). Valg av metode for å avgrense og identifisere rapporteringsenhet vil påvirke innholdet i rapporteringen, det vil si skillet mellom direkte og indirekte utslipp. I EUs retningslinjer gis det nærmere anbefaling om å rapportere 100 prosent av opplysningene om direkte klimagassutslipp fra kilder som eies eller kontrolleres av virksomheten, og det anbefales videre estimering dersom utslippene ikke kan måles pålitelig. Tilsvarende er anbefalt for klimagassutslipp fra produksjon, som følger av kjøpt og forbrukt energi. Der dette ikke er gjennomførbart, anbefaler EU-retningslinjene at det oppgis årsaker til mangler i rapporteringen.

I høringsuttalelser til 2019-retningslinjene er det pekt på at det mangler klargjøring av rapporteringsenhet og ikke skilles mellom det som er under operasjonell kontroll, og det som utgjør grensene for den finansielle rapporteringsenheten. Dermed kan måling og rapportering av utslipp av 
klimagasser gjøres med en annen definisjon av rapporteringsenhet enn den som er brukt i den finansielle rapporteringen.

\subsubsection{Formål, interessenter og nytte}

Regnskapsdirektivet fra 2013 hadde opprinnelig ikke andre krav enn at ledelsens beretning bør inneholde en analyse av miljømessige og sosiale aspekter ved virksomheten som er nødvendig for å forstå foretakets utvikling, resultat eller stilling. De tiltenkte brukerne av regnskapet er ikke omtalt i særlig grad i direktivet, ut over at det pekes på at regnskapsbrukere har mer begrensede behov for opplysninger fra små virksomheter enn fra store virksomheter. Vi må derfor gå til regnskapsstandarder og bakgrunnen for disse for nærmere veiledning om brukere og deres behov for ekstern regnskapsrapportering fra foretak, jf. beskrivelsen av dette tidligere i dette kapittelet.

Med endringen av regnskapsdirektivet i 2014 ble dette endret med hensyn til kravene om ikke-finansiell rapportering. For det første ligger det en tanke om brukere og brukeres etterspørsel etter opplysninger i avgrensningen av hvilke foretak bestemmelsene gjelder for, det vil si store foretak som har interesse for allmennheten. Hva det nærmere skal rapporteres om i form av ikke-finansiell redegjørelse, er avgrenset i artikkel 19a og 20 i regnskapsdirektivet til informasjon som er nødvendig for å forstå virksomhetens utvikling, resultat, stilling og påvirkning på miljømessige, sosiale og menneskelige ressursspørsmål, respekt for menneskerettigheter, bekjempelse av korrupsjon samt mangfold og likestilling. I fortalen i endringsdirektivet (2014) synes det å være lagt vekt på ansvarliggjøring og overvåkning av foretaket (stewardship). Hvem informasjonen som rapporteres, skal være rettet mot, er angitt i bare begrenset utstrekning, men det indikeres at informasjonen er tiltenkt å dekke både investorbehov og forbrukerbehov. Tanken er at rapporteringen skal øke tilliten blant investorer og forbrukere. Forbrukerhensyn er i begrenset utstrekning vektlagt i grunnlaget for finansiell rapportering.

2017-retningslinjene for ikke-finansiell rapportering vektlegger transparens og uttrykker at transparens forventes å gjøre virksomheter mer 
motstandsdyktige og robuste, og at dette gir vekst samt skaper tillit blant interessenter, inkludert investorer og forbrukere.

Hvem tiltenkte brukere av rapporteringen er, kommer også et stykke på vei til syne i retningslinjenes behandling av begrepet vesentlighet. Det vises til at det innen finansiell rapportering eksisterer et vesentlighetsbegrep (se også regnskapsdirektivet artikkel 2). Regnskapsdirektivet bruker også uttrykket «vesentlig risiko», og 2017-retningslinjene bygger videre på dette. Det er ikke bare antatte virkninger av opplysninger for informasjonsbrukeres beslutninger som skal tas i betraktning for å avgjøre om en opplysning er vesentlig. Retningslinjene sier at det kan tas hensyn til forretningsmodell, forretningsstrategi og viktige risikoer, de viktigste bransjespesifikke problemstillingene, virkningen av foretakets aktiviteter og politiske og reguleringsmessige forhold. Ifølge retningslinjene forventes det at virksomheter samarbeider med relevante interessenter og søker å få en god forståelse av deres interesser og bekymringer for å avgjøre hva som er vesentlige opplysninger som må inngå i den ikke-finansielle rapporteringen. Det anbefales også at foretakene redegjør for de ledelsesmessige tiltakene og prosessene som anvendes for å gjennomføre vesentlighetsvurdering.

Mens standarder for finansiell rapportering er rettet mot investorers og kreditorers antatte felles behov for generell finansiell foretaksrapportering, legger EUs retningslinjer for ikke-finansiell rapportering opp til at det skal gjøres en nokså detaljert foretaksspesifikk vurdering av brukerbehov, og at denne skal få betydning for hva som anses som vesentlig informasjon som bør rapporteres.

Retningslinjene fra 2017 angir vesentlighet ut fra to ulike perspektiver. I 2019-retningslinjene er dette beskrevet slik (her oversatt av oss til norsk):

- ... selskapets «utvikling, resultater [og] stilling omhandler økonomisk vesentlighet, dvs. [forhold] som i bred forstand påvirker verdien av selskapet. Klimarelatert informasjon bør rapporteres dersom det er nødvendig for å få en forståelse av selskapets utvikling, resultater og stilling. Dette perspektivet er vanligvis av størst interesse for investorer.» 
- «virkningen av [foretakets] aktivitet» handler om miljømessig og sosial vesentlighet. Klimarelatert informasjon bør rapporteres dersom det er nødvendig for å få en forståelse av hvordan virksomheten påvirker omverdenen. Dette perspektivet er typisk av størst interesse for innbyggere, forbrukere, ansatte, forretningspartnere, lokalsamfunn og sivilsamfunnsorganisasjoner. Imidlertid må et økende antall investorer også ha informasjon om klimapåvirkningen fra selskapene de investerer i, for bedre å forstå og måle klimapåvirkningen fra sine investeringsporteføljer.

Det slås fast i 2019-retningslinjene at vesentlighetsperspektivet i direktivet om ikke-finansiell rapportering dekker både finansiell, miljømessig og sosial vesentlighet. Mens finansiell vesentlighet er definert ut fra antatte brukeres beslutningssituasjoner og beslutningsnytte, er miljømessig og sosial vesentlighet i større grad knyttet til foretakets virkninger på samfunnet.

Flere høringsuttalelser støtter delingen av vesentlighetsbegrepet («double materiality») og mener dette er et steg i riktig retning. Like fullt kommer det også frem i høringsuttalelsene at konseptet er utilstrekkelig definert. Flere av informantene foreslår hvordan forståelsen av vesentlighetsbegrepet i direktivet kan utvikles. Noen foreslår at det trengs ytterligere forklaringer ved å bruke vanlige definisjonskriterier for hvordan de klimarelaterte risikoene for selskapet skal vurderes (økonomisk vesentlighet), og for den eksterne virkningen av selskapet som kan påvirke miljø, lokalsamfunn, forbrukere, innbyggere osv. (miljømessig og sosial vesentlighet). En informant foreslår at selskaper bør rapportere sin egen forståelse av innovative initiativer og hvilke resultat disse tiltakene har ut fra et dobbelt vesentlighetsperspektiv. Uansett er det underliggende budskapet at det trengs større klarhet vedrørende vesentlighetsbegrepet, med hensyn til både forutsetninger og grunnlag for det som er beskrevet om vesentlighet i retningslinjene, om forståelsen og om den tiltenkte praktiseringen. I tillegg kan det dermed pekes på at slik regnskapsdirektivet fremstår per nå, eksisterer det forskjellige brukerperspektiver for den finansielle rapporteringen og for deler av den ikke-finansielle rapporteringen. 


\subsubsection{Kvalitet}

IFRS' konseptuelle rammeverk har et kapittel hvor fundamentale kvalitative egenskaper og forbedrende kvalitative egenskaper ved nyttig finansiell informasjon er beskrevet. De fundamentale egenskapene er relevans og sannferdig representasjon. Sistnevnte ble tidligere kalt pålitelighet. Endringen har vært omdiskutert og har trolig skapt mindre klarhet enn tidligere (Kinserdal, 2019). Relevans betyr at informasjonen kan utgjøre en forskjell for beslutninger som tas av regnskapsbrukere, noe som innebærer at informasjonen kan brukes i prediksjon eller gir bekreftelse av noe som regnskapsbrukeren tidligere har antatt eller vet. Reduksjon av usikkerhet er med andre ord noe som gjør informasjon relevant. Det regnskapsmessige vesentlighetsbegrepet er knyttet til relevans. Sannferdig representasjon innebærer at informasjonen er fullstendig, nøytral og fri for feil så langt det lar seg gjøre, med tanke på at regnskapsbrukeren skal forstå informasjonen som gis. I rammeverket påpekes det at det noen ganger er nødvendig å gjøre avveininger mellom relevans og pålitelighet for å frembringe nyttig informasjon om økonomiske forhold. Sammenlignbarhet, verifiserbarhet, tidsriktighet og forståelighet er de forbedrende egenskapene.

I fortalen til endringsdirektivet fra 2014 står det at målet med direktivet er å øke relevansen, konsistensen og sammenlignbarheten av informasjonen som foretakene skal offentliggjøre. Direktivet benytter disse begrepene i forbindelse med at det angis hva foretakene skal rapportere om.

I 2017-retningslinjene er det beskrevet nøkkelprinsipper for ikkefinansielle redegjørelser. Disse er dels sammenfallende med det som gjelder for finansiell rapportering, men det er også tatt inn prinsipper som primært gjelder hva det skal gis opplysninger om, og i mindre grad egenskaper ved informasjonen. Nøkkelprinsippene går ut på at ikke-finansiell informasjon skal være 1) vesentlig, 2) rettvisende, balansert og forståelig, 3) fullstendig, men konsis, 4) strategisk og fremtidsorientert, 5) interessentorientert og 6) konsekvent og sammenhengende. 2019-retningslinjene presiserer at nøkkelprinsippene i 2017-retningslinjene skal anvendes ved rapportering av klimarelaterte opplysninger.

I retningslinjene anbefales det at en skiller mellom faktainformasjon og informasjon som innebærer synspunkter og fortolkninger, i 
den ikke-finansielle redegjørelsen. Videre gis det i pkt. 3.2 eksempler på hvordan opplysninger kan gjøres mer rettvisende og konsise. Blant annet nevnes robust og pålitelig dokumentasjon, kontroll- og rapporteringssystemer og bruk av uavhengig ekstern revisor.

I punkt 3.6 går det frem at den ikke-finansielle redegjørelsen forventes å være i overensstemmelse med andre elementer i ledelsesberetningen. Dette betegnes som konsekvent og sammenhengende.

Det er flere uttalelser i forutgående høringsrunde som peker på at det er positivt at krav og retningslinjer inntil videre inneholder frihet og fleksibilitet, for foretak har behov for gradvis å utvikle evne og kapasitet til å forbedre rapporteringen av klima-relatert informasjon. Flere av høringsuttalelsene gir uttrykk for at både krav og retningslinjer må bli mer tydelige og konsistente, at det må utvikles ytterligere implementeringsveiledning, og at foretakene trenger tid for å bli i stand til å rapportere klimarelatert informasjon i samsvar med ambisjonsnivåt i retningslinjene.

Flere av informantene i høringsuttalelsene peker på at når det gjelder ikke-finansiell rapportering, vil det være vanskelig å få til en «one size fits all», og at det er nødvendig med fleksibilitet og muligheten til å tilpasse rapporteringen til den enkelte rapporteringsenhetens spesielle karakteristikker. Andre informanter reflekterer annerledes på streng standardisering versus større fleksibilitet. Gitt kvalitetskravet om sammenlignbarhet, vil det by på utfordringer dersom foretakene har mulighet til å skreddersy sin rapportering og at rapporteringen ikke er bindende. Dette er noe som også vil være utforende med tanke på kravet om at rimelig kompetente brukere av opplysninger som rapporteres, skal ha mulighet til å orientere seg tilstrekkelig i rapportene. Det vil dessuten foreligge utfordringer med tanke på verifiserbarhet. Dette pekes på i flere av høringsuttalelsene.

\subsection{Diskusjon og avsluttende kommentarer}

Litteraturgjennomgangen, dokumentanalysen og analysen av høringsuttalelser viser at det er langt igjen før ikke-finansiell rapportering og krav til ikke-finansiell rapportering kan oppnå tilsvarende systematikk og konsistente logikk som over en 100 års periode er utviklet for finansiell 
rapportering. På den annen side er det kjent at finansiell rapportering bygger på noen konstruerte forutsetninger, en viss pragmatisme og flere omdiskuterte regulatoriske løsninger. Bruk av kriterier hentet fra finansregnskapsfeltet ved utvikling av ikke-finansiell rapportering eller evaluering av krav, retningslinjer og standarder for ikke-finansiell rapportering, er sannsynligvis hensiktsmessig fordi det neppe finnes gode alternative rammeverk å bygge på.

Gapet som i dag eksisterer mellom forutsetninger for ikke-finansiell rapportering og rammeverk for finansiell rapportering med hensyn til klargjøring av formål, interessentgrupper (brukere) og nytte, kan trolig reduseres dersom det legges mer innsats i dette før øvrige aspekter ved ikke-finansiell rapportering, herunder sammenhenger mellom ikke-finansiell og finansiell rapportering, videreutvikles og reguleres strammere.

Videre kan gapet med hensyn til kvalitet på informasjonen trolig også reduseres ved at det i større utstrekning utvikles kvalitetskriterier for ikke-finansiell informasjon basert på kvalitetskrav til informasjon i IFRS' konseptuelle rammeverk. Det fremkommer også forholdsvis klart at todelingen av vesentlighetsbegrepet som gjøres av EU retningslinjer for rapportering, og tilhørende brukerorientering, gir utfordringer for sammenlignbarhet, spesielt når det gjelder den ikke finansielle rapporteringen av foretaks virkninger på miljø og samfunn.

En begrensning ved studien er at den har et overordnet perspektiv, men likevel kun dekker ett av flere sett med anbefalinger og retningslinjer for ikke-finansiell rapportering. Det er mulig at det kan utledes et mer samlet solid underliggende fundament som regelutvikling og standardsetting kan bygge videre på dersom det gjøres en analyse og syntese som omfatter grunnlaget for flere av retningslinjene som nå finnes for ikke-finansiell rapportering, eksempelvis GRI, ISO, NASDAQs retningslinjer og Euronexts retningslinjer. Mer detaljerte studier kan avdekke flere nyanser og kunnskap som kan modifisere eller nyansere vår kritikk av utviklingen av ikke-finansiell rapportering.

Vårt datagrunnlag består utelukkende av dokumenter. En slik dokumentanalyse som vi har basert dette kapittelet på, innebærer fortolkning og dermed innslag av subjektivitet. Et bredere tilfang av data, herunder intervju med både brukere av foretaksrapportering, politikere, 
standardsettere og produsenter av foretaksrapportering, kan gi et mer nyansert og presist bilde av hensiktsmessigheten og antatte virkninger av EUs guidelines. Likevel mener vi at dette kapittelet metodisk er gjennomført på en sånn måte at funnene gir et forsvarlig grunnlag for våre konklusjoner. Vi kan likevel, med en viss trygghet, gå ut fra at det å utlede hva som bør rapporteres av ikke-finansiell informasjon ut fra betraktninger om hvem som er interessenter og brukere av den rapporterte informasjonen og hva slags bruk som er aktuell, ikke resulterer i praktiske løsninger som fullt ut tilfredsstiller et komplett sett med prinsipper samtidig som ulike brukergruppers behov og ønsker oppfylles. Det er nærliggende å forvente at videre utvikling av ikke-finansiell foretaksrapportering er utsatt for tilsvarende utfordringer som har gjort seg gjeldende ved utvikling av rammer for og krav til finansiell foretaksrapportering. På den annen side kan den videre utviklingen av krav til ikke-finansiell foretaksrapportering gjøres raskere nettopp fordi det er mulig å bygge på kunnskap og erfaringer fra finansregnskapsfeltet.

EU arbeider videre med å utvikle kravene til og veiledning om ikke-finansiell rapportering. Våren 2020 er det gjennomført høring som vil inngå i grunnlaget for eventuelle forbedringer av direktiv 2014/95/EU. I høringen er det blant annet etterspurt synspunkter på behovet for at det også stilles krav til ikke-finansiell rapportering fra små og mellomstore foretak, men enklere krav enn for store foretak.

\subsection{Forslag til videre forskning}

Videre forskning rettet mot å avdekke mer spesifikke, men felles behov for standardisert foretaksrapportering for ulike interessentgrupper for foretak kan bidra til å avklare nærmere hvordan foretakene må kombinere finansiell og ikke-finansiell rapportering, til beste for brukerne av rapportert informasjon, markeder og samfunnet. Det er også behov for å avdekke forskjeller i informasjonsbehov nærmere for ulike grupper av eksterne interessenter til foretak. Dette fordi det både for informasjonsprodusenter og for brukere av foretaksrapportering er gunstig med klare føringer for hvilke informasjonselementer som bør være integrert med den finansielle rapporteringen, og hvilke som bør utgjøre en selvstendig 
rapport uavhengig av den finansielle rapporteringen. Utforming av hensiktsmessige regulatoriske krav og standarder vil dra nytte av mer kunnskap om argumentene for alternative løsninger på dette området.

Intervju med ulike typer brukere av foretaksrapportering kan bidra til økt forståelse av vektingen av relevans vs. pålitelighet og behovet for sammenlignbarhet. Nåværende praksis med vesentlighetsanalyser som verktøy for foretakets ledelse til å avgjøre hva som skal rapporteres og hvordan, er det flere grunner til å stille spørsmål ved. Dersom vi får $ø$ kende og beslutningskritisk anvendelse av ikke-finansielle rapporteringselementer, blir også pålitelighet og objektivitet for rapporteringen viktig. Dette bør studeres nærmere.

Videre forskning kan også bidra til å avklare behovet for underliggende systemer og intern kontroll knyttet til frembringelse av rapportering av ikke-finansiell informasjon. Eksempelvis kan dette bidra til å initiere debatt om hvorvidt bokføringsloven bør få et tillegg om grunnlag for ikke-finansiell rapportering, og om selskapslovgivningens bestemmelser om ledelsens oppgaver og ansvar bør utvides eller presiseres i samme retning.

\section{Referanser}

Accountancy Europe. (2019). Interconnected standard setting for corporate reporting.

(December 2019). Hentet desember 2019 fra www.accountancyeurope.eu

Aerts, W. \& Cormier, D. (2009). Media legitimacy and corporate environmental communication. Accounting, organizations and society, 34(1), 1-27.

Baboukardos, D. \& Rimmel, G. (2016). Value relevance of integrated reporting disclosures: Evidence from the Johannesburg Stock Exchange. Journal of Accounting and Public Policy, 35(4), 437-452.

Baksaas, K. M. \& Stenheim, T. (2015). Regnskapsteori. Oslo: Cappelen Damm Akademisk.

Ball, R. \& Brown, P. (1968). An empirical evaluation of accounting income numbers. Journal of accounting research, 159-178.

Berle, A. A. \& Means, G. C. (1932). The modern corporation and private property.

Bowen, G. A. (2009). Document analysis as a qualitative research method. Qualitative Research Journal, 9(2), 27.

Brandsås, H. (2019). Bærekraft og rapportering. Revisjon og Regnskap, 6, 31-33. 
Den norske revisorforening. (2019). Samordnet finansiell og ikke-finansiell rapportering. Hentet fra https://www.revisorforeningen.no/fag/nyheter/ samordnet-finansiell-og-ikke-finansiell-rapportering/

EU. Direktiv 2013/34/EU om årsregnskaper, konsoliderte regnskaper og tilhørende rapporter for visse selskapsformer, om endring av europaparlaments- og rådsdirektiv 2006/43/EF og om oppheving av rådsdirektiv 78/60o/EØF og 83/349/EØF.

EU. Direktiv 2014/95/EU om visse store foretaks og konserners offentliggjøring av ikkefinansielle opplysninger og opplysninger om mangfold.

EU. Retningslinjer for ikke-finansiel rapportering (metode til rapportering af ikkefinansielle oplysninger) (2017/C 215/01). (Dansk).

EU. Retningslinjer for ikke-finansiel rapportering: Tilloeg om rapportering af klimarelaterede oplysninger (2019/C 209/01). (Dansk).

Euronext. (2020). Guidelines to issuers for ESG reporting.

Flower, J. (2015). The international integrated reporting council: A story of failure. Critical Perspectives on Accounting, 27, 1-17.

Francis, J. \& Schipper, K. (1999). Have financial statements lost their relevance? Journal of accounting Research, 37(2), 319-352.

GHG-Protocol. (2004). The greenhouse gas protocol - a corporate accounting and reporting standard, revised edition. World Resources Institute and World Business Council.

Gjesdal, F. (1981). Accounting for stewardship. Journal of Accounting Research, 19(1), 208-231.

Global Reporting Initiative (GRI), Global Sustainability Standards Board (GSSB). (2016). GRI Sustainability Reporting Standards. Hentet 20.11.2019 fra https://www. globalreporting.org/standards/gri-standards-download-center

Holthausen, R. W. \& Watts, R. L. (2001). The relevance of the value-relevance literature for financial accounting standard setting. Journal of accounting and economics, 31(1-3), 3-75.

IASB. (2010 og 2018). Conceptual framework for financial reporting. IFRS Foundation.

ISO 14064-1:2018. Specification with guidance at the organization level for quantification and reporting of greenhouse gas emissions and removals.

Kinserdal, H. (2019). Nytt konseptuelt rammeverk fra IASB. Magma, 1, 54-64.

Lee, T. A. (2015). Accounting and the decision usefulness framework. I The Routledge companion to financial accounting theory (s. 130-148). Routledge.

Leuz, C. \& Wysocki, P. D. (2016). The economics of disclosure and financial reporting regulation: Evidence and suggestions for future research. Journal of accounting research, 54(2), 525-622.

Lov om årsregnskap m.v. (regnskapsloven) 17.07.1998 nr. 56.

Lov om bokføring (bokføringsloven) 19.11.2004 nr. 73. 
NASDAQ. (2019). ESG reporting guide.

NOU 1995:30 Ny regnskapslov.

NOU 2015:10 Lov om regnskapsplikt.

Otley, D. T. \& Berry, A. J. (1994). Case study research in management accounting and control. Management Accounting Research, 5(1), 45-65.

Paton, W. A. (1922). Accounting theory, with special reference to the corporate enterprise. Ronald Press.

Paton, W. A. \& Littleton, A. C. (1940). An introduction to corporate accounting standards. American Accounting Association, Monograph No. 3, 1940.

Smith, M. (2019). Research methods in accounting. SAGE Publications.

Sutopo, B., Kot, S., Adiati, A. K. \& Ardila, L. N. (2018). Sustainability reporting and value relevance of financial statements. Sustainability, $10(3), 678$.

Venturelli, A., Caputo, F., Leopizzi, R. \& Pizzi, S. (2019). The state of art of corporate social disclosure before the introduction of non-financial reporting directive: A cross country analysis. Social Responsibility Journal, 15(4), 409-423.

Zenkina, I. V. (2018). Global promotion of integrated reporting by enhancing its informative and analytical value for stakeholders.

Zhou, S., Simnett, R. \& Green, W. (2017). Does integrated reporting matter to the capital market? Abacus, 53(1), 94-132.

UN. (2015). Paris Agreement: Essential elements. Hentet 01.02.2020 fra https://unfccc. int/process-and-meetings/the-paris-agreement/the-paris-agreement 


\title{
Om forholdet mellom revisjonens og skattemyndighetenes vesentlighetsforståelse relatert til revisjon av skatterelevante regnskapsopplysninger
}

\author{
Eivind Ludvigsen
}

Advokat, CeMa Advokat

\section{Ellen M. Kulset}

Førsteamanuensis, Universitetet i Sørøst-Norge og Norges Handelshøyskole

\begin{abstract}
Sammendrag: Vesentlighetsbegrepet spiller en stor rolle i revisjonsfaget når revisor planlegger, gjennomfører og konkluderer på det arbeidet han har utført hos en kunde, ved at det legges til grunn at revisors arbeid er å avdekke og rapportere feil som er å regne som vesentlige enten alene eller i kombinasjon med andre feil. I dette kapittelet analyserer vi forskjellen mellom hvor stor en skatterelevant regnskapsfeil må være for at skattemyndighetene skal handle på grunnlag av den, og hvor stor den må være for at revisjonen skal være innrettet på å avdekke den, samt konsekvenser av denne forskjellen for samspillet mellom revisor og skattemyndigheter. Forskjellen er stor, unntatt for enkelte utvalgte forhold, der det i medhold av særregler om forholdet til skatteforvaltningen stilles store krav til hva revisjonen skal avdekke. Kapittelet viser at det representerer et logisk brudd i regelverket at ikke disse særreglene om hva revisjonen skal avdekke, legger til grunn likere vesentlighetsgrenser for alle de postene som reelt er skatterelevante.
\end{abstract}

Nøkkelord: vesentlighet, ISA 320, skatterelevante regnskapsopplysninger

Sitering av denne artikkelen: Ludvigsen, E. \& Kulset, E. M. (2020). Om forholdet mellom revisjonens og skattemyndighetenes vesentlighetsforståelse relatert til revisjon av skatterelevante regnskapsopplysninger. I T. Stenheim, K. M. Baksaas og E. M. Kulset (Red.), Aktuelle temaer i regnskap og revisjon (Kap. 12, s. 345-378). Oslo: Cappelen Damm Akademisk. https://doi.org/10.23865/noasp.112.ch12

Lisens: CC-BY 4.0. 


\subsection{Innledning, oversikt og premisser \\ 12.1.1 Innledning}

Beslutninger som fattes ved planleggingen av et revisjonsoppdrag, innebærer blant annet at det etableres en grense for hvor store eventuelle feil i regnskapet må være for at revisjonen skal være innrettet på å oppdage dem. Det vil alltid være behov for å fastslå en slik grense ettersom revisjonsoppdraget alternativt ville anta et helt uakseptabelt omfang med hensyn til både tid og kostnader. Denne grensen, som i revisjonsterminologi benevnes «vesentlighet», vil være utledet fra hvor stor man i det enkelte tilfellet antar at en regnskapsfeil, eller summen av regnskapsfeil, må være for å «påvirke de økonomiske beslutningene som treffes av brukerne på grunnlag av regnskapet», jf. ISA 320 (International Standard on Auditing 320), pkt. 2. Historisk har det vært lagt til grunn at man med «bruker» først og fremst tenker på nåværende og potensielle investorer da denne gruppens behov antas å dekke behovene også til andre brukergrupper, jf. IASB (International Accounting Standard Board, 2001). I den nyeste utgaven av IASBs Conceptual Framework legges det til grunn at man først og fremst er opptatt av brukergruppene nåværende og potensielle investorer samt långivere og andre kreditorer, se Conceptual Framework, pkt. 1.2 (IASB, 2018). Skattemyndighetene er ikke en målgruppe som står i fokus i de internasjonale revisjonsstandardene.

Det skal imidlertid normalt mye mindre til for at en feil vil virke inn på de beslutningene som skattemyndighetene treffer overfor de regnskapspliktige (skattepliktige), enn på de økonomiske beslutningene som treffes av andre brukere. Derfor er revisor pålagt å avgi en særlig attestasjon til skattemyndighetene i form av sin signatur på den regnskapspliktiges næringsoppgave (i tillegg til å avgi den ordinære revisjonsberetningen), og det er utviklet en særnorsk revisjonsstandard, SA 3801, som omhandler revisors kontroll av og rapportering om grunnlag for skatter og avgifter. For denne særlige attestasjonen gjelder det delvis en lavere grense for hva som anses som vesentlig, jf. SA 3801 (Den norske Revisorforening, 2007). Men denne lavere vesentlighetsgrensen er utformet slik at den pålegger valg av en lavere vesentlighetsgrense bare for visse bestemte deler av regnskapet, selv om nesten alle de øvrige 
resultatpostene i regnskapet også vil virke inn på fastsettelsen av den regnskapspliktiges skattepliktige inntekt.

For de resultatpostene som ikke omfattes av krav til lavere vesentlighetsgrense i henhold til SA 3801, vil kombinasjonen av revisors revisjonsberetning og signatur på næringsoppgaven derfor kunne gi skattemyndighetene en slags «falsk trygghet». Denne falske tryggheten kan med enkle grep reduseres ved å kommunisere den reelle situasjonen bedre. Det er også i prinsippet tenkelig at den kan reduseres ytterligere ved å senke revisors generelle vesentlighetsgrense noe. Økt digitalisering av revisjonsarbeidet kan potensielt øke mulighetene for dette. Det er dessuten tenkelig at den falske tryggheten kan reduseres, eller gjøres mindre betydningsfull, ved at skattemyndighetene øker sin grense for hvor stor en feil må være for at de skal opprette en sak (heretter skattemyndighetenes handlingsgrense). Dette ville potensielt kunne gi en bedre utnyttelse av skattemyndighetenes kontrollressurser.

Det finnes en betydelig mengde empirisk forskning innenfor temaet revisjonsvesentlighet og på forskjellige typer «forventningsgap» knyttet til vesentlighetsgrenser i revisjonen og til revisjonen generelt (altså situasjoner der bruker forventer noe annet av revisor/revisjonen enn det revisor faktisk leverer). Det finnes imidlertid ingen rettsvitenskapelig forskning på temaet (altså forsøk på å belyse den rettslige vesentlighetsgrensen direkte ved anvendelse av juridisk metode) og heller ingen forskning som belyser forventningsgapet, eller i det hele tatt vesentlighetsgrensene, med utgangspunkt i skattemyndighetenes forventninger som regnskapsbruker som vi er kjent med. Så langt vi kjenner til, finnes det ingen rettsvitenskapelig forskning som belyser gapet (de lege lata eller de lege ferenda) mellom den rettslige vesentlighetsgrensen etter norsk rett og norske skattemyndigheters berettigede forventninger som regnskapsbruker - og det er enkelte sider av dette som er tema for vårt kapittel. Dette kapittelets bidrag er således en nærmere juridisk og rettspolitisk analyse av sammenhengen mellom revisors vesentlighetsgrenser, revisjonsberetning, signatur på næringsoppgaven og skatteforvaltningsretten.

Et sentralt forhold av mulig betydning for analysen er at det i praksis kan være at sentralskattekontorene i mindre grad baserer seg på revisors arbeid, og i mindre grad tar opp spørsmål av beskjeden beløpsmessig 
størrelse, enn de ordinære skattekontorene. Dette er ikke undersøkt nærmere, og kapittelet er skrevet med utgangspunkt i, og fokuserer på, foretak som ikke følges opp av et sentralskattekontor.

Kapittelet er ment å være av interesse for dem som arbeider med det skatteforvaltningsrettslige og revisjonsrettslige forholdet mellom skatt, regnskap og revisjon. Siden kapittelet er så vidt interdisiplinært, gis det først korte innledninger om henholdsvis det regnskaps- og revisjonsfaglige vesentlighetsbegrepet, sammenhengen mellom regnskap og skatt etter norsk rett og sammenhengen mellom revisjon og skatteforvaltning etter norsk rett. Med dette som utgangspunkt skisseres deretter et enkelt stilisert talleksempel som så gjennomgående benyttes til å illustrere den sammenhengen som søkes belyst i analysen av hvert av de etterfølgende rettslige og faktiske temaene, og i sammenfatningen.

\subsubsection{Det regnskaps- og revisjonsfaglige vesentlighetsbegrepet}

Vesentlighet (materiality) er et internasjonalt regnskaps- og revisjonsfaglig grunnbegrep, definert ved at regnskapsmessig feilinformasjon anses som vesentlig dersom rasjonelle aktører ville handlet annerledes uten den aktuelle feilinformasjonen, jf. ISA 320, pkt. 2. ${ }^{1}$ I forbindelse med avslutningen av et revisjonsoppdrag uttaler revisor seg i sin revisjonsberetning om hvorvidt regnskapet «i det alt vesentlige er utarbeidet i samsvar med det gjeldende rammeverket for finansiell rapportering», jf. ISA 70o, pkt. 10. Ulike aktører som regnskapsprodusenter, regnskapsbrukere og revisorer vil imidlertid kunne ha ulike oppfatninger av hva vesentlighet $\mathrm{i}$ regnskapsfaglig forstand innebærer. Det som er i fokus her, er forholdet mellom visse sider av vesentlighetsgrensene slik de fastsettes av revisor, og visse sider av behovene til skatteetaten, som er en viktig regnskapsbruker.

Det revisjonsfaglige vesentlighetsbegrepet reguleres i ISA 320 og ISA 450, der det fremkommer at revisor i forbindelse med sin planlegging av et revisjonsoppdrag fastsetter en totalvesentlighetsgrense samt en

1 «Feilinformasjon» omfatter i denne sammenheng også utelatelser. 
arbeidsvesentlighetsgrense («performance materiality»), i form av ett beløp for hele regnskapet, eller mer praktisk i form av flere beløp, der hvert av dem gjelder for en bestemt del av regnskapet, jf. ISA 320, pkt. 9 og pkt. A13. For å begrense risikoen for at summen av uavdekkede feil og avdekkede ukorrigerte feil overstiger vesentlighetsgrensen, settes arbeidsvesentligheten til et lavere beløp enn den tilsvarende vesentlighetsgrensen som er fastsatt for regnskapet total sett, jf. ISA 320, pkt. 9 og pkt. A13. Fastsettingen av arbeidsvesentlighet skal være gjenstand for et profesjonelt skjønn og ikke bare være en mekanisk beregning, og den skal (i likhet med planlagte handlingsregler innenfor de fleste fagområder) oppdateres eller revurderes under gjennomføringen når ny informasjon tilsier det, jf. ISA 320 pkt. A13 og A14.

Gjennom de siste 60-70 årene er det gjennomført omfattende empirisk forskning for å avklare hvor stor en regnskapsfeil må være for at den skal være vesentlig for brukerne. Forskningen frem til 1982 er beskrevet i en oversiktsartikkel av Holstrum og Messier (1982), og den videre utviklingen derfra og frem til 2005 er, med førstnevnte artikkel som utgangspunkt, beskrevet i en oversiktsartikkel av Messier mfl. (2005). Forskningen har mest vært vinklet mot børsnoterte foretak og til dels andre store foretak.

For børsnoterte foretak indikerer forskningen for eksempel at feil som utgjør minst 10 prosent av det ordinære resultatet, normalt anses som vesentlige av alle de aktuelle gruppene (unntatt når resultatet er nær null), mens feil som utgjør 4-5 prosent eller mindre, normalt anses som uvesentlige av alle gruppene (Holstrum \& Messier, 1982, s. 59). For unoterte foretak eksisterer det mindre forskning, men norsk profesjonslitteratur indikerer at det i disse selskapene kan benyttes høyere vesentlighetsgrenser enn i noterte foretak (Gulden, 2016).

Forskning viser videre (se Eilifsen \& Messier, 2015) at selv om revisors vesentlighetsgrense fornuftig kan settes til eksempelvis 5 prosent av overskuddet i et gitt, noenlunde representativt, typetilfelle, så kan denne prosentuelle grensen ikke anses som helt fast. Ulike omstendigheter kan i det enkelte tilfellet tilsi at grensen blir satt noe høyere eller noe lavere. Bestridte/diskutable feil kan for eksempel være beløpsmessig noe høyere før de blir ansett som vesentlige, enn ubestridte/udiskutable feil. Vesentlighetsgrensen kan være lavere blant annet for feil som er klare 
og ubestridte, og for feil knyttet til endringer eller inkonsistens i prinsippanvendelse. Arbeidsvesentligheten blir gjerne satt lavere når revisor opplever kompleksiteten som høy, og når overskuddet er nær null. Det observeres også en viss tilbøyelighet til å basere vesentlighetsgrensen for et regnskapsår med særlig høyt overskudd på et «normalt» årsresultat fremfor å basere det slavisk på årets overskudd.

Forskning knyttet til ulike regnskapsbrukeres forståelse av vesentlighetsbegrepet viser at jurister/dommere synes å ha et noe strengere syn på hva som er vesentlig, enn andre grupper (de mener altså typisk at vesentlighetsgrensen bør settes noe lavere enn hva andre brukergrupper typisk mener), se for eksempel Jennings mfl. (1991). Merk imidlertid at dette er en relativt gammel studie, slik at dette kan ha endret seg. Denne brukergruppen uttrykker også en høy grad av enighet om at det vil være ønskelig med eksplisitte kvantitative standarder for vesentlighetsgrensene.

De faktiske vesentlighetsgrensene, som har vært observert gjennom atferd og uttalelser fra regnskapsbrukere og andre, har i stor grad påvirket revisjonsbransjens praksis, som i sin tur har påvirket eller dannet grunnlag for utviklingen av rettslige vesentlighetsgrenser. I Norge har denne dynamikken mellom faktisk og rettslig vesentlighetsforståelse også blitt forankret i loven, ved at revisorloven (revl.) $\$$ 5-2 1 . ledd benytter seg av begrepet «vesentlig», og ved at forarbeidene uttaler at dette skal forstås som en lovfesting av innarbeidet praksis (se nærmere om dette i 12.2.1 nedenfor).

Det er naturligvis ikke opplagt hva som er revisjonsbransjens praksis, herunder om denne er noenlunde ensartet, om den utvikler seg over tid, osv. Eilifsen og Messier (2015) studerer de skriftlige retningslinjene til de åtte største revisjonsselskapene i USA og finner at disse i stor grad har samsvarende retningslinjer. Vesentlighetsgrensen fastsettes som utgangspunkt som en prosentsats av et resultatbegrep, omtrent som beskrevet i tidligere forskning, men med mulighet for i stedet å basere grensen på salgsinntekter, eiendeler eller egenkapital når konkrete forhold tilsier det. Når det gjelder arbeidsvesentlighet, fastsetter sju av revisjonsselskapene denne som et beløp i intervallet 50 til 75 prosent av totalvesentlighetsgrensen, mens det siste revisjonsselskapet setter denne i intervallet 70 til 90 prosent av den totale vesentlighetsgrensen (Eilifsen \& Messier, 2015). 
Når en enkeltbruker, en gruppe regnskapsbrukere, eller samfunnet som sådan har større forventninger til revisjonen enn det som følger av den rettslige vesentlighetsgrensen, vil det foreligge et forventningsgap som ikke representerer et regelbrudd. Forventningsgapet i forhold til den rettslige vesentlighetsgrensen kan i prinsippet søkes redusert ved å kommunisere denne grensen klarere og bedre (herunder eventuelt ved å publisere de konkrete vesentlighetsgrensene som er fastsatt for hvert enkelt regnskap) og/eller ved å la den rettslige vesentlighetsgrensen påvirkes også direkte av tilstrekkelig velbegrunnede forventninger, fremfor bare å la den formes av bransjepraksis.

\subsubsection{Forholdet mellom regnskap og skatt etter norsk rett}

Frem til skattereformen av 1992 var det en nær sammenheng mellom norske skatteregler og regnskapsregler, formulert som en regel om at regnskapet dannet utgangspunktet for fastsettingen av skattepliktig inntekt. ${ }^{2}$ Ved skattereformen 1992 ble en stor del av disse koblingene opphevet, først og fremst fordi man anså det som uheldig at størrelsen på skattepliktig inntekt skulle være avhengig av skjønnsmessige regnskapsmessige vurderinger, se NOU 1989: 14, s. 235. Direkte skulle de gjenværende koblingene bare gjelde tidfesting, og bare når det ikke var fastsatt skattemessige spesialregler (og slike spesialregler ble fastsatt for mange viktige poster). Med virkning fra 2005 ble skatteretten formelt koblet av fra de gjenværende bindingene til regnskapsretten gjennom en endring av skatteloven (sktl.) $\$ 14-2$. Det skatterettslige realisasjonsprinsippet skulle fra da av gjelde som generell hovedregel ved beskatningen, se Hauge (2012) for en fullstendig behandling av dette. ${ }^{3}$ Skatteloven og regnskapsloven (rskl.) har fra da av formelt vært to atskilte systemer. De inneholder på

2 Se daværende sktl. $\$ 50$ første ledd. Det oppstod mange spørsmål om hvor langt denne koblingen rakk, men det er på det rene at den var svært omfattende.

3 Endringen hadde sammenheng med innføringen av IFRS (International Financial Reporting Standards) i regnskapsretten. 
mange områder samme eller lignende løsning for samme forhold og med samme eller lignende begrunnelse, men er altså uavhengige regelsett.

For skatteforvaltningen er det annerledes. Skatteforvaltningen og regnskapet bygger begge på den samme bokføringen (registreringen). Det er først og fremst bokføringsloven (bfl.) og bokføringsforskriften (bff.) som regulerer selve plikten til å registrere, spesifisere og dokumentere inntekter og kostnader løpende mens driften pågår. Regnskapsloven hviler på det grunnlaget som på denne måten er lagt gjennom bokføringen når det deretter skal produseres årsregnskaper eller perioderegnskaper. Det samme gjør skatteforvaltningsloven (sfl.), som bygger på at de skattepliktige er pålagt å etterleve bfl. og bff., og den pålegger selvsagt ikke noe parallelt system for de løpende grunnlagsregistreringene. Skatteforvaltningslovens system for den skatteforvaltningsrettslige koblingen mellom regnskap og skatt er derfor at det, med en sammenhengende hjemmelskjede via forskrift og delegasjonsvedtak, er fastsatt et omfattende sett med skjemaer med tilhørende rettledninger. ${ }^{4}$ Det fremste og mest overordnede av disse skjemaene er «næringsoppgaven». Teknikken som er valgt, er ikke å ta direkte stilling til fastsettelsen av skattepliktig inntekt uavhengig av regnskapet, men tvert imot å ta utgangspunkt i den skattepliktiges regnskap som helhet for deretter å definere forskjellene mellom regnskap og skatt, som det så korrigeres for. Denne fremgangsmåten er logisk fordi regnskapet i sin tur er knyttet til den samme bokføringen som skatteforvaltningen er knyttet til.

Den formelle hjemmelskjeden er at sfl. $\$ 8$-15 (jf. $\$ 8-2$ ) gir departementet hjemmel til å utforme skjemaer mv. Skatteforvaltningsforskriften $\$ 8-1-1$ og delegasjonsvedtak 16. september $2016 \mathrm{nr}$. 1067 (med senere endringer) delegerer denne myndigheten videre til Skattedirektoratet. Sistnevnte fastsetter hvert år en næringsoppgave for aksjeselskaper (RF-1067) med tilhørende rettledning (RF-1068). I næringsoppgavens post 0999 fremgår det at det er den skattepliktige inntekten som er beregnet der som skal overføres videre til «selve» skattemeldingen. I rettledningen er det presisert (både på side 1 og side 4) at de resultatstørrelsene som skal føres på side 3 i næringsoppgaven, er de regnskapsmessige tallene. Rådataene til disse kan bare hentes fra bokføringen, noe som også følger av bokføringsloven $\$ 6$ (jf. også $\$ \$ 2,3,4$ og 5). Tilsvarende fremgår det også av sfl. $\$ 11$ at de skattepliktige plikter (og forutsettes) å etterleve bokføringsloven, også i relasjon til fastsetting og kontroll av skatt. Plikten til å utarbeide og levere næringsoppgave var tidligere forankret direkte i ligningsloven $\$ 4-4 \mathrm{nr}$. 1. Samme paragraf nr. 7 påla departementet å fastsette skjema for næringsoppgaven, og i delegasjonsvedtak 24. oktober $1991 \mathrm{nr} .742$ delegerte departementet denne myndigheten videre til Skattedirektoratet. Det er Skattedirektoratet som, i henhold til denne hjemmelskjeden, har fastsatt og oppdatert skjemaer (og tilhørende rettledninger). 
For skatteforvaltningsrettslige formål er dermed de to uavhengige regelsettene, rskl. og sktl., to "uavhengige» grener som begge vokser ut fra den samme stammen. Dersom en skattepliktig ikke har registrert en inntektspost i sin bokføring, vil denne inntektsposten (med noen få unntak) heller ikke komme med i regnskapet eller i næringsoppgaven/skattemeldingen. Tilsvarende vil gjelde hvis en skattyter, i sin bokføring, har registrert en kostnad som ikke er reell. Feilen vil (med få unntak) da gå inn både i regnskapet og i næringsoppgaven/skattemeldingen.

Til tross for at rskl. og sktl. er uavhengige regelsett, er derfor nesten alle slike feil som stammer fra bokføringen, inkludert alle de skjønnsmessige vurderingene som gjøres direkte i forbindelse med bokføringen, av interesse for skattemyndighetene på samme måte som for andre regnskapsbrukere. Men forskjellen vil være at skattemyndighetene også vil være interessert i å gjøre noe med en del av de feilene som beløpsmessig er for små til at de vil være utslagsgivende for andre regnskapsbrukere.

Unntakene fra denne sammenhengen vil først og fremst gjelde poster som ikke knytter seg til en transaksjon med en ekstern motpart, for eksempel avskrivninger, tapsavsetninger, ukuransavsetninger og garantiavsetninger. Skatterettslig vil de to førstnevnte av disse alltid bli å fastsette ut fra egne sjablongregler i sktl., og de to sistnevnte vil ikke komme i betraktning. Regnskapsmessig vil man for slike poster først vurdere seg frem til hvor store de skal være, for deretter å registrere dette inn i bokføringen (gjerne i forbindelse med årsavslutningen), i stedet for å «hente dem» fra bokføringen til regnskapet, slik man gjør for andre poster. For disse postene kan regnskap og skatt være uavhengige av hverandre også i skatteforvaltningen.

\subsubsection{Forholdet mellom revisjon og skatteforvaltning etter norsk rett}

Siden nesten alle resultatposter i regnskapet virker inn på fastsettelsen av den regnskapspliktiges skattepliktige inntekt, er også revisors kontroll av nesten alle resultatposter av betydning for skattemyndighetene. Feil som beløpsmessig er lavere enn revisors arbeidsvesentlighetsgrense, vil ikke nødvendigvis bli avdekket ved revisjonen selv om denne er gjennomført fullt ut i henhold til regelverket. Mange av disse feilene er imidlertid mer 
enn store nok til at skattemyndighetene kan, eller bør reise endringssak som følge av dem, fordi skatteforvaltningsretten er uavhengig av de vesentlighetsgrensene som er kartlagt gjennom forskning, nedfelt i bransjepraksis og forankret i revisorloven.

Deler av dette problemet er avhjulpet ved at det gjelder en lavere (arbeids)vesentlighetsgrense for deler av den kontrollen som knytter seg til revisors signatur på næringsoppgaven. Det er imidlertid en alvorlig begrensning knyttet til denne fremgangsmåten, nemlig at den lavere vesentlighetsgrensen pålegger revisor å velge en lavere vesentlighetsgrense bare for noen utvalgte deler av regnskapet. De aktuelle delene kalles ofte for «skatteområdet». Denne betegnelsen er villedende, for det er på det rene at «skatteområdet» ikke er i nærheten av å omfatte alle de resultatpostene som har betydning for skattefastsettelsen.

Når skattemyndighetene foretar en gjennomgang av skattemeldingen og næringsoppgaven til et foretak, vil de således normalt se en ren revisjonsberetning og i tillegg revisors signatur på næringsoppgaven. Dette vil samlet sett oppleves som en ganske solid attestasjon og kan gi selv erfarne kontrollører et relativt sterkt inntrykk av at revisjonen må ha luket ut i hvert fall de fleste enkle feil. Men det reelle forholdet vil være at mange skatterelevante poster generelt er revidert med en vesentlighetsgrense som ligger langt over skattemyndighetenes handlingsgrense. Regelverket fører dermed til at revisors samlede uttalelser kan gi skattemyndighetene en «falsk trygghet».

\subsubsection{Enkelt gjennomgående talleksempel}

Utgangspunktet for problemstillingen kan, med forankring i det som er sagt i punktene ovenfor, vises ved et forenklet eksempel:

Sett at regnskapet til A AS viser et regnskapsmessig resultat før skattekostnad på 25 millioner kroner. En million kroner av selskapets kostnader er klassifisert som ikke fradragsberettigede, og skattepliktig alminnelig inntekt for selskapet er på 26 millioner kroner. Vi forutsetter at revisor har satt totalvesentlighetsgrensen for revisjonen til en million kroner (ca. 4 prosent av antatt resultat), og at arbeidsvesentlighetsgrensen er satt til 500 ooo kroner. 
I samsvar med kravene i SA3801 må revisor operere med en lavere arbeidsvesentlighetsgrense og «anvende andre og mer omfattende kontrollhandlinger enn vesentlighetsgrensen for revisjon av årsregnskapet nødvendigvis skulle tilsi» (SA 3801, pkt. 15) ved kontrollen av størrelsen på de kostnadene som er definert som ikke fradragsberettiget, da disse kostnadene er inkludert i «skatteområdet» Ved revisors kontroll vil det derfor bli foretatt undersøkelser av eksempelvis reisekostnader og sosiale kostnader for å se om det er flere kostnader som skulle vært definert som ikke fradragsberettigede. Ved disse undersøkelsene vil revisor planlegge og utføre arbeidet sitt med en betydelig lavere arbeidsvesentlighetsgrense enn 500 ooo kroner.

Sett imidlertid nå at en salgsinntekt på 150 ooo kroner av en eller annen grunn ikke er kommet med i regnskapet, og at dette er den eneste feilen som finnes i regnskapet. Dette er ikke et forhold som knytter seg til noen spesiell skatteregel om at skattepliktig inntekt skal være forskjellig fra regnskapsmessig inntekt. Det er heller ikke en del av det man i revisjonssammenheng kaller «skatteområdet», men bare en del av den generelle revisjonen av regnskapet generelt. Feilen på 150 ooo kroner vil da være så liten at revisjonsselskapet ikke nødvendigvis vil gjennomføre revisjonshandlinger som vil avdekke den. Sannsynligheten vil imidlertid være mye høyere for at revisor avdekker en beløpsmessig feil av samme størrelse dersom denne befinner seg innenfor «skatteområdet». Men også den manglende salgsinntekten er en skattepliktig inntekt, og den påvirker skattepliktig inntekt på samme måte som eventuelle feil i de ikke fradragsberettigede kostnadene ville gjort.

Det innledende eksempelet er naturligvis både forenklet og satt på spissen. Det kan eksempelvis hende at revisor finner den nevnte feilen på 150 ooo kroner i eksempelet, selv om revisjonen egentlig ikke har vært innrettet på å finne feil ned til denne størrelsen. Revisor skal da rapportere dette til skattemyndighetene så sant feilen ikke er ubetydelig, jf. SA 3801, pkt. 23, selv om det ikke rapporteres til de øvrige regnskapsbrukerne. ${ }^{5}$ For feil som først blir identifisert, er det altså ikke noen umulighet å

5 Slik rapportering til skattemyndighetene skjer i utgangspunktet ved å nekte å signere næringsoppgaven. 
praktisere en lavere vesentlighetsgrense for skatt enn ellers. Men vi fokuserer i dette kapittelet på planleggingen av revisjonen av årsregnskapet og valg av revisjonshandlinger. Her er det ikke mulig å velge forskjellige vesentlighetsgrenser for skatt og annet generelt for hele regnskapet. En ukjent feil i regnskapet blir en ukjent feil i skattegrunnlaget. I så henseende er eksempelets dilemma realistisk nok.

\subsection{Lovbestemmelsene, revisjonsstandardene og skattemyndighetenes uttalelser om revisors vesentlighetsgrenser}

\subsubsection{Revisorloven med forarbeider}

Det rettslige utgangspunktet for fastleggelsen av revisors plikter i denne sammenheng er revl. $\$$ 5-2 1. ledd, som sier at revisor skal

... påse at vedkommende har tilstrekkelig grunnlag til å vurdere om det foreligger brudd på lover og forskrifter av vesentlig betydning for årsregnskapet. (vår utheving)

I NOU 1997: 9, se pkt. 12.1.5, som dannet bakgrunnen for lovbestemmelsen, blir begrepet vesentlighet benyttet aktivt uten at det knyttes noen andre avklaringer til det enn at bestemmelsen generelt er en lovfesting av innarbeidet praksis, og at de eksisterende standardene er relevante. I senere forarbeider skjer det ikke noen ytterligere avklaringer av dette. ${ }^{6}$

Rettslig sett er det dermed klart at anerkjente revisjonsstandarder må tillegges betydelig vekt ved avgjørelsen av grensen for hva som skal anses som vesentlig. Forarbeidene er imidlertid ikke helt klare på om loven bare representerer en lovfesting av den praksis som allerede var innarbeidet før den ble vedtatt, eller om den overlater til standardsetterne å utvikle vesentlighetsgrensen til enhver tid. Standarden, og bransjens praktisering av den, har imidlertid ikke endret seg så mye i etterkant av

6 Se blant annet Ot.prp.nr.75 (1997-98), pkt. 13, Ot.prp.nr.78 (2008-09), pkt. 16.1 og Prop.117 L (2009-2010), pkt. 15.7. 
revisorlovens ikrafttredelse at denne uklarheten kommer på spissen for noen praktiske formål som berører vårt kapittel.?

\subsubsection{Skatteforvaltningslovens bestemmelser om revisors plikter}

Revisorlovens fastleggelse av revisors plikter suppleres av bestemmelsen $\mathrm{i}$ sfl. $\ 8$-15 og skatteforvaltningsforskriften $₫ 8-2-6$. Sistnevnte lyder:

Når skattepliktige har plikt til å ha revisor, skal næringsoppgave [] være signert av revisor.

Det er næringsoppgaven med underliggende vedleggsskjemaer som er skatteforvaltningslovens versjon av årsoppgjøret i denne sammenheng, og som er gjenstand for signatur fra revisor. ${ }^{8}$

Imidlertid er den siterte ordlyden fra skatteforvaltningsforskriften \$ 8-2-6 ikke noe mer nøyaktig enn revl. $\$$ 5-2 1 . ledd. Det fremgår altså ikke direkte av forskriften hvor store feil som skal til for at revisor skal holde sin signatur tilbake. ${ }^{9}$ Også i forhold til denne bestemmelsen blir det dermed et spørsmål om hva vesentlighetsgrensen skal være. Rent språklig kan denne ordlyden i seg selv åpne for et relativt stort spenn av fortolkningsmuligheter. Disse kan spenne fra en forutsetning om at revisor nærmest innestår for alt som står i næringsoppgaven, til en forutsetning om at revisors innsikt er et rent biprodukt av de revisjonshandlingene som følger av revl., slik at vesentlighetsgrensene automatisk blir de samme. Skjemaene selv, og rettledningene til disse, er fastsatt med hjemmel i sfl. De relativt omfattende rettledningene ${ }^{10}$ burde dermed helst ha inneholdt et bidrag til en avklaring, men disse sier ikke et ord om vesentlighetskravet.

7 Vi går av denne grunn heller ikke inn på spørsmålene om det begrepsmessig kan sies å foreligge en «rettslig standard» for vesentlighet.

8 Signeringen skjer i praksis ved en godkjenning i Altinn som i seg selv fremstår som ganske generell. I det daglige arbeidet kan også dette tenkes å bidra til å opprettholde en viss uklarhet og/ eller redusert bevissthet om hva revisor egentlig bekrefter. Dette har vi imidlertid ikke lagt noen vekt på.

$9 \quad$ Faktisk fremgår det ikke engang uttrykkelig at signaturen skal holdes tilbake ved tilstrekkelig store feil, men det er alminnelig enighet om at bestemmelsen skal forstås slik.

10 RF-1168, som er rettledningen til RF-1167 (alminnelig næringsoppgave), er eksempelvis på 11 sider. 
Forarbeider, rettspraksis og litteratur gir også svært liten veiledning om hva som nærmere ligger i dette.

\subsubsection{Revisjonsstandardene}

Den gjeldende standarden for vesentlighet ved planlegging og gjennomføring av revisjon er ISA 320. ${ }^{11}$ Standarden er klar på at det naturligvis ikke skal skje en mekanisk beregning av vesentlighetsgrenser, men utøves et profesjonelt skjønn. ISA 320 sier følgende i punkt 2:

Selv om rammeverk for finansiell rapportering kan drøfte vesentlighet på forskjellige måter, forklarer de vanligvis at: [] Feilinformasjon, herunder utelatelser, er å anse som vesentlige dersom de enkeltvis eller samlet, rimelig kan forventes å påvirke de økonomiske beslutningene som treffes av brukerne på bakgrunn av regnskapet. (vår utheving)

Rent faktisk og rettslig er også skattemyndighetene en bruker som kan treffe beslutninger basert på regnskapsinformasjon. Men den empiriske forskningen på hva som er vesentlig, og dermed utviklingen av bransjepraksis og standardsetting knyttet til dette (jf. pkt. 12.1.2 ovenfor), har ikke hatt skattemyndighetenes spesielle handlingsmønster for øye. Det er derfor vanlig å anta at skattemyndighetenes særbehov, utover de behovene som også øvrige regnskapsbrukere har, ikke skal tillegges betydning etter denne generelle standarden. Ordvalget «brukerne» i det ovenstående sitatet styrker denne antagelsen. Det er videre antatt at det er investorenes og kreditorenes behov som settes i høysetet jf. ISA 320, fotnote 2, og IASB (2018).

Litt lenger ned i samme punkt er det samme slått fast uttrykkelig (og som det vil fremgå av pkt 2.4 nedenfor, kan Skattedirektoratet også hevdes å ha akseptert dette):

Skjønnsmessige vurderinger av forhold som er vesentlige for brukerne av regnskapet bygger på en vurdering av behovet for finansiell informasjon som er felles for brukerne som en gruppe. Den mulige virkningen av feilinformasjon

11 Vesentlighetsvurderingen av feilinformasjon som allerede er avdekket under revisjonen, reguleres av ISA 450. 
på bestemte individuelle brukere, hvis behov kan variere i stor grad, tas ikke i betraktning.

Når det gjelder skatt, har man i stedet rettet interessen mot revisjon av de skattemessige forholdene som ikke bygger direkte på regnskapet, altså de beløpene som man må korrigere det regnskapsmessige resultatet opp eller ned med for å komme frem til skattepliktig inntekt.

Attestasjonen av disse forholdene kalles gjerne for «særattestasjoner», og disse reguleres som tidligere nevnt av SA 3801 Revisors kontroll av og rapportering om grunnlag for skatter og avgifter. Denne benyttes i praksis i stor grad som retningsgivende for revisors signatur på næringsoppgaven.

SA 3801 anerkjenner i pkt. 3 den sammenhengen mellom skattefastsettelse, regnskap og bokføring som det er redegjort for i vårt delkapittel 12.1.4 over. Det fremgår av standardens punkt 15-17, sammenholdt med dennes punkt 4, at det som det kreves er at revisor foretar ytterligere revisjonshandlinger for de spesielle skatte- og avgiftsmessige opplysningene som er gjengitt på sidene 1 og 4 i næringsoppgaven, samt i eventuelle vedlegg. Dette er opplysninger om de tallene mv. som skal være annerledes ved skattefastsettelsen enn ved fastsettelsen av regnskapet. I tillegg krever standardens punkt 13 og 14 at det må vurderes om det er behov for å foreta noen ekstra revisjonshandlinger for transaksjoner med nærstående parter og for eventuelle andre forhold som revisor mener det knytter seg en spesiell skatterisiko til i det enkelte tilfellet. For feil som allerede er avdekket, følger det av standarden som helhet, og særlig punkt 18, at det er en svært lav vesentlighetsgrense. Her er det svært lite som skal til for at revisor skal ha plikt til å holde signaturen på næringsoppgaven tilbake. SA 3801, punkt 18 knytter denne grensen direkte til hvilken konklusjon skattemyndighetene selv ville ha trukket dersom de hadde kjent til opplysningene.

I eksempelet som vi startet med i innledningen ovenfor, ville altså SA 3801 sørget for at beløpet på en million kroner i ikke-fradragsberettigede kostnader ble gjenstand for ytterligere revisjonshandlinger. Innenfor denne spesielle kostnadsarten ville man dermed avdekket også feil som var betydelig mindre enn de feilene som revisjonshandlingene fastsatt generelt etter ISA 320 kunne påregnes å avdekke. En feilkontering av eksempelvis 20 ooo kroner i representasjonskostnader ville derfor, etter 
SA 3801, kanskje blitt avdekket (og korrigert eller rapportert) av revisjonen, mens 150 ooo kroner i ikke regnskapsført salgsinntekt imidlertid ikke kunne påregnes å bli oppdaget.

Rapportering og beregning av skattepliktig inntekt skjer gjennom næringsoppgaven. Den består av 4 sider, hvorav sidene 2-4 henger tallmessig sammen. Side 2 og 3 gjengir regnskapet etter regnskapsmessige regler og konkluderer med et regnskapsmessig resultat som er det samme som i det offisielle regnskapet. ${ }^{12}$ På side 4 regner man seg deretter fra dette regnskapsmessige resultatet og frem til et skattepliktig resultat ved å legge til ikke fradragsberettigede kostnader, trekke fra skattefrie inntekter osv. ${ }^{13}$ Den store majoriteten av inntekter og kostnader er imidlertid fullt skattepliktige og fullt fradragsberettigede. Derfor vil ikke bare feil på side 4 i næringsoppgaven, men også den store majoriteten av feil på side 2 og 3 i denne føre til rapportering av uriktig skattepliktig inntekt. Da blir det svært upresist og ufullstendig å regne tallene på side 2 og 3 som mindre skatterelevante enn korreksjonene på side 4, og det kan synes uheldig å la vesentlighetsgrensen for tallene på side 2 og 3 være upåvirket eller lite påvirket av skattemyndighetenes lavere terskel for å disponere annerledes.

Revisjonsstandardene inneholder dermed, sett fra et skatteforvaltningsrettslig perspektiv, et logisk dilemma som er på grensen til å være en selvmotsigelse: en generell vesentlighetsgrense som er for mild (høy) til å dekke skattemyndighetenes behov, kombinert med en mye strengere vesentlighetsgrense "på skatteområdet» / «for særlig skatterelevante poster». Slike ord klinger kanskje fint, men mister mye av sin mening når vi tar i betraktning at også flesteparten av de postene som er utenfor det såkalte «skatteområdet», er skatterelevante.

12 Inndelingen kan være noe annerledes enn i regnskapet, men uten at det skal endre det regnskapsmessige resultatet.

13 Postene på denne siden i næringsoppgaven er gjenstand for spesifikasjon i de spesielle vedleggene. 


\subsubsection{Skattemyndighetenes uttalelser om revisors vesentlighetsgrenser}

Lignings- $A B C$ var frem til 2016 skatteetatens håndbok og skulle gi uttrykk for antatt eller ønsket ligningspraksis. ${ }^{14} \mathrm{Her}$ var det uttalt under stikkordet «Revisjonsplikt», punkt 3.2, at revisor skulle unnlate å underskrive (næringsoppgaven), dersom det er avdekket «vesentlige» feil som påvirker ligningsoppgavene. ${ }^{15}$ Heller ikke her ble det direkte sagt noe nærmere om hva som er «vesentlig», og ingen ting om hvor store feil revisor må innrette seg på å avdekke. Omtalen viste til Skattedirektoratets melding om innberetning til Finanstilsynet KO nr. 4/2000, 30. november 2000 ${ }^{16}$, og til revisjonsstandard SA 3801. Den nevnte meldingen følges opp av Skattedirektoratet i Skattedirektoratets melding nr. 11/o1, 17. april 2001 (som senere er oppdatert ved Skattedirektoratets melding 12. desember 2016), der det er gjort nærmere rede for direktoratets syn på vesentlighetsgrensen (heretter kalt «Meldingen»).

Meldingen omtaler de aktuelle vesentlighetsprinsippene i punkt $1.2 \mathrm{og}$ i punkt $3 .{ }^{17}$ Omtalen er kortfattet (ca. én side). Vesentlighet når det gjelder valg av revisjonshandlinger, omtales slik i punkt 1.2.2.1:

I henhold til god revisjonsskikk, jf. SA 3801 - Revisors kontroll av skatter og avgifter - benyttes samme vesentlighetsgrense ved kontroll av resultatregnskap og balanse i næringsoppgaven som ved revisjon av årsregnskapet. Ved kontroll av resultatregnskap og balanse i næringsoppgaven vil revisor dermed normalt ikke foreta ytterligere revisjonshandlinger i forhold til hva som er utført i forbindelse med den lovbestemte revisjonen av årsregnskapet.

Meldingen nevner ikke det mulige behovet for å vurdere eventuelle særlige skatterisikoer som er påpekt i SA 3801. Slik sitatet viser, går den

14 Lignings- $A B C$ ble fra 2017 splittet i to forskjellige håndbøker: Skatte- $A B C$ (som er avgrenset til å behandle materielle skatteregler), og Skatteforvaltningshåndboken, som gjelder selve skatteforvaltningen av inntekts- og formuesskatt. Sistnevnte utgis bare elektronisk. Ingen av disse omtaler spørsmålet nærmere.

15 Se også tilsvarende generelle uttalelse i Skatteforvaltningshåndboken $\$$ 2-8-6.

16 Ny SKD-melding ble publisert 11/o9/2019 (SKD - 2019-5). Denne inneholder ingen materielle endringer av betydning for dette kapittelet.

17 Vesentlighet spesielt knyttet til lønnsinnberetning er i tillegg omtalt i Meldingens punkt 2.2, og vesentlighetsgrensen knyttet til rapportering av allerede identifiserte feil er omtalt i Meldingens punkt 3 . 
dermed et lite hakk lenger i retning av å nøye seg med de revisjonshandlingene som generelt er valgt etter ISA 320, enn den standarden (SA 3801) som Meldingen viser til. Den er også et hakk mer eksplisitt i sin fastslåing av at revisjonen av side 2 og 3 i næringsoppgaven ikke omfattes av noen lavere vesentlighetsgrense («ytterligere revisjonshandlinger»).

Dersom man tar dette, og da særlig den siste setningen i sitatet, helt bokstavelig, og tillegger det avgjørende vekt, er det nærliggende å konkludere med at den skjerpede vesentlighetsgrensen overfor skattemyndighetene bare gjelder:

1) vesentlighetsgrensen generelt for enhver feil når den først er identifiser ${ }^{18}$

2) valg av revisjonshandlinger som gir en lavere vesentlighetsgrense knyttet til informasjonen på side 1 og 4 i næringsoppgaven, eventuelt med tilhørende vedlegg ${ }^{19}$

Et par andre uttalelser i Meldingen er egnet til å reise litt tvil om hvorvidt det ovenstående er veloverveid fra Skattedirektoratets side: For det første den begrunnelsen som gis i slutten av punkt 1.2.2.2 for at det er en lavere vesentlighetsgrense eksempelvis for side 4 i næringsoppgaven: ${ }^{20}$

Årsaken til dette er at informasjonen er av særlig betydning for mottaker av revisors attestasjon, skattemyndighetene.

Denne begrunnelsen synes svakt fundert. Den utelatte omsetningen på 150 ooo kroner i eksempelet ovenfor kan aldri bli mindre viktig for skattemyndighetene enn en uriktig håndtering av et like stort beløp på side 4 i selvangivelsen. Det motsatte er derimot fullt mulig siden deler av side 4

18 Meldingens pkt. 1.2.2.2 er uklart og kan nærmest tas til inntekt for at heller ikke dette gjelder ubetinget, men spørsmålet avklares etter vår oppfatning i Meldingens pkt. 3.

19 Meldingen i seg selv er ikke helt klar på at den lavere vesentlighetsgrensen som skal gjelde for side 1 og 4, også skal gjelde for vedleggene, jf. Meldingens pkt. 1.2.2.3, siste setning. SA 3801 pkt. 17 taler imidlertid for det sistnevnte. Vi legger også et slikt synspunkt til grunn, men konklusjonene i dette kapittelet ville gjelde selv om kravet til ytterligere revisjonshandlinger skulle forstås slik at det ikke omfattet vedleggene.

20 I meldingen er dette av en eller annen grunn formulert med et par forbehold, slik at det ser ut som dette bare gjelder «vanligvis», og bare for allerede avdekkede feil. 
i næringsoppgaven og de tilhørende vedleggene (RF-1217, RF-1084 osv.) bare gjelder tidfestingen av poster som uansett er skattepliktige/fradragsberettigede. Feil tidfesting har i utgangspunktet mindre betydning for skattemyndighetene enn feil av permanent karakter. Sitatet tyder derfor på at Skattedirektoratet egentlig ikke har gått fullt og helt inn i selve den problemstillingen som vi her studerer, nemlig at også resultattall i sin alminnelighet er skatterelevante.

Og for det andre den begrunnelsen som gis i punkt 1.2.2.3 for at det samme (altså en lavere vesentlighetsgrense) også skal gjelde for vedlegg som avskrivningsskjema (RF-1084) og spesifikasjon av midlertidige forskjeller (RF-1217):

Opplysningene fra disse skjemaene påvirker skattekostnaden og er således av stor betydning for skattemyndighetene.

Her synes begrunnelsen enda svakere siden begge eksemplene som er benyttet, faktisk hovedsakelig gjelder nettopp tidfesting, som jo er mindre viktig for skattemyndighetene enn at alle inntektene er tatt med. Det kan i tillegg nevnes at begrepet "skattekostnaden" i sitatet representerer et mildt sagt uheldig ordvalg. Dette er jo en av de ytterst få regnskapsmessige resultatpostene som reelt sett $i k k e$ har betydning for skatten. Det må imidlertid kunne antas at Skattedirektoratet her strengt tatt ikke har ment skattekostnaden, men rett og slett skatten.

Også dette sitatet tyder på at Skattedirektoratet egentlig ikke har gått inn i problemstillingen som vi er opptatt av her, nemlig at også alminnelige resultattall er skatterelevante.

Det er uheldig at Meldingen synes lite konsistent på enkelte punkter, og det er uheldig at heller ikke skattemyndighetenes uttalelser inneholder noen utfordring av forestillingen om at det er mulig å foreta en effektiv utskillelse av et «skatteområde», men i stedet nærmest bygger indirekte opp under denne. Meldingens konklusjoner er imidlertid nokså uttrykkelige, og de har vært publisert og tilgjengelige helt siden 2001, og ble oppdatert og gjentatt i 2016. Etter vårt syn ville det derfor per i dag være svært vanskelig for skattemyndighetene å vinne frem med en tenkt påstand om at revisor plikter å etablere en lavere vesentlighetsgrense enn den generelle for side 2 og 3 i næringsoppgaven. 
Rettstilstanden er dermed at de fleste feil som fører til uriktig skattefastsettelse, bare kan påregnes å bli avdekket av revisjonen hvis de er beløpsmessig store nok til å være vesentlige også generelt for andre regnskapsbrukere enn skattemyndighetene.

\subsection{Skatteforvaltningsloven (eller ligningsloven) og ligningspraksis om hvor store feil som skal til for at skattemyndighetene skal reagere}

Skatteforvaltningsloven $\$ 12-1(2)$ lyder: ${ }^{21}$

Før fastsettingen tas opp til endring etter første ledd, skal skattemyndighetene vurdere om det er grunn til det under hensyn til blant annet den skattepliktiges forhold, den tid som er gått, spørsmålets betydning og sakens opplysning.

Dersom skattyteren eksempelvis har utvist forsett eller grov uaktsomhet, eller dersom spørsmålet er av prinsipiell karakter, kan det være god grunn til at skattemyndighetene bør ta saken opp selv om beløpet i seg selv er for lite til å være interessant.

For saker der noe slikt ikke er tilfellet, finnes en veiledende beløpsgrense i Skattedirektoratets veiledende retningslinjer 20. mai $2009 \mathrm{nr}$. $555 .{ }^{22}$ Der uttales følgende under overskriften «Spørsmålets betydning»:

Det må vurderes hvor stor endring i skatter og avgifter som kan være aktuell.

Størrelsen av denne endringen må sammenholdes med skattyters økonomiske

21 Den tilsvarende bestemmelsen i ligningsloven $\$$ 9-5 nr. 7 var: «Før spørsmål om endring tas opp etter $n r .1$ eller $n r .3-6$ skal det vurderes om det er grunn til det under hensyn til blant annet spørsmålets betydning, skattyterens forhold, sakens opplysning og den tid som er gått [].» I sfl. er skattyterens forhold flyttet frem til starten av oppramsingen, og spørsmålets betydning er flyttet fra å være først til å være nummer tre i oppramsingen. Dette er gjort bevisst for å understreke at skattyters forhold er sentralt (sammen med tiden som er gått), se Skatteforvaltningshåndbokens kommentarer til $\$$ 12-1 2 . ledd med videre henvisning til forarbeidene. De samme kildene slår likevel fast at ligningspraksis etter ligningsloven $\$ 9-5 \mathrm{nr}$. 7 fortsatt vil ha betydning. De fire oppregnede momentene er heller ikke noen uttømmende liste over hva det kan være aktuelt å ta hensyn til (jf. innledningsordene «blant annet»).

22 Disse er gitt med hjemmel i Skattedirektoratets instruksjonsmyndighet og gjelder i utgangspunktet fortsatt, også etter ikrafttredelsen av skatteforvaltningsloven. 
stilling. Som hovedregel bør endring ikke foretas hvis det dreier seg om beløp under beløpsgrensene i ligningsloven $₫ 8$ - $3 \mathrm{nr} .2$ a.

Den aktuelle beløpsgrensen etter ligningsloven $₫ 8$ 8-3 nr. 2 a. var 1000 kroner i inntektsendring, altså vanligvis $240-280$ kroner i potensiell endring av skatt i de tilfellene som det per i dag er aktuelt å reise endringssak for. Denne beløpsgrensen er ikke tatt uttrykkelig med i sfl., noe som i hvert fall ikke taler for at grensen er økt. Som ligningspraksis er den dermed av betydning også etter sfl.

At grensen ikke er rigid eller absolutt, er en annen sak. Det ligger både i betegnelsen «Veiledende retningslinjer», i måten det ovenfor siterte avsnittet som helhet er formulert på, og i reservasjonen «som hovedregel». ${ }^{23}$ Som nevnt ovenfor skal beløpet også relateres til skattyterens økonomi, noe som kan føre til at skattemyndighetenes helhetsvurdering i praksis ofte vil ende med at det skal et noe høyere beløp til for en noe større bedrift.

Den beløpsmessige tilnærmingen som det er gitt uttrykk for i Skattedirektoratets veiledende retningslinjer, ble også fulgt opp i Lignings$A B C$, under stikkordet «Endringssak - endring uten klage». Der ble det uttalt at for saker av prinsipiell betydning er beløpsgrensen null, og $\mathrm{i}$ andre saker er den kroner 1000 i inntekt. Lignings- $A B C$ var uttrykk for antatt eller ønsket ligningspraksis og er dermed et uttrykk for at skattemyndighetene som regnskapsbruker ønsker anledning til å ta opp spørsmål uten prinsipiell betydning ned til kroner 10oo, i hvert fall for små bedrifter. Denne «beløpsgrensen» er verken gjentatt eller tatt avstand fra i Skatteforvaltningshåndboken og har fortsatt betydning som forvaltningspraksis.

Det er altså i praksis en klar og tydelig forskjell mellom revisjonsfagets vesentlighetsgrense og hvilke feil som ville fått skattemyndighetene til å disponere annerledes ved å reise endringssak.

23 En lignende fleksibilitet er også innebygget i den revisjonsfaglige vesentlighetsgrensen som vi sammenligner med. 


\subsection{Kommunikasjonen og forståelsen av forskjellen mellom hvor stor en feil må være for at revisjonen skal være innrettet på å finne den, og hvor stor den må være for at skattemyndighetene skal eller bør handle i forhold til den}

Punkt 12.2 og 12.3 ovenfor har vist at det, til tross for plikten til særattestasjoner, er en meget stor forskjell mellom hvilken størrelse en feil må ha for at revisor har en rettslig plikt til å innrette revisjonen på å avdekke den, og hvilken størrelse den må ha for at skattemyndighetene forvaltningsrettslig kan eller bør reagere på den. Omfanget og karakteren av denne forskjellen er underkommunisert i revisjonsstandarden og synes å være lite forstått av skattemyndighetene.

Den ene av forfatterne av dette kapittelet har gjennom mange års virke som skatteadvokat erfart at skattemyndighetene i praksis tar opp en del saker som gjelder beløp på noen ganske få tusen kroner, selv om sakene ikke er av prinsipiell eller preventiv karakter, og at de i forbindelse med saker om små beløp viser liten forståelse for at det er helt naturlig at revisor ikke har sett de aktuelle feilene. ${ }^{24}$

Et inntrykk er faktisk at skatteforvaltningen $i$ praksis ikke er så veldig interessert i det arbeidet som revisor har utført, herunder om næringsoppgaven er signert. Det kan virke som det prinsipielt eksisterer, eller har eksistert, en ikke uttrykt forventning om at revisjonen skal finne tilnærmet alle regnskapsfeil, og derfor en resignasjon vedrørende revisjonsforventningene som helhet ved erkjennelsen av at dette ikke skjer. De fleste ansatte i skatteforvaltningen vil nok eksempelvis intuitivt tenke at revisoren i eksempelet ovenfor, som ikke oppdager 150 ooo kroner i utelatt salgsinntekt, har gjort en litt dårlig innsats. Disse observasjonene er i seg selv ikke så mye mer enn anekdotiske bevis, men en analyse av SA 3801 og Meldingen trekker i samme retning, og det samme gjør en stor empirisk undersøkelse gjennomført i regi av NARF²5 i 2013 (Opsahl

\footnotetext{
24 Disse erfaringene er gjort både førstehånds og gjennom samtaler med revisorer, regnskapsførere, økonomisjefer og næringsdrivende, osv.

25 Foreningen har i dag skiftet navn til Regnskap Norge.
} 
\& Kristensen, 2013). Denne undersøkelsen konkluderer med at ansatte i regnskapsbransjen er av den oppfatning at skatteetaten bruker for mye ressurser på å kontrollere uvesentlige forhold. 2362 medlemmer i NARF responderte på undersøkelsen, og deres gjennomgående syn var at de anså nesten halvparten (47 prosent) av alle de feilene som skatteetaten avdekket, som «uvesentlige».

Det er mulig å utlede prinsippene for hvor stor en feil må være for at revisjonen skal være innrettet på å finne den, avhengig av hvilken type feil det dreier seg om, av SA 3801. Dette er også gjort i punkt 12.2 ovenfor. Det kan imidlertid ikke forventes at det store flertallet av personer på brukersiden, altså de ansatte i skatteforvaltningen, skal være skolert og trent i vesentlighetsforståelse og den terminologien som knytter seg til dette siden få av dem har en tyngre bakgrunn fra revisjonsfaget. ${ }^{26}$ I innledningen til SA 3801 (punkt 5) står det at

Formålet med attestasjonen av næringsoppgaven er å gi brukeren betryggende, men ikke absolutt sikkerhet ... (vår utheving)

De aller fleste er uansett innforstått med at ingen sikkerhet er absolutt, så reservasjonen «men ikke absolutt» tilfører ikke så mye. Ordet «betryggende» må nødvendigvis relatere seg til den tiltenkte bruken, i dette tilfellet skatteforvaltning - som også knytter seg til svært små feil. Formuleringen «betryggende, men ikke absolutt sikkerhet» er derfor isolert sett egnet til å skape store uriktige forventninger.

Videre er prinsippene for revisors kommunikasjon til skattemyndighetene samlet under en egen overskrift i punktene 20-26 i standarden, hvorav punkt 20 er av generell karakter, 21 og 22 handler om spesielle forhold og de resterende handler om kommunikasjon av feil som allerede er avdekket. I denne delen av standarden, som vil være det ansatte i skatteforvaltningen naturlig fokuserer på, finner man ingen påpekning av at det er en grense for hvor stor en feil må være for at revisjonen skal

26 Skatterevisorenes forening er den eneste revisororganisasjonen i skatteetaten og hadde per 1. januar 2020530 medlemmer, ifølge foreningens egen hjemmeside. Dette indikerer at det er godt under 10 prosent av skatteetatens ca. 6500 ansatte som har revisjonsbakgrunn (og etaten har en høy organisasjonsprosent, slik at innslaget av uorganisert arbeidskraft vanskelig kan få endret den indikerte prosentandelen). De fleste av disse igjen har 3-årig revisorutdanning. 
være innrettet på å finne den. Ikke noe sted i standarden finner man noe uttrykkelig forbehold om at mange feil som er av interesse for skattemyndighetene, vil være for små til at de blir oppdaget ved revisjonen.

Meldingen på sin side inneholder, som påpekt i punkt 12.3 ovenfor, en del formuleringer som antyder at skattemyndighetene har liten forståelse for eller bevissthet om at resultattall i alminnelighet er skatterelevante.

\subsection{Aktuelle tiltak}

\subsubsection{Oversikt}

Som det fremgår av analysen ovenfor, er det et ønske fra lovgiver og et premiss for sfl. at skattemyndighetene skal dra nytte av revisors arbeid. Samtidig er det klar forskjell mellom hvor stor en feil må være for at skattemyndighetene rettmessig kan forvente at revisor avdekker den, og hvor stor en feil må være for at skattemyndighetene kan komme til å reise endringssak, unntatt for noen få utvalgte forhold. Denne forskjellen er lite tydelig kommunisert og kan være gjenstand for beskjeden bevissthet og forståelse.

Vi vil i denne delen av kapittelet drøfte hvilke muligheter som finnes for å redusere gapet mellom størrelsen på feil som revisor kan forventes å avdekke, og feil som kan få skattemyndighetene til å reagere. Her vil vi skille mellom tiltak som omhandler bedre kommunikasjon av hva revisors arbeid innebærer, tiltak knyttet til revisors vesentlighetsbeslutninger og endring av skattemyndighetenes handlingsgrense. Disse kategoriene av tiltak kan også kombineres.

\subsubsection{Bedre kommunisering av forholdet Generelt}

Det er velkjent at det ofte er behov for lov- og forskriftsendringer som i seg selv ikke tar sikte på å endre gjeldende rett, men bare på å formidle denne bedre. ${ }^{27}$ I vårt tilfelle er det imidlertid da ikke bare et spørsmål om hvil-

27 F. eks. innføringen av en helt ny skattelov i 1999, der det fremgikk helt uttrykkelig av forarbeidene at denne loven i seg selv ikke skulle innebære noen materielle endringer (jf. Ot.prp.nr.86 (1997-98, punkt 1). 
ken eller hvilke lover eller forskrifter som eventuelt bør omformuleres, men også om tydeliggjøringen bør skje gjennom lov-/forskriftsendringer, eller om den bør komme gjennom andre kilder, som for eksempel revisjonsstandard, uttalelse fra Skattedirektoratet, osv. Vi knytter derfor først en kommentar til hva som etter vårt syn bør formidles bedre, og omtaler deretter aktuelle kilder som kan bære frem en slik forbedret formidling, og den verdien dette kan ha.

\section{Hva som bør formidles bedre}

Hva som etter vårt syn bør formidles bedre, kan sammenfattes relativt enkelt: For det første er det slik at selv om også ganske små feil kan føre til at revisor skal holde tilbake sin signatur på næringsoppgaven, hvis de først er avdekket, så må man huske på at feil som er under en viss beløpsmessig størrelse, ikke nødvendigvis blir avdekket ved en fullt ut forskriftsmessig gjennomført revisjon.

Og for det annet: For feil på side 1 og 4 i næringsoppgaven er vesentlighetsgrensen lavere enn ellers, men for feil på side 2 og 3 er den som for revisjonen generelt, og derfor mye høyere enn det beløpet som skal til for at skattemyndighetene skal vurdere endringssak.

Hva som er den beste formuleringen, vil være avhengig av om den eventuelt skal stå i en lov, forskrift, revisjonsstandard eller annen type kilde. Vi mener imidlertid generelt at meningsinnholdet, uavhengig av hvilke kilder det skal innarbeides i, helst bør formuleres så direkte som mulig, uten å gå veien om bruk av faguttrykk. Vi mener også at det, i de kildene det eventuelt innarbeides i, bør presenteres åpent som et eget tema. Det bør altså helst ikke være slik at leseren må sammenholde tekst som er plassert under forskjellige temaer/overskrifter, for å utlede det aktuelle meningsinnholdet.

\section{Hvilke rettskilder eller kanaler en forbedret formidling even- tuelt bør skje gjennom}

Revisors plikter når det gjelder vårt tema, er i prinsippet regulert med hjemmel i revl. $\$ 5-2$, sfl. $\$ 8-15$ og sff. $\$ 8-2-6$, med videre detaljering i SA 3801, samt Skattedirektoratets skjemaer med rettledninger, og er også beskrevet i Skattedirektoratets melding (Meldingen), og 
i Skatteforvaltningshåndboken. Det ideelle er å innarbeide en endring i alle, eller nesten alle, disse. Det er mulig at selve ordlyden i revl. $\$ 5$-2 er et unntak, fordi denne er så generell i alle henseender at det uansett kanskje fremstår som klart nok at man må konsultere standarder og/eller andre underliggende kilder for å kunne ta stilling til hva som ligger i begrepet «vesentlig». ${ }^{28}$

\section{Verdien av en forbedret formidling av forholdet}

En bedre klargjøring og formidling av den reelle situasjonen kan legge til rette for å gi revisjonsbransjen og skattemyndighetene økt forståelse for hverandres arbeid. Det kan i sin tur være med på å bygge eller opprettholde tillit og til å bygge kompetanse i hvordan disse aktørene best kan forholde seg til hverandres konklusjoner og arbeid. Videre kan en slik forbedret formidling gjøre det realistisk for alle berørte til enhver tid å ta stilling til om det er samsvar mellom revisjonsstandarden og skattemyndighetenes uttrykte oppfatning. Endelig kan det også gjøre det mer realistisk for lovgiver til enhver tid å vurdere om det er ønskelig med endringer.

\subsubsection{I grenseland mellom endring og forbedret formidling}

Et tiltak i grenseland mellom forbedret formidling og materiell (eller i hvert fall prosessuell) rettsendring ville være å pålegge revisor å kommunisere til skattemyndighetene hvilken vesentlighetsgrense som er benyttet i det enkelte tilfellet. Formell forankring for dette kunne etableres ved en endring i skatteforvaltningsforskriften. Praktisk implementering kunne foretas helt enkelt ved å innføre to nye poster i næringsoppgaven, i umiddelbar tilknytning til revisors signatur. En post for valgt vesentlighetsgrense knyttet til side 1 og 4 i næringsoppgaven og en post for valgt vesentlighetsgrense knyttet til side 2 og 3 . I rettledningen, og helst

28 Forslaget til ny revisorlov inneholder forslag til presiseringer/tydeliggjøringer av revisors plikter på enkelte områder, men ikke noen av betydning for det temaet som omtales i dette kapittelet (se NOU 2017: 15, kap. 26, særlig \$\$ 9-1, 9-4, 9-7 og 9-10). 
også i selve næringsoppgaven, kunne/burde dette angis i et enkelt språk. Målet er å formidle enklest mulig hvor stor en feil, etter revisors beste skjønn, må være for at man skal kunne påregne at den blir avdekket av de revisjonshandlingene revisor i det aktuelle tilfellet har gjennomført. Som nevnt i 12.1.2 ovenfor, er det påvist at jurister og dommere synes å uttrykke en høy grad av enighet om at det ville være ønskelig med eksplisitte kvantitative standarder for vesentlighetsgrensene. Å innføre en slik konkret kvantifisering overfor skattemyndighetene er langt mer realistisk enn en generell kvantifisering i standardene. I tillegg er det også påvist at kommunisering av vesentlighetsgrensene generelt kan ha positiv nytteeffekt, se for eksempel Fisher (1990).

\subsubsection{Senke den generelle vesentlighetsgrensen}

Lavere vesentlighetsgrenser gir høyere revisjonskostnader, og valg av vesentlighetsgrenser er en avveining mellom nytte og kostnad. Avveiningen som ligger til grunn for de vesentlighetsgrensene vi har i dag, er basert på omfattende vurderinger gjennom mange tiår og fortjener den respekten som følger av dette. Utgangspunktet er således at det ikke er ønskelig å rokke ved de aksepterte prinsippene for valg av vesentlighetsgrenser. For ikke-børsnoterte foretak mener vi likevel at tiden nå er moden for to nye innfallsvinkler som ikke tidligere har vært forsøkt eller utredet.

Den ene av disse innfallsvinklene er generell og knyttet til et fenomen som ikke har vært aktuelt å vurdere tidligere - nemlig økt digitalisering/ automatisering av revisjonen. Introduksjonen av ny teknologi har potensial til å forbedre og/eller effektivisere revisjonen på måter som ikke har vært tilgjengelig tidligere. Slike forbedringer kan, her som ellers, «tas ut» av forskjellige aktører (for eksempel revisorene eller revisjonskundene) og på forskjellige måter (for eksempel redusert pris, økt fortjeneste, bedre kvalitet, osv.). Dette er en diskusjon som pågår nå. Likevel pågår den uten at spørsmålet om hvorvidt en del av forbedringspotensialet kan tenkes tatt ut i form av lavere generell vesentlighetsgrense, synes å være satt på dagsordenen. Som det fremgår ovenfor, kan en slik endring for ikkebørsnoterte foretak skape samfunnsmessig nytte via skattemyndighetenes bruk av revisors arbeid - og deler av revisjonsbransjen er i en situasjon 
der den har behov for å demonstrere tydeligere at samfunnet har nytte av en fortsatt revisjonsplikt for foretak av beskjeden størrelse. Denne spesielle innfallsvinkelen kan etter vårt syn være et unntak fra prinsippet om at man ikke bør rokke ved aksepterte prinsipper for valg av vesentlighetsgrenser. Dersom den kombineres med den omleggingen av de spesielle vesentlighetskravene knyttet til signaturen på næringsoppgaven som er omtalt rett nedenfor, mener vi også at den vil være et realistisk tiltak for alle berørte parter.

Den andre innfallsvinkelen går således ut på å legge om den differensieringen av vesentlighetsgrensen som per i dag gjelder for næringsoppgaven (altså differensieringen mellom side 1 og 4 vs. side 2 og 3), ved å fjerne den og helst erstatte den med en annen type differensiering som er noe mer treffende med tanke på det behovet som skattemyndighetenes reelt har. Den nåværende differensieringen mellom vesentlighetsgrense for henholdsvis side 1 og 4 kontra side 2 (og 3) er svakt begrunnet og er mer enn moden for å bli vurdert på nytt. Rasjonelt sett er feil på side 1 og 4 egentlig ikke viktigere for skattemyndighetene enn feil på side 3. Det kan derfor være en idé å jevne ut denne forskjellen slik at generell avdekkingsterskel ble satt litt lavere mot at den også skulle gjelde for side $1 \mathrm{og}$ 4. På denne måten kan man i prinsippet gi skattemyndighetene en større nytte for den samme revisjonskostnaden. De vil bli informert om flere av de feilene som beløpsmessig ligger rett under den nåværende generelle avdekkingsterskelen, mot at de til gjengjeld ikke vil blitt informert om en del beløpsmessig langt mindre feil på side 1 og 4 . Dette ville være et godt bytte for skattemyndighetene. Illustrert ved det gjennomgående talleksempelet har vi for eksempel at skattemyndighetene ikke lenger vil kunne påregne at revisor avdekker de $20000 \mathrm{i}$ representasjonskostnader som er kontert som reisekostnader, men i stedet kan de påregne at det er mer sannsynlig at revisjonen avdekker de 150 ooo i manglende salgsinntekt noe som rasjonelt sett vil kunne bli et meget godt bytte.

Det er grunn til å tro at det er historiske årsaker som ligger til grunn for den nåværende differensieringen. Da denne ble innført, i 1950, 29

29 Se John Christian Langli, «Hvem er brukerne av årsregnskapene til små aksjeselskaper, og trenger de reviderte regnskaper» (2009). 
eksisterte det en rekke skjønnsmessige regnskapsmessige betraktninger som hadde virkning krone for krone på skattepliktig inntekt, for eksempel ukurans i varelageret, avsetninger til tap på kundefordringer og avskrivninger på driftsmidler. For å utføre disse skjønnsmessige vurderingene var det viktigere med økonomisk kompetanse enn vanlig skatterettslig kompetanse, så skattemyndighetene hadde et klart behov for å kunne støtte seg på revisors vurderinger. Samtidig eksisterte det den gang et klart forsiktighetsprinsipp for regnskapsavleggelsen (altså at det var viktigere å unngå overvurdering av inntekt og verdier enn å unngå undervurdering). I praksis må det derfor ha vært klart at det eksempelvis skulle ganske store undervurderinger av et varelager (overvurdering av nedskrivningene) til for at revisor skulle sette foten ned for det, hvis man ikke skulle tenke spesielt på skattemyndighetenes behov. I denne situasjonen var det derfor rasjonelt å innføre et prinsipp om at revisor måtte se på denne typen skatterelevante disposisjoner med en lavere vesentlighetsgrense enn hva som ellers ville gjeldt for disse disposisjonene.

I våre dager er denne begrunnelsen forsvunnet sammen med de skattereglene som gjorde størrelsen av skattepliktig inntekt avhengig av skjønnsmessige regnskapsmessige vurderinger som i sin tur var underlagt et forsiktighetsprinsipp (noe som jo blir det motsatte av et forsiktighetsprinsipp med tanke på skattefastsettelsen). Dermed vil skatteforvaltningen nå være tjent med å jevne ut oppmerksomheten, slik at revisjonsressursene brukes der de gir mest. Nærmere bestemt ved å styre direkte etter feilens størrelse fremfor å styre etter hvilken side i næringsoppgaven den presenteres på.

\subsubsection{Heve skattemyndighetenes handlingsgrense}

En heving av skattemyndighetenes handlingsgrense kunne materielt sett gå ut på at man rett og slett økte den beløpsgrensen som per i dag er satt til 1000 kroner i Skattedirektoratets veiledende retningslinjer og i Lignings-ABC. Det ville i så fall være naturlig å presisere at dette bare gjelder i saker der skattyteren har opptrådt aktsomt og lojalt (noe som vanligvis også innebærer at skattyteren har oppfylt sin 
opplysningsplikt). Det burde i så fall gjøres unntak for tilfeller der det uansett skal reises endringssak mot den samme skattyteren, som følge av andre forhold, og den aktuelle feilen vil representere lite merarbeid. Unntak kunne også vært naturlig i situasjoner der det aktuelle skattekontors kapasitetssituasjon på det aktuelle tidspunkt er slik at man klart vil ha ressurser også til viktigere gjøremål selv om saken tas opp. Unntaket for saker av prinsipiell karakter kan også være naturlig å beholde..$^{\circ}$ I tillegg kunne det være aktuelt som en «modernisering» å tilføye et unntak for feil som er systemgenerert, fordi slike feil har så stor sannsynlighet for gjentagelse. Endelig kunne man også lagt til et generelt unntak for saker der det påviselig er andre særlige grunner. En slik endring kan, om ønskelig, initieres av lovgiver, departementet eller Skattedirektoratet, og tilsvarende forankres i forskrift eller i Skattedirektoratets veiledende retningslinjer.

Sett fra samfunnets side er det lite heldig at skattekontoret eksempelvis benytter to dagsverk av en kontrollør, og deretter ett til to dagsverk av en skattejurist og så litt arbeid til kvalitetssikring og registrering osv. for å rette opp i en sak som går ut på at et aksjeselskap kanskje har krevd fradrag for 25 ooo kroner for mye. Rettingen vil øke statens skatteinntekter med 5500 kroner med en skattesats på 22 prosent. Med en gjennomsnittlig årslønn på eksempelvis 520000 kroner vil man da ha brukt nærmere dobbelt så mye på personalkostnader som man får inn i skatt. Statens reelle kostnader er i virkeligheten veldig mye høyere enn dette. Det er også slik at det reelle alternativet for skatteetaten sjelden eller aldri vil være å spare disse personalkostnadene, men snarere å benytte de samme ressursene til å arbeide med saker som enten gjelder mye større beløp eller mer kritikkverdige forhold. En slik endringssak som i dette talleksempelet representerer dermed direkte misbruk av samfunnets ressurser når det ikke faller inn under noen av de unntakene som er foreslått ovenfor med hensyn til en mulig høyere handlingsgrense.

30 De fleste saker som er av prinsipiell karakter, dreier seg om noe større beløp, men selvsagt ikke alle. 
Sett fra skatteetatens side kan det også tenkes at en slik heving av deres handlingsgrense vil være en positiv avklaring ved at den kan bidra til å gjøre det tydeligere hvordan det er ønskelig at oppgaver prioriteres. Basert på undersøkelsen gjennomført av NARF som er omtalt ovenfor, synes det også klart at dette vil øke skatteetatens anseelse hos revisorer og regnskapsførere.

Sett fra næringslivets side vil skattebeløpene som på denne måten «spares», forutsetningsvis være uinteressante, men det sier seg selv av reduksjonen i antall saker å håndtere vil bli oppfattet som klart positivt. Dersom tiltaket skal vurderes, vil et eget spørsmål være hvilke beløp det eventuelt kan være riktig å øke handlingsgrensen til. Eksempelet ovenfor taler for at det rasjonelt sett vil være en fordel for skattekreditor å øke grensen relativt sett ganske mye.

\subsection{Oppsummering: bidrag og implikasjoner samt aktualisering av videre forskning}

Vi har i dette kapittelet definert et gap som det ikke har vært fokusert på i eksisterende forskning, nemlig gapet mellom den rettslige vesentlighetsgrensen etter norsk rett og norske skattemyndigheters berettigede forventninger som regnskapsbruker. Vi har beskrevet omfanget og karakteren av dette gapet og konsekvenser det har for samspillet mellom revisjonen og skatteforvaltningen, i en situasjon der et stort tilfang av regnskapsfeil kan tilsi handling fra skatteetaten, uten at disse feilene er i nærheten av den størrelsen som skal til for at revisjonen skal være innrettet på å avdekke dem. Videre har vi i dette kapittelet påpekt, og argumentert for, ønskede endringer i denne rettstilstanden. Prinsipielt deler de påpekte endringsmulighetene seg inn i henholdsvis bedre kommunisering av rettstilstanden (og dermed gapet), økning og omforming av den skatteforvaltningsrettslige handlegrensen og reduksjon og omforming av revisjonsvesentlighetsgrensen. Konkrete endringstiltak kan være kombinasjoner av, eller grensetilfeller mellom, disse tre prinsipielle kategoriene.

Etter vårt syn er tiden moden for å modernisere regelverket for samspillet mellom revisjon og skatteforvaltning på en slik måte, og vi har i 
dette kapittelet blant annet gitt fire konkretiseringer med direkte henblikk på en slik modernisering:

For det første: en bedret formidling av revisjonens iboende begrensninger og hvilke feil revisjonen kan forventes å avdekke. For det andre: innføring av en ny post i næringsoppgaven, for angivelse av den vesentlighetsgrensen revisor har anvendt i forbindelse med revisjon av postene i næringsoppgaven. For det tredje: en uttrykkelig avskaffing av den særlig lave vesentlighetsgrensen som gjelder spesifikt for side 1 og 4 i næringsoppgaven, og en reduksjon av den generelle vesentlighetsgrensen som benyttes i forbindelse med revisjon av postene i næringsoppgaven til et nivå som ligger mellom dagens særgrense for side 1 og 4 i næringsoppgaven og det som ellers er fastsatt for revisjonen generelt, for eksempel slik at det ikke lenger blir et skille mellom fastsatte vesentlighetsgrenser for børsnoterte og ikke-børsnoterte selskaper. For det fjerde: en heving av skattemyndighetenes handlingsgrense etter de prinsipper som er antydet i punkt 12.5.5 ovenfor. Vi ser ikke nødvendigvis på disse konkretiseringene som relevante og anvendelige for børsnoterte foretak eller andre foretak som er gjenstand for oppfølging fra et sentralskattekontor.

Endringene må eventuelt forankres som beskrevet under hvert av punktene ovenfor, og de vil kunne bidra til å gi revisjonsbransjen og skattemyndighetene en bedret forståelse for hverandres arbeid med tilhørende bedret tillit dem imellom.

Etter vår oppfatning aktualiserer bidragene fra dette kapittelet fire fokusretninger for fremtidig forskning. For det første: en mer direkte kartlegging av forståelsen av revisjonsvesentlighet blant skatteetatens ansatte (helst både av subjektivt opplevd forståelse og objektivt demonstrert forståelse). For det andre: en tilsvarende kartlegging blant skatteetatens ansatte av forståelsen av forvaltningens adgang til å velge hvilke forhold det innenfor visse rammer skal reises endringssak om. For det tredje: en kartlegging av i hvilken grad revisjonsbransjen er innstilt på å yte et bidrag for å forbedre samspillet med skatteetaten. Og sist, men ikke minst: en analyse av i hvilken grad digitalisering, automatisering og standardisering av maskinlesbar rapportering åpner eller forbedrer muligheter til å modernisere samspillet mellom revisjonen og skatteforvaltningen etter de linjene som vi har beskrevet i dette kapittelet. 


\section{Referanser}

\section{Lover, forskrifter, forarbeider og meldinger}

Ligningsloven (1980). Lov om ligningsforvaltning. LOV-1980-06-13-24 (OPPHEVET).

Bokføringsloven (2004). Lov om bokføring. LOV-2004-11-19-73.

Regnskapsloven (1998). Lov om årsregnskap m. v. LOV-1998-07-17-56.

Revisorloven (1999). Lov om revisjon og revisorer. LOV-1999-01-15-2.

Skatteloven (1999). Lov om skatt av formue og inntekt. LOV 1999-03-26-14.

Skatteforvaltningsloven (2016). Lov om skatteforvaltning. LOV-2016-05-27-14.

Bokføringsforskriften (2004). Forskrift om bokføring. FOR-2004-12-01-1558.

NOU 1989: 14. Bedrifts og kapitalbeskatningen - en skisse til reform.

NOU 1997: 9. Om revisjon og revisorer.

NOU 2017: 15. Revisorloven - Forslag til ny lov om revisjon og revisorer.

Ot.prp.nr.75 (1997-98). Om lov om revisjon og revisorer (revisorloven).

Ot.prp.nr.78 (2008-09). Om lov om endringer i revisorloven og enkelte andre lover (gjennomføring av revisjonsdirektivet).

Prop.117 L (2009-2010). Endringer i regnskapsloven og enkelte andre lover.

Skattedirektoratets melding KO nr. 4/2000, 30. november 2000.

Skattedirektoratets melding nr. 11/2001, 17. april 2001.

Skattedirektoratets melding nr. 7/2016, 12. desember 2016.

Skattedirektoratets melding nr. 5/2019, 10. september 2019.

\section{Regnskaps- og revisjonsstandarder}

IASB (2001). Framework for the Preparation and Presentation of Financial Statements.

IASB (2018). Conceptual Framework for Financial Reporting.

International Auditing and Assurance Standards Board / Den norske

Revisorforening (2009). ISA 320. Vesentlighet ved planlegging og gjennomføring av en revisjon. Norsk utgave av internasjonal revisjonsstandard 320. New York, NY:

The International Federation of Accountants (IFAC).

International Auditing and Assurance Standards Board / Den norske

Revisorforening (2009). ISA 450 Vurdering av feilinformasjon identifisert under revisjonen. Norsk utgave av internasjonal revisjonsstandard 450. New York, NY:

The International Federation of Accountants (IFAC).

International Auditing and Assurance Standards Board / Den norske

Revisorforening (2016). ISA 70o. Konklusjon og reapportering om regnskaper.

Norsk utgave av internasjonal revisjonsstandard 70o. New York, NY: The

International Federation of Accountants (IFAC). Den norske Revisorforening (2007). SA 3801, Revisors kontroll av og rapportering om grunnlag for skatter og avgifter. 


\section{Artikler, bøker m.m.}

Eilifsen, A. \& Messier, W. F. Jr. (2015). Materiality guidance of the major public accounting firms. Auditing: A Journal of Practice \& Theory, 34(2), 3-26.

Fisher, M. H. (1990). The effects of reporting auditor materiality levels publicly, privately, or not at all in an experimental setting. Auditing: A Journal of Practice \& Theory, 9(Suppl), 3-26.

Gulden, B. P. (2016). Revisjon. Teori og metode. Oslo: Cappelen Damm Akademisk.

Hauge, H. (2012). Realisasjonsprinsippet - skatterettslig tidfesting av kostnader scerlig om avsetninger og betingede kostnader. 1. utgave. Oslo.

Holstrum, G. L. \& Messier, W. F. Jr. (1982). A review and integration of empirical research on materiality. Auditing: A Journal of Practice \& Theory, 2(1), 45-63.

Jennings, M., Reckers, P. M. J. \& Kneer, D. C. (1991). The auditor's dilemma: The incongruous judicial notions of the auditing profession and actual auditor practice. American Business Law, 29(1), 99-125.

Langli, J. C. (2009). Hvem er brukerne av årsregnskapene til små aksjeselskaper, og trenger de reviderte regnskaper. Praktisk økonomi \& finans, 1, 104-119.

Lignings ABC. (2016).

Messier, W. F. Jr., Martinov-Bennie, N. \& Eilifsen, A. (2005). A review and integration of empirical research on materiality: Two decades later. Auditing: A Journal of Practice \& Theory, 24(2), 153-187.

Opsahl, H. \& Kristensen, R. (2013). Skattemoral som samfunnsansvar, Magma, 2, 65-69.

Skattedirektoratet. Skatteforvaltningshåndboken (skatteetatens nettbaserte oppslagsverk for skatteforvaltningsrett). Hentet fra https://www.skatteetaten.no/ rettskilder/type/handboker/skatteforvaltningshandboken/gjeldende/ 


\section{Balansert målstyring som økonomistyringsverktøy i norske foretak: Utviklingstendenser i perioden 2015-2018}

Daniel Johanson

Førsteamanuensis, Norges Handelshøyskole

Dag Øivind Madsen

Professor, Universitetet i Sørøst-Norge

Tonny Stenheim

Professor, Universitetet i Sørøst-Norge

Sammendrag: Tidligere forskning har vist at norske foretak benytter ulike typer styringsverktøy. I dette kapitlet fokuserer vi på et spesifikt styringsverktøy, balansert målstyring (BMS). og ser nærmere på utviklingstendenser knyttet til spredningen, bruken og effektene av BMS i praksis i perioden 2015-2018. Studien bruker data fra to elektroniske spørreundersøkelser av bruken av BMS i norske foretak gjennomført i 2015 og 2018. Undersøkelsen fra 2015 omfattet bare store foretak, mens den fra 2018 omfattet både store og mellomstore foretak. Resultatene viser at BMS er et utbredt styringsverktøy blant store og mellomstore norske foretak. Selv om flertallet bruker BMS som et relativt enkelt prestasjonsmålingssystem, er det en tendens at bruken blir mer avansert. Disse funnene blir diskutert i lys av den internasjonale forskningslitteraturen om BMS spesielt og økonomistyringsverktøy generelt.

Nøkkelord: balansert målstyring, styringsverktøy, utviklingstendenser

Sitering av denne artikkelen: Johanson, D., Madsen, D. Ø. \& Stenheim, T. (2020). Balansert målstyring som økonomistyringsverktøy i norske foretak: Utviklingstendenser i perioden 2015-2018. I T. Stenheim, K. M. Baksaas og E. M. Kulset (Red.), Aktuelle temaer i regnskap og revisjon (Kap. 13, s. 379-414). Oslo: Cappelen Damm Akademisk. https://doi.org/10.23865/noasp.112.ch13

Lisens: CC-BY 4.0. 


\subsection{Innledning}

I dette kapitlet fokuserer vi på intern rapportering og styring. Kapitlet tar for seg et av de mest brukte styringsverktøyene internt i organisasjoner: balansert målstyring (BMS). BMS har en lang historie innen $ø$ konomistyringsfaget og ble introdusert på begynnelsen av 1990-tallet av Robert Kaplan og David Norton (Kaplan \& Norton, 1992). BMS har vært gjenstand for sterk interesse blant forskere innen økonomistyring og ledelse (Hoque, 2014), og det publiseres stadig nye studier med BMS som tema (f.eks. Bescos, Deville \& Foulquier, 2020; Sharma \& Sharma, 2020).

BMS har blitt relativt utbredt i praksis, og konsulentselskapet Bain \& Companys undersøkelser viser at styringsverktøyet over lengre tid har hatt en stabilt høy adopsjon i forhold til de fleste andre ledelses- og styringsmodeller (Rigby \& Bilodeau, 2015, 2018). En rekke andre studier viser også at adopsjonen av BMS er utbredt i ulike deler av verden (f.eks. Al Sawalqa, Holloway \& Alam, 2011; Anand, Sahay \& Saha, 2005; Kald \& Nilsson, 2000; Nielsen \& Sørensen, 2004). Adopsjon defineres ofte som en dikotom variabel (enten-eller-beslutning) i tradisjonell diffusjonsforskning. Kritikk er blitt rettet fra ulike hold (f.eks. Røvik, 2011; Wanderley, Cullen \& Tsamenyi, 2014) og går ut på at adopsjon varierer i både innhold og utstrekning mellom organisasjoner, og at implementeringsprosessen pågår over lengre tid.

En rekke studier viser at det er betydelig variasjon når det gjelder hvordan og i hvilken grad BMS har blitt spredt og brukt. For eksempel viser studier at BMS forekommer i mange ulike varianter (Perkins, Grey \& Remmers, 2014; Speckbacher, Bischof \& Pfeiffer, 2003), og at spredningen og bruken er påvirket av lokale forhold som forretningskultur og ideologi (Ax \& Bjørnenak, 2005; Bourguignon, Malleret \& Nørreklit, 2004), men også foretakets størrelse (Andersen, Cobbold \& Lawrie, 2001; Basuony, 2014; Madsen, 2015). Det er derfor viktig å kartlegge spredning og bruk av BMS i ulike land, i ulike sektorer og på tvers av foretak av ulik størrelse.

I dette kapitlet ser vi nærmere på endringen i spredningen og bruken av BMS i norske foretak. Selv om det er en del tidligere forskning på BMS i Norge (Fallan, Olsen, Daleq \& Hobbel, 2015; Johanson \& Madsen, 2017; Kjøde, 2003; Oliversen, 2014; Olsen, 1999; Pedersen \& Bødtger, 2014; Stemsrudhagen, 2004; Wennersberg, Engeskar, Panteleeva \& Helgesen, 2016), har de fleste studiene undersøkt bruken av BMS ved å måle denne 
på et tidspunkt (tverrsnittstudie). Her prøver vi å undersøke utviklingen over tid.

Studien har to formål. For det første å beskrive, diskutere og teoretisere utviklingstendensene i bruk og spredning av BMS i store foretak fra 2015 til 2018. Det er etter hva vi kjenner til, svært få studier som undersøker utviklingen i bruk og spredning av BMS over tid, og siden vi har spørreskjemadata fra to ulike tidspunkt, har vi mulighet til å belyse dette. For det andre supplerer vi med nye data på utforming og bruk av BMS i mellomstore foretak. Det gir et grunnlag for å beskrive og analysere forskjeller i bruk og spredning av BMS som følge av variasjon i størrelsen på foretakene.

Studien tar utgangpunkt i tre konkrete forskningsspørsmål:

1) Hvor utbredt er bruken av BMS i store foretak i Norge, og i hvilken grad har bruken av BMS endret seg fra 2015 til 2018?

2) Hvilke organisatoriske effekter har BMS, og hvordan har disse effektene endret seg fra 2015 til 2018?

3) Hvilke forskjeller er det i bruk og effekter av BMS mellom store og mellomstore foretak i Norge basert på data fra 2018?

En rekke tidligere studier har vist at BMS har hatt en relativt stor innflytelse på styringen av norske foretak (Johanson \& Madsen, 2017). Det er imidlertid slik at bruken av styringsverktøy varierer over tid, og derfor er det av stor interesse å kartlegge utviklingstendenser. Dette må gjøres ved å benytte data over tid, og i denne studien gjør vi et relativt sjeldent forsøk på dette. Vi beskriver og analyserer sentrale utviklingstendenser knyttet til bruken av BMS i praksis. Betingelsesteori (eng. contingency theory) viser til at foretakenes størrelse er en viktig faktor i utforming og bruk av styringssystemer (for eksempel Chenhall, 2003). Det vil derfor være av interesse å se på forskjeller med hensyn til bruk og utforming av BMS mellom store og mellomstore foretak.

\subsection{Kort om BMS}

Kapitlet er orientert mot forskningslitteraturen som ser på utbredelsen og bruken av BMS. Forskningen på BMS spenner over et vidt spekter 
av temaer (Hoque, 2014) og er også kort omtalt på norsk (Madsen \& Stenheim, 2014a). ${ }^{1}$ Under følger en kort beskrivelse av bakgrunnen til og utviklingen av selve BMS-konseptet.

\subsubsection{Bakgrunn}

På slutten av 1980-tallet var det en rivende debatt i økonomistyringsfaget (Johnson \& Kaplan, 1987; Kaplan, 1984). Mange hevdet at datidens styringsverktøy ikke lenger var i stand til å forsyne ledere med tilstrekkelig relevant styringsinformasjon (Bjørnenak, 2010). Kritikken var først og fremst rettet mot tradisjonelle kalkylemetoder, og aktivitetsbasert kalkulasjon (ABC) ble løftet frem som en mer relevant og nøyaktig metode for kostnadskalkulering (Cooper \& Kaplan, 1988). Hovedargumentet var at det interne regnskaps- og styringssystemet $\mathrm{i}$ for stor utstrekning var blitt påvirket av eksternregnskapet. Etter hvert ble kritikken rettet mer bredt mot at økonomistyringssystemer var utdaterte og ikke kunne fange opp informasjon om kunder, interne prosesser og læring og vekst, som er viktige indikatorer på fremtidig ytelse. BMS var en av løsningene som ble lansert på 1990-tallet i kjølvannet av denne debatten, og som skulle bidra til at ledere fikk et helhetlig bilde av faktorer som ville påvirke foretakets kortsiktige og langsiktige ytelse på ulike områder.

Et tradisjonelt problem innen økonomisk styring er at foretak og ledere har vært for ensidig opptatt av finansiell informasjon. Denne informasjonen er ofte historisk og egner seg i mindre grad til å si noe om drivere av fremtidig ytelse. Enkelte sammenligner det med å styre en bil bare ved se gjennom bakspeilet. Man får lite eller ingen informasjon om konkurrentene eller hvilke farer som lurer lenger fremme. Kaplan og Norton (1992) presenterte BMS som et dashbord som gir ledere et bredt spekter av styringsinformasjon som kan brukes til å styre foretaket, slik at det når sine

1 I dette kapitlet fokuserer vi ikke på hvordan man praktisk kan gå frem for å implementere, utvikle og tilpasse BMS. For lesere som er interessert i dette anbefaler vi følgende skandinaviske bøker som behandler dette inngående: Christensen og Bukh (2013); Gjønnes og Tangenes (2012); Hoff (2008) og Hoff og Holving (2015). 
strategiske mål. De brukte en metafor om lederen som en flypilot som bruker instrumentpanelet i cockpiten til å styre flyet trygt til destinasjonen (Nørreklit \& Mitchell, 2007).

Videre kan BMS bidra til å redusere lederes vektlegging av kortsiktige resultater, det såkalte nærsynthetsproblemet (Merchant \& Van der Stede, 2012). Ved bruk av BMS vurderes foretakets ytelse ved hjelp av ulike perspektiver. Dette vil gjøre at sub-optimale beslutninger lettere kommer til syne. Kjente eksempler er å kutte i markedsførings- eller innovasjonsbudsjettet for å øke kortsiktig finansiell ytelse. Dersom man benytter andre perspektiver enn bare det finansielle, vil slike beslutninger raskt vises i de andre perspektivene. Bruk av BMS vil derfor kunne bidra til at lederes handlinger i større grad vil gjenspeile det som skaper økonomisk verdi for eierne av foretaket på lang sikt.

\subsubsection{Utvikling}

BMS har utviklet seg mye siden det ble introdusert, og har tatt opp i seg nye ideer og inspirasjon fra andre konsepter og teorier (Barnabè \& Busco, 2012; Kaplan, 2008; Kaplan, 2012). I sin opprinnelige form fra 1992 ble BMS presentert som et flerdimensjonalt målesystem hvor hensikten var å gi ledere et bedre beslutningsgrunnlag. Den opprinnelige versjonen av BMS handlet i hovedsak om å kombinere finansielle og ikke-finansielle ytelsesmål og resultatmål. Kaplan og Norton kalte det for et dashbord bestående av ulike måleparametere gruppert i fire perspektiver. Blikket ble imidlertid raskt utvidet. Fra og med 1996 (Kaplan \& Norton, 1996) har det blitt mer oppmerksomhet på hvordan målene kobles til virksomhetens strategi gjennom en kartlegging av sammenhengene mellom årsak og virkning (se f.eks. Braam \& Nijssen, 2004; Stemsrudhagen, 2003).

Rundt årtusenskiftet begynte Kaplan og Norton for alvor å omtale den «strategifokuserte organisasjonen» (Kaplan \& Norton, 2001). Kaplan og Norton har også introdusert begrepet strategikart, som etter hvert har blitt det mest fremtredende elementet i BMS-konseptet. Strategikart brukes for å visualisere og kommunisere foretakets strategi til hele organisasjonen (Kaplan \& Norton, 2001, 2004). Bruken av slike kart skal 
bidra til at alle delene av organisasjonen trekker i riktig retning. Denne ønskede tilstanden kaller Kaplan og Norton «alignment» (Kaplan \& Norton, 2006). På norsk brukes gjerne begrepet målkongruens, det vil si at det er samsvar mellom virksomhetens strategiske mål og de ansattes handlinger.

I de senere årene har Kaplan og Norton også begynt å diskutere strategi som en egen funksjon innen organisasjonen («the office of strategic management») og spesielt lagt vekt på strategiimplementering. Særlig i sin siste bok, Execution Premium, legger de vekt på dette (Kaplan \& Norton, 2008). Kaplan (2008) beskriver selv at de har utviklet konseptet fra å være et snevert prestasjonsmålingssystem til å bli et utvidet og langt bredere ledelsesverktøy som bidrar til å beskrive, kommunisere og iverksette organisasjonens strategi.

I løpet av de siste to tiårene har det altså skjedd en betydelig endring i måten BMS har blitt presentert på i litteraturen. Særlig tydelig er den skjerpede oppmerksomheten på strategi. Siden årtusenskiftet har oppmerksomheten på prestasjonsmåling kommet mer i bakgrunnen. Dette betyr derimot ikke at utviklingen er i konflikt med tidligere versjoner av BMS. Prestasjonsmåling spiller fortsatt en sentral rolle i implementering og oppfølging av en strategi. Det betyr heller ikke at målekortet/dashbordet ikke lenger er aktuelt. For eksempel ser man i praksis at mange organisasjoner ofte bruker enklere versjoner av BMS hvor det nettopp er prestasjonsmåling som står i fokus.

\subsubsection{Kritikk}

Selv om BMS har fått stor betydning både i akademia og i praksis, har konseptet også vært gjenstand for mye kritikk. Denne kritikken retter seg mot ulike sider ved konseptet og bruken av det. Særlig tre temaer har vært mye diskutert i BMS-litteraturen: 1) antagelsen om årsakvirkning-sammenhenger mellom lead- og lag-indikatorer og mellom de ulike perspektivene i konseptet (Nørreklit, 200o), (2) antakelsen om at organisasjoner implementerer strategi i en rasjonell ovenfra-og-ned prosess (Nørreklit, Nørreklit, Mitchell \& Bjørnenak, 2012) og (3) bruken av dramatisk og forførende retorikk ved innsalg av BMS-konseptet 
(Nørreklit, 2003). I tillegg har det (4) blitt påstått at bruken av BMS hindrer kreativitet, innovasjon og organisasjonslæring (Antonsen, 2014; Voelpel, Leibold \& Eckhoff, 2006), (5) at BMS er en ledelsesmote (Ax \& Bjørnenak, 2005; Cooper, Ezzamel \& Qu, 2017), og (6) at BMS primært er et konsulentprodukt (Ittner \& Larcker, 1998) og er å anse som «gammel vin på nye flasker» (Bourguignon et al., 2004). Disse tre siste går mer på hvordan BMS brukes.

\subsection{BMS: Spredning, bruk og effekter}

Det finnes en omfattende internasjonal forskningslitteratur på ulike sider ved BMS, og en rekke forskere har gjort ulike forsøkt på å oppsummere og systematisere disse studiene (Abdel-Kader, Moufty \& Laitinen, 2011; Banchieri, Planas \& Rebull, 2011; Basuony, 2014; Cooper \& Ezzamel, 2016; Hoque, 2014; Lueg \& Carvalho e Silva, 2013; Lueg \& Vu, 2015; Madsen \& Stenheim, 2015). Disse litteraturgjennomgangene viser at forskningen spenner over mange områder og temaer. I dette kapitlet vil vi særlig fokusere på forskningen som har sett på (1) spredning, (2) bruk og (3) effekter av BMS.

\subsubsection{Adopsjon og spredning}

Den første av disse tre forskningsretningene har undersøkt spredning (engelsk: diffusion) av BMS. Som påpekt av eksempelvis Ax og Bjørnenak (2007), handler diffusjon om spredning av noe i en populasjon. I vårt tilfelle vil dette være spredning av styringsverktøyet BMS i en populasjon av norske foretak. Studier som har undersøkt spredning av BMS, har for eksempel undersøkt på hvilke måter potensielle adoptører av BMS har kommet i kontakt med styringsverktøyet, hvilke motiver og rasjonaler som har drevet beslutningen om å adoptere BMS, og hvordan spredningen av BMS har variert over livssyklusen til styringsverktøyet. En rekke tidlige studier har pekt på den rollen som konsulenter har hatt som spredningsagenter, for eksempel i Finland (Malmi, 2001) og i Sverige (Ax \& Bjørnenak, 2005). Kaplan og Nortons konsulentselskap Palladium Group har også hatt en betydelig påvirkning i populariseringen av BMS (Cooper 
et al., 2017; $\mathrm{Qu}, 2004$ ). Madsen (2014a) fant at konferanser og seminarer, konsulenter og brukere var viktige kontaktpunkter i spredningen av BMS i Skandinavia.

Forskere har også undersøkt hvilke motiver og rasjonaler som har ligget bak beslutninger om å adoptere BMS, ofte ved bruk av teorier om ledelsesmoter (engelsk: management fashion theory) (Abrahamson, 1991, 1996). Malmi (2001) fant fem hovedmotiver for adopsjon av BMS i Finland, for eksempel kvalitetsarbeid og motepress. Rautiainen (2009) undersøkte adopsjonen av BMS i kommunal sektor og fant ut at en rekke til dels sammenvevde motiver (rasjonelle, mimetiske og eksperimentelle) kunne ligge bak adopsjonen.

En relatert forskningsretning er å undersøke hvordan populariteten til BMS har endret seg over tid, dvs. over livssyklusen til styringsverktøyet. For å undersøke dette har forskere brukt teorier om ledelsesmoter (Abrahamson, 1996), som antyder at ledelseskonsepter som BMS vil ha en klokkeformet livssyklus-kurve. Braam, Benders og Heusinkveld (2007) har undersøkt utviklingen av BMS i Nederland basert på hvor mange ganger et ledelseskonsept er blitt omtalt i media ("print-media indicators»). De fant at oppmerksomheten rundt BMS er sterk og vedvarende. De trakk derfor den konklusjonen at BMS trolig er en varig og i stor grad institusjonalisert ledelsesmote. BMS’ evne til å opprettholde sin popularitet antyder at livssyklusen følger et lengre forløp enn det som er typisk for ikke-vedvarende ledelsesmoter. Det er flere mulige forklaringer på den vedvarende oppmerksomheten og populariteten. En forklaring kan knyttes til det store tolkningsrommet til BMS, det Benders og Van Veen (2001) kaller «interpretative viability». BMS er fleksibelt og lite rigid, så det kan tilpasses på ulike måter når det gjelder for eksempel valg av perspektiver og styringsparametere. En annen forklaring er at det får nye anvendelsesområder. For eksempel er BMS blitt mer populært i ulike deler av offentlig sektor (Fallan et al., 2015; Olsen, 2012).

\subsubsection{Bruk}

Den andre av disse tre forskningsretningene har undersøkt bruken av BMS og hvordan det varierer på tvers av private foretak, offentlige 
virksomheter og frivillige organisasjoner. En rekke forskere har pekt på at BMS-konseptet har et visst tolkningsrom (engelsk: interpretive space) med hensyn til implementering og bruk (Ax \& Bjørnenak, 2005; Braam, 2012; Braam, Heusinkveld, Benders \& Aubel, 2002; Madsen, 2014b). For eksempel kan utdanningsbakgrunn og yrkeserfaring påvirke hvordan BMS blir tolket, implementert og brukt. Personer med bakgrunn fra regnskap og finans vil tolke BMS annerledes enn de som kommer fra en «mykere» HR-bakgrunn (Braam et al., 2002). Lueg og Carvalho e Silva (2013) viser at BMS-konseptet modifiseres på ulike måter når det tas i bruk i praksis. Hansen og Mouritsen (2005) argumenterer for at BMS er et såkalt grenseobjekt (engelsk: boundary object), noe som betyr at konseptet ofte blir modifisert for å tilpasses problemer og forhold som er spesifikke for organisasjonen. Andre forskere har vist at BMS «oversettes» på ulike måter når det passerer nasjonale og organisatoriske grenser (Wagensveld, 2013; Wongkaew, 2007).

Forskere har også forsøkt å kategorisere BMS-bruk i ulike BMS-generasjoner eller BMS-typer (Brudan, 2005; Lawrie \& Cobbold, 2004; Perkins et al., 2014; Soderberg, Kalagnanam, Sheehan \& Vaidyanathan, 2011; Speckbacher et al., 2003). Kategoriseringen skiller mellom enklere former for BMS-bruk (f.eks. Type I, First Generation, Level 1, BSC 1.0) og mer sofistikerte og avanserte former (Type III, Third Generation, Level 5, BSC 3.0) som inneholder elementer som kobler BMS til organisasjonens insentivsystemer og strategikart.

I dette kapitlet vil vi særlig fokusere på Speckbacher mfl. (2003) siden dette er den mest innflytelsesrike typologien og den er velegnet til å beskrive ulike mønstre i måten BMS brukes på i praksis. Speckbacher mfl. (2003) baserte sin klassifisering på en empirisk studie i de tysktalende landene, dvs. Tyskland, Østerrike og Sveits. Forfatterne skiller mellom tre typer BMS i praksis (tabell 13.1), fra Type I (prestasjonsmålingssystem) til Type III (strategisk ledelsessystem). Tabell 13.1 viser at Type II og Type III introduserer nye elementer i tillegg til de fire perspektivene og tilhørende styringsparametere. Type III kan kategoriseres som den mest sofistikerte, og her brukes BMS for å implementere foretakets strategi ved bruk av strategiske mål, handlingsplaner, resultater og koblinger til insentiv- og belønningssystemer. 
Tabell 13.1 Ulike BMS-typer og sentrale elementer (Speckbacher et al., 2003)

\begin{tabular}{ll}
\hline BMS-type & Sentrale elementer \\
\hline Type I BMS & Flerdimensjonalt rammeverk for strategisk prestasjonsmåling \\
& $\begin{array}{l}\text { Fire perspektiver som kombinerer finansielle og ikke-finansielle } \\
\text { styringsparametere (KPI-er) }\end{array}$ \\
Type II BMS & $\begin{array}{l}\text { Bygger på type I-BMS, men i tillegg beskrives og analyseres foretakets } \\
\text { strategi ved hjelp av årsak-virkning-sammenhenger }\end{array}$ \\
Type III BMS & $\begin{array}{l}\text { Bygger på type II-BMS, men i tillegg implementeres foretakets strategi ved å } \\
\text { definere strategiske mål, handlingsplaner, resultater og koblinger til insentiv- } \\
\end{array}$ \\
& og belønningssystemer \\
\hline
\end{tabular}

Nyere forskning antyder også at måten BMS blir implementert og brukt på, har betydning for hvilke effekter som kan forventes. For eksempel fant Lucianetti (2010) at de som anvendte strategikart, oppnådde mer suksess. På samme måte viser en nyere litteraturgjennomgang at strategikart kan være «the missing link» som kan forklare i hvilken grad man lykkes med BMS og oppnår tiltenkte effekter av BMS-implementeringen (Lueg, 2015; Lueg \& Julner, 2014).

\subsubsection{Effekter}

Den tredje av disse tre forskningsretningene har undersøkt effektene av implementering og bruk av BMS. Det sentrale spørsmålet i denne forskningslitteraturen er om implementering og bruk av BMS gir noen effekter på foretakets, eller mer generelt virksomhetens, ytelse. Det finnes flere studier som finner en positiv sammenheng mellom bruk av BMS og ytelse (Crabtree \& DeBusk, 2008; De Geuser, Mooraj \& Oyon, 2009; Ittner, Larcker \& Randall, 2003; Singh \& Sethi, 2017). Singh og Sethi (2017) finner for eksempel positive sammenhenger mellom adopsjon av BMS og ansattes atferd, organisatorisk kapabilitet og oppfattet prestasjon. De hevder at BMS har en positiv påvirkning på jobbtilfredshet, motivasjon, rolleklarhet og strategisk oppmerksomhet, som igjen resulterer i bedre ytelse. De finner også støtte for at BMS øker organisatorisk kapabilitet. Med det mener de innovative prosesser, benchmarkingaktiviteter og ledelseskapabilitet som kan føre til konkurransefortrinn. De Geuser mfl. (2009) finner at BMS skaper verdi for foretaket, og at verdiøkningen hovedsakelig kommer fra tre kilder: (1) den rollen BMS 
har i oversettelsen av foretakets strategi, (2) den evnen BMS har til å påvirke ledelsespraksisen i foretaket, og (3) den rollen BMS har i fordeling av ressurser til strategiske mål. De hevder at vektleggingen av strategi er det som skaper fordelene ved bruk av BMS, gjennom at BMS tvinger foretakene til å oversette strategi til strategiske mål og initiativer som kan måles og evalueres. Ittner mfl. (2003) ser på bruk av ulike strategiske prestasjonsmålinger og deres effekt på aksjekursen. De finner at bruk av ulike mål, finansielle og ikke-finansielle, har en positiv effekt på aksjekursen. Crabtree og DeBusk (2008) undersøker sammenhengen mellom bruk av BMS og aksjeavkastning. De finner at foretak som adopterer BMS, har høyere gjennomsnittlig aksjeavkastning enn foretak som ikke bruker BMS.

Det er likevel vanskelig å dokumentere en sterk sammenheng mellom BMS og ytelse (Braam \& Nijssen, 2004; Davis \& Albright, 2004; De Geuser et al., 2009). Det er mange mellomliggende variabler som påvirker denne relasjonen. Det er også nærliggende å tro at effektene er avhengige av hvordan BMS tolkes og forstås (Braam \& Nijssen, 2004). En virksomhet som tolker og implementerer BMS som et målesystem, vil antakeligvis få andre effekter enn en virksomhet som implementerer det som et mer overgripende strategisk ledelsessystem (Braam \& Nijssen, 2004). Det er også blitt argumentert for at det finnes en sammenheng mellom hvordan BMS implementeres og brukes, og ytelsen (Braam \& Nijssen, 2004; Davis \& Albright, 2004). Bruk av BMS som komplementerer virksomhetens strategi, kan forbedre konkurranseposisjonen og ytelsen, mens annen bruk som ikke er knyttet til virksomhetens strategi, ikke vil ha positiv effekt og muligens kan redusere ytelsen (Braam \& Nijssen, 2004; Davis \& Albright, 2004; De Geuser et al., 2009).

\subsection{Metode og data}

\subsubsection{Populasjon, utvalg og svarprosent}

Studien har som mål å foreta en kartlegging av bruken av BMS i norske foretak over tid. Siden studien skal gjennomføre en kartlegging, er det mest effektivt å gjøre dette ved å sende ut spørreskjemaer til de foretakene som inngår i populasjonen vi ønsket å kartlegge. Dataene er samlet inn 
via to elektroniske spørreundersøkelser gjennomført for norske foretak i 2015 (Alsaker \& Andersen, 2015) og 2018 (Eriksen, 2018).

Spørreundersøkelsen fra 2015 ble gjennomført bare for store foretak. Undersøkelsen i 2018 ble gjennomført for et tilsvarende utvalg foretak som i 2015, men i tillegg ble det trukket et utvalg foretak klassifisert som mellomstore foretak (verken klassifisert som store eller små foretak). Den siste spørreundersøkelsen ble innrettet på denne måten for å kunne avdekke forskjeller i bruk av BMS fra 2015 til 2018 for store foretak. Et annet formål for denne siste studien var å avdekke forskjeller i bruk mellom store og mellomstore foretak i 2018.

I undersøkelsen fra 2015 ble populasjonen av store foretak definert med utgangspunkt i Kapitals liste over Norges 500 største foretak ordnet etter omsetning. Det ble derimot satt noen ytterligere kriterier for å definere populasjonen eller utvalgsrammen. Blant annet ble det lagt inn krav om at foretakene hadde minst 200 ansatte. Dessuten ble holdingsselskaper tatt ut. I tillegg ble datterselskaper som stod oppført på listen samme med morselskapet, tatt ut siden det er nærliggende å anta at datterselskapene ikke har egen økonomiavdeling og dermed eget styringsverktøy. Foretak som er antatt styrt fra utlandet, er også fjernet fra utvalgsrammen. Utvalgsrammen i 2015 endte på 280 med endelig svarprosent på 32,1 (90/280). Det er en god svarprosent også målt mot studier publisert i internasjonale topp-tidsskrifter innen økonomistyring (Hiebl \& Richter, 2018).

I undersøkelsen som ble gjennomført i 2018, ble Kapitals liste og de samme kriteriene benyttet som i undersøkelsen fra 2015. Blant annet ble foretak med mindre enn 200 ansatte fjernet for på den måten å kunne kartlegge de aller største foretakene i Norge målt etter både omsetning og antall ansatte. ${ }^{2}$

Utvalgsrammen i 2018 endte på 261 med en endelig svarprosent på 21,1 (55/261). Denne svarprosenten må anses som akseptabel (Cook, Heath \& Thompson, 2000; Shih \& Fan, 2008). Det er ikke blitt gjennomført noen rigorøs frafallsanalyse, men en overordnet gjennomgang indikerer

2 En annen viktig grunn var å unngå overlapping med utvalget av mellomstore foretak som diskutert i neste avsnitt. 
ikke større skjevheter med hensyn til foretakenes størrelse eller bransjetilknytning. I forkant av 2015-undersøkelsen ble det gjort en pretest av spørreskjemaet. Spørsmålene i 2018-undersøkelsen var nærmest identiske med dem som ble benyttet i 2015-undersøkelsen, og det ble derfor ikke gjennomført noen pretest i forbindelse med denne undersøkelsen.

I 2018 ble det også gjennomført en spørreundersøkelse blant foretak som ikke er definert som store foretak, for på den måten å kunne avdekke forskjeller mellom store og mellomstore foretak. Alle foretakene i denne kategorien har færre ansatte og lavere omsetning enn dem som tilhører kategorien store foretak. Selve utvalgsrammen var etablert ved at det er hentet inn informasjon fra Proff.no, med kriterier basert på ansatte (100-200) og omsetning (320 til 1325 millioner kr). Ingen av foretakene i denne gruppen regnes som små foretak (jf. også regnskapsloven $\$ 1-6$ ) da alle har over 50 ansatte og en salgsinntekt som overstiger 70 millioner kr. Disse foretakene vil her bli definert som mellomstore foretak, selv om de i norsk kontekst kan ses som store. ${ }^{3}$ Også for denne kategorien er det brukt flere av de kriteriene som ble benyttet i undersøkelsen fra 2015. Det vil si at foretak som tilhører samme konsern, foretak som styres fra utlandet, og holdingselskaper ble tatt ut av utvalgsrammen. Utvalgsrammen endte her på 251 foretak med en endelig svarprosent på 25,9 (65/251).

Tabell 13.2 nedenfor oppsummerer de tre undersøkelsene med hensyn på utvalg, respondenter og svarprosent.

Tabell 13.2 Oppsummering av de tre spørreundersøkelsene

\begin{tabular}{|c|c|c|c|}
\hline & $\begin{array}{c}2015 \text { (tidspunkt 1, } \\
\text { utvalg av store foretak) }\end{array}$ & $\begin{array}{c}2018 \text { (tidspunkt 2, } \\
\text { utvalg av store foretak) }\end{array}$ & $\begin{array}{l}2018 \text { (tidspunkt 2, utvalg } \\
\text { av mellomstore foretak) }\end{array}$ \\
\hline Utvalg & 280 & 261 & 251 \\
\hline Respondenter & 90 & 55 & 65 \\
\hline Svarprosent & 32,1 & 21,1 & 25,9 \\
\hline
\end{tabular}

3 Det er mer krevende å definere mellomstore foretak da det foreligger flere ulike definisjoner. 


\subsubsection{Utforming av spørreskjema}

Undersøkelsene bygger i stor utstrekning på spørsmål benyttet i Speckbacher mfl. (2003) sin spørreundersøkelse, men også på nyere studier som har benyttet spørreskjema som innsamlingsverktøy for å avdekke bruk av BMS. Spørreskjemaet bestod av fire deler:

- Kjennetegn ved foretaket

- Kjennskap/kunnskap om BMS og ulike kilder til informasjon om BMS

- Implementering av BMS

- Forventede og opplevde fordeler og ulemper knyttet til BMSimplementering

Spørreskjemaet som ble brukt i 2018, er tilnærmet identisk med det som ble benyttet av Alsaker og Andersen (2015). Dette ble gjort for å være rimelig sikker på at respondentene i 2018 ville tolke spørsmålene på en tilsvarende måte som i 2015. En vel så viktig effekt av å benytte tilnærmet likt spørreskjema er at det muliggjør sammenligning. Noen spørsmål er imidlertid unike for undersøkelsen fra 2018 og fokuserer på endringer mellom 2015 og 2018. Spørreskjemaene ble utformet slik at det ikke ville ta mer enn 10 minutter å besvare dem. Respondentene var typisk økonomidirektører og controllere med kjennskap til foretakets styringssystemer.

\subsection{Forskningsspørsmål 1: Hvor utbredt er bruken av BMS i store foretak i Norge, og i hvilken grad har bruken av BMS endret seg fra 2015 til 2018?}

Det første forskningsspørsmålet omhandler utbredelsen og bruken av BMS i Norge. I denne delen vil vi derfor se nærmere på kjennskap og bruk, adopsjonstidspunkt samt bruk av ulike BMS-typer og kritiske ytelsesindikatorer. Underveis vil vi spesielt undersøke og analysere utviklingen fra 2015 til 2018. 


\subsubsection{Kjennskap og bruk}

Et viktig formål med studien var å undersøke i hvilken grad BMS brukes som styringsverktøy i norske foretak. Resultatene fra undersøkelsen i 2018 viser at 89 prosent av respondentene oppgir at de kjenner til BMS. Denne høye graden av kjennskap til BMS er ikke overraskende siden styringsverktøyet har vært i bruk i Norge i over 20 år (Madsen, 2012). I tillegg var respondentene i denne del av undersøkelsen fra de største norske foretakene. Store foretak har vanligvis mer kjennskap til og mer erfaring med styringsverktøy (CIMA, 2009). Tabell 3 bryter videre ned antallet respondenter i brukere og ikke-brukere og brukere av ulike typer av BMS i 2018.

Vi ser av tabell 3 at 49 prosent av respondentene bruker BMS. Dette kan sammenlignes med antall brukere i studien fra 2015, som utgjorde 41 prosent. Dette antyder at andelen som bruker BMS i de største norske foretakene, har økt med åtte prosentenheter. Dette er interessant da bruken av BMS på verdensbasis har gått ned fra 53 prosent i 2008 til 29 prosent i 2017 (Rigby \& Bilodeau, 2009, 2018). Merk også at blant dem som kjenner til BMS, er det 49 prosent som oppgir at de bruker styringsverktøyet. De fleste BMS-kjennerne er av Type I eller III, mens det er overraskende få av Type II. En mulig forklaring på hvorfor det er få av mellomtypen, kan være at brukerne enten velger enklere prestasjonsmålingssystemer eller å gå «all-in» for en mer omfattende og ambisiøs implementering av BMS. Ved nærmere kategorisering av disse respondentenes svar på andre spørsmål viser det seg at 14 prosent ikke kan karakteriseres verken som BMS Type I, II eller III. I 2015 utgjorde denne gruppen 8 prosent. Vi velger uansett å inkludere dem i gruppen som bruker BMS. ${ }^{4}$

Blant dem som oppgir at de ikke bruker BMS i dag, er det en mindre andel (11 prosent) som har forkastet verktøyet (økning fra 6 prosent i 2015). At en del foretak har sluttet med BMS, er heller ikke overraskende siden forskning har vist at det er stor variasjon når det gjelder i hvilken

4 Tilsvarende tall fra undersøkelsen i 2015 var 8 prosent. 
grad man lykkes med implementeringen (Braam \& Nijssen, 2004). En mulig årsak til at noen har forkastet BMS, kan være at verktøyet ikke har levd opp til forventningene som ble satt til det. I Norge var det særlig tidlig på 200o-tallet veldig høye forventninger knyttet til BMS (Madsen, 2012).

Tabell 13.3 Oversikt over kjennskap til og bruk av BMS blant store norske foretak 2018

\begin{tabular}{llcccc}
\hline & & Antall & Andel & Antall & Andel \\
\hline BMS ikke-kjennere & & & & 6 & $11 \%$ \\
BMS-kjennere & & & & & \\
& Type I & 12 & $22 \%$ & & \\
& Type II & 1 & $2 \%$ & & \\
& Type III & 6 & $11 \%$ & & \\
& Andre & 8 & $14 \%$ & & \\
& Brukere 2018 & & & 27 & $49 \%$ \\
& Tidligere brukere & 6 & $11 \%$ & & \\
& Aldri brukt & 16 & $29 \%$ & & \\
& Ikke-brukere 2018 & & & 22 & $40 \%$ \\
\hline Totalt antall/total andel & & & & 55 & $100 \%$ \\
\hline
\end{tabular}

Tabell 13.4 viser stor variasjon i bruk av BMS på tvers av bransjer i 2018. Dette er et interessant funn siden det finnes lite forskning som har forsøkt å forklare forskjeller i BMS-bruk mellom bransjer. Er det flere energi-foretak som bruker BMS fordi økonomistyringsverktøyet har større relative effektivitetsfordeler i denne bransjen enn i andre? En alternativ forklaring kan være at styringsverktøyet gjennom for eksempel imitasjon har utviklet seg til en slags bransjenorm (DiMaggio \& Powell, 1983). På den annen side kan det bemerkes at det er et stort antall ikke-brukere i utvalget fra bygg, anlegg og industri. I undersøkelsen fra 2015 var det ikke noe foretak fra denne bransjen som brukte BMS (Alsaker \& Andersen, 2015). En forklaring på dette kan være at andre styringsverktøy, som for eksempel Lean, har en sterk posisjon i denne bransjen i Norge (Kalsaas, 2017; Rolfsen \& Jensen, 2014). Det tyder på at bransjetilhørighet kan være en viktig variabel i BMS-studier. 
Tabell 13.4 Fordeling av brukere og ikke-brukere i ulike bransjer blant store norske foretak i 2018

\begin{tabular}{lcc}
\hline Bransjetilhørighet & $\begin{array}{c}\text { Brukere } \\
\text { Andel i hver bransje }\end{array}$ & $\begin{array}{c}\text { Ikke-brukere } \\
\text { Andel i hver bransje }\end{array}$ \\
\hline Energi & $15 \%$ & $6 \%$ \\
Transport & $3 \%$ & $12 \%$ \\
Bygg, anlegg og industri & $13 \%$ & $33 \%$ \\
Service & $8 \%$ & $17 \%$ \\
Annet & $5 \%$ & $7 \%$ \\
\hline
\end{tabular}

\subsubsection{Adopsjonstidspunkt}

For å få innsikt i utbredelsen av BMS spurte vi respondentene om når de adopterte BMS. Som tabell 13.5 viser, er det en betydelig andel foretak som har brukt BMS i en årrekke. I 2015 var det 17 prosent som adopterte BMS før 2001, mens hele 30 prosent adopterte verktøyet i perioden 2001-2005. Dette er ikke overraskende siden det er dokumentert at tidlig 200o-tall var «hype-perioden» for BMS i Norge (Madsen, 2012). I undersøkelsen fra 2018 ser vi at det er over 20 prosent som adopterte før 2001, men at det også er en stor andel relativt ferske adoptører (29 prosent). Det indikerer at BMS fortsatt anses som et attraktivt styringsverktøy, og at det ikke er i ferd med å dø ut.

Tabell 13.5 Adopsjonstidspunkt for BMS i 2015 sammenlignet med 2018 for store norske foretak

\begin{tabular}{|c|c|c|c|c|}
\hline \multirow[t]{2}{*}{ Adopsjonstidspunkt } & \multicolumn{2}{|c|}{ Undersøkelse 2015} & \multicolumn{2}{|c|}{ Undersøkelse 2018} \\
\hline & Adopsjonsandel & $\begin{array}{l}\text { Hvorav tidligere } \\
\text { brukere per } 2015\end{array}$ & Adopsjonsandel & $\begin{array}{l}\text { Hvorav tidligere } \\
\text { brukere per } 2018\end{array}$ \\
\hline Før 1995 & $7 \%$ & & Ikke målt & \\
\hline 1995-2000 & $10 \%$ & & $21 \%$ & \\
\hline 2001-2005 & $30 \%$ & $13 \%$ & $17 \%$ & $4 \%$ \\
\hline $2006-2010$ & $30 \%$ & $3 \%$ & $29 \%$ & $13 \%$ \\
\hline 2011-2015 & $23 \%$ & & $29 \%$ & \\
\hline 2016-2018 & Ikke målt & & $4 \%$ & \\
\hline Totalt & $100 \%$ & & $100 \%$ & \\
\hline
\end{tabular}




\subsubsection{BMS-typer}

Tabell 13.6 viser at blant dem som bruker BMS, har andelen som kan kategoriseres som Type I, gått ned fra 77 prosent til 64 prosent. Andelen Type II har også gått ned fra 13 prosent til 5 prosent, mens andelen Type III har økt kraftig fra 10 prosent til 31 prosent. Sett under ett er det fortsatt slik at flertallet av de foretakene vi undersøkte, i stor grad bruker BMS som et flerdimensjonalt målesystem. Dette er et interessant resultat siden det skiller seg noe fra funnene i den internasjonale litteraturen om BMS (Lueg \& Carvalho e Silva, 2013; Soderberg et al., 2011; Speckbacher et al., 2003). Studier i andre land viser også at Type I er vanlig, men at andelen Type II og III er noe høyere enn i Norge. Funnene våre støtter også tidligere forskning på BMS i Skandinavia hvor det ble funnet at de fleste tolket og oppfattet BMS som et måle- og rapporteringssystem (Madsen, 2011).

Det er altså en tendens til at foretak i andre land i større grad bruker mer ambisiøse og sofistikerte BMS-modeller enn norske foretak. En mulig forklaring på denne forskjellen kan være at norske foretak er mindre og har færre ressurser som kan brukes på å utvikle avanserte styringssystemer. Det kan legges til at vi for øvrig ikke finner noe mønster i BMS-bruk med hensyn til størrelse eller bransje i Norge. Dette er også blitt testet med ikke-parametriske statistiske metoder.

Tabellen viser at det er færre som bruker den enkleste typen BMS i 2018 enn i 2015. Videre er det tydelig at flere foretak bruker den mest avanserte formen (Type III) i 2018. Ifølge dataene er det ikke noe foretak som har implementert BMS i tidsrommet 2015-2018, som har gått direkte for Type III. Det indikerer at eksisterende brukere av BMS har beveget seg i retning av de mest avanserte typene av verktøyet. Respondentene ble også eksplisitt spurt om de endret bruken av BMS de siste tre årene. Det var relativt få som svarte på dette spørsmålet, men svarene indikerer likevel at det vært en bevegelse mot mer avanserte former for BMS. Tre foretak responderte at bruken hadde blitt mindre avansert, fire foretak at det ikke var vesentlige endringer i bruken, mens sju foretak responderte at bruken av BMS var mer avansert. 
Tabell 13.6 Type BMS i 2018 i store norske foretakene sammenlignet med 2015

\begin{tabular}{lcc}
\hline & Undersøkelse 2015 & Undersøkelse 2018 \\
\hline Type I & $77 \%$ & $64 \%$ \\
Type II & $13 \%$ & $5 \%$ \\
Type III & $10 \%$ & $31 \%$ \\
\hline Total andel & $100 \%$ & $100 \%$ \\
\hline
\end{tabular}

\subsubsection{Kritiske ytelsesindikatorer}

Tabell 13.7 viser at det er en tendens til at foretakene i 2018 bruker et $ø$ kende antall kritiske ytelsesindikatorer (KPI-er). Det er for eksempel hele ni foretak som oppgir at de bruker flere enn 50 KPI-er. Et økt antall KPI-er øker kompleksiteten i økonomistyringssystemet og kan være en indikasjon på en bevegelse mot mer sofistikerte typer av BMS-system. Når det er sagt, anbefales det i BMS-litteraturen at man ikke bruker særlig mer enn 20 KPI-er (Hoff \& Holving, 2015). Bruk av et svært høyt antall KPI-er indikere problemer med å prioritere hva som er viktig, og kan lede til «information overload» (Hoff \& Holving, 2015).

Tabell 13.7 Kritiske ytelsesindikatorer

\begin{tabular}{ccc}
\hline Antall KPI-er & Frekvens 2015 & Frekvens 2018 \\
\hline $0-9$ & 4 & 2 \\
$10-19$ & 14 & 9 \\
$20-29$ & 2 & 9 \\
$30-39$ & 4 & 4 \\
$40-49$ & 2 & 2 \\
$50-59$ & 1 & 1 \\
$60-69$ & 0 & 5 \\
$70-79$ & 0 & 0 \\
$80-89$ & 1 & 0 \\
$90-99$ & 2 & 0 \\
100 eller flere & 0 & 3 \\
\hline
\end{tabular}

I neste del går vi over fra å se på hvor mye og hvordan BMS brukes, til å undersøke hva som er de organisatoriske effektene av å bruke BMS. 


\subsection{Forskningsspørsmål 2: Hvilke organisatoriske effekter har BMS, og hvordan har disse effektene endret seg fra 2015 til 2018?}

I denne delen vil vi se nærmere på hva respondentene oppgir som de organisatoriske effektene av å adoptere og implementere BMS, og i hvilken grad dette har endret seg i perioden 2015 til 2018. Vi vil understreke at vi her undersøker respondentenes oppfattede effekter, noe som kan skille seg fra de faktiske effektene.

\subsubsection{Fordeler}

Vi undersøkte hva respondentene opplevde som fordelene knyttet til bruk av BMS. Som tabell 13.8 viser, er det tydelige forskjeller mellom hva respondentene forventet av fordeler ved BMS i forkant av implementeringen, og det som ble oppnådd. De mest åpenbare forskjellene mellom forventede og oppnådde fordeler er særlig interessante å se nærmere på. I 2015 var forventningen høyere enn det som er oppnådd når det gjaldt «videreutvikling av strategi» og «forbedre bedriftens resultater på lang sikt», mens oppnådde fordeler var større enn forventet når det gjaldt å «forbedre strategisk læring». Generelt er forskjellene mellom forventede og oppnådde fordeler størst i 2015, mens de er mindre i 2018.

Resultatene viser at de viktigste fordelene med BMS er at styringsverktøyet forbedrer sammenhenger mellom strategiske mål og handlinger, at det utvikler et konsistent system av mål, og at det øker oppmerksomheten på ikke-finansielle verdidrivere. Disse fordelene peker seg nokså klart ut i 2015, men er også det som hyppigst er nevnt i undersøkelsen fra 2018. Det er også en del interessante forskjeller, for eksempel er det store forskjeller mellom 2015 og i 2018 når det gjelder betydningen av å «forbedre bedriftens resultater på lang sikt».

\subsubsection{Utfordringer}

Vi spurte respondentene om hva de opplevde som utfordringer med bruk av BMS (tabell 13.9). Tabellen viser at det var flere som rapporterte om 
Tabell 13.8 Fordeler med BMS i 2015 og 2018

\begin{tabular}{|c|c|c|c|c|}
\hline \multirow[t]{2}{*}{ Fordeler med BMS } & \multicolumn{2}{|c|}{$\begin{array}{l}\text { Prosentandel av } \\
\text { BMS-brukere } 2015\end{array}$} & \multicolumn{2}{|c|}{$\begin{array}{l}\text { Prosentandel av } \\
\text { BMS-brukere } 2018\end{array}$} \\
\hline & Forventet & Oppnådd & Forventet & Oppnådd \\
\hline Videreutvikle strategien & 14 & 4 & 7 & 7 \\
\hline Avklare og kommunisere strategien & 14 & 13 & 9 & 6 \\
\hline $\begin{array}{l}\text { Forbedre sammenhengen mellom } \\
\text { strategiske mål og handlinger }\end{array}$ & 71 & 70 & 20 & 19 \\
\hline$\varnothing k t$ fokus på strategi & 10 & 17 & 1 & 7 \\
\hline Utvikle et konsistent system av mål i selskapet & 57 & 48 & 13 & 12 \\
\hline $\begin{array}{l}\text { Forbedre forståelsen av årsak-virkning- } \\
\text { sammenhenger i bedrifter }\end{array}$ & 10 & 13 & 6 & 7 \\
\hline $\begin{array}{l}\text { Legge større vekt på ikke-finansielle drivere i } \\
\text { virksomhetsstyringen }\end{array}$ & 52 & 43 & 12 & 14 \\
\hline Forbedre bedriftens resultater på lang sikt & 62 & 35 & 7 & 3 \\
\hline $\begin{array}{l}\text { Kartlegge strategiske handlinger som } \\
\text { bedriften må utføre for å nå bedriftens mål }\end{array}$ & 10 & 13 & 7 & 9 \\
\hline $\begin{array}{l}\text { Forbedre strategisk læring (kontroll og } \\
\text { tilbakemelding) }\end{array}$ & 5 & 17 & 4 & 1 \\
\hline Tilrettelegge for et insentivsystem & 0 & 4 & 7 & 7 \\
\hline Ta mer hensyn til interessenter & 0 & 4 & 1 & 0 \\
\hline Forbedre kundefokuset & 10 & 9 & 1 & 3 \\
\hline $\begin{array}{l}\text { Identifisere muligheter for endringer i } \\
\text { forretningsprosessene }\end{array}$ & 19 & 17 & 3 & 3 \\
\hline Støtte opp under en vekststrategi & 0 & 4 & 0 & 1 \\
\hline Respondenter & 21 & 23 & 69 & 69 \\
\hline
\end{tabular}

implementeringsutfordringer i 2015 enn i 2018. På samme tid peker tid og ressurser og manglende deltakelse seg ut både i 2015 og 2018. Tid og ressurser er den vanligste utfordringen. Dette er ikke overraskende siden det i BMS-litteraturen pekes på at det kan ta lang tid å få på plass et velfungerende BMS-system. Det er et problem også ved implementering av andre økonomistyringsverktøy som for eksempel tradisjonell ABC (Kaplan \& Anderson, 2004). Det vil være rimelig å anta at mer sofistikerte typer av BMS (Type II og III) vil kreve bruk av mer tid og ressurser ved implementering enn enkle Type I-modeller.

Andre vanlige problemer er manglende deltakelse fra resten av organisasjonen og problemer med å se sammenhengen i styringsverktøyet. Manglende deltakelse er også et hyppig problem i bruk av BMS. 
En forklaring kan være at et strategisk fokusert BMS (Type III) gir en «top-down»-tilnærming i utformingen av for eksempel KPI-er. En sannsynlig konsekvens av dette er at ansatte lenger ned i organisasjonen kjenner lite eierskap til KPI-ene.

Manglende deltakelse kan medføre at BMS blir marginalisert i organisasjonen (Madsen \& Slåtten, 2015), og at det bare blir et rapporteringsverktøy som ikke har noen relevans for andre enn den BMS-ansvarlige. Når det gjelder problemer med å se sammenhengen i styringsverktøyet, er dette relatert til mangel på forståelse av verktøyet og hvordan det henger sammen med foretakets øvrige styringssystemer.

Noen respondenter trekker også frem manglende engasjement fra toppledelsen, inkompatibel organisasjonskultur og mangel på en sterk pådriver med overordnet ansvar for BMS-prosjektet. Dette er sentrale faktorer som gjør det vanskelig å få BMS til å fungere godt i organisasjonen. Flere tidligere BMS-studier (Madsen \& Slåtten, 2015; Wickramasinghe, Gooneratne \& Jayakody, 2007) har vist at verktøy ofte «stues bort» hvis lederne ikke viser interesse og engasjement, og det vil være viktig med en sterk pådriver («BMS-general») for å skape slikt engasjement og interesse fra ledere og andre i organisasjonen (Madsen \& Stenheim, 2014b).

Tabell 13.9 Utfordringer med bruk av BMS i 2015 og 2018

\begin{tabular}{lcccc}
\hline & \multicolumn{2}{c}{$\mathbf{2 0 1 5}$} & \multicolumn{2}{c}{$\mathbf{2 0 1 8}$} \\
\hline Utfordring & Antall & Andel & Antall & Andel \\
\hline Tids- og ressurskrevende & 14 & 67 & 18 & 35 \\
Manglende deltakelse & 7 & 33 & 11 & 21 \\
Tekniske problemer & 4 & 19 & 0 & 0 \\
Manglende engasjement fra toppledelsen & 3 & 14 & 1 & 2 \\
Ikke kompatibel organisasjonskultur & 3 & 14 & 5 & 10 \\
Mangel på sterk pådriver med overordnet ansvar & 3 & 14 & 3 & 6 \\
Problemer med å se sammenhengen i & 6 & 29 & 7 & 13 \\
styringsverktøyet & & & & 0 \\
Manglende kontinuitet & 0 & 0 & 0 & 6 \\
Motstand mot merkelappen BMS & 0 & 0 & 3 & 4 \\
Utvikling av strategikart & 0 & 0 & 2 & 4 \\
Annet & 3 & 14 & 2 & \\
\hline
\end{tabular}




\subsubsection{Tilfredshet}

Vi spurte respondentene om i hvilken grad de var tilfredse med styringssystemet før og etter implementeringen av BMS. Generelt viser dataene fra 2015 at tilfredsheten med styringssystemet var høyere etter implementering, med hensyn til både presisjon og relevans.

I 2018 spurte vi også om tilfredshet totalt sett, styringssystemets presisjon, styringssystemets relevans og styringssystemet som prestasjonsmålingssystem. De fleste foretakene var middels fornøyd med styringssystemet som ble benyttet før BMS ble implementert, og gjennomsnittet lå på 2,70 på en skala fra 1 til 5 . Her er for øvrig foretakene fra begge utvalgene tatt med. Ser vi på tilfredshet med styringssystemet etter at BMS ble implementert, gir det et noe annerledes bilde. De fleste foretakene er over middels fornøyd med styringssystemet etter at BMS ble implementert, med et gjennomsnitt på 3,74 .

Resultatene fra andre studier, både fra Norge og internasjonalt, viser lignende resultater. Av andre studier som brukte en Likert-skala (1-5), finner Bjørnenak (2013), Rigby og Bilodeau (2013, 2015, 2018) og Johanson og Madsen (2017) lignende resultater. Bjørnenak (2013) så på opplevd nytteverdi av BMS blant norske sparebanker. Her scoret verktøyet i gjennomsnitt 3,68. Rigby og Bilodeau (2013, 2015, 2018) ser på hvor fornøyd foretak fra hele verden er med BMS. I 2012 og 2014 scoret BMS i gjennomsnitt 3,90, mens i 2017 var scoren 3,93. Johanson og Madsen (2017) bygger på Alsaker og Andersens (2015) masteroppgave, og resultatene viser at de største norske foretakene er over middels fornøyde med BMS etter implementering, med en gjennomsnittlig score på 3,95.

Til nå har vi sett på spredning og bruk (del 5) og organisatoriske effekter av BMS. I neste del ser vi nærmere på om det kan være forskjeller i bruk og effekter av BMS mellom store og mellomstore foretak. 


\subsection{Forskningsspørsmål 3: Hvilke forskjeller er det i bruk og effekter av BMS mellom store og mellomstore foretak i Norge basert på data fra 2018?}

Det siste forskningsspørsmålet handler om forskjeller mellom store og mellomstore foretak. Undersøkelsen fra 2018 viser til at 26 prosent av de foretakene vi klassifiserte som mellomstore, bruker BMS. Det kan sammenlignes med 49 prosent av store norske foretak med over 200 ansatte oppga av de brukte BMS. Det er følgelig en vesentlig forskjell i andel brukere av BMS mellom de to utvalgene.5 Dette er i samsvar med det som er forventet, siden mindre foretak typisk bruker færre styringsverktøy (Rigby \& Bilodeau, 2018) og dette gjelder også for utbredelse og bruk av BMS (Basuony, 2014; Madsen, 2015).

Tabell 13.10 viser forskjeller i bruk av BMS mellom foretak med over og under 200 ansatte. Resultatene viser at det også i foretak med under 200 ansatte, er en overveiende andel brukere av BMS Type I. Interessant nok er det betydelig færre brukere av Type 1 i denne gruppen foretak enn i store foretak, noe som gjelder for undersøkelsene fra både 2018 og 2015. Dette er noe overraskende da det ofte betraktes som en etablert sannhet at større organisasjoner krever mer avansert og omfattende styring enn mindre organisasjoner (Hudson, Smart \& Bourne, 2001). En forklaring kan være at mellomstore foretak kalkulerer med en relativt større kostnad ved å implementere BMS. De vil derfor implementere et mer omfattende og sofistikert system for å sikre at BMS blir en permanent og relevant del av styringssystemet. Det bør imidlertid bemerkes at resultatene fra undersøkelsene må tolkes med forsiktighet da det er relativt få respondenter.

Tabell 13.10 Type av BMS brukt av foretak av ulik størrelse i 2018

\begin{tabular}{lcc}
\hline & Foretak under $\mathbf{2 0 0}$ ansatte & Foretak over $\mathbf{2 0 0}$ ansatte \\
\hline Type I & $42 \%$ & $63 \%$ \\
Type II & $25 \%$ & $6 \%$ \\
Type III & $33 \%$ & $31 \%$ \\
\hline Total andel & $100 \%$ & $100 \%$ \\
\hline
\end{tabular}

5 En enkel kjikvadrattest indikerer at det er mer sannsynlig at mellomstore foretak ikke bruker BMS. 
Tilfredshet med BMS er diskutert i avsnittet om effekter av BMS. Om vi sammenligner de to utvalgene med hensyn til tilfredsheten, ser vi at mellomstore foretak er marginalt mer tilfredse enn store foretak. På skalaen 1-5, gir mellomstore foretak en gjennomsnittlig score på 3,9 og store foretak en gjennomsnittlig score på 3,6. Det er en liten tendens til at tilfredsheten til store foretak har gått ned de siste årene; undersøkelsen fra 2015 fant en gjennomsnittlig score på 3,95.

Det at foretak med minimum 200 ansatte gir BMS en score på 3,6, kan tyde på at tilfredsheten med bruken blant de største foretakene i Norge er gått noe ned de siste tre årene, fra 3,95 i 2015 (Johanson \& Madsen, 2017). Selv om undersøkelsen fra 2018 viser noe lavere tilfredshet enn undersøkelsen fra 2015, så avviker ikke resultatet i særlig grad fra andre nasjonale og internasjonale studier.

\subsection{Diskusjon}

\subsubsection{Adopsjon og spredning}

De empiriske funnene i begge undersøkelsene viser at BMS fortsatt har en utstrakt bruk i norske foretak. Dataene våre indikerer ikke store endringer $\mathrm{i}$ adopsjon og spredning av BMS i Norge i perioden 2015 til 2018, men indikerer at BMS har blitt en vedvarende trend og i stor grad har blitt institusjonalisert som en del av «god praksis» innen økonomisk styring. Dataene viser at BMS fortsatt adopteres av foretak, og at det ikke er i ferd med å «dø ut».

Disse funnene kan også diskuteres i lys av for eksempel ledelsesmoteteori (engelsk: fads and fashions) (Abrahamson, 1996) som legger vekt på at spredning og popularitet av ledelses- og økonomistyringsverktøy i stor grad er drevet av sosiale og institusjonelle prosesser. I denne litteraturen har man tradisjonelt sett for seg at livssyklusen til slike verktøy best kan beskrives med en klokkeformet kurve (Abrahamson \& Fairchild, 1999), selv om det over tid har vokst frem en erkjennelse av at moteriktige styringsverktøy også kan bli institusjonaliserte og bli mer permanent forankret i praksis (Perkmann \& Spicer, 2008). BMS er et interessant case i så måte. Som styringsverktøy har det eksistert i nesten 30 år, og selv om det fortsatt har en solid posisjon i 
$ø$ konomistyringslitteraturen, er det nye verktøy som «Big data analytics», «Lean» og «Beyond budgeting» som i dag oppfattes som innovative modeller (Becker, Messner \& Schäffer, 2020; Rigby \& Bilodeau, 2018). Dataene fra undersøkelsene gir derfor en viss støtte til Madsen (2011), som argumenterte for at BMS hadde blitt en institusjonalisert ledelsesmote i Norge.

\subsubsection{Bruk}

Undersøkelsene viser at det er Type I, altså BMS som et prestasjonsmålingssystem, som dominerer, selv om det i 2018 er tegn på at BMSmodellene i foretakene blir mer sofistikerte. Dette er konsistent med tidligere studier i en norsk kontekst som også har vist at BMS hovedsakelig brukes som et måle- og rapporteringssystem (Madsen, 2012). Hva er mulige forklaringer på hvorfor BMS primært brukes som Type I i norske foretak? Skyldes det manglende kunnskap om verktøyets potensial? Er det en rasjonell beslutning basert på kost-nytte-vurderinger? Det kan tenkes at en del foretak primært har utfordringer knyttet til prestasjonsmåling (Ittner \& Larcker, 2003) og i mindre grad søker etter løsninger på andre typer problemer.

\subsubsection{Effekter}

Dataene viser at foretakene opplever at det er positive sider ved BMS så vel som implementeringsutfordringer. Når det gjelder fordeler med BMS, er det en del avvik mellom forventede og oppfattede fordeler, noe som kan skyldes (for) høye forventninger. Dette er en vanlig observasjon for ledelsesmoter. Populariteten til styringsverktøyet kan falle fordi det ikke klarer å innfri forventningene (Benders \& Van Veen, 2001). Som nevnt, var det på begynnelsen av 200o-tallet en slags hallelujastemning rundt BMS i Norge (Madsen, 2012) og det kan tenkes at en del foretak ble revet med. Det er mulig at senere adoptører er mer edruelige når det gjelder forventede fordeler og potensielle implementeringsutfordringer, noe som kan gjøre at det blir lettere å unngå å bli desillusjonert. Det vil i sin tur potensielt kunne øke suksessgraden. 
Generelt er det interessant at norske foretak (både i 2015 og 2018) er så tilfredse med BMS, særlig siden de i stor grad benytter seg av BMS Type I. Bjørnenak (2013) finner på samme måte at foretak stort sett er «fornøyd med alt man gjør» knyttet til bruk av styringsverktøy, noe som betyr at opplevd tilfredshet kanskje ikke er et godt mål på suksess.

\subsection{Konklusjon}

\subsubsection{Oppsummerende kommentarer}

I dette kapitlet har vi presentert sentrale utviklingstendenser knyttet til spredning, bruk og effekter av BMS i norske bedrifter. Resultatene viser at BMS er et viktig økonomistyringsverktøy i norske bedrifter som i stor grad bruker BMS til intern rapportering og styring. Likevel ser vi visse tendenser til endringer i hvordan BMS blir brukt - i retning av bruk av BMS som et strategisk ledelsesverktøy. Et annet sentralt funn er at BMS virker å være en vedvarende trend som i høy grad har blitt institusjonalisert som en del av «god praksis» innen feltet økonomisk styring.

Bidraget fra denne studien er ikke nødvendigvis bare relatert til resultatene, men også til implikasjonene for fremtidig forskning på BMS og andre styringsverktøy. Vi har gjort et sjeldent forsøk på å beskrive og analysere utviklingstendenser knyttet til bruken av styringskonsepter. De fleste spørreundersøkelser er rene tverrsnittsundersøkelser. Bain og Company's undersøkelser er et unntak og har blitt gjennomført med jevne mellomrom siden 1993. På den annen side har også denne undersøkelsen svakheter ved at den bruker «tick-the-box»-spørsmål og ikke kartlegger variasjon i bruken av f.eks. BMS. Vår studie har fokusert på bare et styringsverktøy og har også vært i stand til å si noe om hvordan BMS brukes.

\subsubsection{Begrensninger og videre forskning}

Vi vil understreke at det naturligvis er en del begrensninger ved vår studie som det er viktig å merke seg. For det første gjelder vanlige begrensninger ved spørreundersøkelser, for eksempel svarprosent og frafallsproblematikk. Svarprosentene i de to undersøkelsene er noe lavere enn det som har vært anbefalt i metodelitteratur (Grønmo, 2004), men samtidig er den 
høyere enn i mange av dagens elektronisk spørreundersøkelser (Cook et al., 2000; Shih \& Fan, 2008). Det bør også bemerkes at svarprosenten er noe lavere i 2018.

Det er derfor flere mulige måter denne studien kan utvides på. Det ville være svært interessant med flere datapunkter, for eksempel ved en replisering av studien i 2022 (og muligens 2025). Med unntak av Bain og Company's internasjonale studier av ledelsesverktøy og trender er det svært få slike studier i litteraturen. Et slikt longitudinelt datasett vil kunne bidra med ny innsikt om BMS og vil også kunne bidra med ny empiri som kan belyse «management fashion»-teorien. Ofte finnes det lite data om bruken av ledelsesverktøy i organisasjoner på etterspørselssiden (Clark, 2004).

En annen utvidelse vil være å gjøre sammenligninger med andre land. Det ville kanskje være mest naturlig å sammenligne med de andre skandinaviske landene siden man ofte antar at disse har mange likheter når det gjelder størrelse, forretningskultur og andre institusjonelle forhold (Grenness, 2003; Jönsson, 1996). Det vil derfor være interessant dersom man finner forskjeller i adopsjon, bruk og effekter av BMS her. Til slutt kan det også tenkes mer kvalitativt orienterte studier. Dette kan for eksempel være studier av hvordan BMS virker sammen med resten av organisasjonens styringssystemer (Johanson \& Madsen, 2013). Det vil også være interessant med longitudinelle casestudier av hvordan BMS brukes over tid i enkeltorganisasjoner, for eksempel ved hjelp av virusperspektivet (Johanson \& Madsen, 2019; Røvik, 2011). Dette teoretiske perspektivet bruker virus som metafor for å analysere spredning av økonomistyringsverktøy og kan gi et mer mangefasettert bilde av sprednings- og implementeringsprosessen.

\section{Referanser}

Abdel-Kader, M., Moufty, S. \& Laitinen, E. K. (2011). Balanced scorecard development: A review of literature and directions for furture research. I M. G. Abdel-Kader (Red.), Review of management accounting research (s. 214). Hampshire: Palgrave Macmillan.

Abrahamson, E. (1991). Managerial fads and fashions: The diffusion and rejection of innovations. Academy of Management Review, 16(3), 586-612. 
Abrahamson, E. (1996). Management fashion. Academy of Management Review, 21(1), 254-285.

Abrahamson, E. \& Fairchild, G. (1999). Management fashion: Lifecycles, triggers, and collective learning processes. Administrative Science Quarterly, 44, 708-740.

Al Sawalqa, F., Holloway, D. \& Alam, M. (2011). Balanced Scorecard implementation in Jordan: An initial analysis. International Journal of Electronic Business Management, 9(3), 196-210.

Alsaker, H. \& Andersen, E. (2015). Hvor sofistikert og utbredt er Balansert målstyring i store norske bedrifter, og er bedriftene tilfredse med styringsverktøyet? En deskriptiv analyse om implementering av Balansert målstyring $i$ store norske bedrifter. Norwegian School of Economics, Bergen, Norway.

Anand, M., Sahay, B. \& Saha, S. (2005). Balanced scorecard in Indian companies. Vikalpa, 3o(2), 11-25.

Andersen, H., Cobbold, I. \& Lawrie, G. (2001). Balanced scorecard implementation in SMEs: Reflection on literature and practice. Paper presented at the 2GC Conference Paper, Presented at SMESME Copenhagen, Denmark.

Antonsen, Y. (2014). The downside of the balanced scorecard: A case study from Norway. Scandinavian Journal of Management, 30(1), 40-50.

Ax, C. \& Bjørnenak, T. (2005). Bundling and diffusion of management accounting innovations - the case of the balanced scorecard in Sweden. Management Accounting Research, 16(1), 1-20.

Ax, C. \& Bjørnenak, T. (2007). Management accounting innovations: Origins and diffusion. I T. Hopper, D. Northcott \& R. W. Scapens (Red.), Management accounting innovations: Origins and diffusion (3. ugt., s. 357-376). Hertfordshire: Prentice-Hall.

Banchieri, L. C., Planas, F. C. \& Rebull, M. V. S. (2011). What has been said, and what remains to be said, about the balanced scorecard? Proceedings of Rijeka Faculty of Economics - Journal of Economics and Business, 29(1), 155-192.

Barnabè, F. \& Busco, C. (2012). The causal relationships between performance drivers and outcomes: Reinforcing balanced scorecards' implementation through system dynamics models. Journal of Accounting \& Organizational Change, 8(4), 528-538.

Basuony, M. A. (2014). The balanced scorecard in large firms and SMEs: A critique of the nature, value and application. Accounting and Finance Research, 3(2), 14.

Becker, S. D., Messner, M. \& Schäffer, U. (2020). The interplay of core and peripheral actors in the trajectory of an accounting innovation: Insights from beyond budgeting. Contemporary Accounting Research, n/a(n/a).

Benders, J. \& Van Veen, K. (2001). What's in a fashion? Interpretative viability and management fashions. Organization, 8(1), 33-53.

Bescos, P.-L., Deville, A. \& Foulquier, P. (2020). BSC and long-term deployment: An actors' perspective. Journal of Applied Accounting Research. 
Bjørnenak, T. (2010). Økonomistyringens tapte relevans, del 1 og 2 eller fra ABC til beyond budgeting på 20 år. Magma, 13(4), 49-54.

Bjørnenak, T. (2013). Styringssystemer og lønnsomhet: en studie av norske sparebanker. Magma - Tidsskrift for økonomi og ledelse, 6, 31-36.

Bourguignon, A., Malleret, V. \& Nørreklit, H. (2004). The American balanced scorecard versus the French tableau de bord: The ideological dimension. Management Accounting Research, 15(2), 107-134.

Braam, G. (2012). Balanced scorecard's interpretative variability and organizational change. I C.-H. Quah, \& O. L. Dar (Red.), Business dynamics in the 21st century. Rijeka, Croatia: InTech.

Braam, G., Benders, J. \& Heusinkveld, S. (2007). The balanced scorecard in the Netherlands: An analysis of its evolution using print-media indicators. Journal of Organizational Change Management, 20(6), 866-879.

Braam, G., Heusinkveld, S., Benders, J. \& Aubel, A. (2002). The reception pattern of the balanced scorecard: Accounting for interpretative viability. SOM-Theme G: Cross-contextual comparison of institutions and organisations. Nijmegen, The Netherlands: Nijmegen School of Management, University of Nijmegen.

Braam, G. \& Nijssen, E. (2004). Performance effects of using the balanced scorecard: A note on the Dutch experience. Long Range Planning, 37, 335-349.

Brudan, A. (2005). Balanced scorecard typology and organisational impact. KM Online Journal of Knowledge Management, 2(1).

Chenhall, R. H. (2003). Management control systems design within its organizational context: findings from contingency-based research and directions for the future. Accounting, Organizations and Society, 28(2-3), 127-168.

Christensen, K. S. \& Bukh, P. N. (2013). Succes med balanced scorecard. Copenhagen, Denmark: Gyldendal A/S.

CIMA. (2009). Management accounting tools for today and tomorrow. London, UK: Chartered Institute of Management Accountants (CIMA).

Clark, T. (2004). The fashion of management fashion: A surge too far? Organization, 11(2), 297-306.

Cook, C., Heath, F. \& Thompson, R. L. (2000). A meta-analysis of response rates in web-or internet-based surveys. Educational and Psychological Measurement, $60(6), 821-836$.

Cooper, D. J., \& Ezzamel, M. 2016. A critical analysis of the balanced scorecard: Towards a more dialogic approach. I J. Haslam \& P. Sikka (Red.), Pioneers of critical accounting: A celebration of the life of Tony Lowe (s. 201-230). London: Palgrave Macmillan UK.

Cooper, D. J., Ezzamel, M. \& Qu, S. Q. (2017). Popularizing a management accounting idea: The case of the balanced scorecard. Contemporary Accounting Research, 34(2), 991-1025. 
Cooper, R. \& Kaplan, R. S. (1988). Measure costs right: Make the right decisions. Harvard Business Review, 66(5), 96-103.

Crabtree, A. D. \& DeBusk, G. K. (2008). The effects of adopting the balanced scorecard on shareholder returns. Advances in Accouting, incorporating Advances in International Accounting, 24, 8-15.

Davis, S. \& Albright, T. (2004). An investigation of the effect of balanced scorecard implementation on financial performance. Management Accounting Research, $15(2), 135-153$.

De Geuser, F., Mooraj, S. \& Oyon, D. (2009). Does the balanced scorecard add value? Empirical evidence on its effect on performance. European Accounting Review, 18(1), 93-122.

DiMaggio, P. J. \& Powell, W. W. (1983). The iron cage revisited: Institutional isomorphism and collective rationality in organizational fields. American Sociological Review, 48(2), 147-160.

Eriksen, T. A. 2018. Utbredelse og bruk av balansert målstyring i store norske bedrifter: er det skjedd endringer de siste tre årene?: en deskriptiv analyse av bruken av balansert målstyring blant store norske bedrifter.

Fallan, E., Olsen, T.-E., Daleq, B. \& Hobbel, M. A. (2015). Bruk av balansert målstyring i norske kommuner. Magma, (8), 62-75.

Free, C. \& Qu, S. (2011). The use of graphics in promoting management ideas: An analysis of the balanced scorecard, 1992-2010. Journal of Accounting \& Organizational Change, 7(2), 158-189.

Gjønnes, S. H. \& Tangenes, T. (2012). Økonomi- og virksomhetsstyring Strategistøtte ved prestasjonsstyring, ressursstyring og beslutningsstøtte: Bergen: Fagbokforlaget.

Grenness, T. (2003). Scandinavian managers on Scandinavian management. International Journal of Value-Based Management, 16, 9-21.

Grønmo, S. (2004). Samfunnsvitenskapelige metoder. Bergen: Fagbokforlaget.

Hansen, A. \& Mouritsen, J. (2005). Strategies and organizational problems: Constructing corporate value and coherences in balanced scorecard processes. I C. S. Chapman (Red.), Controlling strategy: Management, accounting and performance measurement (s. 125-150). New York: Oxford University Press.

Hiebl, M. R., \& Richter, J. F. (2018). Response rates in management accounting survey research. Journal of Management Accounting Research, 30(2), 59-79.

Hoff, K. G. (2008). Strategisk økonomistyring. Oslo: Universitetsforlaget.

Hoff, K. G. \& Holving, P. A. (2015). Balansert målstyring - Strategisk virksomhetsstyring satt $i$ system (2. utg.). Oslo: Universitetsforlaget.

Hoque, Z. (2014). 20 years of studies on the balanced scorecard: Trends, accomplishments, gaps and opportunities for future research. The British Accounting Review, 46(1), 33-59. 
Hudson, M., Smart, A. \& Bourne, M. (2001). Theory and practice in SME performance measurement systems. International Journal of Operations og Production Management, 21(8), 1096-1115.

Ittner, C. D. \& Larcker, D. F. (1998). Innovations in performance measurement: Trends and research implications. Journal of Management Accounting Research, $10,205-238$.

Ittner, C. D. \& Larcker, D. F. (2003). Coming up short on nonfinancial performance measurement. Harvard Business Review, 81(11), 88-95.

Ittner, C. D., Larcker, D. F. \& Randall, T. (2003). Performance implications of strategic performance measurement in financial services firms. Accounting, Organizations and Society, 28(7), 715-741.

Johanson, D. \& Madsen, D. Ø. (2013). Økonomisk styring i Norge - en kartlegging av styringssystemer i norske bedrifter. Magma - Tidsskrift for økonomi og ledelse, 16(6), 18-30.

Johanson, D. \& Madsen, D. Ø. (2017). Balansert målstyring - et dynamisk styringsverktøy? Utviklingen i praksis og fremtidig potensial. I T. Nesheim \& I. Stensaker (Red.), Fokus på fremtidens foretaksløsninger (s. 91-107). Bergen: Fagbokforlaget.

Johanson, D. \& Madsen, D. Ø. (2019). Diffusion of management accounting innovations: A virus perspective. Journal of Accounting \& Organizational Change.

Johnson, H. T. \& Kaplan, R. S. (1987). Relevance lost: The rise and fall of management accounting. Boston: Harvard Business School Press.

Jönsson, S. (1996). Perspectives of Scandinavian management. Göteborg: Bokförlaget BAS.

Kald, M. \& Nilsson, F. (2000). Performance measurement at Nordic companies. European Management Journal, 188(1), 113-127.

Kalsaas, B. T. (2017). Lean construction. Forstå og forbedre prosjektbasert produksjon. Bergen: Fagbokforlaget.

Kaplan, R. S. (1984). Yesterday's accounting undermines production. Harvard Business Review, 62(4), 95-101.

Kaplan, R. S. (2008). Conceptual foundations of the balanced scorecard. Handbooks of Management Accounting Research, 3, 1253-1269.

Kaplan, R. S. (2012). The balanced scorecard: Comments on balanced scorecard commentaries. Journal of Accounting and Organizational Change, 8(4), 539-545.

Kaplan, R. S. \& Anderson, S. R. (2004). Time-driven activity-based costing. Harvard Business Review, 82(November), 131-138.

Kaplan, R. S. \& Norton, D. P. (1992). The balanced scorecard - measures that drive performance. Harvard Business Review, (January-February), 71-79.

Kaplan, R. S. \& Norton, D. P. (1996). The balanced scorecard: Translating strategy into action. Boston, MA: Harvard Business School Press. 
Kaplan, R. S. \& Norton, D. P. (2001). The strategy-focused organization: How balanced scorecard companies thrive in the new business environment. Boston, MA: Harvard Business School Press.

Kaplan, R. S. \& Norton, D. P. (2004). Strategy maps: Converting intangible assets into tangible outcomes. Boston, MA: Harvard Business School Press.

Kaplan, R. S. \& Norton, D. P. (2006). Alignment: Using the balanced scorecard to create corporate synergies. Boston, MA: Harvard Business School Press.

Kaplan, R. S. \& Norton, D. P. (2008). Execution premium: Linking strategy to operations for competitive advantage. Boston, MA: Harvard Business School Press.

Kjøde, L. A. (2003). Innovasjon, diffusjon og suksess av nye begreper innen økonomisk styring: En studie av aktivitetsbasert kalkulasjon og balansert målstyring $i$ Norge. Norwegian School of Economics and Business Administration, Bergen.

Lawrie, G. \& Cobbold, I. (2004). Third-generation balanced scorecard: Evolution of an effective strategic control tool. International Journal of Productivity and Performance Management, 53(7), 611-623.

Lucianetti, L. (2010). The impact of the strategy maps on balanced scorecard performance. International Journal of Business Performance Management, 12(1), 21-36.

Lueg, R. (2015). Strategy maps: The essential link between the balanced scorecard and action. Journal of Business Strategy, 36(2), 34-40.

Lueg, R. \& Carvalho e Silva, A. L. (2013). When one size does not fit all: A literature review on the modifications of the balanced scorecard. Problems and Perspectives in Management, 11(3), 86-94.

Lueg, R. \& Julner, P. (2014). How are strategy maps linked to strategic and organizational change? A review of the empirical literature on the balanced scorecard. Corporate Ownership \& Control, 11(4), 439-446.

Lueg, R. \& Vu, L. (2015). Success factors in balanced scorecard implementations - a literature review. Management Revue, 26(4), 306-327.

Madsen, D. Ø. (2011). The impact of the balanced scorecard in the Scandinavian countries: A comparative study of three national management fashion markets. Unpublished Ph.D. Thesis, Norwegian School of Economics, Department of Strategy and Management, Bergen, Norway.

Madsen, D. Ø. (2012). The balanced scorecard i Norge: En studie av konseptets utviklingsforløp fra 1992 til 2011. Praktisk økonomi og finans, (4), 55-66.

Madsen, D. Ø. (2014a). How do managers encounter fashionable management concepts? A study of balanced scorecard adopters in Scandinavia. International Journal of Management Concepts and Philosophy, 8(4), 249-267.

Madsen, D. Ø. (2014b). Interpretation and use of the balanced scorecard in Denmark: Evidence from suppliers and users of the concept. Danish Journal of Management og Business, 78(3/4), 13-25. 
Madsen, D. Ø. (2015). The balanced scorecard in the context of SMEs: A literature review. Review of Business Research, 15(3), 75-86.

Madsen, D. Ø. \& Slåtten, K. (2015). The balanced scorecard: Fashion or virus? Administrative Sciences, 5(2), 90-124.

Madsen, D. Ø. \& Stenheim, T. (2014a). Balansert målstyring: En kort oversikt over forskningslitteraturen. Magma, 17(4), 22-33.

Madsen, D. Ø. \& Stenheim, T. (2014b). Perceived benefits of balanced scorecard implementation: Some preliminary evidence. Problems and Perspectives in Management, 12(3), 81-90.

Madsen, D. Ø. \& Stenheim, T. (2015). The balanced scorecard: A review of five research areas. American Journal of Management, 15(2), 24-41.

Malmi, T. (2001). Balanced scorecards in Finnish companies: A research note. Management Accounting Research, 12, 207-220.

Merchant, K. A. \& Van der Stede, W. A. (2012). Management control systems: Performance measurement, evaluation, and incentives (3. utg.). London: Prentice Hall.

Nielsen, S. \& Sørensen, R. (2004). Motives, diffusion and utilisation of the balanced scorecard in Denmark. International Journal of Accounting, Auditing and Performance Evaluation, 1, 103-124.

Nørreklit, H. (2000). The balance on the balanced scorecard a critical analysis of some of its assumptions. Management Accounting Research, (March), 65-88.

Nørreklit, H. (2003). The balanced scorecard: What is the score? A rhetorical analysis of the balanced scorecard. Accounting, Organizations and Society, 28(6), 591-619.

Nørreklit, H. \& Mitchell, F. (2007). The balanced scorecard. I T. Hopper, D. Northcott \& R. W. Scapens (Red.), Issues in management accounting.

Nørreklit, H., Nørreklit, L., Mitchell, F. \& Bjørnenak, T. (2012). The rise of the balanced scorecard! Relevance regained? Journal of Accounting \& Organizational Change, 8(4), 490-510.

Oliversen, F. (2014). Erfaringer med bruk av balansert målstyring: En surveyundersøkelse blant norske mellomstore og store bedrifter. Norwegian School of Life Sciences, Ås, Norway.

Olsen, L. E. (1999). The balanced scorecard: styringsdimensjoner i norsk industri en empirisk undersøkelse. Norwegian School of Economics and Business Administration, Bergen.

Olsen, T.-E. (2012). Diffusion and adoption of management accounting innovations in the public sector: The case of Norwegian health entities and institutions within higher education. Norwegian School of Economics, Bergen, Norway.

Pedersen, H. S. \& Bødtger, M. S. (2014). Balansert målstyring i norske små og mellomstore bedrifter: en surveyundersøkelse av utbredelse og praksis. Norwegian School of Life Sciences, Ås, Norway. 
Perkins, M., Grey, A. \& Remmers, H. (2014). What do we really mean by 'balanced scorecard'? International Journal of Productivity and Performance Management, $63(2), 148-169$.

Perkmann, M. \& Spicer, A. (2008). How are management fashions institutionalized? The role of institutional work. Human Relations, 61(6), 811-844.

$\mathrm{Qu}, \mathrm{S}$. (2004). A sociological analysis of the rise and dissemination of management accounting innovations: Evidence from the balanced scorecard. Fourth Asia Pacific Interdisciplinary Research in Accounting Conference. Singapore.

Rautiainen, A. I. (2009). The interrelations of decision-making rationales around BSC adoptions in Finnish municipalities. International Journal of Productivity and Performance Management, 58(8), 787-802.

Rigby, D. \& Bilodeau, B. (2009). Management tools \& trends 2009. London: Bain \& Company.

Rigby, D. \& Bilodeau, B. (2013). Management tools \& trends 2013. London: Bain \& Company.

Rigby, D. \& Bilodeau, B. (2015). Management tools \& trends 2015. London: Bain \& Company.

Rigby, D. \& Bilodeau, B. (2018). Management tools \& trends 2018. London: Bain \& Company.

Rolfsen, M. \& Jensen, H. C. (2014). Lean bygging. I M. Rolfsen(Red.), Lean blir norsk Lean i den norske samarbeidsmodellen (s. 130-139). Bergen: Fagbokforlaget.

Røvik, K. A. (2011). From fashion to virus: An alternative theory of organizations' handling of management ideas. Organization Studies, 32(5), 631-653.

Sharma, D. \& Sharma, U. (2020). Analysis of balanced scorecard usage by private companies. Pacific Accounting Review.

Shih, T.-H. \& Fan, X. (2008). Comparing response rates from web and mail surveys: A meta-analysis. Field Methods, 2o(3), 249-271.

Singh, R. K. \& Sethi, S. (2017). The balanced scorecard: Churning the existing literature. Amity Global Business Review, 12(2).

Soderberg, M., Kalagnanam, S., Sheehan, N. T. \& Vaidyanathan, G. (2011). When is a balanced scorecard a balanced scorecard? International Journal of Productivity and Performance Management, 60(7), 688-708.

Speckbacher, G., Bischof, J. \& Pfeiffer, T. (2003). A descriptive analysis of the implementation of balanced scorecards in German-speaking countries. Management Accounting Research, (December), 361-388.

Stemsrudhagen, J. I. (2003). Balansert målstyring: Fra måling til strategisk ledelse. Magma, 6, 40-46.

Stemsrudhagen, J. I. (2004). The structure of balanced scorecards: Empirical evidence from Norwegian manufacturing industry. I M. J. Epstein \& J. Manzoni (Red.), Studies in managerial and financial accounting: Performance measurement 
and managerial control: Superior organizational performance (s. 303-321). Oxford: Elsevier.

Voelpel, S. C., Leibold, M. \& Eckhoff, R. A. (2006). The tyranny of the balanced scorecard in the innovation economy. Journal of Intellectual Capital, 7(1), 43-60.

Wagensveld, J. (2013). The travel and translation of balanced scorecards.

Wanderley, C., Cullen, J. \& Tsamenyi, M. (2014). Variation in management accounting practices: The balanced scorecard adaptation. Working paper.

Wennersberg, C., Engeskar, A., Panteleeva, E. \& Helgesen, Ø. (2016). Adoption and diffusion of the balanced scorecard innovation among businesses in Møre og Romsdal. I M. Kvangarsnes, J. I. Håvold \& Ø. Helgesen (Red.), Innovasjon og entreprenørskap - Fjordantologien 2015 (s. 147-173). Oslo: Universitetsforlaget.

Wickramasinghe, D., Gooneratne, T. \& Jayakody, J. (2007). Interest lost: The rise and fall of a balanced scorecard project in Sri Lanka. Advances in Public Interest Accounting, 13, 237-271.

Wongkaew, W. (2007). Managing multiple dimensions of performance: A field study of balanced scorecard translation in the Thai financial services organisation. University of Warwick, UK. 


\section{Forfatteromtaler}

\section{Redaktørene}

Kjell Magne Baksaas er statsautorisert revisor og er ansatt som dosent ved USN Handelshøyskolen ved Universitetet i Sørøst-Norge, der han er faglig ansvarlig for næringsmaster i regnskap og revisjon. Han har høyere revisorstudium fra Norges Handelshøyskole (NHH). Fagområdet hans er finansregnskap og regnskapsteori. Han har mye FoU-aktivitet knyttet til digitalisering, regnskapsregulering og regnskap som juridisk fagområde. Han har vært medlem av regnskapsstandardstyret ved Norsk Regnskapsstiftelse (NRS) og Finanstilsynets regnskapsfaglige ekspertutvalg. Han deltar i pedagogisk utviklingsarbeid, blant annet som leder av nasjonalt fagorgan i regnskaps- og revisjonsfag ved Universitets- og høgskolerådet (UHR). E-post: kmb@usn.no

Ellen M. Kulset er førsteamanuensis og statsautorisert revisor og underviser i revisjon ved USN Handelshøyskolen ved Universitetet i Sørøst-Norge og ved Norges Handelshøyskole (NHH). Når det gjelder forskning, er hun først og fremst interessert i fagfeltet revisjon og da særlig revisjonsmetode, men hun har i denne boken også bidratt innenfor mer tverrfaglige emner i skjæringsfeltet mellom revisjon, regnskap og jus. Ellen M. Kulset har en ph.d. i revisjon fra NHH. Videre er hun utdannet siviløkonom og har høyere revisorstudium fra NHH. Hun har tidligere vært ansatt som doktorgradsstipendiat ved samme sted og har arbeidet som manager i finansgruppen i KPMG i Oslo. E-post: ellen.kulset@usn.no

Tonny Stenheim er professor i bedriftsøkonomisk analyse ved USN Handelshøyskolen ved Universitetet i Sørøst-Norge, der han er faglig ansvarlig for masterprogrammet i økonomi og ledelse. Han har master i regnskap og revisjon fra Norges Handelshøyskole (NHH), er cand.mag og cand.merc med hovedfag i bedriftsøkonomisk analyse fra Høgskolen i 
Buskerud (nå Universitetet i Sørøst-Norge) og har en ph.d i regnskapsteori fra Handelshøjskolen i København (CBS). Han var sekretær for Regnskapslovutvalget som ble nedsatt av regjeringen i 2014, og han har vært involvert i det etterfølgende departementale arbeidet med endringer av regnskapsloven. Stenheim har publisert en rekke artikler innen finansregnskap og økonomistyring og har skrevet fag- og lærebøker innen regnskapsrett og regnskapsteori. E-post: tonny.stenheim@usn.no

\section{Øvrige bidragsytere}

Sjur Annexstad er siviløkonom og har mastergrad i økonomistyring ved Høgskolen i Innlandet, samt to bachelorgrader ved Høgskolen i Gjøvik (nå NTNU) i henholdsvis sykepleie (2007) og økonomi og ledelse (2010). Han har lang erfaring fra helsevesen og bank, hvorpå han i sistnevnte bransje arbeidet som finansrådgiver og bedriftsrådgiver. Han har siden arbeidet med økonomistyring og administrasjon innenfor industri- og håndverksbransjen, og arbeider i dag innen regnskap. E-post: sjur.annexstad @gmail.com

Even Fallan er førsteamanuensis ved Høgskolen i Innlandet. Han underviser og forsker innen skatt, finansregnskap og miljø- og samfunnsansvarsrapportering, og er knyttet til forskningstradisjonen «positive accounting» - atferdsmessige aspekter ved rapporteringspraksis, regulering og bruk av regnskap. I samarbeid med professor Lars Fallan har han forsket på miljø- og samfunnsansvarsrapportering siden 1990-tallet. Even Fallan har en ph.d. fra Copenhagen Business School (CBS), er cand.merc. og siviløkonom fra Norges Handelshøyskole (NHH) og er høgskolekandidat fra Trondheim økonomiske høgskole (TØH). Han har arbeidet ved blant annet TØH, NHH, KPMG og Kultur- og kirkedepartementet. E-post: even.fallan@inn.no

Daniel Johanson er siviløkonom fra Handelshögskolan ved Göteborgs universitet og tok doktorgrad i foretaksøkonomi (regnskap og økonomistyring) samme sted i 2006. Han har siden 2010 vært ansatt som førsteamanuensis ved Institutt for regnskap, revisjon og rettsvitenskap ved 
Norges Handelshøyskole (NHH). Han forsker innen fagområdene økonomistyringssystemer, eierstyring (corporate governance), spredning av teknikker innenfor økonomistyring og digitalisering (digital transformation). E-post: daniel.johanson@nhh.no

Per Ståle Knardal er førsteamanuensis i regnskap og økonomistyring ved NTNU Handelshøyskolen. Han har mastergrad i utøvende musikk fra Royal Northern College of Music i England, er utdannet siviløkonom fra Trondheim økonomiske høgskole (TØH) (nå NTNU Handelshøyskolen) og har doktorgrad i økonomistyring fra samme sted. Han har erfaring som musiker, revisor, konsulent og festivalsjef. Han har publisert flere artikler om økonomistyring innen kulturfeltet og underviser i regnskap og økonomistyring. E-post: per.s.knardal@ntnu.no

Eivind Ludvigsen er advokat og økonom. Han har erfaring som blant annet partner i Ernst \& Young, grunnlegger av CeMa Advokat, group tax advisor i Telenor ASA, universitetslektor og fagansvarlig for skatterett ved Universitetet i Sørøst-Norge, manager i Andersen Legal samt skatterådgiver og revisjonsmedarbeider i Revisjonsfirmaet Møller \& Co. Primære forskningsinteresser er internprising og andre interdisiplinære problemstillinger knyttet til samspillet mellom jus, økonomi og regnskap. Han har tidligere publisert flere artikler innenfor dette området. E-post: el@ cema.no / eivind.ludvigsen@usn.no

Dag Øivind Madsen er professor ved USN Handelshøyskolen ved Universitet i Sørøst-Norge. Madsen er utdannet siviløkonom og har en ph.d. fra Norges Handelshøyskole (NHH). I tillegg har han en master i regnskap og finans (MSc) fra London School of Economics og en cand. mag.-grad fra Universitetet i Bergen. Madsens forskning er hovedsakelig knyttet til økonomistyring sett fra et organisasjonsteoretisk perspektiv. E-post: dagm@usn.no

Kirsti Helene Rødfjell Meidelsen er førstelektor ved Handelshøgskolen i Bodø ved Nord universitet, og hun underviser i revisjon, regnskap og skatt. Kirsti er også partner og statsautorisert revisor i KPMG. Hun er 
siviløkonom fra Handelshøgskolen i Bodø og har master i regnskap og revisjon fra Norges Handelshøyskole $(\mathrm{NHH})$. Hun har ti års erfaring fra privat revisjon og fire års erfaring som regnskapssjef i Widerøe. E-post: kirsti.h.meidelsen@nord.no

Anders Berg Olsen er førstelektor og faglig programansvarlig for master i regnskap og revisjon ved NTNU Handelshøyskolen. Han har revisorutdanning fra Trondheim økonomiske høgskole (TØH) (nå NTNU Handelshøyskolen) og Norges Handelshøyskole (NHH), er statsautorisert revisor og er cand.jur. fra Universitetet i Oslo (UiO). Han har tidligere erfaring som konsulent, revisor, internrevisjonssjef og økonomisjef. Han har tidligere utgitt en bok om avdekking av økonomisk kriminalitet og har vært medforfatter av en lærebok og oppgavebok i skatterett. E-post: anders.b.olsen@ntnu.no

André Opsahl er universitetslektor ved Universitetet i Sørøst-Norge. Han er siviløkonom fra Norges Handelshøyskole (NHH) med hovedprofil i økonomisk styring. Han har også en mastergrad i regnskap og revisjon fra samme utdanningsinstitusjon og er statsautorisert revisor. Hans forskningsinteresse knytter seg til regnskap og bedriftsøkonomiske temaer. E-post: andre.opsahl@usn.no

Sissel With Stephansen er statsautorisert revisor og førstelektor i finansregnskap ved Nord universitet. Hun har en master i regnskap og revisjon fra BI og har erfaring med privat revisjon fra Ernst \& Young. Hennes faginteresse er innenfor regnskap, skatt og revisjon. E-post: sissel.w. stephansen@nord.no

Kjell Ove Røsok er siviløkonom og statsautorisert revisor, og han har en ph.d. i finansregnskap fra Norges Handelshøyskole (NHH). I perioden 1989-2012 jobbet Kjell Ove som revisor i Arthur Andersen og i Ernst \& Young, der han var revisjonspartner fra 2002. Fra 2012 har han vært ansatt ved $\mathrm{NHH}$, og han er nå førsteamanuensis og programleder for NHHs masterprogram i regnskap og revisjon. Han er aktiv som både 
underviser og forsker innen finansregnskap med søkelys på IFRS. E-post: kjell.rosok@nhh.no

Tom Erik Wiklund er siviløkokonom og ph.d.-stipendiat ved Høgskolen i Innlandet. Han har bachelor fra NTNU og mastergrad innenfor økonomistyring fra Høgskolen i Innlandet. Han har tidligere arbeidet med virksomhetsstyring i varehandel, og han forsker i dag på digitaliseringsprosesser innenfor regnskap og revisjon. Ph.d.-prosjektet er orientert mot hvordan SAF-T-standarden kan bidra til utvikling innenfor skatteetaten og regnskaps- og revisjonsbransjen, og hvordan de rapporteringspliktige bedriftene opptrer etter at SAF-T ble obligatorisk fra 1. januar 2020. E-post: tom.wiklund@inn.no 
